\author{
UNIVERSIDADE DE SÃO PAULO \\ FACULDADE DE FILOSOFIA, LETRAS E CIÊNCIAS HUMANAS \\ DEPARTAMENTO DE LINGUÍSTICA
}

CAROLINA TOMASI

A Missividade:

Por uma Gramática Tensiva da Semiótica de HQs

São Paulo

2011

[1] 
CAROLINA TOMASI

tomasicarol@usp.br

\section{A Missividade:}

\section{Por uma Gramática Tensiva da Semiótica de HQs}

Dissertação apresentada ao Programa de PósGraduação em Semiótica e Linguística Geral do Departamento de Linguística da Faculdade de Filosofia, Letras e Ciências Humanas da Universidade de São Paulo, para obtenção do título de Mestre em Linguística.

Área de concentração: Semiótica e Linguística Geral.

Orientador: Prof. Dr. Antonio Vicente Pietroforte 
Nome: TOMASI, Carolina

Título: A missividade: por uma gramática tensiva da semiótica de HQs

Dissertação apresentada ao Programa de PósGraduação em Semiótica e Linguística Geral do Departamento de Linguística da Faculdade de Filosofia, Letras e Ciências Humanas da Universidade de São Paulo, para obtenção do título de Mestre em Linguística.

Aprovada em: /2011

Banca Examinadora

Prof. Dr. Antonio Vicente Pietroforte Instituição: Universidade de São Paulo (USP) Julgamento: Assinatura:

Prof. Waldir Beividas Instituição: Universidade de São Paulo (USP) Julgamento: Assinatura:

Prof. Dr. Luiz Geraldo Ferrari Martins Instituição: Mackenzie (SP) Julgamento: Assinatura: 
Para Domingos, Sueli e Felipe Tomasi.

Para Luigina.

Para Stefano Bellan.

Para João Bosco.

Sem vocês, o "duro" da vida atingiria o "mais duro". 


\section{Agradecimentos}

Ao meu orientador, Prof. Antonio Vicente Pietroforte, pelo carinho, amizade e confiança desde a graduação.

Aos amigos que me apoiaram (e muito) na realização deste trabalho: Prof. Ivã Carlos Lopes e Prof. Marcos Lopes.

Ao Prof. Waldir Beividas pelo conforto e apoio nas horas "duríssimas".

Ao Prof. Luiz Tatit pelas primeiras lições de semiótica.

À Prof. a Diana Luz Pessoa de Barros e Prof. Fiorin, meus primeiros "destinadores".

À Prof. ${ }^{a}$ Elizabeth Harkot-de-la-Taille, que acompanhou meus primeiros rascunhos.

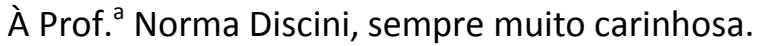

Ao Conrado Mendes, irmão do "sonho", no sufoco e na alegria, uma "parada" na minha solidão.

Ao Jean C. Portela e ao Matheus N. Schwartzmann, pelos bons momentos.

À Camila Ribeiro por me "aturar" em minhas agonias e obstinações.

Ao meu tio Carlos Del Bel, exemplo de conhecimento.

Ao Thiago Del Bel, meu irmãozinho.

À Juliana Di Fiori, minha tranquilidade.

À Carolina Lemos, meu avesso indispensável, companheira de "pão e vinho".

À Daniela Souza Pinto, amiga "vintenária", membro da família.

À Dayane Almeida, companheira de conversas e conselhos, um verdadeiro "desopilar" para o fígado.

À Mariana Luz Pessoa de Barros, sempre de prontidão, meu exemplo de alegria.

Ao Alexandre Marcelo Bueno, pelo carinho, conselho, leituras e conversas.

À Sueli Ramos, pela SOlidariedade nas minhas inSÔnias. 
À Eliane Soares de Lima, "per le dolci parole".

Ao Paulo Demuru, grande amigo desde os primeiros passos acadêmicos.

Ao Chico Merçon, pelo sorriso, lealdade e amizade.

Ao Cleyton e ao Thiago, dupla dinâmica, minha leveza no "maremoto" em busca de um pouco de conhecimento.

Ao Paulinho Mello e à Lu Alves, amigos na alegria e na tristeza.

Ao Pi, amigo de infância.

Ao André Carvalho, pelo carinho e confiança.

À Indaia Bassani, ao Vitor Nóbrega, ao Marcus Lunguinho, trio indispensável.

Aos meus bisavôs e bisavós, avôs e avós, tios e tias, primos e primas, minha semente italiana.

Ao Adilson Gobbes, amigo de longo percurso.

À Edite, meu braço para levantar.

À Erica Flávia, pela paciência e carinho.

Ao Robson e ao Benhur, pela eficiência.

À Bruna P. Zerbinatti e à Paula Martins, pelo companheirismo no percurso acadêmico.

Ao Cristiano Cabianca Ramos, Eduardo Braga Fernandes, Rubinho, Luís Fernando Souza Pinto, Gilson Camargo, Juliana Prado Vita, Eduardo Ferreira, amigos de longa data.

À Patrícia Zamprognio, pelo otimismo.

Ao Prof. Ronald Beline, às Prof. ${ }^{\text {as }}$ Evani Viotti e Ana Paula Scher.

Ao Nilton, da seção de alunos da graduação, pela paciência e tranquilidade.

À Faculdade de Filosofia, Letras e Ciências Humanas da Universidade de São Paulo, pela oportunidade de realização da Pós-Graduação.

Ao Conselho Nacional de Desenvolvimento Científico e Tecnológico (CNPq), pela bolsa concedida para a realização deste trabalho.

Ao Luiz Gê, um artista do coração. 
RESUMO

TOMASI, Carolina. A missividade: por uma gramática tensiva da semiótica de HQs. 2011. 281 f. Dissertação (Mestrado) - Faculdade de Filosofia, Letras e Ciências Humanas, Universidade de São Paulo, 2011.

Esta dissertação ocupa-se do estudo da missividade, utilizando como corpus as HQs de Território de bravos, de Luiz Gê. Seu objetivo principal é examinar a emissividade e a remissividade como elementos fundadores de uma gramática tensiva nas narrativas dos quadrinhos. Inicialmente, abordamos a paixão da obstinação como constituidora do éthos do enunciador. Como a obstinação revela a cifra tensiva da continuidade da parada causada pela tonicidade do antissujeito no percurso do sujeito, tornou-se relevante fazer o levantamento de quadrinhos emissivos e remissivos nas HQs. O resultado encontrado de 75,47\% de quadrinhos de dominância remissiva endereçou-nos para a teoria da missividade de Zilberberg. Essa teoria dá sustentação às análises empreendidas nesta dissertação e possibilitou-nos a constatação de que é o jogo do fazer missivo que estrutura as HQs. Examinamos comparativamente duas $\mathrm{HQs}$ de direções diversas: uma de dominância remissiva e outra de dominância emissiva e verificamos a pertinência do estudo da função do antissujeito, que é de desarranjador da ordem "sujeito $\rightarrow$ objeto". Ele seria responsável por impulsionar o percurso narrativo, assim como impulsiona a paixão da obstinação no enunciador. Não houvesse a presença do antissujeito, a relação entre sujeito e objeto caminharia para o exaurimento da narrativa, ou seja, uma harmonia absoluta. Posteriormente, com apoio na teoria da missividade, verificamos a oportunidade de pesquisar o ritmo e a retórica nas $\mathrm{HQs}$ como outros fatores tensivos engendradores do sentido. Examinamos, ainda, a aceleração e desaceleração promovedoras desse ritmo das HQs e chegamos ao estabelecimento de um paralelo entre as HQs de Luiz Gê e as estéticas clássica e barroca. Esses conceitos implicaram uma revisão da retórica sob o ponto de vista tensivo. Daí, o interesse deste trabalho pelos tropos metafóricos e metonímicos aqui vistos segundo as cifras tensivas da aceleração e desaceleração, respectivamente.

Palavras-chave: Semiótica tensiva. Fazer missivo. Estética. Ritmo. Retórica. História em quadrinhos. 


\section{ABSTRACT}

TOMASI, Carolina. The missivity: by a tensive grammar semiotics of comics. 2011. $281 \mathrm{f}$. Dissertação (Mestrado) - Faculdade de Filosofia, Letras e Ciências Humanas, Universidade de São Paulo, 2011.

The purpose of this work is to study the missivity, using as a corpus Luiz Gê's Território de bravos comics. The main purpose is to examine emissivity and remissivity as founding elements of a tensive grammar in the narratives present in the comics. Initially, we broach the obstinate passion as constituting the éthos of the enunciator. Once obstinacy reveals the tensive cipher in the continuity of the pause caused by antisubject's tonicity in subject's way, it became relevant to collect emissive and remissive drawings in Gê's comics. The conclusion of the survey $-75.47 \%$ of prevalent remissive drawings - has brought us to Zilberberg's missivity theory. This theory supports the analysis undertook in this work and provided the means to us to testify that the missive playing structures comics. We examined in comparative terms two comic stories which go along two diverse ways: one of them in remissive dominance, the other in emissive dominance; we found pertinence in the study of antisubject's function - that is, to derange the "subject $\rightarrow$ object" sequence. This antisubject would account for impelling the narrative way, as well as He impels enunciator's obstinate passion. If the antisubject was not present, the subject-object would go to a depletion of the narrative, that is, an absolute harmony. Afterwards, supported by the missivity theory, we could verify the convenience of researching the rhythm and rhetoric in the comics as other tensive factors that originate sense. We still examined the acceleration and deceleration that promote that rhythm in the comics, and this way could establish a comparison between Luiz Gê's stories and classic and baroque esthetics. These concepts implied a revision of the rhetoric under a tensive point of view. Thus this work concerns itself with the metaphorical and metonymical tropos here seen in conformity with, respectively, acceleration and deceleration tensive ciphers.

Keywords: Tensive semiotics. Missive making. Esthetics. Rhythm. Rhetoric. Comics. 
TOMASI, Carolina. La missivité: pour une grammaire tensive de la sémiotique de la bande dessinée. 2011. 281 f. Dissertação (Mestrado) - Faculdade de Filosofia, Letras e Ciências Humanas, Universidade de São Paulo, 2011.

Cette dissertation s'occupe de l'étude de la missivité, et pour cela elle fait usage des bandes dessinées Território de bravos, de Luiz Gê, en tant que corpus. Son but principal est d'examiner l'émissivité et la remissivité en tant qu'éléments fondateurs d'une grammaire tensive chez les récits des BDs. D'abord nous ferons face à la passion de l'obstination en tant que constitutrice de l'éthos de l'énonciateur. Comme l'obstination dévoile la chiffre tensive de la continuité de l'arrêt occasioné par la tonicité de l'anti-sujet dans l'itinéraire du sujet, c'est important de faire la recherche de dessins émissives et rémissives dans les HQs. Le résultat trouvé $-75,47 \%$ de dessins avec prédominance remissive - nous a conduisé à la théorie de la missivité de Zilberberg. Cette théorie soutient les analises entreprenues dans cette dissertation et nous avons donc pu vérifier que c'est le jeu du faire missive qui structure les BDs. Nous examinerons comparativement deux BDs lesquels poursuivent par deux directions diverses: l'une en dominance rémissive et l'autre en dominance émissive. Et nous verifierons la pertinence de l'étude de la fonction de l'anti-sujet comme désorganisateur de l'ordre "sujet $\rightarrow$ object". II sérait responsable de pousser le parcours narratif, autant qu'il pousse la passion de l'obstination chez l'énonciateur. N'y-aurait-il la présence de l'anti-sujet, le rapport entre sujet et objet marcherait vers l'épuisement du récit, c'est à dire une harmonie absolute. Postérieurement, en s'appuyant sur la théorie de la missivité, nous verifierons l'oportunité de la recherche du rythme et de la rhétorique chez les BDs en tant que d'autres facteurs tensifs qui engendrent le sens. Nous examinerons encore l'accélération et la décélération qui promouvent ce rythme chez les BDs et arriverons à l'établissement d'une comparaison entre les BDs de Luiz Gê et les esthétiques classique et baroque. Tels concepts ont impliqué une révision de la rhétorique de le point de vue tensif. Donc l'intérêt de cet'oeuvre pour les tropos métaphoriques et métonymiques vues ici sélon les chiffres tensives respectivement d'accélération et décélération.

Mots-clefs: Sémiotique tensive. Le faire missif. Estétique. Rythme. Rhétorique. Bande dessinée. 


\section{Sumário}

Introdução, 12

1 Constituição de um enunciador obstinado, 18

1.1 Introdução, 19

1.2 Da paixão, 19

1.3 Tensividade e paixões, 24

1.4 Um enunciador obstinado, 26

1.5 A cifra tensiva da obstinação, 37

1.6 O éthos do enunciador, 43

2 Missividade: emissividade e remissividade, 48

2.1 Fazer missivo, 49

2.2 Tempo e espaço, 68

2.3 Descrição dos quadrinhos: emissivos e remissivos, 70

2.4 Sujeito, objeto e antissujeito na narrativa, 88

2.5 A função do antissujeito na narrativa, 94

3 Missividade em "Entradas e bandeiras" e "Futboil", 111

3.1 Escolha do corpus de análise, 112

3.2 "Entradas e bandeiras": dominância da remissividade, 113

3.2.1 Introdução, 113

3.2.2 Percurso paralelo de dois sujeitos e de dois antissujeitos: emissividade e remissividade, 117

3.2.3 Tensividade e missividade: articulação do tempo e do espaço, 131

3.3 "Futboil": dominância da emissividade em busca do objeto, 137

3.3.1 Cinema e "Futboil": dominância emissiva, 137

3.3.2 Destruição do objeto pelo sujeito, 140

4 Do utilitário ao artístico. Aceleração e desaceleração: o ritmo nas HQs, 154 
4.1 Do utilitário ao artístico, 155

4.2 Aceleração e desaceleração: classicismo e barroco em Território de bravos, 157

4.3 Semiótica e retórica, 163

4.3.1 Argumentação retórica, 166

4.3.2 Tropos visuais em "Entradas e bandeiras", 172

4.3.3 A aceleração metafórica e a desaceleração metonímica: tensão entre dois tropos, 177

4.4 Do ritmo, 180

Conclusão, 191

Referências, 196

Anexo, 205 


\section{Introdução}

Por isso que sempre no início A gente não sabe como começar

Começa porque sem começo Sem esse pedaço não dá pra avançar. Luiz Tatit 
Um estudo científico inicia-se necessariamente com a definição de seu objeto. Um objeto de estudo semiótico, por sua vez, precisa ser visto mais de perto e é necessário entender que nosso interesse pelo objeto depende da afeição que decorre da existência de sua percepção. Segundo Bergson (2006, p. 84), “a percepção, tal como a entendemos, mede nossa ação possível sobre as coisas e, por isso, inversamente, a ação possível das coisas sobre nós".

As escolhas científicas são feitas levando em conta um sujeito sensível e um objeto a ser estudado. Elas são feitas em escala. Em primeiro lugar, a opção pela semiótica; em segundo lugar, o interesse em verificar como a semiótica francesa poderia servir para abordar objetos como as HQs. O terceiro desafio foi optar por um texto em que a tônica não fosse uma narrativa pura e simples, com laços apenas no fazer.

Encontramos em Luiz Gê uma obra que, visual e verbalmente, foge do estereótipo de chargista e quadrinista voltado para um trabalho puramente mimético. A riqueza da expressão de Luiz Gê, assim como particularidades do conteúdo, das figuras discursivas, mostram a singularidade do artista e de sua obra, o que nos sensibilizou sobremaneira. Alguns quadrinhos de Território de bravos parecem telas de artistas contemporâneos, que buscam em sua arte dialogar com outras obras artísticas.

Tomemos, por exemplo, um quadrinho-tela que consta de uma das HQs de Território de bravos. Luiz Gê a denominou "Independência em Marte" (ver reprodução a seguir), estabelecendo uma intertextualidade com o quadro de Pedro Américo, exposto no Museu Paulista da Universidade de São Paulo (Museu do Ipiranga). Veja a seguir o texto de Luiz Gê: 

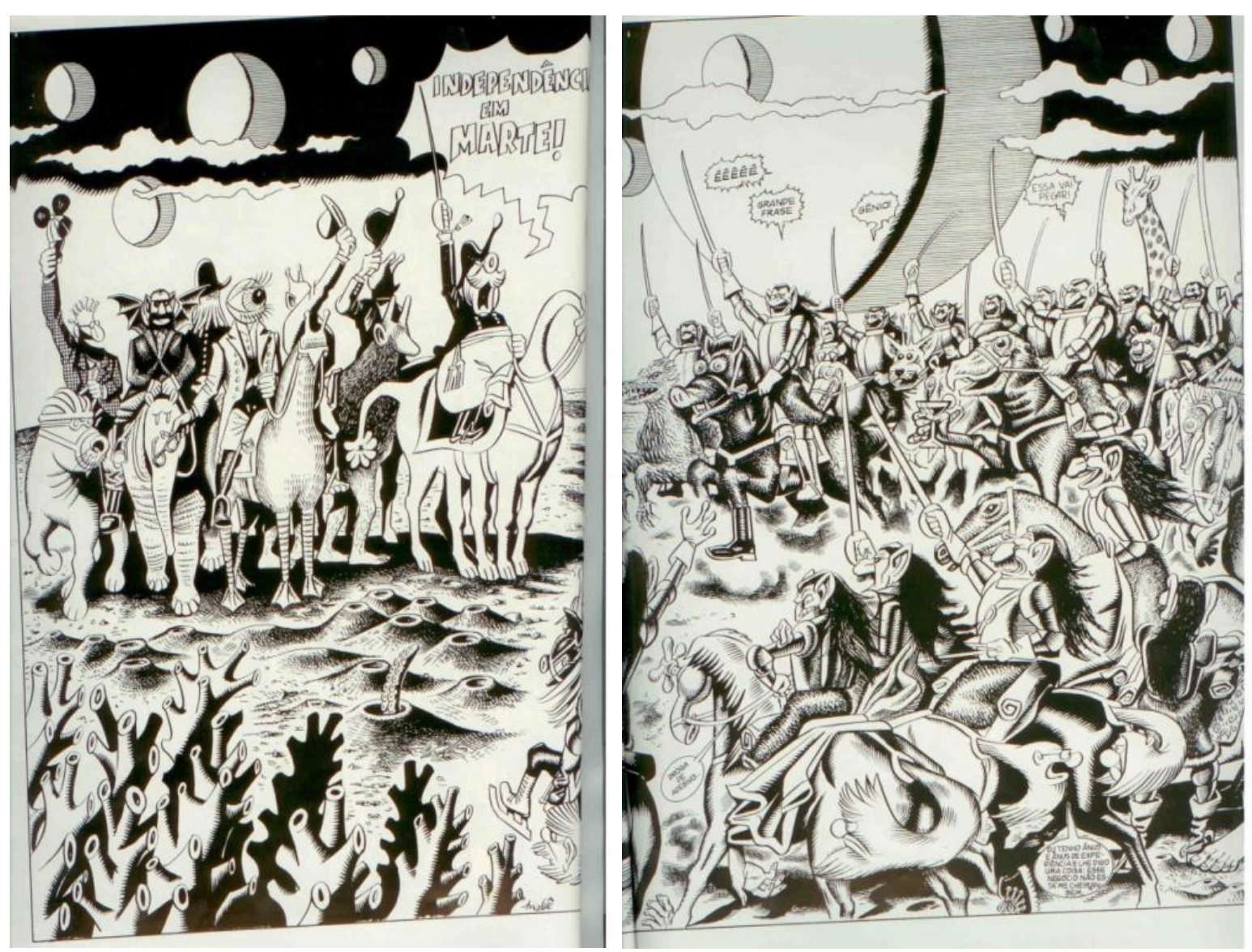

E, agora, a tela do Grito da Independência de Pedro Américo:

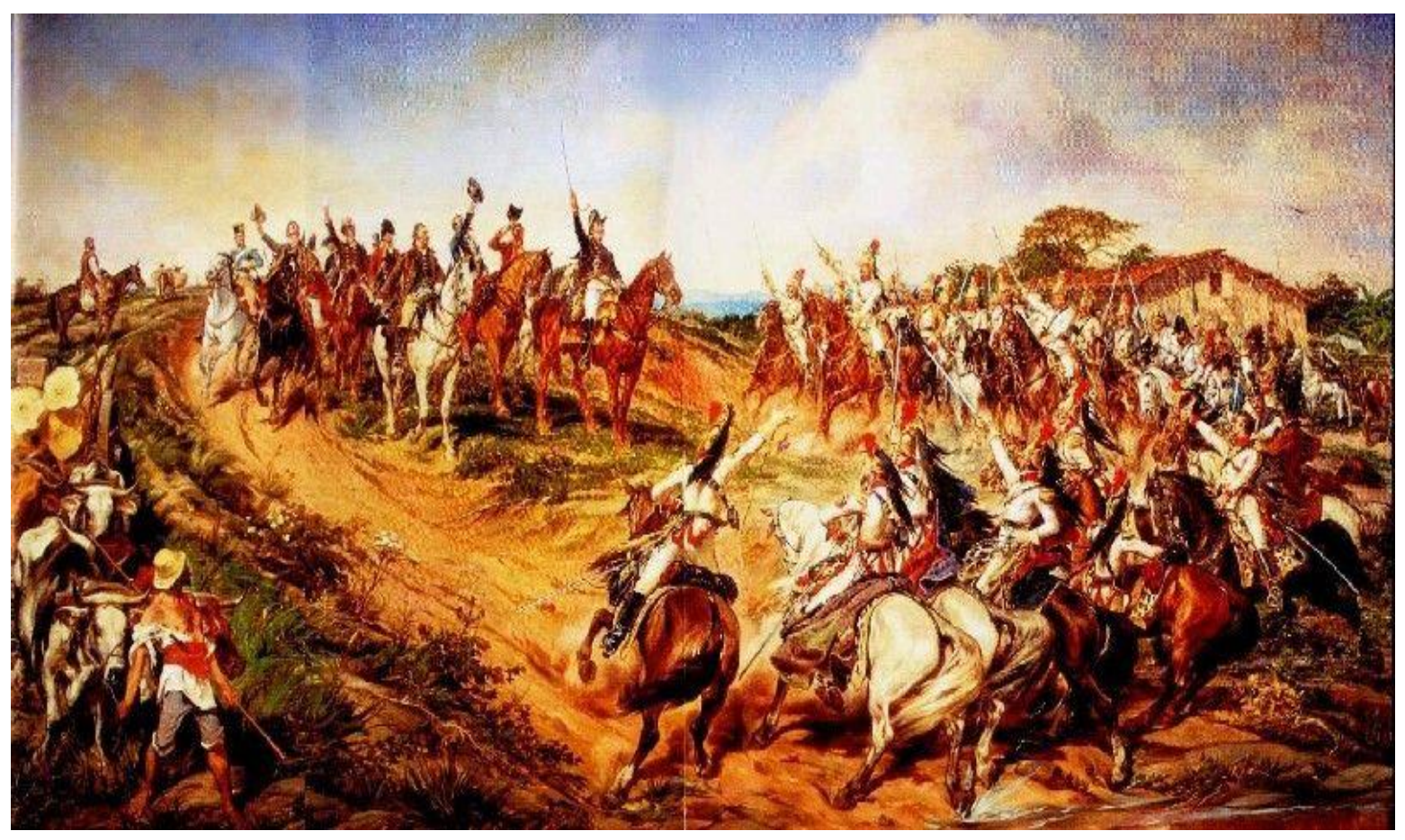


O particípio "esculpido" do título da HQ, "Entradas e bandeiras" ["Histórias Extraordinárias apresentam ENTRADAS E BANDEIRAS uma H.Q. (história em quadrinhos)/dedicada ao Vitor e esculpido por luiz gê (sic)] chama a atenção para a particularidade da obra de Luiz Gê. Como dissemos, sua HQ constituía um objeto artístico. Foi então que nos demos conta de que seria necessário empreender uma investigação semiótica capaz de nos revelar um princípio organizador que as fazia diferente de outras HQs.

A preocupação do enunciador, ator discursivo Luiz Gê, em construir um objeto singular é detectável pelas figuras do mundo estético que ele distribui pelo espaço dos enunciados de Território de bravos. Daí surgiu o interesse por estudá-lo semioticamente, considerando, além do fazer missivo, os conceitos de antissujeito, destinador, sujeito e objeto.

Território de bravos é um livro de sete HQs, em preto e branco, que são precedidas de epígrafes de autores do século XVI ao XX, bem como de tiras de Presidente Reis em todas as HQs, que, em geral, mostram esse ator em variados espaços da cidade, revelando pontos de vista de observação, tiradas humorísticas, ironias, bem como salientando modalizações avaliativas sobre a cidade e seus habitantes.

Esta dissertação tem como corpus de análise o texto da "Apresentação" de Território de bravos, e as HQs que o compõem. Também foram objeto de análise algumas epígrafes do livro e tiras introdutórias das HQs, denominadas por Luiz Gê de "Tiras do Presidente Reis". As histórias "Entradas e bandeiras", "Tubarões voadores", "Errare marcianum est", "Quem matou papai Noel?", "Futboil”, "Uma história de amor" e "Perdidos no espaço" são objetos de análise para elucidações e comparações com a finalidade de verificar como o fazer missivo pode contribuir para o estabelecimento da gramática tensiva das HQs.

No capítulo 1, com base na "Apresentação" de Território de bravos, ocupamo-nos do estudo de um enunciador obstinado. Nesse texto, Luiz Gê declara as adversidades que sofreu durante muitos anos até que conseguiu publicar sua obra; trata-se de um percurso de um sujeito permeado de antissujeitos que alimentaram a obstinação de seu fazer artístico. A escolha de valores remissivos por parte da instância enunciativa instigou-nos a pesquisa do éthos desse enunciador. 
No capítulo 2, tratamos sobretudo da emissividade e da remissividade, bem como analisamos seu funcionamento nas sete HQs de Território de bravos (ver seção 2.3 desta dissertação). Juntamente com o estudo do fazer missivo, fez-se necessário considerar o antissujeito, o sujeito, o objeto e o destinador como conceitos-chave para o desenrolar das narrativas. O jogo desse fazer missivo forneceu-nos, então, a base para a descrição de quadrinhos abertos, fechados e mistos. Para o exame da missividade, valemo-nos dos estudos de Zilberberg (2006b). Quando a instância da enunciação seleciona a criação do tempo, sobressai um estado passional e prevalece um valor remissivo; quando, todavia, essa instância opta pela criação do espaço, há uma difusão e uma dominância emissiva. Daí sugerirmos a investigação de uma gramática reguladora das HQs, uma estrutura apoiada nos valores de difusão (emissivos) e de concentração (remissivos).

No capítulo 3, nossa preocupação foi analisar especificamente duas HQs de Território de bravos, "Entradas e bandeiras" e "Futboil". A primeira, de dominância remissiva, proporcionou-nos a análise do percurso de dois sujeitos e de dois antissujeitos. Já a análise de "Futboil", de dominância emissiva, possibilitou-nos a verificação da articulação do tempo e do espaço em busca do objeto. Ambas as análises aproximam, no que se refere ao andamento, a produção de Luiz Gê das categorias estéticas de classicismo e barroco. Outra comparação possível foi entre "Entradas e bandeiras" e a escultura clássica e "Futboil" e o cinema. Interessa-nos aqui o andamento do classicismo, que é desacelerado, bem como o do barroco, que é acelerado.

Esses traços de contato entre a obra de Gê e as estéticas mencionadas são vistos no capítulo 4. Constitui ainda objeto de nosso estudo o exame da retórica e do ritmo. Em relação à retórica, consideramos tanto a parte argumentativa quanto a dos tropos, uma tendência da semiótica atual. Em relação ao ritmo, verificamos que o estudo da missividade necessariamente implica considerar as oscilações rítmicas que configuram o andamento de uma narrativa.

Enfim, esta dissertação, com base no estudo da missividade e, utilizando como corpus as HQs de Território de bravos, objetivou investigar se a emissividade e a remissividade seriam elementos fundadores de uma gramática tensiva nas narrativas dos quadrinhos. Abordamos inicialmente a paixão da obstinação reveladora da cifra tensiva da continuidade da parada causada pela tonicidade do antissujeito no percurso do sujeito. Daí, 
ter-se tornado relevante fazer o levantamento de quadrinhos emissivos e remissivos nas HQs. O resultado encontrado de $\mathbf{7 5 , 4 7 \%}$ de quadrinhos de dominância remissiva endereçounos para a teoria da missividade de Zilberberg como sustentadora das análises empreendidas nesta dissertação e possibilitou-nos, então, a constatação de que é o jogo do fazer missivo que estrutura as HQs. Examinamos comparativamente duas HQs de direções diversas: uma de dominância remissiva e outra de dominância emissiva e verificamos a pertinência do estudo da função do antissujeito, que é de desarranjador da ordem "sujeito $\rightarrow$ objeto". Ele seria responsável por impulsionar o percurso narrativo, assim como impulsiona a paixão da obstinação no enunciador. Não houvesse a presença do antissujeito, a relação entre sujeito e objeto caminharia para o exaurimento da narrativa, ou seja, uma harmonia absoluta. Foi, então, com apoio na teoria da missividade, que verificamos a oportunidade de pesquisar o ritmo e a retórica nas HQs como outros fatores tensivos engendradores do sentido. Examinamos, ainda, a aceleração e desaceleração promovedoras desse ritmo das HQs e chegamos ao estabelecimento de um paralelo entre as HQs de Luiz Gê e as estéticas clássica e barroca. Esses conceitos implicaram uma revisão da retórica sob o ponto de vista tensivo. Daí, o interesse deste trabalho pelos tropos metafóricos e metonímicos aqui vistos segundo as cifras tensivas da aceleração e desaceleração, respectivamente.

Ao final desta dissertação, apresentamos ainda um anexo com o texto de Território de bravos que nos serviram de corpus para esta pesquisa. 
Constituição de um enunciador obstinado

O querer do obstinado tornou-se, por causa da presença do dispositivo da impossibilidade, um querer "resistente". A. J. Greimas e Jacques Fontanille 


\subsection{Introdução}

Ao ler a "Apresentação" de Território de bravos de Luiz Gê, deparamos com um sujeito apaixonado. O exame dessa paixão não poderia passar despercebido, visto que aí poderia estar um dos segredos do sentido de sua obra.

Inicialmente, observamos que nem sempre os limites das paixões são detectáveis, visto que elas podem imbricar-se. Greimas e Fontanille (1993, p. 21) alertam que as paixões no discurso são portadoras de efeitos de sentido particulares, exalando "um cheiro confuso, difícil de determinar".

Para a semiótica, esse "perfume específico" procede da organização discursiva das estruturas modais.

Não se pode perder de vista que as paixões, objeto de análise da semiótica, emanam das estruturas modais e do nível discursivo. Além disso, a construção do discurso implica sempre uma enunciação pressuposta e esta constrói um sujeito da enunciação (enunciador e enunciatário) pressuposto que, no nível modal-narrativo, revela um sujeito possuidor de paixões. Para Tatit (1997, p. 35), "se todo texto pressupõe uma enunciação humana, não havia como apartá-lo do universo passional sob pena de vê-lo transformado em objeto de análise fictício, destituído de suas partes essenciais". O exame das paixões não se faz, portanto, sem a preocupação com a enunciação. Daí nossa investigação voltar-se neste capítulo para o enunciador obstinado.

A seguir, apresentamos um breve resgate teórico da introdução da paixão nos estudos semióticos.

\subsection{Da paixão}

Os textos, produtos do fazer humano, veiculam paixões. Podemos dizer que o sujeito da enunciação é, no nível modal-narrativo, um sujeito apaixonado ${ }^{1}$. E é esse sujeito que nos interessa aqui examinar.

\footnotetext{
${ }^{1}$ Tatit (2001, p. 176) chama a atenção para o fato de que os valores que caracterizam a tensividade no nível profundo instruem, no nível modal-narrativo, o estado passional do sujeito que, por sua vez, instrui temas e figuras no discurso.
} 
A noção de paixão foi descartada nos anos 60 e 70. A teoria narrativa, resumidamente, começou, por explicar os estados de coisas, mas não os estados de alma (GREIMAS; FONTANILLE, 1993). Ela tratava de textos em que a transferência se dava, basicamente, no nível de objetos consumíveis e entesouráveis ou de textos em que estruturas de manipulação e de sanção eram o foco central. Os textos (verbais e não verbais) mais "complexos" acabaram solicitando à semiótica um estudo mais refinado, visto que não operavam apenas com o fazer do sujeito, mas também (e sobretudo) com as transformações do ser desse sujeito. Há textos, por exemplo, em que o fazer nem ganha cena, como os que Fiorin (2008c, p. 65) chama de "a grande literatura". Foi preciso, então, voltar-se para o estudo dos "estados de alma", as paixões de "papel"2.

A semiótica, ao examinar as paixões, não faz um estudo dos caracteres ou dos temperamentos; ela apenas considera que os efeitos afetivos ou passionais do discurso resultam da modalização do sujeito de estado. As paixões são compostas por elementos linguísticos que geram um efeito de sentido. Fiorin (2007b, p. 10) afirma, em "Semiótica das paixões: o ressentimento", que as paixões estão sempre presentes nos textos e que um componente patêmico perpassa todas as relações e as atividades humanas. Esse componente é o que move a ação humana, e é a enunciação que discursiviza a subjetividade.

Tensão e significação (2001) apresenta uma definição de paixão suficientemente abrangente que permite um desdobramento teórico-sistemático. Dessa forma, a "paixão" se diferencia agora da "ação" não como algo residual da análise narratológica, porém como mudança de ponto de vista. A paixão passa a ser considerada como uma problemática tensiva e sensível, como uma organização sintagmática, modal e aspectual e como matéria de investigação da práxis enunciativa ${ }^{3}$. Atualmente, a semiótica das paixões não seria mais

\footnotetext{
${ }^{2}$ Greimas e Fontanille (1993, p. 18) deixam claro que o estudo que empreendem é de análise de paixões de papel. Afirmam ainda que "a ideia que se faz do que seja uma 'paixão' varia de um lugar para o outro, de uma época para a outra, e que a articulação do universo passional define mesmo, até certo ponto, especificidades culturais". Ver também Barros (In: OLIVEIRA; LANDOWSKI, 1995, p. 93).

3 Para Fontanille e Zilberberg (2001, p. 190): “A práxis enunciativa interessa, além disso, à semiótica das culturas. Com efeito, ela produz 'taxionomias conotativas', ou seja, recortes da macrossemiótica do mundo natural, que são próprios de uma área ou época cultural; essas taxionomias são, por sua vez, constituídas de microssemióticas, linguísticas ou não linguísticas, nas quais cada termo, em razão dos laços de dependência ou diferença que o unem aos demais, conota a filiação a um universo cultural particular. Mais precisamente, é a distribuição das figuras numa determinada microssemiótica que acrescenta uma carga semântica particular, a que chamamos 'conotação'. Mas, nesse caso, não há, sob essa perspectiva, semas especificamente 'conotativos'."
} 
um complemento da semiótica da ação: "ela a engloba e a compreende, sob seu próprio ponto de vista”" ${ }^{4}$ (FONTANILLE; ZILBERBERG, 2001, p. 295-296).

A mudança de ponto de vista ocorreu da seguinte forma: se antes, a preocupação era com o fazer (a ação narratológica), com a entrada da semiótica das paixões, a preocupação passou a ser também de ordem sensível e tensiva.

Greimas e Courtés (1989, p. 483-484) já salientavam que é comum no discurso narrativo a circulação de objetos de valor, em que sua organização pode ser descrita como uma sequência de transferência de valores. Se os valores não forem idênticos, ocorrerá uma avaliação prévia e se estabelecerá um contrato fiduciário entre os sujeitos que participam da troca. Tal contrato estabelece o valor dos valores em jogo.

A expressão contrato fiduciário envolve a questão dos sujeitos que participam dessa troca. Quando há envolvimento de sujeitos e de objetos (e valores neles depositados), há paixão.

Greimas e Courtés (1989, p. 184, verbete Fiduciário), definem que o contrato fiduciário coloca, de um lado, em jogo um fazer persuasivo por parte do destinador e, de outro lado, a adesão do destinatário. Dessa forma, se o objeto do "fazer" persuasivo é o "dizer-verdadeiro" do enunciador, o "contraobjeto" consiste em um "crer-verdadeiro" que o enunciatário atribui ao discurso-enunciado. O contrato fiduciário nada mais é do que um contrato enunciativo que mantém o discurso-enunciado: "a relação fiduciária é a que se estabelece entre os dois planos, o do ser e o do parecer quando, graças ao fazer interpretativo, passa-se de um ao outro, fazendo-se sucessivamente a asserção de um e outro desses modos de existência".

Um exemplo notável de desencadeamento de uma paixão pela crise de confiança em um contrato fiduciário é o da cólera. Em Du sens II, Greimas (1983, p. 233) ressalta:

\footnotetext{
Un point reste toutefois à noter, relatif au rôle de l'intensité: on a l'impression qu'il y a souvent un rapport direct entre l'intensité de l'attente: "souhait", "voeu", "espoir", "aspiration", "désir", "envie", etc., et la gradation correspondante de I'insatisfaction, due à sa non-réalisation.

A l'insatisfaction apparue à la suite de la non-attribution de l'objet de valeur s'ajoute parfois une autre sorte de malaise, provoqué par le comportement du sujet de faire, interprété comme non conforme à l'attente. Ce comportement qui, aux yeux du sujet d'attente fiduciaire, était modalisé par un /devoir-faire/ n'a pas
}

\footnotetext{
${ }^{4}$ Do ponto de vista da ação, a paixão é um efeito superficial, uma perturbação, da ordem da exceção ou do excesso. Do ponto de vista da paixão, a ação é algo que se submete a regras de restrição: discretização dos enunciados, orientação exclusiva segundo o fazer, reconstrução das modalidades por estrita pressuposição a partir da performance etc. (FONTANILLE; ZILBERBERG, 2001, p. 296).
} 
lieu, et le croire du sujet d'état se révèle d'un seul coup injustifié. La déception qui en résulte est une crise de confiance d'un double point de vue, non seulement parce que le sujet 2 a déçu la confiance qu'on avait mise en lui, mais aussi - et peut-être surtout - parce que le sujet 1 peut s'accuser de la confiance mal placée. Ces deux formes de dysphorie, réunies ensemble, sont provoquées par la "frustration" [...], ce "vif mécontentement" qui conduit à l'explosion de la colère 5.

Com base no texto citado de Greimas, podemos estabelecer o esquema da crença em um contrato fiduciário:

\section{S1 crer [S2 dever $\rightarrow(\mathrm{S} 1 \cap \mathrm{OV})]$}

Consideremos agora a paixão da obstinação, que resulta dos enunciados e da enunciação da "Apresentação" de Território de bravos: o sujeito S1 crê que S2 deva conjungi-lo ao objeto de valor. A quebra da fidúcia por S2, com o rompimento do contrato, imaginário ou não da parte de S1, instaura a obstinação que é sobretudo alimentada pelo "não poder ser" conjunto com o objeto de valor juntamente com um "querer ser aquele que faz continuamente" durante todo o percurso dessa paixão. A quebra do contrato fiduciário pode levar a outras paixões, que não vêm ao caso neste trabalho, como o desespero, a frustração, o rancor, a raiva e até mesmo a cólera.

Uma peculiaridade da obstinação é justamente a quebra desse contrato constituir o alimento do obstinado que, ainda mais insistentemente, "quer ser aquele que faz". No caso aqui em estudo, S1 (ator explícito no enunciado como Luiz Gê, sujeito de papel) crê que S2 (mercado editorial explícito no enunciado da "Apresentação") "deva" publicar-Ihe Território de bravos, objeto de valor para Gê; como o mercado editorial não responde positivamente a esse "querer ser aquele que publica", acaba por instaurar a obstinação em nosso enunciador. A trajetória dele é de 18 anos até alcançar a publicação de sua obra. É justamente a constituição desse enunciador obstinado o objeto de estudo deste capítulo.

\footnotetext{
5 "Resta notar, todavia, um ponto relativo ao papel da intensidade: tem-se a impressão de que há geralmente uma relação direta entre a intensidade da espera: 'desejo', 'voto', 'esperança', 'aspiração', 'anseio', 'vontade' etc., e a gradação correspondente da insatisfação, devido à sua não realização. À insatisfação surgida em decorrência da não atribuição do objeto de valor acrescenta-se às vezes um outro tipo de mal-estar, provocado pelo comportamento do sujeito de fazer, interpretado como não conforme ao esperado. Esse comportamento que, aos olhos do sujeito da espera fiduciária, estava modalizado por um 'dever-fazer', não tem lugar, e o crer do sujeito de estado se revela de uma só vez injustificado. A decepção que disso resulta é uma crise de confiança de um duplo ponto de vista: não só porque o sujeito 2 frustrou a confiança que se tinha posto nele, mas também - e talvez sobretudo - porque o sujeito 1 pode se acusar da confiança mal colocada. Essas duas formas de disforia, juntas, são provocadas pela 'frustração' [...], este 'vivo descontentamento' que conduz à explosão da cólera" (tradução nossa).
} 
As paixões não nascem do nada em um texto, verbal ou não verbal. O próprio nome "paixão", segundo Fontanille e Zilberberg (2001, p. 300), foi escolhido como termo genérico e extraído de uma nomenclatura já evocada pelos autores no capítulo sobre emoção. Qual seria o lugar da paixão no conjunto das manifestações "afetivas"? O gradiente (quadro 1.1), proposto por Fontanille e Zilberberg com base na correlação entre a dimensão modal e a dimensão fórica, que dispõe as principais manifestações afetivas, pode ser visto no quadro 1.1.

Quadro 1.1 Gradiente das manifestações afetivas.

\begin{tabular}{|l|l|l|l|l|}
\hline & Emoção & Inclinação & Paixão & Sentimento \\
\hline Dimensão modal & átona & átona & tônica & tônico \\
\hline Dimensão fórica & tônica & tônica & átona & átono \\
\hline
\end{tabular}

Fonte: Adaptado de Fontanille e Zilberberg (2001, p. 300).

Com base no esquema afetivo visto no quadro 1.1, comparemos paixão e emoção, com o propósito de direcionar nosso estudo para a obstinação: (a) do ponto de vista da foria, a emoção é produto da rapidez e da intensidade que, por sua vez, evolui de forma conversa (mais rápido, mais intenso); a paixão, no entanto, é produto da desaceleração e da extensidade, evoluindo de forma contínua (mais lento, mais extenso), corroborando, assim, a duratividade aspectual da paixão; (b) do ponto de vista aspectual, a emoção configura-se como perda da duratividade; já a paixão comporta tal duratividade; (c) do ponto de vista modal, se prevalecem as valências da inibição sobre as da impulsão, instaura-se a surpresa (a emoção); já na obstinação, por exemplo, a impulsão do querer ser prevalece sobre a inibição (sustos) do não poder ser e do saber não ser [ainda]. O obstinado particulariza-se por manter o sujeito em estado de continuar a fazer [fazer apesar de X] (GREIMAS; FONTANILLE, 1993, p. 63).

Assim, do ponto de vista modal, a paixão e o sentimento permitem a identificação das isotopias modais dominantes, assim como a identificação dos dispositivos modais, ou seja, a competência dos sujeitos; no caso das paixões, tal fato ocorre de modo diverso do da emoção. Nesta última, a identificação desses dispositivos modais é "compactada", ou suspensa, de certo modo "ilegível"; na paixão, não o é. Foricamente falando, por um lado, a paixão e o sentimento cedem lugar ao ritmo e à duração (o que se nota pelo poder 
isotopante de um discurso); por outro lado, a emoção é uma "fratura", não nos permitindo reconstituir uma isotopia. Daí retomarmos a frase anterior, segundo a qual as paixões não nascem do nada, e cada manifestação de uma mesma emoção, se não pudesse ser inscrita numa paixão permanente, seria apenas um caso singular, um efeito de "fratura" discursiva (FONTANILLE; ZILBERBERG, 2001, p. 301).

Dessa forma, a emoção, que é incoativa, pode ganhar corpo e atingir a graduação de "paixão", que tem o caráter durativo. No texto da "Apresentação", de Luiz Gê, a emoção ganha corpo e chega à obstinação, ocasionada pela fratura do "não poder ser". A fratura na obstinação é caracterizada por esse antissujeito no percurso narrativo, que configura as impossibilidades do nosso enunciador. Já diante do "saber" da primeira impossibilidade de publicação de sua obra, uma fratura que provoca um impacto, nosso enunciador obstina-se na persecução de seu intento.

Fontanille e Zilberberg (2001, p. 301-302), no que concerne ao valor, alertam que a paixão não está fixada ao conteúdo semântico do objeto, mas às determinações tensivas impostas ao valor desses objetos. Os autores mencionam também dois tipos de valores: os valores de absoluto e os valores de universo. As paixões que decorrem dos valores de absoluto são as paixões de absoluto. Por exemplo: o ciúme, a avareza e a obstinação. As que decorrem dos valores de universo são as chamadas paixões de universo, como o amor ao próximo. A avareza, por exemplo, escolhe os valores de absoluto, uma vez que visa à concentração e, recusando a troca, nega os valores de universo. Da mesma forma, a obstinação concentra intensamente a afetividade em um único objeto, negando também valores universais.

Visto que a semiótica tensiva é fundamental para nossa pesquisa, faremos a seguir um breve resgate teórico da tensividade no estudo das paixões.

\subsection{Tensividade e paixões}

A tensividade, característica inseparável de todo texto (verbal e não verbal), parecia

poder ser dominada, inicialmente, pela projeção das estruturas do descontínuo. Esse fato apenas postergaria a construção de uma gramática aspectual que abrangesse, ao mesmo tempo, as "ondulações temporais" e as "sinuosidades espaciais". Todavia, 
a urgência de completar a teoria das modalidades, equilibrando as modalidades do ser e uma interrogação insistente sobre a natureza dos estados, dinâmicos e inquietos, obrigava a enfrentar diretamente a problemática das paixões (GREIMAS; FONTANILLE, 1993, p. 17).

Dessa forma, as modalidades traduzem o "ser" do sujeito narrativo; por meio delas, podemos compreender como se dá a paixão: “uma paixão-efeito de sentido será sempre analisável como uma sequência de papéis modais que realizam progressivamente um certo dispositivo, numa busca da coerência e da identidade do ser do sujeito" (FONTANILLE; ZILBERBERG, 2001, p. 240).

Os autores de Semiótica das paixões (GREIMAS; FONTANILLE, 1993, p. 61) mostram como uma teoria das paixões pode ser vista com base em uma concepção das modalidades articuladas sobre a tensividade e a aspectualidade.

As paixões, na semiótica, tiveram como berço a resolução de heterogeneidades inerentes à semiótica narrativa. Os enunciados de junção, suas transformações, as modalidades de competência projetavam excedentes que não encontravam explicações.

O regime da paixão é baseado nas modulações contínuas da intensidade semântica e na sua relação com a quantidade actancial ou extensão do espaço e do tempo. A paixão transforma tanto como a ação, porém o que a dirige são as modulações tensivas: intensidade e extensidade. Dessa forma, "a paixão obedeceria principalmente aos esquemas tensivos, enquanto a ação obedece aos esquemas narrativos canônicos" (FONTANILLE, 2007, p. 204).

O que se nota no desenvolvimento da semiótica é que ela atualmente se dedica à tensividade, não ficando restrita apenas ao percurso gerativo do sentido. Enquanto as paixões sintetizam, organizam e solidarizam as tensões da presença ${ }^{6}$; a ação sintetizaria os programas de junção (FONTANILLE, 2007, p. 204). Em poucas palavras, passamos da sintaxe narrativa à sintaxe tensiva. Metodologicamente, outra mudança ocorreu. Nos anos 80, a análise das paixões caracterizava-se pela análise do lexema ou dos papéis passionais: a cólera, a nostalgia, a indiferença, o ressentimento, a obstinação. Contudo, nos anos 90, a análise das paixões consagrou-se cada vez mais ao estudo da dimensão passional do discurso e sobretudo às manifestações passionais não verbais, ou não verbalizadas, como a do "vivenciado" realizada por A. Hénault (FONTANILLE; ZILBERBERG, 2001, p. 297).

\footnotetext{
${ }^{6}$ Cf. também capítulo 5, Presença, em Tensão e significação (2001, p. 123-151).
} 
Passemos agora a considerar a paixão da obstinação na constituição de nosso enunciador obstinado.

\subsection{Um enunciador obstinado}

No texto da "Apresentação" de Território de bravos, deparamos com o "saber" que o enunciador possui em relação às dificuldades que ele sofrerá em seu percurso até a conjunção com seu objeto de desejo (publicar Território de bravos, livro composto de sete histórias em quadrinhos). Em 1975, Luiz Gê morava em Londres, quando Ihe surgiu pela primeira vez a ideia de publicar esse livro (data da publicação: 1993). Trata-se, como veremos, de um sujeito obstinado.

Em Semiótica das paixões, à página 67, Greimas e Fontanille salientam que “o próprio sujeito apaixonado deve também saber que seu objeto escapa-Ihe, senão ele deixa de ser obstinado, para tornar-se 'inconsciente' ou 'inconsequente'".

A investigação lexical, como se fazia nos anos 80 , pode contribuir para 0 aprimoramento de nosso estudo sobre a obstinação. A descrição dos lexemas constitui de forma condensada modelos de previsibilidade para as análises discursivas, proporcionandonos o estudo lexemático uma cifra tensiva, uma direção, um sentido, portanto (GREIMAS, 1983, p. 225).

Pela definição do Dicionário Houaiss (2001), obstinação é:

[...] 1 apego forte e excessivo às próprias ideias, resoluções e empreendimentos; pertinácia, persistência, tenacidade [...] ETIM lat. [...] constância, perseverança, firmeza.

No Dicionário Le Robert Micro (2006), a obstinação é característica daquele que persiste em uma ideia, em uma decisão, sem querer mudá-la. Embora a definição cite paixões, como pertinácia, persistência, tenacidade, teimosia, entre outras, não é nosso objetivo neste trabalho examinar todo o leque dessas paixões, nem no que elas se afastam nem no que elas se aproximam, seja de forma modal, seja aspectual, seja tensiva.

O termo teimosia poderia ser questionado como sinônimo de obstinação, o que poderia causar um equívoco. Teimosia, segundo Houaiss (2001), é a obstinação excessiva; tensivamente, configuraria o "grau mais intenso" da obstinação, podendo causar na análise discursiva um efeito de sentido pejorativo. O resultado da obstinação de nosso enunciador é eufórico: querer ser aquele que publica sua obra. Não podemos desprezar que toda 
obstinação tem como resultado o efeito de sentido de teimosia, mas, como dissemos, não usaremos esse termo aqui para não dar valor disfórico à paixão em estudo.

Considerando dois extremos, temos de um lado a obstinação e de outro, podemos sugerir a presença da paixão da inconstância. Segundo o Dicionário Houaiss (2001), a inconstância caracteriza-se pela falta de perseverança, de firmeza, de obstinação [...] falta de continuidade, de manutenção; mutabilidade. Nesse caso, o sujeito da paixão tem muitos objetos em vista, mas fraca intensidade do querer, diferentemente, portanto, de nosso enunciador obstinado.

Para a semiótica, o sujeito obstinado (GREIMAS; FONTANILLE, 1993, p. 63) é aquele dotado das seguintes modalidades": (a) "um saber não ser (o sujeito sabe que está disjunto de seu objeto)"; (b) um "poder não ser ou um não poder ser (o sucesso da empresa está comprometido)"; (c) "um querer ser (o sujeito insiste de todo jeito em ser conjunto e tudo fará para isso".

Greimas e Fontanille (1993, p. 67-68) afirmam ainda que, se comparada a obstinação com o desespero, as diferenças são mínimas: "a única diferença notável reside na organização sintática do dispositivo".

O desesperado é modalizado segundo o dever ser e o querer ser, mas ele não pode ser e sabe não ser (sabe que não é). Tanto na obstinação quanto no desespero, a modalidade regente é o querer ser. O querer ser de ambos pode resultar, de um lado, em revolta e depressão; de outro, em fazer insistente; daí desembocaria na paixão da teimosia, que é o excesso de obstinação. Essas diferenças mínimas encontram-se no dispositivo modal.

Dessa forma, o querer do obstinado tornou-se, devido à impossibilidade, um querer "resistente", enquanto o querer do desesperado não pode ser mudado em nada pelo "saber" dessa impossibilidade, ou seja, a característica modal é de tipo conflitual (querer ser ao lado de saber não ser e não poder ser). Assim, coabitam tais modalidades sem modificarse reciprocamente, resultando na ruptura interna do sujeito; noutros termos, a coesão modal de tal sujeito em desespero é ameaçada até quebrar-se. O fracasso e a frustração

\footnotetext{
${ }^{7}$ Para Barros (1989-1990, p. 60), a descrição das paixões se faz em termos de sintaxe modal, ou seja, de relações modais e de suas combinações sintagmáticas, que produzem efeitos de sentido "afetivos" ou "passionais".
} 
são resultados desse conflito modal. Para esse sujeito, o conflito é irresolúvel e aniquilador do ser.

Há outras paixões no texto da "Apresentação" sob análise, mas vamos concentrarnos na obstinação por ser esse o estado de alma que é mais relevante para nossa pesquisa.

No caso da obstinação, a coesão modal do sujeito é confirmada; o conflito se resolve para o obstinado com a vitória do sujeito volitivo: apesar desse conflito, para ele, o conhecimento do obstáculo (do antissujeito) suscita o querer. Desse modo, essas duas modalizações pressupostas ("não poder ser" e "saber não ser") nutrem a modalização pressuponente (querer ser).

Esse efeito de sentido de "resistência diante de obstáculos" no obstinado é de natureza aspectual, configurando um "estilo semiótico" que favorece o desdobramento do devir; esse não é o caso do desesperado, que desiste do objeto ao primeiro obstáculo que Ihe surge pelo caminho (cf. GREIMAS; FONTANILLE, 1993, p. 67-69).

A obstinação, regulada pela sintaxe modal do "fazer" mais a sintaxe passional do "ser", manifesta-se sob uma forma aspectual durativa do "continuar", do "resistir", graças ao devir que permanece aberto. Esse devir não seria uma característica do fazer artístico? Em outras partes desta dissertação, verificaremos que a obstinação é também uma característica do fazer artístico, que quer continuar, quer resistir em um espaço árido. E nosso enunciador tem justamente tais características. Daí uma das razões de chamarmos o produto de seu fazer artístico de HQ artística (capítulo 2)

Como vimos, obstinação contém o sentido direcional e continuativo. Para Greimas e Fontanille (1993, p. 63), com base em dicionários de língua, é "disposição para prosseguir num caminho previamente traçado, sem se deixar desencorajar pelos obstáculos", o que confirma o sentido de direção e continução. Dessa forma, a obstinação revela a cifra tensiva da continuidade. No que se refere ao tempo, ela é altamente extensa, pois quanto mais os obstáculos, mais aumenta o querer, a intensidade da obstinação. Nela, por exemplo, a impulsão do "querer ser" prevalece sobre a inibição do "não poder ser" e do "saber não ser" [ainda]. O obstinado particulariza-se por manter o sujeito em estado de continuar a fazer (fazer apesar de $X$, apesar da presença do antissujeito).

$\mathrm{Na}$ "Apresentação" em estudo, verificamos que o sujeito da enunciação quer ser aquele que faz: quer ser aquele que publica sua obra. $\mathrm{O}$ obstinado "querer ser aquele que 
faz" não equivale a "querer fazer" (GREIMAS; FONTANILLE, 1993, p. 63-64). Em vários momentos do enunciado, o enunciador que assina como "Luiz Gê" mostra a coragem e a persistência durante uma trajetória de 18 anos para a publicação do livro que ele nos apresenta.

A incoação e a duratividade são depreendidas, no nível discursivo, dos verbos "começa há (1975), era, percebi" (incoativo) em oposição ao tempo da enunciação pressuposta que é o "ano de 1993" (durativo = 18 anos), ano da assinatura da "Apresentação"; pelas locuções adverbiais em Londres e no Brasil, detectamos a duratividade do "querer ser" fortemente marcado desse sujeito.

No nível modal-narrativo, o objeto desejável do obstinado é, dessa forma, identificado (publicar Território de bravos), e o sujeito projeta, em seguida, os meios e os programas com a finalidade de conjunção com esse objeto. No entanto, ele encontra antissujeitos, dificuldades, que levam à duratividade do seu "querer ser". De toda forma, no entanto, o sujeito insiste em ser conjunto com seu objeto e faz tudo para isso.

No caso de nosso estudo, o sujeito da enunciação (no nível modal-narrativo, sujeito do ser obstinado) tentou em variadas oportunidades (revista Circo, jornal Extra, Jornal da República etc.) querer ser conjunto com a "publicação das HQs de Território de bravos" e, alimentado pelos obstáculos, escreveu as histórias em quadrinhos separadamente, cada uma publicada em um tipo de veículo (jornal, revista etc.). O que se nota é a disposição, o estado de continuar a fazer, de "querer ser" aquele que publica, independentemente de o momento ser mais para a charge política. Dezoito anos depois do nascimento da ideia em Londres, ele consegue publicar em São Paulo o livro, em 1993 (data da assinatura do enunciador projetado no enunciado).

Verifiquemos como essa paixão se dá nos enunciados da "Apresentação" da obra. Logo no primeiro parágrafo, encontramos elementos linguísticos do nível discursivo que nos indicam a "persistência em uma ideia":

A história destas histórias e deste livro começa há um bom número de anos (1975). [...] (Londres) [...] Percebi, então, que aquela concepção teria muito mais sentido no Brasil, pois em comparação com a Europa, aqui havia todo um universo praticamente intocado, para ser registrado e explorado.

[...] À medida em que terminava a escola e me afastava da arquitetura, mais a realidade urbana brasileira da qual São Paulo era um dos paradigmas me parecia um filão inesgotável. Os tempos eram cada vez mais para a charge política, modalidade que retrata basicamente a "vida na corte" e se centra em alguns personagens exponenciais, através da caricatura. Isso deixava os outros $99,9 \%$ da 
realidade em aberto. Só que havia pouco espaço para isso. Pobreza editorial. Pobreza cultural. Pobreza... (LUIZ GÊ, 1993, p. 10). [destaques nossos]

A partir do enunciado "Só que havia pouco espaço para isso. Pobreza editorial. Pobreza cultural. Pobreza...", manifestam-se os obstáculos ao enunciador: a presença de antissujeitos que lhe impedem ou delongam a publicação de Território de bravos.

No texto, há outras paixões além da obstinação: inconformismo, lamentação, emulação. Aristóteles (2003, p. 71), em Retórica das paixões, afirma que "são inclinados à emulação os que se julgam dignos de bens que não possuem (sendo-lhes possível adquirilos)" e que a competição seria, nesse caso, positiva, pois "é um sentimento digno e próprio de pessoas dignas" [destaque nosso].

Os bens, para Aristóteles, são a coragem, a autoridade, a sabedoria. A emulação seria uma paixão da concorrência: ou o sujeito se iguala ou supera o outro, ou seja, ou nosso enunciador se iguala ao chargista ou o supera. O sentido dessa competição é sadio, sem sentimentos baixos ou de violência (Dicionário Houaiss, 2001, verbete emulação). Nosso enunciador se caracterizaria, portanto, também pela paixão da emulação, ou seja, a “competição aristotélica" entre o produtor de HQs artísticas e o chargista político.

Nenhum revés "parecia" constituir-se obstáculo intransponível (de 1975 até 1993) que impedissem a conjunção final com o objeto (a publicação de Território de bravos). 0 sujeito tinha o "saber" de que a jornada seria difícil, bem como a coragem da competição do emulador mais a do obstinado, que o levariam à consecução de seu querer ser. Embora soubesse que a conjunção visada poderia não se realizar, ou mesmo que "poderia não ser", ele "quer ser"; apesar dos inúmeros antissujeitos (veremos adiante nos exemplos retirados dos enunciados verbais da "Apresentação"), ele "quer ser aquele que publica" sua obra, e esse "querer ser" é alimentado pelo próprio antissujeito, ou seja, é a presença do antissujeito que alimenta o obstinado:

A obstinação caracteriza o sujeito que não somente quer fazer, mas quer ser aquele que faz, embora saiba que a conjunção a que ele visa pode não se realizar, ou mesmo pode não ser: ele quer apesar dos obstáculos, e a própria resistência alimenta sua vontade (BERTRAND, 2003, p. 371). [destaques nossos]

Para Bertrand (2003, p. 368), a modalização do ser descreve o modo de existência do objeto de valor em relação ao sujeito. Dessa forma, o objeto passa a ser "desejável ou odiável", "indispensável ou realizável", e o estado de alma (a paixão) fica na dependência da 
modalidade investida no objeto. A modalização do enunciador é resultado da sua relação eufórica ou disfórica com o objeto. No nosso caso, o sujeito tem o objeto como desejável e indispensável, eufórico, e isso produz nele um estado de alma (obstinação).

Há uma escolha da transitividade ininterrupta (querer ser da obstinação), que dá origem a um processo circular no plano narrativo e que nos mostra um compromisso do enunciador com a expansão que não pode ser feita aos pulos, aos saltos, mas sim de modo contínuo.

A obstinação não se coaduna com a aceleração, visto que a chegada antecipada do objeto descaracterizaria essa paixão se o enunciador tivesse conseguido a publicação de Território de bravos ainda nos idos de 1975. O fato de o objeto escapar ao sujeito que configura a obstinação. Os obstáculos e as rupturas desaceleram a junção com o objeto, prolongando tal paixão de nosso sujeito (GREIMAS; FONTANILLE, 1993, p. 63)

Tensivamente, esse sujeito adota os valores contínuos em que o investimento eufórico é definido pela gradação e tem como consequência também a desaceleração do processo. Daí o obstinado ser aquele que quer ser continuamente. As escolhas do nível tensivo aparecem no nível discursivo na forma de elementos linguísticos que nos revelam o querer ser contínuo e desacelerado, pois o percurso é 1975 até 1993, data da assinatura da "Apresentação":

\footnotetext{
A história destas histórias e deste livro começa há um bom número de anos (1975). [...] Mas os que aqui ficam me parecem bons caminhos ou sementes. Luiz Gê, 1993 (p. 10-11) (destaques nossos).
}

Esse estado de continuar a fazer do obstinado coloca "o sujeito em estado de 'fazer apesar de $X^{\prime}$, mesmo quando $X$ é uma previsão que recai sobre a impossibilidade do fazer" (GREIMAS; FONTANILLE, 1993, p. 63):

[...] Tais são alguns dos retratos do território de bravos. Devido à selvageria do ambiente [antissujeito], não foi possível fazer mais, infelizmente [quer ser aquele que faz continuamente]. Mas os que aqui ficam me parecem bons caminhos ou sementes. Já vivi o suficiente para ver que alguns deles até já frutificaram nos intervalos entre as secas crônicas [antissujeitos]. Luiz Gê, 1993 (p. 10-11) [acréscimos e destaques nossos]

Esse sujeito adota os valores de continuidade, apesar das paradas: "aquele que quer ser aquele que faz continuamente" (GREIMAS; FONTANILLE, 1993, p. 63). No nível discursivo, há um enunciador que deixa presente sua expansão, seu continuar a fazer apesar dos 
antissujeitos (paradas): (1) “alguns deles (são algumas HQs que ele publicou aqui e ali) até já frutificaram nos intervalos entre as secas crônicas"; (2) "devido à 'selvageria do ambiente', não foi possível fazer mais, infelizmente". Em (1), temos o "fazer apesar de X" (secas crônicas); em (2), o sujeito em estado de continuar a fazer, apesar da "selvageria do ambiente"; mesmo nas "secas crônicas", "frutificaram" (fazer apesar de X).

Ainda a título de ilustração de nossos argumentos, grosso modo, no filme Gandhi, temos outro caso de sujeito obstinado. Em uma cena, ele apanha e quanto mais apanha, mais quer continuar seu percurso; temos, portanto, a presença do antissujeito como alimentador do estado de querer ser aquele que faz.

Embora o conjunto da definição dessa paixão seja guiado por um projeto de fazer, o dispositivo modal característico da "obstinação" constitui-se por modalizações do ser. Com efeito, um simples querer fazer não bastaria para explicar o prosseguimento indefectível do fazer. Essa paixão acumula os paradoxos: (1) de um querer fazer que sobrevive a um não poder fazer que the serve de base e (2) de um fazer que não cessa, pois que tudo se decide na organização modal do ser. Por isso, o obstinado querer ser aquele que faz não é o mesmo que querer fazer (GREIMAS; FONTANILLE, 1993, p. 64).

É, pois, o "excedente modal" (apesar de $X=$ apesar do antissujeito) regente que garante a perseguição da performance, não obstante o obstáculo, e caracteriza especificamente a obstinação; e é também a presença desse excedente que obriga a formular o dispositivo passional em termos de "organização modal do ser", e não em termos de "competência em vista do fazer" (GREIMAS; FONTANILLE, 1993, p. 63).

$\mathrm{Na}$ "Apresentação" sob estudo, quando o enunciador menciona "devido à selvageria do ambiente, não foi possível fazer mais, infelizmente", o "excedente modal" (não poder ser devido à "selvageria do ambiente") fê-lo organizar-se na perseguição da performance:

SER aquele que publica o livro Território de bravos: organização modal em vista do SER e não do FAZER

O sujeito em questão, neste estudo, é aquele que conjuga o andamento que vai de mais acelerado - quando o objeto começa a se aproximar, mas advêm os obstáculos, os impactos - até menos acelerado - quando o sujeito, diante do impacto (não poder ser), modaliza-se em "querer ser aquele que faz apesar de X". Se ele não desacelerasse, não 
continuaria a ser obstinado, largaria mão do objeto. A desaceleração prolonga, como dissemos, a obstinação no tempo.

A seguir, analisaremos alguns excertos da "Apresentação" de Território de bravos, em que fica evidenciada a presença constante do antissujeito como mola propulsora de nosso enunciador obstinado (Luiz Gê como ator do enunciado):

- "Os tempos eram cada vez mais para a charge política. [...] Isso deixava os 99,99\% da realidade em aberto. Só que havia pouco espaço para isso. Pobreza editorial. Pobreza cultural. Pobreza..." - Antissujeito em negrito.

- $\quad$ "As poucas vezes que tive a oportunidade de trabalhar [...] foram possíveis graças a algum tipo de suporte externo, no caso de encomendas específicas. Ou então quando optava por um procedimento mais humorístico, mas descompromissado. Mas a maioria dessas ideias continua a viver a sua insônia na gaveta." - O efeito da obstinação é evidente no que se refere à continuidade do "querer ser aquele que faz": a maioria de suas ideias continua na gaveta.

- $\quad$ "A primeira [HQ] que foi feita com todas as características imaginadas ainda não tinha o formato que eu pensara." - A presença do "ainda não", no enunciado, evidencia o obstáculo, o excedente modal que caracteriza o sujeito obstinado.

- $\quad$ "Seguem-se alguns anos como chargista político e a quase inexistência de veículos para publicar quadrinhos." - Falta de meio para publicar quadrinhos, enquanto a charge política não encontrava tantos antissujeitos pelo caminho: muitos veículos aceitavam publicar charges.

- $\quad$ "A história não saiu, mas eu não liguei, porque um ano depois ela continuava atual. Dois anos depois também. Veio o terceiro ano e no quarto eu a publiquei na Circo como história editorial do n. 1. Ela continuava atual. Hoje, dez anos depois também..." - Evidencia-se neste trecho o estado continuativo de "ser aquele que faz (publica), apesar de $X$ " que comentamos no que se refere à paixão da obstinação. Essa paixão é extensa no tempo, durativa; além disso, quanto mais empecilho no caminho, mais tônica ela é. 
- $\quad$ "Em 1984, ao ligar a televisão, me surpreendi com um jornalista à la Orson Welles alertando a população sobre uma estranha invasão de tubarões que voavam e atacavam as pessoas em pleno centro da cidade! Tubarões voadores, aquilo não existia??? Mas... seria... seria minha história??? Bom, na realidade não era a minha história, mas o show Tubarões Voadores, de lançamento do disco Tubarões Voadores (de Arrigo Barnabé), cuja música tema Tubarões Voadores era a musicalização da minha história Tubarões Voadores (feita no ano anterior)... Bem, já era alguma coisa...". - Ainda não era a HQ, o "apesar de" continua no percurso do sujeito.

- $\quad$ "[...] desenhos de tubarões passaram a ser pichados por todo lado, fazendo com que eles, de uma certa forma, realmente invadissem a cidade... pela segunda vez. Essa parafernália toda acabou por chamar atenção, outra vez, para os quadrinhos como linguagem num tempo em que eles praticamente não existiam...". - Quando o enunciador menciona que quadrinhos praticamente não existiam, é nítida a noção de "não poder ser aquele que publica". Aqui, embora tenha visto sua história em quadrinhos musicada por Arrigo Barnabé, o enunciador obstinado ainda não se dá por satisfeito, pois quer ser aquele que publica "Tubarões voadores" em Território de bravos. Ela virou a segunda HQ do livro apenas em 1993.

- "No período que se seguiu à Extra, fui editor de arte da revista Status, publiquei meu primeiro livro só de $H Q$ [mas ainda não era Território de bravos], um dos primeiros da Editora Circo, e voltei ao jornal diário [...], com uma tira e uma coluna semanal para o Estadão. Alguma coisa desta tira já foi publicada em livro pela Melhoramentos [...]: 'Kid Senil e seus darkinhos'. Eles eram, na verdade, personagens secundários da tira do Presidente Reis, que por sua vez tem a sua própria história bem atribulada, por sinal, por causa de uma longa 'introdução', e parou quando estava praticamente começando. São tiras desta fase inicial/final que 'costuram' o livro." - Presidente Reis, curiosamente, é o ator que "amarrará" as histórias do livro Território de bravos. (Precedem todas as HQs do livro sob estudo tiras do Presidente Reis em que o ator aparece ora mostrando o cotidiano da cidade, ora expondo um 
juízo valorativo, como já dissemos.) Esse ator é protagonista dos enunciados dessas tiras. Sua figura (desenho) aparece também ao lado da assinatura de Luiz Gê na "Apresentação". No nível discursivo, Presidente Reis figurativiza um obstinado que teve "a sua própria história bem atribulada [...] parou quando estava praticamente começando", mas ele não "desiste" e "retorna" em Território de bravos. O conteúdo da expressão de Presidente Reis é o de um homem com "os pés em movimento". De fato, o "fazer" dele é "querer ser" aquele que caminha pelo espaço das sete HQs, anunciando-as, costurando-as, enfim dando-lhes unidade. Presidente Reis é também interrompido pelo antissujeito, a cada final das tiras. Todavia, o que move o seu percurso são os obstáculos. Quanto mais antissujeitos encontra pelo seu caminho, mais ele continua a explorar o espaço em que se dão as histórias. O movimento é a escolha tensiva principal do obstinado, pois o obstáculo e a ruptura é que fazem com que esse apaixonado continue a "querer ser aquele que faz". Esse movimento tensivo é de expansão e é desacelerado pelas paradas da continuação causadas pelas rupturas (obstáculos). Se o obstinado obtivesse seu objeto antecipadamente, ou estivesse conjunto com ele antes da hora, a paixão da obstinação se descaracterizaria, como já o dissemos. A dupla face do obstinado - (1) querer ser (modalidade de estado, passional) (2) aquele que faz (modalidade do fazer) -, "apesar de não poder ser", é figurativizada também pelos louros na cabeça de Reis, os quais perfazem a isotopia da vitória; é a insistência de um "querer ser". Geralmente, a coroa é adquirida após a conquista, mas, no caso do obstinado, mais importante do que a conquista - querer fazer -, é o QUERER SER - vitorioso - sobretudo.

- "Me foi possível, pela primeira vez na vida, ter constância na prática da HQ." - As dificuldades para a publicação de HQ eram muitas, o que propicia o desenrolar e a manutenção da obstinação em nosso enunciador.

- "Registro explícito do pouco estudado folclore urbano é Futboil, de 1986. Essa história diz muito a respeito do potencial da linguagem dos quadrinhos, no que concerne a registros específicos da realidade. [...] uma dessas experiências que existem para ser registradas apenas por linguagens como a 
dos quadrinhos... e neste caso, como a do cinema (eu acho que esta história daria um ótimo curta). Ainda assim, certas tomadas, cenas aéreas e travellings, como as de cima, mostrando o balão caindo e as crianças correndo atrás dele lá embaixo na rua, são muito mais fáceis e baratas de serem feitas nos quadrinhos. Essa liberdade propiciada pelo desenho é uma das marcas registradas da linguagem. [...] $E$ se não forem registrados visualmente, nem precisa registrar, porque vão pras cucuia mesmo... Os quadrinhos são relativamente fáceis de produzir. Caso houvesse um mercado rico em publicações, temas como esse com certeza varreriam muitas áreas diferentes do cotidiano e acabariam por construir um universo para a memória." - O saber sobre o possível fracasso (por falta de espaço para publicação) é necessário para aparição do querer ser. Esse sujeito apaixonado sabe que seu objeto Ihe escapa; daí que um observador exterior presente poderia constatar inúteis os esforços do obstinado nesse querer indefectível (cf. GREIMAS; FONTANILLE, 1993, p. 67). Esses esforços do enunciador são marcados pela crença de que seu fazer é relevante, muito embora constante seja o antissujeito: "caso houvesse um mercado rico para publicações", "potencial da linguagem dos quadrinhos", "certas tomadas [...] são mais fáceis e baratas de serem feitas nos quadrinhos". Se há a tentativa por parte do enunciador de convencimento de que seu "querer ser" é justificável, é porque ele tem a consciência de que o obstáculo também é fortemente presente nesse percurso: "Romper com essa avassaladora e praticamente inescapável influência estrangeira e criar um novo olhar [...] passa por vários caminhos" (ter veículos para se expressar, por exemplo).

- Dessa forma, para o obstinado, o conhecimento do obstáculo ("secas crônicas") instiga o "querer": "Os quadrinhos são enriquecedores porque captam a realidade por ângulos que normalmente não seriam registrados por outras linguagens. [...] A alguns pode parecer não importante que o desenho procure reproduzir diretamente a realidade do entorno no qual o artista vive. Mas é." O efeito de sentido de resistência da "selvageria do ambiente", elemento que não pode faltar na obstinação, é de natureza aspectual 
(durativa), configurando um estilo semiótico por excelência que favorece o desdobramento do devir: "Devido à selvageria do ambiente, não foi possível fazer mais, infelizmente. [...] alguns deles até já frutificaram nos intervalos entre as secas crônicas." O enunciador ainda quer ser aquele que faz continuamente: um devir ainda presente.

Se para o enunciador obstinado o antissujeito é fundamental, poderíamos encontrar também nos enunciados das sete HQs de Território de bravos a presença dominante do antissujeito? Para essa avaliação, no capítulo 2 desta dissertação fizemos um levantamento de todos os quadrinhos do livro. No total, são 428 quadrinhos. Em $\mathbf{7 5 , 4 7 \%}$ deles, o antissujeito realizou uma parada no percurso narrativo ou se aproximou do campo de presença do sujeito.

Ora, a maioria das escolhas enunciativas em Território de bravos vale-se de enunciados passionais e nominais. A escolha do enunciador é, em geral, por valores remissivos, que são os valores de parada. O enunciador na "Apresentação", um apaixonado pela obstinação, deixa rastros no enunciado ao escolher tais valores, em que o antissujeito tem lugar de importância no desenvolvimento das sete HQs. Esses rastros deixados pela enunciação conduzem-nos também ao estudo do éthos (ver seção 1.6 deste capítulo).

Não é disfórica, portanto, a participação do antissujeito nas narrativas. Ao contrário, como veremos nesta dissertação, ele é o introdutor das paradas, um tipo de mola propulsora no percurso do sujeito. Os estudos tensivos nos mostram a importância de tais paradas nas narrativas, um movimento que é capaz de dar direção, a chave para o sentido. A seguir, discutiremos sobre a cifra tensiva da obstinação.

\subsection{A cifra tensiva da obstinação}

Em uma nota de rodapé, Greimas e Fontanille (1993, p. 41) reproduzem o esquema tensivo de Zilberberg, que elaborou um quadrado conciliando a tensividade e a categoria modal. Esse modelo seria um quadrado semiótico composto por quatro formas tensivas (modulações do devir).

Os autores de Semiótica das paixões chamam a opção de Zilberberg de "sedutora" e acrescentam não ser compatível com a descrição que eles apresentam em relação ao nível 
profundo. Alegam, também, que, se as formas tensivas são categorizáveis, é porque estariam estabilizadas e, dessa forma, não seriam mais tensivas, sugerindo que o problema poderia estar na questão da formulação.

Todavia, utilizaremos a seguir (figura 1.1) o esquema de Zilberberg, bem como o sugerido por Tatit (2001), pois tal esquema nos pareceu operacional no estudo da paixão da obstinação.

As categorias sugeridas por Zilberberg e por Tatit são providas de tensividade, não são estanques e discretizáveis, mas se relacionam, gerando um continuum: por exemplo, a uma continuação da continuação sobrevém uma parada da continuação que é seguida pela continuação da parada quando sobrevém uma parada da parada, que é sucedida pela continuação da continuação, novamente. O ponto de vista do enunciador sob estudo, segundo o esquema proposto, é de continuidades em meio à dominância de descontinuidades, ou seja, as paradas devidas ao antiprograma dão combustível para o sujeito obstinadamente continuar o seu percurso.

No texto de Luiz Gê sob análise, as rupturas mencionadas são descritas no nível discursivo como "intervalos entre as secas crônicas". Ora, as figuras do discurso corroboram o nível tensivo, afirmando a continuidade e a desaceleração do sujeito obstinado. A continuação da continuação dá lugar ao intervalo, parada da continuação, para, em seguida, advir a continuação da parada, sucedida pela parada da parada para voltar para a continuação da continuação.

O sujeito obstinado se caracterizaria por se nutrir da continuação da parada (o "apesar de X" é, muitas vezes, durativo) para "querer ser" (parada da parada) aquele que faz continuativo (continuação da continuação). "Os apesares de" expostos na "Apresentação" (vamos resgatá-los novamente a seguir por meio de exemplos retirados do nível discursivo) causariam, dessa forma, outras tantas paradas da continuação (intervalos) nesse percurso continuativo do obstinado (estado continuativo do fazer apesar de X) que garantem ao obstinado a extensão e a duratividade em busca da performance. Veja na figura 1.1 a representação esquemática da tensividade na obstinação. 


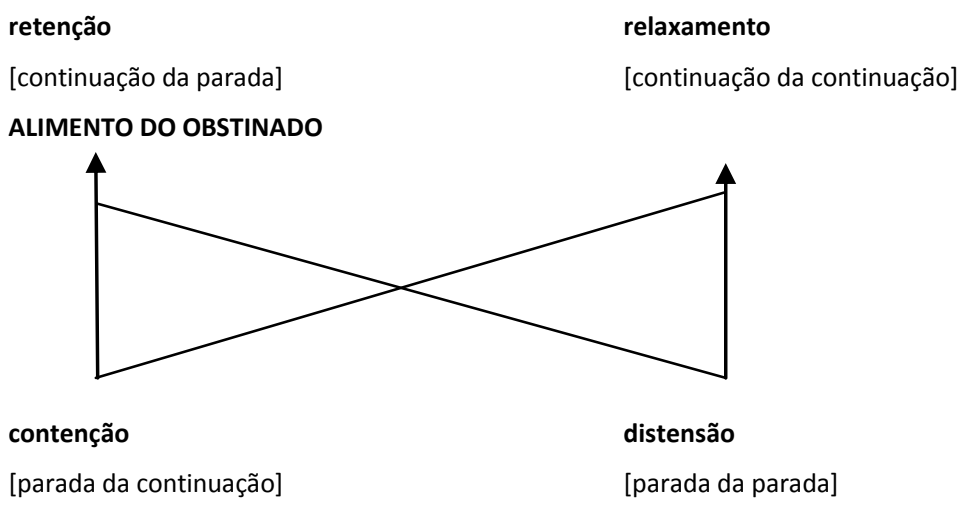

Fonte: Adaptada de Tatit (2001, p. 156).

Figura 1.1 Representação esquemática da tensividade na obstinação.

Os níveis tensivo, modal-narrativo e discursivo convivem juntamente; eles se revelam, no entanto, cada um a seu modo. O mais evidente ao nosso olhar é o nível discursivo. Vamos, então, utilizar os elementos linguísticos desse nível para mostrar como essas grandezas se dão no nível tensivo. Dividiremos, a seguir, colocando lado a lado, nível tensivo, nível modal-narrativo e discursivo.

1975 - “A história [...] deste livro começa há um bom número de anos (1975) [...] (Londres), onde [...] me diverti fazendo uma história em quadrinhos para uma revista underground."

\begin{tabular}{|l|l|l|}
\hline Nível tensivo & Nível modal-narrativo & Nível discursivo \\
\hline Relaxamento & Competência modal & "me diverti [...] \\
(continuação da continuação) & & $\begin{array}{l}\text { fazendo uma história em } \\
\text { quadrinhos" - nesse momento, } \\
\text { ainda não temos a obstinação. }\end{array}$ \\
\hline
\end{tabular}

1975 - "Os tempos eram cada vez mais para charge política [...] havia pouco espaço para isso. Pobreza editorial. Pobreza cultural. Pobreza..." "Foi assim que [...] pintou a ideia do presente livro." "As poucas vezes que tive a oportunidade de trabalhar [...] foram possíveis graças a algum tipo de suporte externo, no caso de encomendas específicas." "Mas a maioria dessas ideias continua a viver a sua insônia na gaveta."

\begin{tabular}{|c|c|c|}
\hline Nível te & Nível modal-narrativo & Nível discursivo \\
\hline $\begin{array}{l}\text { Contenção } \\
\text { (parada da continuação) } \\
\text { Até "pintou a ideia" não havia a } \\
\text { paixão da obstinação; era apenas a } \\
\text { continuação do estado anterior. }\end{array}$ & $\begin{array}{l}\text { (1) Estado passional (obstinação): } \\
\text { querer ser, mesmo sabendo não } \\
\text { poder ser. } \\
\text { (2) O "excedente modal" "obriga" a }\end{array}$ & $\begin{array}{l}\text { (1) "Os tempos eram cada vez mais } \\
\text { para charge [...] pouco espaço para } \\
\text { isso. Pobreza editorial. Pobreza } \\
\text { cultural. Pobreza..." } \\
\text { (2) "As poucas vezes que tive a }\end{array}$ \\
\hline
\end{tabular}




\begin{tabular}{|c|c|c|}
\hline $\begin{array}{l}\text { Todavia, a falta de lugar (1) e (2) } \\
\text { para publicar mantinha as ideias do } \\
\text { enunciador na gaveta: começo da } \\
\text { busca obstinada da conjunção com } \\
\text { o objeto: a publicação de Território } \\
\text { de bravos. Aumento da tonicidade - } \\
\text { intensidade (querer ser aquele que } \\
\text { faz): ideia de ser aquele que publica } \\
\text { (fazer) Território de bravos. }\end{array}$ & $\begin{array}{l}\text { formulação do dispositivo modal } \\
\text { em termos de organização modal } \\
\text { do ser e não em termos de } \\
\text { competência em vista do fazer. Daí } \\
\text { o paradoxo da obstinação: um } \\
\text { querer fazer que sobrevive a não } \\
\text { poder fazer que lhe serve de } \\
\text { reforço. Cabe aqui a suposição de } \\
\text { dois segmentos sintáticos: sintaxe } \\
\text { modal do fazer e sintaxe modal do } \\
\text { ser, passional, autônomos, mas, ao } \\
\text { mesmo tempo, articulados. } \\
\text { (3) Alimento da obstinação: } \\
\text { excedente modal (não poder fazer) } \\
\text { que garante a perseguição da } \\
\text { performance, mesmo com } \\
\text { obstáculos (paradas da } \\
\text { continuação). }\end{array}$ & $\begin{array}{l}\text { "Mas a maioria das ideias } \\
\text { (3) "presença do estado } \\
\text { continua a viver a sua insônia na } \\
\text { gaveta” } \\
\text { continuativo do fazer, querer ser } \\
\text { aquele que faz, embora não possa } \\
\text { fazer). }\end{array}$ \\
\hline
\end{tabular}

1976 - “Ironicamente, a primeira história que fiz [...] foi 'Gino Amleto Meneghetti' [...] (que não está neste álbum)."

\begin{tabular}{|l|l|l|}
\hline Nível tensivo & Nível modal-narrativo & Nível discursivo \\
\hline Retenção & Estado passional (obstinação): & "que não está neste álbum". \\
(continuação da parada) & continua a querer ser aquele que & Continua a querer ser (cf. GREIMAS; \\
A intensidade afetiva, o desejo & faz. & FONTANILLE, 1993, p. 63), apesar de \\
máximo (tônico), é "querer ser \\
$\begin{array}{l}\text { aquele que faz": publicar Território } \\
\text { de bravos. }\end{array}$
\end{tabular}

1979 - Era uma tira ainda e não a publicação do livro Território de bravos: "Foi uma espécie de tira dupla diária para o Jornal da República, em 1979."

\begin{tabular}{|l|l|l|}
\hline Nível tensivo & Nível modal-narrativo & Nível discursivo \\
\hline Retenção & Estado passional (obstinação): & "foi uma espécie de tira". Alimento \\
(continuação da parada) & continua a querer ser. & $\begin{array}{l}\text { ser, apesar de ainda não poder ser. } \\
\text { A realização de Território de bravos } \\
\text { só ocorreu em } 1993 .\end{array}$ \\
\hline
\end{tabular}


1979 até 1983 - "Seguem-se alguns anos como chargista político e a quase inexistência de veículos para publicar quadrinhos."

Ainda, o não poder ser, excedente modal, chamado assim pelos autores de Semiótica das paixões, continua a alimentar a paixão da obstinação: "inexistência de veículos para publicar quadrinhos" (não poder ser), que atingirá sua performance, como dissemos, em 1993, com a publicação de Território de bravos. Temos, então, a continuação da parada.

1984 - "A primeira história deste álbum, a Editorial, ficou como registro. Ela foi feita em 1984 para o jornal Extra, que durou apenas um número. Aliás como indicava seu nome. A história não saiu, mas eu não liguei, porque um ano depois ela continuava atual. Dois anos depois também. Veio o terceiro ano e no quarto eu a publiquei na Circo como história editorial do n. 1 [...]."

\begin{tabular}{|c|c|c|}
\hline Nível tensivo & Nível modal-narrativo & Nível discursivo \\
\hline $\begin{array}{l}\text { Retenção } \\
\text { (continuação da parada) } \\
\text { Poderíamos dizer que houve uma } \\
\text { "parada da parada" pela publicação } \\
\text { no Extra, mas digamos que não, } \\
\text { pois a continuação da parada } \\
\text { permaneceu, pois a intensidade } \\
\text { afetiva estava depositada na } \\
\text { publicação de Território de bravos. } \\
\text { Caracteriza-se, assim, o aspecto } \\
\text { continuativo do obstinado, pois, se } \\
\text { houvesse a quebra, a parada da } \\
\text { parada, a obstinação não seria mais } \\
\text { alimentada pelo não poder ser } \\
\text { aquele que faz. }\end{array}$ & $\begin{array}{l}\text { Estado passional (obstinação): } \\
\text { continua a querer ser. }\end{array}$ & $\begin{array}{l}\text { "a história não saiu, mas eu não } \\
\text { liguei..." Ao dizer "não liguei", } \\
\text { podemos pensar o contrário; o } \\
\text { obstinado é aquele que ganha } \\
\text { energia com o não poder ser, pois } \\
\text { "quer ser aquele que faz", insistindo } \\
\text { de toda forma em ser conjunto e } \\
\text { tudo fará para isso. Alimenta-se a } \\
\text { obstinação: continuar a querer ser, } \\
\text { apesar de ainda não poder ser. }\end{array}$ \\
\hline
\end{tabular}

1984 - "Ao ligar a televisão, me surpreendi com um jornalista [...] alertando a população sobre uma estranha invasão de tubarões que voavam e atacavam as pessoas em pleno centro da cidade! Tubarões voadores, aquilo não existia??? Mas... seria... seria minha história??? Bom, na realidade não era minha história, mas o show Tubarões Voadores [...] cuja música [...] era a musicalização da minha história Tubarões Voadores. [...] Bem, já era 
alguma coisa..." "Essa parafernália toda acabou por chamar atenção [...] para os quadrinhos [...] eles praticamente não existiam."

\begin{tabular}{|c|c|c|}
\hline Nível tensivo & Nível modal-narrativo & Nível discursivo \\
\hline $\begin{array}{l}\text { Retenção } \\
\text { (continuação da parada) } \\
\text { A concessão é o que rege o afeto da } \\
\text { obstinação: continuar a querer ser } \\
\text { ainda que não possa ser. } \\
\text { Continuar... apesar de... }\end{array}$ & $\begin{array}{l}\text { Estado passional (obstinação): } \\
\text { continua a querer ser. }\end{array}$ & $\begin{array}{l}\text { "na realidade não era minha } \\
\text { história, mas o show [...] já era } \\
\text { alguma coisa"; "os quadrinhos... } \\
\text { eles praticamente não existiam". } \\
\text { Alimento para o obstinado: } \\
\text { continuar a querer ser, apesar de } \\
\text { ainda não poder ser. }\end{array}$ \\
\hline
\end{tabular}

1984 - “Ainda para a Extra [...] elaborei uma ideia..."

Período que se seguiu à Extra - "[...] Publiquei meu primeiro livro só de HQ." "Voltei ao jornal diário." "Alguma coisa desta tira já foi publicada em livro pela Melhoramentos." "Eles eram [...] personagens secundários da tira do Presidente Reis, que [...] tem a sua própria história bem atribulada [...] por causa de uma longa 'introdução', e parou quando estava praticamente começando."

A dupla face do obstinado - (1) querer ser (modalidade de estado, passional) (2) aquele que faz (modalidade do fazer) -, "apesar de não poder ser".

[1993] - “Me foi possível pela primeira vez, na vida, ter constância na prática da HQ" até a chegada das "histórias do presente álbum" em que ele, no presente da enunciação pressuposta, assina e entrega ao enunciatário pressuposto a publicação do livro Território de bravos.

O ritmo da obstinação construiu-se, como vimos, pelo ritmo do movimento que, se fosse acelerado demais, anteciparia a chegada da conjunção com o objeto, descaracterizando o ser afetivo do obstinado.

A obstinação revela a cifra tensiva da continuidade da parada devida à força e a importância do antissujeito no percurso do sujeito. E é essa força do antiprograma que nutre tal paixão.

Como já dissemos, para o enunciador obstinado o antissujeito é fundamental. A contagem de todos os quadrinhos do livro feito no capítulo 2 desta dissertação revela que, 
em $\mathbf{7 5 , 4 7 \%}$ das HQs, o antissujeito realizou uma parada na narrativa, ou se aproximou do campo de presença do sujeito.

Por meio desse levantamento realizado nos enunciados, notamos que a escolha do enunciador é pela dominância remissiva. São esses rastros deixados pelo enunciador no enunciado quando ele opta por valores de parada. Daí o antissujeito ter lugar de importância no desenvolvimento das sete HQs. Esses rastros conduzem-nos ao estudo do éthos.

\subsection{O éthos do enunciador}

Benveniste (2005, v. I, p. 286) apresenta a enunciação como a instância do ego, hic et nunc. O eu é instaurado no ato de enunciar: eu é quem diz eu. A pessoa a quem o eu se dirige é designado tu: "Eu designa aquele que fala e implica ao mesmo tempo um enunciado sobre o 'eu' [...]. Na segunda pessoa, 'tu' é necessariamente designado por eu e não pode ser pensado fora de uma situação proposta a partir do 'eu'; [...]" (BENVENISTE, 2005, v. I, p. 250).

Dessa forma, o eu e o $t u$, actantes da enunciação e compositores da ação enunciativa, constituem o sujeito da enunciação, porque o "eu" produz o enunciado e o "tu" é levado em consideração pelo "eu" na construção desse mesmo enunciado (FIORIN, 2008b, p. 137).

A espacialidade e a temporalidade linguísticas são organizadas a partir do "aqui" e "agora", espaço e tempo enunciativos do "eu". A debreagem (enunciativa e enunciva) é um mecanismo da enunciação que instaura nos textos pessoa, tempo e espaço.

A debreagem enunciativa projeta no enunciado o "eu-aqui-agora" da enunciação. Ao instalar o "eu", está implicado um "tu", como já o dissemos. A debreagem enunciva é construída com o "ele-alhures-então"; nesse caso, ocultam-se os actantes, os espaços e os tempos da enunciação. Na debreagem enunciva, o enunciado constrói-se com os actantes, os espaços e os tempos do enunciado.

A debreagem de tipo enunciativa produz um efeito de sentido de subjetividade, ao passo que a enunciva gera um efeito de sentido de objetividade. Com as marcas deixadas pela enunciação no enunciado de Território de bravos, podemos reconstruir o ato enunciativo. O "eu" quando projetado no enunciado é chamado de narrador, teoricamente 
diferente do "eu" pressuposto (enunciador) (FIORIN, 2008b, p. 138; GREIMAS; COURTÉS, 1989, p. 148).

O enunciador e o enunciatário são o autor e o leitor, não de carne e osso, mas os que estão implícitos; noutros termos, temos a imagem do autor e do leitor construída pelo próprio texto dentro da cena enunciativa. Em diferentes textos, essas posições se concretizam e tais actantes tornam-se atores da enunciação. O ator é um exemplo de concretude temático-figurativa do actante. Por exemplo, o enunciador é sempre um eu. No texto da "Apresentação" de Território de bravos, esse EU é concretizado no ator LUIZ GÊ, de papel, discursivo. Não se trata de Luiz Gê em tamanho real, de carne, mas de uma imagem de Gê produzida pelo texto sob análise.

A questão em foco é verificar como se constrói essa imagem do enunciador, ou melhor, do ator da enunciação. Para Fiorin (2008b, p. 139), o éthos não é explícito no enunciado, mas na enunciação. Quando um aluno diz "eu sou estudioso", está explicitando uma imagem sua apenas no enunciado. Todavia, isso não leva à construção do seu éthos. A característica de estudioso será construída por seu comportamento global: se é curioso com relação ao conhecimento, se visita biblioteca, se pesquisa, enfim no modo como ele estuda, quanto estuda e o quanto lê etc.

A enunciação não é da ordem do inefável, ou seja, pode ser depreendida do enunciado. Dessa forma, o éthos pode ser explicitado na enunciação enunciada, isto é, pelos rastros da enunciação no enunciado. Por meio dessas marcas, podemos apreender um sujeito construído pelo discurso, obtendo, assim, a imagem do autor discursivo, implícito (éthos).

O éthos do enunciador pode ser examinado por meio da análise do ator da enunciação. Como fazer para diferenciar o caráter do enunciador e o do narrador? Enquanto o narrador está presente no enunciado, o caráter do enunciador pode ser depreendido da totalidade de sua obra. Mas não apenas da totalidade, visto que, como na metonímia, a parte compreende o todo, assim também se pode dizer que o todo está na parte. Seria curioso um autor revelar um caráter em parte de sua obra e outro caráter em outra parte de sua obra. Por isso, mesmo que um contato tenha sido apenas com parte de uma obra, é possível dela depreender o caráter da totalidade. 
Luiz Gê, no texto de "Apresentação", por exemplo, é o ator da enunciação; ele menciona, por meio do discurso, a trajetória da totalidade de sua obra. O enunciador delega a Presidente Reis o papel de narrador de Território de bravos que, por sua vez, delega a outros narradores em cada uma das outras HQs. Na "Apresentação", por exemplo, encontramos também uma identidade entre o caráter do enunciador (Luiz Gê) e o do narrador (Presidente Reis): ambos possuem trajetória semelhante.

Em Território de bravos, tanto o narrador Reis quanto o ator da enunciação (Luiz Gê) são obstinados, conforme vimos anteriormente; diversos obstáculos atravancam o percurso deles, mas não desesperam, nem desistem. Luiz Gê revela as dificuldades que enfrentou para publicar seu livro de HQ: dezoito anos de superação de obstáculos. Semelhante trajetória teve o narrador ("costurador" do livro) de Território de bravos:

\footnotetext{
No período que se seguiu à [revista] Extra fui editor de arte da revista Status, publiquei meu primeiro livro só de $\mathrm{HQ}$, um dos primeiros da Editora Circo, e voltei ao jornal diário (tinha saído da Folha em 1984), com uma tira e uma coluna semanal para o Estadão. Alguma coisa desta tira já foi publicada em livro pela Melhoramentos e ainda está em catálogo: "Kid Senil e seus Darkinhos". Eles eram, na verdade, personagens secundários da tira do Presidente Reis, que por sua vez tem a sua própria história bem atribulada, por sinal, por causa de uma longa "introdução", e parou quando estava praticamente começando. São tiras desta fase inicial/final que "costuram" esse livro (LUIZ GÊ, 1993, p. 11) [destaques nossos].
}

A prática de HQs era muito adversa, e os percalços eram muitos no percurso de um artista plástico quadrinista, diferentemente do que ocorria com a trajetória de um chargista na década de 1980: “Me foi possível, pela primeira vez na vida, ter constância na prática de HQ." Logo nos primeiros parágrafos da "Apresentação", o autor reforça o conhecimento que tinha das dificuldades do caminho:

\footnotetext{
Os tempos eram cada vez mais para a charge política, modalidade que retrata basicamente a "vida na corte" e se centra em alguns personagens exponenciais, através da caricatura. Isso deixava os outros $99,9 \%$ da realidade em aberto. Só que havia pouco espaço para isso. Pobreza editorial. Pobreza cultural. Pobreza... (LUIZ GÊ, 1993, p. 10).
}

Conforme estamos analisando, é possível depreender o éthos do enunciador de Território de bravos, que é o mesmo que encontramos em Quadrinhos em fúria. Analisemos alguns atores dos enunciados: (1) Gino Amleto Meneghetti enfrenta a polícia, sobe na cúpula, mas obstinadamente não desiste; (2) os habitantes de Território de bravos, atores de cada uma das HQs, enfrentam em seu cotidiano várias adversidades que interrompem seus 
percursos, mas são bravos, obstinados, não desistem nunca; (3) Presidente Reis, como mencionamos, perambula, abre a cortina de cada uma das HQs do livro e, a cada tira, encontra um obstáculo em seu caminho. Bravamente, ele levanta e continua; (4) os atores das epígrafes, situados em tempo e em espaço anteriores aos das sete histórias do livro, anunciavam já uma cidade repleta de adversidades, cujos moradores, para serem dignos de habitarem aquele espaço, deveriam ser obstinados, não desistindo do território à primeira dificuldade encontrada. Vejamos um trecho da primeira epígrafe que antecipa "Entradas e bandeiras":

\footnotetext{
Quando algum forasteiro se apresenta para fazer parte da república, tem de sujeitar-se a uma espécie de quarentena, não por motivos sanitários, mas a fim de ser observado quanto às suas aptidões e desígnios. Depois de prolongada observação é enviado a fazer extensas e penosas jornadas [...]. O noviço que fraqueja na prova, ou procura desertar, é morto sem misericórdia. Quem se alista entre os paulistanos o faz por toda a vida, pois só com muita dificuldade concedem permissão para alguém se retirar.
}

Mesmo no "enunciado enunciado", livre de marcas enunciativas, podemos notar o tom obstinado: “Depois de prolongada observação é enviado a fazer extensas e penosas jornadas" e se o "noviço" fraquejar é banido do grupo.

Ao lado desse tom, há um que foca o cotidiano da metrópole e outro, histórico, que antecipa cada uma das historinhas (enunciados das epígrafes). O enunciador combina o lado urbano com o lado histórico, valendo-se, para isso, de atores da urbe em meio a quadros históricos de um passado imaginado.

As recorrentes epígrafes, relato de viajantes de várias épocas a respeito do espaço da cidade desde sua fundação (século XVI), são repetições composicionais discursivas que antecedem cada uma das HQs. O efeito de sentido dessa repetição é reforçar o processo da cidade: foi desbravada e é ainda desbravada. A realidade urbana não é um fato acabado que não se modificará, visto que antes não era assim e, posteriormente, o espaço se transformará na relação com tempo.

Coincidem também os destinos dos atores de Território de bravos e de outras obras de Gê: são percursos intercalados por paradas e antissujeitos; não há finais heroicos, mas finais. Tudo acaba de modo simples e com um humor trágico: os finais das tiras de Reis, o final de "Entradas e bandeiras", o final de "Tubarões voadores", de "Gino Amletto" etc. Não há finais felizes, mas a realidade cotidiana do fato urbano em meio à fantasia que introduz o 
trágico (a quebra) no cotidiano, como se o mágico da arte em meio àquela urbe fosse algo avassalador. Daí, os finais "tragi-mágicos".

Fiorin (2008b, p. 150) afirma que o "caráter de um enunciador se constitui sempre em oposição a outro". Dessa forma, o caráter de nosso enunciador sob análise estabelece-se no interdiscurso com o chargista. Para se diferenciar deste último, as escolhas enunciativas de Luiz Gê são pela HQ artística que quer se conservar como uma tela, e elas tratam da "realidade em aberto" (o devir já comentado): "os tempos eram cada vez mais para a charge política [...] isso deixava os outros $99,9 \%$ da realidade em aberto. Só que havia pouco espaço para isso" [destaque nosso].

Nosso enunciador, obstinado, tinha a posse do saber, um sujeito, portanto, que sabia das dificuldades que ia encontrar para publicar a sua $\mathrm{HQ}$ artística.

Esse sujeito, diante das adversidades, não desistiu. Dezoito anos depois, temos a confirmação desse éthos da obstinação: a maioria dos quadrinhos analisados mostra-nos a presença do antissujeito, do fazer remissivo, de passionalização. Enquanto a charge tem seu desenrolar veloz, e é da égide utilitária, Território de bravos e as tiras de Presidente Reis têm seus enunciados delongados pelas paradas, e são também da égide do artístico (como veremos nos capítulos 2 e 3).

"Presidente Reis" está configurado em formato de tiras, constituindo elas próprias uma sequência narrativa, com os movimentos contínuos de retenção e relaxamento, à semelhança das HQs do livro sob análise; nelas, verificamos que o movimento da HQ artística é diferente do movimento do utilitarismo e da velocidade das charges políticas que são de consumo imediato. Estas últimas, no entanto, são fundamentais para a construção do éthos de nosso enunciador, uma vez que ele se opõe a elas (FIORIN, 2008b, p. 150). Ele está para a arte, assim como o chargista político está para o mundo utilitário.

Neste capítulo, examinamos as características do enunciador e concluímos que sua perseguição continuativa do objeto levou-o à configuração de um sujeito, cujo éthos é marcado pela obstinação. Nos capítulos 2 e 3, analisamos os enunciados desse enunciador para verificar os mecanismos que escolheu para estruturar suas HQs, que revelam uma gramática: a emissividade em meio à dominância remissiva nos quadrinhos e a importância do antissujeito como direcionador do sentido. 
Missividade: Emissividade e Remissividade

o movimento evolutivo seria coisa simples, determinaríamos rapidamente sua direção se a vida descrevesse uma trajetória única, comparável à de uma bala maciça lançada por um canhão.

Henri Bergson 


\subsection{Fazer missivo}

Este capítulo introduz teoricamente o fazer missivo e, consequentemente, seus dois funtivos, emissividade e remissividade, bem como a noção de sujeito, objeto e antissujeito em uma narrativa. A missividade, constante de Razão e poética do sentido de Zilberberg (2006b, p. 129-146), serve de base para as análises das histórias em quadrinhos (HQs) de Território de bravos, do artista plástico Luiz Gê, apresentadas nesta dissertação.

É de salientar que o nível missivo é precedido pelo nível tensivo; a delimitação desses níveis, todavia, justifica-se apenas para explicitação teórica, visto que ambos caminham lado a lado no engendramento do sentido. O fazer missivo recebe os valores tensivos e proporciona ao nível narrativo dois tipos de valores, os remissivos e os emissivos, que são articulados rítmica e sintaxicamente, produzindo as matrizes das descontinuidades e das continuidades que vão estruturar os discursos verbais e não verbais, como é o caso das HQs de Território de bravos.

Para Zilberberg (2006b, p. 138), que propõe novos patamares de abstração nos estudos semióticos dos textos, um nível é um corte no processo de transvaloração ${ }^{1}$. As oscilações tensivas são valores primordiais selecionados pelo sujeito da enunciação nas etapas mais elementares da configuração do sentido.

De acordo com a obra supracitada, a enunciação é produzida por uma oscilação tensiva que privilegia os limites e as concentrações, ou as progressões e as expansões do fluxo fórico (foria = força que leva adiante). Nos limites e nas concentrações, cria-se o tempo com suas tensões expectantes, e nas progressões e expansões cria-se o espaço com suas

\footnotetext{
${ }^{1}$ Zilberberg (In GREIMAS; COURTÉS, 1986, v. 2, p. 242-246), em Sémiotique: dictionnaire raisonné de la théorie du langage, define transvaloração como o termo que indica "por si mesmo sua necessidade. O prefixo trans refere-se às operações de transcodificação e de transposição (ver Prefácio de Du sens I [Sobre o sentido]), as quais, fora de sua virtude operatória, fazem opção de um postulado de continuidade. O radical valoração cumpre a proposta saussuriana segundo a qual a língua só conhece valores: 'vemos então que nos sistemas semiológicos, como os elementos estão reciprocamente em equilíbrio segundo regras determinadas, a noção de identidade se confunde com a de valor e vice-versa' [...]. Assim como para Hjelmslev: 'uma forma linguística é um valor expresso. As relações aqui em questão estão em todas as línguas de valores expressos [....'” [tradução nossa]. No prefácio do livro Sobre o sentido, Greimas $(1975$, p. 13) ressalta que "a significação é portanto apenas esta transposição de um nível de linguagem a outro, de uma linguagem a uma linguagem diferente, e o sentido é apenas esta possibilidade de transcodificação" (destaque nosso).
} 
difusões e seus desmembramentos narrativos. Adiante, veremos que isso resulta em duas categorias, fechamento e abertura, que serão fundamentais para o desenvolvimento desta dissertação.

Afirma Zilberberg (2006b, p. 137) que a instância da enunciação tem um poder de configuração complexo, oscilante, regulador, rítmico, criador de tempo, quando o fazer remissivo sobrevém, concentrando, nominalizando e modalizando; e criador de espaço, quando o fazer emissivo surge, difunde, narrativiza e verbaliza. O fazer missivo, portanto, recebe valores tensivos e proporciona ao nível narrativo valores emissivos e remissivos.

Conforme veremos nas análises apresentadas no capítulo 3 nesta dissertação, dois são os movimentos nas progressões narrativas das HQs de Território de bravos: quando a instância da enunciação seleciona a criação do tempo, o quadrinho é fechado (aproximação do enunciador), nominalizante e modalizante, sobressaindo algum estado passional (medo, susto, admiração etc.). Nesse caso, prevalece um valor remissivo. Todavia, quando a instância da enunciação seleciona a criação do espaço, temos uma abertura do quadrinho (distanciamento do enunciador). Aqui, há uma difusão, predominando a narrativização e a verbalização (acontece alguma coisa, há uma performance), bem como a escolha de um valor emissivo.

Guardadas as proporções, teríamos aqui uma gramática que rege a estruturação das HQs, diferentemente, pois, das categorias cromáticas, eidéticas e topológicas, da expressão, que possuem a nosso ver baixa produtividade na configuração do sentido das HQs. Pietroforte $(2009$, p. 19) corrobora nosso ponto de vista quando alerta que, em semióticas plásticas, como fotografia, pintura, escultura, arquitetura, as categorias da expressão de Floch, como cromáticas, eidéticas e topológicas, são eficazes nas análises semióticas, mas, quando a pretensão é examinar HQs por meio do semissimbolismo, o alcance da teoria pode ser limitado. Nossa proposta seria no sentido de estabelecer uma gramática das HQs com base nas categorias de abertura e fechamento, cujo ritmo se dá pela concentração e expansão (ver capítulo 4).

Assim, consideramos as HQs um processo cujos elementos são interdependentes. Para Hjelmslev (1975, p. 138), a solidariedade é a "interdependência entre termos num processo". Nesse caso, as categorias de abertura e fechamento formam uma rede de interdependência no processo sintagmático da HQ; portanto, essas categorias são solidárias. 
Enquanto as categorias cromáticas, eidéticas e topológicas variam de acordo com a manifestação de cada processo sintagmático de uma tela, de um filme, de uma fotografia, as categorias de abertura e fechamento são estruturantes, pertencentes a um nível mais profundo, conduzindo às categorias emissivas e remissivas, que dão sustentação à nossa investigação.

Para efeito deste estudo, define-se aberto o quadrinho que manifesta em seu conteúdo uma ação do sujeito (emissividade) e considera-se fechado o quadrinho em que há em seu conteúdo a presença de um antissujeito que impede a ação do sujeito (remissividade). É de ressaltar que emissividade e remissividade não são categorias estanques; daí, na contagem adiante exposta, observarmos a existência de quadrinhos mistos (remissividade, que vai da abertura para fechamento, que tende para a emissividade, que vai do fechamento para abertura, e vice-versa). Nos quadrinhos da figura 2.1 , vemos exemplos de quadrinhos abertos, fechados e mistos.

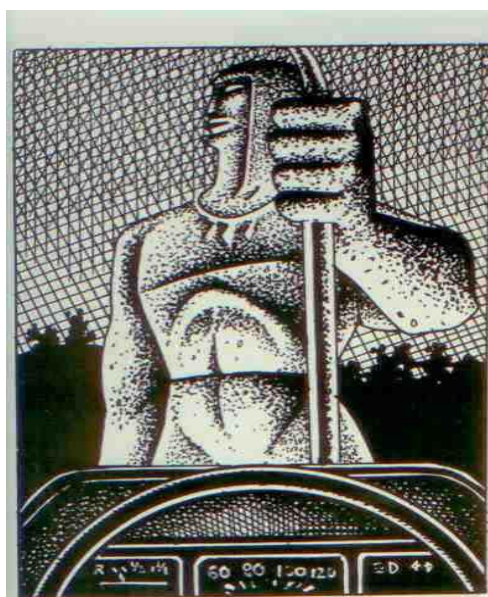

Quadrinho 1: fechado

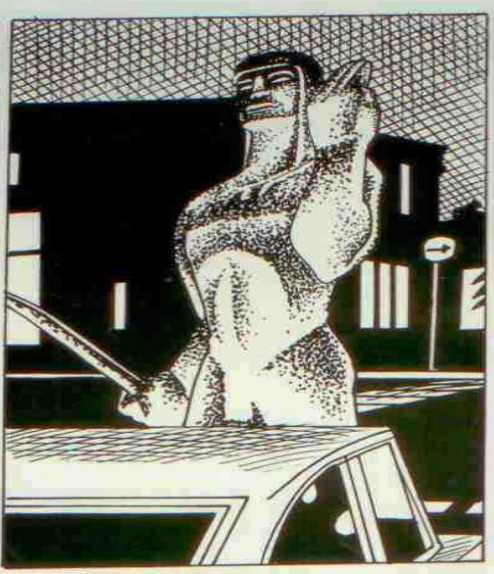

Quadrinho 2: fechado

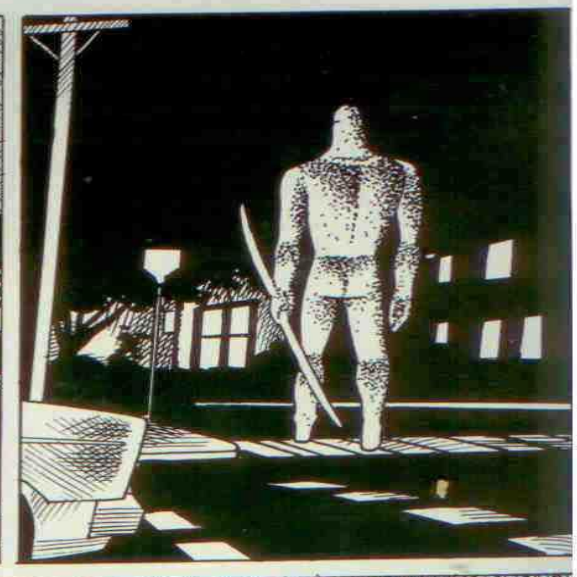

Quadrinho 3: misto [Fechado (automóvel) que tende a aberto (estátua)]

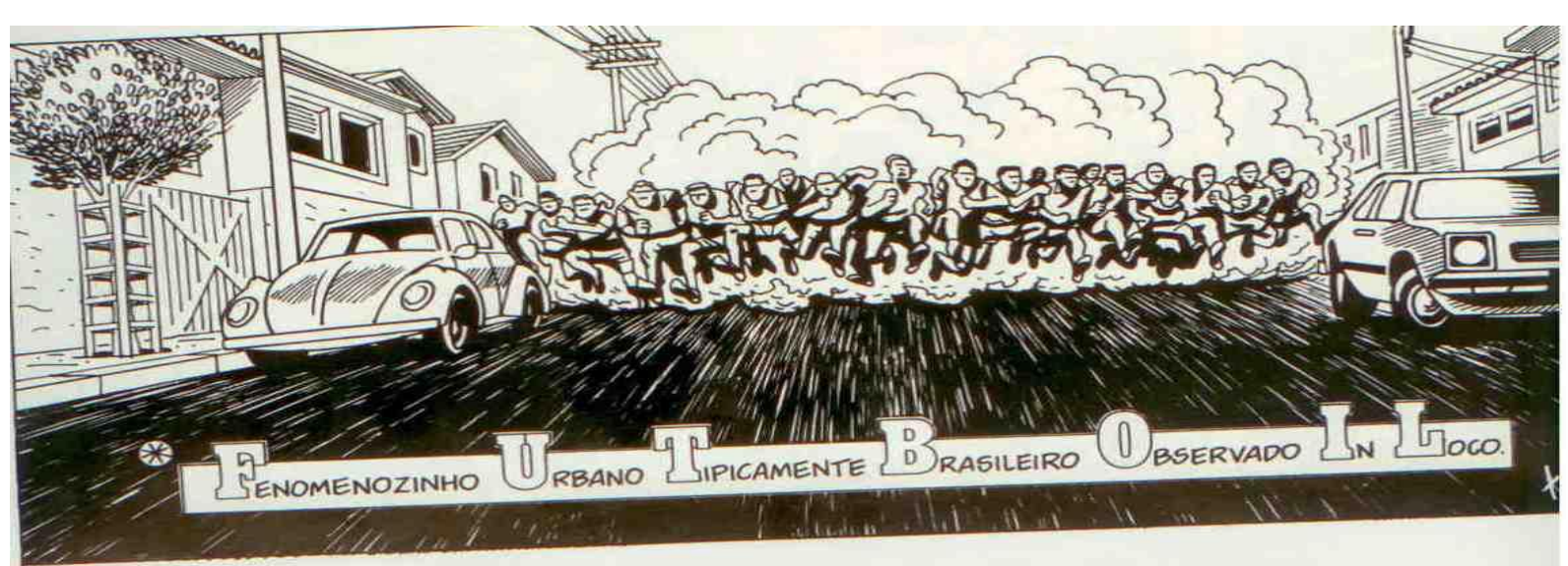




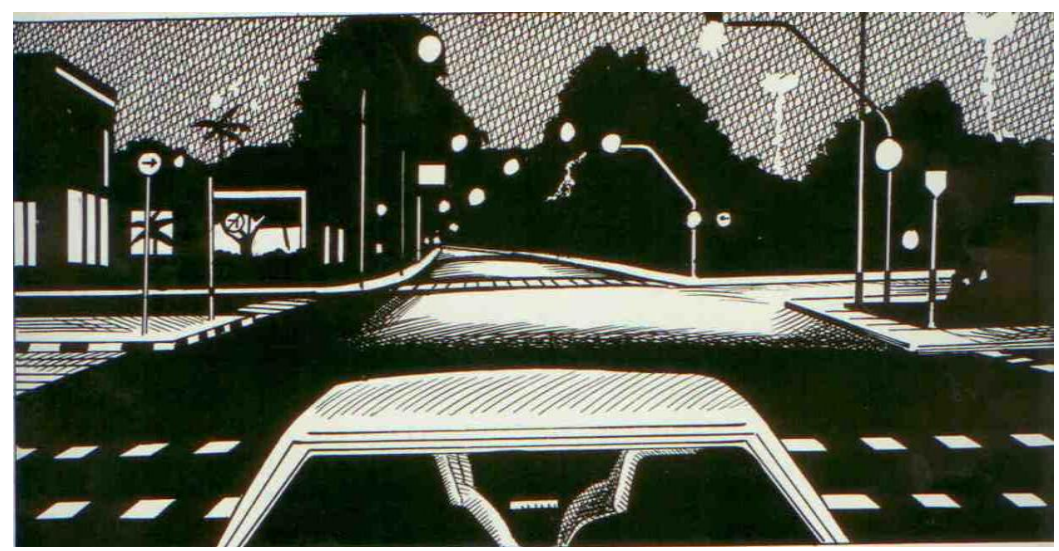

Quadrinho 5: misto [fechado que tende a aberto]

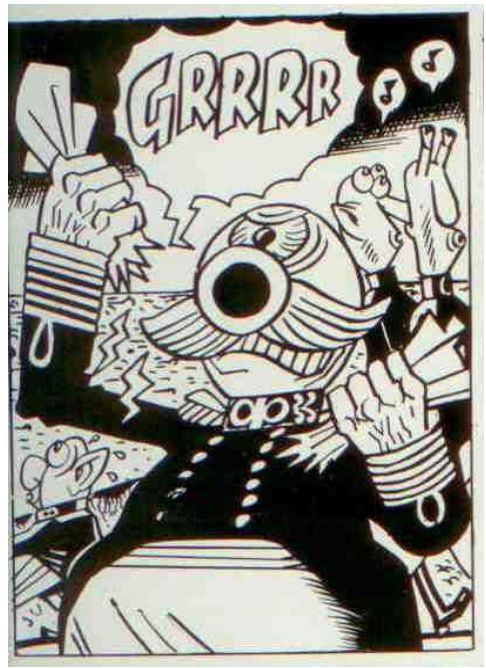

Quadrinho 7: fechado

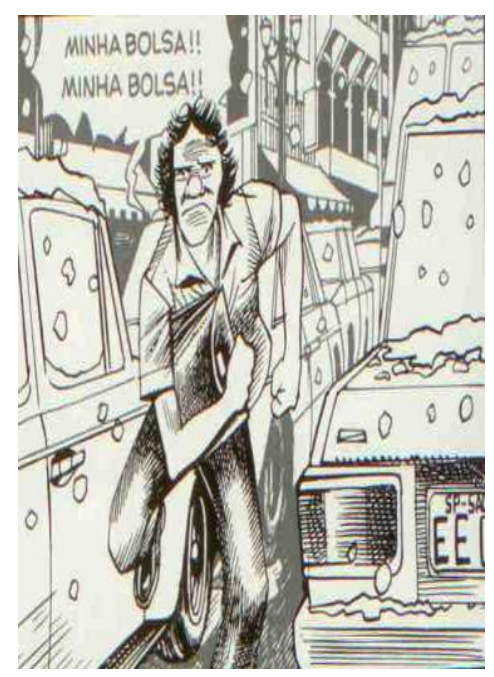

Quadrinho 8: fechado

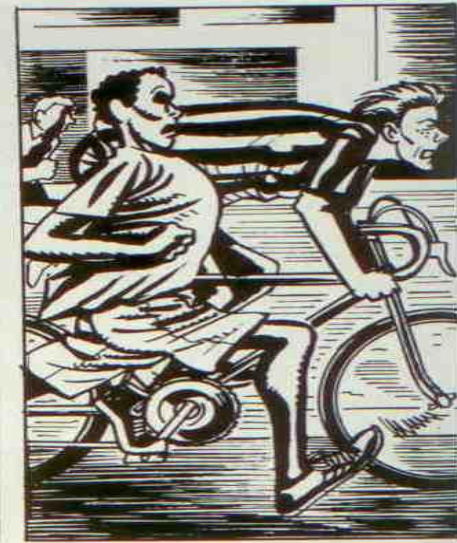

Quadrinho 6: aberto

Figura 2.1 Exemplos de quadrinhos abertos, fechados e mistos.

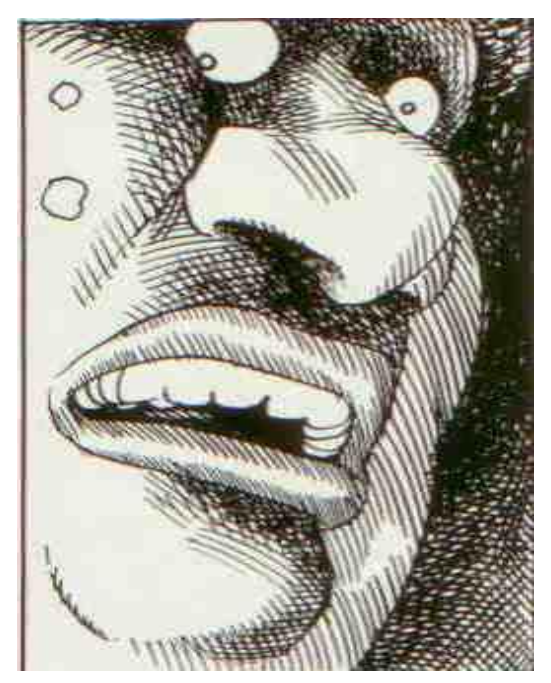

Quadrinho 9: aberto

No quadrinho 1 da figura 2.1, por exemplo, o antissujeito, na figura do ator estátua no nível discursivo, caminha pelo espaço da cidade de São Paulo, provocando a parada no percurso do sujeito, que é representado pela figura dos passageiros do automóvel que querem voltar para casa para dormir. Temos, então, um quadrinho fechado, nominalizante. No quadrinho 2 da figura 2.1, verificamos a continuação da parada na ação do sujeito (atores passageiros do automóvel) e início de abertura para o percurso do antissujeito, ou seja, quadrinho fechado, tendendo à abertura. No quadrinho 3 da figura 2.1, temos uma abertura para o percurso do programa do antissujeito e um fechamento para o percurso do programa do sujeito.

Ressaltamos que as categorias de abertura e fechamento são, como dissemos, interdependentes, conhecendo a gradação, que chamamos a seguir de quadrinho misto, como é o caso do quadrinho 3 da figura 2.1, que é remissivo para o sujeito 1 (atores 
passageiros do automóvel) e emissivo para o sujeito 2 (ator estátua), indo do fechamento para a abertura. No quadrinho 4 da figura 2.1, aberto, temos um quadrinho verbal, emissivo. No quadrinho 5, o fazer remissivo dá lugar ao emissivo, configurando um quadrinho misto. Os quadrinhos 6 e 9 configuram a emissividade; são verbais, abertos (ocorre a performance: correr). Os de número 7 e 8 são fechados, evidenciando paixões (irritação e medo); são nominais, portanto.

Ao tratarmos dos termos sujeito e antissujeito, é preciso levar em conta que a utilização dessa nomenclatura depende do ponto de vista da análise (como veremos na seção 2.4). Dessa forma, se o analista se põe a examinar o percurso do ator estátua do nível discursivo, este pode se constituir em sujeito; se, por outro lado, se põe a verificar o percurso do ator automóvel, este pode se constituir em sujeito. Sujeito e antissujeito trocam de posição conforme, portanto, o ponto de vista adotado pela análise.

Para continuar nossa exposição, um esclarecimento metodológico: são sete as HQs de Território de bravos; dessas sete, como veremos no capítulo 3, duas constituem corpus de análise. Todavia, procedemos à contagem dos quadrinhos de todas as histórias de Território de bravos para verificar como estão estruturados: emissivo (quadrinho aberto), remissivo (quadrinho fechado), misto (mistura de fechado e aberto). Em que proporção ocorre cada uma dessas categorias?

Como veremos adiante, a opção do enunciador pela maioria dos quadrinhos remissivos (fechados) conduz a narratividade às paradas, causadas pelo antissujeito no campo de presença do sujeito. Esse antissujeito, como vimos no capítulo 1, é o responsável pela composição do nosso enunciador obstinado. Reafirmamos que a obstinação depende de um excedente modal (não poder ser aquele que faz), causado por um antissujeito. Daí os rastros da enunciação no enunciado: presença de obstáculos, que, no nível narrativo, se configuram como antissujeitos.

Adotamos para a contagem mencionada os seguintes critérios:

1. Emissividade e remissividade.

2. Abertura e fechamento.

3. Verbalização e nominalização.

Todavia, essa tricotomia reduz-se a uma só equação, que pode ser simplificada assim:

Emissividade(verbalização)[abertura] vs. Remissividade(nominalização)[fechamento] 
Ou seja, justapomos emissividade, verbalização e abertura, bem como fechamento, nominalização e remissividade.

Na seção 2.3 desta dissertação, distinguimos quadrinhos abertos, fechados e mistos em cada HQ de Território de bravos. Na análise realizada no capítulo 3, verificamos como a emissividade e a remissividade podem ser aplicadas nas estruturas das HQs e a contribuição dessa gramática para seu estudo. Partimos da hipótese de que quadrinhos fechados, ou que caminham para o fechamento, produzem o efeito de sentido de aproximação, passionalização, que engendram o efeito estético: no quadro 3.6 desta dissertação, confrontamos uma $\mathrm{HQ}$ dominantemente remissiva com outra de dominância emissiva e verificamos que a remissiva é preponderante na obra de Luiz Gê e responsável pelo efeito da HQ artística.

Quadrinhos abertos e fechados são catalogados, como dissemos, seguindo o conceito de emissividade e remissividade. As categorias de fechamento e abertura tomam como pressuposto o espaço. Noutros termos, chamamos de aberto o quadrinho emissivo que conjuga abertura de espaço em virtude da verbalização, do desenvolvimento de um fazer, e de fechado, o quadrinho remissivo que conjuga fechamento de espaço por causa da nominalização, da passionalização, como vimos nos exemplos dos quadrinhos de 1 a 9 da figura 2.1.

Pensar em fechamento de espaço pela remissividade é pensar em criação de tempo (cronopoiese), assim como pensar em abertura de espaço pela emissividade é pensar em repouso no tempo (cronotrofia). Daí ser relevante, neste momento, uma explanação teórica desses termos utilizados por Zilberberg (2006b, p. 137) quando trata do fazer missivo (veja na seção 2.2 outras considerações sobre o tempo e o espaço).

Quando partimos de uma tensividade que se estabelece entre a parada, provocada pelo antissujeito, e a parada da parada, orientada pelo sujeito, podemos constatar na parada (fechamento do espaço) uma espera no tempo (cronopoiese) e na parada da parada (abertura do espaço) um repouso no tempo (cronotrofia), ou seja, temporalidade e espacialidade estão relacionadas com fechamento e abertura.

Os termos cronopoiese e cronotrofia iniciam-se por crono, do grego, que significa tempo. O primeiro vem acompanhado de poiese, ou seja, poese, criação, fabricação, 
confecção (HOUAISS, 2001, verbete poese); o segundo vem acompanhado de trofia, ou seja, ação de alimentar, alimento, nutrição, nutriente (HOUAISS, 2001, verbete trofia).

O fazer remissivo é cronopoiético, espacialmente fechado, e possui uma temporalidade expectante, isto é, nele há uma criação (poiese) do tempo de espera. Nesse caso, o processo é nominal, nos termos de Hjelmslev (1991), conforme veremos a seguir. Ora, se é nominal, a criação do tempo é da ordem do ser e não do fazer. Para configurar-se da ordem do ser, o espaço fecha-se e sobressaem-se valores passionais.

O fazer emissivo é cronotrófico, espacialmente aberto, e possui uma temporalidade originante, porque alimentada (trofia). Ele repara uma perda, uma falta. Nesse caso, o processo é verbal, nos termos de Hjelmslev (1991, p. 175). Se é verbal, a alimentação do tempo traduz-se em temporalidade de origem, reparadora, da ordem do fazer (performance), sobressaindo as modalizações do "fazer". Quando é da ordem do fazer, do verbal, o espaço abre-se. Daí que, na remissão, temos a prevalência do antiprograma do antissujeito, uma passionalização e, na emissão, o desenvolvimento de um programa pelo sujeito.

A um processo nominal, associado por Hjelmslev (1991, p. 175) ao termo intenso, de um lado, correspondem quadrinhos remissivos, que são fechados e, portanto, manifestamse as "paradas", as paixões, assim como um antissujeito presente, ou que está prestes a manifestar-se e já foi percebido pelo sujeito no campo de presença.

A um processo verbal, que Hjelmslev (1991, p. 175) associa ao termo extenso, de outro lado, correspondem quadrinhos emissivos, que são abertos e, portanto, manifestamse as "paradas das paradas"; nesse caso, temos progressão narrativa: a ação do sujeito em busca de seu objeto prevalece sobre a do antissujeito, como dissemos.

Todavia, os termos extenso e intenso, bem como intensivo e extensivo, não causariam uma confusão terminológica, visto que Zilberberg (2006a; 2006b) utiliza também os termos intensidade e extensidade? Intensidade/extensidade e intensivo/extensivo "não se recobrem mutuamente" nos escritos de Hjelmslev e Deleuze, autores que se serviram dessas categorias (cf. ZILBERBERG, 2006a, p. 216).

Em Eléments de grammaire tensive, Claude Zilberberg (2006a, p. 214-215), ao discorrer sobre o verbete extensivo, afirma que a obra de Hjelmslev contém os pares intensivo/extensivo, intenso/extenso e intensional/extensional. Salienta, no entanto, que 
considerará apenas os dois primeiros pares. A distinção entre intenso e extenso é relativa à categorização linguística. Assim, seriam extensas as grandezas que assinalam uma direção, pois elas são dinâmicas. Nesse caso, temos no plano da expressão as modulações; no plano do conteúdo, temos os morfemas verbais: "grosso modo, os morfemas extensos são os morfemas verbais; os morfemas intensos são os morfemas nominais" (HJELMSLEV, 1991, p. 175) (destaque nosso).

Zilberberg salienta que a dinâmica nos planos do conteúdo e da expressão é da competência das grandezas extensas e que a importação desse termo seria delicada, visto que para Hjelmslev o contraste é entre uma dinâmica e uma estática; do ponto de vista de nossos estudos tensivos, temos não uma, mas duas dinâmicas: uma gramática intensiva e outra extensiva.

Em La categoria dei casi (HJELMSLEV, 1999, p. 198-199):

Questa scelta di un solo termine della zona come base del sistema dipende da un principio secondo cui una sola casella va scelta come intensiva, mentre le altre sono estensive. La casella que viene scelta come intensiva ha una tendenza a concentrare il significato, mentre le caselle scelte come estensive hanno una tendenza ad estendere il significato sulle altre caselle in modo tale da invadere il complesso del dominio semantico occupato della zona ${ }^{2}$.

Como se pode notar, Hjelmslev apoia sua demonstração sobre a estruturação lexical, afirmando que a casa dita intensiva concentra a significação, enquanto a casa dita extensiva expande a significação sobre as demais casas, invadindo todo o domínio semântico. Explicitando a citação acima, podemos tomar o feminino como termo intensivo, visto restringir a abrangência semântica. O masculino, nesse caso, é extensivo. Suponhamos:

O homem é um animal racional. (homem, nesse exemplo, pode indicar homem e mulher = termo extensivo) A mulher é um animal racional. (mulher, nesse exemplo, só pode indicar o gênero feminino = termo intensivo) O brasileiro gosta de sambar. (brasileiro, nesse exemplo, pode indicar brasileiro e brasileira = termo extensivo) A brasileira gosta de sambar. (brasileira, nesse exemplo, só pode indicar o gênero feminino = termo intensivo)

\footnotetext{
${ }^{2}$ Esta escolha de apenas um termo da área como base do sistema depende de um princípio segundo o qual apenas uma casa é escolhida como intensiva, enquanto as outras são extensivas. A casa escolhida como intensiva tem a tendência de concentrar o significado, enquanto as casas escolhidas como extensivas têm uma tendência de estender o significado sobre outras casas de modo tal que invada o complexo do domínio semântico ocupado pela área (tradução nossa).
} 
Zilberberg (2006a, p. 215) homologa esses termos da perspectiva tensiva, considerando não mais a oposição intensidade/intensivo versus extensidade/extensivo, mas a oposição concentrado/difuso.

No verbete extensidade do glossário da obra citada, Zilberberg (2006a, p. 216-217) afirma que de Aristóteles a Kant conhece-se a distinção entre as grandezas intensivas, que se relacionam com a qualidade, e as grandezas extensivas, que se relacionam com a quantidade. Desse ponto de vista, esse par (intensivo/extensivo) não constituiria nenhum problema. A dificuldade reside no fato de que Hjelmslev introduz, como vimos, a articulação [INT- vs. EXT.] em três oposições distintas:

\author{
[intensivo vs. extensivo] \\ [intenso vs. extenso] \\ [intensional vs. extensional]
}

mas não utiliza, como podemos observar, o termo extensidade em seus textos.

Segundo Zilberberg (2006a, p. 215-216), a semiótica tensiva explicita a relação entre intensidade e extensidade, intervindo como mediação entre o modelo hjelmsleviano, que se volta para a extensão, e o modelo deleuziano, que se volta para a energia. Em ambos os modelos, a intensidade, ou seja, a tensão entre o impactante e o tênue é latente e é manifestada, expressa, no modelo tensivo de correlação inversa (ver gráfico 2.1).

Para esclarecer, vejamos o modelo deleuziano, voltado à energia, de que Zilberberg trata. Ora, o que seria energia para Deleuze? Em Diferença e repetição, Deleuze (2006, p. 315) afirma:

Só conhecemos formas de energia já localizadas e repartidas no extenso, extensos já qualificados por formas de energia. A energética definia uma energia pela combinação de dois fatores, o intensivo e o extensivo (por exemplo, força e comprimento para a energia linear, tensão superficial e superfície para a energia de superfície, pressão e volume para a energia de volume, altura e peso para a energia gravitacional, temperatura e entropia para a energia térmica...). É claro que, na experiência, a intensio (intensidade) é inseparável de uma extensio (extensidade) que a refere ao extensum (extenso). Nestas condições, a própria intensidade aparece subordinada às qualidades que preenchem o extenso (qualidade física de primeira ordem ou qualitas, qualidade sensível de segunda ordem ou quale). Em suma, só conhecemos intensidade já desenvolvida num extenso e recoberta por qualidades. A partir daí tendemos a considerar a quantidade intensiva como um 
conceito empírico e ainda mal fundado, misto impuro de uma qualidade sensível e do extenso, ou mesmo de uma qualidade física e de uma quantidade extensiva.

Deleuze (2006, p. 315 e 321) afirma ainda que, como a intensidade é diferença, ela apresenta uma tendência correspondente no extenso, que a desenvolve, e na qualidade, que a recobre. Essa diferença tende a anular-se no extenso; noutros termos, a diferença se explica, embora inexplicável, porque tende a anular-se no sistema em que se explica. A diferença é implicada. Para ela, explicar-se é anular-se. O explicado é da ordem da extensidade; o implicado, da intensidade, portanto: "a intensidade se explica, desenvolve-se numa extensão" (p. 321):

\section{Implicada = diferença [da intensidade] que tende a anular-se \\ na ordem extensa, que a explica [explicado]}

Ora, se não houver nenhum antiprograma eficaz previsto, essa intensidade tenderá à anulação; daí a importância da função do antissujeito nas narrativas, objeto de nossas discussões na seção 2.5 deste capítulo.

Zilberberg (2006a, p. 215) sugere uma ponte entre os conceitos intensivo/extensivo de Hjelmslev e intensidade/extensidade de Deleuze, fazendo a seguinte homologação:

\begin{tabular}{|l|l|l|}
\hline Hjelmslev $\rightarrow$ & intensivo & extensivo \\
\hline Deleuze $\rightarrow$ & intensidade (implicado) & extensidade (explicado) \\
\hline
\end{tabular}

Do ponto de vista tensivo, temos:

\begin{tabular}{|l|l|l|}
\hline $\begin{array}{c}\text { intensidade } \\
\text { intensivo }\end{array}$ & \multicolumn{2}{|c|}{$\begin{array}{c}\text { extensidade } \\
\text { extensivo }\end{array}$} \\
\hline & concentrado & difuso \\
\hline
\end{tabular}

Salienta Zilberberg (2006a, p. 217), porém, diferenças entre o modelo de Hjelmslev e o de Deleuze, que não são equivalentes, evidentemente. Sinteticamente, para a semiótica tensiva:

- A implicação dá estatuto à intensidade e a explicação permite conceber a dissipação da intensidade. 
- O par implicado vs. explicado, que em Hjelmslev corresponde ao par intenso e extenso, no modelo tensivo corresponde ao par concentrado vs. difuso, ambos da extensidade.

- Do ponto de vista tensivo, a tensão na extensidade gera a [concentração vs. difusão].

Zilberberg (2006a, p. 216) apoia-se, como vimos, em Deleuze para afirmar que a relação entre intensidade e extensidade é assimétrica: "mais... menos...", "menos... mais..." Seria mais apropriado, em vez de dizer intensidade e extensidade, mencionar "da intensidade à extensidade".

E haveria necessidade de pensar a intensidade como um dividendo e a extensidade como um divisor, isto é, a intensidade decresce, dividindo-se e distribuindo-se, como se o valor fosse o quociente, o resultado. Se se dilui a intensidade, aumenta-se a extensidade (e temos difusão); na intensidade elevada, tem-se o impactante (e temos concentração); na fraca intensidade, tem-se o tênue.

Na correlação inversa dos eixos, ao reduzir-se a tonicidade (tênue) no eixo da intensidade, inicia-se um processo de ampliação da difusão no eixo da extensidade. Se a tonicidade é máxima (impactante), ao contrário, temos concentração. Na atonia (tênue), por exemplo, a correlação extensa é a difusão.

Vejamos como se distribuem tais categorias no gráfico 2.1 de correlação inversa.

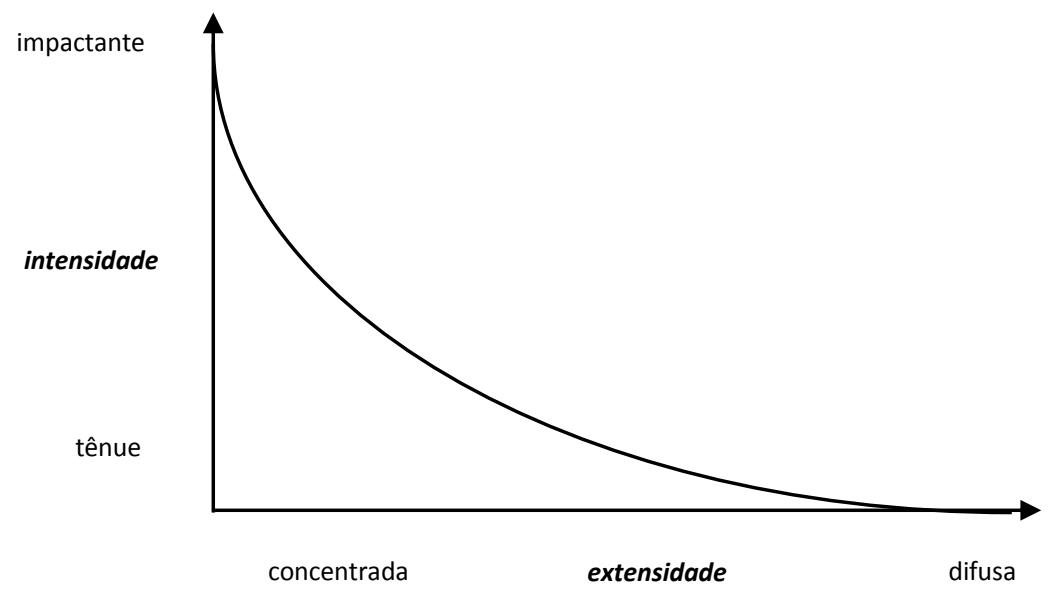

Fonte: Zilberberg (2006a, p. 216).

Gráfico 2.1 Correlação inversa. 
Além da correlação inversa, há ainda a correlação conversa, segundo a qual temos "mais... mais..." e "menos... menos..." (gráfico 2.2).

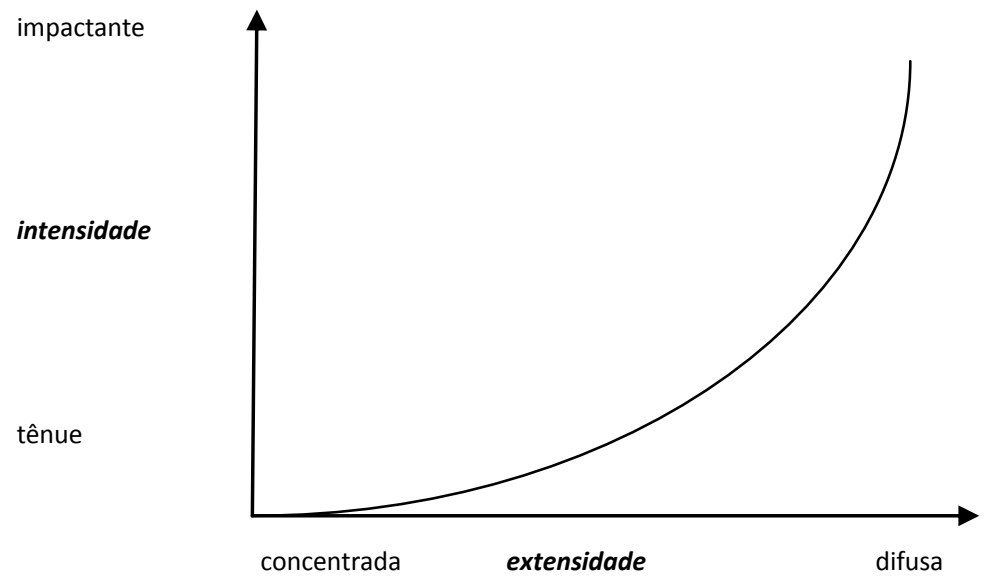

Fonte: Zilberberg (2006a, p. 208).

Gráfico 2.2 Correlação conversa.

Para Zilberberg (2006a, p. 212), o espaço tensivo, do ponto de vista paradigmático, compreende, portanto, dois eixos:

- Na linha das ordenadas, o eixo da intensidade. Sobre esse eixo, incidem os estados de alma que afetam o sujeito.

- Na linha das abscissas, o eixo da extensidade. Sobre esse eixo, incide a consistência variável dos estados de coisas.

Do ponto de vista sintagmático, o eixo da intensidade, que está voltado para o sujeito é o que rege, enquanto o da extensidade é o regido.

Quando se fala em eixo da extensidade, portanto, não podemos considerá-lo isoladamente, pois o "eixo da extensidade" já é o resultado da diluição da intensidade, como vimos anteriormente. Daí concentração e difusão serem resultados dessa diluição. Dessa forma, a concentração seria a pouca diluição da intensidade e a difusão seria a muita diluição de tal intensidade. Ademais, a intensidade é direcional, ou seja, vai na direção da extensidade, anulando-se. O espaço tensivo configura-se como complexo, fundamentado na dependência da extensidade para com a intensidade, bem como nos estados de coisas para com os estados de alma. Os fatos semióticos são filiados ao espaço tensivo, que é produzido pela projeção da intensidade na extensidade; a direção é do sensível para o inteligível (ZILBERBERG, 2006a, p. 212-217). A estesia encaminha-se para a anestesia, inexoravelmente. 
Outro exemplo a considerar é que toda concentração dirige-se a seu oposto, a difusão (caso em que a tonicidade dá lugar à atonia), a não ser que um dispositivo retensivo eficaz seja instalado, como é o caso do antissujeito nas narrativas (cf. seção 2.5 deste capítulo).

O exame de como essa intensidade é mais ou menos diluída na extensidade mostra relação com o fazer remissivo que concentra, nominaliza, e com o fazer emissivo que difunde, verbaliza (ZILBERBERG, 2006b, p. 137). Daí, um jogo entre difusão e concentração. Considerando as sete HQs de Território de bravos, verificamos, por meio da contagem de quadrinhos (abertos, fechados, mistos), esse jogo entre concentrado e difuso, remissivo e emissivo.

Vejamos nas figuras 2.2 a 2.6 um exemplo desse jogo entre difusão e concentração em “Quem matou papai Noel?", uma HQ de Território de bravos.

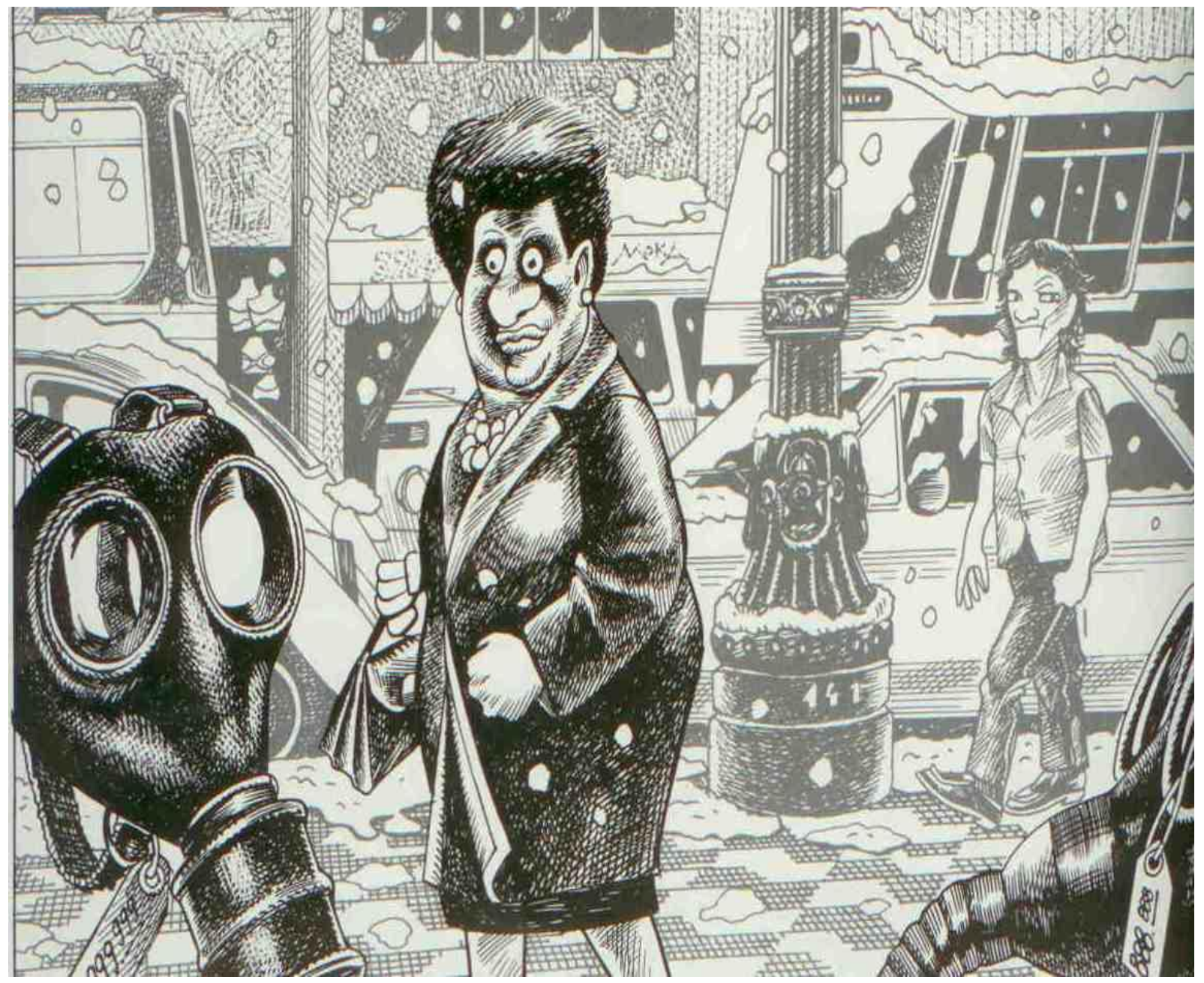

Figura 2.2

Fazer emissivo: difusão, observando-se, porém, a entrada do antissujeito no campo de presença do sujeito. 


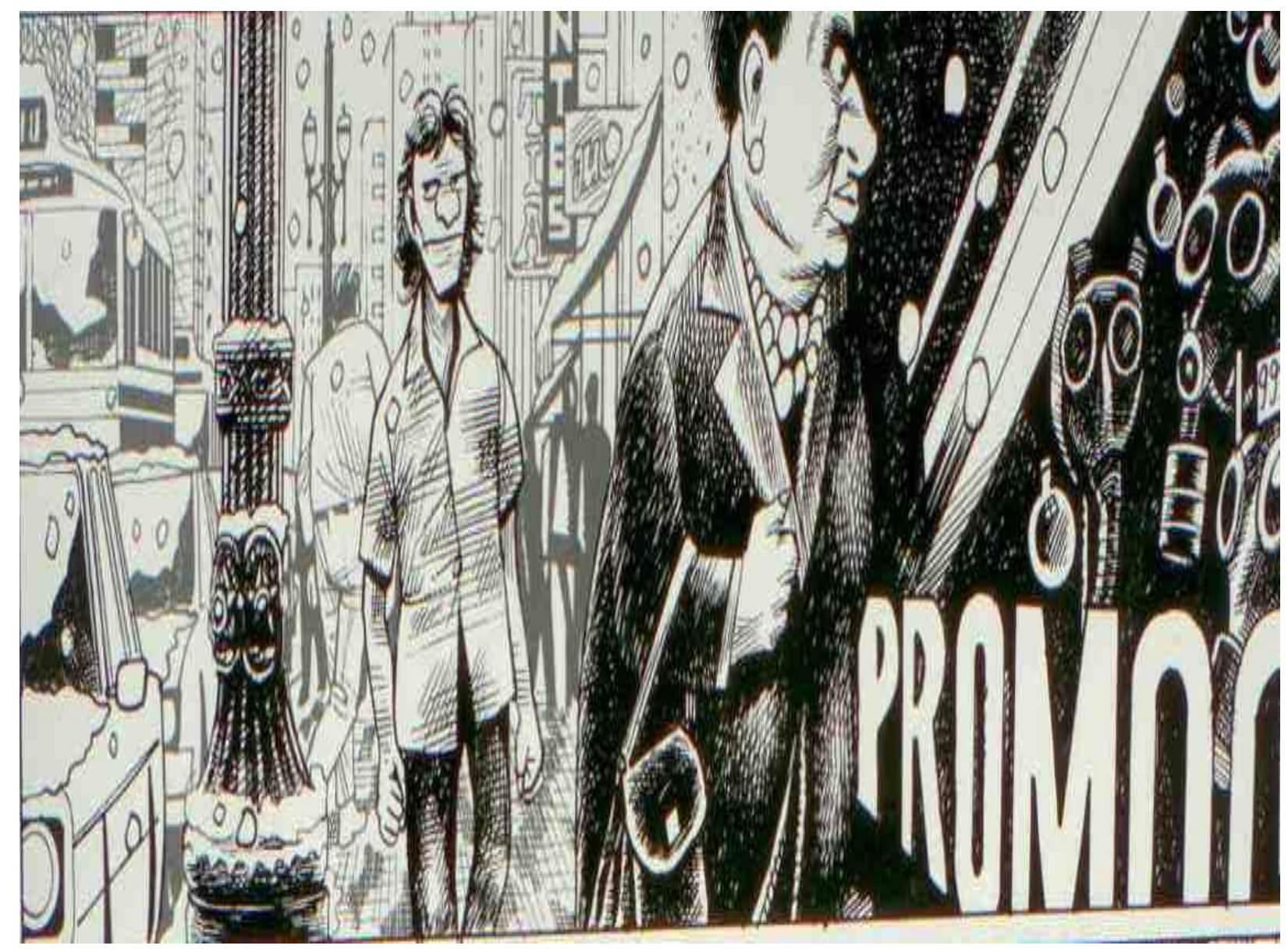

Figura 2.3 Fazer emissivo, observando-se, porém, o sobrevir do fazer remissivo: difusão a caminho da concentração.
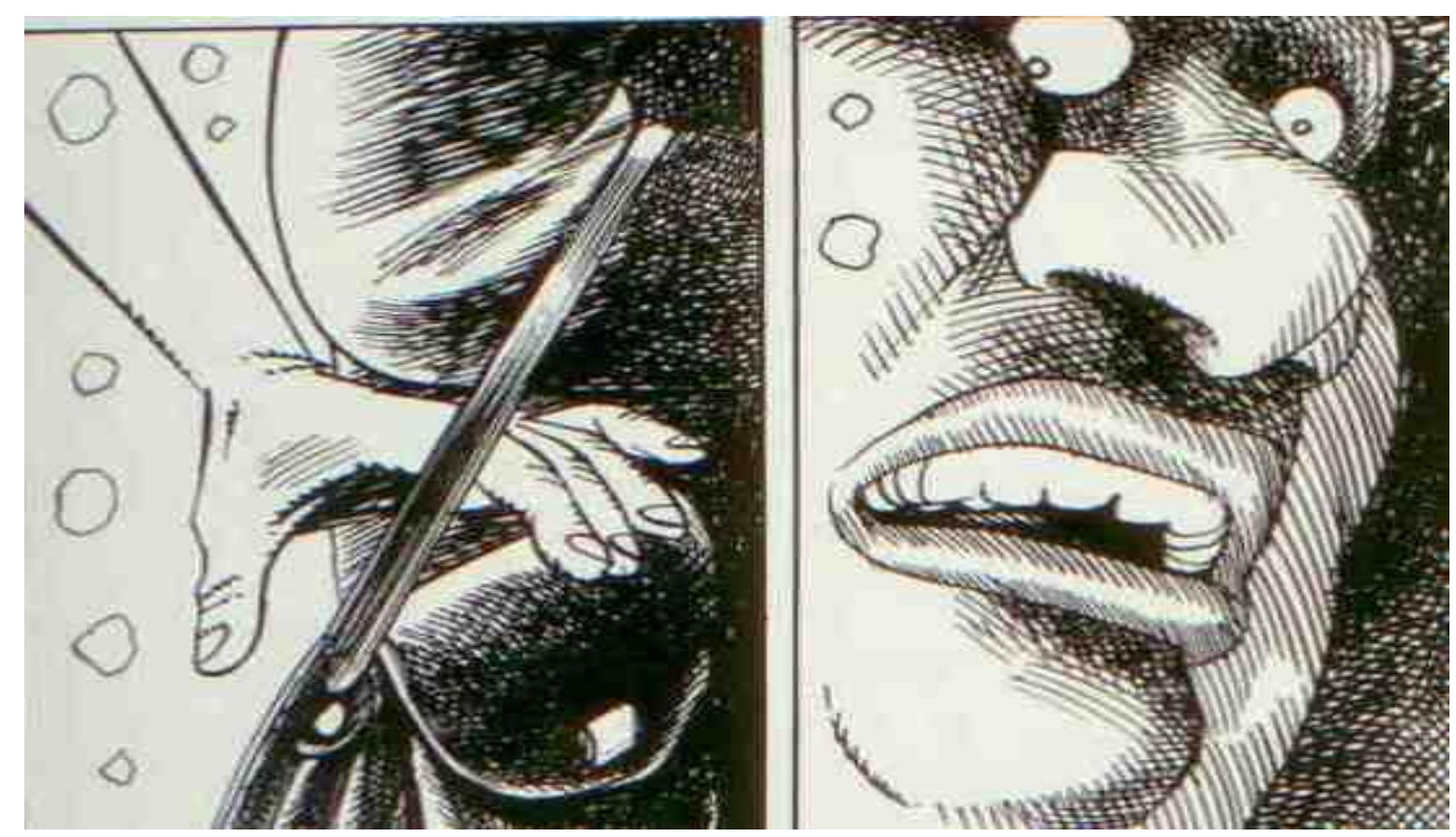

Figura 2.4 Fazer remissivo (concentração): eficácia do antiprograma (fazer do antissujeito). 
Nota-se um salto entre esses dois quadrinhos para o seguinte. Dessa forma, não se vai da concentração para a difusão diretamente como nos mostra o enunciado do quadrinho, mas a passagem se dá de modo gradual.

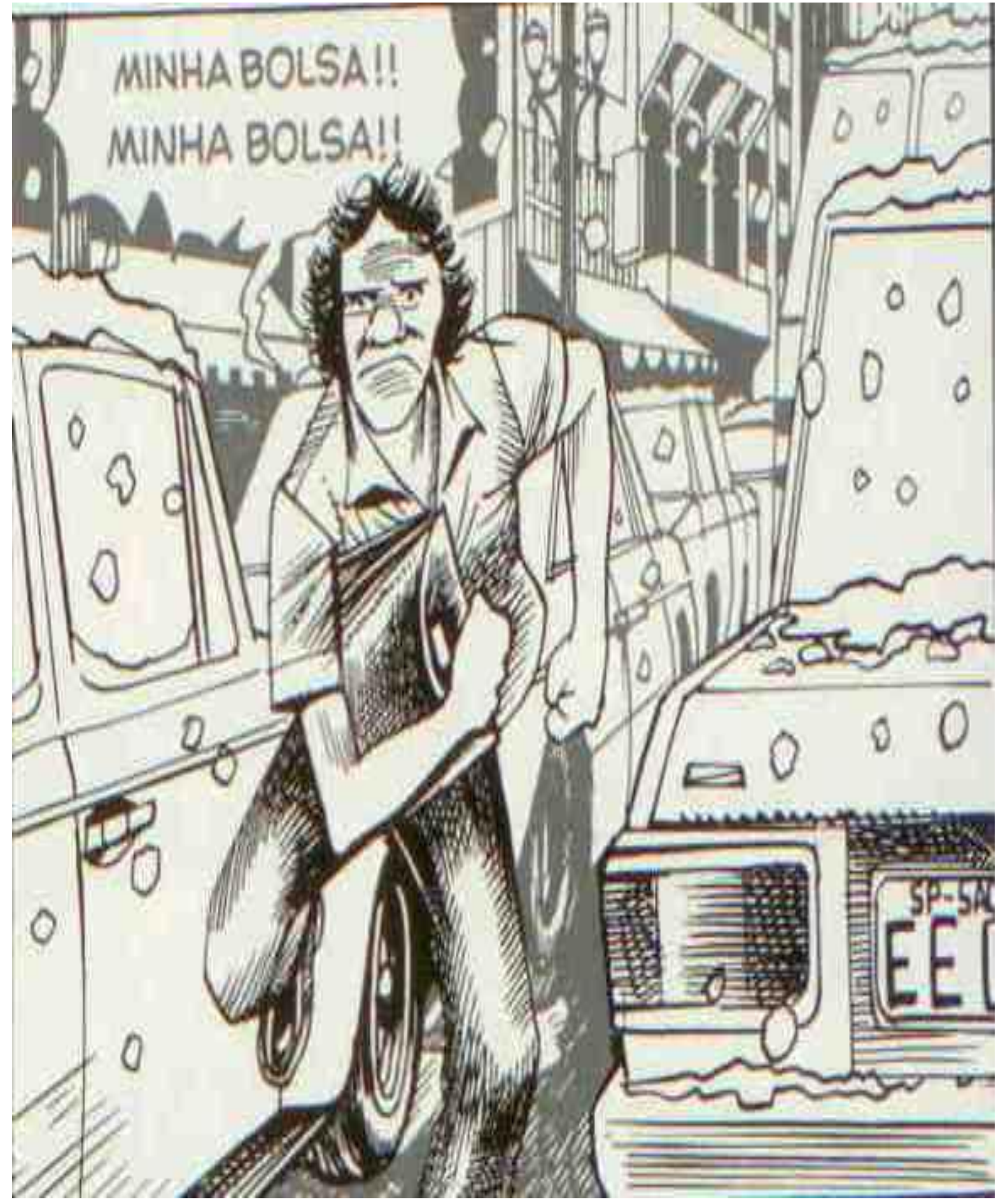

Figura 2.5

Fazer emissivo do antiprograma (difusão [fazer do antissujeito]). 


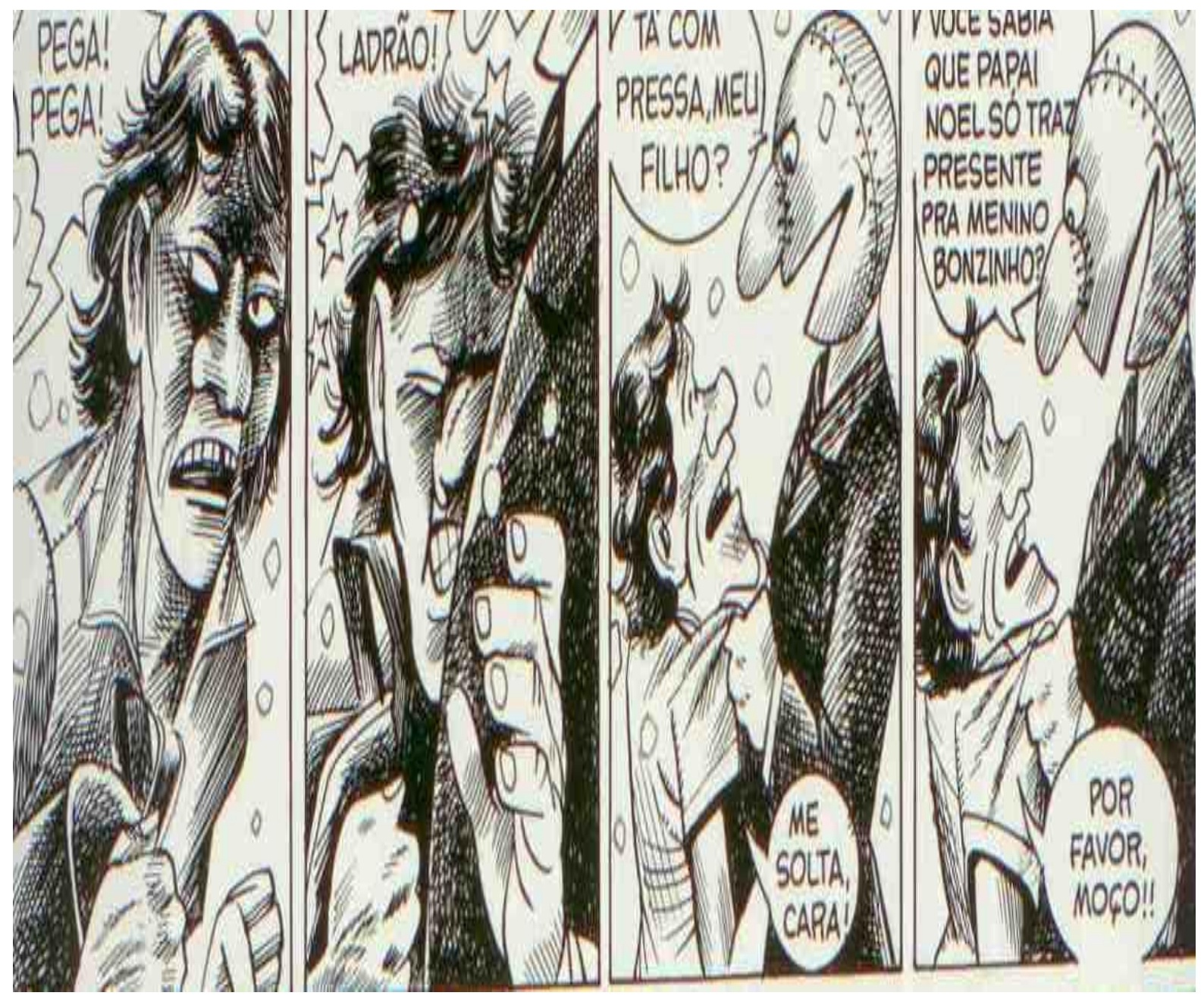

Figura 2.6

Fazer remissivo = concentração novamente, observando-se um antissujeito, com um antiprograma eficaz, no programa do primeiro antissujeito.

Para outras considerações relativas à diluição da intensidade na extensidade, podemos tomar Kant (1999, p. 160), que afirma:

Ora toda a sensação é capaz de uma diminuição, de modo a poder decrescer e aos poucos desaparecer. [...]

Toda a sensação, por conseguinte também toda realidade no fenômeno por pequena que seja, possui um grau, isto é, uma quantidade intensiva que sempre ainda pode ser diminuída [...].

Esse trecho de Kant parece constituir-se numa abordagem avant la lettre da teoria semiótica tensiva zilberberguiana. Da mesma forma, podemos ver no "Prefácio Interessantíssimo" de Mário de Andrade (1987, p. 71) posição tensiva semelhante, quando afirma: "As decadências não vêm depois dos apogeus./O apogeu já é a decadência, porque sendo/estagnação não pode conter em si um progresso,/uma evolução ascensional." E o povo de modo intuitivamente semiótico diz: "depois do topo é só ladeira abaixo". 
No livro Semiótica à luz de Guimarães Rosa, Tatit (2010, p. 11) relaciona Guimarães Rosa também como um precursor da teoria tensiva de Zilberberg:

Os contos "As margens da Alegria" e "Os Cimos" nos ofereceram os instrumentos adequados para a explicitação das condições tensivas e narrativas que norteiam as ideias de Greimas em seu intrigante volume intitulado De l'Imperfection.

Essas mesmas considerações podem ser aplicadas ao autor de Território de bravos (1993). Guardadas as proporções, todo enunciador, ao enunciar, deixa marcas no enunciado, que mostram a competência de seu fazer enunciativo. Esses rastros denunciam a existência de uma gramática estrutural que rege tal fazer. Esse saber da própria competência é uma característica do artista moderno, haja vista a densidade de produções metalinguísticas, encontráveis na contemporaneidade. Nesses casos, o enunciador parece interessar-se sobretudo pelo saber fazer objetos semióticos, plenos de movimento tensivo: descendência e ascendência das quantidades de mais e de menos, bem como do jogo do fazer remissivo e emissivo, das concentrações e difusões, como vimos, no exemplo anterior, na HQ "Quem matou papai Noel?".

A novela televisiva é uma amostra clara do domínio das escolhas enunciativas que se fundamentam num princípio tensivo: é preciso diariamente, na última cena do capítulo diário, introduzir um fazer remissivo (antiprograma), que interrompa o programa de um sujeito em seu fazer, na busca da conjunção com seu objeto. Esse fazer remissivo concentra para, em seguida, diluir-se (difusão); dessa forma, o sujeito se sobrepõe ao antissujeito e continua a perfazer seu programa narrativo, que será novamente interrompido por outro fazer remissivo, e assim a novela ganha sucessivos capítulos, mantendo a conjunção do enunciatário com o enunciado.

Semelhantemente, na HQ ocorre o mesmo fenômeno: na sucessão de quadrinhos, o jogo de concentração e difusão produz a tensividade necessária para manter o enunciatário com ela à mão. Desse modo, a progressão narrativa dá-se quadrinho a quadrinho: concentra, difunde, difunde, concentra etc. A tensão invade a leitura do enunciatário. No caso dos enunciados de Território de bravos, o saber do enunciador revela competência em concentrar e difundir, sem levar o enunciatário ao fastio provocador do tédio.

Nas sete HQs de Território de bravos, o enunciatário é surpreendido no final: por exemplo, em "Entradas e bandeiras", os passageiros do automóvel assustam-se com a estátua de Borba Gato que Ihes passa por cima; em "Futboil", os meninos destroem o objeto 
desejado; em "Uma história de amor", o enunciatário é levado a crer que se trata de um duelo medieval por uma donzela; contudo, nos últimos quadrinhos da $\mathrm{HQ}$, surpreende-se ao dar-se conta de que se trata de uma brincadeira de criança no espaço da rua.

A título de ilustração, o procedimento do artista Luiz Gê é o mesmo que vemos em "Famigerado" de Guimarães Rosa (1985, p. 13-17). O enunciatário é conduzido a uma espera, mas é surpreendido com um desfecho inesperado.

Nosso estudo do fazer missivo pode, então, desenvolver-se com a seguinte homologação, cujos fundamentos vão de Hjelmslev, passam por Deleuze e chegam a Zilberberg, como mencionamos anteriormente:

Fazer emissivo/difusão/dominância de quadrinho verbal ::

Fazer remissivo/concentração/dominância de quadrinho nominal

Tomando como exemplo um quadrinho da HQ "Entradas e bandeiras" (figura 2.7), notamos a concentração da tensividade localizada nas feições do ator. O enunciado é intenso e é nominal, bem como da ordem do ser. Essa intensidade revela a passionalidade, representando uma parada, ou seja, alguma coisa não acontece: no plano do conteúdo, temos o ator mulher paralisado pela paixão do medo; uma interrupção aconteceu. É saliente, é compacto, fechado, local, nominalizante, da ordem do ser, portanto. Na figura 2.7, podemos ainda observar um ponto tenso entre a espera e a recordação.

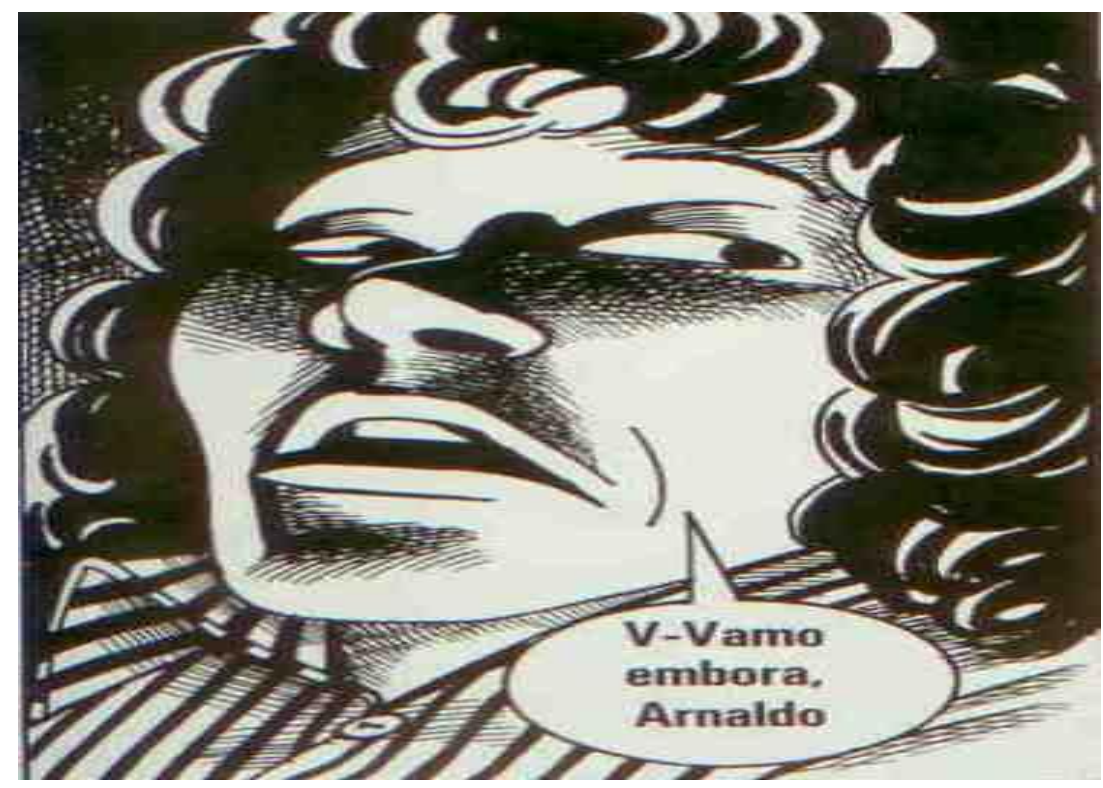

Figura 2.7 Tensão entre espera e recordação: da ordem da concentração.

[66] 
Outro exemplo é o da figura 2.8 em que o termo extenso possui valor de desdobramento, de verbalização (figurativização do carro em movimento - plano do conteúdo), de continuidade; nesse caso, temos a expansão da tensividade. Além disso, os valores extensos fazem jus à temporalidade corrente, ao tempo que corre, que se estende, que é difuso.

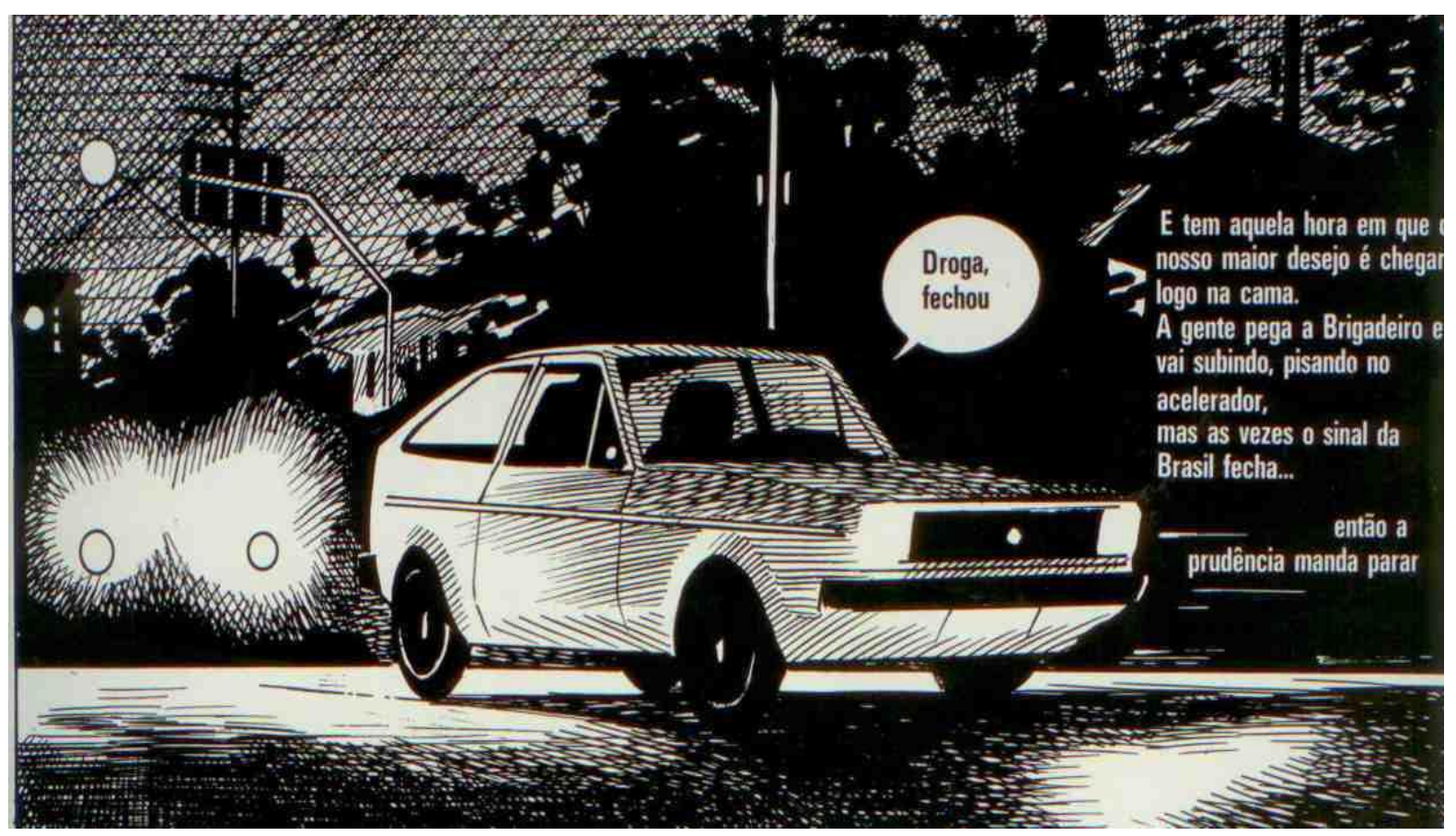

Figura 2.8

Temporalidade originante: da ordem da difusão.

Dessa forma, do ponto de vista da concentração (figura 2.7), há uma "temporalidade expectante" que espera a processualização, que deverá extenuá-la, e há uma espacialidade que concentra, uma expansão da pequenez, que consome o espaço ao redor (fechamento). É a espera do processo seguinte. Do ponto de vista da difusão, há uma "temporalidade originante", da ordem do fazer (figura 2.8), que repara uma perda e há uma espacialidade que difunde, que ocupa (abertura), distende, nos termos de Zilberberg (2006b, p. 132).

Como as categorias emissivas e remissivas pertencem a uma só função, elas não podem ser separadas. Daí que a contagem de quadrinhos leva em consideração os quadrinhos que, anteriormente, chamamos de "mistos", que são aqueles que transitam de um fazer remissivo para um emissivo, ou de um emissivo para um remissivo, o que nos mostra que essas categorias são interdependentes. E que o fazer missivo é, portanto, uma grandeza complexa, uma função de dois funtivos (emissivo e remissivo) que, em relação, constituem uma gramática das HQs, como mencionamos na seção 2.1 deste capítulo. 
A complexidade do quadrinho misto configura ao mesmo tempo uma abertura que tende ao fechamento e um fechamento que tende a uma abertura, ou vice-versa. E esse jogo de aberturas e fechamentos provoca verbalizações, nominalizações, difusões, concentrações, que interferem no andamento da HQ. Tal complexidade é uma característica de objetos semióticos, que são de natureza relacional, construindo-se pelo estabelecimento de relações (GREIMAS; COURTÉS, 1989, p. 313).

Estruturalmente, a função é a missividade, e os funtivos ficam na dependência da estabilização dos valores articulados pelo discurso. São categorias graduais e não discretas. O gesto missivo subjuga o tempo, permitindo-nos dois regimes figurais: a temporalidade remissiva, ou expectante, e a temporalidade emissiva, ou originante.

Ainda segundo Zilberberg (2006b, p. 133-134), ao antiprograma, que se constitui pela parada, corresponde um fazer remissivo; ao programa, que se constitui pela parada da parada, corresponde um fazer emissivo da ordem do continuativo. Os valores do fazer emissivo são de ardor, de arroubo, enquanto os do remissivo são de inibição, de parada, de stase.

Continuidade e descontinuidade são produtos de dois processos solidários: a descontinuidade é o que cessa ou interrompe (stase), e a continuidade, por seu turno, é o que não cessa, modalizando o ser como repouso, equilíbrio, relaxamento. Ora, se o continuativo continuasse indefinidamente, haveria relaxamento de tal ordem, que levaria a pensar em algo como o tédio total. A existência do continuativo justifica-se tão somente pela existência da possibilidade de paradas. Sem o descontínuo, a continuação perde sua razão de ser, ou, então, não há por que falar em continuação se não há a possibilidade da descontinuidade.

Fechamento e abertura são dois processos responsáveis pela criação ou não de tempo e espaço, como veremos na seção seguinte.

\subsection{Tempo e espaço}

Retomando nossas considerações retroapresentadas, em que vimos que o fazer remissivo é cronopoiético e o emissivo é cronotrófico, podemos verificar que, no fazer missivo, o eu do nível figural ocupa um posto de intersecção e de arbitragem entre tempo e espaço: o tempo seria apenas a contenção do espaço, assim como o espaço seria somente o 
desdobramento do tempo. Para esse estudo, apoiamo-nos em Tatit (1997, p. 15-22) e Zilberberg (2006b, p. 137). O poder de organização do fazer missivo atua igualmente tanto em relação ao espaço, quanto em relação ao tempo. Talvez seja difícil de conceber, mas tempo e espaço são inversamente proporcionais: se o tempo se atrofia, o espaço se abre; se o tempo se expande, o espaço se fecha.

No gráfico 2.3, vemos que as categorias de emissividade e remissividade colocam em relação tempo e espaço no plano do conteúdo (ZILBERBERG, 2006b, p. 147).

\begin{tabular}{llll}
\hline $\begin{array}{l}\text { Tensivo } \\
\text { Missivo }\end{array}$ & Tensão & Distensão & Figural \\
& Parada & Parada da parada & \\
Temporalidade & - & & \\
Espacialidade & Espera & Repouso & Figurativo \\
& Fechamento & Abertura &
\end{tabular}

Fonte: Zilberberg (2006b, p. 147).

Gráfico 2.3 Articulação de tempo e espaço.

É de acrescentar que abertura e fechamento não se reduzem, portanto, a mera focalização de movimento de câmera do cinema, nem a mera sequência de imagens de HQs. Para nosso estudo, levamos em conta a emissividade e a remissividade dos quadrinhos como estruturantes do sentido das histórias analisadas no capítulo 3 desta dissertação. Embora emissividade e remissividade, na maioria das vezes, possam corresponder a distanciamento e aproximação, nossa preocupação fundamental não é verificar categorias de distanciamento e aproximação ao espelho de movimentos de câmera, mas verificar como as categorias emissividade/abertura e remissividade/fechamento estruturam as HQs.

Beividas (2006, p. 124) chama a atenção para a impropriedade do uso em semiótica de terminologia técnica dos cineastas (angulações, travellings, enquadramentos, closes, contra-plongés). Por isso, nossa opção, nesta dissertação, por conceitos semióticos de enunciação, sujeito, antissujeito, missividade e paixão para a investigação do processo textual das HQs de Território de bravos. Para nós, a gramática das HQs concentra-se na emissividade e remissividade, categorias fundamentais para relaxamento ou retenção, que implicam passagem pela distensão e contenção narrativa. Interessa-nos apenas nos estudos 
desta dissertação o fazer missivo, responsável pela tensividade provocadora dos efeitos de sentido.

Na seção 2.3, apresentamos a descrição dos quadrinhos das HQs de Território de bravos, considerando aberturas, fechamentos e mistura de ambos. Essa descrição denominamos "contagem".

\subsection{Descrição dos quadrinhos: emissivos e remissivos}

A contagem dos quadrinhos das sete histórias de Território de bravos foi feita, como já dissemos, com base no fazer missivo, dividindo-os em remissivos (fechados [F]) e emissivos (abertos [A]) e na mistura dessas categorias (misto: fechado que tende a aberto $[F \rightarrow A]$ e aberto que tende a fechado $[A \rightarrow F])$. O cálculo pode ser convertido em uma proporção matemática que possibilita verificar na obra de Luiz Gê a relevância das paradas e, por conseguinte, a frequência da presença do antissujeito que causa tais paradas em Território de bravos. Acrescente-se que às categorias de aberto e fechado correspondem as de verbal e nominal, como vimos anteriormente.

Para tal contagem, orientamo-nos pelos espaços brancos, verticais e horizontais, que separam visualmente um quadrinho do outro. Embora tenhamos feito a contagem de todas as HQs de Território de bravos, aqui nesta dissertação serão objeto de análise (capítulo 3) apenas as HQs "Entradas e bandeiras" e "Futboil", que consideramos suficientes para a demonstração de nosso ponto de vista, pois a primeira é de dominância remissiva e a segunda, emissiva. Além disso, a limitação do corpus nos permitiu maior aprofundamento no estudo.

Por exemplo, quando o quadrinho se fecha (dois primeiros quadrinhos abaixo, da direita para a esquerda), instaura-se uma parada (antiprograma), sobressaindo alguma forma de paixão (quadrinho nominal e remissivo), notável ou no olhar dos atores do enunciado, ou na face deles, ou em algum de seus gestos. Todavia, se o sujeito realiza seu programa (terceiro quadrinho abaixo), interrompendo o programa do antissujeito (parada da parada), o quadrinho se abre, sobressaindo, então, uma ação do sujeito (quadrinho verbal e emissivo; ver seção 2.1). Evidentemente, cada "parada" implica uma "parada da parada", e vice-versa, movimentos necessários para a progressão narrativa. 


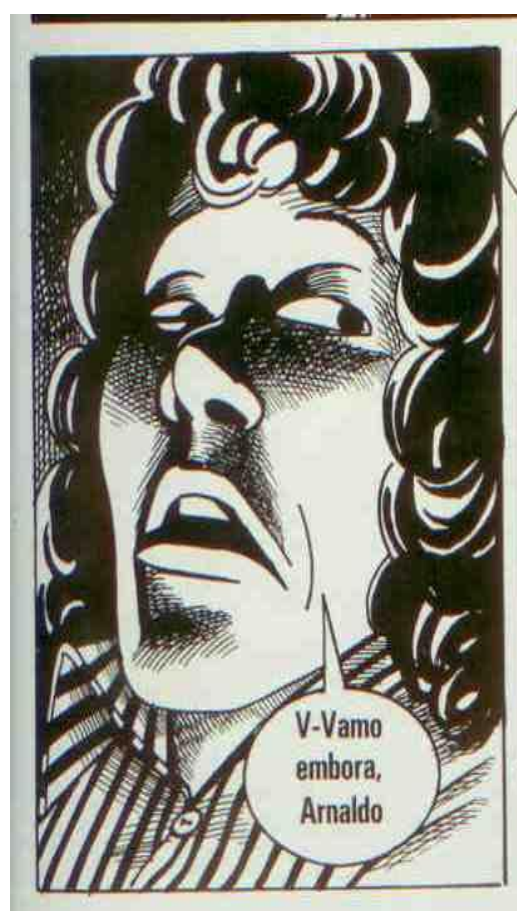

Quadrinho fechado/nominal (parada) $=$ Remissivo

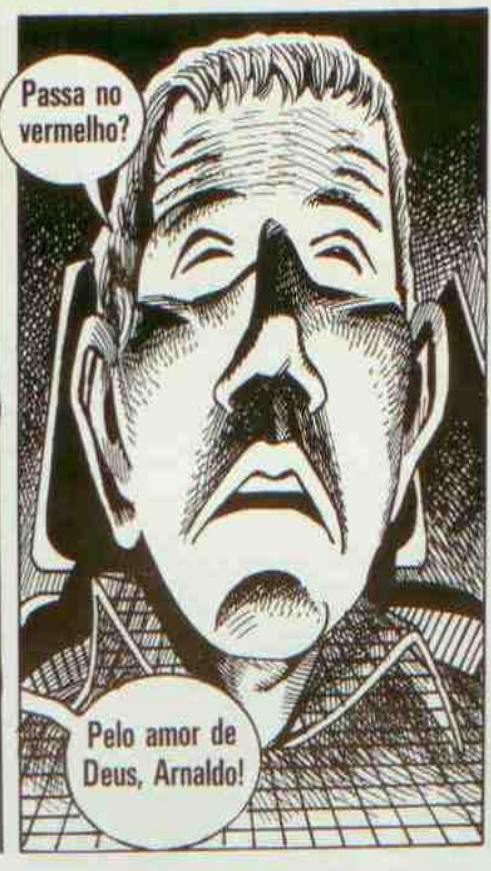

Quadrinho fechado/nominal (continuação da parada)

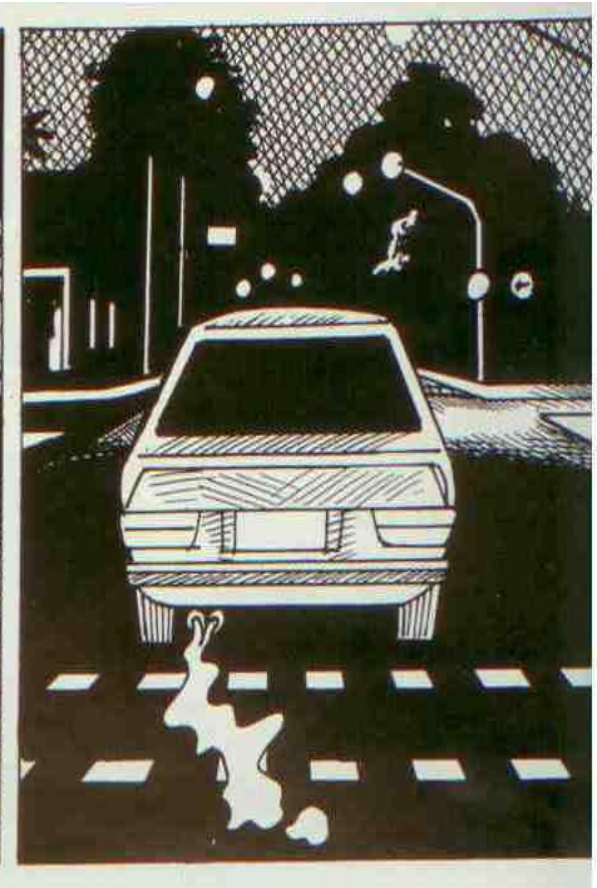

Quadrinho aberto/verbal (parada da parada)

Figura 2.9 Movimentos da progressão da narrativa.

Vejamos como se dá a distribuição dos quadrinhos abertos, fechados e mistos nas histórias de Território de bravos. Acompanha as contagens breve análise de cada HQ.

1. "Entradas e bandeiras"

Eis a contagem dos quadrinhos dessa HQ:

\begin{tabular}{|l|l|l|}
\hline FECHADO (F) & ABERTO $(A)$ & MISTO $(A \rightarrow F ; F \rightarrow A)$ \\
\hline 26 & 4 & 8 \\
\hline
\end{tabular}

Os 38 quadrinhos dessa $\mathrm{HQ}$ possuem uma alternância entre fechamento e abertura, remissividade e emissividade. Vejamos como se dá a sequência dos quadrinhos em "Entradas e bandeiras":

AAFF $\rightarrow$ AFFFFFFFFFFFFF $\rightarrow$ AFFFF $\rightarrow$ AFFFF $\rightarrow$ AFFF $\rightarrow$ AF $\rightarrow$ AFFAAFFA $\rightarrow$ FF $\rightarrow$ A

Nessa classificação, a dominância de quadrinhos fechados (concentrados), que contam com a presença de antissujeitos que interrompem a narrativa do sujeito 
(remissividade), produz o efeito de sentido nominalizante. Enquanto a prevalência de quadrinhos fechados produz, devido à intensidade, um efeito de sentido passional, o pouco número de quadrinhos abertos e extensos produz um efeito de sentido pouco verbalizante em "Entradas e Bandeiras".

2. "Tubarões voadores"

A contagem dos quadrinhos dessa $\mathrm{HQ}$ é a seguinte:

\begin{tabular}{|l|l|l|}
\hline FECHADO (F) & ABERTO $(\mathrm{A})$ & MISTO $(\mathrm{A} \rightarrow \mathrm{F} ; \mathrm{F} \rightarrow \mathrm{A})$ \\
\hline 14 & 9 & 14 \\
\hline
\end{tabular}

Em "Tubarões voadores", notamos equilíbrio entre quadrinhos fechados e quadrinhos mistos. Nessa $\mathrm{HQ}$, tubarões voadores invadem o cotidiano dos moradores de uma cidade (pelas figuras do nível discursivo do Sumário de TB, deduzimos ser São Paulo). Como veremos na análise, poderíamos tomar tanto os tubarões como os moradores da cidade como sujeito do nível narrativo, pois ambos têm seu percurso. Para a contagem, não importa de que perspectiva se constitui o sujeito, visto que é mais relevante para nosso levantamento a parada e a parada da parada, o fazer remissivo e o emissivo.

Vejamos a sequência dos quadrinhos em "Tubarões voadores":

$\mathrm{FF} \rightarrow \mathrm{AA} \rightarrow \mathrm{FA} \rightarrow \mathrm{FA} \rightarrow \mathrm{FA} \rightarrow \mathrm{FFFFFFAA} \rightarrow \mathrm{FFFAFA} \rightarrow \mathrm{FAFA} \rightarrow \mathrm{FFAAFAA} \rightarrow \mathrm{FF} \rightarrow \mathrm{AA} \rightarrow \mathrm{FAFA} \rightarrow \mathrm{FFAAA} \rightarrow \mathrm{FA} \rightarrow \mathrm{F}$

$\mathrm{O}$ reduzido número de quadrinhos abertos nessa $\mathrm{HQ}$ produz um efeito de parada nas atividades cotidianas em virtude do percurso dos tubarões. A diferença do ritmo de quadrinhos abertos e fechados entre "Entradas e bandeiras" e "Tubarões voadores" mostra que neste último a presença equilibrada de quadrinhos mistos (14) e de fechados (14) produz um efeito de sentido que no nível discursivo pode ser visto como um simulacro do ataque dos tubarões. 
3. "Errare marcianum est"

Observemos a contagem de seus quadrinhos:

\begin{tabular}{|l|l|l|}
\hline FECHADO $(F)$ & ABERTO $(A)$ & MISTO $(A \rightarrow F ; F \rightarrow A)$ \\
\hline 17 & 5 & 3 \\
\hline
\end{tabular}

Nessa $\mathrm{HQ}$, o número elevado de quadrinhos fechados, de remissividade portanto, evidencia no nível narrativo o percurso do antissujeito, provocador de interrupção no percurso do sujeito. Pelo nível discursivo, notamos que dois atores (antissujeito da narrativa) agentes da Roto-Rooter, vindos de fora do espaço, trazem más notícias (corte do financiamento pela agência) ao Gerente Geral e sua comitiva. Esse fato interrompe a sua rotina com a finalidade de programar a independência da Roto-Rooter. A frequência elevada de interrupção no percurso pode ser notada pela grande quantidade de quadrinhos fechados e pela presença do fazer remissivo que interrompe a emissividade anterior.

Vejamos a sequência dos quadrinhos em "Errare marcianum est":

$$
\text { AA } \rightarrow \text { FFAFFFF } \rightarrow \text { AFFFFFFFFAFFFF } \rightarrow \text { AAFA }
$$

Trata-se de uma $\mathrm{HQ}$, portanto, marcada pela escolha de valores remissivos por parte da instância da enunciação.

4. "Quem matou Papai Noel?"

Vejamos a contagem dos quadrinhos dessa $\mathrm{HQ}$ :

\begin{tabular}{|l|l|l|}
\hline FECHADO $(F)$ & ABERTO $(A)$ & MISTO $(A \rightarrow F ; F \rightarrow A)$ \\
\hline 43 & 10 & 29 \\
\hline
\end{tabular}

O título da HQ "Quem matou Papai Noel?”, no nível discursivo, leva o enunciatário a imaginar uma sequência de quadrinhos verbais, emissivos, repletos de ações. No entanto, a dominância das descontinuidades instaladas pelo antissujeito provoca o efeito de sentido passional (quadrinhos nominais, fechados e remissivos). A seguir, a sequência dos quadrinhos dessa $\mathrm{HQ}$ : 
AFFF $\rightarrow$ AAFFF $\rightarrow$ AFAFFFFFA $\rightarrow$ FA $\rightarrow$ FFFAFFFFA $\rightarrow$ FFFF $\rightarrow$ AA $\rightarrow$ FFFA $\rightarrow$ FA $\rightarrow$ FA $\rightarrow$ FF $\rightarrow$ AAAAF $\rightarrow$ AAFFF $\rightarrow$ AFA $\rightarrow$ FA $\rightarrow$ FFF FFFFFFFA $\rightarrow$ FA $\rightarrow$ FA $\rightarrow$ FA $\rightarrow$ FA $\rightarrow$ FA $\rightarrow$ FA $\rightarrow$ FA $\rightarrow$ FA $\rightarrow$ FF $\rightarrow$ AA $\rightarrow$ FA $\rightarrow$ FFFFFA $\rightarrow$ FFFFFFF $\rightarrow$ AFAA

Interrupções frequentes, provocadas pelo antissujeito, contribuem para uma quase ausência de verbalização, de continuidade. No nível discursivo, o ator Arlindo tem pouco dinheiro para presentear os filhos. No narrativo, o sujeito espera entrar em conjunção com o objeto esperado. Todavia, o antissujeito não permite tal conjunção. Temos aqui uma HQ extremamente nominal e passional: o sujeito tem ataques de cólera ao perceber que não pode alcançar o objeto almejado. Daí o excesso de quadrinhos fechados, nominais e remissivos, como vimos no diagrama acima.

\section{5. "Futboil"}

Observemos como se comportam os quadrinhos:

\begin{tabular}{|l|l|l|}
\hline FECHADO (F) & ABERTO $(A)$ & MISTO $(A \rightarrow F ; F \rightarrow A)$ \\
\hline 22 & 47 & 24 \\
\hline
\end{tabular}

Diferentemente das quatro HQs anteriores, nesta predominam quadrinhos abertos, emissivos, em que o sujeito está em busca do objeto. No nível discursivo, meninos correm atrás de um balão que cai do céu. Na primeira cena, o quadrinho vai da abertura (verbal: jogavam bola) para o fechamento (interrompem [parada] a partida de futebol para dar início à corrida em busca de um balão). Essa HQ confirma o ponto de vista que defendemos nesta dissertação: se há escolha de valor emissivo, o quadrinho é aberto (verbal); se a instância enunciativa escolhe valor remissivo, o quadrinho é fechado (nominal). Em um caso, temos progressão narrativa (difusão); em outro, concentração, que pode fazer aflorar valores patêmicos. Portanto, mais uma vez, temos configurada estruturalmente uma gramática das HQs; noutros termos, nominalização (fechamento, remissividade) e verbalização (abertura, emissividade) inter-relacionam-se para permitir a continuidade ou a descontinuidade do programa narrativo.

Temos, então, na quinta HQ de TB, o seguinte diagrama: 
A $\rightarrow$ FFFFA $\rightarrow$ FFFAA $\rightarrow$ FFFFAAAAAAAAFAAAAAAAAAAAFAAFAAFFAFAAFAAA $\rightarrow$ FF $\rightarrow$ AFF $\rightarrow$ AAAAAAA $\rightarrow$ FFAAAAFFA $\mathrm{A} \rightarrow \mathrm{FAAAAAAAA} \rightarrow \mathrm{FA} \rightarrow \mathrm{FA} \rightarrow \mathrm{FA} \rightarrow \mathrm{FFFFA} \rightarrow \mathrm{FAA} \rightarrow \mathrm{FA} \rightarrow \mathrm{FA} \rightarrow \mathrm{FF} \rightarrow \mathrm{AA} \rightarrow \mathrm{FAF} \rightarrow$ AFAAFF $\rightarrow$ AFFA

6. "Uma história de amor"

Nossa contagem dos quadrinhos dessa HQ revelou:

\begin{tabular}{|l|l|l|}
\hline FECHADO (F) & ABERTO $(A)$ & MISTO $(A \rightarrow F ; F \rightarrow A)$ \\
\hline 58 & 7 & 32 \\
\hline
\end{tabular}

"Uma história de amor", sexta HQ de Território de bravos, é dividida em duas partes: a primeira vai do quadrinho 1 ao 87 e a segunda, de 88 a 97. São dois espaços que se relacionam, um revela no enunciado a fantasia e outro, o cotidiano da vida no espaço urbano. Ao tomar contato com a segunda parte da $\mathrm{HQ}$, ao enunciatário é revelado que aquilo que parecia duelo medieval era "fantasia" de criança. Ser e parecer estão em jogo, nesse caso. O que na primeira parte parece duelo não é; é ilusão, apenas brincadeira de criança.

Nesse jogo, euforiza-se o ludus, espaço apropriado às manifestações artísticas. À semelhança dos jogos, cuja característica fundamental é a fantasia, também as artes se caracterizam pela criação de mundos fantásticos. Nesse sentido, os últimos quadrinhos sugerem, no enunciado, a vida fechada em apartamentos da cidade em oposição à vida fantasiosa (quadrinhos de 1 até 87):

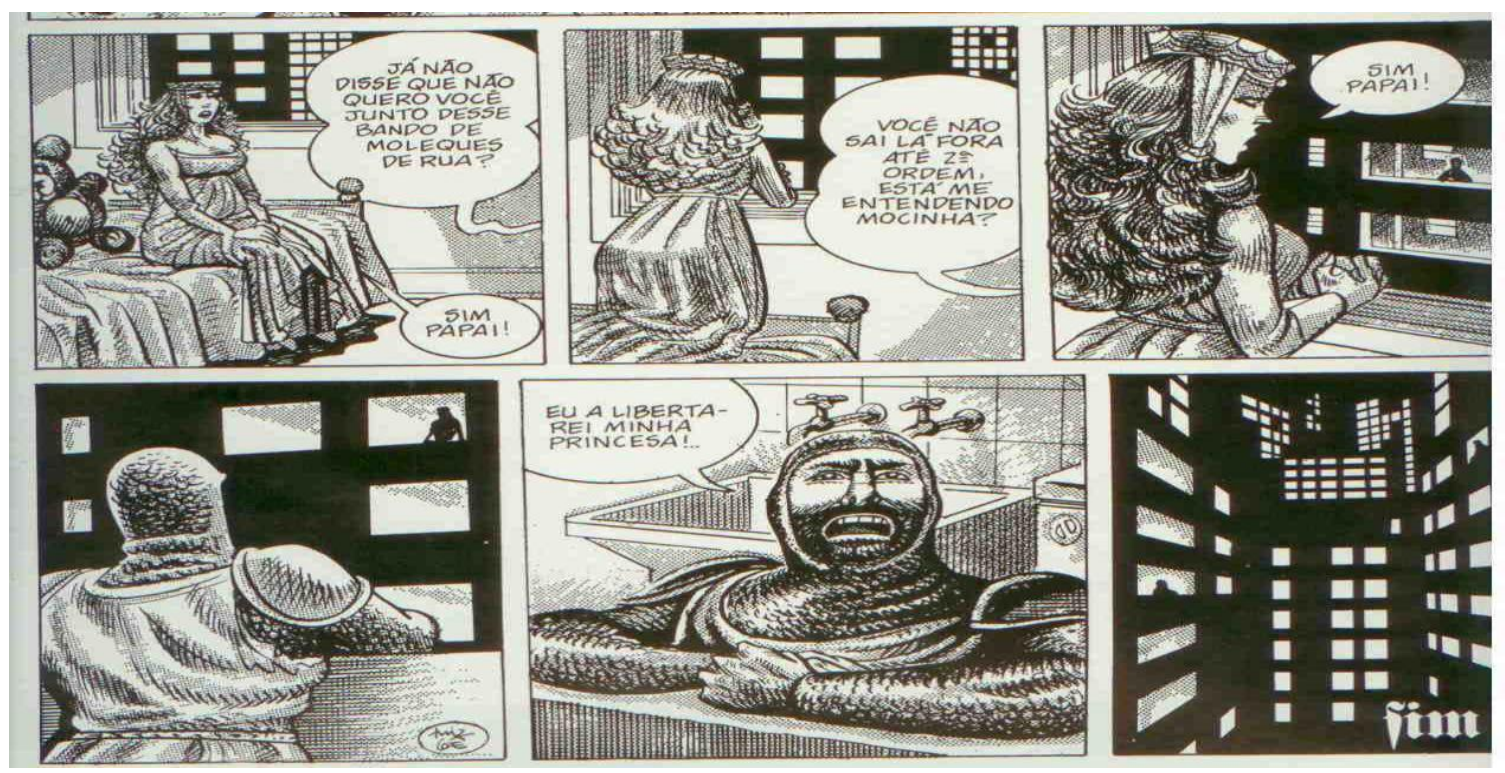

Figura 2.10 
Quadrinhos nominais (fechados, remissivos) revelam aqui a forte presença do antissujeito na primeira parte dessa $\mathrm{HQ}$; temos em verdade um simulacro: parece antissujeito, mas não é. É apenas um simulacro de um folguedo, como brincadeira de bandido e mocinho, em que se constitui o ator bandido em antissujeito; no caso dessa HQ, não é uma brincadeira de bandido e mocinho, mas de uma donzela que é objeto da disputa de dois sujeitos (quando há disputa, um deles é antissujeito do outro). Todavia, verificamos na segunda parte dessa $\mathrm{HQ}$ que o antissujeito, o que não parece mas é, é figurativizado no pai de Helena e na mãe de Marcello, todos atores do enunciado.

Os sujeitos (atores crianças) querem continuar a brincadeira, mas são impedidos pela ação do antissujeito (atores pais) que os retira da fantasia e os recoloca no cotidiano com seus deveres (ações deônticas, como comer, lavar as mãos, dormir etc.). Enquanto o antissujeito da fantasia é constituído apenas por uma delegação de papéis na brincadeira de "donzela e cavaleiros", de ações da ordem do ludus, o antissujeito do cotidiano promove ações da ordem da obrigação, do bem e não do bom. No enunciado, as figuras das "crianças" promovem a isotopia da liberdade, que pode instaurar e superar um antissujeito, a qualquer momento, conforme estipulado pelo jogo.

A título de ilustração, na música "João e Maria", de Chico Buarque, podemos verificar como a fantasia pode criar sujeitos e antissujeitos na narrativa, numa simples troca de atores do enunciado, assumindo a cada momento do "fazer-de-conta" uma figura diferente. (Agora eu era o herói/Agora eu era o rei/Era o bedel/ Era também juiz/Finja que agora eu era o seu brinquedo/Eu era o seu pião/O seu bicho preferido [...] Agora era fatal/Que o fazde-conta terminasse assim):

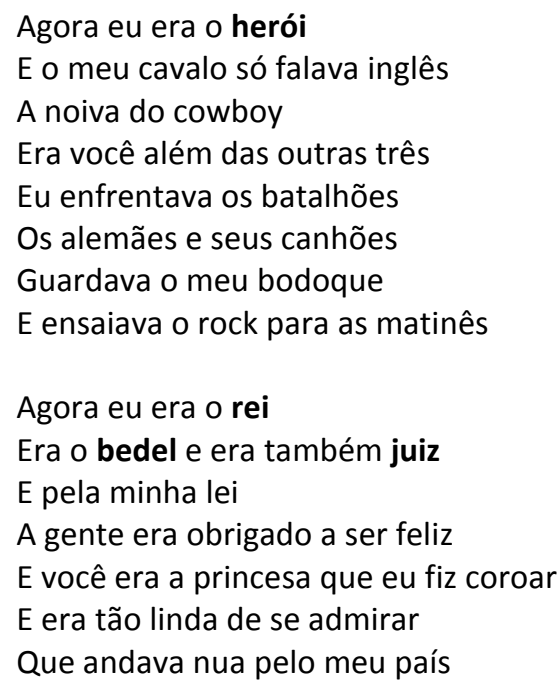


Não, não fuja não

Finja que agora eu era o seu brinquedo

Eu era o seu pião

O seu bicho preferido

Vem, me dê a mão

A gente agora já não tinha medo

No tempo da maldade acho que a gente nem tinha nascido

Agora era fatal

Que o faz-de-conta terminasse assim

Pra lá deste quintal

Era uma noite que não tem mais fim

Pois você sumiu no mundo sem me avisar

E agora eu era um louco a perguntar

O que é que a vida vai fazer de mim?

Da mesma forma, os atores de "Uma história de amor" constroem um mundo de fantasia por meio da brincadeira, o "faz-de-conta" do duelo, interrompido pelo mundo utilitário quando os pais os chamam de volta para o apartamento. A figura da liberdade do mundo da fantasia manifesta-se aqui como um escape para a opressão do cotidiano.

As figuras paternas promovem a isotopia da restrição de liberdade em relação ao sujeito da fantasia. Daí o efeito de sentido dominante em Território de bravos de a fantasia dever conviver com o cotidiano e este solicitar a entrada da fantasia (parada da continuação do percurso do sujeito do dever). Na HQ em questão, o antissujeito é presença marcada, visto o número elevado de quadrinhos fechados (nominais e remissivos). Veja os diagramas a seguir, levando em conta a divisão em duas partes da HQ em questão:

Quadrinhos 1 a 87 [brincadeira das crianças: donzela e cavaleiro]

$$
\begin{aligned}
\text { A } \rightarrow \text { FA } \rightarrow \text { FFFFFFFFFF } & \rightarrow \text { AF } \rightarrow \text { AAFFAAFA } \rightarrow \text { FAFFFA } \rightarrow \text { FAA } \rightarrow \text { FA } \rightarrow \text { FFFFFFFFFFF } \rightarrow \text { AFFFFFF } \rightarrow \text { AFFFFFFFFFFF } \rightarrow \text { AF } \rightarrow \text { AA } \rightarrow \text { FFFA } \rightarrow \text { FA } \\
& \rightarrow \text { FA } \rightarrow \text { FA } \rightarrow \text { FFA } \rightarrow \text { FA } \rightarrow \text { FF } \rightarrow \text { AF } \rightarrow \text { AF } \rightarrow \text { AFFFFF } \rightarrow \text { AA } \rightarrow \text { FA } \rightarrow \text { FFA } \rightarrow \text { FFF } \rightarrow \text { AFFF } \rightarrow \text { AF } \rightarrow \text { AFA }
\end{aligned}
$$

Quadrinhos 88 a 97 [cotidiano dos atores do enunciado no apartamento] 
O que se nota nas duas partes dessa $H Q$ são dois tipos de remissividade (fechamento). Enquanto na primeira parte da HQ há a delegação de um antissujeito "criado" pelo fazer-de-conta (um fechamento, portanto), um antiprograma pertencente ao duelo infantil, na segunda parte a remissividade configura outro antiprograma que se constitui em novo fechamento, agora da ordem do cotidiano. Nesse segundo caso, o mundo da fantasia cede espaço para o simulacro do mundo natural: os atores pais, que no nível narrativo se constituem em antissujeito do sujeito (atores crianças), acabam com a brincadeira, obrigando as crianças a retomarem a rotina. Dessa forma, enquanto no jogo o antissujeito é uma brincadeira, um faz-de-conta, cujas peças podem ser movimentadas, conforme as escolhas enunciativas dos jogadores, no cotidiano, o aparecimento de um antissujeito não pode ser regulado pelo sujeito, a seu bel-prazer; daí o espaço para o sobrevir, o inesperado.

No duelo fantasiado em "Uma história de amor", o sobrevir pode ser regulado pelo parvenir. Dessa forma, na brincadeira da primeira parte da $\mathrm{HQ}$, a previsibilidade da surpresa é regulada; na segunda parte da $\mathrm{HQ}$, no cotidiano das crianças, mesmo que saibam das características repressoras de comportamento dos pais, elas não podem "prever" o inesperado. Assim, talvez os pais surpreendam as crianças no momento em que não tinha que ser ainda, colocando um fim na brincadeira.

Os atores crianças, como numa poiese, põem e dispõem, conforme as necessidades do jogo. Temos, então, um antissujeito instaurado à semelhança da criação de um objeto artístico. Ora, quando um enunciador artista, poeta, contista, quadrinista, cria um objeto, ele também escolhe valores emissivos e remissivos, sem nenhuma restrição de ordem deôntica: o antissujeito capaz de instaurar paradas nos percursos (fazer remissivo) pode ser superado ao gosto do enunciador. Dois valores fundamentais ressaltam-se de "Uma história de amor": liberdade versus restrição. A primeira está euforizada nos quadrinhos de 1 a 87 . A segunda, disforizada nos quadrinhos de 88 a 97.

Ao realizar a contagem de quadrinhos abertos e fechados dessa sexta $\mathrm{HQ}$ de Território de bravos, notamos que o enunciador escolhe valores que privilegiam a fantasia, colocando em seu enunciado figuras que nos levam à isotopia das artes.

Exemplos dessa escolha de valores artísticos por parte da instância enunciativa levam o enunciatário de Luiz Gê a deparar com elementos da ordem da intertextualidade, uma característica da arte moderna e contemporânea. No enunciado da capa de Território de 
bravos, verificamos um diálogo com filmes de faroeste, dos quais são importadas as figuras do cavaleiro em busca do desbravamento de um espaço não habitado. Essas figuras mostram um tempo e um espaço de uma cidade ainda despovoada e de uma cidade moderna em que sobressaem figuras de automóveis com passageiros, presos em um engarrafamento. O teto dos automóveis da cidade povoada corresponde ao chão da antiga cidade, como se pode ver no pé da capa no anexo desta dissertação.

A intertextualidade com as mais variadas artes continua presente em outras HQs de Território de bravos. No enunciado da primeira HQ, a figura do "Monumento às Bandeiras" de Brecheret é outro exemplo que manifesta a isotopia das artes no livro de Luiz Gê. Em "Tubarões voadores", há intertextualidade com o filme Os tubarões, que Spielberg dirigiu em 1975. A paródia na obra do artista plástico sob análise produz um efeito de sentido diferente do de Spielberg: enquanto no filme o ator homem está no espaço dos tubarões, em Luiz Gê são os atores tubarões que invadem o espaço do homem. Noutros termos, o espaço da fantasia não conhece as restrições do mundo cotidiano, isotopia que reencontraremos em "Uma história de amor".

Em "Errare macianum est", o enunciador estabelece um diálogo intertextual com a tela de "O Grito da Independência" de Pedro Américo (ver Introdução), que pode ser vista no Museu Paulista (Museu do Ipiranga). E, finalmente, em "Uma história de amor", a intertextualização dá-se com Marcello Grassmann, desenhista e xilógrafo, de tradição expressionista e fantástica da arte da Europa Central. Grassmann desenha o mundo de damas e cavaleiros medievais de fantasmagorias e monstros criados pelo sonho da razão, à moda de Goya.

A obra de Marcello Grassmann pode ser vista no MAM, na Pinacoteca, no MASP. O enunciado da HQ de Luiz Gê dialoga com "A morte e a donzela" de Grassmann cujos desenhos são feitos com lápis litográfico. Como veremos nas análises do capítulo 3 desta dissertação, o enunciador seleciona valores que rompem com o cotidiano; daí um enunciado marcado por remissividade. A paixão dos atores, por exemplo, é revelada no enunciado de "Uma história de amor" por quadrinhos nominais e remissivos, fechados, portanto. A expressão facial dos atores, quando tomados pela paixão, dialoga com o expressionismo alemão. 
Se tomarmos dois desenhos de Grassmann, como os seguintes da série "A morte e a donzela" (figura 2.11 A e B), verificaremos que os enunciados de Luiz Gê de fato dialogam intertextualmente com eles. Muitos dos traços do xilógrafo sobressaem em uma "História de amor" (figura 2.12):

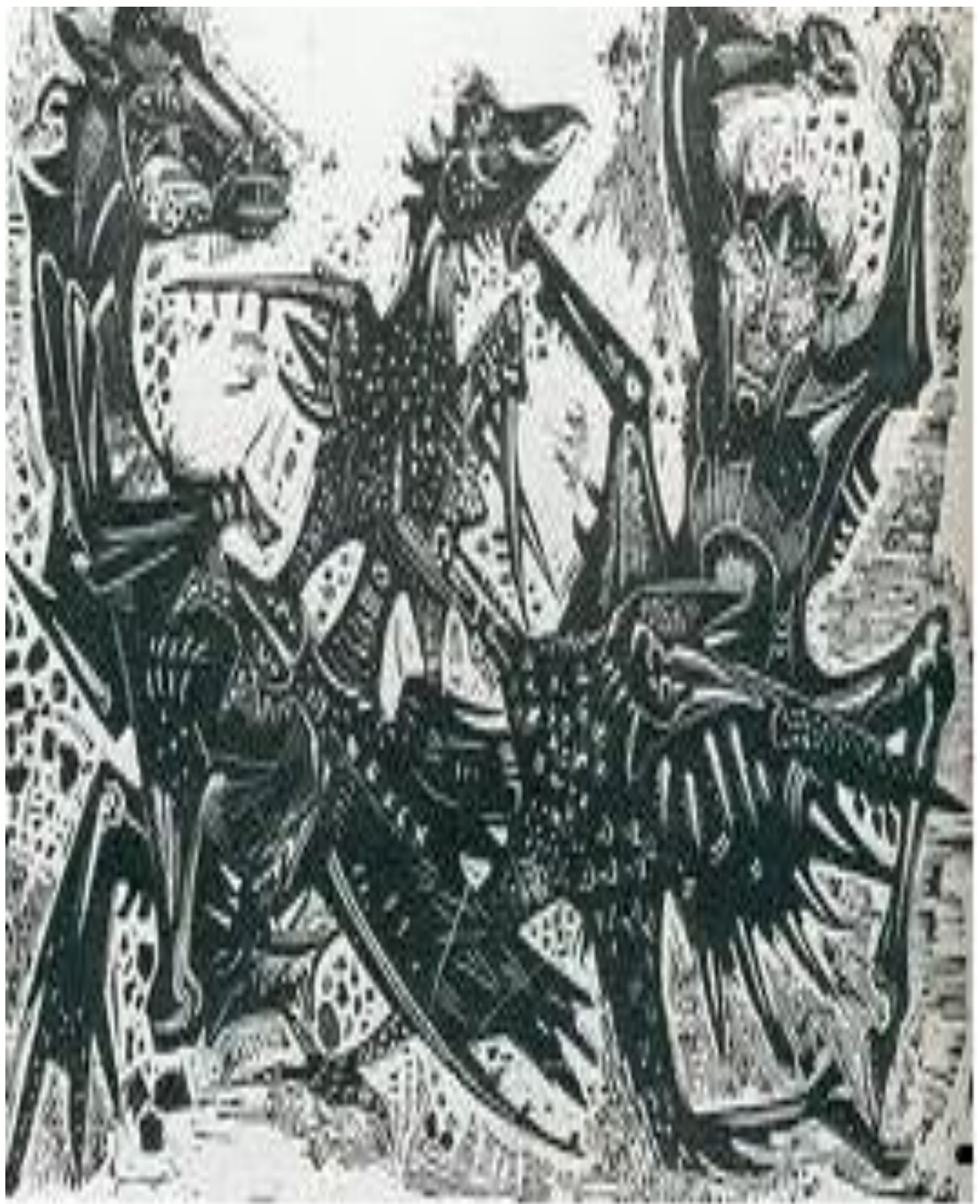

Figura 2.11A 


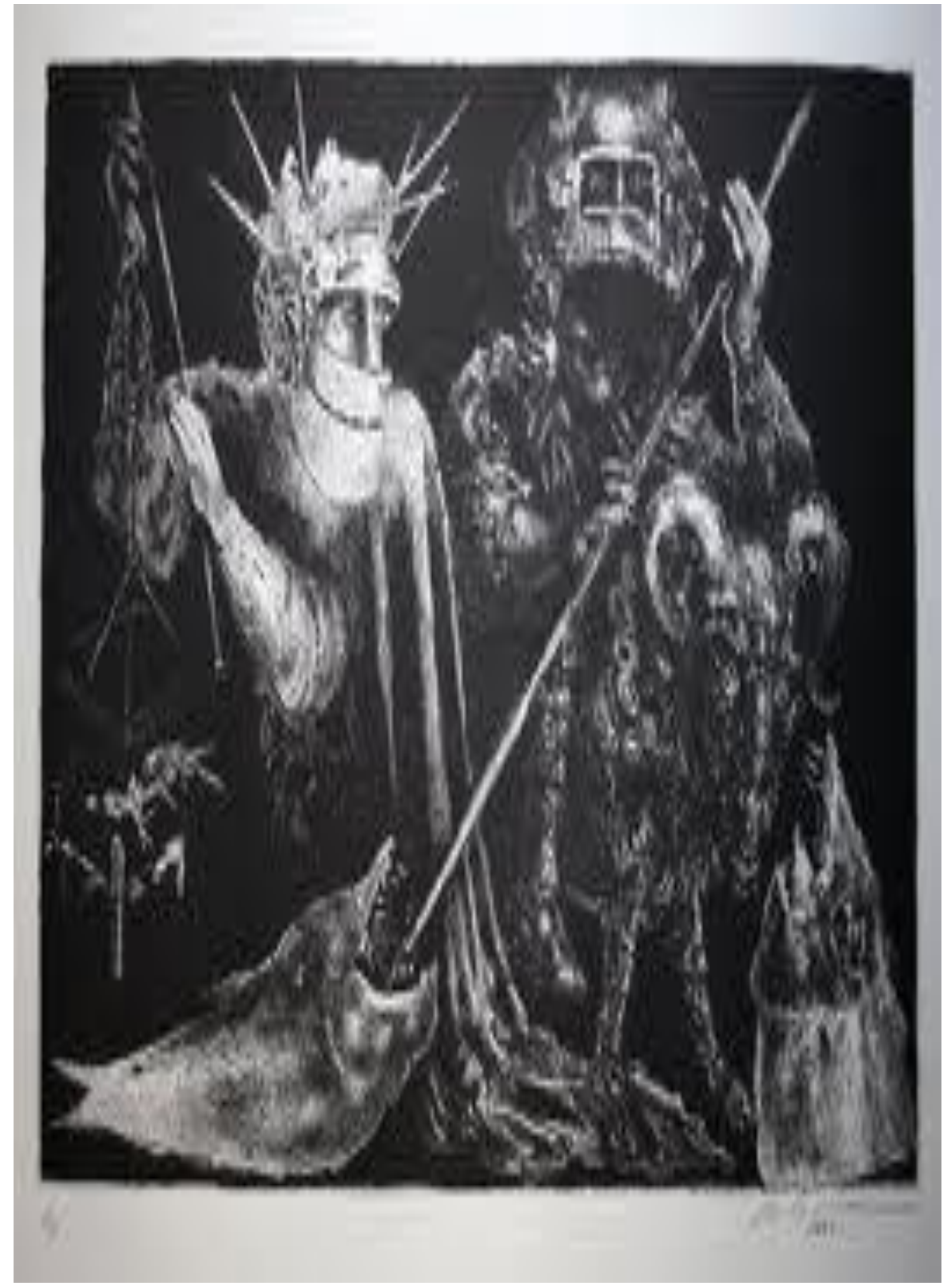

Fonte: Disponível em: <http://www.germinaliteratura.com.br/officina15.htm>. Acesso em: 13 set. 2010.

Figura 2.11B 
Em Luiz Gê (p. 57):

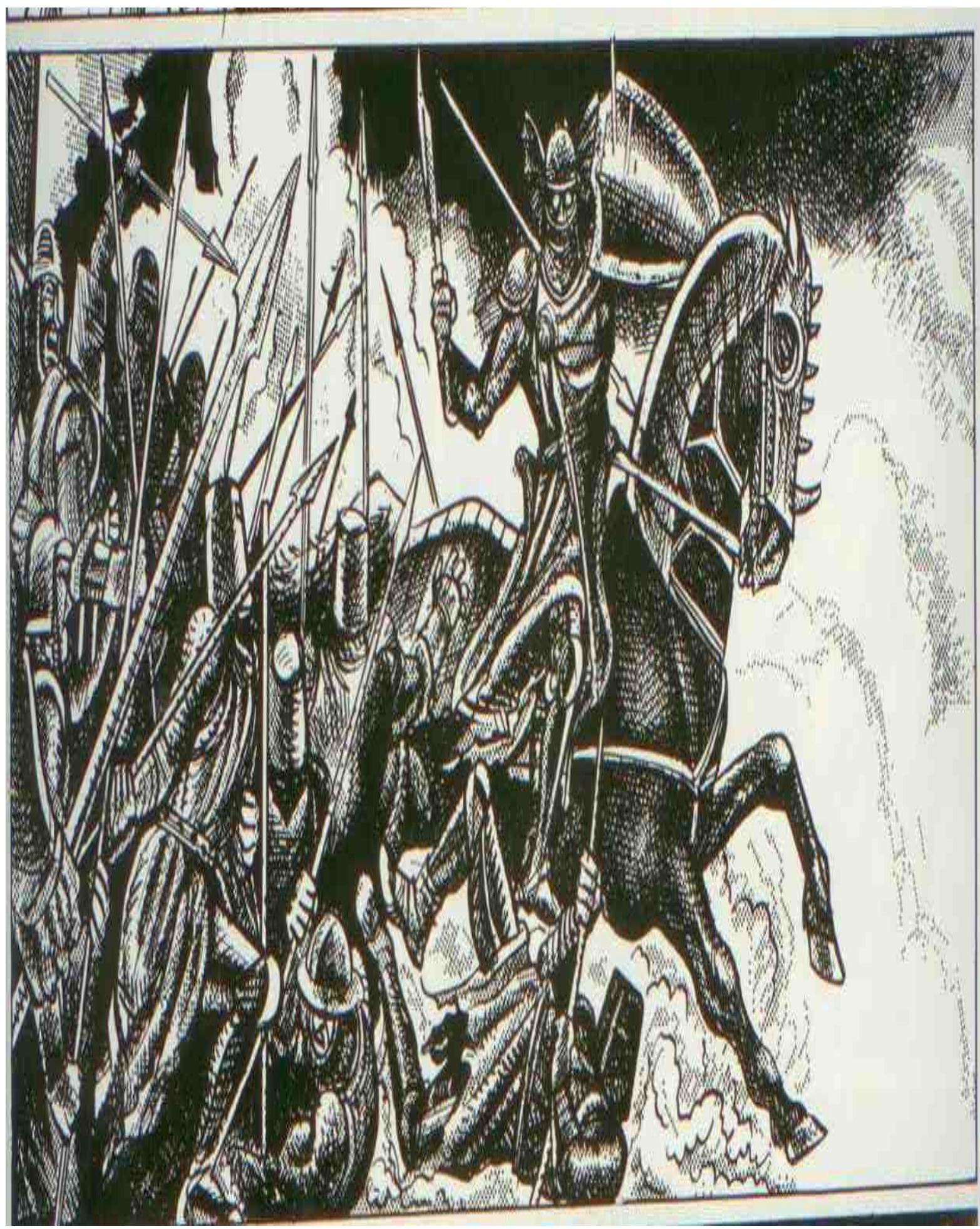

Figura 2.12

Ambos, Grassmann e Gê, nesse caso, são expressionistas, ocupando-se da remissividade, da prevalência do ser sobre o fazer, do nominal sobre o verbal. 
É essa constância de opção pela remissividade, pela nominalização, que faz de nosso artista Luiz Gê não um simples contador de histórias em quadrinhos que leva em conta sobretudo a narrativa, mas um artista preocupado com o ser e não com o fazer apenas. Tanto é assim que até a contagem dos quadrinhos da sexta $\mathrm{HQ}$ sobressaem valores remissivos, nominais, que configuram paixões e não ações puras e simples, como em Quino, Milo Manara, Lourenço Mutarelli, por exemplo, autores que se ocupam particularmente de valores emissivos (difusos).

Ao escolher figuras das artes (diálogo com obras de Pedro Américo, Grassmann, Brecheret), nosso enunciador euforiza a arte e transforma as HQs em objeto artístico. Daí denominarmos Território de bravos de HQ artística. Diferentemente, pois, de quadrinistas em cujo objetivo predomina um fazer emissivo, com histórias de narrativas canônicas. São textos que Fiorin (2008c, p. 65) chama de a "grande literatura" que acabaram por solicitar à semiótica um estudo mais refinado, como os estudos das paixões e o da tensividade. Enquanto nos textos canônicos predomina a implicação no percurso dos sujeitos, nas HQs artísticas e nos textos da "grande literatura" é a concessão que é predominante na narrativa dos sujeitos.

$\mathrm{Na}$ implicação, temos a previsibilidade; uma lógica regula a linearidade dos enunciados. Na concessão, temos a surpresa, o survenir, governado pelo sensível. Se o enunciador de Território de bravos tivesse optado por simplesmente desfiar histórias, talvez escolhesse outra estrutura narrativa, fazendo predominar valores emissivos, verbais; abertos, portanto.

7. "Perdidos no espaço"

A contagem dos quadrinhos dessa $\mathrm{HQ}$ é a seguinte:

\begin{tabular}{|l|l|l|}
\hline FECHADO (F) & ABERTO (A) & MISTO $(A \rightarrow F ; F \rightarrow A)$ \\
\hline 14 & 23 & 19 \\
\hline
\end{tabular}

Se confrontarmos o último quadrinho da tira de Presidente Reis (figura 2.13), que antecede "Uma história de amor" com o último quadrinho da mesma $\mathrm{HQ}$, verificaremos que a solidão do homem moderno é um tema comum: solidão do ator Presidente Reis, cercado de centenas de pessoas, à procura, em um orelhão, de algum atendente do CVV (Centro de 
Valorização da Vida), e solidão dos atores crianças fechados em um apartamento (figura 2.14).
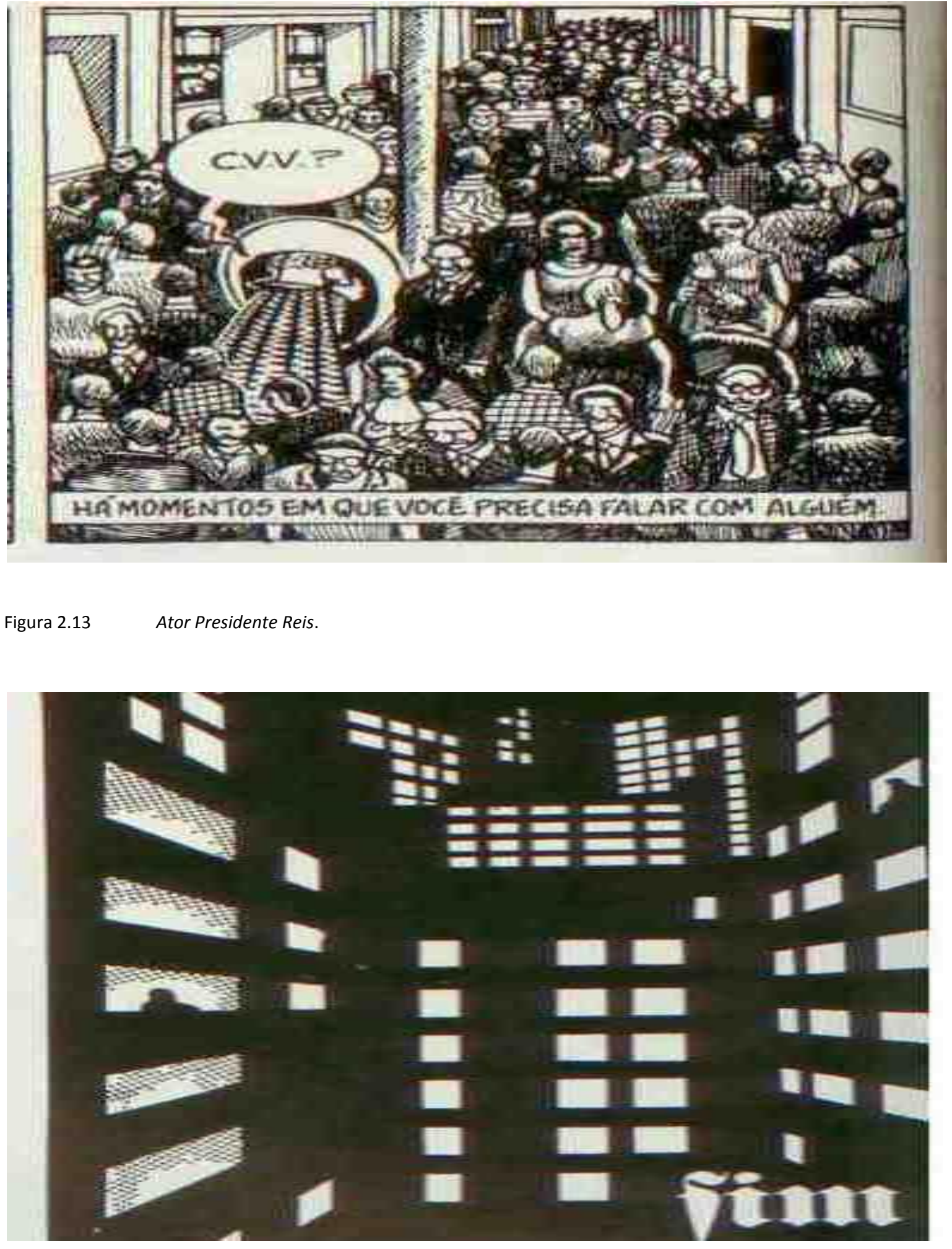
Em "Perdidos no espaço", última HQ do livro, novamente o enunciador retoma o tema da solidão e temos um ator no enunciado sozinho diante de um aparelho de televisão. Paralelamente a esse percurso do sujeito em estado de relaxamento, de tédio do cotidiano, sem perspectiva de aparecimento de antissujeito para interromper a ordem da rotina, verificamos um segundo percurso figurativizado por um ator tatu-bola de jardim que desenvolve seu programa pelo interior do apartamento. Esse segundo sujeito, diferentemente do primeiro, tem seu percurso constantemente ameaçado por antissujeitos figurativizados pelo ator gafanhoto e, por último, pelo ator homem. Como em uma fábula, o ator tatu-bola de jardim figurativiza ações humanas de ataque, de guerra, de defesa, sobressaindo a isotopia da guerra. A propósito, o apartamento transforma-se em um espaço em que o sujeito 2 (ator tatu) desenvolve um percurso semelhante ao de um soldado que segue as ordens de um destinador maior, sempre tendo em vista superar o antissujeito (ator gafanhoto, depois ator homem).

A isotopia da guerra é figurativizada nessa HQ por "capitão", "tenente", "nave de combate", "alerta", "velocidade máxima", "bombordo 0-30", "timoneiro", "ativar superpotência", "3/4 à frente", "alternar rumo para estibordo 0-20", "velocidade de cruzeiro até segunda ordem", "reduzir velocidade a 1/3", "deixe-me paralisá-lo, senhor", "cancelar ordens de combate", "toda força à frente", "motores entrando em superaquecimento", "alô, comandante", "fechar couraça! fechar couraça!", "acionar geometria defensiva".

As figuras de gafanhoto e do tatu-bola parecem realizar (mas não realizam) um percurso de atores que poderiam configurar uma isotopia da natureza; no entanto, configuram uma isotopia em que prevalecem elementos bélicos: o sujeito (ator tatu bola) tem em seu campo de presença, em um primeiro momento, um antissujeito figurativizado por um ator de seu espaço natural (gafanhoto). Ele tem competência (saber fazer) para superar o primeiro obstáculo (antissujeitos da macrossemiótica do mundo natural), mas não tem o mesmo saber nem o poder para superar o segundo antissujeito, ator homem.

É de ressaltar nessa HQ a ausência de antissujeito para o sujeito 1, figurativizado pelo ator homem. Daí prevalecerem na HQ quadrinhos abertos, emissivos, em que não há para o sujeito 1 nenhum obstáculo à vista, que Ihe causaria uma parada no relaxamento de seu cotidiano. A presença do sujeito 2 não configura antissujeito para o sujeito 1 , visto que ele tem o saber e o poder para superar a bel-prazer o ator-tatu bola de jardim, jogando-o no 
vaso sanitário. No entanto, o percurso do sujeito 2 (ator tatu) transforma-se no principal programa dessa HQ. Este último, sim, tem antissujeito, paradas, remissividade, nominalizações (prevalência de quadrinhos fechados).

A seguir, mostramos a prevalência de quadrinhos abertos, indicativos da emissividade e do relaxamento do cotidiano do sujeito 1 . No entanto, somando quadrinhos mistos com fechados, temos um quantitativo que supera os abertos, e novamente podemos verificar no percurso do sujeito 2 a tendência de nosso enunciador pela remissividade que nominaliza, manifestando paixões movidas pelas aproximações do antissujeito com seu antiprograma.

A $\rightarrow$ FAAAAAAAAA $\rightarrow$ FA $\rightarrow$ FA $\rightarrow$ FA $\rightarrow$ FA $\rightarrow$ FFFF $\rightarrow$ AAAAAA $\rightarrow$ FAAA $\rightarrow$ FF $\rightarrow$ AFFFF $\rightarrow$ AAA $\rightarrow$ FAAAAAA $\rightarrow$ FFA $\rightarrow$ FFFFFFF $\rightarrow$ AF $\rightarrow$ AA $\rightarrow$ FAFA $\rightarrow$ FFF $\rightarrow$ AA

Concluindo essas observações, o apagamento do percurso do sujeito 1 (ator homem) pode ser notado pelo uso de metonímia no enunciado (a parte pelo todo). Em nenhum momento nos enunciados dessa $\mathrm{HQ}$, há a figura do rosto do homem, que seria sua identidade. Vemos apenas pernas, sapatos, mão, dedos, braço (figura 2.15).

A isotopia da solidão e da guerra é também verificável na tira que antecede essa HQ: Presidente Reis cercado de automóveis parados no congestionamento grita desesperadamente (figura 2.16): “Há alguém vivo aí???”. É como se ele fosse o único sobrevivente em um campo de batalha. A essa isotopia da solidão acrescenta-se a da falta de identidade. Essa não identificação (não aparece em nenhum momento da $\mathrm{HQ}$ a figurativização do rosto), própria de regimes opressores, configura o efeito de sentido de ausência de responsabilidade em uma ação. Como se trata de uma relação entre um sujeito mais poderoso (sujeito 1) e um mais frágil (sujeito 2), tatu-bola, não haveria como sancionar diretamente o autor da ação. Noutros termos, teríamos um sujeito de força maior, tônico, em oposição ao outro sujeito, átono, identificado no nível discursivo por um tatu-bola. Como em "Entradas e bandeiras", "Perdidos no espaço" configura-se uma fábula. 

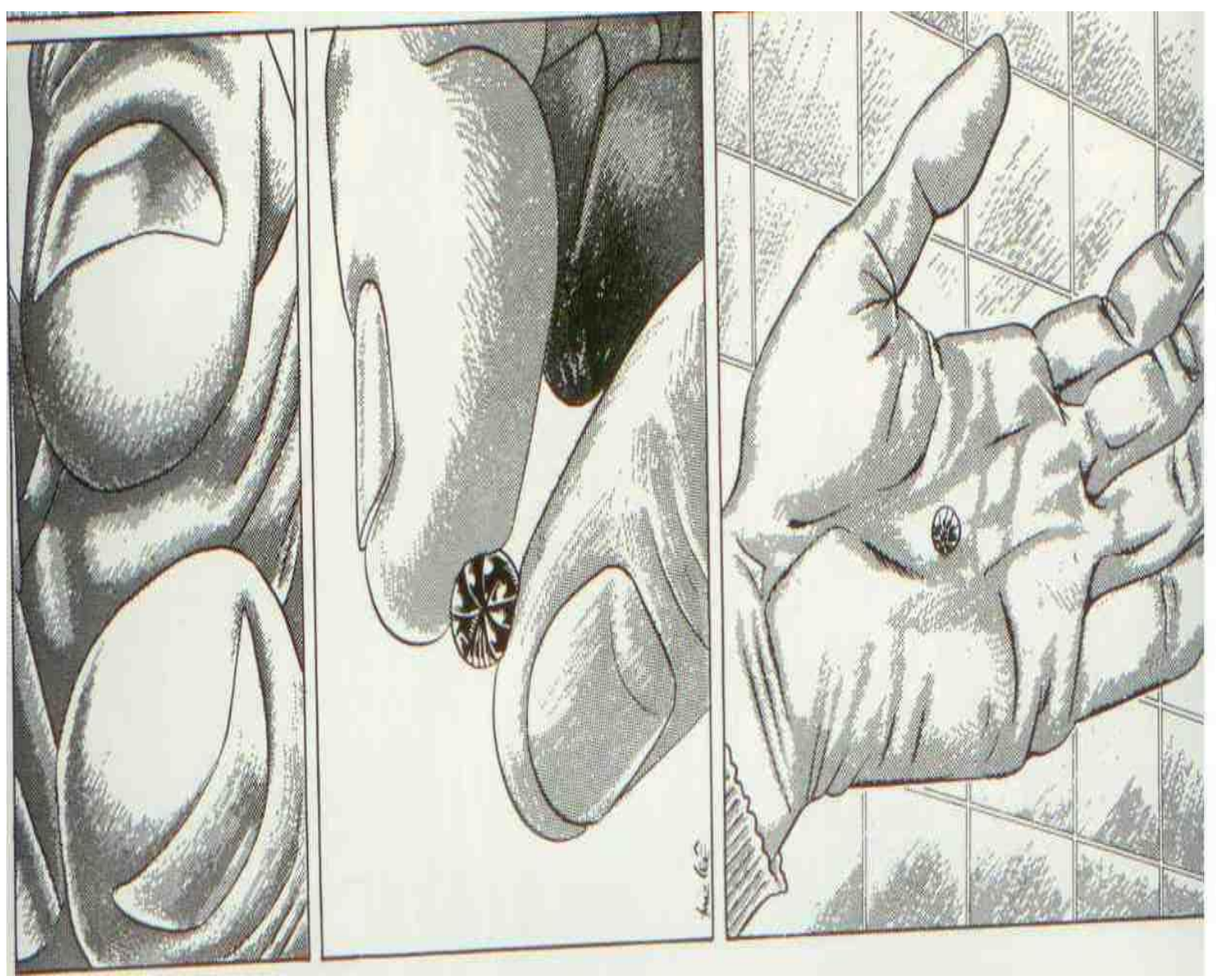

Figura 2.15

Figuras metonímicas do homem (dedo e mão).

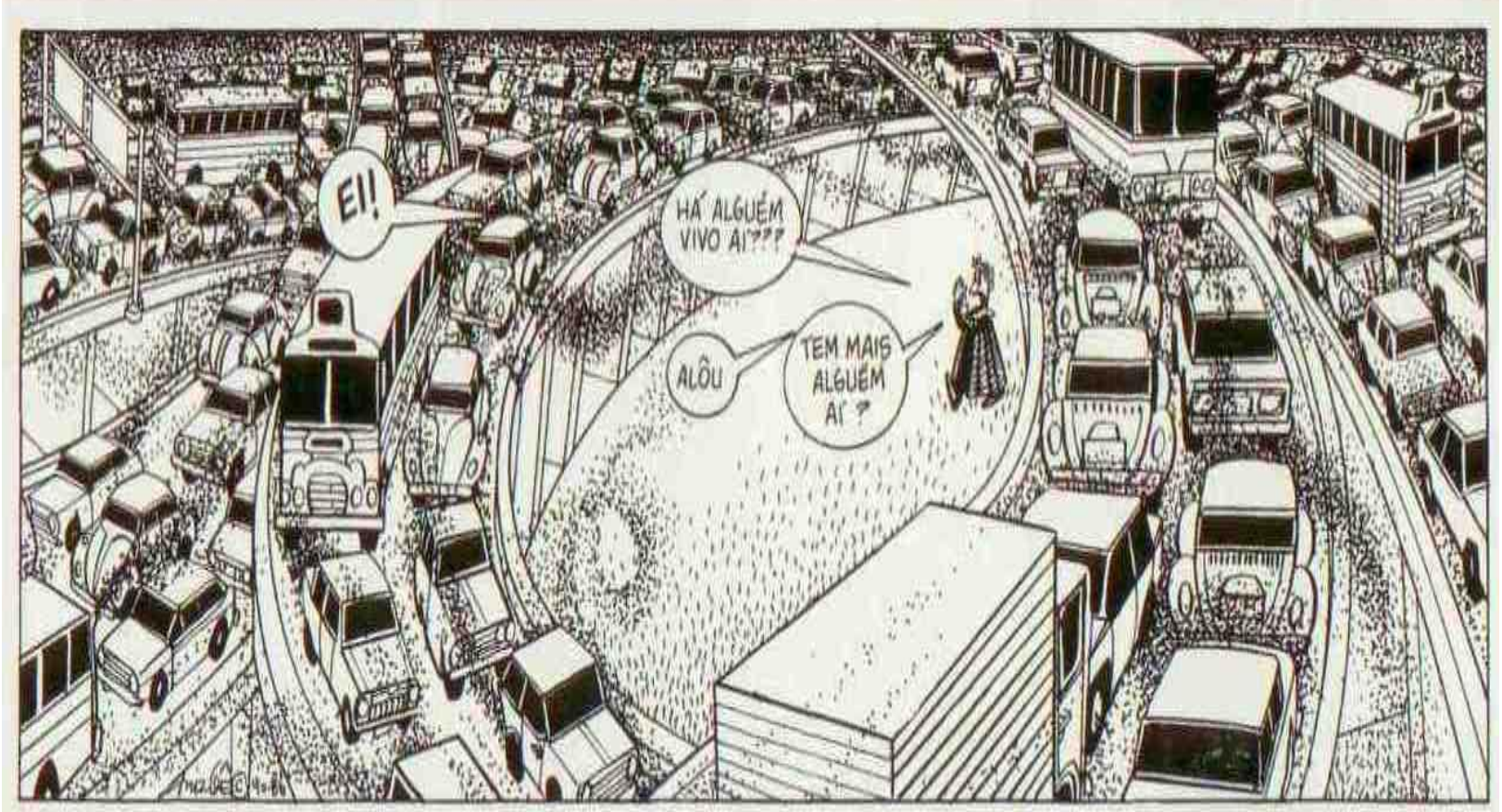

Figura 2.16 Ator Presidente Reis à procura de alguém. 
Vejamos agora uma tabela geral da contagem de todas as HQs de Território de bravos:

\begin{tabular}{|l|l|l|l|}
\hline HISTÓRIAS DE TB & FECHADO (F) & ABERTO $(A)$ & MISTO (A $\rightarrow F ; F \rightarrow A)$ \\
\hline 1. Entradas e bandeiras & 26 & 4 & 8 \\
\hline 2. Tubarões voadores & 14 & 9 & 14 \\
\hline 3. Errare marcianum est & 17 & 5 & 3 \\
\hline $\begin{array}{l}\text { 4. Quem matou Papai } \\
\text { Noel? }\end{array}$ & 43 & 10 & 29 \\
\hline $\begin{array}{l}\text { 5. Futboil } \\
\text { 6. Uma história de } \\
\text { amor }\end{array}$ & 58 & 47 & 24 \\
\hline 7. Perdidos no espaço & 14 & 7 & 32 \\
\hline Total & 194 & 23 & 19 \\
\hline
\end{tabular}

Como as sete HQs de Território de bravos compreendem 428 quadrinhos, verificamos que $45,33 \%$ correspondem a quadrinhos remissivos, $24,53 \%$ são emissivos e $30,14 \%$ estão na transição de missividade; noutros termos, ora emissivo para remissivo, ora remissivo para emissivo.

Somando a categoria remissiva com a mista, que é composta de ambos os fazeres (emissivo e remissivo), temos um total de $\mathbf{7 5 , 4 7 \%}$, o que nos leva à conclusão de que a maioria das HQs de Território de bravos vale-se de enunciados passionais e nominais. $\mathrm{Na}$ escolha do enunciador, prevalecem, portanto, valores dominantemente remissivos. Como a presença do antissujeito na narrativa introduz paradas e remissividades, consideramos oportuno examinar a função do antissujeito como alimentador da progressão narrativa, bem como o estudo do sujeito e do objeto.

\subsection{Sujeito, objeto e antissujeito na narrativa}

Etimologicamente, sujeito e objeto provêm da mesma raiz latina. Subjectus, $a, u m$, significa posto debaixo, colocado abaixo, submetido, dependente com respeito às coisas, que é alvo de, exposto a golpes, exposto à inveja, exposto a vicissitudes; objectus, $a$, um, significa posto diante, apresentado à vista, obstáculo (SARAIVA, 2000, verbete subjectus e objectus). Se o sujeito se interessa por um objeto, a distância que os separa já se constitui semioticamente em obstáculo, como vimos na raiz da palavra objeto. Para entrar em 
conjunção com esse objeto, deverá, pois, superar esse obstáculo, ou seja, a distância que os disjunge.

Ao confrontarmos o verbete sujeito com o de objeto (objectus, us), verificamos, como já dissemos, que ambas as palavras têm o mesmo radical:

$$
\text { Ob-jectus Sub-jectus }
$$

Ob é prefixo latino que indica "diante de", "para", "por causa de", "por" e sub, de igual forma, é prefixo latino que indica "embaixo de", "por baixo de", "perto de", "imediatamente antes de", "em direção a".

Objeto é "a ação de pôr diante, interposição, obstáculo, barreira" (HOUAISS, 2001, verbete objeto). Dessa forma, o conceito de sujeito implica separação em relação ao objeto, implica obstáculo, barreira. Para Lalande (1985, v. 2, p. 573), o termo sujeito é definido como "aquilo que é submetido à reflexão". Nesse sentido, o sujeito dobra-se sobre algo, que não é ele próprio, ou seja, no conceito de sujeito já encontramos o objeto sobre o qual ele se curva (reflete-se); algo que se distingue dele, que o "faz fazer".

Ora, se o objeto está diante do sujeito e o sujeito vai em direção a ele, observamos uma tensão que os separa. As disjunções impostas ao sujeito pelo antissujeito fazem aflorar descontinuidades tensivas na narrativa. A busca é uma conjunção à distância. Para Lalande (1985, v. 2, p. 577), sujeito é o que está "submetido a uma necessidade inevitável". Dessa forma, de um lado, se o sujeito está em conjunção com o objeto, ele tem necessidade de delongar essa conjunção; de outro lado, se está em disjunção com ele, é inevitável o movimento em direção ao objeto. A duração desse afastamento depende do antissujeito. Todavia, se excessiva a duratividade desse afastamento, pode ocorrer, por exemplo, o desinteresse do sujeito em relação ao objeto.

Enquanto a relação entre sujeito e objeto é sintagmática, a relação entre sujeito e antissujeito é paradigmática. Em termos práticos, tomando como exemplo a HQ "Uma história de amor", podemos verificar no quadrinho da figura 2.17 como se dão as relações sintagmáticas e paradigmáticas. 

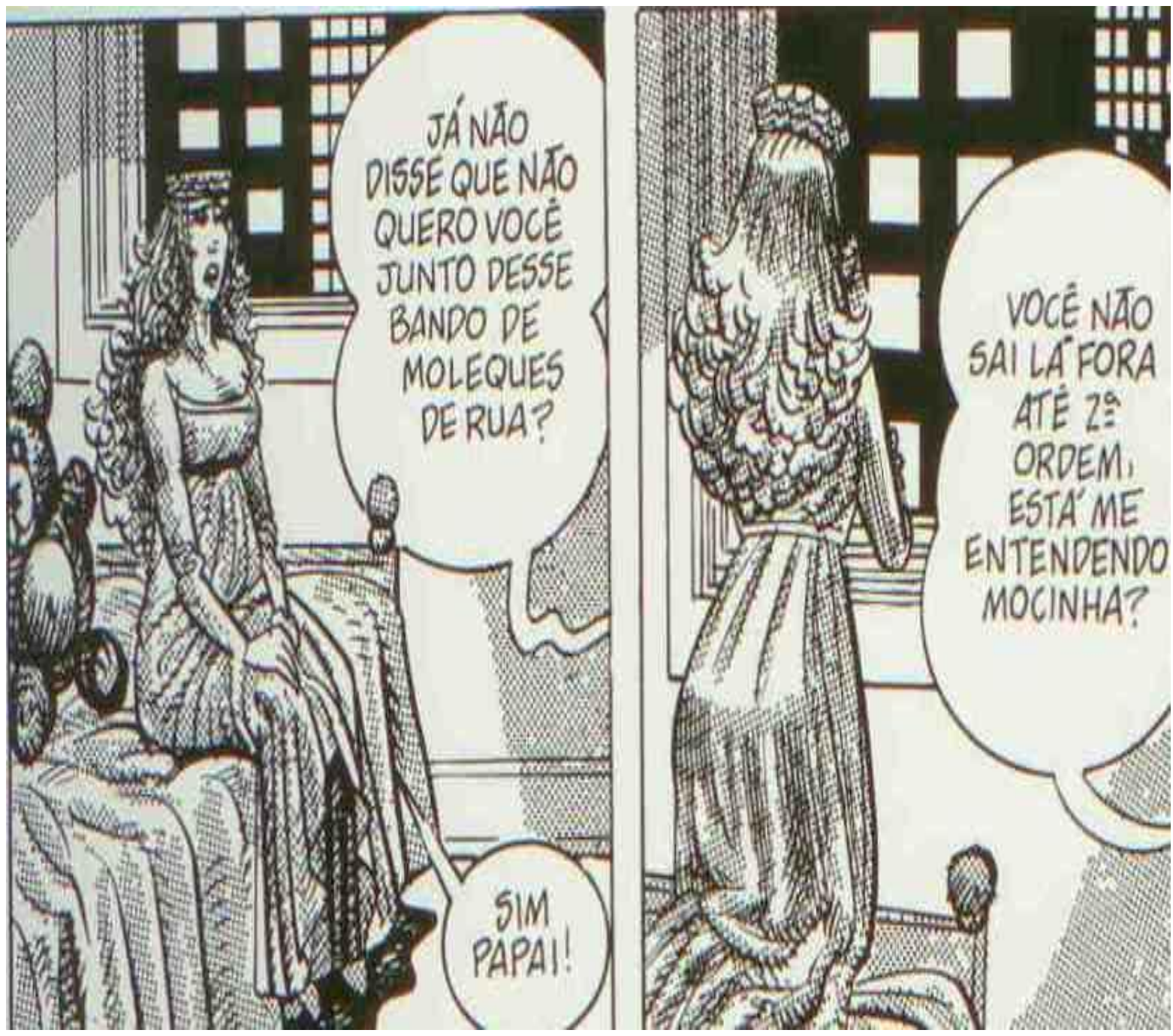

Figura 2.17

O sujeito, ator mocinha, quer fazer algo: sair para brincar. A relação dela com o objeto "sair para brincar" é uma relação sintagmática, porque há uma relação de transitividade entre sujeito e objeto. A relação, porém, entre ela, sujeito, e seu pai, antissujeito, é uma relação paradigmática, pois ou prevalece o objeto do pai ("ela não brinca na rua") ou o objeto dela ("ela brinca na rua"). Não há, portanto, transitividade, entre sujeito e antissujeito.

Passemos agora a examinar os conceitos de objeto e de sujeito em Greimas e Courtés (1989). Para os dicionaristas citados, objeto ou objeto-valor é "lugar de investimento dos valores (ou das determinações) com as quais o sujeito está em conjunção ou em disjunção" (GREIMAS; COURTÉS, 1989, p. 313). Já no verbete sujeito, os autores (1989, p. 446-447) afirmam que o sujeito semiótico implica o surgimento de um antissujeito 
que ele tem de enfrentar. O sujeito semiótico envolve também uma instância de aquisição de competência, que é de natureza modal: querer ou dever, saber e poder.

Portanto, uma narrativa convoca sempre a existência de um sujeito e de um antissujeito; um programa narrativo pressupõe "direção a". Por exemplo, se o sujeito, no início da narrativa, está em conjunção com o objeto, será necessária uma interrupção por parte do antissujeito para que o sujeito se coloque novamente em direção ao objeto afastado; a direção estabelece o sentido nas narrativas. Tal direção é movida pelas paradas e interrupções.

O uso dessa terminologia, sujeito e antissujeito, é necessário para evitar ambiguidades nas análises. Além disso, um ator no nível discursivo ora pode ser visto como sujeito, ora como antissujeito, dependendo do interesse da análise. Por exemplo, na HQ "Tubarões voadores" os tubarões constituem sujeito em relação aos habitantes da cidade; estes últimos, todavia, podem ser considerados sujeitos em relação aos tubarões, dependendo evidentemente do ponto de vista da observação empreendida.

O uso dessa terminologia semiótica também permite passar ao largo de moralizações por parte do analista. Tomemos o exemplo de Marsciani e Zinna, nos quadrinhos Diabolik: a ação de um assassino, moralmente não compartilhada porque realiza o valor morte, pode tornar-se aceitável se assumirmos a perspectiva de seu programa de ação. Nesse caso, o assassino passa a ser o sujeito: "isto advém porque, como veremos, o herói negativo vive euforicamente o valor que aos olhos do herói positivo se apresenta como um desvalor. Se narramos sempre a história do herói e não do anti-herói é porque em geral a narrativa deseja realizar os valores socialmente condivididos e valorizados como desejáveis" (MARSCIANI; ZINNA, 1991, p. 103) [tradução nossa].

Dessa forma, evitamos uma tomada de posição moralista, maniqueísta. Daí a teoria semiótica preferir os termos sujeito e antissujeito, ou dar preferência a valores assumidos positivamente, euforicamente, e a valores assumidos negativamente, ou disforicamente, desinteressando-se pela natureza do termo descritivo que recebe valoração. Se utilizássemos os termos da teoria literária, como, por exemplo, herói e anti-herói, daríamos margem a considerações não semióticas, marcadas por valores maniqueístas, não compatíveis com a ciência objeto de nossos estudos. 
A título de exemplificação, tomemos ainda o mito de Adão e Eva. A serpente, segundo a tradição bíblica, é identificada com o diabo. É um ator que recobre sincreticamente o papel de antidestinador e antissujeito, ou, para usarmos um termo que exprime neutralização entre duas invariantes ${ }^{3}$, é um arquiactante.

No mito, Eva é manipulada pela serpente que a convence a comer a maçã. O programa narrativo da serpente apresenta-se como um programa de manipulação contrário ao programa de manipulação de Deus, ou seja, apresenta-se como um "fazer" que o outro quer fazer (modalidade volitiva) e, por isso, opõe-se ao discurso divino que se apresenta como um "fazer" que o outro não deve fazer (modalidade deôntica). Enquanto o discurso intimidatório de Deus atribui um valor negativo ao objeto, com consequente sanção que sua posse possa provocar, o discurso da serpente apresenta-se como tentação, vista como um poder positivo. Isso faz com que Eva seja o lugar polêmico em que se confrontam os discursos contrários do destinador e do antidestinador. Nesse embate em que se desenvolve a dimensão cognitiva do sujeito, o discurso da tentação domina o discurso da intimidação, efetivando o conflito em favor da ação: ela come a maçã (cf. MARSCIANI; ZINNA, 1991, p. 104).

Com base nesses exemplos, podemos verificar a conveniência da utilização dos termos sujeito e antissujeito, visto que ambos permitem uma abordagem livre de juízo moralista. No programa da serpente, o discurso divino busca impedir que a serpente alcance a performance de seu percurso; no programa de Deus, o discurso da serpente busca impedir que a divindade alcance seu objeto. E, assim, constituímos uma análise não maniqueísta, marcada pela ausência de herói e anti-herói, de bem e de mal. A abordagem semiótica permite que se aflorem efeitos de sentido que de outra forma poderiam ficar submersos. Tradicionalmente, uma análise que toma o assassino como antissujeito leva a um sentido $X$, enquanto se o analista dispõe a considerar o assassino como sujeito, poderá surpreender-se com efeitos de sentido encobertos.

Nas artes, por exemplo, é comum artistas (enunciadores) alcançarem efeitos surpreendentes quando rompem com focalizações corriqueiras e assumem percursos de sujeitos considerados pela tradição como antissujeitos.

\footnotetext{
${ }^{3}$ Hjelmslev (1975, p. 93).
} 
Em outro exemplo, o poema "Maçã" de Manuel Bandeira retoma o mito de Adão e Eva, com a diferença, porém, de que a mulher, figurativizada no fruto proibido do jardim do Éden, é vista de forma eufórica. Enquanto da transgressão de Eva adveio sua expulsão do paraíso (sanção) no mito bíblico, em Bandeira a transgressão é vista positivamente, porque gera a vida. Em uma narrativa, a mulher é vista como introdutora do mal (morte), na outra é vista como introdutora do bem (vida). Trocam-se os papéis; o que era antissujeito convertese em sujeito. Noutros termos, no texto bíblico a maçã faz o homem perder a conjunção com o paraíso; portanto, antissujeito. Em Bandeira, a maçã guarda em seu interior a semente da vida, elemento de conjunção com a vida, não mais antissujeito. Além disso, se a mulher era vista como introdutora do mal (antissujeito), em Bandeira (1993, p. 168-169), a mulher porta valores de vida. Eis o poema citado:

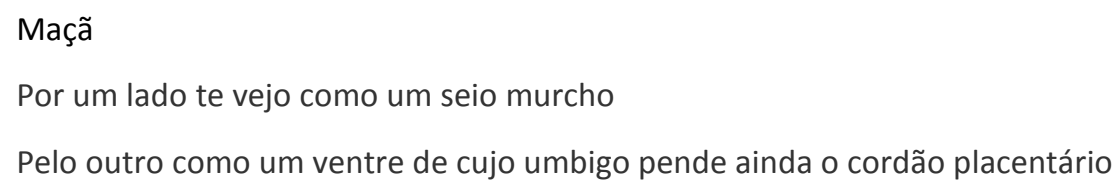

Um analista, portanto, poderá considerar um actante como sujeito ou antissujeito, dependendo do enfoque tomado. Da mesma forma, um enunciador poderá privilegiar os valores do percurso cujos efeitos de sentido deseja fazer sobressair: assim, se deseja valorizar a ação do sujeito X, o antissujeito será Y, e vice-versa. Retomando Saussure (1996, p. 15), o ponto de vista é que cria o objeto. No verbete anti-sujet, na acepção 3 do Sémiotique: dictionnaire raisonné de la théorie du langage II, Gracia Latella ressalta que 
[o] ato cognitivo de reconhecimento é, como dissemos, mutuamente exercido pelos dois actantes (a distinção sujeito/antissujeito que é acima de tudo uma questão de focalização da relação sobre um dos dois) que poderemos chamá-los simultaneamente (sujeito/antissujeito), desde que eles se encontrem em uma interação particular como sujeitos de interação. A confrontação de actantes tornase, assim, o "face a face" de um sujeito e de um antissujeito, semioticamente competentes, modalizados (frequentemente de modo inegável), que se reconhecem como tais, efetuando ambos, enquanto sujeitos de interação, operações cognitivas e manipulações modais para as quais eles geram mutuamente seus percursos respectivos, tornando-se assim manipuladores um do outro (GREIMAS; COURTÉS, 1986, p. 15) [tradução nossa].

Feitas tais considerações acerca de sujeito, objeto e antissujeito, passemos a considerar propriamente a função do antissujeito na narrativa e suas consequências tensivas.

\subsection{A função do antissujeito na narrativa}

As categorias do nível narrativo são regidas por forças selecionadas no nível tensivo. Assim, tanto os contratos entre destinador e destinatário quanto as relações de conjunção que definem sujeito e objeto são manifestações da continuidade, selecionada em nível profundo, sobre as interações subjetais e objetais. Os conflitos entre as funções de sujeito e de antissujeito e as disjunções entre sujeito e objeto fazem surgir as descontinuidades tensivas (cf. TATIT, 2001, p. 25).

Na relação entre sujeito e objeto, temos uma identidade actancial, uma junção desprovida de conflito; já na relação entre sujeito e antissujeito, temos uma descontinuidade actancial, responsável pela disjunção de sujeito e objeto.

A função do antissujeito é dar sentido, dar direção a qualquer narrativa, como veremos adiante nas análises de "Entradas e bandeiras" e de "Futboil". Quão maior a presença do antissujeito, mais acentuado é o efeito de descontinuidade entre os actantes sujeito e objeto. O sentimento de falta decorre do aumento da distância e da tensão entre os actantes mecionados. O sujeito fica em desarmonia, mas seu percurso ganha sentido em direção ao objeto que lhe falta.

Se, por um lado, a função do antissujeito é desarranjar a ordem "sujeito $\rightarrow$ objeto", por outro lado, é ele que impulsiona o percurso narrativo, visto que o sujeito pode ter o objeto ao seu alcance. Não houvesse a presença do antissujeito, a relação entre sujeito e objeto caminharia para o exaurimento da narrativa, ou seja, uma harmonia absoluta 
(jectum); nesse caso, teríamos a perda dos prefixos sub e ob, conforme mencionamos anteriormente.

Em "Entradas e bandeiras", se tomarmos o ator estátua (figura 2.18), por exemplo, como antissujeito, verificaríamos que é ele que direciona o sujeito, ator passageiro do veículo, para valores artísticos, que não são os mesmos valores utilitários do sujeito. Enquanto o antissujeito veicula valores relacionados ao mundo da arte, da liberdade, da fruição do espaço da rua, os valores dos passageiros são ligados ao mundo da ausência de liberdade, da falta da fruição do espaço público, ou seja, temos aqui uma oposição entre ético e estético. Daí o antissujeito romper com a ordem social estabelecida: o viver utilitário da cidade. Verificaremos outros detalhes dessa análise no capítulo 3.

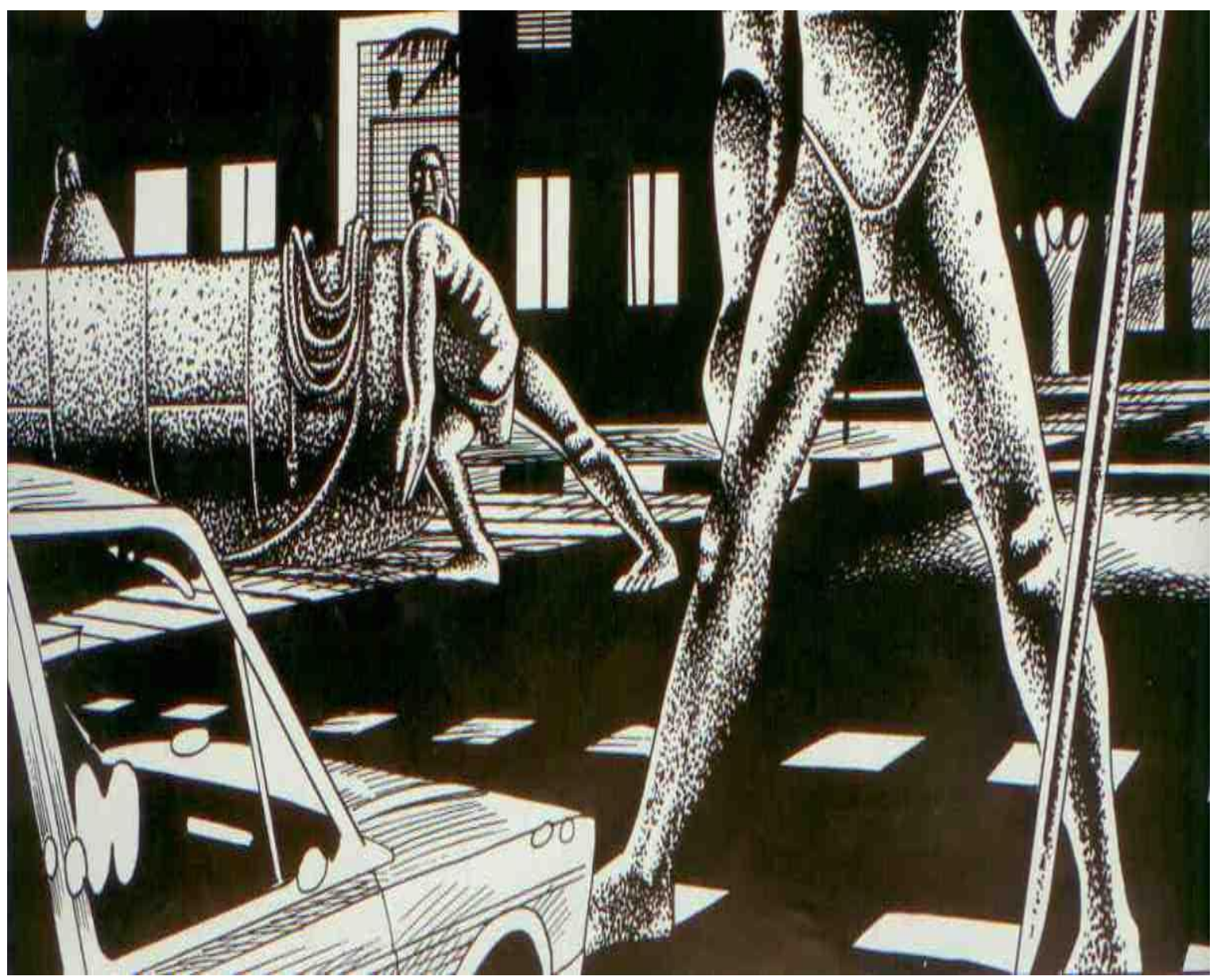

Figura 2.18

As noções de sujeito e de antissujeito levam-nos a uma reflexão sobre dois funtivos de uma função do nível profundo: foria [euforia e disforia]. Essas categorias foram abordadas com base em esquemas inteligíveis: "a categoria tímica articula-se em euforia/disforia" (GREIMAS; COURTÉS, 1989, p. 462). 
Euforia e disforia possuem papel fundamental na transformação dos microuniversos em axiologias: enquanto a euforia representa uma dêixis do quadrado semiótico, a disforia representa a oposta, valorizando positiva e/ou negativamente cada um dos termos da estrutura elementar da significação. A aforia seria o termo neutro. Tais considerações dão margem à introdução da foria no mundo sensível. Ela "regula o contato tensivo do homem com o mundo e com os seus semelhantes" (TATIT, 2001, p. 99).

À página 100, o autor citado nos chama a atenção para o fato de que, em vez de tratarmos de categorias semânticas universais vida e morte, por exemplo, que não são isentas de conotação a priori, seria preferível utilizar os termos euforia e disforia. Enquanto o primeiro termo se junta à noção de continuidade, o segundo se junta à de sua suspensão, à descontinuidade.

Foria provém do grego, phorós, força que leva adiante. A euforia leva o sujeito favoravelmente em direção ao seu objeto, ou seja, tudo o que conduz à junção com os valores desejados. Nesse sentido, neutralizaria as tensões. Todavia, o antissujeito, com seus valores disfóricos para o sujeito, tende a produzir paradas no percurso do sujeito em direção ao objeto; o antissujeito, por meio da descontinuidade, impede o sujeito de tomar posse de seu objeto. Daí as tensões nas narrativas, bem como as noções de andamento, duração e de ritmo (ver no capítulo 4 outras considerações sobre ritmo).

É ainda de observar que, enquanto o antissujeito é responsável pela descontinuidade, o destinador é responsável pela continuidade do processo e pela superação das paradas que impedem ou retardam a conquista do sujeito em seu percurso. $\mathrm{O}$ antissujeito é promovedor da parada disfórica no percurso do sujeito, que possivelmente desfrutava de um cotidiano sem obstáculos, ao passo que o destinador nega a parada, instaurando a parada da parada, e restabelece a ação do sujeito. Compete ao destinador, então, gerir as retomadas de percurso que nos assegura a continuidade narrativa (TATIT, 2001, p. 155; TATIT, 2010, p. 25).

Considerando que um sujeito semiótico "não existe enquanto sujeito senão na medida em que se lhe pode reconhecer pelo menos uma determinação, ou seja, que ele está em relação com um objeto-valor qualquer" (GREIMAS; COURTÉS, 1989, p. 173), da mesma forma um objeto só se constitui objeto se estiver em relação com um sujeito. Assim, a junção é uma condição necessária para a existência tanto de um quanto de outro. 
Tomando o verbete existência semiótica de Greimas e Courtés (1989, p. 173), verificamos que, anteriormente à junção, sujeito e objeto são virtuais (não conjuntos). A função denominada junção possui dois tipos de relação: conjunção e disjunção. Se o sujeito está disjunto de seu objeto de valor, temos sujeito e objeto atualizados; todavia, após a conjunção, temos sujeito e objeto realizados:

Sujeito virtualizado: não conjunto

Sujeito atualizado: disjunto

Sujeito realizado: conjunto

A essas três posições, Greimas e Fontanille (1993, p. 52) acrescentam a não disjunção. Essa existência semiótica é denominada sujeito potencializado: é uma negação do sujeito atualizado, mas ainda não realizado. Antes de Semiótica das paixões (1991, na edição original), no momento da aquisição de competências, o querer e o dever determinam um sujeito virtualizado e o saber e o poder determinam um sujeito atualizado; apenas na performance o sujeito se realiza. Faltaria, portanto, verificar que lugar caberia ao sujeito potencializado no percurso.

Para Greimas e Fontanille (1993, p. 52-53), pode-se "imaginar, provisoriamente, que o sujeito de busca, antes de receber o querer e o dever, é instaurado quando descobre a existência de um sistema de valores e que essa instauração prévia faria dele um sujeito potencializado". O sujeito potencializado pode ser chamado de quase-sujeito do nível tensivo, visto que está potencialmente propenso a se converter em sujeito do saber na instância inicial do percurso gerativo ou a ser convocado para compor o sujeito discursivo na instância mais concreta.

Tatit (1997, p. 39) considera que "os semioticistas situam o sujeito potencializado no topos da não disjunção, na medida em que a passagem do sujeito atualizado ao sujeito realizado só pode ser praticada a partir da negação da disjunção e da asserção da conjunção". Vejamos o esquema apresentado em Musicando a semiótica (1997, p. 39): 


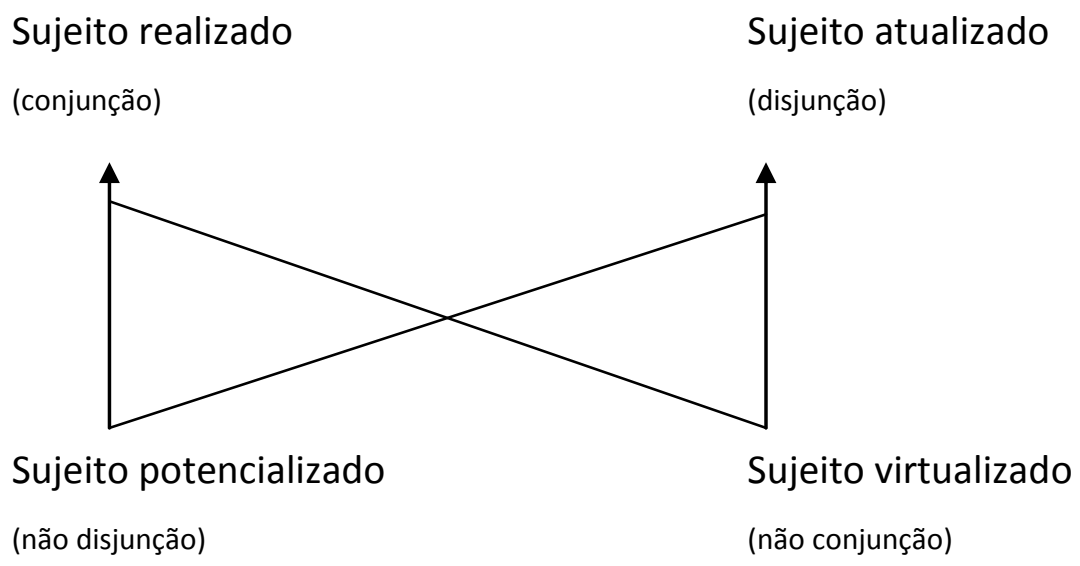

Fontanille e Zilberberg ([1998] 2001, p. 134) e, posteriormente, Tatit (2001, p. 138; 2010, p. 97) retomam a introdução da potencialização de Semiótica das paixões (1991, no original) e remanejam a posição das categorias citadas. Para Fontanille e Zilberberg (2001, p. 58), esse remanejamento lhes pareceu necessário, porque a acepção linguística corrente da atualização seria de "subida" das estruturas virtuais para a de manifestação e, por isso, em direção à realização.

Considerando a potencialização, ela faz com que as formas do uso retornem ao sistema, uma espécie de memória esquemática. Na nota 12 de Tensão e significação (2001, p. 134), os autores citados afirmam: "Se as palavras possuem um sentido, a atualização está a um passo da realização, ou seja, situa-se, como termo complementar, na mesma dêixis que esta e não em posição contrária." A potencialização, por sua vez, foi deslocada para a dêixis da virtualização; antes estava ao lado do estado de não disjunção e passa para o lado do estado de não conjunção: temos um estado de inanidade modal. Daí proporem a nova homologação:

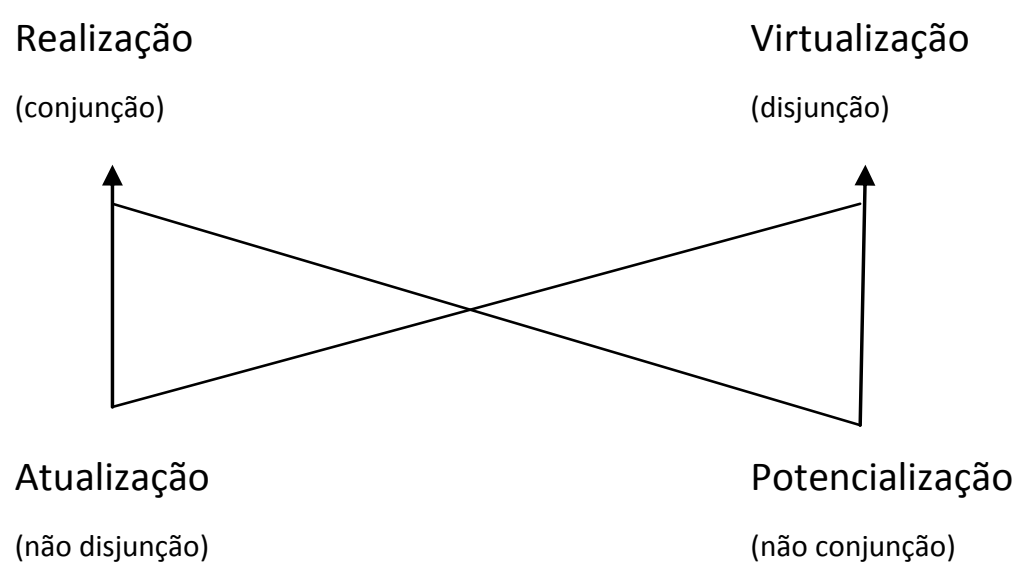


Com base na nova reformulação dos modos de existência semiótica, o sujeito tem sua identidade plena quando em total comunhão com o objeto, que é o caso do sujeito realizado. E o antissujeito? Este último, quando o sujeito é realizado, experimenta simultaneamente a condição de atonização. Trata-se, então, de um antissujeito potencializado, momentaneamente inativo. Vejamos um exemplo na HQ "Quem matou Papai Noel?", em que esse antissujeito está momentaneamente potencializado (figura 2.19).

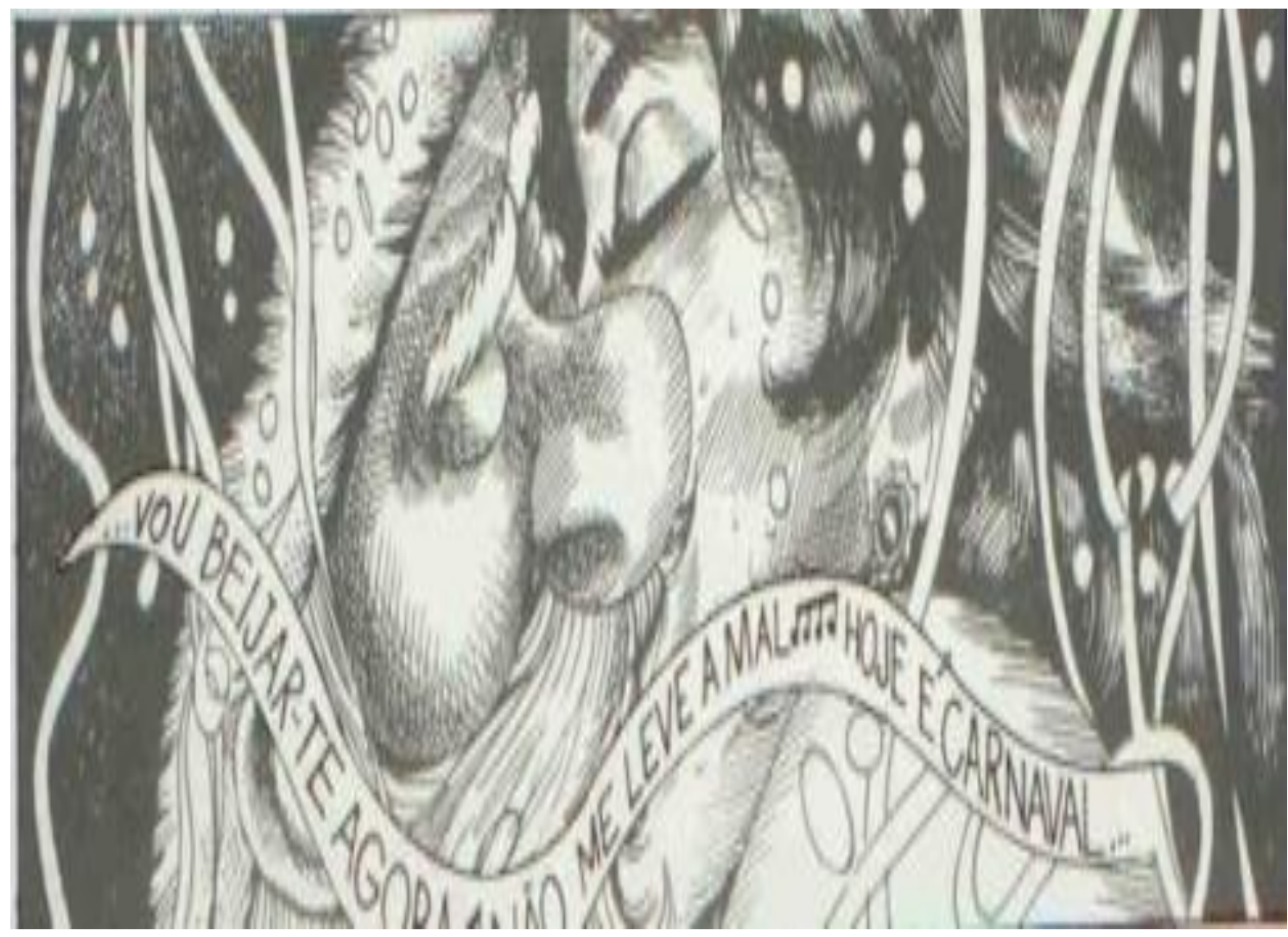

Figura 2.19

Após a realização do encontro do sujeito com o objeto, como vimos acima, estágio de plenitude, sobrevém novamente o estado de potencialização da experiência no percurso do sujeito, isto é, o evento acontecido (a conjunção entre sujeito e objeto) passa para a memória do sujeito, e outra vez pode surgir nele um novo desejo virtual de REatualização (TATIT, 2010, p. 97). Tal perda de densidade de presença é uma condição para que essa experiência de plenitude permaneça subjetivamente no universo do sujeito, porque a situação de plenitude experimentada não pode se delongar ad infinitum. A saudade, a 
lembrança, pode adquirir um caráter permanente e permitir ao sujeito reviver a situação de plenitude em virtude da recuperação da densidade de presença do momento vivido. No quadrinho da figura 2.20, que é continuação do retroapresentado (figura 2.19), o sujeito relembra o momento extraordinário de uma experiência vivida.

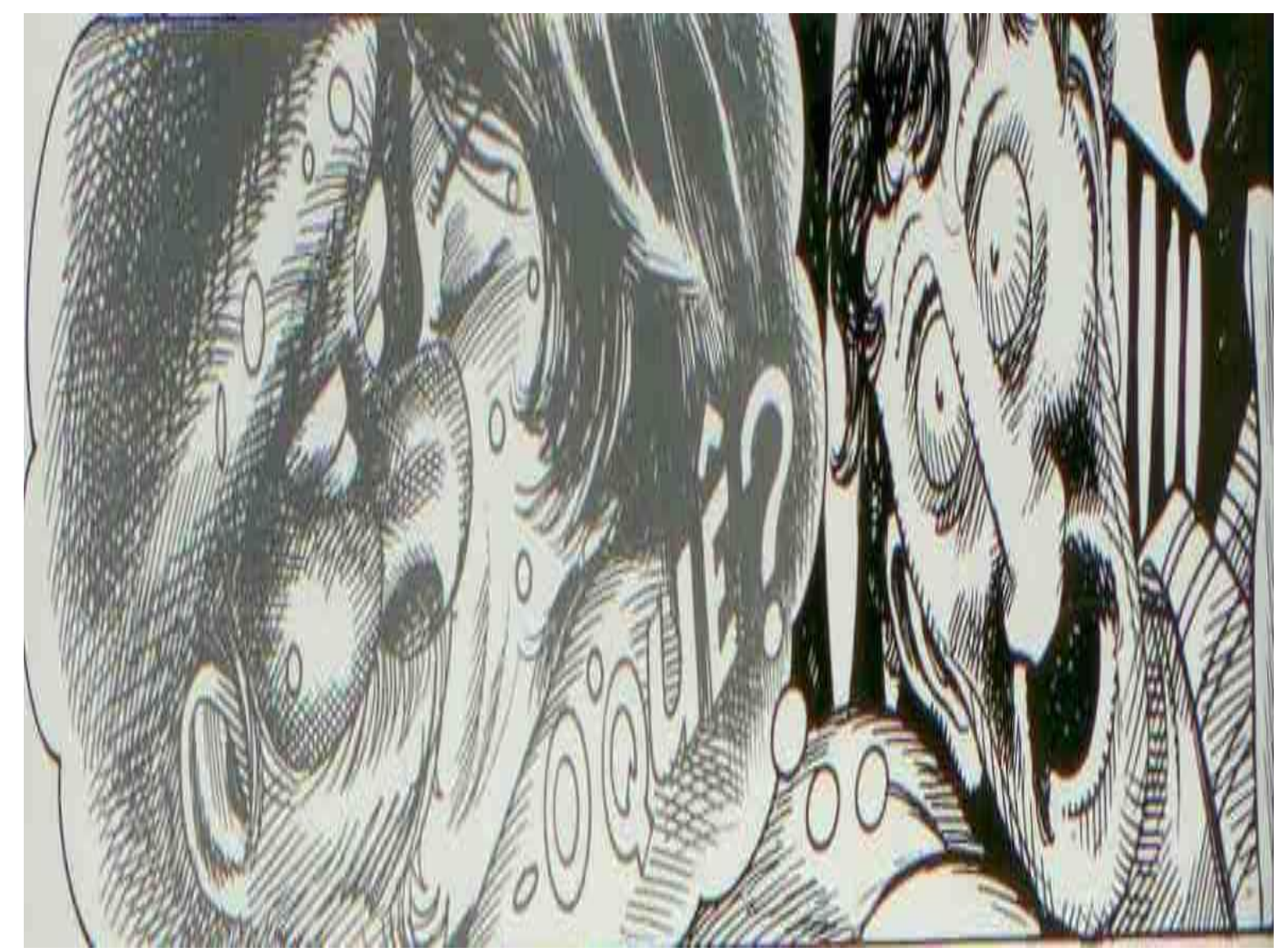

Figura 2.20

Um exemplo esclarecedor de Semiótica à luz de Guimarães Rosa: sensibilizados por uma canção, de tempos em tempos, temos o desejo de tornar a ouvi-la. O encanto ultrapassa o contato da primeira vez e, mesmo ouvindo-a outras vezes, ainda que possamos momentaneamente nos satisfazer, poderemos sentir novamente o desejo de ouvi-la em outras ocasiões. Isso se explica pelo fato de que, ao suspender a audição, continuamos o trabalho de assimilação, mas sentimos falta do objeto, isto é, "da canção que tanto agiu em nosso mundo subjetivo, remodelando-o para outras experiências" (TATIT, 2010, p. 98). Outros exemplos seriam a emoção vivida diante de uma obra de arte. Há pessoas que veem um filme indefinidas vezes, outras releem um romance, um poema, uma $H Q$, 
incansavelmente. Para um torcedor fanático, o replay do gol visto pela milionésima vez ainda pode provocar-lhe a emoção vivida no primeiro momento.

Esquematicamente, temos:

Plenitude $=$ realização $\rightarrow$ Presença transferida para a memória $=$ Potencialização $\rightarrow$ Presença latente $=$ Virtualização $\rightarrow$ Recomposição da presença [falta] $=$ Atualização $\rightarrow$ Necessidade de atualização do encontro do objeto pelo sujeito = Desejo de realização

E no quadrado:

$\begin{array}{ll}\text { plenitude } & \text { incompletude } \\ \text { conjunção } & \text { disjunção } \\ \text { (realização) } & \text { (virtualização) }\end{array}$

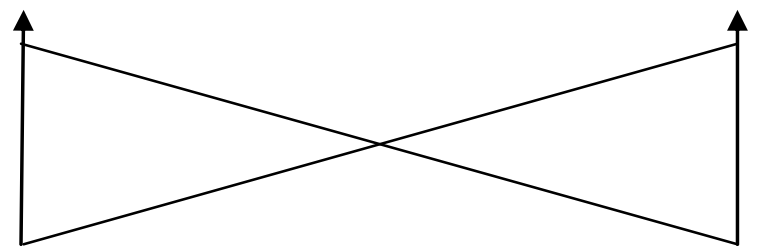

falta perda

não disjunção não conjunção

(atualização)

(potencialização)

Dessa forma, os modos de existência, reguladores do campo perceptivo do sujeito, são essenciais para a preservação das sensações boas de um encontro especial com o objeto. Posteriormente a uma conjunção plena do sujeito com seu objeto em que temos a densidade máxima de presença, é preciso um arrefecimento da tonicidade dessa presença. Nesse caso, teríamos uma acomodação no domínio de uma extensidade átona para a conservação dos efeitos que impactaram o sujeito. Uma conjunção prolongada indefinidamente resultaria insuportável para tal sujeito. 
A própria felicidade se não conhecesse uma parada resultaria numa sensação tormentosa. Pertence-Ihe o traço fundamental da descontinuidade. Embora para o sujeito seja desejável a continuidade da presença dos estados conjuntivos, são justamente as seguidas interrupções que o modalizam para novas conjunções. Assim, temos um ciclo (cf. esquema e quadrado acima): à realização do encontro com o objeto do desejo segue a potencialização da experiência vivida (memória). E é na memória que o sujeito assimila a vivência extraordinária que pode dar origem a novo desejo virtual de REatualização.

Consideremos agora a atualização do antissujeito. Quando aumenta a densidade de presença do antissujeito, que até então estava neutralizado entre potencialização e virtualização, o destinador perde a densidade de presença. Daí o antissujeito atualizar-se com os valores descontínuos que Ihe são próprios. Sua existência introduz paradas no percurso do sujeito. Um exemplo de atualização do antissujeito (figura 2.21).

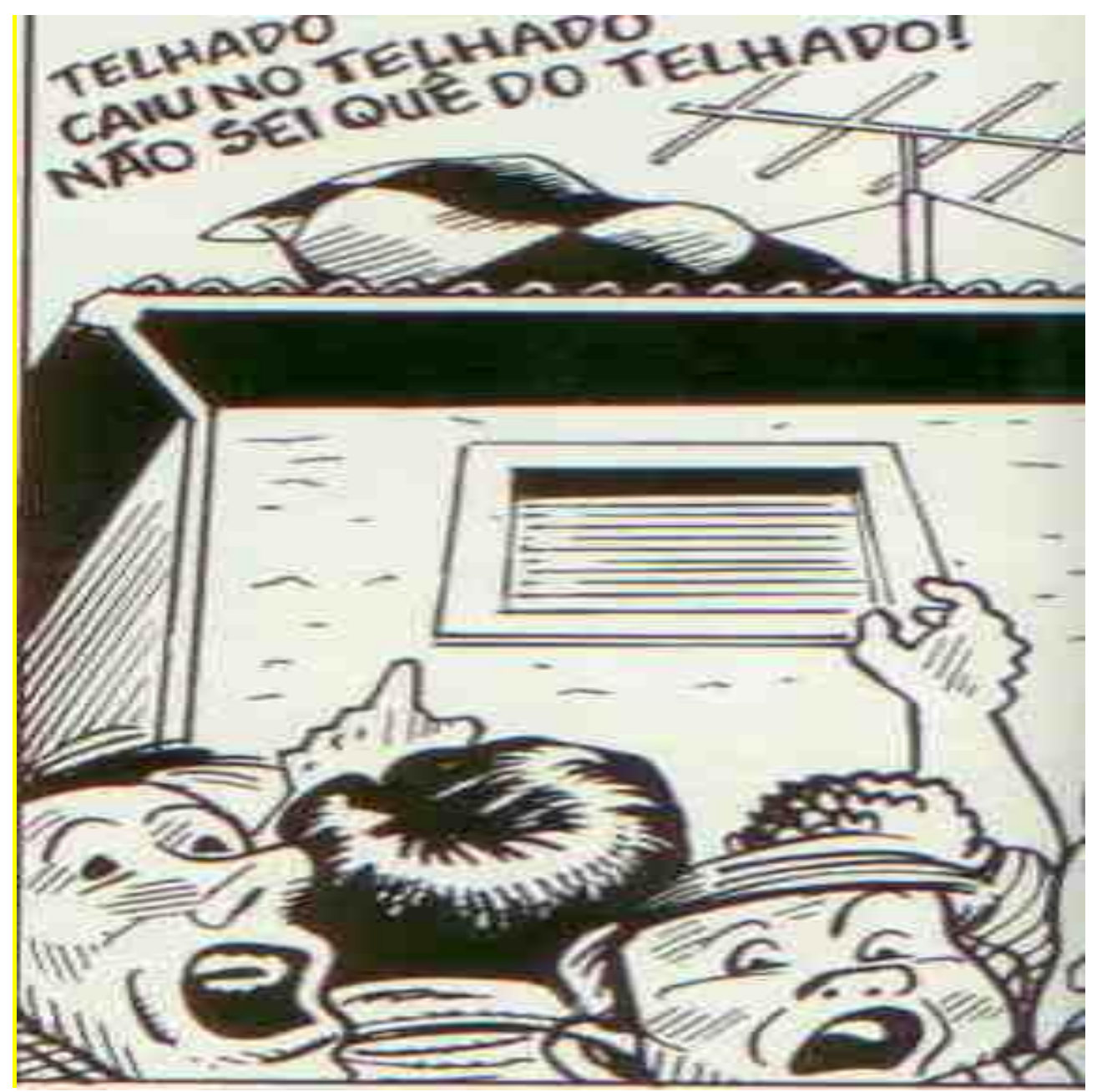

Figura 2.21 
No quadrinho da figura 2.21, de "Futboil", o sujeito (ator "grupo de garotos") tem como objeto um fazer: pegar um balão que está caindo. É um sujeito virtualizado, porque está disjunto de seu objeto. Se tal balão fosse um objeto cuja posse tivesse sido perdida, teríamos um sujeito potencializado (não conjunto), um sujeito que perdeu a posse de um objeto antes conjunto, mas que deseja entrar em conjunção com ele novamente. Todavia, a nova entrada em conjunção com tal objeto passa pela virtualização (disjunção), ponto a partir do qual o sujeito reinicia sua caminhada para a reatualização (não disjunção ou falta). Daí seguirá para a possível plenitude ou realização (conjunção).

O sujeito, representado no nível discursivo pelos garotos (ver figura 2.21), abandona um objeto, o jogo de futebol de rua, para correr atrás de outro objeto, um balão que está caindo. Nesse caso, não houve uma ativação da memória (potencialização $\rightarrow$ virtualização) e um desejo de REatualização, porque não tinham ainda estado em conjunção com tal balão. Podemos verificar a superação do antissujeito no quadrinho seguinte (figura 2.22), em que o sujeito alcança o objeto de seu desejo.

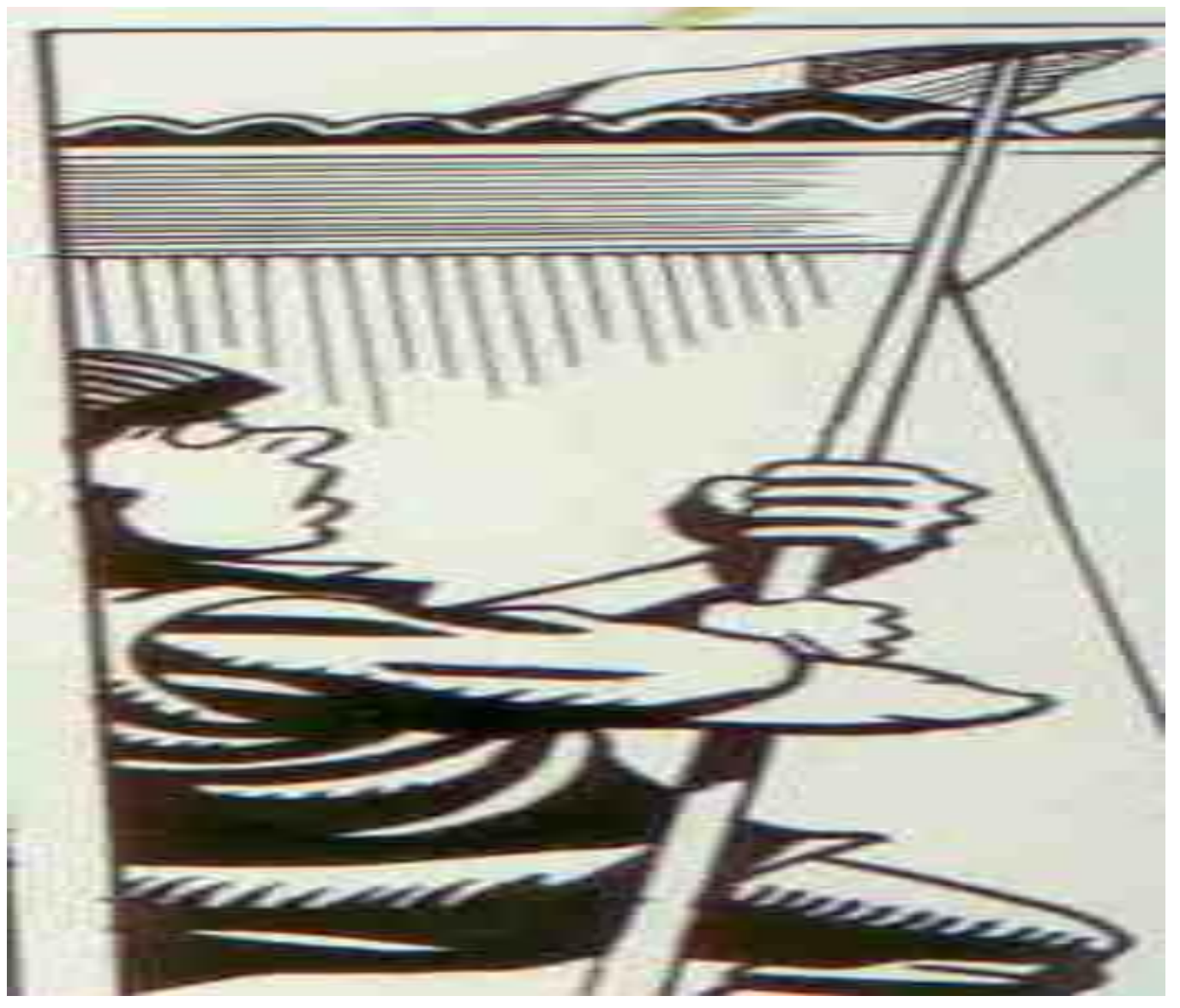

Figura 2.22 
Essa conjunção instantânea conhece imediatamente uma parada, visto que o grupo de garotos, os atores que desempenhavam o papel actancial de sujeito, passa a desempenhar o papel de antissujeito: o ator que toma contato por primeiro com o balão tem a sua posse ameaçada pelo antissujeito constituído pelos atores "outros garotos" (figura 2.23).

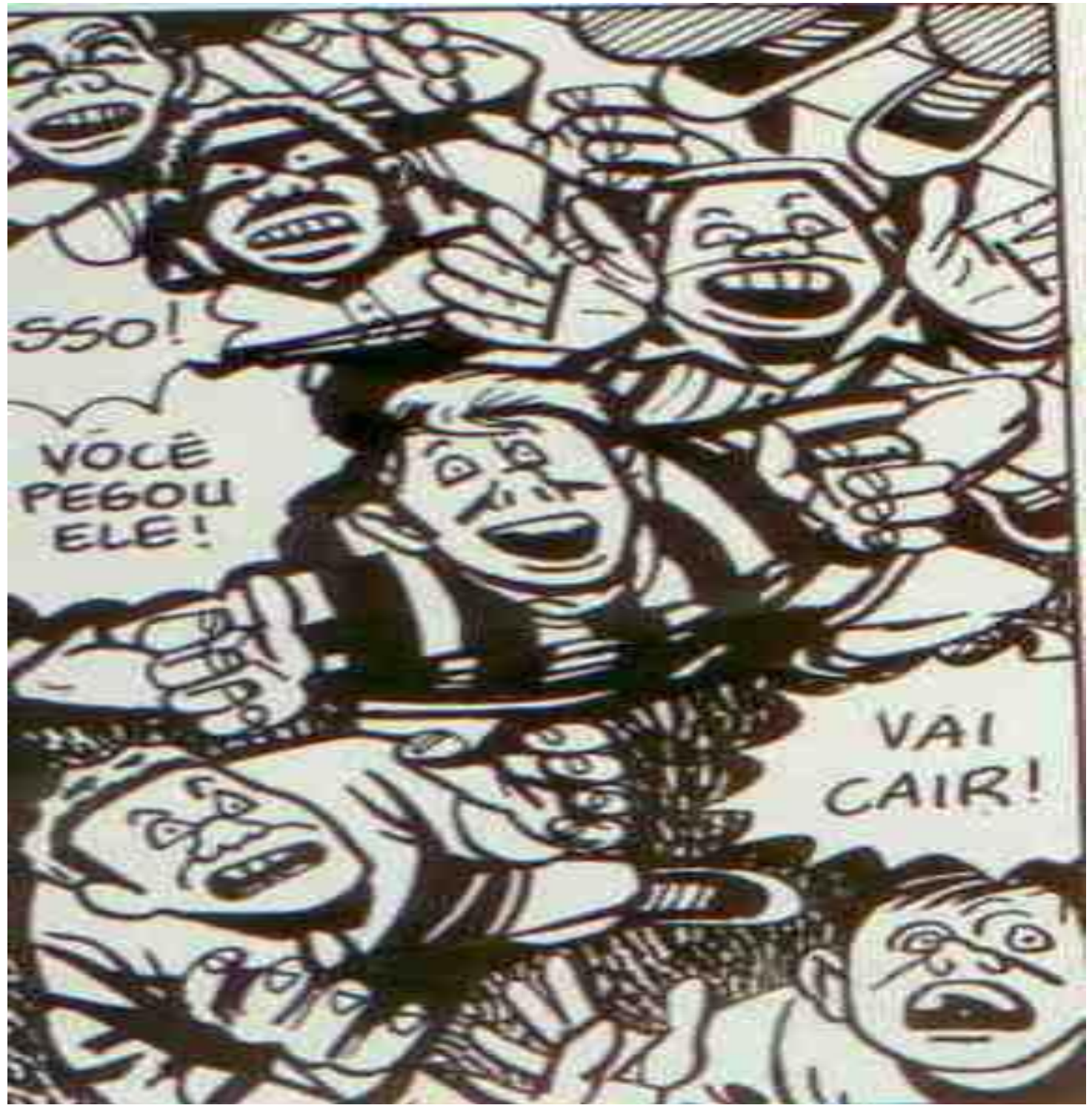

Figura 2.23

Poderíamos afirmar que, se sujeito e antissujeito mantêm a densidade de presença em grau máximo de intensidade, há um litígio, que pode levar à destruição do objeto, como na HQ "Futboil", cujo balão é disputado pelo sujeito (ator "menino com varinha") e pelo antissujeito (ator "grupo de meninos"), e temos como consequência a destruição do objeto 
de desejo. No enunciado "ninguém rasga!!", "ninguém rasga!!”, verificamos uma ameaça ao objeto. Sujeito e antissujeito estão em disputa; a intensidade é máxima, e o objeto é quase desmantelado (figura 2.24).
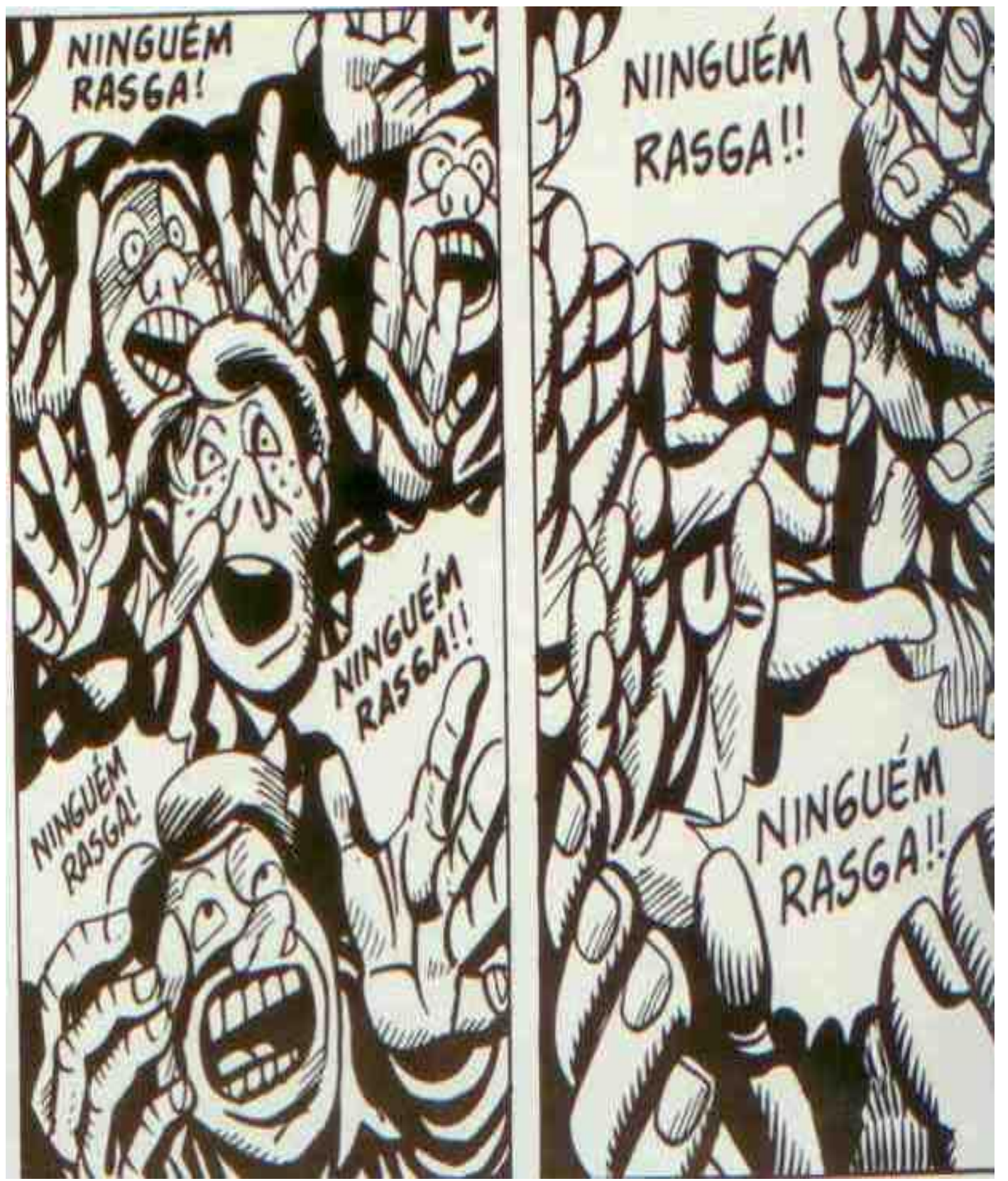

Figura 2.24

No quadrinho da figura 2.25 , há uma intensidade que é diluída pela destruição do objeto. Restam sujeito e antissujeito sem o objeto do desejo. E o narrador, delegado pela instância da enunciação, aparece atrás do balão despedaçado, dizendo que nesse jogo ninguém levou nada, nem sujeito nem antissujeito. 


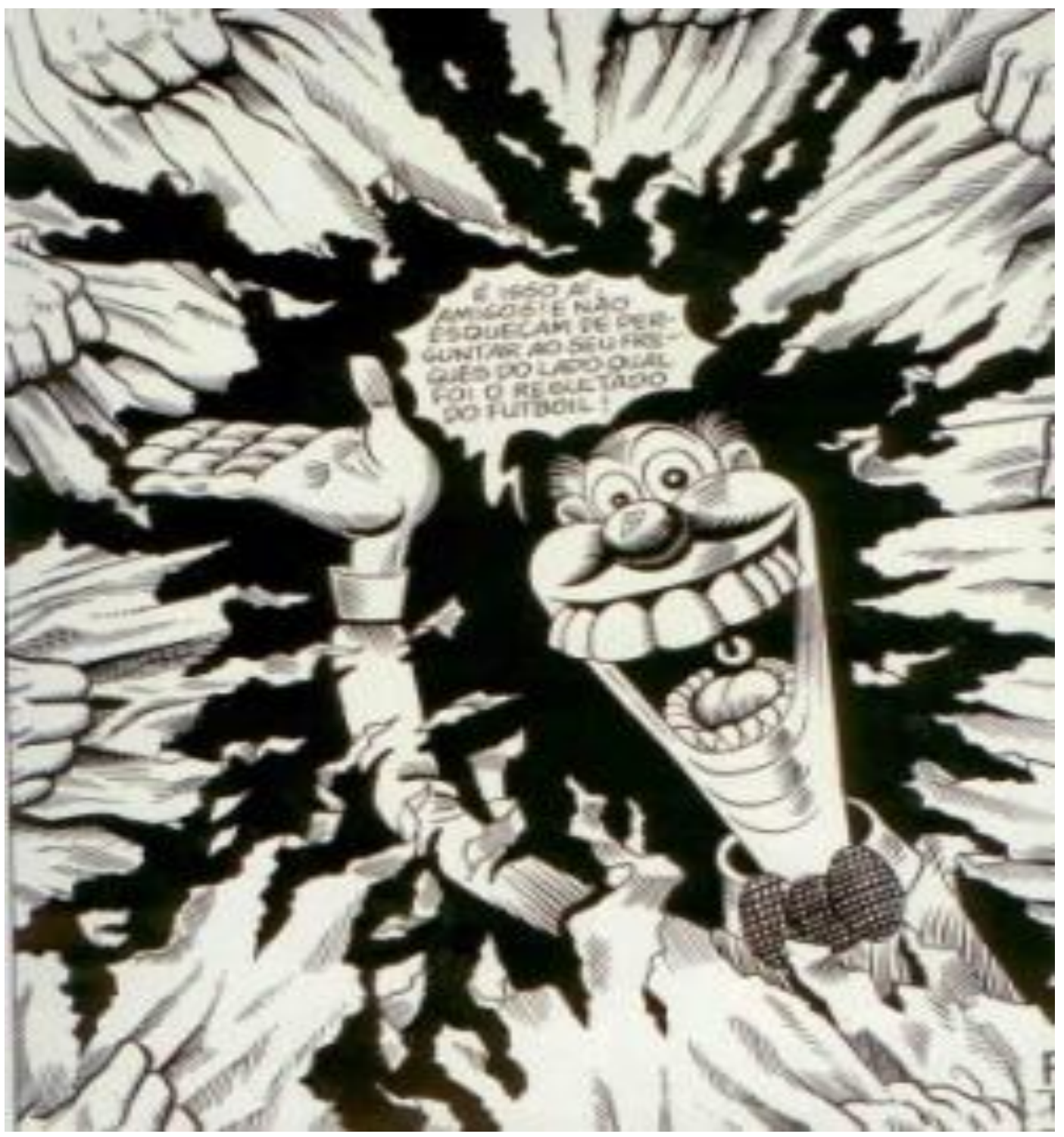

Figura 2.25

Em "A construção da imagem na história em quadrinhos", Antonio Vicente Pietroforte (2007, p. 67-83) faz menção ao desprezo do enunciador (ator palhaço): “É isso aí, amigos! E não esqueça de perguntar ao freguês ao lado qual foi o resultado do Futboil". Como já dissemos, em Território de bravos a intertextualidade, como na arte contemporânea, por exemplo, é uma constante. Aqui, temos uma menção clara à canção de Noel, "Conversa de botequim":

Seu garçom, faça o favor de me trazer depressa

Uma boa média que não seja requentada,

Um pão bem quente com manteiga à beça,

Um guardanapo e um copo d'água bem gelada. 
Feche a porta da direita com muito cuidado

Que eu não estou disposto a ficar exposto ao sol.

Vá perguntar ao seu freguês do lado

Qual foi o resultado do futebol.

Se na canção de Noel, "Conversa de botequim", o freguês com sua conversa jocosa, de boteco, estabelece um diálogo lúdico com o garçom, aqui, em "Futboil", de Luiz Gê, o enunciador-palhaço, ao sugerir ao enunciatário que pergunte sobre o resultado do Futboil, substitui o chiste do enunciador da canção por um enunciado irônico. Na ironia, o que se afirma no enunciado, nega-se na enunciação. Assim, o enunciador-palhaço, numa atitude de desprezo ao Futboil (não nos esqueçamos que a expressão é um acróstico de "Fenomenozinho Urbano Tipicamente Brasileiro Observado In Loco", p. 46 de Território de bravos), pede ao enunciatário que confira o resultado desse "fenomenozinho", cujo final é de destruição do objeto de desejo. Um jogo em que todos saíram perdendo, o avesso da vitória (ver análise de "Futboil" no capítulo 3).

Guardadas as proporções, as narrativas de disputa de amor (possessividade, ciúme em grau máximo, por exemplo) podem levar à destruição do objeto, como vemos na história das artes. Em Carmen de Bizet, por exemplo, o sujeito, ator Dom José, destrói o objeto de seu desejo (Carmen), porque esta é também objeto de desejo do antissujeito, ator Scamillo. Aqui, o antissujeito de Dom José é o ator Scamillo, e vice-versa. Interessa-nos, pois, mostrar como o grau máximo de densidade de presença em termos de tonicidade no sujeito e no antissujeito pode levar à destruição do objeto. No caso, se não há acordo entre sujeito e antissujeito, a tonicidade é diluída com o extermínio do objeto. Vemos, então, o balão destruído, assim como vemos Carmen morta em Bizet. O destinador, responsável pelas continuidades no percurso narrativo, sanciona negativamente sujeitos que resolvem a intensidade de posse do objeto de forma destrutiva, sem acordo.

Diferentemente de objetos cuja posse não possa ser partilhada, o saber é exemplo de objeto socializável, isto é, mais de um sujeito pode entrar em conjunção com ele.

Na história da psicanálise, Jung nos anos de 1900 colocou-se em contato com a obra de Freud; este último foi, no início, um grande destinador de Jung. Todavia, o saber adquirido pelo destinatário desviou-o para caminhos diversos. Jung jamais conseguiu aceitar a posição de Freud de que as causas dos conflitos psíquicos sempre envolveriam algum 
trauma de natureza sexual. Freud, por sua vez, não admitia o interesse de Jung pelos fenômenos espirituais como fontes válidas de estudo. O que podemos concluir daí é que o objeto saber não pode ser destruído quando é partilhado. O que temos aí é uma multiplicação do objeto (saber) e não uma divisão dele.

Destinador e antissujeito podem alternar a posição no quadrado dos modos de existência semiótico. Assim, se o sujeito experimenta a fusão momentânea com objeto, configura-se um quadro de potencialização do antissujeito (atonização) e de atualização do destinador (tonicidade). Contudo, essa posição pode alternar-se: o destinador pode tornarse átono e o antissujeito, tônico, atualizando-se. Um antiprograma narrativo atenua o poder do destinador, que é responsável pela continuidade do programa do sujeito, nutrindo-lhe seus desejos. No nível tensivo, esse antiprograma, com seu antissujeito à frente, pressupõe uma atonização progressiva do percurso do sujeito.

Um exemplo típico da presença do antiprograma que atenua a força continuativa do destinador pode ser visto na figura 2.26.
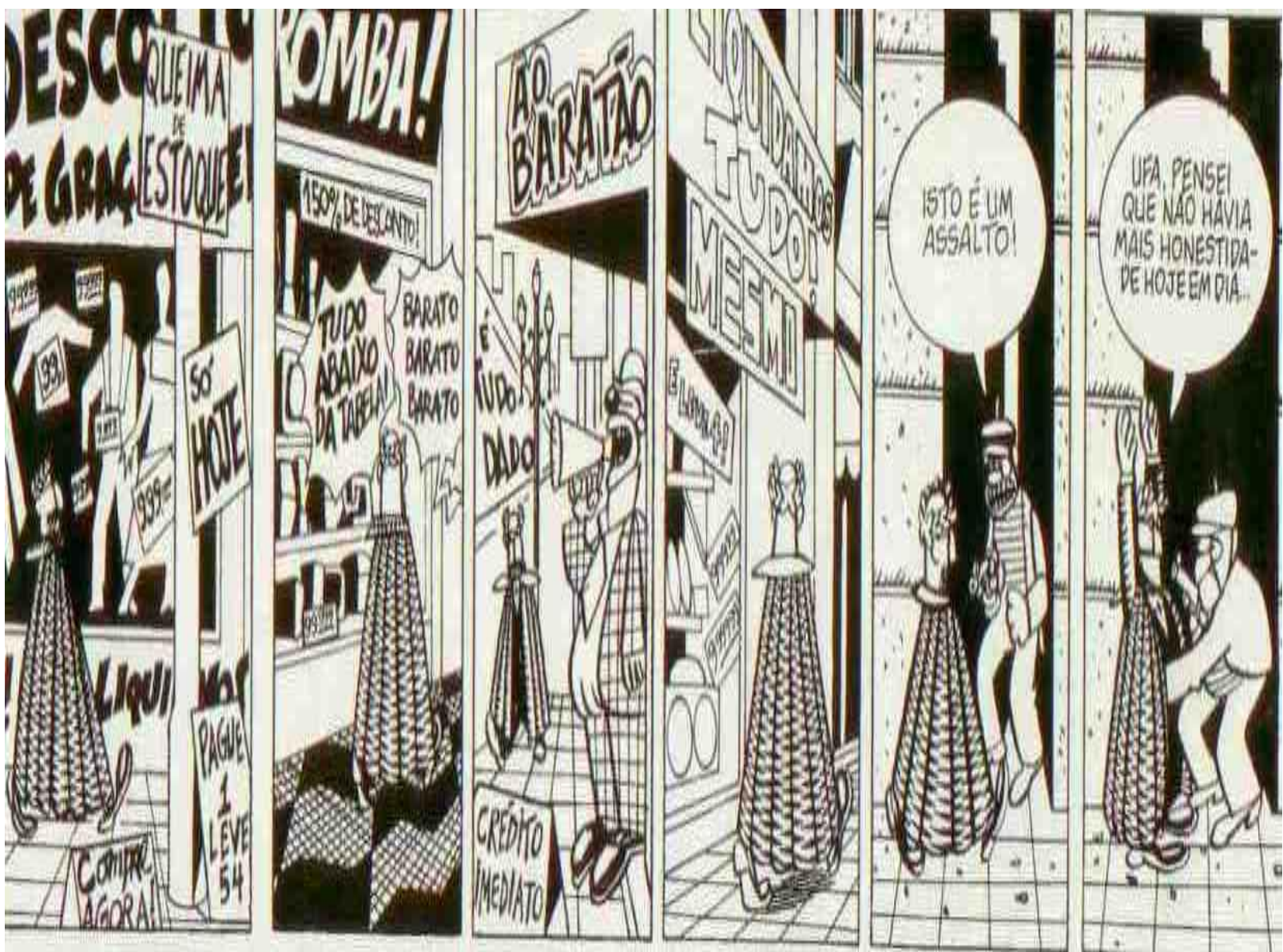

Figura 2.26 
Nessa tira de Presidente Reis que antecede à HQ "Futboil", o sujeito, no papel do ator Presidente Reis, percorre o espaço da cidade. A força do destinador, responsável pela continuidade do programa do sujeito na narrativa, é atenuada pela intensificação do antissujeito que promove a parada no percorrer do sujeito. Nota-se uma parada por um antissujeito "verdadeiro" (o enunciado diz: "isto é um assalto!"), parece e é ladrão, enquanto nos quatro quadrinhos anteriores dessa tira, o dizer do enunciado nega o da enunciação e, portanto, temos uma mentira; as figuras do comércio parecem portar valores de honestidade, mas não portam tais valores. Os enunciados afirmam "baratão", "queima de estoque", "liquidamos tudo!", mas é um engodo, um assalto sem arma.

O efeito de sentido de humor advém de o antissujeito escolher valores de "verdade", de "honestidade", eufóricos para o sujeito. O ator "ladrão" assalta e diz que é um assalto, enquanto os atores do comércio figurativizados nos cartazes "assaltam", mas não o dizem; ao contrário, anunciam "liquidação", "oferta", enfim, objetos valiosos, manipulando o sujeito por tentação para "fazê-lo comprar". No caso do antiprograma narrativo do antissujeito, que sincretiza também o papel de antidestinador, manipula o sujeito por intimidação, ou seja, o objeto de valor é negativo ("isto é um assalto", ver na tira figura da "arma").

Para concluir esta seção, a função do antissujeito é dar direção a uma narrativa, conforme já o dissemos e como veremos nas análises desta dissertação (ver capítulo 3). Se prevalecer a presença do antissujeito, mais acentuado será o efeito de descontinuidade entre os actantes sujeito e objeto. O percurso do sujeito ganha sentido quando se põe em direção ao objeto que Ihe falta. Se, por um lado, a função do antissujeito é abalar a ordem "sujeito $\rightarrow$ objeto", por outro lado, é ele que impulsiona o sujeito em seu percurso narrativo para alcançar o objeto de desejo.

No verbete antissujeito, na acepção 2 do Sémiotique: dictionnaire raisonné de la théorie du langage II, Gracia Latella afirma que, "ao contrário, a relação de pressuposição recíproca, simétrica, conflitual, que caracteriza o par sujeito/antissujeito permite dar uma representação mais adequada das relações intersubjetivas feitas de conflitos e de tensões" (GREIMAS; COURTÉS, 1986, p. 14) [tradução nossa].

Ressaltamos que, sem a presença do antissujeito, a relação entre sujeito e objeto caminharia para o esvaziamento da narrativa. As narrativas, em geral, possuem um 
movimento que se repete, a ser verificado nas análises do capítulo 3. Esse movimento produz um ritmo aspectual (v. capítulo 4) que constitui um continuum que é portador de limites e durações de paradas e retomadas. Enfim, o movimento que caracteriza as narrativas é o mesmo que caracteriza a existência humana: a continuidade promovida por um destinador tende em certo momento a cessar (parar), assim como o que cessa tende em determinado momento a retomar a continuidade (parada da parada). Daí a importância do antissujeito nas narrativas, porque é justamente ele que alimenta as descontinuidades. Sem ele, as narrativas inexistiriam por lhes faltar o combustível indispensável, o mesmo "mote" do sujeito, enunciador obstinado, tratado no capítulo 1.

É com base, pois, nesses elementos teóricos retroapresentados que analisaremos, no Capítulo 3, duas HQs de Território de bravos: "Entradas e bandeiras" e "Futboil". 
Missividade em "Entradas e bandeiras" e "Futboil"

Quando somos muito favorecidos pelas coisas, acontece de esse favor acarretar alguns perigos. Uma vida invadida pela doçura é uma vida intimamente ameaçada.

Paul Valéry 


\subsection{Escolha do corpus de análise}

Selecionamos duas HQs que se revelaram significativas para o estudo que estamos empreendendo nesta dissertação.

"Entradas e bandeiras", com 68,42\% de quadrinhos remissivos (fechados), 21,06\% de quadrinhos mistos (emissivos e remissivos) e 10,52\% de quadrinhos emissivos (abertos), constitui-se numa narrativa em que predomina a nominalização, a passionalização (remissividade) e, por isso, foi escolhida.

"Futboil", com 23,65\% de quadrinhos fechados; $25,82 \%$ de mistos e 50,53\% de abertos, apresenta a maioria de quadrinhos emissivos (verbalização), visto que aos abertos podemos acrescentar os mistos, pois estes transitam entre aberto e fechado. Percentuais equivalentes foram encontrados em "Uma história de amor"; todavia, por razões de tempo e espaço nesta dissertação, ficamos com a análise apenas de "Futboil".

As demais HQs, "Tubarões voadores (fechados e mistos - 37,83\% cada um; abertos 24,34\%), "Errare marcianum est" (fechados - 68\%; mistos - 12\%; abertos - 20\%), "Quem matou Papai Noel?" (fechados - 52,43\%; mistos - 35,38\%; abertos - 12,19\%), "Perdidos no espaço" (fechados - 25\%; mistos - 33,93\%; abertos - 41,07\%), de uma forma ou de outra e porque nos interessa o estudo da missividade, estão representadas nas HQs que compõem o corpus de análise ("Entradas e bandeiras" e "Futboil”).

Tomar duas HQs como objeto de análise não significa, porém, excluir de nossos estudos as outras histórias de Território de bravos. Como foi visto no capítulo 2, na seção de contagem dos quadrinhos, utilizamos as sete HQs do livro para análise e exposição de nossas considerações semióticas. 


\section{2 "Entradas e bandeiras": dominância da remissividade}

A vida é breve, a arte é longa, a ocasião fugidia, a experiência enganosa, o julgamento difícil.

Hipócrates

\subsubsection{Introdução}

"Entradas e bandeiras" é a primeira HQ de Território de bravos. Antecipando-a, temos uma epígrafe de Francisco Correal, de 1685, e uma tira do Presidente Reis, ambas na mesma página. Como todas as demais HQs do livro, trata-se de uma história curta voltada para um aspecto diferente da vida metropolitana: "Pensei também em dividi-las por bairros ou regiões da urbe. Para separá-las usaria comentários a respeito da cidade feitos por viajantes de várias épocas, desde a fundação, no século XVI” (LUIZ GÊ, 1993, p. 10). Presidente Reis é o ator principal do enunciado de uma tira (com esse mesmo nome) publicada em periódicos. A ele cabe, em Território de Bravos, costurar o livro, dar-lhe direção. De certa forma, além de suas características de cicerone, mostrando ironicamente aspectos da cidade, ou provocando efeitos de humor, as tiras de Presidente Reis, no conjunto, formam uma narrativa. Comumente, iniciam-se com um fazer emissivo e a latência remissiva aflora ao final de cada tira em que o sujeito tem seu percurso interrompido por uma parada. São exemplos dessas considerações as figuras 3.1 e 3.2.

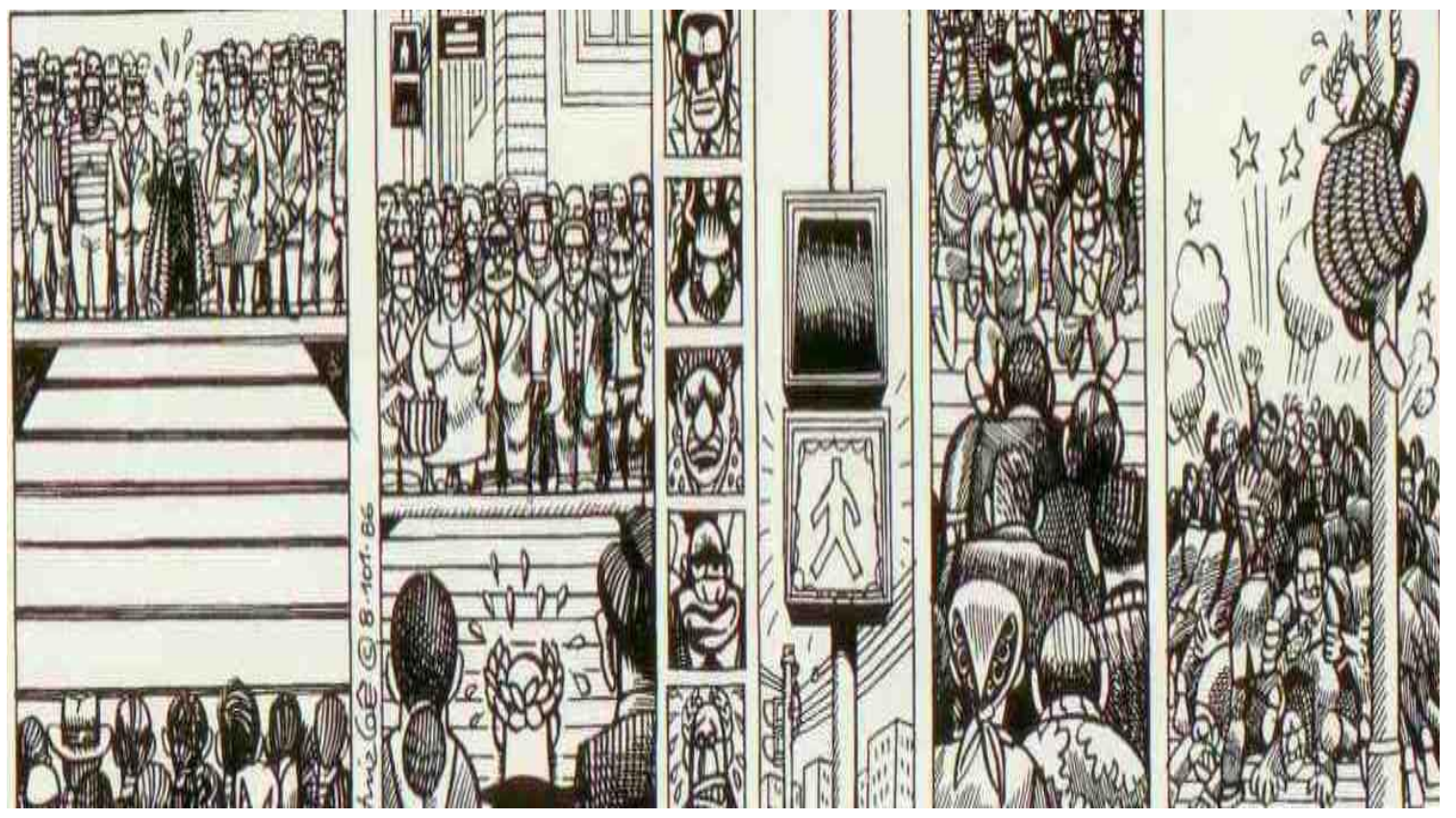

Figura 3.1 
Como nas HQs, observamos também nas tiras a presença constante de um antissujeito no percurso do sujeito. A dominância de antissujeito, como vimos no capítulo 1 , leva à obstinação por alimentar a continuidade da narrativa apesar dos obstáculos; noutros termos, são as descontinuidades introduzidas pelo antissujeito que mantêm a continuidade do percurso do sujeito em busca de seu objeto. Os enunciados também confirmam essa obstinação, ou seja, não obstante as paradas, eles não se interrompem, uma força os leva adiante (foria).

Assim como nas tiras, nas HQs de Luiz Gê, a concessão é dominante e os "apesares de" nutrem o percurso do sujeito, bem como a progressão narrativa. Se as implicações normalmente endereçam o texto para uma logicidade entediante, de poucos arroubos, que configurariam HQs mais parecidas com as de consumo rápido, as concessivas proporcionam às histórias de Território de bravos o estatuto dominantemente artístico, visto que são da ordem da surpresa, prevalecendo nelas as passionalizações e remissividades, bem como a dominância do antissujeito como provedor das paradas que levam à conservação dos enunciados.

A tira seguinte aparece no fechamento do livro: o costurador, destinador no nível narrativo que promovia as continuidades, encerra a obra. Enquanto esse destinador promovia as continuações, os antissujeitos promoviam as paradas, oscilação necessária do fluxo narrativo (TATIT, 2010, p. 24-25). Vejamo-la:
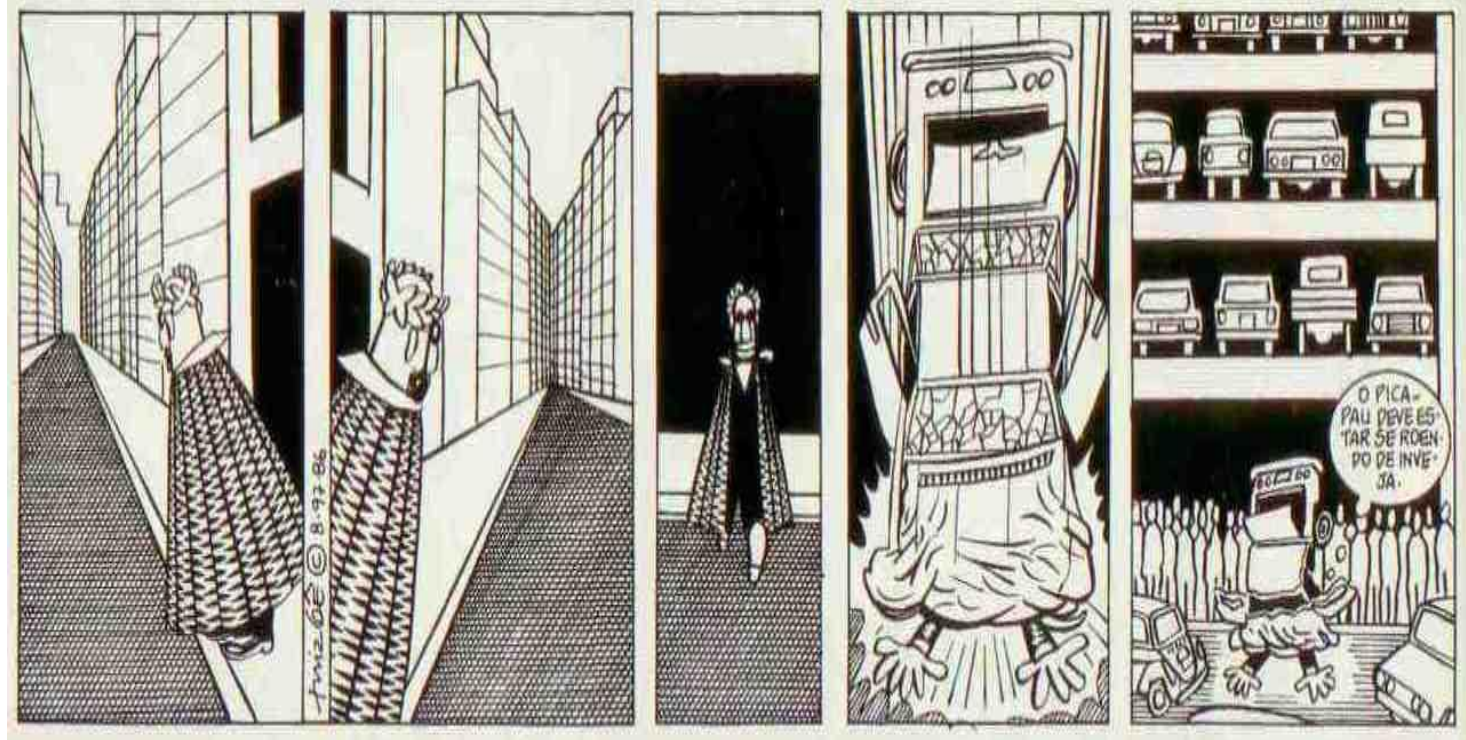

Figura 3.2 
A HQ "Entradas e bandeiras" é uma história de seis páginas, composta de 38 quadrinhos. É toda em branco e preto e é constituída na sua grande maioria de quadrinhos sem balão, que the dão um aspecto muito particular, mais voltado aos elementos visuais. Abre essa HQ uma epígrafe de Francisco Correal. Nela, é de ressaltar que parte do enunciado do texto citado afirma: [os moradores] "dizem-se livres e não querem estar sujeitos ao portugueses". É essa "liberdade" que parece constituir-se em ponto nodal para o enunciador.

No desenrolar da $\mathrm{HQ}$, verificamos que o habitante dessa cidade é, na verdade, um prisioneiro de uma vida mercantilista, em que prevalece apenas o trabalho. Ao juntar-se com a tira do Presidente Reis, temos um efeito de sentido de ironia, pois o enunciado nega a enunciação. Onde estaria a liberdade? A própria tira de Reis, abaixo da epígrafe, menciona no enunciado: "A megalópole é a personificação do trabalho! Coisa horrorosa! E ainda dizem que o trabalho dignifica!". A oposição entre liberdade e opressão aqui é curiosa. O homem só teria acesso ao espaço se trabalhasse: "proibida a entrada de pessoas estranhas ao serviço"; outras formas de expressão como a arte estariam alijadas desse espaço urbano. É justamente isso que vamos examinar na $\mathrm{HQ}$ sob análise. Na tira a seguir da figura 3.3, Presidente Reis tem seu percurso interrompido, porque lhe interessam outros valores que não o do mundo do trabalho. Daí a placa obstando sua entrada no espaço, uma forma de remissividade para esse sujeito (no nível narrativo).

A oposição de sentido que vemos entre o tempo de Correal (1685), em que a liberdade é euforizada, e o tempo da tira de Presidente Reis (atual momento da urbe), em que o trabalho (opressão) é disforizado pela instância enunciativa, mas euforizado pelo espaço urbano, confirma que a realidade de um tempo não é perene. O homem tem diferentes pontos de vistas que produzem objetos diferentes nas mais variadas épocas. Uma coisa é São Paulo do século XVII vista pelo sujeito do século XVII, outra é o simulacro de São Paulo, vista por um artista do século XX.

Vejamos como aparecem sequencialmente (figura 3.3) na mesma página de "Entradas e bandeiras" o espaço e tempo antigos e espaço e tempo atual dos enunciados de Território de bravos: 


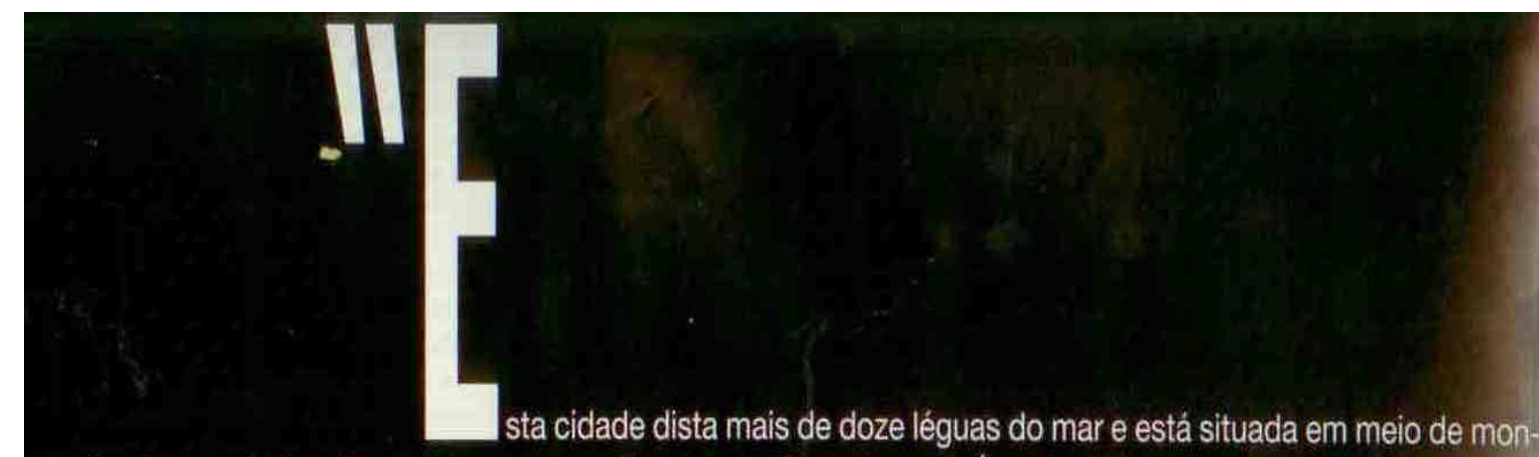
tanhas inacessiveis e da grande e espessa floresta de "Pernabacca". É uma espécie de república originariamente composta de toda a casta de gente sem fé nem lei, mas que a necessidade da conservação forçou a adaptar certa forma de governo. (...) A tirania dos governadores do Brasil deu origem a esta pequena república, tão ciosa de sua independência que não permite a forasteiro algum a entrada em seu dominio. (...) Nos últimos quinze ou vinte anos, porém, o seu número multiplicou-se pelo menos dez vezes. Dizem-se livres e não querem estar sujeitos aos portugueses. (...) Quando algum forasteiro se apresenta para fazer parte da república, tem de sujeitarse a uma espécie de quarentena, não por motivos sanitários, mas afim de ser observado quanto às suas aptidões e designios. Depois de prolongada observação é enviado a fazer extensas e penosas jornadas, com ordem de trazer dois escravos indios. Estes escravos são empregados nas minas e no cultivo da terra. 0 noviço que fraqueja na prova, ou procura desertar, é morto sem misericórdia. Quem se alista entre os paulistas o faz por toda a vida, pois só com muita dificuldade concedem permissão para alguém se retirar."

Francisco Correal, 1685
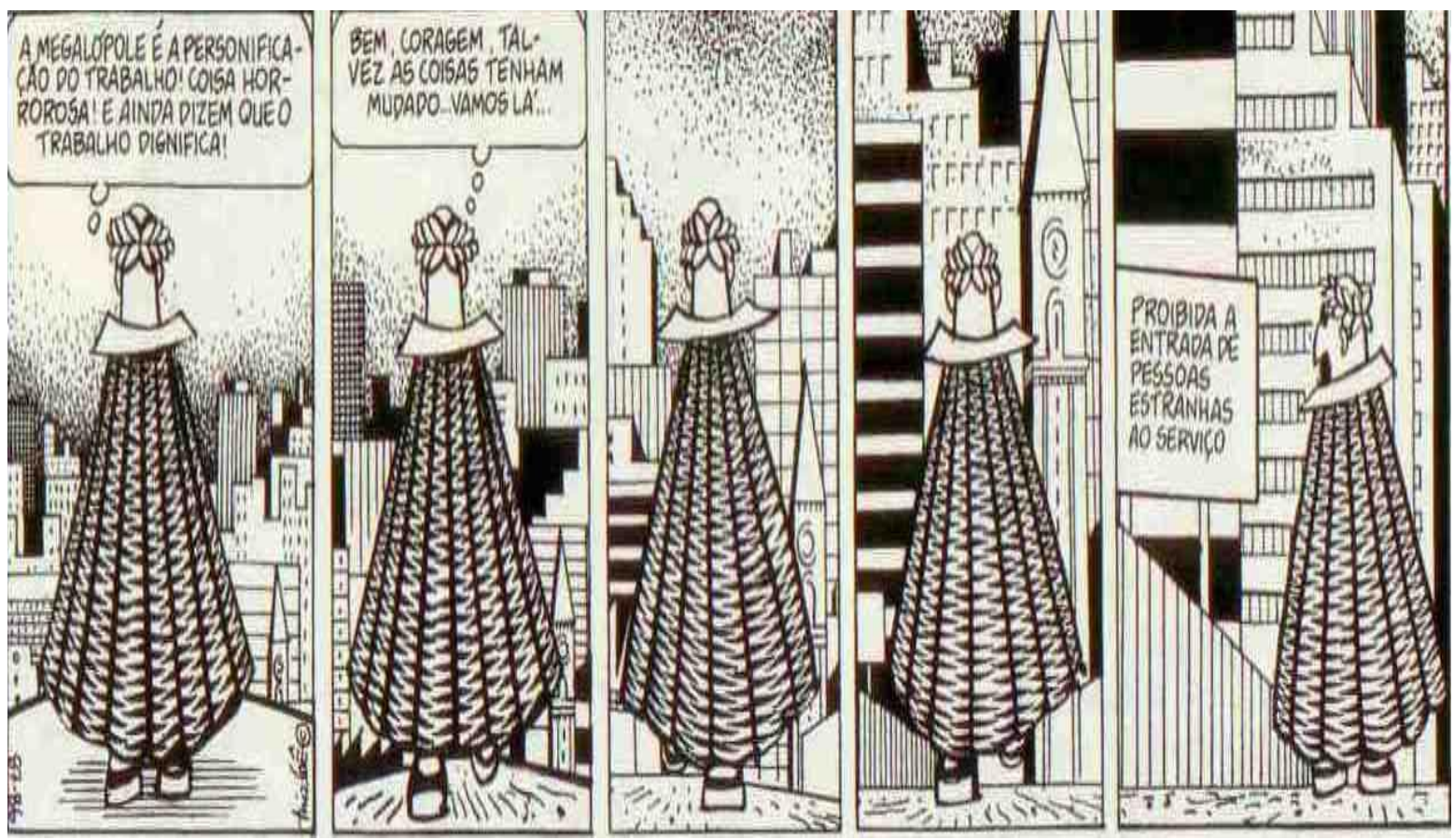

Figura 3.3

Como já dissemos, a maioria dos quadrinhos de Território de bravos é semioticamente concentrada, remissiva, o que lhes dá uma característica nominal e passional. 
A história, resumidamente, se passa nas imediações do Parque Ibirapuera em um cruzamento da Av. Brasil com a Av. Brigadeiro Luís Antônio. Um automóvel com dois passageiros sobe a Brigadeiro e no cruzamento com Av. Brasil o farol fecha. Eles estão cansados e querem retornar para casa a fim de descansarem. Nos textos verbais, sobressai o conflito relativo a obedecerem às leis de trânsito ("parar no sinal vermelho, porque "devem" e não porque "querem") e a seguirem seus desejos de chegar à cama de sua casa. Logo na primeira parada, no farol, são surpreendidos por estátuas do Monumento às bandeiras que estão perambulando pelas imediações (segunda parada). As estátuas estão transportando partes do monumento. Em seguida, com o caminho livre, o carro começa a andar. Todavia, no quadrinho 34, entra no campo de presença do automóvel a estátua do Borba Gato, que estava atrasada e seguia as demais estátuas do Monumento às bandeiras. Uma terceira e última parada se dá, e esta definitiva: temos, então, o esmagamento do automóvel por Borba Gato.

\subsubsection{Percurso paralelo de dois sujeitos e de dois antissujeitos: emissividade e remissividade}

No primeiro quadrinho de "Entradas e bandeiras", no nível discursivo, verificamos um automóvel em movimento. É noite e os atores "passageiros do automóvel" retornam para casa (figura 3.4).

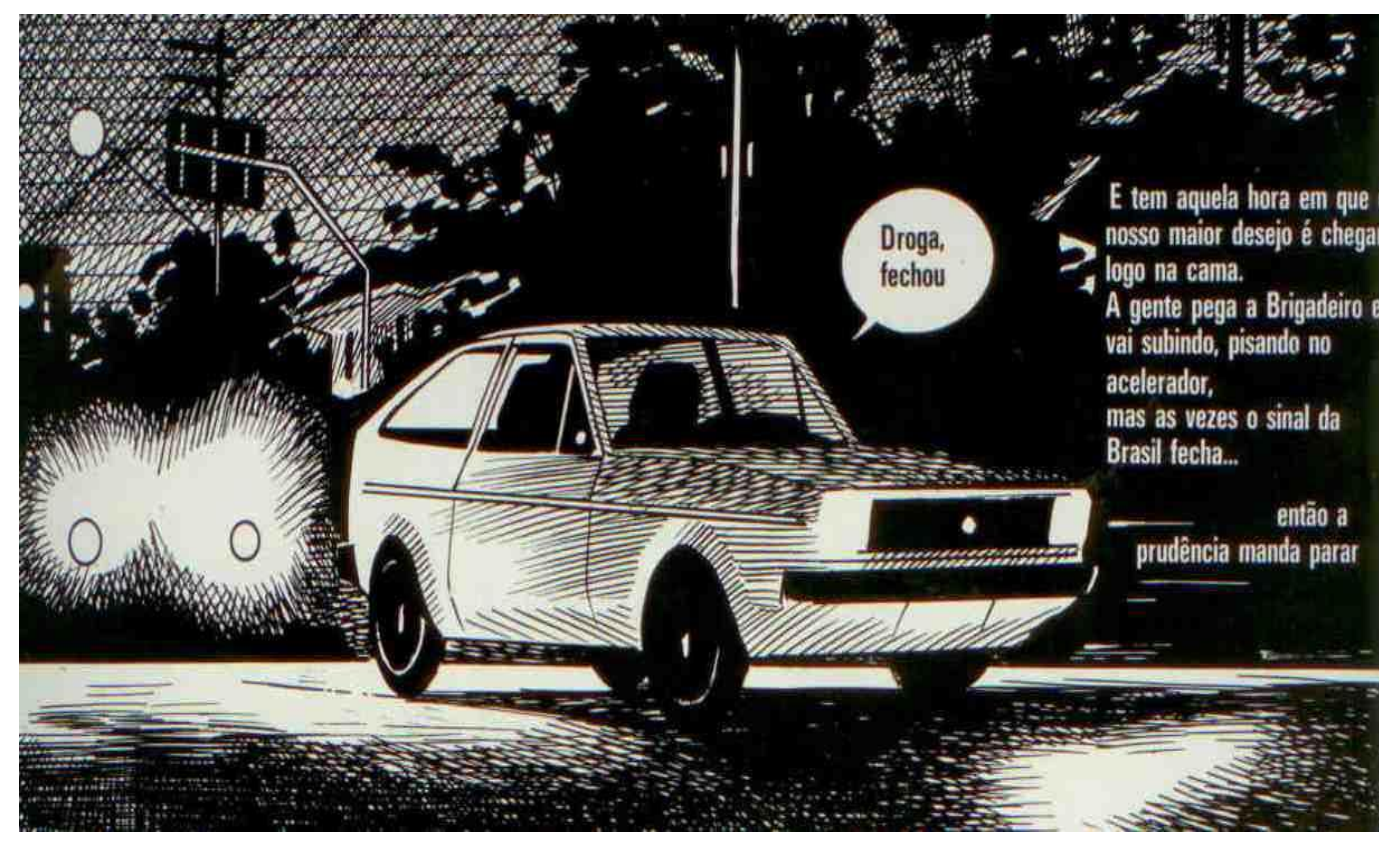

Figura 3.4 
No enunciado, o automóvel sobe a Avenida Brigadeiro Luís Antônio da cidade de São Paulo, espaço das sete HQs de Território de bravos. Colhemos essas informações espaciais também no terceiro quadrinho (figura 3.5).

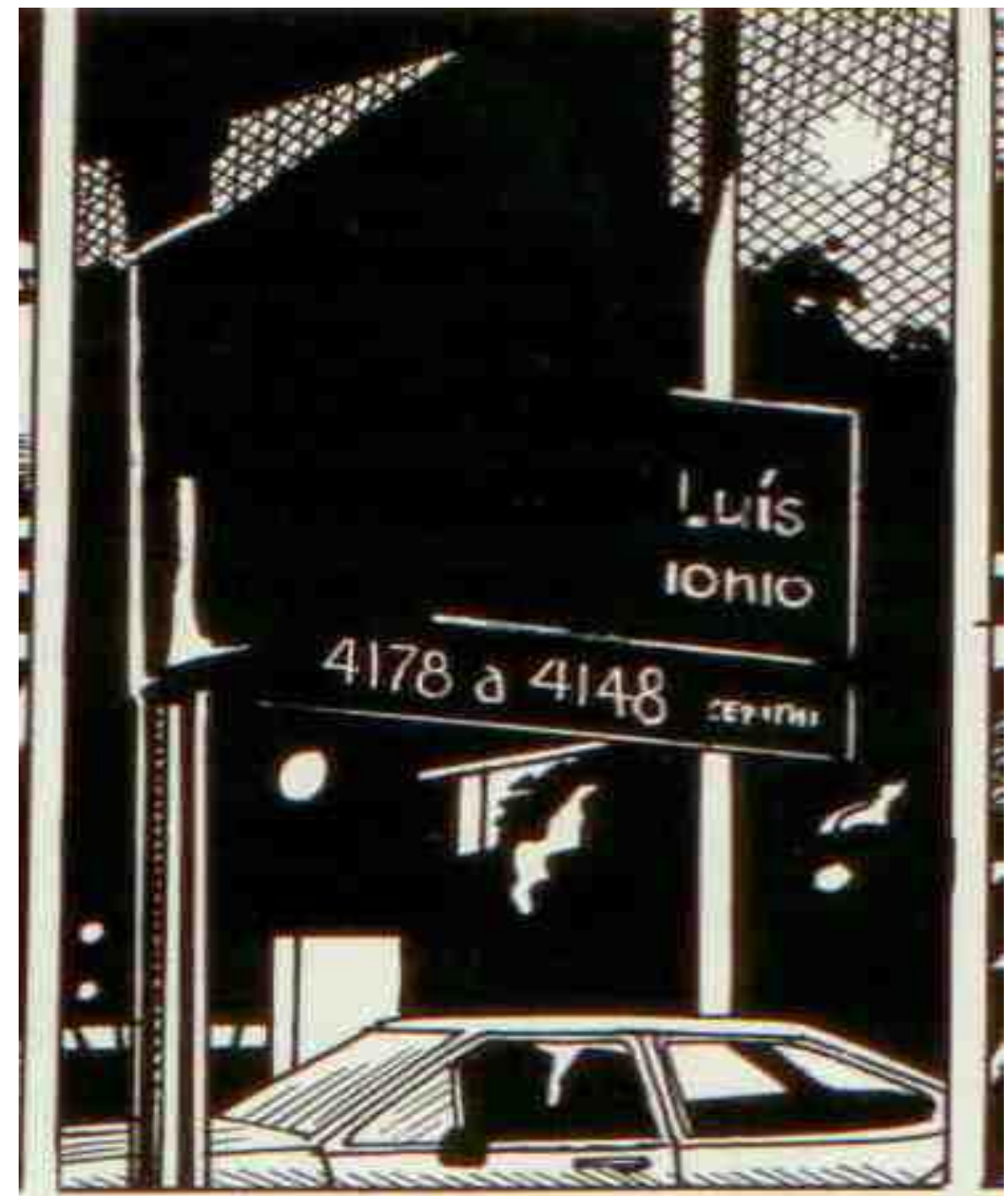

Figura 3.5

A cidade de São Paulo é figurativizada também no sumário ("planta turística", p. 8, no anexo desta dissertação) que antecede o frontispício de Território de bravos; nesse mapa, o enunciatário pode tomar contato com os diversos bairros da cidade em que ocorrem as sete histórias do livro: "Perdidos no espaço", na Vila Mariana; "Entradas e Bandeiras", na Av. Brigadeiro Luís Antônio (Parque do Ibirapuera); "Futboil", no Brás etc. Na página 9 (ver anexo), há ainda um mapa do território antigo da cidade. Na "Apresentação" do livro, novamente o enunciador menciona São Paulo como espaço das HQs. Além disso, logo abaixo 
do primeiro quadrinho da $\mathrm{HQ}$ sob análise, encontramos o seguinte enunciado verbal (figura 3.6).

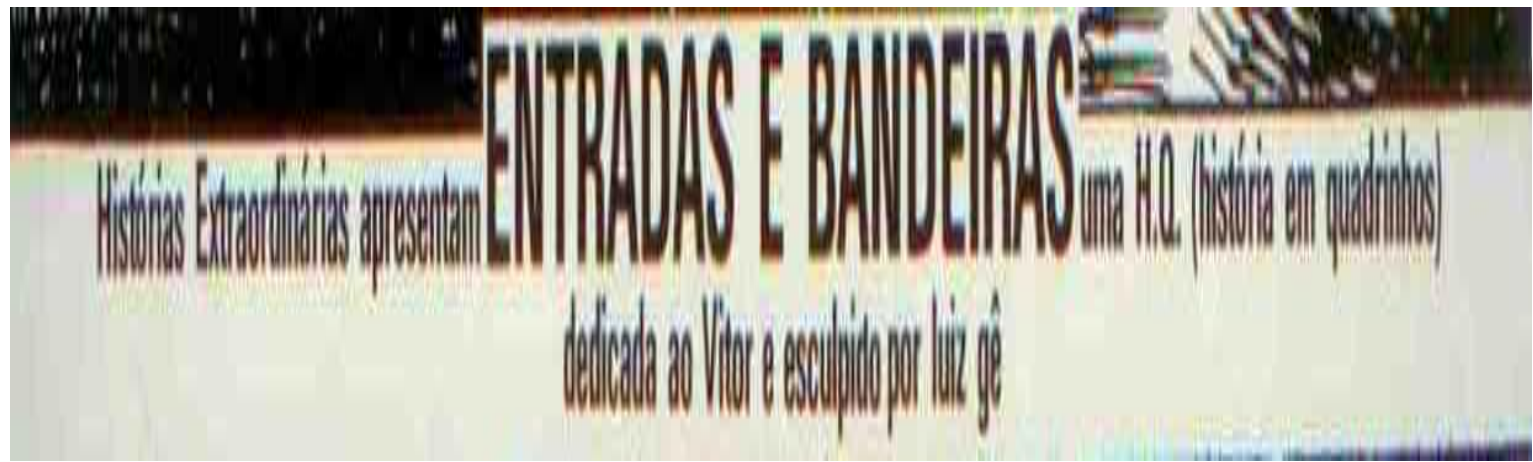

Figura 3.6

A título de esclarecimento, esse "Vitor" que aparece como ator do enunciado acima é o artista plástico Victor Brecheret, autor de Monumento às bandeiras, que se situa nas imediações da Av. Brigadeiro Luís Antônio com a Av. Brasil. No interior da HQ, deparamos no último quadrinho com a figura da estátua de Borba Gato, esculpida por Júlio Guerra. A estátua que se localiza em Santo Amaro, um bairro de São Paulo, é vista aqui transitando pelas imediações do Ibirapuera, alguns quilômetros distantes de seu lugar de origem.

Essa intertextualidade (aqui, os textos que dialogam entre si são todos obras de arte) é comum em toda a obra, a começar por seu título e pela capa, que parodia o Western do cinema americano (ver capa no anexo), como já comentado nesta dissertação. Ora, como estamos considerando Território de bravos uma obra artística, não nos pareceu sem importância ressaltar esse diálogo com as obras de arte que ocorre no interior das HQs.

Situado o espaço em que se desenrola o enunciado de "Entradas e bandeiras", tomemos o percurso do sujeito, figurativizado pelos atores passageiros do automóvel.

Um destinador, responsável pela continuidade da narrativa, impulsiona o sujeito, figurativizado pelos atores passageiros do automóvel, a desencadear uma ação. Esse destinador acompanha à distância o percurso do sujeito e tende a intervir sempre que há ameaça à continuidade no programa desse sujeito. Como o destinador porta valores emissivos, o compromisso com a continuidade é sua função-chave. Em "Entradas e bandeiras", deparamos com um destinador transcendente portador de valores da ordem social. Entre esses valores sociais, destacam-se o de organização da cidade, de obrigações 
individuais, de respeito às leis, de ordem no trânsito etc. Trata-se, portanto, de valores éticos do mundo utilitário. Contrapondo-se a esses valores, a instância enunciativa escolhe e afirma valores artísticos distribuídos pela cidade.

No início da narrativa, o sujeito, nas figuras dos passageiros do automóvel, está conjunto com tais valores de ordem social. Seu interesse é chegar à sua própria casa o mais rápido possível. O sujeito está modalizado, então, pelo querer. Um querer intenso, todavia, pode defrontar-se com obstáculos do dever. Obstáculos que se constituem em antissujeito. Assim é que no enunciado do primeiro quadrinho, no nível discursivo, temos:

E tem aquela hora em que o nosso maior desejo é chegar logo na cama.

A gente pega a Brigadeiro e vai subindo, pisando no acelerador, mas às vezes o sinal da Brasil fecha... então a prudência manda parar (grifo nosso).

Como vemos, o texto é explícito em afirmar que o sujeito deseja, MAS é impedido no seu desejo de chegar rapidamente a seu destino. O destinador ético empurra o sujeito para a frente, mas surpreendentemente instaura uma parada no percurso pelo "dever parar" do sinal vermelho. O desejo entra, então, em conflito com o dever. Para Zilberberg (2006b, p. 252) é "como se o querer reagisse à parada e o dever à continuação". Continua o autor afirmando que o querer perdura na mesma medida que o dever faz cessar.

No plano do conteúdo da linguagem verbal, no enunciado "mas às vezes o sinal fecha", a conjunção adversativa mas representa a parada, anunciando um espaço que se fechará pelo limite imposto pela intensidade dessa parada. O espaço aberto do início do primeiro quadrinho, de tempo originante (cronotrófico), é extenso; ele se endereça para o fechamento do tempo expectante (cronopoiese), que é intenso.

O desejo de chegar logo à cama está do lado do querer, pertence ao bom, que é da ordem da continuação, da expansão, do fazer emissivo. O ator da figura feminina, pela percepção do olhar, não só vê o semáforo fechado, como também se assusta com o ator estátua do nono quadrinho (ver figura 3.7). 


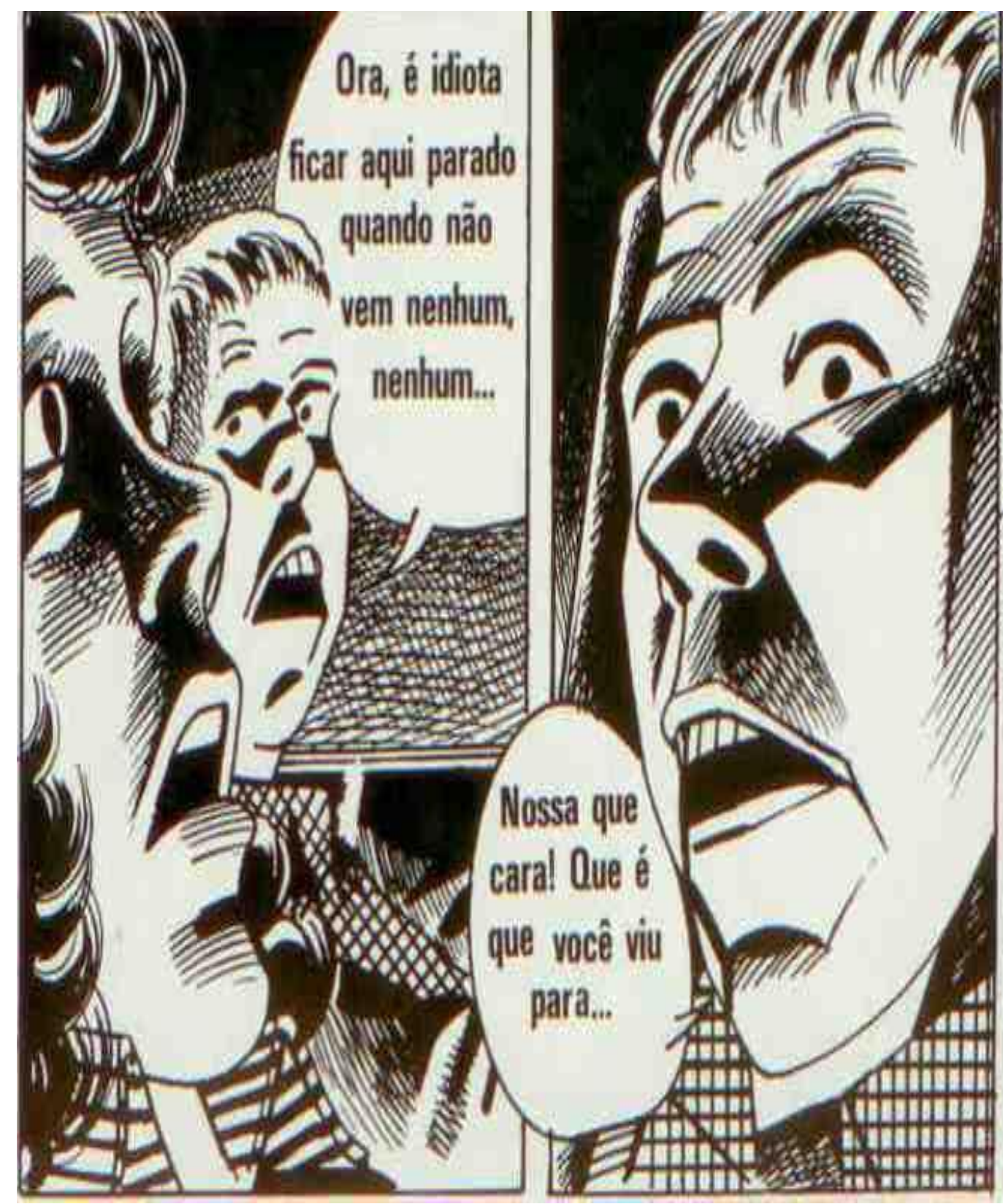

Figura 3.7

Nos quadrinhos de 1 a 5 da HQ (ver anexo no final desta dissertação) ${ }^{1}$, tudo parece tender a um relaxamento, a uma continuidade rumo à casa dos atores do automóvel. No entanto, a primeira parada estabelecida pelo sinal fechado regula a modalidade do dever, do ético, no enunciado verbal: "então a prudência manda parar". O mas da parada, que rege o querer, que é da ordem do bom, é concessivo, enquanto o então é implicativo, rege o dever

\footnotetext{
${ }^{1}$ Para a contagem dos quadrinhos, utilizamos o espaço vertical branco que separa um do outro. A história inteira é composta de 37 quadrinhos.
} 
(da ordem do bem). A retenção provocada pelo farol vermelho, que figurativiza o cotidiano de uma cidade, produz a interrupção do tempo passante e circunscreve o espaço.

O ator homem, mesmo não querendo, faz o automóvel parar porque deve. O juízo avaliativo de um dos atores mostra o absurdo a que vida social e ética leva, com regras estúpidas ("ora, é idiota ficar aqui parado quando não vem nenhum, nenhum...") que fogem a qualquer lógica. O cotidiano estabelece leis de utilidade que são, por sua inflexibilidade, geradoras de situações inúteis. Todavia, temos aqui paralelamente dois destinadores. $\mathrm{O}$ da arte tem em vista justamente a "parada" dos valores utilitários, erigida em valor eufórico, pois que depende dela o homem voltar a ressemantizar o objeto artístico (ver e enxergá-lo) já dessemantizado pela correria da cidade e pela continuidade da continuidade do cotidiano: os atores dos automóveis só veem naquele espaço um cruzamento, um contorno destituído de significado: "ao mesmo tempo é verdade que o mundo é o que vemos e que, contudo, precisamos aprender a vê-lo" (MERLEAU-PONTY, 2007, p. 16).

No quadrinho 10, a parada está figurativizada pelo semáforo vermelho e pela personificação $^{2}$ de um ator componente do Monumento às bandeiras, que se interpõe à passagem do automóvel, produzindo no percurso do ator mulher, no interior do carro, a inibição, stase, a parada da continuação. Por meio dessa personificação, os atores estátuas são sujeitos de um programa. Tal programa, que é manifestado nos quadrinhos 9 a 29 (ver anexo), realiza, como dissemos, o valor emissivo, difuso, verbalizado e narrativizado; o percurso dos sujeitos (atores estátuas) salienta que a temporalidade é originante na perspectiva do extenso e reparadora de uma falta. Esse é o lado da espera, memória do porvir; o eu (dos sujeitos atores estátuas) circula, é ativo. Ao lado desse valor emissivo dos sujeitos (atores estátuas) está o valor remissivo dos sujeitos, os atores do automóvel, que se encontram na parada, em tensão, numa temporalidade da espera. Nesse ponto de "Entradas e bandeiras", o tempo não está esvaziado de valores remissivos, há espera e há também surpresa a esperar, pois ainda não é o fim da história (ZILBERBERG, 2006b, p. 146).

O quadro 3.1 apresenta a articulação entre os níveis tensivo e missivo. É de salientar que sujeito 1 e sujeito 2 são catalogados para efeito de explanação do quadro. Todavia, mais adiante, mostraremos que sujeito 1 e sujeito 2 são respectivamente antissujeitos um do

\footnotetext{
${ }^{2}$ Segundo Greimas e Courtés (1989, p. 332), personificação "é um procedimento narrativo que consiste em atribuir a um objeto (coisa, entidade abstrata ou ser não humano) propriedades que permitam considerá-lo como um sujeito, ou melhor, que consiste em dotá-lo de um programa narrativo no qual possa exercer um fazer".
} 
outro, pois têm percursos paralelos e disputam o mesmo objeto: o espaço da cidade. Se disséssemos como analistas que as estátuas do nível discursivo são antissujeitos dos habitantes da cidade, já estaríamos de antemão estabelecendo um juízo valorativo. Quando se trata da disputa de um mesmo objeto (no caso, ambos querem conquistar o espaço da cidade), não seria adequado afirmar qual é o antissujeito e qual é o sujeito. Daí a proposta do título dessa análise: são dois sujeitos e dois antissujeitos, que perfazem percursos paralelos.

Quadro 3.1 Articulação entre níveis tensivo e missivo no percurso dos sujeitos 1 e 2 em "Entradas e bandeiras".

\begin{tabular}{|l|l|l|l|}
\hline & $\begin{array}{l}\text { Sujeito } \mathbf{1} \text { (manifestado } \\
\text { pelos do } \\
\text { automóvel) }\end{array}$ & $\begin{array}{l}\text { Sujeito 2 (manifestado } \\
\text { pelos atores estátuas) }\end{array}$ & \\
\hline Tensivo & Retenção & Distensão & Figural \\
\hline Missivo & Parada & Parada da parada & Figural \\
\hline Temporalidade & Espera & Repouso & Figurativo \\
\hline Espacialidade & Fechamento & Abertura & Figurativo \\
\hline
\end{tabular}

Fonte: Elaborado com base em Zilberberg (2006b, p. 147).

O movimento da $\mathrm{HQ}$ inicialmente seria (figuras 3.8A e B):

Distensão (difusão) $\rightarrow$ Retenção (concentração) = Nível tensivo

No nível discursivo:

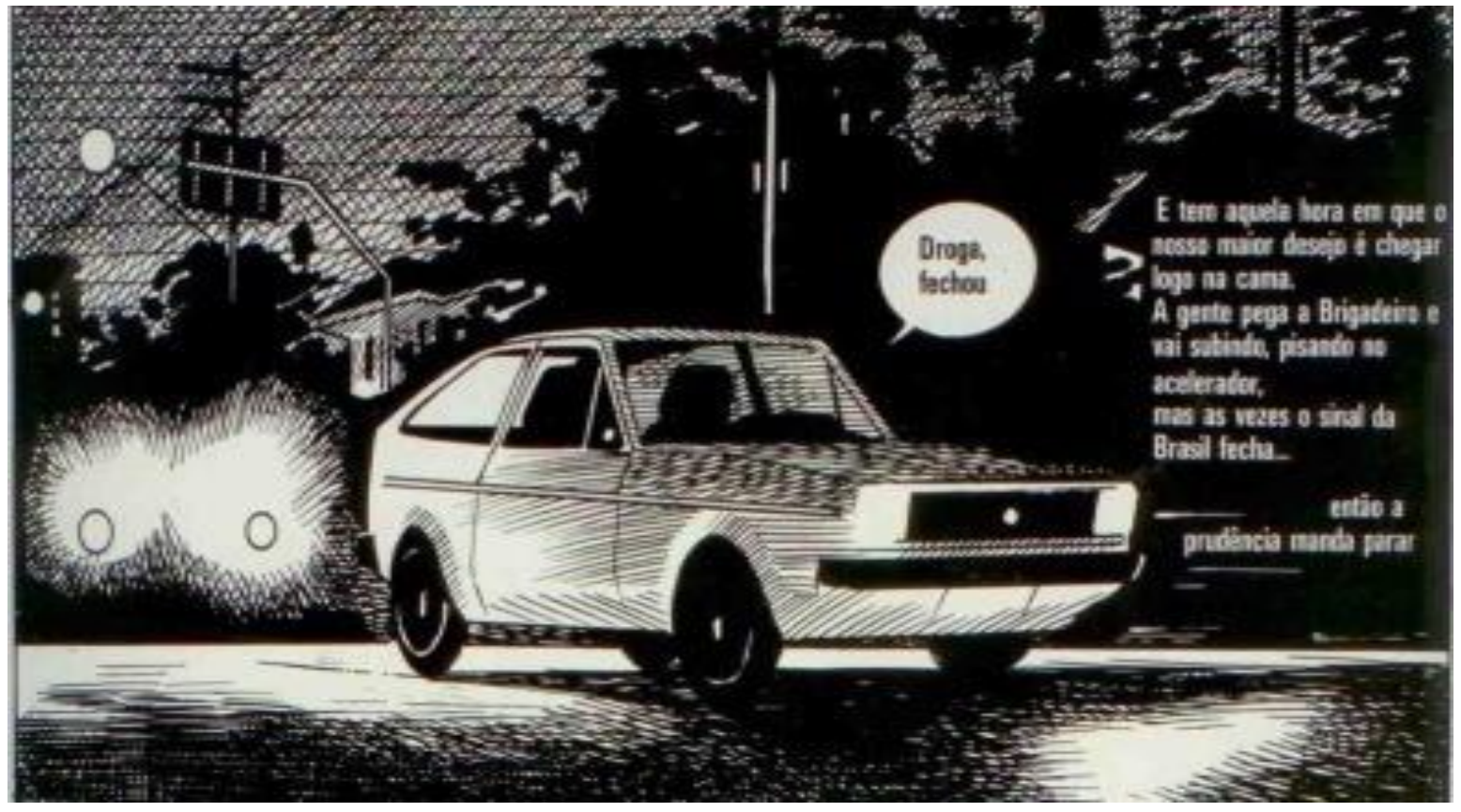

Figura 3.8A

Difusão. 


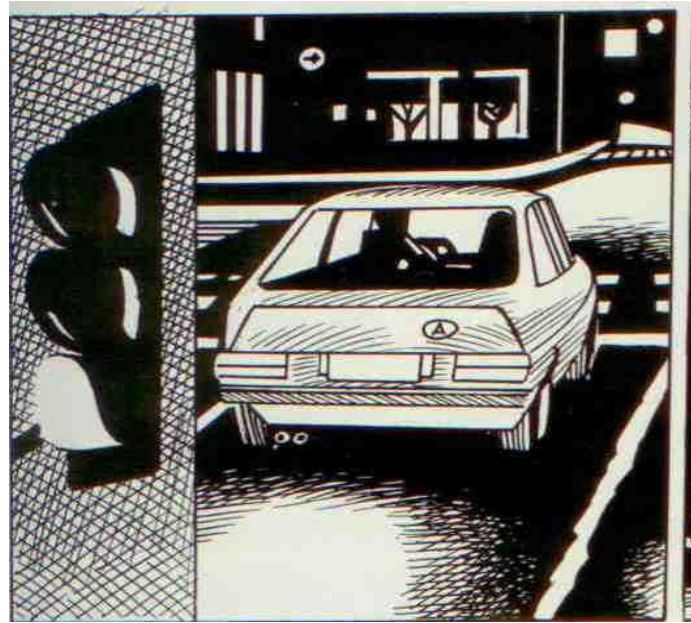

Figura 3.8B

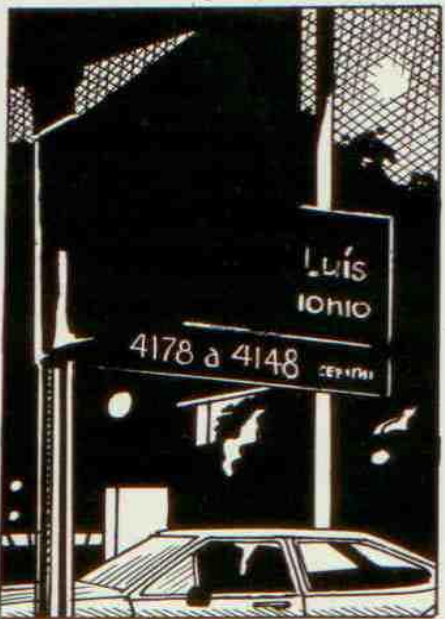

Em processo de concentração

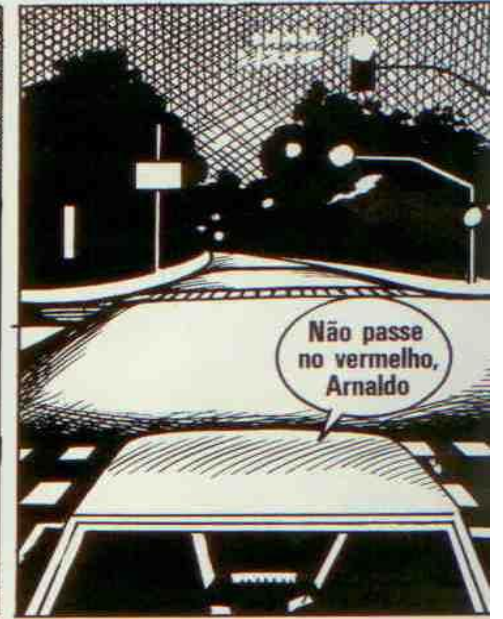

[Concentração].

Todavia, na narrativa desta $\mathrm{HQ}$, no lugar de um programa e de um antiprograma apenas, temos dois programas, dois sujeitos, dois destinadores, dois antiprogramas, dois antissujeitos etc. que se desenvolvem no mesmo espaço, lado a lado, com percursos paralelos.

O fechamento (remissivo) e a abertura (emissivo) dessa narrativa, a concentração e a difusão funcionam, no entanto, alternadamente. Nossa análise parte do ponto de vista de que são dois sujeitos, disputando o mesmo espaço, mas com valores diversos. Enquanto o sujeito 1 (atores passageiros) tem como programa de uso a conjunção do espaço para atingir o programa de base que seria a conjunção com os valores éticos e sociais, o sujeito 2 (atores estátuas) tem como programa de uso a conjunção com a mobilidade, mas o programa de base seria a conjunção com valores artísticos, ou seja, deslocar-se no espaço para se "fazer ver" como ARTE. Um sujeito não funciona como antissujeito do outro, porque, em verdade, são dois os destinadores. Um é governado por obrigações éticas e outro por valores estéticos. Como, porém, os percursos se cruzam no mesmo espaço, temos a alternância de remissividade e emissividade: se S1 está de posse de valores emissivos (difusos), S2 estará de posse de valores remissivos (concentrados) e vice-versa.

O fundamental em "Entradas e bandeiras" é que em determinado ponto da narrativa os percursos dos sujeitos se cruzam no embate pelo objeto (espaço): os carros (que figurativizam o mundo industrial, da utilidade) cruzam com as estátuas (que figurativizam o mundo da arte). É nesse cruzamento que se faz ressaltar a inversão de valores do homem moderno. Podemos ver na figura do automóvel a isotopia da velocidade e do que é 
"passageiro", enquanto na obra de arte o que é permanente e duradouro. A obra de arte dessemantizou-se, como já dissemos, aos olhos do homem, cujo interesse resume-se ao prosaísmo de ações rotineiras e banais. Por isso, o percurso da estátua, guiada por um destinador transcendente artístico, não é de um antissujeito do homem, mas de um sujeito que quer prevalecer na posse do objeto (o espaço). Não se constituem meros objetos de adorno, mas são integrantes do espaço da cidade.

Esses sujeitos podem ser assim caracterizados (quadro 3.2).

Quadro 3.2

\begin{tabular}{|l|l|}
\hline Nível narrativo & Nível discursivo \\
\hline S1 & Atores “passageiros do automóvel” \\
\hline S2 & $\begin{array}{l}\text { Atores “estátuas [figuras do Monumento às } \\
\text { Bandeiras e Borba Gato] }\end{array}$ \\
\hline
\end{tabular}

São propriamente dois percursos de direções opostas: S1, inicialmente conjunto com a mobilidade, deseja a conjunção com o repouso (cama); enquanto S2, recém-saído da condição de imobilidade (estátua), deseja manter-se conjunto com tal mobilidade, transitar à frente do homem para provocar-lhe a percepção.

No nível discursivo, as figuras "atores do Monumento às Bandeiras" e "Borba Gato" (S2) seriam objetos semióticos, alvo de desejo de um sujeito, passivos, portanto. Normalmente, ocupariam um lugar determinado pelo homem, de imobilidade. Todavia, nessa $\mathrm{HQ}$, esses objetos não são objetos, mas sujeitos ativos, com um percurso de mobilidade. O enunciador de "Entradas e bandeiras" permuta os valores. Enquanto S1 se concentra e adota valores de parada, S2 se difunde e adota valores de continuidade:

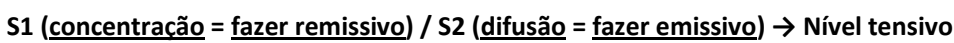

$\downarrow$

$\downarrow$

Os atores passageiros do automóvel / Os atores estátuas (Monumento às bandeiras e Borba Gato) $\rightarrow$ Nível discursivo
}

O destinador estético, compromissado com a continuidade do percurso de S2, dá-lhe mobilidade, levando S1, de características móveis, à passividade. Para Zilberberg (2006b, p. 145), a estética é um lugar de troca. O objeto, em geral, ganha o lugar de sujeito factivo e ativo, e o sujeito ganha um lugar passivo e pático. Nos quadrinhos 26 e 31, a inércia do objeto estético é substituída pela ação de um sujeito factivo e a ação de um sujeito animado 
(ator mulher) é substituída pela passividade, pela concentração, fazendo sobressair a surpresa e o susto, um tipo de inquietação.

É de se questionar: como S2 se configura antissujeito de S1, por lhe paralisar o percurso (os atores do automóvel são parados pelas estátuas), S1 seria um empecilho no percurso de S2? Ocorre aqui um (a) sincretismo actancial e (b) atorial (GREIMAS; COURTÉS, 1989, p. 426; TATIT, 2001, p. 51). No primeiro caso, temos alguns atores que investem um actante só: (a) o conjunto dos atores estátuas forma um sujeito (S2) e os atores homem e mulher formam outro sujeito (S1). No segundo caso, (b) cada ator comporta dois ou mais actantes: o ator homem é ao mesmo tempo sujeito e antissujeito de S2; o ator estátua é ao mesmo tempo sujeito e antissujeito de S1.

São sujeitos que visam a valores diferentes, mas, quando os percursos se interseccionam (figura 3.9), um sujeito transforma-se em antissujeito do outro (o automóvel é antissujeito para a obra de arte, a obra de arte é antissujeito para o automóvel).
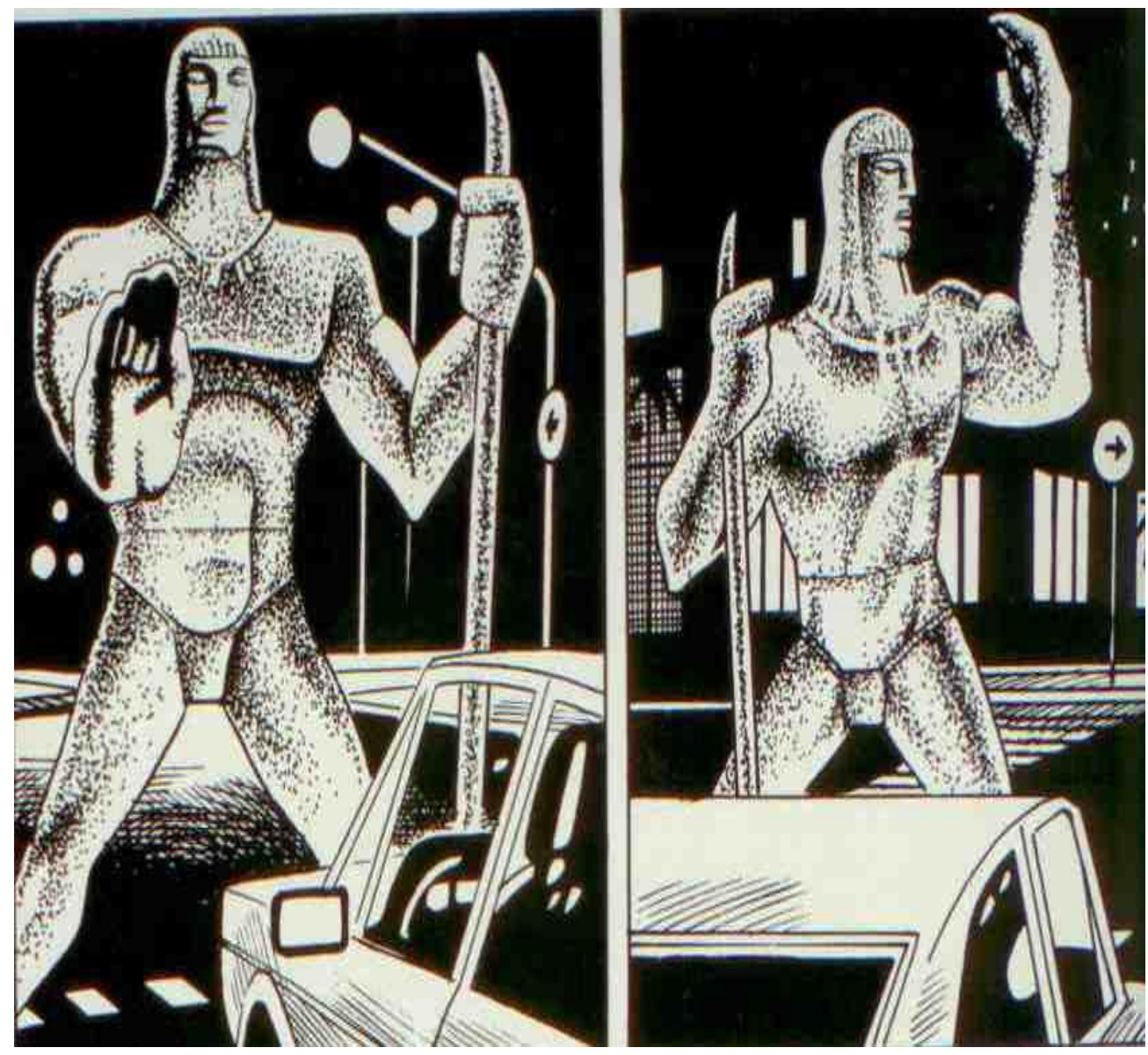

Figura 3.9 
Nos dois quadrinhos acima, no nível discursivo, o carro constitui-se em empecilho para a figura da estátua. Nesse momento, o ator estátua sincretiza também o papel de sujeito e de destinador dos demais sujeitos (atores estátuas). Há uma concentração, quando o fazer remissivo sobrevém para ambos os programas narrativos. Dos quadrinhos 10 até o 29, o percurso de S1 permanece interrompido, concentrado. Por outro lado, o percurso de S2 é difuso, da ordem da emissividade.

Fantasticamente, é essa igualdade de condições da arte com os atores humanos que faz com que os atores estátuas perambulem pelas ruas para se fazerem "perceber", como se sugerissem a falta de percepção do homem para com os objetos estéticos distribuídos pela cidade. A repetição desse cotidiano utilitário dos sujeitos da cidade leva ao desgaste de tal percepção em relação aos objetos artísticos.

Os atores do automóvel em "Entradas e bandeiras", por exemplo, entram em conjunção com a falta de percepção da totalidade dos valores da cidade. Eles veem, mas não enxergam, ou se veem não veem o objeto artístico como arte.

Para a coletividade, os objetos saem da esfera do artístico e entram na esfera do utilitário. A escolha pelo enunciador do movimento contínuo de $\mathrm{S} 2$, nessa $\mathrm{HQ}$, parece constituir-se num desejo de reposicionamento do objeto artístico entre os sujeitos. Daí, os objetos de arte serem sujeitos ativos, vivos. Noutros termos, S2, em vez de adotar valores de continuação da parada, adota valores emissivos (difusos), necessários à factividade de seu programa narrativo.

Poderíamos também dizer que a interrupção do percurso de S1 provocada por S2 corresponde a uma estratégia de manipulação do destinador estético para que S1 perceba S2. Este último entra no campo de presença daquele para ser desejado pelo olhar de S1, competente apenas para "enxergar" valores utilitários do cotidiano prático.

Desfila-se então à frente do enunciatário uma série de quadrinhos que se constituem em verdadeiras telas que são simulacros de partes da escultura de Brecheret, figurativizadas em "Entradas e bandeiras". Se normalmente os habitantes da cidade passam pelo Ibirapuera sem perceber o belo do conjunto granítico que ali se encontra, aqui na $\mathrm{HQ}$ eles podem fruílas em detalhes tonificados pela concentração. Assim é que passam pelo campo de presença do enunciatário joelhos, pernas, pés, cabeças, troncos, formando um painel que faz lembrar o classicismo com seus detalhes de escultura. A metonímia (ver capítulo 4, seção 4.3, 
Semiótica e retórica) utilizada pelo enunciador é tonificante, é da área da triagem, da separação, impactante, portanto (ZILBERBERG in: CAÑIZAL; CAETANO, 2004, p. 77). Trata-se possivelmente de um paradoxo, pois um objeto, inicialmente, sai da passividade e ganha o estatuto de sujeito e, ao ganhar tal estatuto, deseja retomar a posição de objeto, não de um objeto qualquer, mas de um objeto de desejo no campo de visão de outro sujeito. Vejamos os quadrinhos de 12 a 17 na figura 3.10.
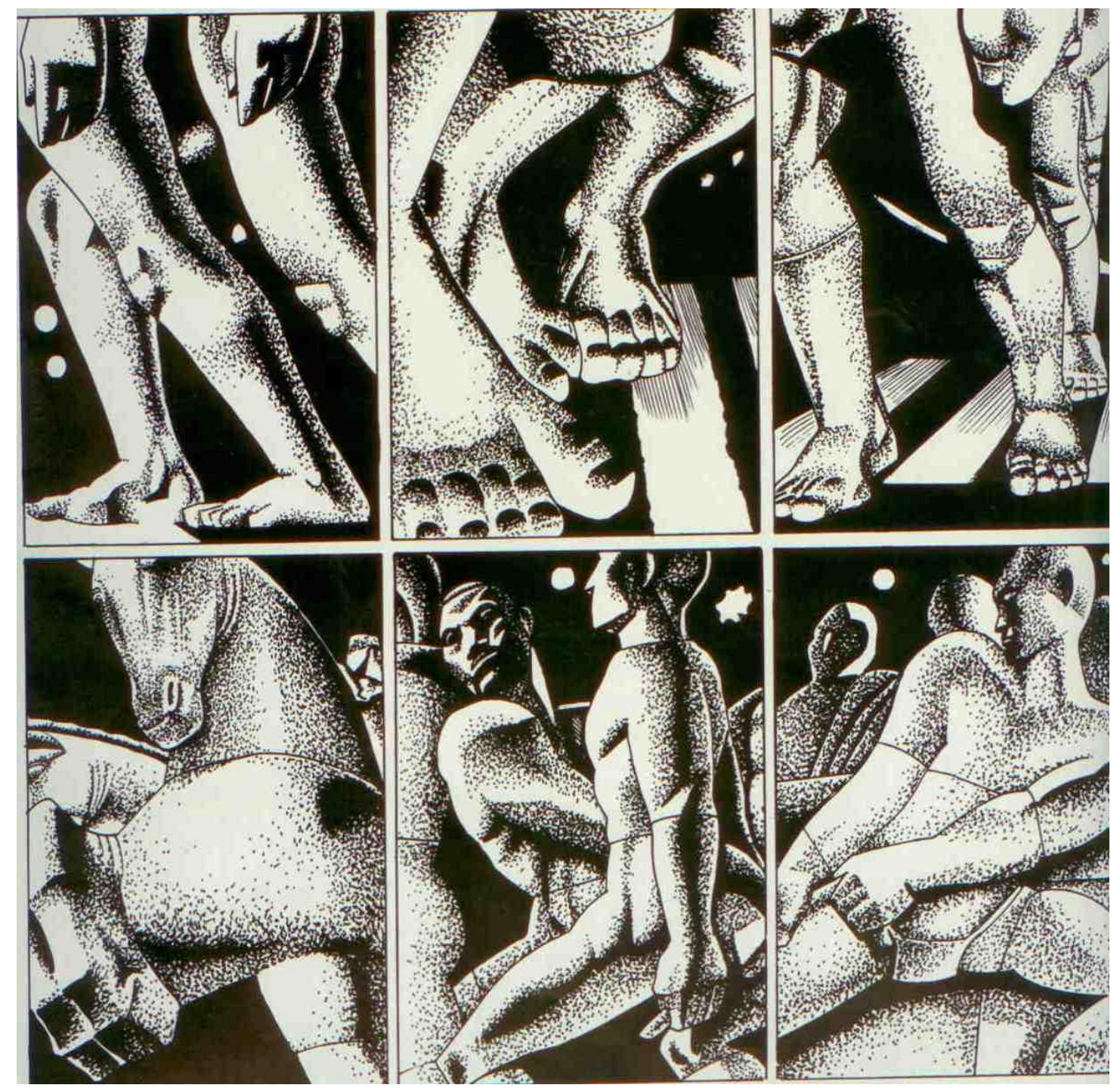

Figura 3.10

Um legítimo antissujeito de S1, se é que assim podemos dizer, é o farol, causador da primeira parada em seu programa, e esse sinal de trânsito figurativiza o dever. Afinal, a oposição fundamental nessa $\mathrm{HQ}$ se dá entre valores do mundo ético e valores do mundo estético, entre utilitarismo e arte. 
O destinador de S1 é o vigilante dos valores sociais do cotidiano: “'Guardião' dos valores juntivos e artífice maior da direção (ou intencionalidade) narrativa, o destinador renova em suas manobras continuativas a ideia de que há uma ascendência dos valores emissivos sobre os remissivos" (TATIT, 2010, p. 25). Dessa forma, o destinador de S1 zela pelo cumprimento do programa. Se, no primeiro quadrinho de "Entradas e bandeiras", um antissujeito avançava no campo de percepção de S1, no quarto quadrinho (figura 3.11) o antissujeito já está instalado e ocorre a primeira parada no percurso de S1:

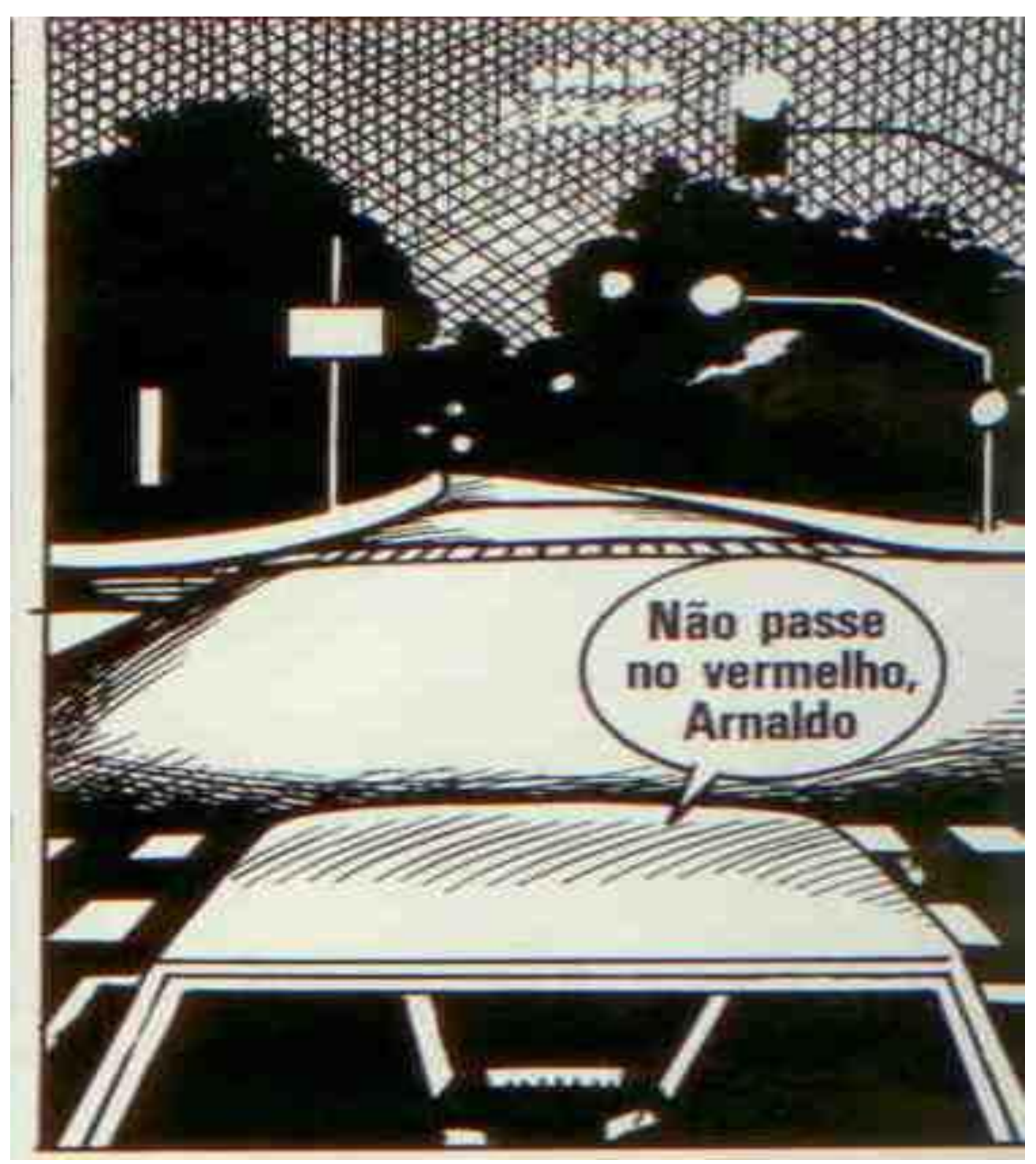

Figura 3.11

$\mathrm{O}$ ator do enunciado (passageiro do carro) é um sujeito em conjunção com valores éticos: "Não passe no vermelho, Arnaldo". Ora, um ritmo e uma direção (ver considerações sobre ritmo no capítulo 4) regem as narrativas das sete HQs de Território de bravos: a 
continuidade, se dominante, depende do fechamento latente para atingir novamente a abertura.

Ao tomar conhecimento da primeira parada, S1 sente necessidade premente de expansão. Daí o movimento concentração/expansão (figura 3.12), estudados no capítulo 2.
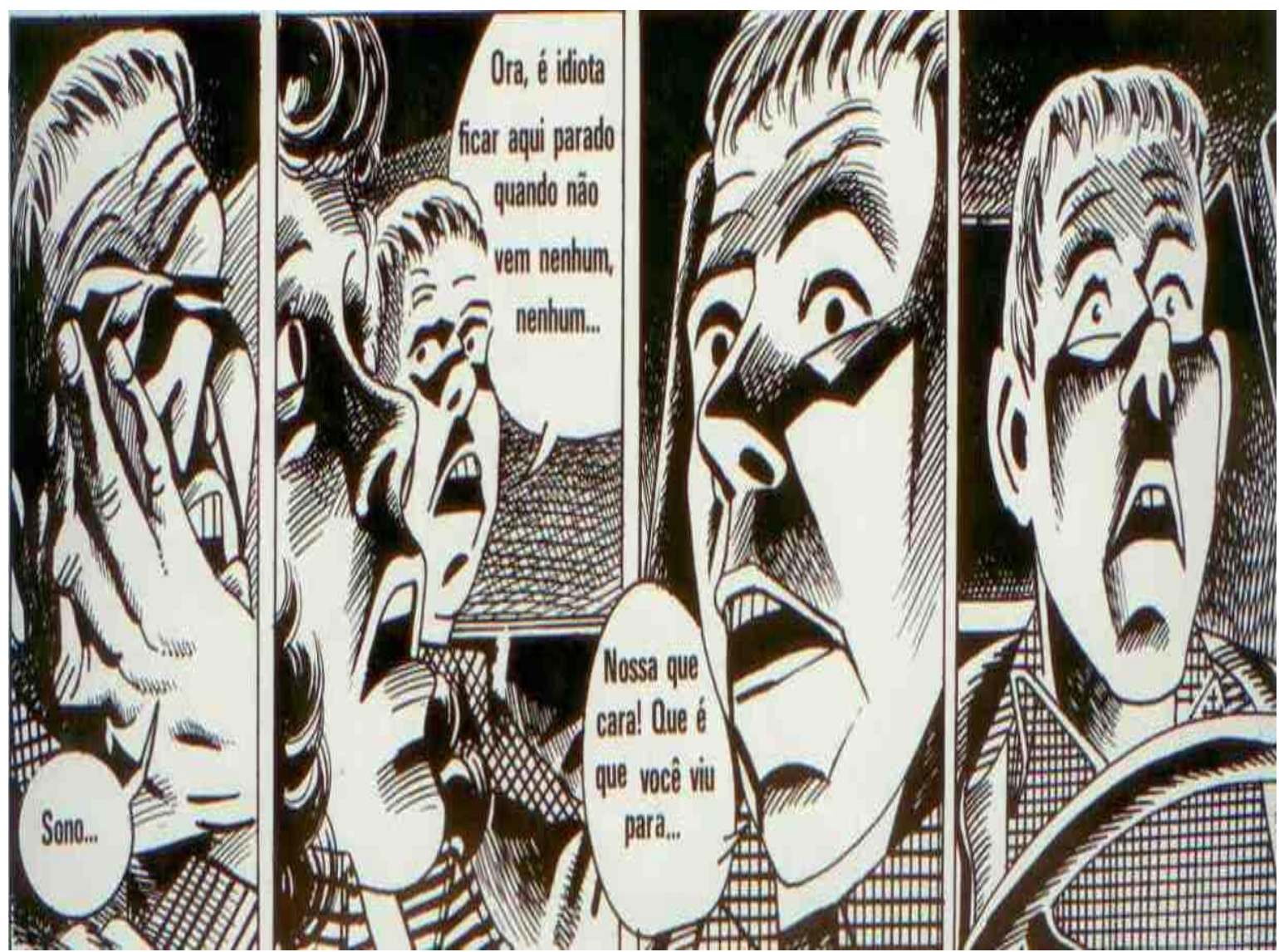

Figura 3.12

Em outras palavras, o ator do enunciado sofre na condição de sujeito ["Ora, é idiota ficar aqui parado quando não vem nenhum, nenhum..."], mas não abre mão do sentido de progresso narrativo. Subjaz a esse desejo da continuação narrativa a força progressiva do destinador que o impulsiona para a continuidade de seu percurso. $O$ destinador reafirma em suas manobras continuativas a ideia de que há uma ascendência dos valores emissivos sobre os remissivos e que a conjunção conduziria à disjunção (TATIT, 2010, p. 25).

A seguir, a tensividade e a missividade em "Entradas e bandeiras" como reveladoras do estético em face do ético. 


\subsubsection{Tensividade e missividade: articulação do tempo e do espaço}

O programa do sujeito na figura dos atores passageiros (S1) e o programa do sujeito na figura das estátuas ( $\mathrm{S} 2$ = Monumento às bandeiras e Borba Gato) são paralelos ${ }^{3}$ em "Entradas e bandeiras", como já o dissemos. Vejamos, no quadro 3.3, como são articulados os programas no nível discursivo, quadrinho a quadrinho (ver HQ na íntegra no anexo), da história analisada, com base no esquema de Zilberberg (2006b, p. 147).

Quadro 3.3

Análise tensiva, missiva e espaço-temporal de "Entradas e bandeiras".

\begin{tabular}{|c|c|c|c|c|c|}
\hline Quadrinhos & Programa & Tensivo & Missivo & Tempo & Espaço \\
\hline 5 a 8 & S1 & Retenção & Parada & Espera & Fechamento \\
\hline 30 a 32 & S1 & $\begin{array}{l}\text { Retenção (ameaça } \\
\text { de distensão) }\end{array}$ & $\begin{array}{l}\text { Parada (ameaça de } \\
\text { parada da parada) }\end{array}$ & Espera & $\begin{array}{l}\text { Obs.: No quadrinho } 30 \\
\text { da HQ, ameaça de } \\
\text { abertura do espaço. } \\
\text { Quadrinhos } 31 \text { e } 32 \text { da } \\
\text { HQ, espaço fechado. }\end{array}$ \\
\hline 33 & S1 & Distensão & Parada da parada & Repouso & Abertura \\
\hline 34 & S1 & $\begin{array}{l}\text { Distensão, mas o } \\
\text { sujeito percebe o } \\
\text { surgimento da } \\
\text { parada novamente, } \\
\text { da concessão. É a } \\
\text { surpresa chegando. }\end{array}$ & $\begin{array}{l}\text { Parada da parada, } \\
\text { juntamente com a } \\
\text { chegada de nova } \\
\text { parada. }\end{array}$ & $\begin{array}{l}\text { Repouso que } \\
\text { tende à } \\
\text { espera. }\end{array}$ & $\begin{array}{l}\text { Abertura (explosão) } \\
\text { que tende ao } \\
\text { fechamento } \\
\text { (implosão). }\end{array}$ \\
\hline
\end{tabular}

\footnotetext{
${ }^{3}$ É de considerar que, enquanto S2 está de posse de valor emissivo, S1 está de posse de valor remissivo.
} 


\begin{tabular}{|c|c|c|c|c|c|}
\hline & & & & & $\begin{array}{l}\text { intenso, que ainda } \\
\text { não pertencia à } \\
\text { história: a chegada da } \\
\text { surpresa. }\end{array}$ \\
\hline 37 & S1 e S2 & $\begin{array}{l}\text { Os valores } \\
\text { remissivos triunfam } \\
\text { no momento em } \\
\text { que S1 é } \\
\text { extenuado. Para S1, } \\
\text { não há mais espera } \\
\text { nem surpresa a } \\
\text { esperar, nem } \\
\text { retenção, nem } \\
\text { distensão: } \\
\text { prevalência do } \\
\text { permanente sobre } \\
\text { o passageito } \\
\text { (esmagamento do } \\
\text { carro) no nível } \\
\text { discursivo. } \\
\text { S2: distensão }\end{array}$ & $\begin{array}{l}\text { S1: parada da } \\
\text { parada, levando a } \\
\text { uma continuação } \\
\text { da continuação, a } \\
\text { um relaxamento } \\
\text { total (eliminação } \\
\text { do carro, objeto } \\
\text { do mundo } \\
\text { utilitário. Estado } \\
\text { continuativo de } \\
\text { Borba Gato). } \\
\text { S2: continuação da } \\
\text { continuação: } \\
\text { ator estátua Borba } \\
\text { Gato continua em } \\
\text { expansão. }\end{array}$ & $\begin{array}{l}\text { S1: tempo } \\
\text { esvaziado, é o } \\
\text { final da } \\
\text { narrativa. } \\
\text { S2: repouso, } \\
\text { tempo } \\
\text { originante. }\end{array}$ & $\begin{array}{l}\text { Final do percurso de } \\
\text { S1: uma vez que o } \\
\text { tempo funciona em } \\
\text { razão do espaço e o } \\
\text { tempo esvaziou-se, o } \\
\text { espaço também se } \\
\text { extinguiu por ser ele a } \\
\text { imagem do tempo }{ }^{4} \text {. } \\
\text { S2: Espaço aberto. }\end{array}$ \\
\hline
\end{tabular}

Como vimos no quadro $3.3, \mathrm{~S} 2$, representado pelos atores do Monumento às bandeiras e por Borba Gato, assume valores emissivos. Em nenhum momento de "Entradas e bandeiras", ele assume valores remissivos, como nos mostra o quadrinho 18 da HQ (ver anexo) em que um ator estátua faz o automóvel parar para que o percurso de S2 (atores que compõem o Monumento) continue na posse de valores emissivos, diferentemente, pois, do que é o percurso dominantemente remissivo de S1 (atores que estão dentro do automóvel). Este último assume valor remissivo por quase toda a narrativa, com exceção dos quadrinhos 1 a 4 (em geral, as narrativas começam com tempo originante) ${ }^{5}$ e dos quadrinhos 33 e 34 em que S1 assume transitoriamente a emissividade. É de ressaltar que valores emissivos e remissivos não são absolutos, estanques, ou seja, são oscilantes.

A emissividade inicial apresenta-se como relaxamento, continuação da continuação; esses valores assumidos pelo sujeito instruem o nível narrativo com o estado de não

\footnotetext{
${ }^{4}$ Cf. Zilberberg (2006b, p. 147).

${ }^{5}$ A contagem dos quadrinhos pode ser feita no anexo a este trabalho, como já dissemos, considerando as divisões comuns às histórias em quadrinhos (espaço branco vertical entre quadrinhos, ou linha vertical). Os quadrinhos vão de 1 a 37 em "Entradas e bandeiras".
} 
conjunção com a "cama" (valores prosaicos). Tal sujeito é figurativizado, no nível discursivo, pelas pessoas do automóvel. A figura "cama" identifica desejo e necessidade de descanso do homem da metrópole, mergulhado que está cotidianamente em afazeres extenuantes.

No quadrinho 5 do anexo, pode-se ver que um dos atores do automóvel diz estar com sono. As figuras do automóvel, do semáforo da Av. Brigadeiro Luís Antônio, por sua vez, têm um valor tensivo associado à descontinuidade, à parada. Os sujeitos figurativizados pelos atores do automóvel são orientados por um destinador cuja função é desobstruir obstáculos e restaurar a continuidade por meio do processo conhecido como parada da parada. Os sujeitos figurativizados pelos atores estátuas são orientados também por um destinador. O destinador de S1 parece ocupar-se de valores éticos, de obrigações, como o são os valores do homem de uma cidade grande, industrializada e de serviços, como São Paulo, em que é necessário, sempre depois da labuta diária, o descanso para, no dia seguinte, retomar os deveres da ética. Portanto, o destinador desse sujeito é a ética. Já o destinador de S2 ocupa-se de valores estéticos. Dessa forma, o destinador desse sujeito é a estética. É de notar que estamos diante de uma oposição fundamental, ou seja, de um lado, o prosaísmo das ações do cotidiano e, de outro, a arte (da égide do artístisco), uma oposição entre o passageiro e o permanente.

É de observar ainda que S2 (atores estátuas do Monumento às bandeiras e Borba Gato) não é antissujeito de S1 (atores do automóvel), como vimos anteriormente; eles assumem valores diversos, visto que homem e arte, ao mesmo tempo, querem ocupar o mesmo espaço da cidade de São Paulo.

Ao final dessa $\mathrm{HQ}$, os valores estéticos são tidos como permanentes e os valores utilitários (ver capítulo 4, seção Do utilitário ao artístico), figurativizados por homem e carro, são tidos como efêmeros (no nível discursivo, o automóvel é esmagado, metonímia de valores utilitários, pelo ator estátua Borba Gato, metonímia de valores artísticos). Enquanto a marca do utilitarismo é a velocidade da sua solvência, a da arte é a da conservação. Homologando, temos:

Figura discursiva do homem e do carro (utilitarismo): passageiro :: Figura discursiva da estátua (artístico): permanente 
A emissividade de S2 opõe-se à remissividade de S1. No nível discursivo, paradoxalmente a mobilidade momentânea das estátuas é condição para a sua conservação. Por outro lado, a interrupção momentânea da mobilidade do homem é condição para a percepção de valores artísticos no seu campo de presença.

Para Zilberberg (2006b, p. 145), enquanto a estetização ativa um objeto e apassiva um sujeito, na etização temos um sujeito ativo ao lado de "um passivo, pático, decidido a obedecer às ordens ditas morais", além do que deixa de existir a ativação do objeto.

A estética, no caso de "Entradas e bandeiras", é o lugar de troca entre um objeto ativo, factivo, e um sujeito passivo, pático. Assim, os atores do Monumento às bandeiras e o ator Borba Gato são, no nível narrativo, os objetos ativos, enquanto S1 (atores passageiros do automóvel), não só é passivo, pático, como também ativo. Na dimensão ética, o sujeito é partido; estabelece-se um confronto entre sujeito ativo e sujeito passivo. Dessa forma, os atores do automóvel, enquanto sujeitos responsáveis, éticos, querem chegar à cama, por desejo (bom) e por dever (bem) e para poderem retomar o cotidiano no dia seguinte. Ao lado de um sujeito ativo (bom), há um passivo (bem) que obedece às ordens morais de um destinador transcendente, portanto.

Por essa razão, endereçamos daqui por diante a análise para a semiótica do objeto, como estabelece Zilberberg (2006b, p. 142 ss). No quadro 3.4, examinamos as dimensões pragmática e cognitiva dos valores emissivos e remissivos.

\begin{tabular}{|l|l|l|}
\hline \multicolumn{2}{|c|}{ Quafração do objeto. 3.4} & Dimensão cognitiva \\
\hline Valores emissivos & Dimensão pragmática & $\begin{array}{l}\text { perobjeto } \\
\text { (crer) }\end{array}$ \\
\hline Valores remissivos & $\begin{array}{l}\text { Subobjeto } \\
\text { (amar) }\end{array}$ & $\begin{array}{l}\text { an-objeto } \\
\text { (saber) }\end{array}$ \\
\hline
\end{tabular}

Fonte: Elaborado com base em Zilberberg (2006b, p. 143).

As modalidades do crer e do saber atribuem cifras tensivas diferentes a seu objeto. A primeira privilegia os valores emissivos; nesse caso, podemos falar de perobjeto. A modalidade do saber enfatiza os valores remissivos e é extenuadora do objeto, tanto que Zilberberg a chama de an-objeto. A adivinhação pelo "saber", quando revelada, por exemplo, anula o seu objeto no exato instante da decifração. Da mesma forma, o objeto de 
arte, se compreendido na totalidade pelo saber, deixa de provocar interesse, espanto, e nesse caso teríamos a anulação do objeto artístico. O saber é da ordem da resolução. Daí a operação cognitiva do saber anular o objeto no momento da revelação.

Diferentemente, considerando a dimensão estética, o crer conserva seu objeto; a estética é, portanto, conservadora (ZILBERBERG, 2006b, p. 144). A conservação existe sob duas formas: (1) conservação pragmática: as estátuas tanto do Monumento às bandeiras quanto de Borba Gato têm um reduto no espaço da cidade de São Paulo; (2) conservação cognitiva (a arte ocupa em nossa cognição o espaço da memória).

A arte está no museu e na memória. Já o "não saber" (ignorância) dividiria o espaço em dois: ou está apenas no museu (inacessível para muitos) ou apenas na memória (ZILBERBERG, 2006b, p. 143). Se ocupasse um espaço só na memória, poderia se dessemantizar, assim como os gestos utilitários o são. Só passaria, portanto, a ser da égide da arte e da conservação se o objeto estivesse tanto na esfera pragmática (museu) quanto na cognitiva (memória).

A atividade estetizante é de caráter enigmático, porque não podemos dividir o espaço em pragmático e cognitivo; só podemos fazê-lo em termos analíticos, como no quadro 3.4. Passando para o nosso objeto, a mobilidade das estátuas configura um enigma. Por meio da modalidade do saber, a repetição cotidiana e utilitária provoca o desgaste das obras de arte postas no espaço pragmático em que circulam os sujeitos. Daí, em "Entradas e bandeiras", esse objeto retomar a condição de enigma, quando deixa a imobilidade para adquirir a condição de passante. Imóveis ficam os homens com o susto desse enigma.

Zilberberg (2006b, p. 144) ressalta que o objeto estetizado é um objeto tensivo: é paradoxal. O estético procede do subobjeto quando é da ordem do amor e do perobjeto quando é da ordem do crer. A ativação do objeto, por meio da personificação dos atores do monumento, e a passivação do sujeito (atores humanos paralisados) produzem um efeito de sentido de "emoção estética" 6 . Isso fica mais claro se retomarmos o quadro 3.3 em que os valores emissivos estão dominantemente do lado do sujeito 2 (S2) e são da ordem da expansão; essa difusão se dá, portanto, para fins de conservação. Os monumentos (S2) não podem ser da ordem da parada, pois, caso contrário, não se conservariam na cidade. Dá-se, então, a ativação do objeto e S2 torna-se um perobjeto.

\footnotetext{
${ }^{6}$ Cf. Zilberberg (2006b, p. 144-145).
} 
No Dicionário Houaiss (2001), o prefixo per tem o efeito de sentido de "movimento através de", "travessia", "perambular", "duração", "continuidade", "perenidade". Ora, a própria definição do dicionário nos dá a cifra tensiva do que Zilberberg chama de perobjeto: é o que dura, o contínuo, o que atravessa, o que continua; portanto, o perobjeto possui valores de dominância emissiva. Essas considerações de Zilberberg (2006b, p. 142-145) caracterizam o sujeito estético (S2) de "Entradas e bandeiras".

Se as estátuas não ganhassem estatuto ativo, estariam relegadas a continuarem "paradas" e dessemantizadas no reduto pragmático. Ao deixarem o reduto pragmático (estátuas paradas), o estético (S2) ganha a dimensão cognitiva de perobjeto que tem a cifra tensiva da duração, da conservação.

Essas considerações encaminham nossa análise para um ponto que merece outros esclarecimentos: se o prosaísmo está para a fala, que é dissolutiva em seu plano de expressão, pertence ao cotidiano (que, na análise, como vimos, é figurativizado pela figura do automóvel); a estética, por seu lado, tem uma enunciação durativa, uma forma de controle que o sujeito da enunciação exerce sobre o objeto enunciado. Assim, o estético (poético) conserva seu plano da expressão, suspendendo a passagem imediata do significante ao significado, o que prolonga e estabiliza o gesto enunciativo. Troca-se o instante do prosaísmo pela duração enunciativa, uma espécie de surpresa à atividade cotidiana ${ }^{7}$.

A conservação estética intersecciona-se com as características do obstinado (cf. capítulo 1), que, como vimos, quer ser aquele que faz apesar dos obstáculos. A mesma movimentação da arte em busca de seu espaço, que ocorre em "Entradas e bandeiras", de certa forma, é o movimento que encontramos na "Apresentação" de Território de bravos já analisada no capítulo 1. Assim como o enunciador revela-se um obstinado na consecução de sua obra, guardadas as proporções há uma reiteração desse fato em relação a S2 (atores estátuas do Monumento às bandeiras e Borba Gato), que, apesar dos obstáculos, querem afirmar-se como arte naquele espaço.

\footnotetext{
${ }^{7}$ Cf. Tatit (1997, p. 51) e Greimas (2002, p. 91). Para Fiorin (In: LANDOWSKI; DORRA; OLIVEIRA, 1999, p. 101), "a experiência estética é um evento extraordinário enquadrado pela cotidianeidade, é uma surrealidade englobada pela realidade". Para Tatit (In: LANDOWSKI; DORRA; OLIVEIRA, 1999, p. 200), "a apreensão estética compreende um breve lapso de tempo e uma inesperada cristalização do espaço, sentidos como um instante de distensão que dura entre duas sucessões de programas meticulosos e banais que, por sua vez, traduzem a tensão da rotina diária".
} 
Até aqui estudamos a dominância da remissividade e da concentração em meio à emissividade e à difusão como característica da conservação artística na $\mathrm{HQ}$ analisada. $\mathrm{Na}$ próxima seção, focalizaremos a predominância da emissividade em "Futboil", comparando-a com a predominância da remissividade em "Entradas e bandeiras".

\section{3 "Futboil": dominância da emissividade em busca do objeto}

A percepção das coisas exteriores é fraca, prejudicada por mil véus, provenientes das nossas taras físicas e morais.

Mário de Andrade

E com isto esvaiu-se-Ihe aquela visão fantástica e sutil.

Machado de Assis

\subsubsection{Cinema e "Futboil": dominância emissiva}

Uma das características das escolhas enunciativas de Luiz Gê, sujeito de papel, é produzir cada enunciado dos quadrinhos como se eles fossem um recorte sobre um movimento de câmera contínuo, distribuídos ao longo das páginas de Território de bravos. Os enquadramentos (aproximação e distanciamento), como dissemos no capítulo 2, podem ser traduzidos em abertura e em fechamento, categorias semióticas, e não mera focalização de movimento de câmera do cinema, nem mera sequência de imagens de HQs. Para nós, abertura e fechamento traduzem-se no conteúdo em emissividade e remissividade, categorias que subentendem a presença tônica ou não de um antissujeito.

Daí nosso estudo teórico apoiar-se no fazer missivo dos quadrinhos como estruturante do sentido das HQs. Retomando a homologação utilizada no capítulo 2, acrescentamos mais um elemento para poder, de certa forma, abrir mão, no nosso estudo, de terminologias cinematográficas (BEIVIDAS, 2006, p. 124):

\section{Fazer emissivo/difusão/distanciamento :: Fazer remissivo/concentração/aproximação}

"Futboil", pela contagem realizada no capítulo 2, é uma HQ que contém em sua maioria quadrinhos emissivos, o que traduz um bom exemplo do movimento contínuo. Das sete HQs de Território de bravos, ela é a que melhor reproduz o movimento cinematográfico. Esse efeito de cinema é resultado, portanto, do elevado número de difusões em meio a um número reduzido de quadrinhos remissivos (concentrados). Veremos na seção 4.2 que essa 
HQ difere de "Entradas e bandeiras", na medida em que esta última está para a escultura clássica, assim como "Futboil" está para o cinema e o barroco.

Como vimos no capítulo 2 , seção 2.2 , os quadrinhos, em sua maioria remissivos, dão à "Entradas e bandeiras" o estatuto de arte, em que cada fechamento e cada concentração tem o intuito de conservar o objeto semiótico, fazendo durar o plano da expressão, como faz o classicismo por meio da desaceleração. Desse ponto de vista, a estética é quase um culto, uma devoção (ZILBERBERG, 2006b, p. 144). Os enunciados de "Entradas e bandeiras", de um lado, fazem o enunciatário parar, delongar os olhos na "escultura" de cada quadrinho, como verificamos na análise anterior. "Futboil", por outro lado, com suas aberturas e emissividade, leva o enunciatário a correr os olhos sobre cada quadrinho, a cada virada de página, numa continuidade que só se esgota ao final da $\mathrm{HQ}$, o que configura um efeito de sétima arte.

A aproximação de "Futboil" com o cinema apoia-se particularmente no tratamento que este último dá ao tempo e ao espaço. A narrativa não se ocupa de apresentar o desenrolar dos acontecimentos em uma sequência linear, havendo cortes e saltos que aceleram o percurso do sujeito. A remissividade (fechamento) não é aleatória, mas, como já dissemos, é regulada conforme a emissividade (abertura): “o uso do close-up, por exemplo, não só tem critérios espaciais como também representa uma fase a ser atingida ou a ser suplantada no desenvolvimento temporal do filme. Num bom filme, os close-ups não são distribuídos de maneira arbitrária e caprichosa" (HAUSER, 2003, p. 971). Em "Futboil", por exemplo, no último quadrinho o enunciatário depara com um fechamento máximo que indica a consecução do propósito do destinador. Daí o palhaço surgir como destinador julgador, sancionando negativamente a inabilidade dos sujeitos (meninos) que, ao jogarem, em vez de desfrutarem do jogo, destroem o objeto do desejo. Aqui, a vitória configura-se uma derrota (figura 3.13), uma espécie de vitória de Pirro, ou seja, uma vitória obtida a alto preço, potencialmente acarretadora de prejuízos irreparáveis. 


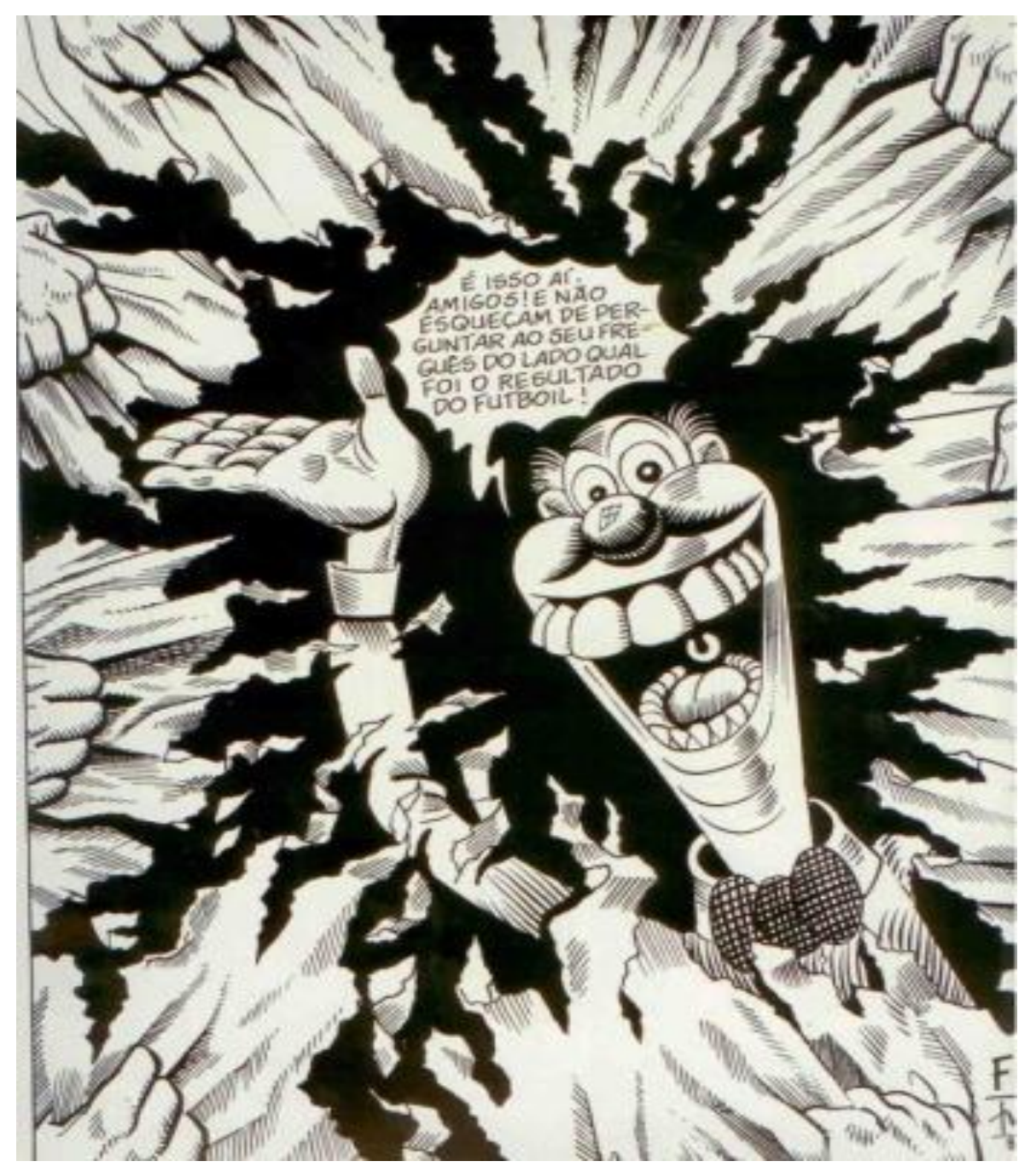

Figura 3.13

Ao comparar "Futboil" com o cinema e "Entradas e bandeiras" com a escultura, retomamos as homologações feitas nesta dissertação. Da mesma forma que emissividade está para difusão, que está para aceleração, que está para o cinema, que está para "Futboil"; remissividade está para concentração, que está para desaceleração, que está para a escultura clássica, que está para "Entradas e bandeiras". Como veremos no capítulo 4, seção 4.2, a arte barroca, ao contrário, é acelerada (para esclarecimento sobre arte clássica e barroca, ver adiante quadro 3.5). Ao escolher a dominância da difusão, o enunciador de "Futboil" opta por apresentar um quadro de ações, verbalizado, configurando a vida cotidiana na cidade. Ao optar pela dominância da concentração, o enunciador de "Entradas e bandeiras" apresenta-nos um quadro de passionalizações, nominalizado, que configuram, de certa forma, o conflito entre a opressão dos deveres do homem e a liberdade da arte. 
Na seção 3.3.2, discorreremos sobre o plano do conteúdo dos enunciados da HQ sob análise.

\subsubsection{Destruição do objeto pelo sujeito}

"Futboil" tematiza a quebra do cotidiano por um acontecimento inusitado: pessoas que descansavam em casa, que transitavam pelas ruas e calçadas, garotos que jogavam futebol têm seu cotidiano interrompido pela queda de um balão. $\mathrm{O}$ acontecimento tem o poder de retirar o sujeito da sua rotina e de deixá-lo exposto e vulnerável aos encantos do objeto (TATIT, 2010, p. 45). O sujeito, antes dono de seu percurso, chega a funcionar como "presa" da atratividade exercida pelo objeto. E, à página 46, o autor citado afirma que “justamente por estar mergulhado num universo em que a vida lhe parece incompleta - e, portanto, imperfeita - o sujeito alimenta a espera de um estado pleno, caracterizado por sua fusão com o objeto, como se [...] pudessem constituir um ser integral”.

Em relação a esse objeto, temos dois tipos de sujeito: o que o repele e o que o quer de qualquer maneira. A parte desinteressada do objeto, em "Futboil", configura o antissujeito da parte interessada. Os interessados no balão são os meninos que brincam na rua, e os que repelem o balão são os mais velhos. Daí que o percurso do sujeito (atores meninos) é interrompido pelo antissujeito (atores mais velhos). Num total de 92 quadrinhos, há 47 abertos, 23 mistos e 22 fechados. Considerando isoladamente para efeito de estudo essas categorias, temos 51\%, $25 \%$ e $24 \%$, respectivamente. Todavia, se juntarmos quadrinhos abertos e mistos, visto que os mistos são transitivos, compostos de fazeres emissivos e remissivos que se alternam, temos $76 \%$ de quadrinhos que tendem à emissividade, à difusão. Quando o emissivo impera, os valores remissivos escolhidos pelo mesmo enunciador - normalmente representado por um narrador (nessa $\mathrm{HQ}$, narrador palhaço) - são de presença recessiva; a dominância aqui é emissiva, portanto. Em "Futboil", à medida que o valor emissivo cresce, o valor remissivo vai se tornando mais sensível, emergindo claramente na $\mathrm{HQ}$ sob análise. Até o trigésimo segundo quadrinho, o fazer emissivo é dominante e, no nível discursivo, os garotos correm atrás de um balão, sem grandes obstáculos por parte do antissujeito. 
A dominância emissiva, o estado de latência do antissujeito, acaba por fazer irromper os valores remissivos na narrativa. Daí o surgimento de antissujeitos em "Futboil" (figuras 3.14 a 3.18$)$.
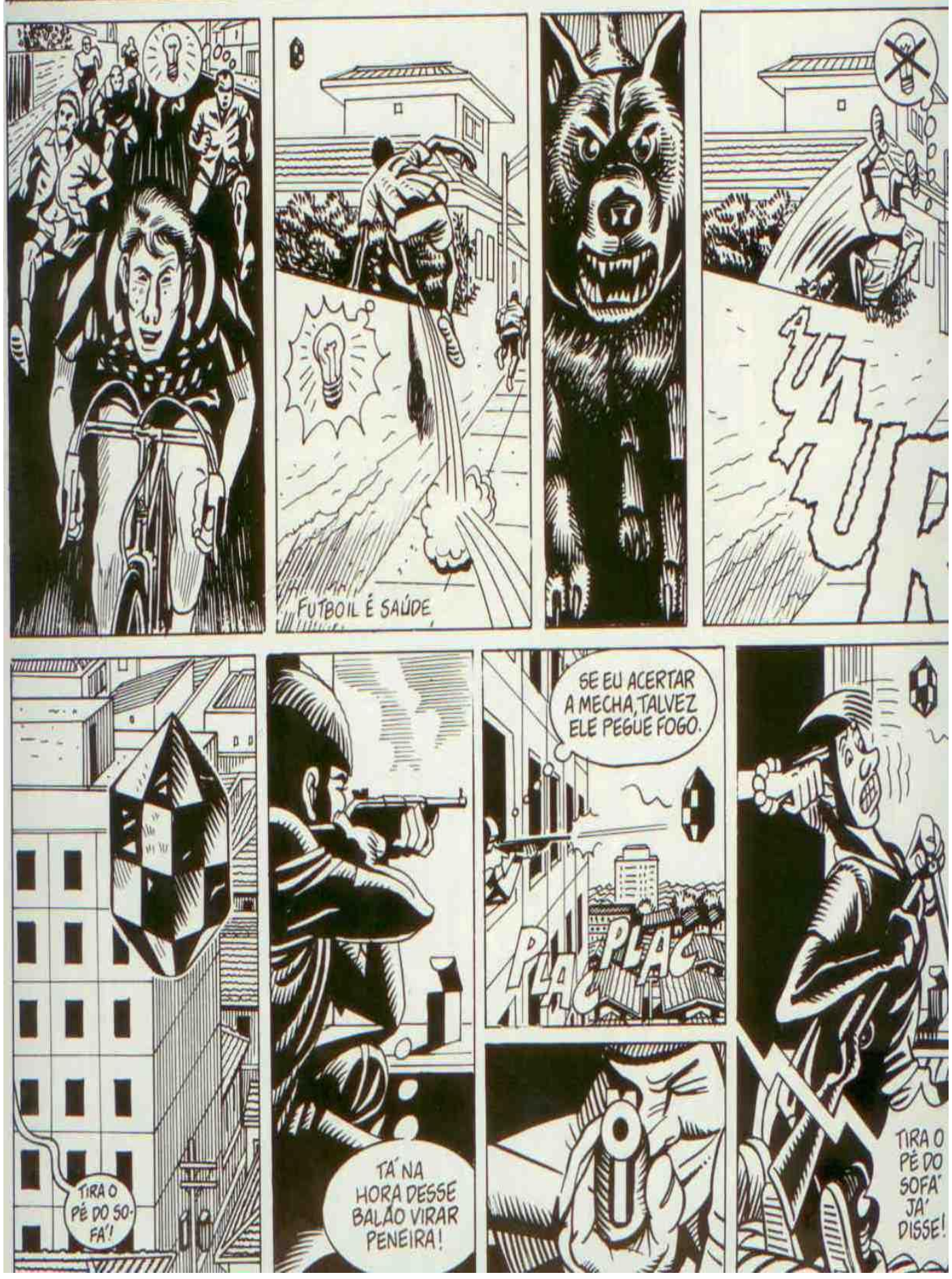

Figura 3.14 Antissujeitos: no terceiro quadrinho, figura do cachorro; no sexto quadrinho, a do garoto com a espingarda na mão. 


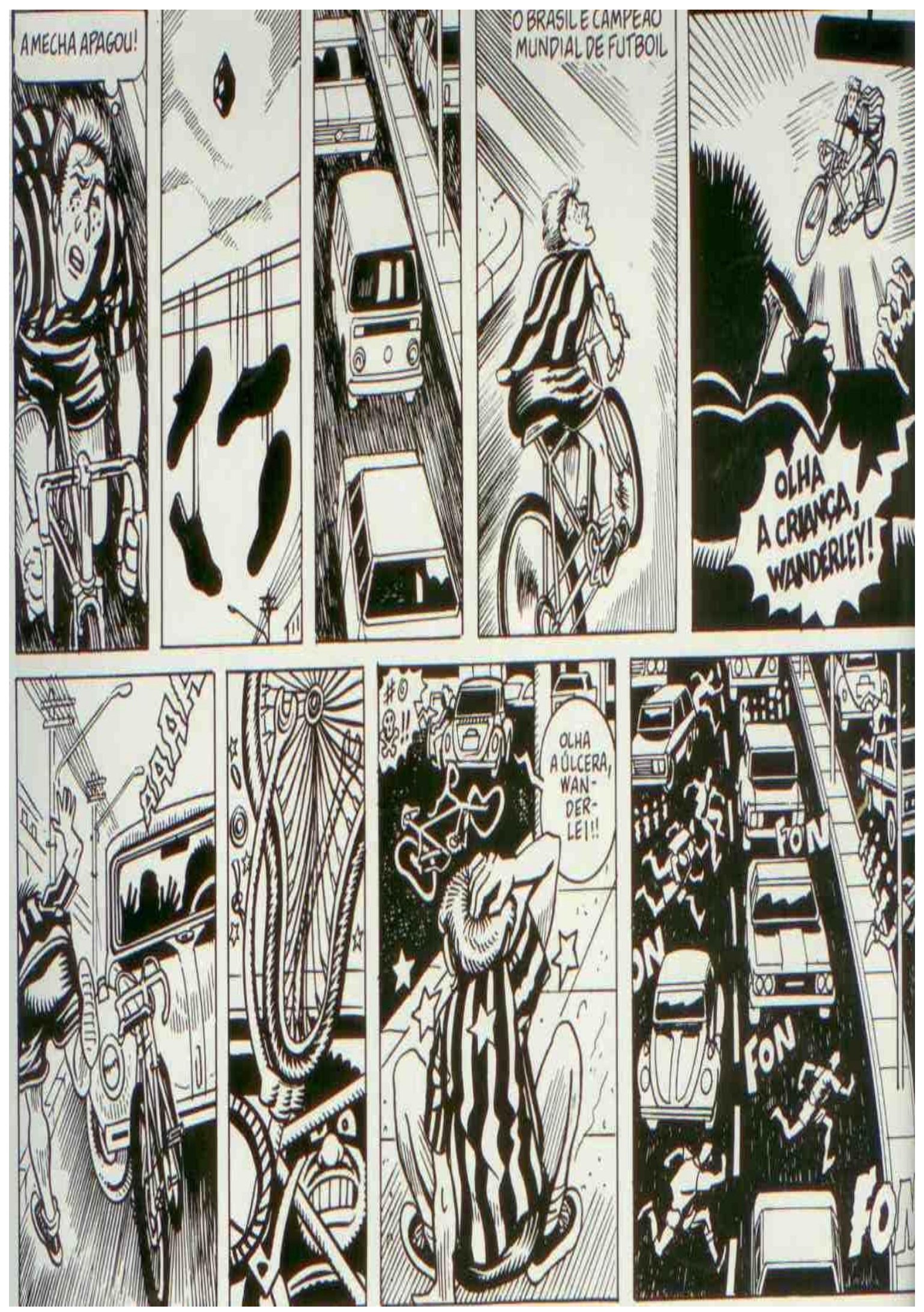

Figura 3.15

Antissujeitos: no sexto quadrinho, figura do choque do menino com o carro. Ele cai (parada). 


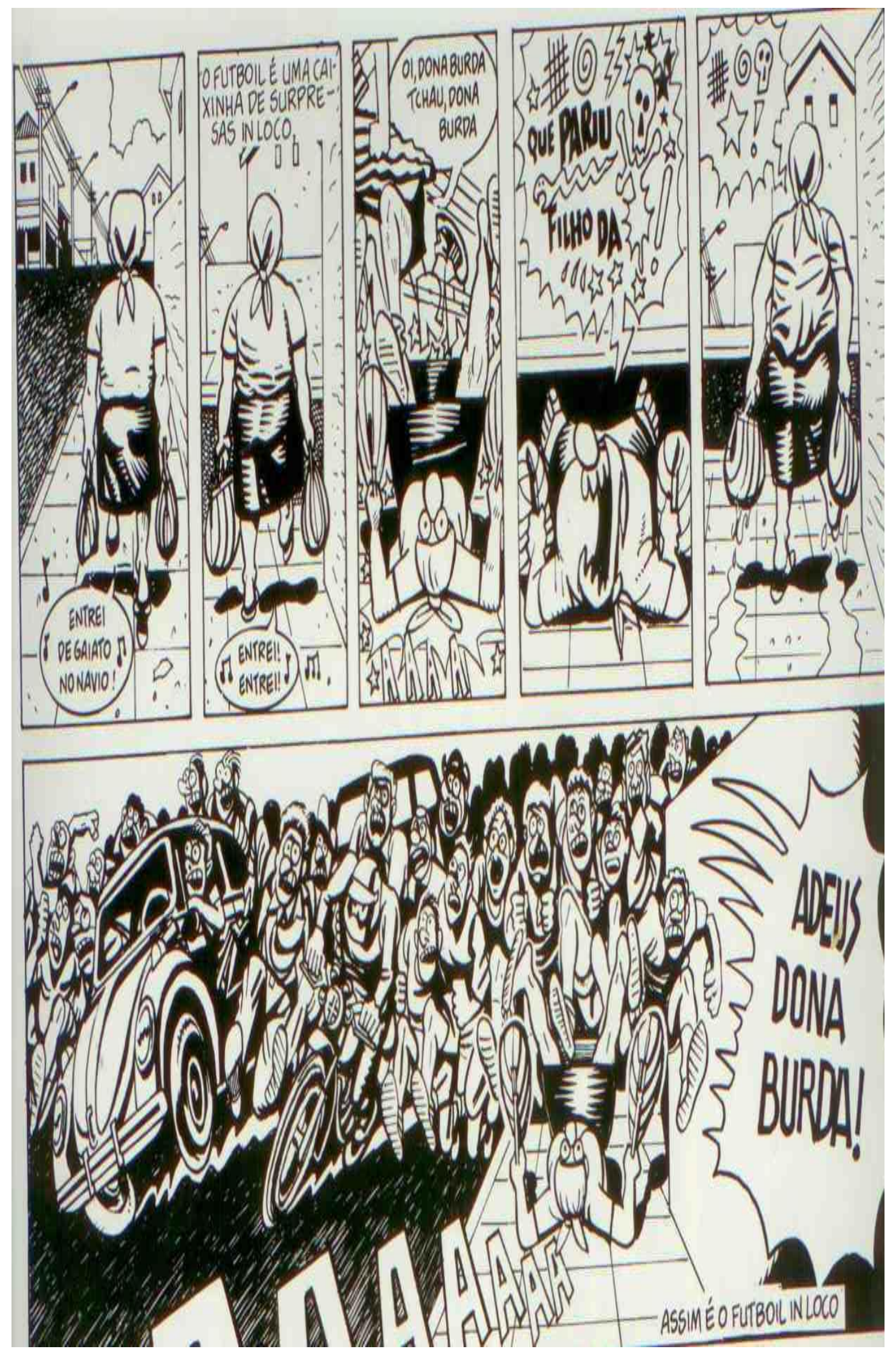

Figura 3.16 Antissujeito: no terceiro quadrinho, figura da Dona Burda no caminho dos meninos. 

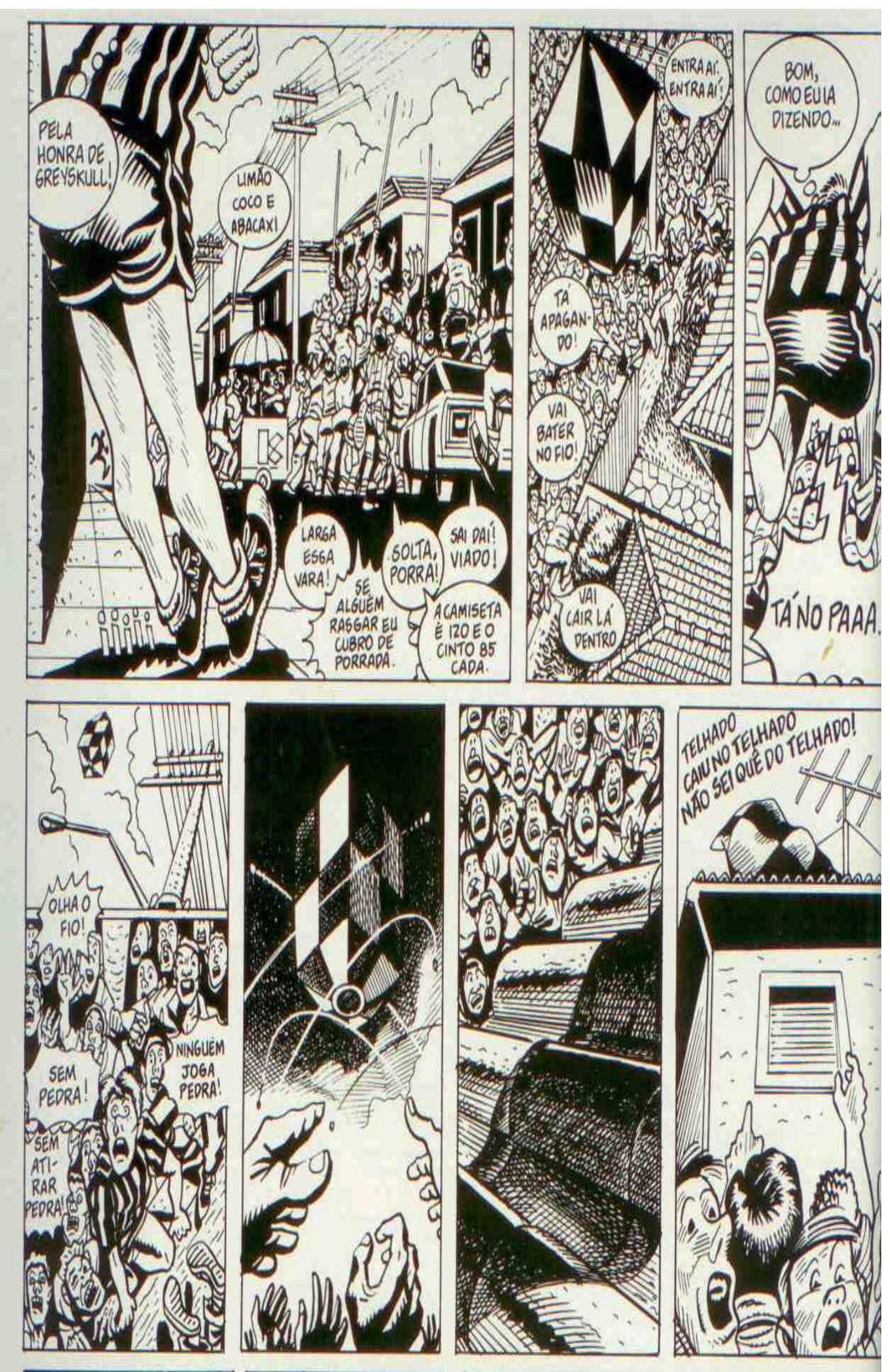

Figura 3.17 Antissujeito: no quinto quadrinho, quando o balão estava quase no "papo", caiu no telhado (nova parada). 


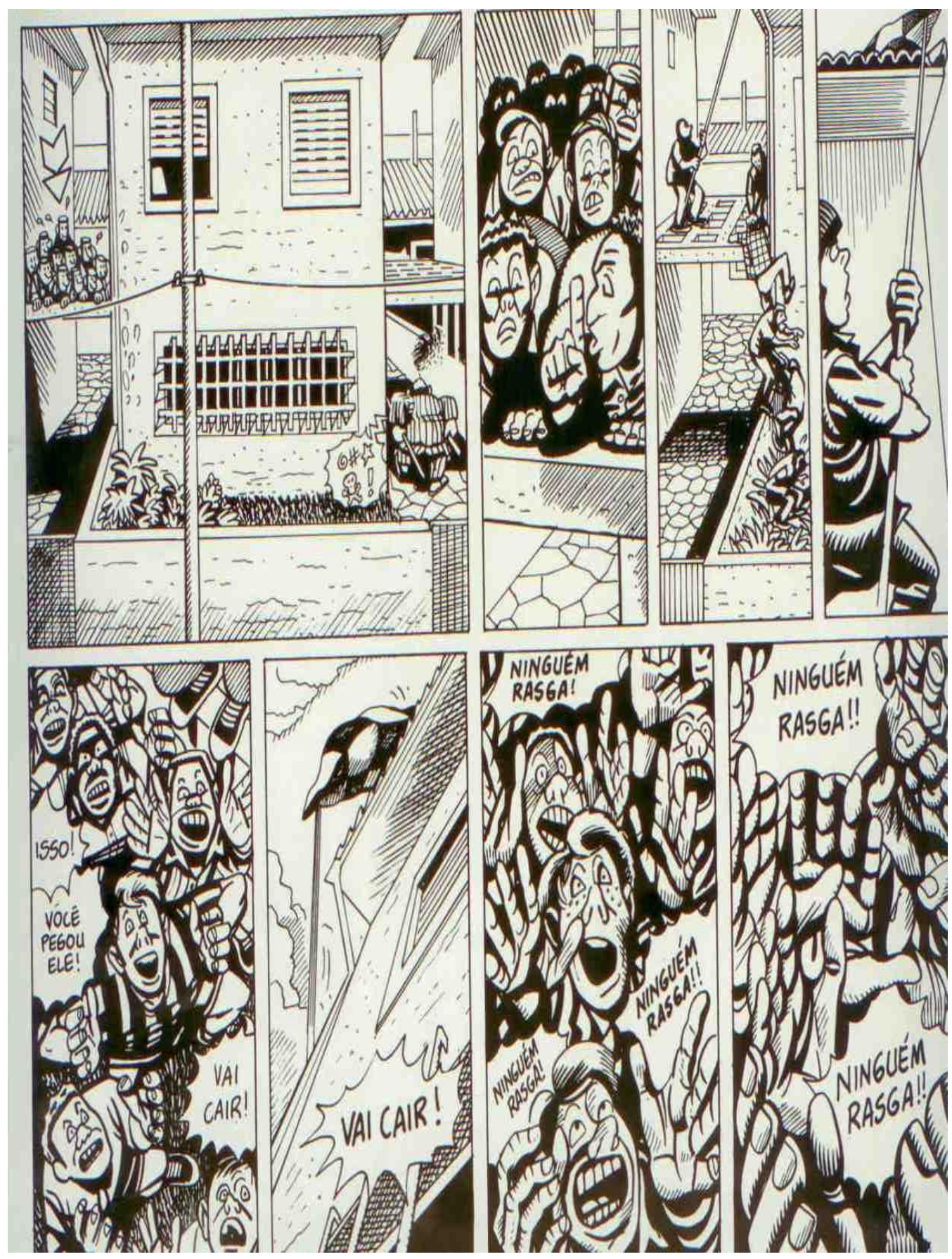

Figura 3.18

No quarto quadrinho, menino com a varinha na mão para finalmente conseguir o "prêmio"; todavia, os meninos rasgam o balão (fim do objeto desejado).

O valor remissivo emerge como consequência de uma espécie de "lei rítmica que subordina o progresso narrativo à alternância, não necessariamente simétrica, dos períodos de distensão e contenção ou, em outros termos, de prevalência, ora dos valores emissivos, ora dos remissivos" (TATIT, 2010, p. 48). O enunciador de Território de bravos subordina o progresso narrativo às alternâncias das concentrações (fazer remissivo) e difusões (fazer emissivo), o que nos levou à contagem realizada no capítulo 2, cujo resultado nos mostra a 
dominância, em Território de bravos, da escolha remissiva. Ora, a dominância de um é a latência do outro. Daí o movimento narrativo oscilar entre distensões e contenções. A dominância tanto do fazer emissivo quanto do remissivo manifesta oscilação de um fazer para o outro e vice-versa.

"Entradas e bandeiras" é resultado da dominância remissiva, o que nos moveu a compará-la com a escultura clássica, segundo conceito de Wöfflin (2006, p. 169) e Zilberberg (2006a, p. 167), visto ser concentrada, fechada, prevalecendo a desaceleração e a conservação da função artística. Já "Futboil” é resultado da dominância emissiva, cuja movimentação, difusão e aceleração nos leva a compará-la com a estética barroca e ao andamento cinematográfico.

No quadro 3.5, fazemos uma pequena comparação entre classicismo e barroco e as HQs sob análise; no capítulo 4, seção 4.2, retomaremos esse assunto com a finalidade de uma explanação teórico-analítica mais minuciosa.

Quadro 3.5 Confronto entre arte renascentista e barroca em "Entradas e bandeiras" e "Futboil".

\begin{tabular}{|c|c|c|}
\hline $\begin{array}{ll} & \text { definidos } \rightarrow \\
\text { definidores } & \\
\downarrow & \end{array}$ & $\begin{array}{l}\text { arte renascentista } \\
\text { "Entradas e bandeiras" } \\
\downarrow\end{array}$ & $\begin{array}{l}\text { arte barroca } \\
\text { "Futboil" } \\
\downarrow\end{array}$ \\
\hline espacialidade $\rightarrow$ & fechado (respeito ao quadro) & $\begin{array}{l}\text { aberto (transbordamento do } \\
\text { quadro) }\end{array}$ \\
\hline aspectualidade $\rightarrow$ & perfectivo & imperfectivo \\
\hline existência $\rightarrow$ & estado ("solenidade") & acontecimento (fugacidade) \\
\hline andamento $\rightarrow$ & desaceleração & aceleração \\
\hline
\end{tabular}

Fonte: Adaptado de Zilberberg (2006a, p. 167).

O enunciador de "Futboil", ao lado do narrador palhaço (que no nível narrativo é destinador), escolhe a dominância de valores emissivos em meio a algumas paradas para mostrar que a continuidade atrás de um balão não fracassou por causa das paradas (fazer remissivo) introduzidas pelo antissujeito, mas pela própria mão do sujeito que tanto queria seu objeto. O resultado de "Futboil" é o fracasso de um percurso em que ganhar o objeto significa destruí-lo: "disputa-se pela derrota" (PIETROFORTE, 2007, p. 83). 
No último quadrinho da HQ é que temos a revelação do "narrador palhaço" e o seu desprezo pelo Futboil (fenomenozinho tipicamente brasileiro). Considerando o esquema narrativo canônico, com seus percursos do destinador manipulador, o percurso do sujeito e o percurso do destinador julgador, no último quadrinho o palhaço figurativiza o destinador julgador: num espaço predominantemente voltado para as relações comerciais e industriais (a história se passa no Brás, bairro caracterizado como berço da indústria paulista), pouco espaço sobra para as relações lúdicas e artísticas. Daí o último quadrinho ser tônico, vindo como forma de susto para o enunciatário. Metonimicamente, temos mãos que rasgam o balão e a cabeça de um palhaço no centro afirmando "É isso aí amigos! E não esqueçam de perguntar ao freguês do lado qual o resultado do Futboil!", numa clara alusão à necessidade de distensão do cotidiano, como na brincadeira que o freguês faz ao garçom na mesa do bar, na música de Noel, já comentada no capítulo 2 desta dissertação.

A sanção do destinador julgador é de repulsão à atitude do sujeito, ou seja, "os garotos não sabem brincar, porque destroem o objeto da brincadeira: o balão". o maior antissujeito do sujeito nessa HQ é o próprio sujeito. Retomando o quadrinho 26 de "Futboil", verificamos tratar-se de um acróstico: "Fenomenozinho Urbano Tipicamente Brasileiro Observado In Loco". O diminutivo com carga semântica disfórica, juntamente com o advérbio aspectual durativo "tipicamente" e com o adjetivo restritivo "brasileiro", contribuem para configurar a isotopia do individualismo, em que cada um quer o balão para si, em detrimento de valores coletivos. Por isso, não sabe desfrutar os prazeres do ludismo e, se estendermos à "Entradas e bandeiras", verificaremos que é justamente a busca de valores utilitários (de absoluto) que impede o sujeito de perceber os valores artísticos, que são propriamente valores universais.

Tanto o ludismo como o artístico exigem posturas sensíveis do sujeito em seu campo de presença. Em "Futboil", a mesma competição do mundo cotidiano é transferida para a brincadeira com resultado catastrófico: ninguém fica com o objeto. Em "Entradas e bandeiras", a movimentação do monumento no espaço da história configura o sentido de "fazer-se ver" aos olhos de um sujeito que perdeu a percepção de valores que não sejam utilitários e éticos (ver seção 4.1 do capítulo 4 desta dissertação). É como se as estátuas, ao ganharem movimento, pedissem licença para existir e serem vistas. Novamente, há um destinador julgador que sanciona negativamente o homem desse espaço. 
Dessa forma, as continuidades promovidas pelo destinador e as descontinuidades promovidas pelo antissujeito são neutralizadas pelo sujeito em "Futboil", ou seja, o próprio sujeito transforma-se no final da $\mathrm{HQ}$ em antissujeito, estraçalhando o objeto. Todos os antissujeitos do percurso, bem como as paradas, ficam mais atonizados se comparados ao sujeito que destrói o objeto de seu desejo.

Pietroforte (2007, p. 78-79) chama a atenção para a categoria semântica da transgressão versus integração que ocorre no nível fundamental do percurso gerativo do sentido. Transgressão é entendida aqui como abandono de posições estabelecidas pela rotina e integração, como a aceitação das regras do cotidiano. O balão figurativizaria a arte, o jogo. A busca do balão configura a isotopia da liberdade, da fuga do cotidiano, da procura de valores lúdicos, a transgressão (na figura dos meninos) e opõe-se aos afazeres dos mais velhos, voltados para valores éticos e práticos, valores de integração (na figura de Dona Burda, dos mais velhos):

\footnotetext{
Quando se examina a projeção das forias, a tensão fica evidente: para os mais velhos, há euforização da integração e disforização da transgressão; para os meninos, ela se projeta ao contrário, euforiza-se a transgressão e disforiza-se a integração. [...]

Como a transgressão é o valor inscrito no objeto balão, há uma distribuição das relações juntivas com esse objeto e a curva de tensão inversa estabelecida pela categoria semântica. A conjunção com o balão figurativiza a tônica na intensidade da transgressão e a disjunção, a tônica na extensidade da integração (PIETROFORTE, 2007, p. 78-79)
}

Na comparação de "Entradas e bandeiras" com "Futboil", nota-se a coerência do enunciador. O final de ambas as HQs produz o efeito de sentido de um sujeito destituído da percepção de valores artísticos. Entrar na conjunção com o balão e conservá-lo seria admitir um sujeito competente para perceber e apreciar valores não pertencentes ao mundo pragmático. Se em "Entradas e bandeiras", o sujeito não tem competência para perceber a riqueza estética do espaço em que transita; em "Futboil", deparamos com a mesma incompetência para entrar na posse de valores lúdicos, da fantasia, próprios do mundo da arte, que passam à distância de valores marcados pelo automatismo do dia a dia desses sujeitos.

Na primeira etapa da $\mathrm{HQ}$, no enunciado do nível discursivo, os meninos, inicialmente da égide da transgressão, percebem o balão e correm atrás dele, divergindo dos mais velhos, que não o percebem e continuam em seus afazeres práticos. Nessa primeira etapa, meninos 
e velhos no nível narrativo separam-se. Os primeiros são sujeitos e os segundos, antissujeitos.

$\mathrm{Na}$ segunda etapa da $\mathrm{HQ}$, os meninos passam a ser, no nível narrativo, antissujeitos de si mesmos, tanto que destroem o objeto de busca (balão). Nesse momento, os meninos não conseguem ficar conjuntos com os valores de transgressão. Destroem o balão e voltam para a integração do cotidiano. Daí não ser destituído de sentido "Futboil" denominar-se "fenomenozinho", ou seja, algo de valor reduzido. Ocorre uma fratura no cotidiano do sujeito (o aparecimento do balão); contudo, esse sujeito, tomado pelo fulgor dos objetos que o arrebatam (figurativização do ludismo, da arte), tende, após a fratura, a retomar o cotidiano o mais rápido possível. Ludismo é utilizado aqui com o sentido que lhe é próprio: ação que se esgota em si mesma, que não tem fins utilitários, senão divertir-se. É característica do ludismo a negação de ritos dessemantizados, algo oposto ao cotidiano em que as coisas se dessemantizam pelo automatismo e pela repetição.

Para Huizinga (1996, p. 11-13), são características fundamentais do jogo, da arte: (a) ser livre, ser ele próprio liberdade; além disso, o jogo não é vida corrente nem real, mas evasão da vida real; (b) ser desinteressado, visto que não pertence à vida comum e se situa fora do mecanismo de satisfação "imediata" das necessidades e dos desejos; (c) distinguir-se da vida comum pelo lugar e duração que ocupa; daí seu isolamento e sua limitação; (d) possuir uma ordem específica e absoluta; ele cria ordem e é ordem, introduzindo na confusão da vida e na "imperfeição" do mundo uma "perfeição" temporária e limitada (GREIMAS, 2002, p. 88).

Mesmo depois do término do jogo, ele permanece como uma criação nova do espírito, um tesouro a ser conservado pela memória. A busca do balão, um folguedo juvenil, um jogo, é fratura que absorve os jogadores de maneira intensa e total, desprovida das ambições materiais do cotidiano; esse jogo é praticado dentro dos limites espaciais e temporais da HQ "Futboil". Se os sujeitos não destruíssem o resultado do jogo (o balão), poderiam continuar com o grupo social formado e com o segredo do desfrute do encanto da fratura. Seriam sujeitos únicos da transgressão que se diferenciariam dos mais velhos, que são regidos pela integração (caso da D. Burda, por exemplo). Buscar o balão é lutar por alguma coisa, por um valor que não está na mediocridade do cotidiano automatizado. Finalmente, é de dizer que o jogo, a fratura, é dotado de um fim em si mesmo, que é 
acompanhado de um sentimento de tensão e de alegria e da consciência de ser diferente da vida cotidiana (HUIZINGA, 1996, p. 12, 16, 24, 33).

Para Greimas (2002, p. 80 ss), os comportamentos humanos cotidianos são programados e perdem paulatinamente seu significado; daí que incontáveis programas de uso não precisem ser controlados um a um; gestos transformam-se em gesticulações, pensamentos em clichês. A banalização de todos os atos humanos transforma o lazer em produto negociável para dessemantizar a liberdade do sujeito. A arte seria uma procura de saída para esse labirinto, uma busca de embelezamento da vida, uma criação de lugares imaginários alimentados de espera e esperança.

Como já dissemos, "Futboil" é uma HQ em que nos é apresentado o cotidiano de um bairro de São Paulo. Crianças jogam bola, adultos transitam pela cidade em seus afazeres, quando um balão irrompe no céu, fraturando o cotidiano e chamando a atenção das crianças, que apreendidas pelo objeto se põem em busca do lugar em que se dará a queda.

Ao final desse jogo, o enunciatário é surpreendido com o resultado frustrante: não ocorre a posse do balão, pois os próprios sujeitos, na ânsia da posse individual desse objeto, rasgam-no. A HQ contempla dois momentos: (a) antes do aparecimento do balão, crianças jogam futebol; (b) surgimento do balão e abandono do futebol para a busca desenfreada do objeto fulgurante. Trocar o futebol pela busca do balão é abandonar um objeto desgastado pelo uso cotidiano para entrar em conjunção com a novidade.

Vejamos como se dão as dessemantização de ritos do cotidiano em "Futboil" (figuras 3.19 e 3.20$)$.

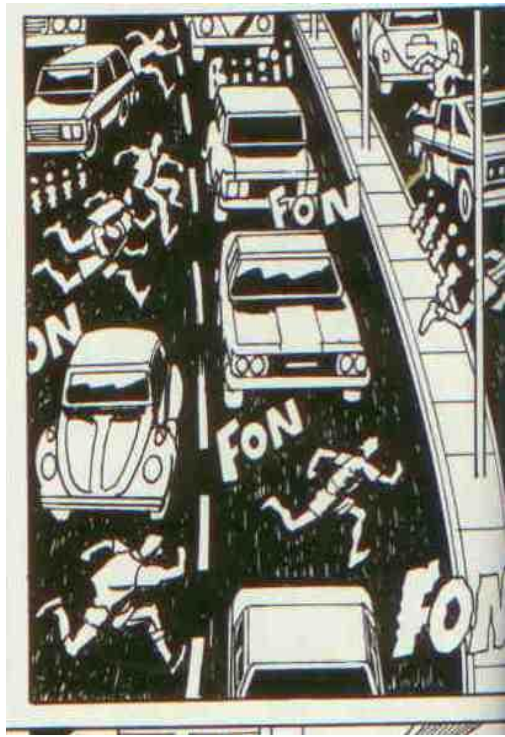

Figura 3.19 Carros na rua

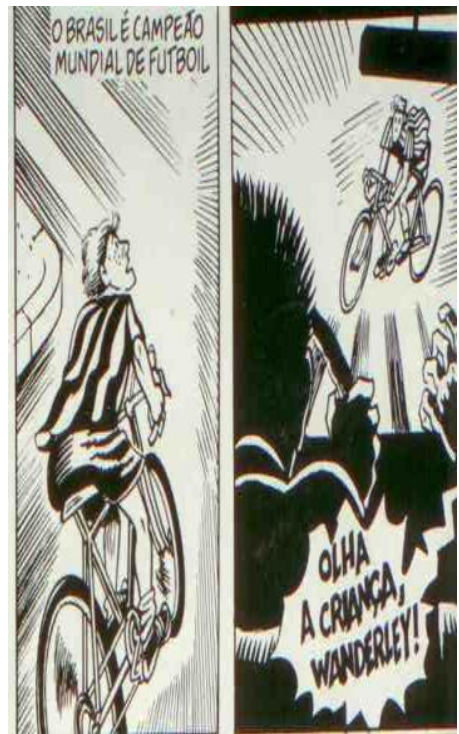

Motorista e ciclista na rua

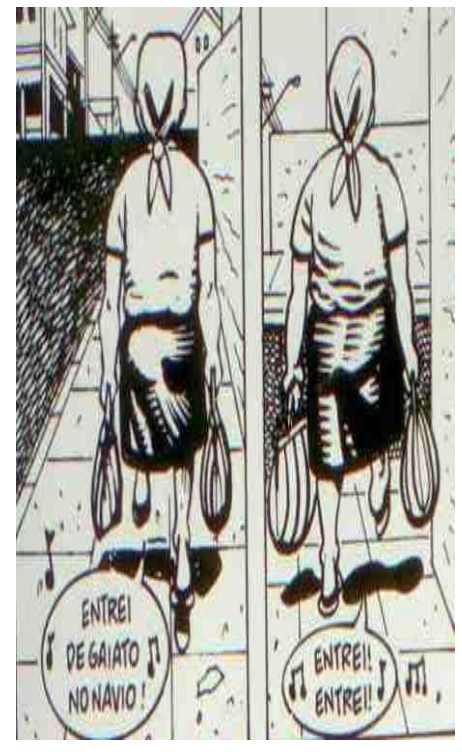

D. Burda caminhando com compras. 


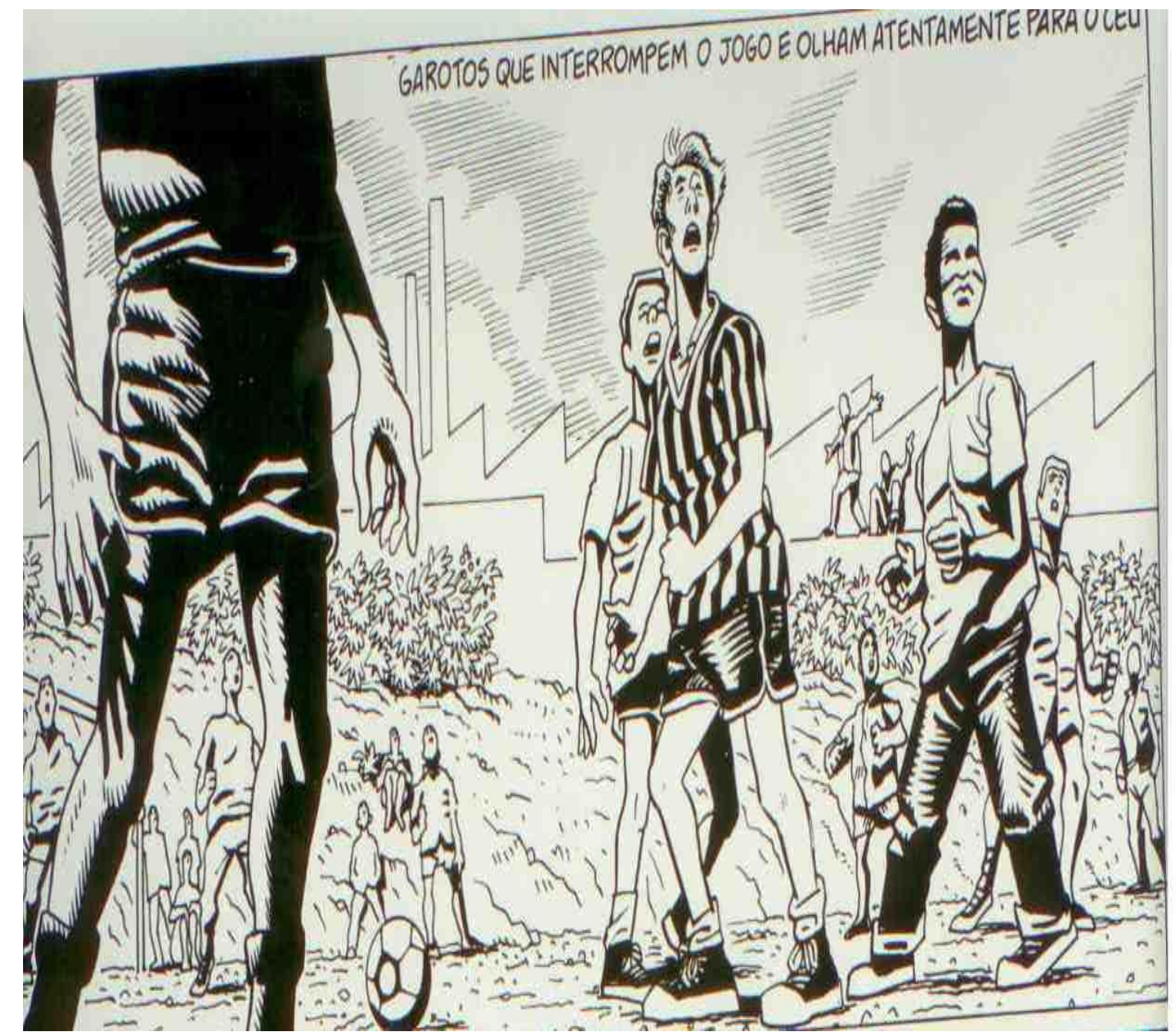

Figura 3.20 Futebol já dessemantizado por pertencer ao cotidiano dos garotos. Eles param o jogo e olham para cima.

A queda do balão, portanto, causa uma fratura nesse cotidiano, como dissemos. Conforme salienta Tatit (2010, p. 46),

justamente por estar mergulhado num universo em que a vida the parece sempre incompleta - e, portanto, imperfeita - o sujeito alimenta a espera de um estado pleno, caracterizado por sua fusão com o objeto, como se temporariamente ambos os actantes pudessem constituir um ser integral.

O evento do balão, que integra o enunciado da HQ sob análise, pôde aqui ser visto como uma fratura na rotina dos sujeitos. E ainda completam o efeito de sentido de "Futboil" as epígrafes que antecedem o enunciado da HQ propriamente dita.

Território de bravos é composto, como já o dissemos, de sete HQs que são antecedidas por epígrafes que manifestam pontos de vista histórico, sociológico e antropológico em relação a São Paulo. São manifestações estereotipadas, distantes do dia a 
dia, do paupável, da vida de sua gente. O enunciador opta por valores de um "velho novo mundo imaginado", da fratura da fantasia e da arte.

Assim é que precedem "Futboil" três epígrafes, bem como uma tira de Presidente Reis. A primeira epígrafe é de Gina Lombroso Ferrero (1908), a segunda é de Domville-Fife (1909) e a terceira é de Joseph Burnichon (1910). Na primeira, sobressaem as isotopias de empreendedorismo dos habitantes de São Paulo, bem como de suas atividades incessantes. Na segunda, sobressai a isotopia do cosmopolitismo de São Paulo. Na terceira, a isotopia do dinamismo da cidade, "a cidade mais ativa do Brasil", capital comercial e industrial.

Essas epígrafes do início do século XX produzem o efeito de sentido de uma cidade voltada exclusivamente para as atividades comerciais e industriais, uma cidade de um dinamismo irrefreável. Todavia, o enunciatário se choca quando toma contato com os quadrinho de "Futboil". Aqui, o mundo das relações comercias é substituído por folguedos infanto-juvenis. Afinal, São Paulo de "Futboil" não é só trabalho, obrigações. No interior da HQ, a fratura (a queda de um balão e sua busca frenética) apreende a percepção de meninos, provocando o abandono do futebol para entrarem em conjunção com um objeto que lhes faz transgredir ações do dia a dia. Enquanto a população dos mais velhos (D. Burda, por exemplo) se pauta pela integração aos valores éticos (deônticos), a garotada se pauta por valores lúdicos.

Todavia, superado o momento do deslumbramento, o sujeito (meninos) tende a retomar a vida vivida. Por isso, o último quadro é esclarecedor, quando o enunciatário pode verificar que a posse definitiva do balão não se dá, ou seja, o contato com o objeto é um relâmpago passageiro, levando o sujeito novamente à integração com seus valores do cotidiano. Diferentemente do que ocorre com a garotada, ao penetrar o campo de presença dos adultos, o balão não provoca nenhum tipo de apreensão.

Uma possível relação semissimbólica se dá entre as categorias da expressão alto vs. baixo e as categorias do conteúdo transgressão vs. integração (cf. PIETROFORTE, 2007, p. 82). No plano térreo, da aproximação (baixo), ocorrem as coisas do cotidiano, do mundo utilitário, valores que aprisionam o homem; no plano aéreo, do distanciamento (alto), ocorrem a fratura, o lúdico, a fantasia, a arte que libertam o homem do seu dia a dia: 


\section{PE:baixo :: PC:utilitarismo/integração \\ PE:alto :: PC:ludismo/transgressão}

Finalmente, o palhaço, em "Futboil", ao mostrar-se, revela as escolhas do enunciador: a emissividade eleita leva ao fracasso do sujeito: correm, correm, correm por nada, outro efeito de humor. E os antissujeitos, que salpicam o percurso do sujeito, são átonos e latentes, pois a tonicidade e dominância pertencem ao próprio sujeito. É esse sujeito que é o seu próprio e maior antissujeito: eles mesmos rasgam o balão.

Até aqui, vimos como o antissujeito dá direção à narrativa, bem como a missividade é uma categoria básica na construção do sentido. Vimos também que o enunciador obstinado tem na remissividade sua mola propulsora.

Por considerar artísticas as HQs de Luiz Gê, examinamos no capítulo seguinte, em um primeiro momento, os conceitos de utilitarismo e de artístico; em um segundo momento, aproximamos as HQs sob análise das estéticas clássica e barroca para, em um terceiro momento, estudar a aceleração e a desaceleração, resultado do jogo do fazer missivo, como constitutivas do ritmo na semiótica dos quadrinhos.

Para os estudos do utilitarismo e do artístico, utilizamos "Entradas e bandeiras"; para os estudos do classicismo e do barroco, apoiamo-nos em "Entradas e bandeiras", "Tubarões voadores" e "Futboil"; para os estudos retóricos, valemo-nos da HQ "Entradas e bandeiras"; para os estudos de ritmo, confrontamos esta última com "Futboil". 
Do utilitário ao artístico. Aceleração e desaceleração: o ritmo nas HQs

A observância dos ritmos, das rimas, da melodia verbal impede os movimentos diretos do meu pensamento.

Paul Valéry

O que está em jogo é um ritmo tensivo: o destino do limite é a gradação e vice-versa.

Luiz Tatit 


\subsection{Do utilitário ao artístico}

Em "Entradas e bandeiras", o enunciatário está diante de um texto em que é apresentado o cotidiano de uma metrópole, mas é surpreendido com a "vitalidade" de obras de arte que deixam seu espaço fixo e perambulam pela cidade. Um acontecimento fantástico?

Há dois espaços diferentes. De um lado, o prosaísmo dos habitantes da metrópole, com sua vida de trabalho, o trânsito, a fome, o cansaço, o sono, os semáforos. De outro lado, no nível narrativo, um antissujeito especial do ponto de vista de um sujeito, figurativizado nos atores passageiros do automóvel. Este último tem com um percurso a fazer. Dois percursos, dois sujeitos, como vimos no capítulo 2, que se cruzam na narrativa da HQ. Paralelamente, vidas humanas são obstadas em sua trajetória por obras de arte que perambulam, e estas últimas, por sua vez, têm o seu percurso interrompido por vidas humanas que tomam posse de seu espaço.

Nitidamente, temos uma oposição entre a ética do cotidiano (valores utilitários) e a estética (valores artísticos). A oposição entre as linguagens verbal e visual podem indicar essa mesma oposição. Vejamos: o número de balões de linguagem verbal nessa $\mathrm{HQ}$, por exemplo, é muito reduzido. De um total de 38 quadrinhos, há 14 enunciados verbais apenas. Os textos verbais, diferentemente dos textos visuais, apresentam linguagem utilitária, como é de valor utilitário a rotina dos habitantes daquele espaço da $\mathrm{HQ}$.

Para Tatit (1997, p. 46), a forma artística é um rito de desaceleração da linguagem. Ora, podemos então afirmar que a forma utilitária proporciona a aceleração da linguagem. A artística impede a transposição do plano da expressão para o plano do conteúdo, bem como valoriza a organização rítmica do plano da expressão. Jakobson $(2005$, p. 130$)$ diria que o paradigma projeta-se no sintagma: "a função poética projeta o princípio de equivalência do eixo de seleção sobre o eixo de combinação". Nos balões, observamos apenas a existência de diálogos puramente pragmáticos. Ora, esse utilitarismo contrapõe-se à exuberância da 
forma plástica dos enunciados visuais, em que é possível notar uma preocupação artística da parte do enunciador.

Valéry (2007, p. 201) é esclarecedor ao tratar de diferentes formas de linguagem, utilitárias e artísticas:

[...] nos empregos práticos ou abstratos da linguagem, a forma, ou seja, o físico, o sensível e o próprio ato do discurso não se conserva; não sobrevive à compreensão; desfaz-se na clareza; agiu; desempenhou sua função; provocou a compreensão; viveu.

E, ao contrário, tão logo essa forma sensível adquire, através de seu próprio efeito, uma importância tal que se imponha e faça-se respeitar; e não apenas observar e respeitar, mas desejar e, portanto, retomar - então alguma coisa de novo se declara: estamos insensivelmente transformados e dispostos a viver, a respirar, a pensar de acordo com um regime e sob leis que não são mais de ordem prática ou seja, nada do que se passar nesse estado estará resolvido, acabado, abolido por um ato bem determinado. Entramos no universo poético.

A rapidez seria uma das características da eficácia e produtividade das linguagens utilitárias. Transita-se pelas palavras, transformando-as em valores abstratos independentemente da matéria que os veiculou. A expressão transforma-se em conteúdo com fins comunicativos. No caso da linguagem visual de "Entradas e bandeiras", por exemplo, os enunciados não têm fins pragmáticos, ou seja, a preocupação é de que o plano de expressão não se transponha facilmente em conteúdo, não se dissolva. Quando o utilitário dá lugar ao artístico, temos uma desaceleração que leva à conservação, que é característica do estético (TATIT, 1997, p. 46-48). O enunciado perde em transparência e ganha em opacidade. Em uma comunicação cotidiana, o plano da expressão é imediatamente descartado, diferentemente, pois, do objeto semiótico que estamos analisando, em que o plano da expressão não se converte rapidamente em conteúdo. Por isso, o objeto artístico não pode ser descartado, como seria a linguagem do dia a dia.

Nas HQs artísticas, objeto de análise desta dissertação, o encanto que provocam faz preservar o plano da expressão por meio de recursos rítmicos comprometidos com a matéria plástica. A expressão rítmica pode causar algum estranhamento; é de salientar, todavia, que qualquer objeto semiótico dispõe de um andamento que supõe um ritmo. As oscilações entre o fazer remissivo e emissivo, estudadas no capítulo 2, dão apoio a essas afirmações. O fazer missivo é responsável pelos avanços e retrocessos narrativos, estabelecendo um ritmo que ora se desacelera, ora se acelera, ora contrai, ora distende, ora concentra, ora difunde (ver considerações sobre ritmo neste capítulo). 
Com base nos conceitos de aceleração e desaceleração, difusão e concentração, aproximamos, na seção 4.2, a arte de Luiz Gê dos movimentos da história das artes.

\subsection{Aceleração e desaceleração: classicismo e barroco em Território de bravos}

Considerando as categorias de tempo, aspecto e andamento, o autor de Eléments de grammaire tensive entende que tais categorias não são exclusivas de semióticas verbais. Para tanto, apoia-se na terceira oposição, forma aberta versus forma fechada de Wölfflin (2006, p. 167-209).

O autor de Conceitos fundamentais da história da arte vê na obra de Rafael composições que constituem algo absolutamente fechado em si mesmo e considera que no Cinquecento italiano alcançou-se um estilo "tectônico" de grau máximo ou de máximo de perfeição. Segundo Wölfflin (2006, p. 167-168), é necessária uma distinção inequívoca entre composição fechada (tectônica) e o estilo atectônico do século XVII. Daí a adoção de conceitos de forma fechada e aberta que caracterizam melhor os termos tectônico e atectônico. Tais conceitos seriam mais exatos que rigoroso e livre, regular e irregular. Define forma fechada como tipo de representação que apresenta a imagem como uma realidade limitada em si mesma, que se volta para si; já a forma aberta pretende parecer ilimitada.

Embora esses conceitos aberto (atectônico) e fechado (tectônico) tragam alguma luz para a compreensão da arte do século XVI e XVII, eles não são suficientes, pois o problema não estaria na representação horizontal ou vertical, de frente ou de perfil,

\footnotetext{
no aspecto tectônico ou atectônico, mas em saber se a figura, o conjunto do quadro, se apresenta como uma realidade visível intencional ou não. Na concepção dos quadros do séc. XVII, a busca do instante passageiro também significa um aspecto da "forma aberta" (WÖLFFLIN, 2006, p. 170). [destaque nosso]
}

Ao analisar a arte do século XVII (barroco), contrapondo-a à do século XVI (clássica), Wölfflin (2006, p. 169) afirma que no barroco o conjunto sugere "a impressão" de representar algo mais do que um fragmento casualmente extraído do mundo visível. 0 classicismo, mimético, buscava a representação rigorosa da semiótica do mundo natural.

Com base nesses conceitos, Zilberberg (2006a, p. 167) constrói um quadro elucidativo, endereçando-os para a semiótica tensiva (quadro 4.1). 
Quadro 4.1 Tensividade na arte renascentista e barroca.

\begin{tabular}{|l|l|l|}
\hline \multicolumn{1}{|c|}{ definidos $\rightarrow$} & arte renascentista & $\downarrow$ \\
$\downarrow$ & $\downarrow$ & arte barroca \\
definidores & & \\
\hline espacialidade $\rightarrow$ & $\begin{array}{l}\text { fechado (relativo ao } \\
\text { quadro) }\end{array}$ & $\begin{array}{l}\text { aberto (transbordamento } \\
\text { do quadro) }\end{array}$ \\
\hline aspectualidade $\rightarrow$ & perfectivo & $\begin{array}{l}\text { Imperfectivo } \\
\text { (fugacidade) }\end{array}$ \\
\hline existência $\rightarrow$ & estado ("solenidade") & aceleração \\
\hline andamento $\rightarrow$ & desaceleração & \\
\hline
\end{tabular}

Fonte: Adaptado de Zilberberg (2006a, p. 167).

Zilberberg (2006a, p. 167) entende que as categorias arroladas condicionam-se reciprocamente; são interdependentes. Assim, um estilo atinge a consistência quanto mais for "trans-histórico", ou seja, atravessar o sistema das categorias e receber das correlações conversas ou inversas a inflexão que lhe é própria.

A expressão e o conteúdo seriam resultado da desaceleração que o artista imprime na consecução de sua obra. Por isso, Zilberberg (2006a, p. 168) sugere a utilização de conceitos temporais para o exame de obras de arte. $O$ andamento poderia ser vivo ou lento; o aspecto imperfectivo ou perfectivo. Evidentemente, tais conceitos implicam graduação: o andamento pode ser mais vivo ou menos vivo, mais lento ou menos lento; o aspecto pode ser mais imperfectivo ou menos imperfectivo, mais perfectivo ou menos perfectivo.

Tomando "Entradas e bandeiras", notamos em sua composição uma desaceleração que implica uma expressão concentrada, ocupada de detalhes mínimos. Nessa HQ, é perceptível o estilo que Wölfflin (2006, p. 168) chama de solene, uma arte imponente, o que levou também ao éthos de um artista obstinado, como vimos no capítulo 1, que persegue a solenidade da forma plástica, particularmente em "Entradas e bandeiras". Com relação ao quadro 4.1, ela é espacialmente fechada e temos uma aspectualidade perfectiva, como podemos notar na figura 4.1 . 

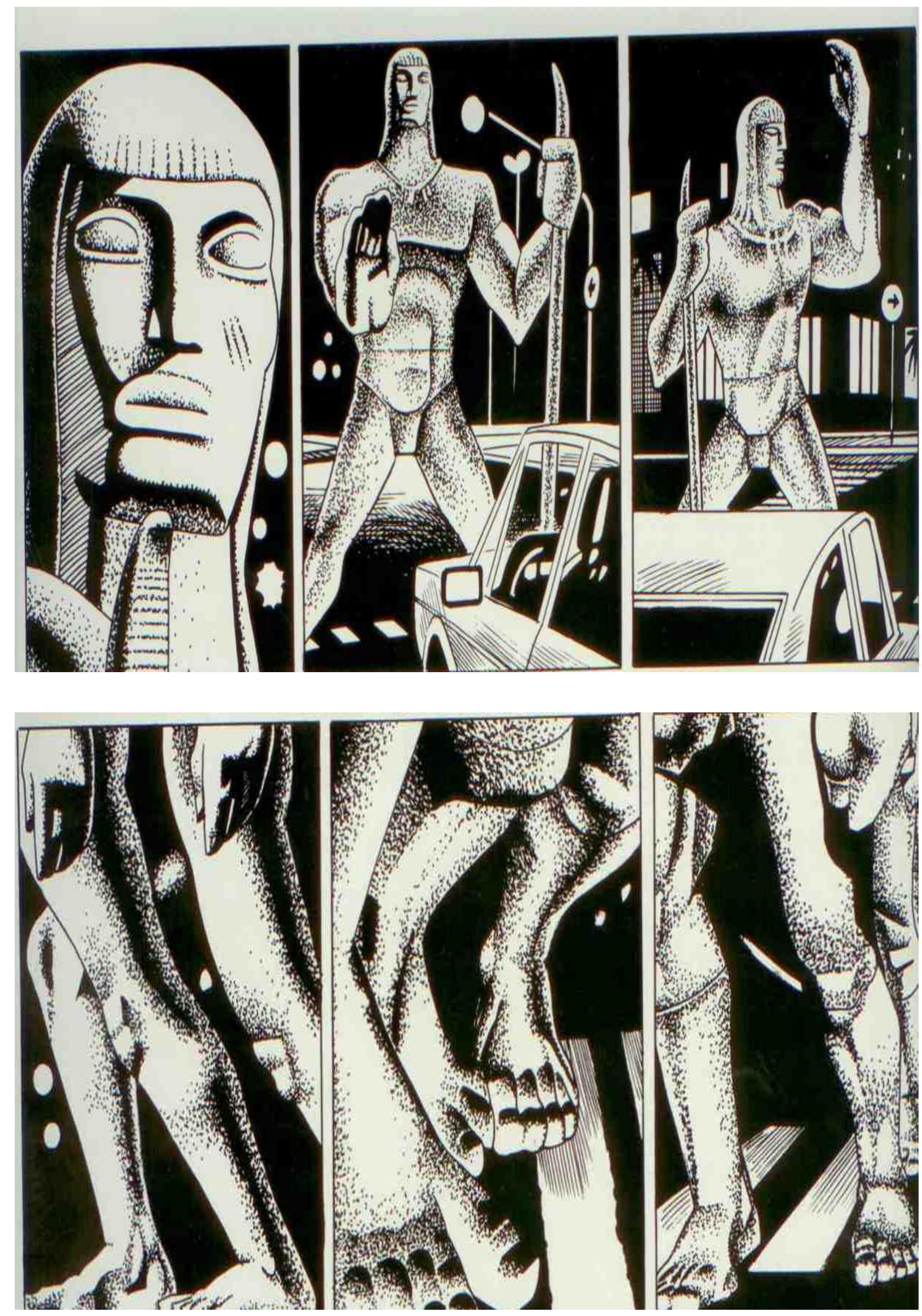

Figura 4.1 
Como se pode observar nos quadrinhos sequenciais retroapresentados, a remissividade é pontual, perfectiva. Não temos nesse caso o aspecto durativo da imperfectividade, própria do fazer emissivo. Assim como a arte renascentista, "Entradas e bandeiras" privilegia a desaceleração, o fazer remissivo, o descontinuativo, as paradas. 0 percurso do sujeito 2, no nível discursivo, é representado pelos atores-estátuas. De certa forma, esse sujeito desacelera, introduzindo a parada, no percurso do sujeito 1, que, na situação narrativa inicial, estava de posse de valores emissivos. As estátuas desenvolvem um programa de parada no programa dos homens da cidade, desacelerando a busca de valores utilitários e éticos. Elas, antes imóveis, passam agora "solenemente" a desfilar pelo espaço público.

Se a HQ "Entradas e bandeiras" se aproxima do classicismo, com seu andamento desacelerado, em "Tubarões voadores" (segunda HQ de Território de bravos) temos o oposto: uma espacialidade mais aberta, em que os elementos constitutivos transbordam do quadro, e uma aspectualidade imperfectiva (ataque durativo dos tubarões pela cidade). A desaceleração de "Entradas e bandeiras" dá lugar em "Tubarões voadores" e em "Futboil" à aceleração (ver quadro 3.5 do capítulo 3). O percurso do sujeito na figura dos tubarões voadores adota valores emissivos, continuativos, acelerados, portanto. Em vez de estado (solenidade), temos acontecimento, fugacidade. Diferentemente de "Entradas e bandeiras", em "Tubarões voadores", nota-se a insuficiência do espaço do quadrinho. Os elementos da expressão não podem ser contidos pelas linhas que separam classicamente os quadrinhos. Daí a presença de alguns deles completamente sem linhas laterais e de outros em que há transbordamento de seus elementos, tanto os visuais quanto os verbais do balão (figura 4.2). 


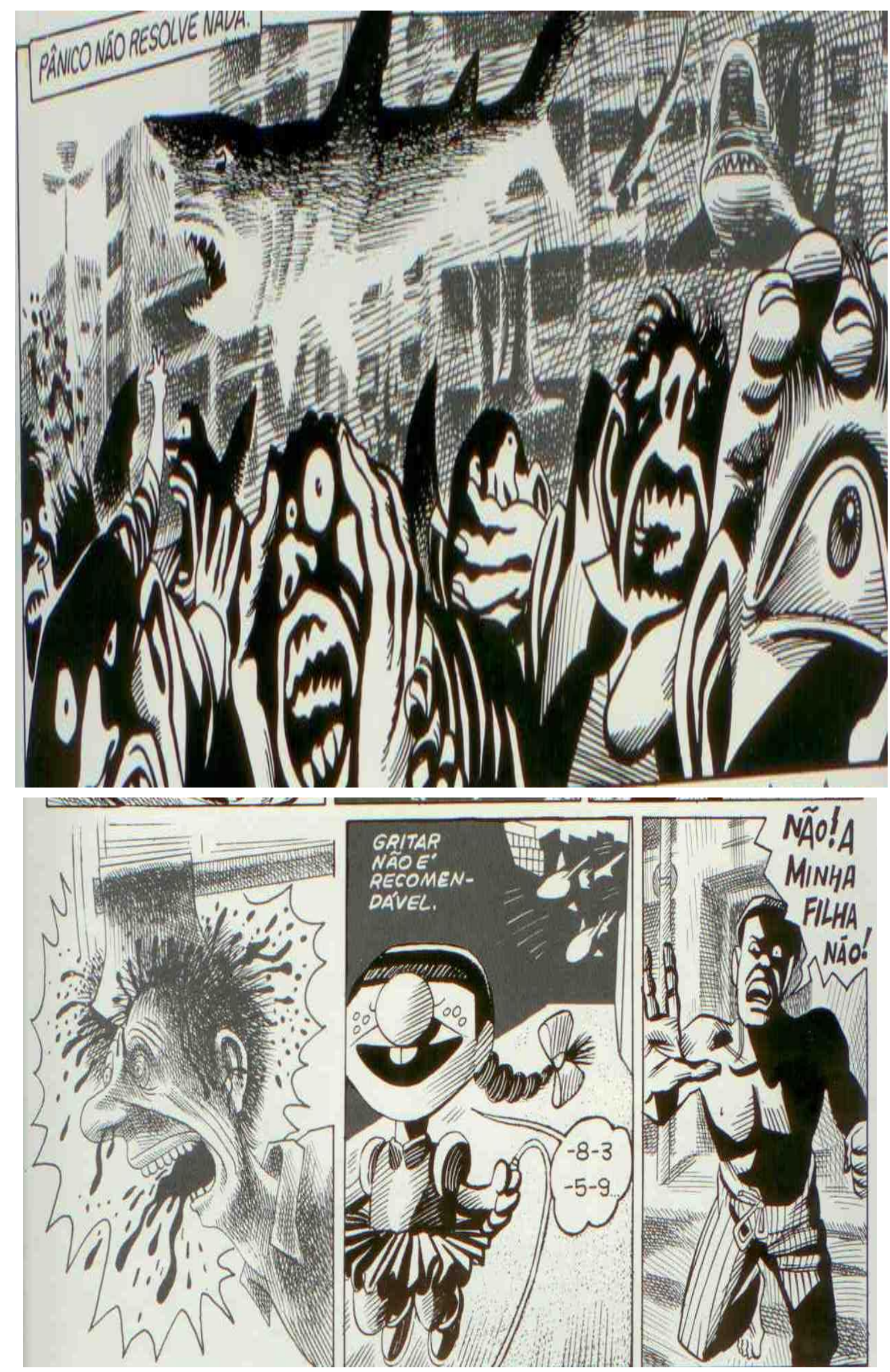

Figura 4.2 
Nos quadrinhos, é de observar que os elementos estão vazando ou transbordando das linhas limitadoras. No segundo quadrinho da figura 4.2 (figura de homem com machado à cabeça), há ausência completa da linha vertical à esquerda da figura e da linha horizontal sob ela. No livro original em papel, no lado esquerdo da figura 4.2 é perceptível o transbordamento do quadro: a asa do tubarão transborda da linha. Embora tenhamos tomado apenas dois exemplos da HQ "Tubarões voadores", esse procedimento é comum em muitos de seus quadrinhos.

Enquanto o andamento é vivo em "Tubarões voadores" e "Futboil", é lento em "Entradas e bandeiras"; enquanto o aspecto imperfectivo prepondera nas duas primeiras, em "Entradas e bandeiras" prepondera a perfectividade.

Vejamos como se distribuem tais categorias no gráfico 4.1 de correlação conversa:

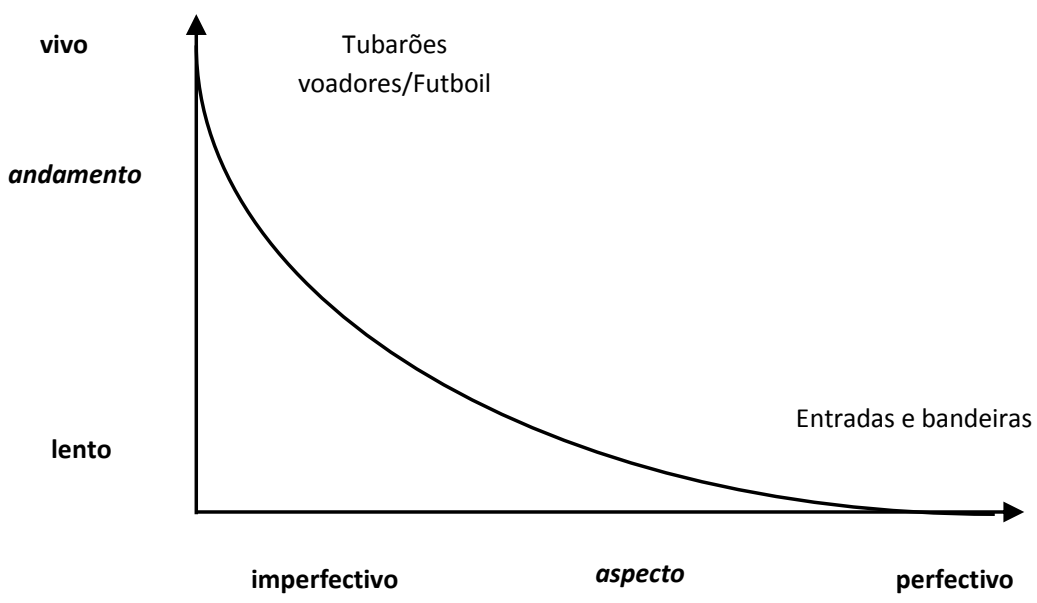

Fonte: Elaborado com base em Zilberberg (2006a, p. 168).

Gráfico 4.1 Correlação entre andamento e aspecto.

Noutros termos, em "Tubarões voadores", o "pontual" irrompe e durativiza: ocorre um ataque de tubarões que voam e que perdura na cidade (atacou $\rightarrow$ está atacando); o susto, que geralmente é pontual, ganha duratividade.

Em "Entradas e bandeiras", por outro lado, a aspectualização é pontual e perfectiva: "a estátua parou o automóvel (1a parada)"; “a estátua pisou no automóvel (2 2 a parada)", configurando dois momentos pontuais de parada na HQ.

Grosso modo, enquanto "Entradas e bandeiras", com seu estado solene, aproxima-se do classicismo; "Tubarões voadores" e "Futboil", com sua fugacidade, aproximam-se do barroco. 
Feitas essas comparações entre Território de bravos e as estéticas do classicismo e do barroco, endereçamos os estudos semióticos das HQs para a retórica tensiva, que se constitui em fundamento para análise das acelerações e desacelerações dos tropos nas HQs. Finalmente, abordamos a constituição do ritmo nas HQs.

\subsection{Semiótica e retórica}

A retórica pertence de direito ao campo semiótico. Claude Zilberberg

Desconsiderar a retórica sem se dar conta de que a sua aceitação ou sua rejeição afetam a teoria do sentido parece ser um lugar comum na atualidade (cf. ZILBERBERG, 2006a, p. 173). E logo a seguir, à página 199, o autor citado afirma que a semiótica soube reconhecer sua dívida para com Propp (1984), mas desconheceu a lição de Aristóteles na Poética, para o qual o acontecimento, no plano do conteúdo, e a teatralidade, no plano da expressão, constituem, a par da narrativa e do "esquema narrativo canônico", um dos caminhos possíveis do sentido.

Para Zilberberg (2006b, p. 200), a retórica tropológica tem afinidade com as valências $^{1}$. Os tropos vistos pelo ângulo semiótico, no entanto, merecem uma revisão conceitual (FIORIN, 2008a, p. 71-91).

Em Eléments de grammaire tensive (2006a, p. 165), o autor salienta que é difícil de precisar hoje o lugar da retórica nos estudos da ciência da linguagem. Como parâmetro dos discursos, a retórica já não chama a atenção, com exceção do texto "Antiga Retórica", publicado em A aventura semiológica, de Roland Barthes (2001, p. 3-102).

Zilberberg (2006a, p. 165), analisando a retórica, identifica-a como instrumento para considerar o que pode ser conveniente para persuadir o enunciatário. Todavia, a partir dos

\footnotetext{
${ }^{1}$ Fontanille e Zilberberg (2001, p. 19-22) refinam o conceito de Greimas e Fontanille (1993, p. 44), afirmando que "com as valências, estamos diante de gradientes de intensidade (por exemplo, o gradiente de intensidade afetiva) e gradientes de extensidade (por exemplo, o gradiente da 'funcionalidade', dos papéis domésticos do cão, ou da hierarquia dos gêneros e das espécies). A intensidade e a extensidade são os funtivos de uma função que se poderia identificar como a tonicidade (tônico/átono), a intensidade à maneira da 'energia', que torna a percepção mais viva ou menos viva, e a extensidade à maneira das 'morfologias quantitativas' do mundo sensível, que guiam ou condicionam o fluxo de atenção do sujeito da percepção. [...] O valor é então a função que associa as duas valências e essas duas valências (esses gradientes orientados e correlatos) são os funtivos do valor. A valência pode, pois, dar margem a duas análises: de um lado, ela é uma orientação gradual num conjunto de grandezas tônicas ou átonas; de outro, ela varia sob o controle de uma valência, por relação à qual é percebida como associada e dependente".
} 
estudos semióticos de Greimas, a persuasão, que antes era vista como pertencente apenas ao nível discursivo, passa a ser abordada em função da narratividade (manipulação); passa a se distinguir um "fazer crer" em que o enunciador faz o enunciatário crer que "deve fazer", ou seja, faz o enunciatário "querer fazer".

Tomando como base o verbete [fazer] persuasivo do Dicionário de semiótica (GREIMAS; COURTÉS, 1989, p. 333), verificamos que o fazer persuasivo é uma das formas do fazer cognitivo e, portanto, está relacionado com a instância da enunciação. O enunciador convoca todo tipo de modalidades para fazer o enunciatário aceitar o contrato enunciativo proposto, tornando a comunicação eficaz.

O discurso persuasivo, segundo Zilberberg (2006a, p. 165-166), é dividido entre uma argumentologia e uma tropologia. A primeira é implicativa e de atonia reduzida; e a segunda é concessiva e de maior tonicidade. Enquanto a argumentologia pode reportar-se ao conceito de função, a tropologia pode reportar-se ao de funcionamento. Neste último caso, ocupa-se dos fenômenos de expressão, bem como da intensidade que rege a extensidade, base da hipótese tensiva.

Barthes (2001, p. 15) ressalta que a retórica é "a arte de extrair de qualquer assunto o grau de persuasão que ele comporta" ou "a faculdade de descobrir especulativamente aquilo que em cada caso pode ser próprio a persuadir".

A antiguidade clássica, nos estudos retóricos, reconhecia três tipos de raciocínio: o apodítico (em que as conclusões eram tiradas por silogismo de premissas indiscutíveis); o dialético (em que se argumentava com base em premissas prováveis que levavam a conclusões possíveis, uma delas a mais aceitável); e, finalmente, o retórico (em que, como o dialético, partia-se de premissas prováveis e chegava-se a conclusões não apodíticas com base no silogismo retórico: o entimema). Para Eco (1974, p. 73), contudo,

\footnotetext{
para obrigar o leitor a prestar atenção a premissas e argumentos, é preciso estimular-Ihe a atenção; e para tal concorrem as translações e as figuras retóricas, embelezamentos mediante os quais o discurso surge, de repente, inusitado e novo, ostentando uma imprevista cota de informação. Todos conhecem os mais célebres desses artifícios retóricos, como a metáfora, que designa um objeto por meio de outro, posto em relação ao primeiro como termo de uma comparação subentendida; a metonímia, que designa um objeto por meio de outro que tem com o primeiro relações de contiguidade [...].
} 
A retórica, pois, não objetivava apenas obter um assentimento racional, mas também um consenso emotivo e propunha-se como uma técnica para arrastar o enunciatário. Com o passar dos anos, a retórica deixou de lado a preocupação exclusiva com o raciocínio e passou a sobrevalorizar as figuras de linguagem.

A semiótica, que nos últimos tempos se volta para a retórica (ZILBERBERG, 2006a; BADIR; KLINKENBERG, 2008), renova-a, introduzindo considerações sobre enunciação, enunciado. Por exemplo, na ironia ou antífrase, afirma-se no enunciado e nega-se na enunciação; no eufemismo, atenua-se no enunciado e intensifica-se na enunciação; na hipérbole, intensifica-se no enunciado e atenua-se na enunciação (FIORIN, 2008a, p. 79, 84). Para Denis Bertrand (2009, p. 1-2), em "Entimema e textualização", publicado originalmente em Langages, ano 34, n. 137, 2000 ("Sémiotique du discours et tensions rhétoriques"),

\begin{abstract}
a renovação do pensamento semiótico acerca da retórica está menos relacionada à reparação de uma falta - por que a semiótica preteriu o edifício retórico ao longo de seu desenvolvimento? - que a uma evolução das orientações de sua pesquisa. Voltada agora para apreensão do discurso em ato, a semiótica esforça-se para descrever, na base de seus fundamentos teóricos, a construção do sentido de um modo mais próximo da enunciação viva. Em tal perspectiva, a semiótica não podia deixar de interrogar novamente a retórica, enfocando-a, evidentemente, como um todo; isto é, rejeitando toda a divisão histórica entre retórica da argumentação e retórica dos tropos para tentar restabelecer a reflexão sobre a base comum em que originariamente ambas foram fundadas. No centro dessa nova abordagem, as hipóteses analíticas da "retórica tensiva" foram avaliadas essencialmente em um reexame tropológico.
\end{abstract}

Nosso objetivo é estudar a gramática tensiva de Zilberberg com olhos voltados para a semiótica verbo-visual de "Entradas e bandeiras", considerando não só os estudos tropológicos, mas também os relativos à argumentação, numa tentativa de interrogar novamente a retórica, enfocando-a, evidentemente, como um todo; isto é, rejeitando a divisão histórica entre retórica da argumentação e retórica dos tropos, para fazer uma reflexão sobre a base comum entre a semiótica e a retórica.

Daí que a análise a seguir terá como proposta verificar em que medida a gramática tensiva de Zilberberg toca a retórica e o tesouro das figuras, como menciona Zilberberg (2006c, p. 200): “a semiótica 'abasteceu-se' em primeiro lugar na linguística e na antropologia estrutural, em seguida, na fenomenologia, por vezes na psicanálise, na teoria das catástrofes com Petitot, mas ignorou a retórica, como arte do discurso e como tesouro das figuras". Cabe-nos, então, verificar "retoricamente" as HQs sob análise. Comecemos pela 
argumentação retórica, para, em seguida, analisarmos os tropos visuais em "Entradas e bandeiras".

\subsubsection{Argumentação retórica}

Segundo Zilberberg (2006c, p. 194), a enunciação permite avaliar o controle direto e indireto que o sujeito da enunciação exerce sobre o enunciado. A gramática tensiva ocupase do fato "maciço" da "melhoração" e da "pejoração" (correlação conversa: quanto mais... mais... quanto menos... menos... e correlação inversa: quanto mais... menos... quanto menos... mais...).

O sujeito do discurso acredita descrever o que "percebe", bem como que é "objetivo" em suas afirmações, passando ao largo de toda sua subjetividade tal como o senso comum o manipulou para nisso acreditar. Embora queira fazer prevalecer o inteligível, ele é regido pelo sensível em suas manifestações ${ }^{2}$. Assim, o discurso não descreve tão somente; a todo momento, o sujeito do discurso toma posição e sanciona.

Dois são os caminhos do sujeito, segundo Zilberberg (2006c, p. 194-197):

1. Sintaxe intensiva: manipulação das estruturas da contrariedade. O sujeito pode substituir o espaço da subcontrariedade pelo da sobrecontrariedade e proclamar a insuficiência das grandezas admitidas no campo de presença. $\mathrm{O}$ sujeito pode ainda substituir o espaço da sobrecontrariedade pelo da subcontrariedade, proclamando o excesso. Pode o sujeito chegar a declarar a insuficiência do excesso, assim como a insuficiência da insuficiência. Assim, transforma o sujeito limites em graus (primeiro caso), ou insere dentro dos intervalos dos subcontrários [S2 $\leftrightarrow \mathrm{S} 3$ ] um intervalo de menor invergadura. Os valores míticos discursivizados são o sublime e o mediano. O sublime assume sua própria desmedida e denuncia o mediano como "nulo", já o mediano, por sua vez, em nome da ponderação, desqualifica o sublime como "empolado" e "grandiloquente".

\footnotetext{
${ }^{2}$ Por ser regido pelo sensível, o sujeito do discurso é levado à criação de tropos. No caso da hipérbole, por exemplo, é perceptível nitidamente a substituição de um argumento quantificável, preciso matematicamente (Estou com um quilo de alegria) por um tropo que dá vazão ao sensível. Daí o sensível comandar o inteligível no emprego do exagero, da intensificação de uma manifestação por meio da hipérbole que é um superlativo tensivo. Nesse caso, temos a superioridade da ordem do "mais... mais..." (ZILBERBERG, 2006c, p. 194-195).
} 
2. Sintaxe extensiva: a afirmação da superioridade intrínseca das operações de triagem sobre as operações de mistura promove a reiteração da triagem (triar a triagem). Estamos em presença de valores de absoluto (triagem), concentrados e reflexivos. Na afirmação inversa, misturar as misturas, temos como resultado valores de universo: mistura e difusão. A proclamação de valores de absoluto limita-se com o "nada" (ninguém, nenhum, nenhuma). A proclamação dos valores de universo anula a distinção, o comedimento constitutivo do sentido.

A implicação, convocada pelo silogismo e pelo entimema, deve compor-se com a concessão. Dessa forma, a direção espacial vai do hermético ao escancarado, passando pelo fechado e pelo aberto (quadro 4.2).

Quadro 4.2 Direção.

\begin{tabular}{|l|l|l|l|}
\hline HERMÉTICO (S1) & FECHADO (S2) & ABERTO (S3) & ESCANCARADO (S4) \\
\hline
\end{tabular}

Essa análise nos permite verificar a oposição ingênua entre dois subcontrários: o /aberto/ e o /fechado/. Permite também verificar duas oposições mais "raras":

1. Uma oposição entre um subcontrário, o /fechado/, e o sobrecontrário, o /hermético/. Nesse caso, temos aquilo que se pode abrir (fechado) e aquilo que não se pode abrir (hermético).

2. A oposição entre o /aberto/ e o /escancarado/. O aberto apresenta-se como aquilo que se pode fechar; e o /escancarado/ como aquilo que não se pode fechar.

A tensão seria a dependência do espaço para com a tonicidade e essas grandezas envolveriam a veridicção; elas são possíveis ou não possíveis. A implicação produz sintagmas motivados: fechar o aberto e abrir o fechado, pois o fechado é algo que se pode abrir, e o aberto é algo que se pode fechar. Essa latência pode se tornar uma argumentação superficial, como se pode ver no seguinte quadrinho: 


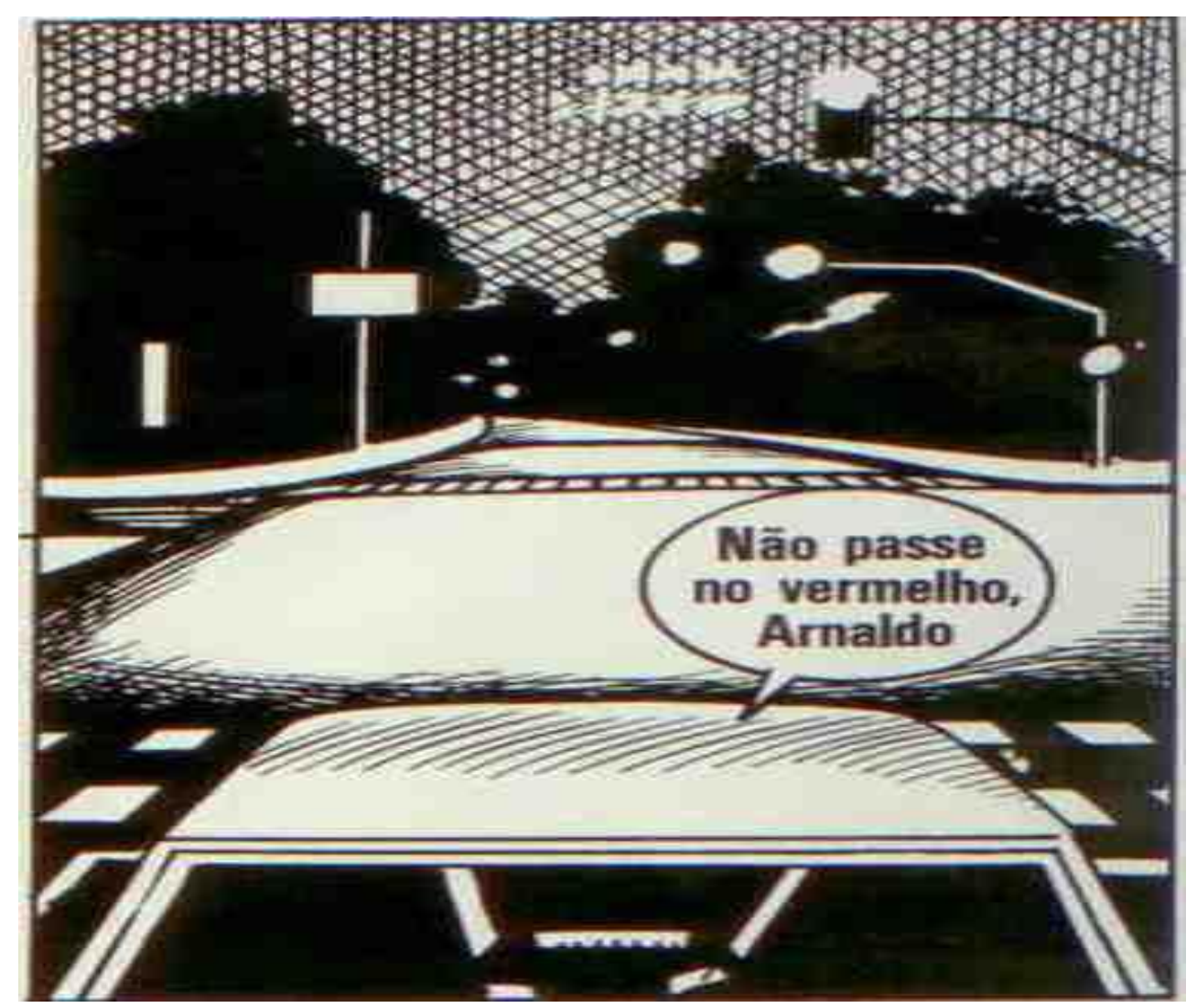

No quadrinho acima, a motivação sintagmática vem da seguinte argumentação:

“Dever parar", PORQUE o FAROL AVERMELHOU.

Vejamos outro exemplo de retórica argumentativa:
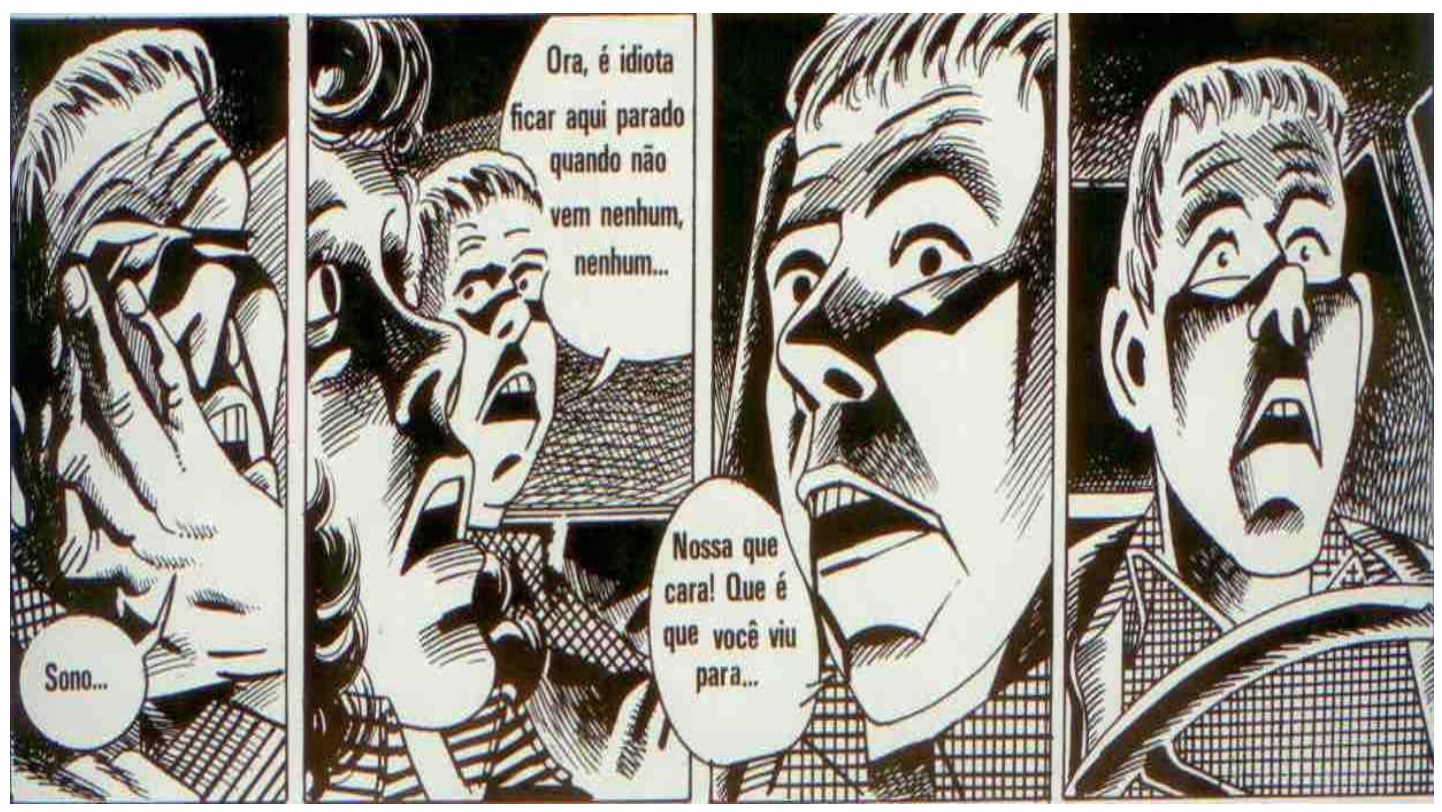

“Querem ir para casa” descansar , PORQUE os atores têm sono. 
Nada de surpresa no discurso. A lógica é puramente implicativa, nesse exemplo. É a ordem da regra, do destinador mantenedor da ordem que rege o sujeito 1 sob análise, conforme vimos anteriormente. Esse actante destinador tem o compromisso com a continuidade (transitoriedade) do programa do sujeito. Dessa forma, quanto mais implicações no percurso, melhor.

Na concessão, temos os sintagmas: abrir o hermético (o que não se abre) e fechar o escancarado (o que não se fecha). A discursivização da concessão opõe o irrealizável e a realização advinda. Embora esse dispositivo seja hermético, eu abro; se escancarado, eu fecho. Nesse caso, verifica-se uma passagem da ordem da monotonia da regra para a tonificante (descontínua) do acontecimento. Passamos do "porque" para o "embora":
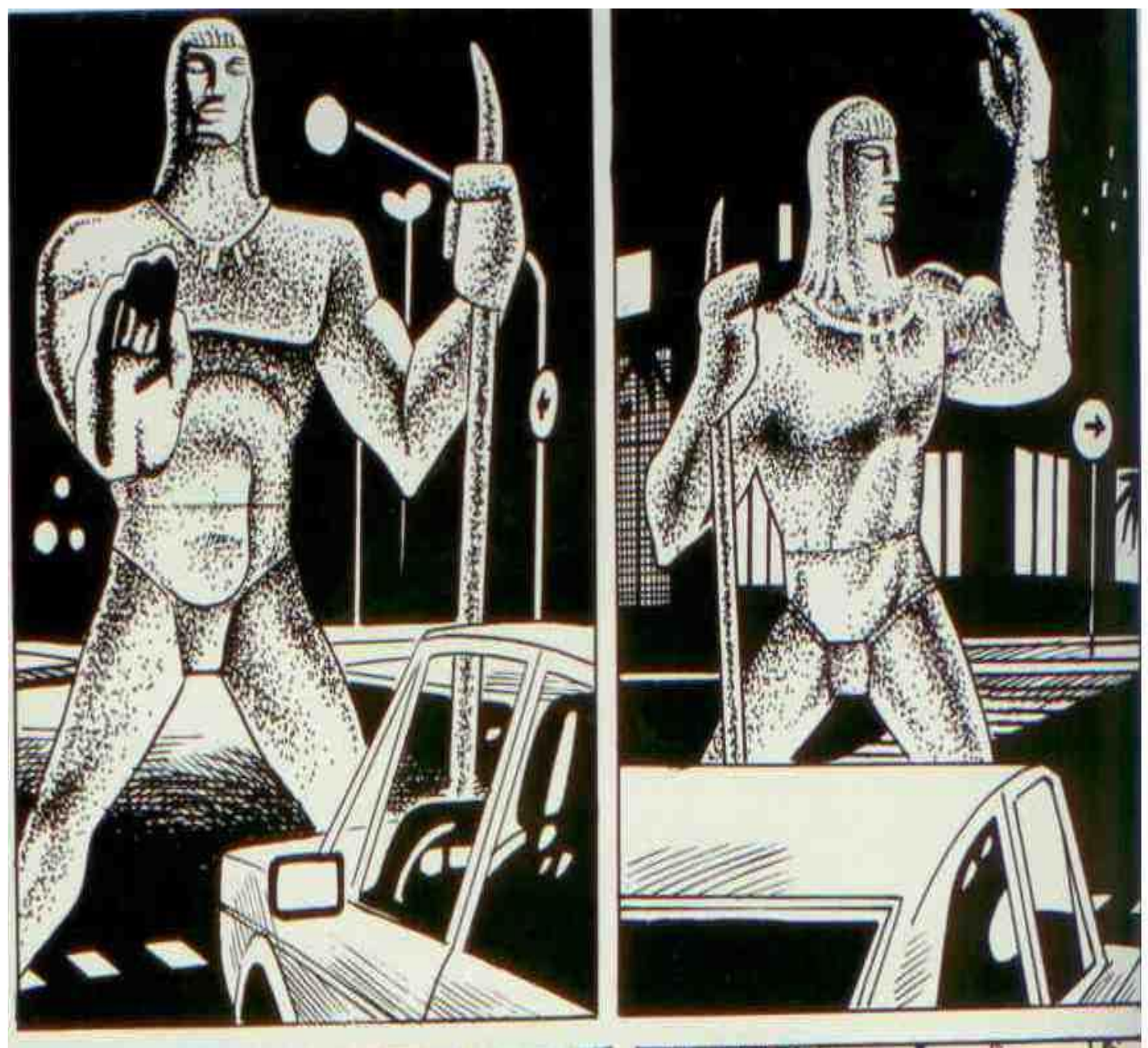

“EMBORA O FAROL PUDESSE ABRIR, o automóvel não andou [ruptura]." “EMBORA ESTÁTUAS NÃO TENHAM MOBILIDADE, elas andam.” 
Se continuássemos na ordem dos "porquês" do discurso implicativo, a sequência seria: "Automóvel andou, PORQUE o farol abriu". No entanto, a previsibilidade implicativa do silogismo é substituída pela descontinuidade concessiva.

Se a ordem implicativa fosse mantida, os passageiros do automóvel monotonamente iriam para casa dormir. Todavia, a concessão da ordem descontínua do acontecimento introduz a parada no cotidiano dos atores.

Os subcontrários entram no discurso, convocando a implicação e os sobrecontrários, mobilizando a concessão. O acontecimento, ao sobrevir no campo de presença do sujeito, rompe com os sistemas das expectativas vigentes. Se os passageiros do automóvel estivessem na ordem do implicativo, nada poderia sobrevir, e teríamos um pervir. Todavia, o sobrevir chega, rompendo o enfadonho da regra.

O acontecimento define-se como aquilo que acontece e tem importância para o homem. Consideremos que "aquilo que acontece pertence ao andamento. É da ordem do sobrevir, da subitaneidade. É andamento mais rápido que o homem possa experimentar" (ZILBERBERG, 2006c, p. 198). No caso sob análise, o casal do carro é surpreendido pela magnitude das estátuas "móveis" que param o veículo.

Consideremos ainda que "o que tem importância para o homem" é da ordem da tonicidade. O sujeito instalado na ordem racional, senhor de suas esperas sucessivas, vê-se desviado de seus caminhos habituais e projetado no "brusco". Os passageiros do veículo, diante da estátua, não têm saída, estão presos ao espaço hermético do carro, e, mais que isso, às regras sociais de organização do trânsito.

O andamento e a tonicidade agem ambos sobre o sujeito: "A tonicidade não vem devastar uma parte do sujeito e sim ele todo" (ZILBERBERG, 2006c, p. 198). E continua o autor citado: "Para essa semiose fulgurante, o acontecimento quando merece tal denominação arrebata para si todo o agir, não deixando ao sujeito nada além do suportar." Não resta, pois, outra saída para os passageiros, senão suportar o bloqueio feito pelas estátuas. O sujeito passa sem transição, sem modulação, de S1 para S4. Assim, o acontecimento é a um só tempo "a medida e a derrota do sujeito" (ZILBERBERG, 2006c, p. 199). 
Agora, vejamos as dinâmicas extensivas do acontecimento: temporalidade $e$ espacialidade. Como o sujeito já não é senhor da temporalidade (foi parado pela estátua), há uma necessidade de recuperar o tempo aniquilado pelo acontecimento.

Ora a recomposição da temporalidade está condicionada à desaceleração e a atonização: retorno ao comedimento que o acontecimento suspendeu. O sujeito deseja reaver pouco a pouco o controle e o domínio da duração. Sentir-se novamente capaz de comandar o tempo ao seu bel-prazer. Os passageiros desejam chegar à sua casa o mais rápido possível. Todavia, são acometidos por outra concessividade:

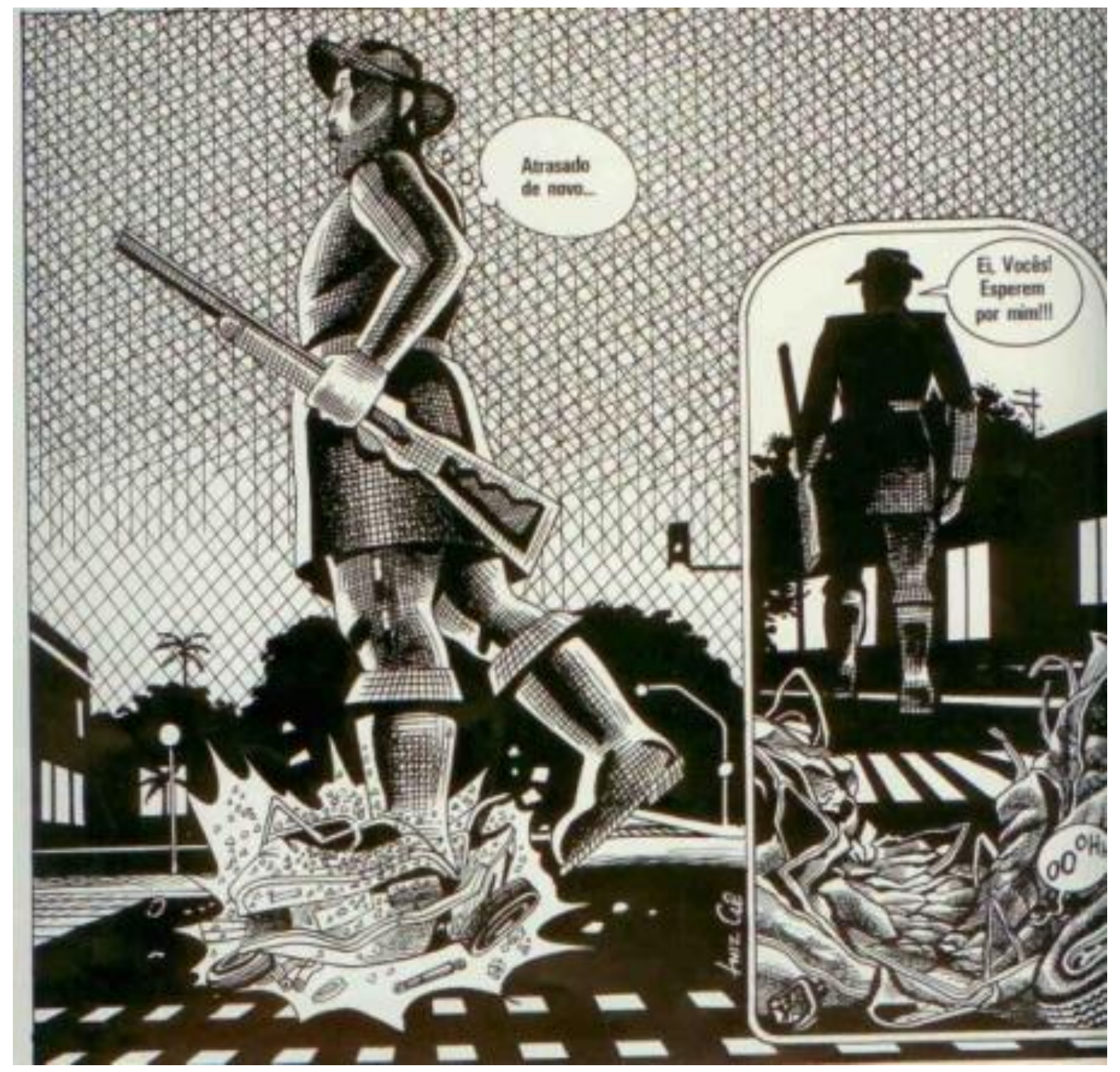

Aqui, temos um raciocínio semelhante à:

EMBORA o carro andasse, foi parado.

EMBORA a estátua "Borba Gato" não tivesse mobilidade, passou pelo automóvel. 
Considerando a espacialidade, verificamos que também ela sofre com o acontecimento. Toda circulação exige uma abertura e um fechamento. No caso do acontecimento, ela é virtualizada. Zilberberg (2006c, p. 199) afirma: "ausentando-se o aberto do campo de presença, só o fechado acaba se mantendo ali". Assim, no quadrinho de "Entradas e bandeiras" exposto acima, quando da presença do acontecimento, o espaço aberto e livre de Borba Gato e a ausência de abertura no campo de presença dos passageiros do automóvel (S1) configuram a manutenção do espaço fechado: S1, estupefato, fica petrificado sem poder sair do lugar.

A implicação (passageiros do automóvel voltam para casa PORQUE têm sono), convocada pelo silogismo, compõe-se com a concessão (EMBORA estátuas sejam imóveis, na HQ elas andam e imobilizam o automóvel) no discurso de "Entradas e bandeiras".

$\mathrm{Na}$ fábula da HQ sob análise, nesse acontecimento que ocorre nas imediações do Parque do Ibirapuera, lugar de exposição "permanente" da obra de Brecheret, a escolha enunciativa opta pela valorização do estético e a superação dos valores utilitários e automatizados. Parece chamar a atenção para a falta de percepção que os habitantes de São Paulo desenvolveram em relação ao espaço urbano. Interessam-lhes sobretudo valores do mundo utilitário que lhes impedem desfrutar das obras de arte que estão espalhadas pela cidade. Daí a enunciação escolher valores estéticos em movimento pelo espaço público, numa atitude de "fazer-se ver", de "mostrar-se" para esse homem que "enxerga", mas "não vê" os valores da arte: dorme, acorda, levanta, come, corre, trabalha, retorna para casa, come de novo, num movimento contínuo e banal, à semelhança do trabalho de Sísifo, que contribui para a dessemantização do artístico pela repetição cotidiana.

Para lembrar os dizeres de Zilberberg (2006b, p. 144), a arte é permanente, é da ordem da conservação, enquanto o homem tem uma vida limitada, passageira, passante como os automóveis o são.

Para dar seguimento aos estudos de semiótica e retórica, faremos uma explanação tensiva dos tropos em "Entradas e bandeiras".

\subsubsection{Tropos visuais em "Entradas e bandeiras"}

Tendo visto alguns elementos argumentativos, passemos agora à outra parte da retórica, que trata dos tropos (cf. ZILBERBERG, 2006c, p. 195). A retórica comporta não só 
uma vertente argumentativa, que define o discurso pelo objetivo utilitário ou prático que escolhe, ignorando "o rumor do mundo", mas também uma vertente tropológica que permite entender como os afetos regem a parte inteligível do discurso.

A concessão é um acidente do discurso; sem ser anunciada, reverte as competências e as esperas dos sujeitos. Algumas direções retóricas, como elevação, surpresa, a amplificação e o sublime, regem os discursos e produzem figuras, tropos. Zilberberg (2006a, p. 182) cita dois estudiosos da retórica: Dumarsais e Fontanier. Segundo o primeiro, "[...] as figuras quando são empregadas com propriedade dão vivacidade, força ou graça ao discurso"; para o segundo, "os Tropos surgem, ou por necessidade e por extensão, para suprir as palavras que faltam na língua para algumas ideias, ou por escolha e por figura, para apresentar as ideias com imagens mais vivas e mais marcantes que seus próprios signos".

Para Dumarsais, a "vida" é constituída pela vivacidade, força ou graça, já para Fontanier, a vida é mais viva e mais marcante. Zilberberg (2006a, p. 182) denomina essas grandezas de valências intensivas. A intensidade é composta por andamento e tonicidade; o andamento pode ser vivo ou lento, e a tonicidade, tônica ou átona.

A surpresa pertence à concessividade; há uma tensão entre o estilo implicativo (conformidade com a opinião) e o estilo concessivo. As expressões novas produzem o inesperado. O estilo implicativo é confirmativo e compartilhado, enquanto o concessivo é inaugural e momentaneamente singular. A amplitude leva o enunciatário a não se contentar com o restabelecimento e a ingressar no recrudescimento (tornar-se mais intenso). $\mathrm{O}$ recrudescimento admite variedades, segundo o parvenir ou sobrevir. A amplificação é uma das vias principais da retórica; noutros termos, é um acréscimo de palavras que fortifica o discurso, com base no que foi dito. Nela,

\footnotetext{
[...] o estilo se eleva gradativamente em frases que se acumulam cerradamente umas sobre as outras. [...] Quer isso resulte do desenvolvimento de lugares comuns, quer do encarecimento da realidade, ou dos artifícios, quer ainda do sábio arranjo dos fatos, ou das emoções (pois a amplificação tem milhares de formas), deve o orador, não obstante, saber que, de per si, sem o sublime, nenhum desses meios se manteria eficaz [...]; suprimir nas demais formas de amplificação o sublime é como arrancar a alma do corpo; logo se the enfraquece e esvazia a eficácia, quando não avigorada pelo condão do sublime (LONGINO in: ARISTÓTELES, HORÁCIO E LONGINO, 2008, p. 83). [destaque nosso]
}

Como vemos, o sublime é "a alma do corpo". Essa figura cobre a isotopia da força, da intensidade. A gradação de todo discurso compreende sempre porções de mais e porções de menos, que também advêm dos tropos que o compõem. 
Fontanier retoma a amplificação e acrescenta essa noção de gradação que "consiste em apresentar uma sequência de ideias ou de sentimentos numa ordem tal que o que segue diga sempre um pouco mais ou um pouco menos do que aquilo que veio antes, a depender do tipo de progressão, ascendente ou descendente" (ZILBERBERG, 2006a, p. 184).

O sublime identifica-se com a superlatividade das figuras: são superlativos tensivos. Nesse caso, temos a superioridade do sobrevir sobre o parvenir (ZILBERBERG, 2006c, p. 194200). Um exemplo disso é a hipérbole, da ordem do "mais... mais...", quando ocorre uma imposição dos sobrecontrários (hermético e escancarado).

Para Lausberg (2004, p. 158), hipérbole "é uma amplificação crescente aplicada nos verba singula e isto com evidente intenção de provocar estranhamento para além da credibilidade [...] e serve, na retórica, para despertar pateticamente no público afetos partidários". O autor de Elementos de retórica literária, à página 159, afirma que a "hipérbole pura é um sobrepujamento gradual do verbum proprium et univocum para além da credibilidade. [...] É especialmente aplicada às categorias espaciais".

Vejamos a título de explicitação um exemplo de hipérbole [em destaque] em Os lusíadas (CAMÕES, 2003, p. 54, canto segundo, 91):

\footnotetext{
Respondem-Ihe da terra juntamente, Co raio volteando com zunido; Anda em giros no ar a roda ardente, Estoura o pó sulfúreo escondido.

A grita se alevanta ao céu, da gente;

O mar se via em fogos acendido

E não menos a terra; e assi[m] festeja

Um ao outro, a maneira de peleja.
}

Outro exemplo de hipérbole [em destaque] podemos encontrar em um poema contemporâneo de Pietroforte (2010, p. 58):

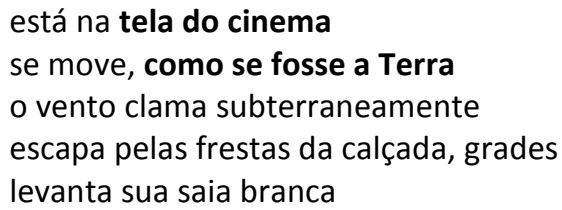

de Vitória 
Ora, como se dá a hipérbole visualmente? É o que vamos ver agora em alguns exemplos retirados de "Entradas e Bandeiras"; para fazer sobressair valores estéticos, o enunciador opta pelo gigantismo das estátuas em relação à pequenez humana:
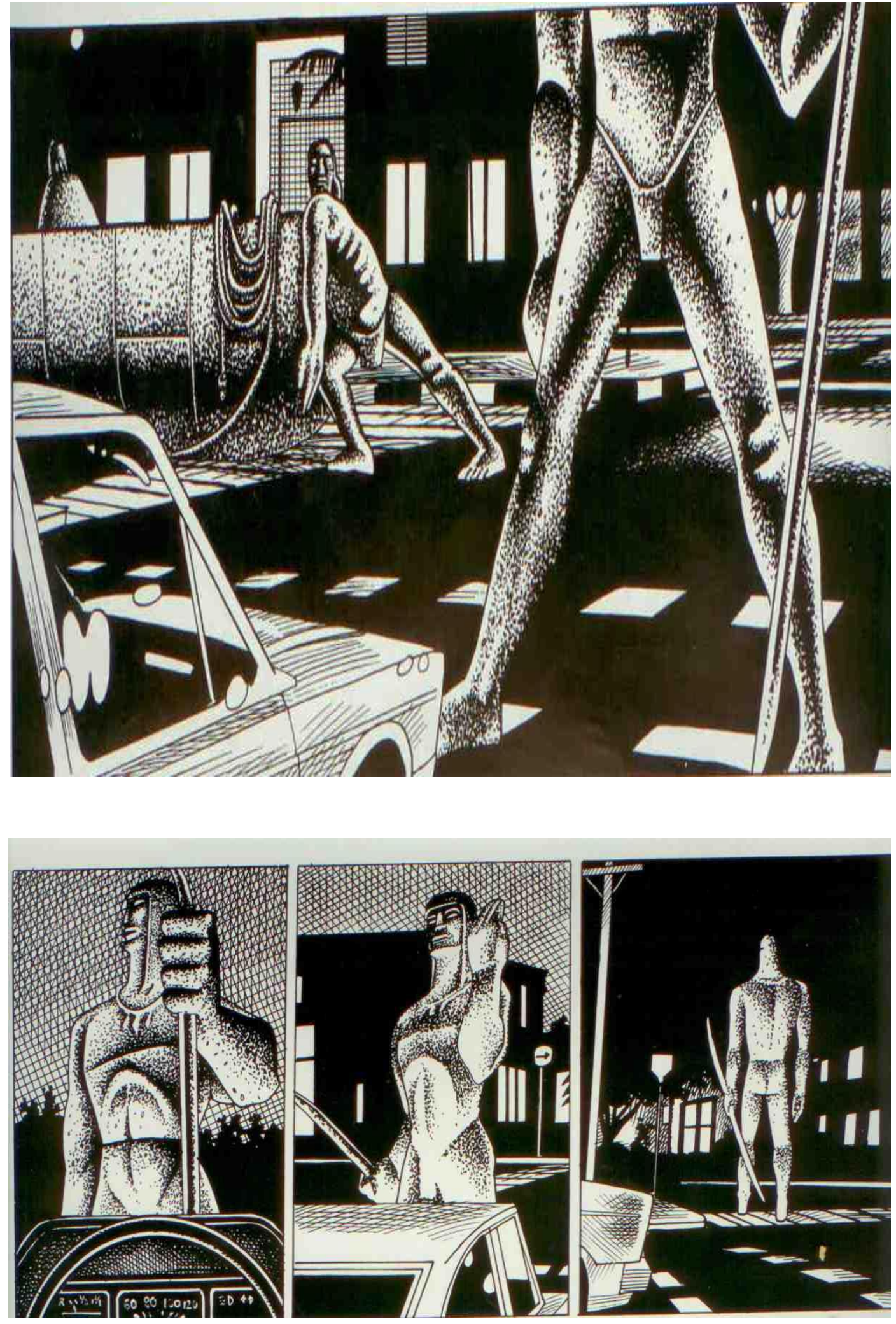
Nos exemplos apresentados, verificamos a grandiloquência da arte em relação ao homem e ao seu mundo de utilidades, efeito de sentido provocado pela hipérbole, pela desproporção das figuras discursivas nos quadrinhos. O próprio significante tem aí um valor tônico. A hipérbole, como dissemos, é da ordem do "mais... mais...".

No último quadrinho de "Entrada e bandeiras" já mostrado nesta seção, Borba Gato pisa o automóvel; aí é notável a amplificação, provocadora de estranhamento, de impacto. Esse efeito hiperbólico pode ser notado não só no plano do conteúdo, como também no da expressão do enunciado do grito humano:

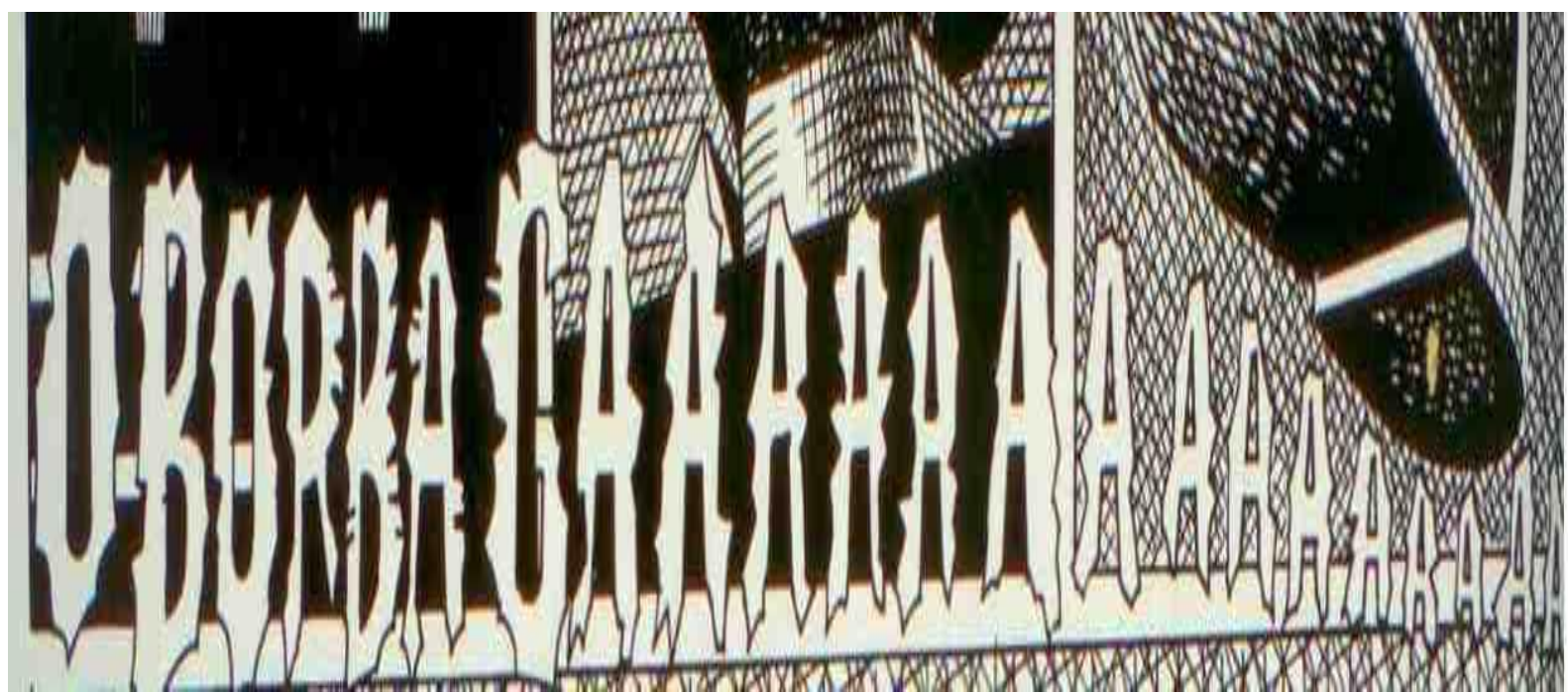

A hipérbole contribui também para a constituição de semissimbolismos no enunciado, que se dão da seguinte forma:

1.

Plano da expressão: "letras vazadas hiperbólicas, em tamanho garrafal, ocupam o espaço de três quadrinhos" e "altura do som do grito"

Plano do conteúdo: "grandiosidade de Borba Gato"

PE : letra vazada enorme e altura elevada do som :: PC : grandiosidade de Borba Gato

2.

Plano da expressão: "repetição e duração do fonema /a/"

Plano do conteúdo: "duração do susto"

PE : repetição e duração do fonema /a/ :: PC : duração do susto 
3.

Plano da expressão: "redução gradativa do tamanho da letra"

Plano do conteúdo: "redução da tonicidade da vida dos passageiros do automóvel"

PE : redução gradativa do tamanho da letra :: PC : redução da tonicidade

da vida dos passageiros do automóvel

Vejamos agora como se configuram a metáfora e a metonímia em Território de bravos.

\subsubsection{A aceleração metafórica e a desaceleração metonímica: tensão entre dois tropos}

Classicamente, a metáfora era entendida como analogia entre duas grandezas, e a metonímia como uma relação de contiguidade, de coexistência, de interdepêndencia.

Como vimos, para a retórica clássica, tanto uma quanto outra são figuras de palavras: enquanto na metáfora ocorre a substituição de uma palavra por outra, que apresenta relação de similaridade entre o termo de partida e o de chegada, na metonímia, há a substituição de uma palavra por outra que apresenta relação de contiguidade entre o termo substituído e o substituinte.

Fiorin (2008a, p. 118) chama a atenção para a insuficiência dessa definição, visto tais tropos serem procedimentos discursivos de constituição do sentido: "nelas o narrador rompe, de maneira calculada, as regras de combinatória das figuras, criando uma impertinência semântica que produz novos sentidos". Por isso, ambas as figuras não são propriamente a substituição de uma palavra por outra, mas uma nova possibilidade de leitura criada pelo discurso. Se entre uma possibilidade e outra houver uma intersecção de traços semânticos, temos metáfora. Se entre as duas possibilidades de leitura houver inclusão, temos metonímia.

Por isso, Fiorin (2008a, p. 74) afirma:

A metáfora e a metonímia não são fenômenos que concernem à palavra isolada, são antes procedimentos discursivos, pois só na combinatória sintagmática elas são construídas e percebidas. É a não pertinência de um dado sentido num sintagma que determina a compreensão de que um novo sentido foi acrescentado a um determinado signo denotado. 
Além disso, a metáfora e a metonímia são processos que pertencem a todas as linguagens, não é exclusividade da linguagem verbal. É comum encontrá-las no cinema, na fotografia, em HQs. Zilberberg (2006a, 2006c) introduz uma nova maneira de ver a retórica tropológica. Segundo ele, a metáfora, por exemplo, efetua uma mistura de duas grandezas. Assim,

que faz uma metáfora, senão efetuar uma mistura entre duas grandezas, ora a partir de suas morfologias relevantes, ora a partir de suas características tensivas? [...] sob o ponto de vista da intensidade, as coisas são ainda mais nítidas: não se pode dizer que haja, num primeiro momento, coisas, e, depois, qualidades; pelo contrário, há sobrevires, emergências súbitas, acentuações à cata de plausíveis significantes receptores (ZILBERBERG, 2006c, p. 200).

Como salientou Zilberberg, do ponto de vista da semiótica tensiva, não há coisas primeiramente e depois qualidades, mas "sobrevires, emergências súbitas". Para a retórica clássica, quando substituímos, por exemplo, "sol" por "bola que corre pelo céu", estamos reconhecendo no sol uma qualidade de bola. A primeira possibilidade de leitura de "bola" é de uma bola que está em chamas; todavia, em "bola que corre pelo céu", há uma impertinência semântica, pois no céu não há "bola". O discurso leva o enunciatário a ler essa expressão como "sol". Portanto, há uma metáfora, visto que entre os dois significados temos uma intersecção sêmica: o traço /forma redonda/ é comum ao sol e à bola. A qualidade esférica pertence ao sol e à bola; ocorre que no discurso metafórico intensificamos a grandeza esfericidade. De todas as qualidades do sol, nesse discurso intensifica-se apenas a qualidade esférica. Daí Zilberberg afirmar "acentuações à cata de plausíveis significantes receptores". Acentua-se uma qualidade (plano do conteúdo) que será recebida por um significante (plano de expressão).

Ora, como na metáfora intensificamos uma qualidade, poderíamos dizer que ocorreu uma triagem. Por exemplo: quando o enunciador afirma que Gino Amleto (personagem de uma HQ de Luiz Gê) é Nero, constatamos uma triagem (ZILBERBERG, 2006a, p. 240), ou seja, selecionamos um traço de Amleto que se identifica com Nero, um valor de exclusão e não de participação. Houve, portanto, uma intensificação de um traço. Todavia, se tomarmos o chapéu de Amleto e passamos a ver Amleto no chapéu, temos uma metonímia. Nesse caso, haveria uma mistura (ZILBERBERG, 2006a, p. 240), uma participação? O chapéu de Amleto comportaria traços de chapéu mais traços de Amleto. Na metonímia, não há triagem de uma 
qualidade, um traço, mas a participação de todos os traços. Na metáfora, realiza-se a triagem de um traço, intensificando-o.

Dessa forma, os pés que se veem nos quadrinhos da figura 4.3 constituem tanto uma metonímia quanto uma metáfora. Bastam os pés para identificarmos as figuras dos atores "estátuas" do Monumento de Brecheret de "Entradas e bandeiras"; nesse caso, temos metonímia. Se, todavia, identificarmos os pés grosseiros como o de alguém dotado de força descomunal, colossal, temos então uma metáfora. Essa ambiguidade é própria dos discursos, sobretudo dos discursos de qualidade artística.
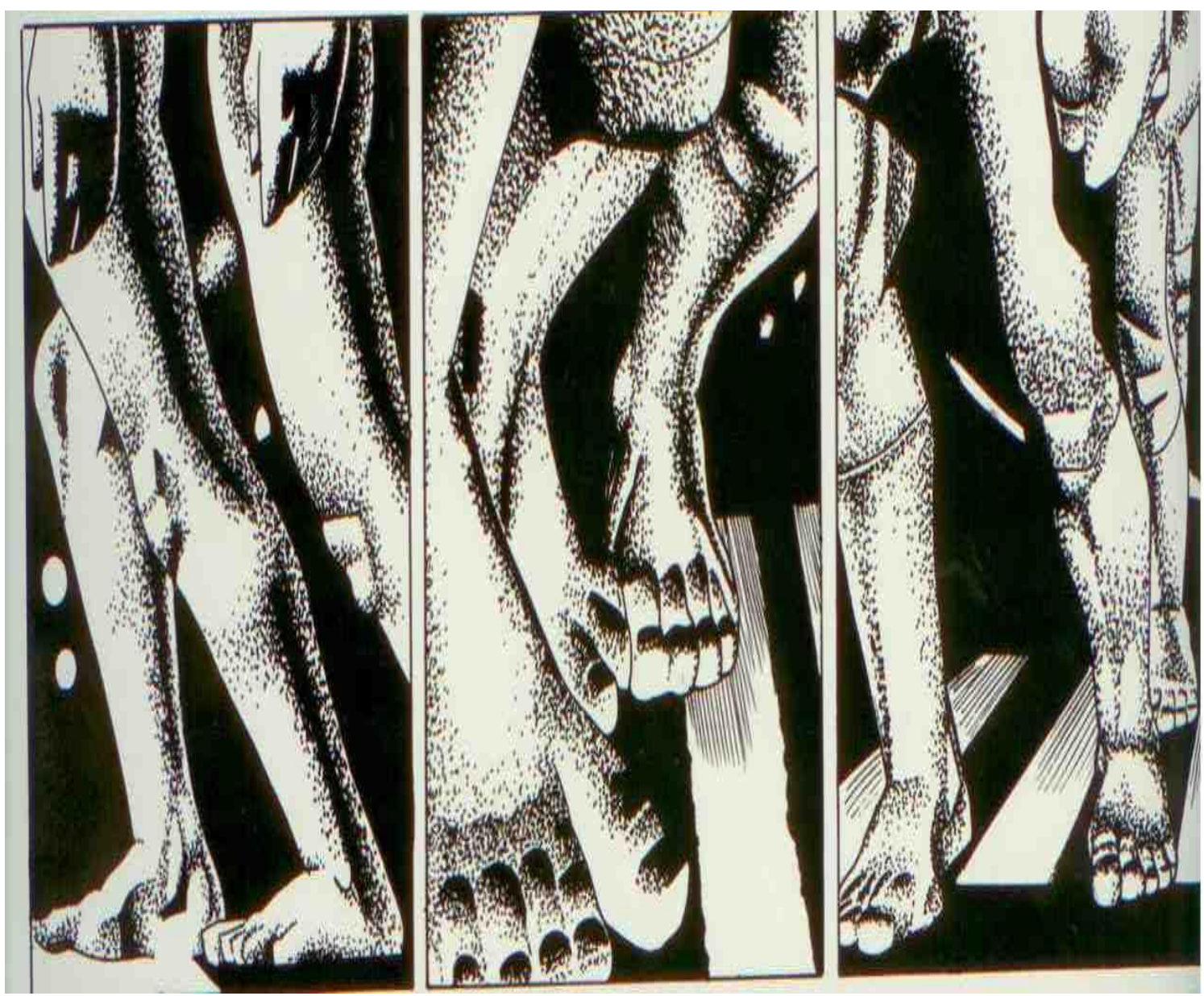

Figura 4.3

Para Lausberg (2004, p. 162), “os limites entre metonímia e metáfora são pouco nítidos [...] a metáfora apresenta uma metonímia de valor mágico". De nossa parte, sugerimos que talvez a semiótica tensiva, com sua noção de continuum, seja uma saída para contornar os limites. 
Podemos considerar a metáfora vivificante (mais acelerada) e a metonímia lenta (menos acelerada) e que esses tropos podem ser vistos como um procedimento gestaltiano. Dessa forma, na metáfora o todo permite identificação imediata; o efeito de sentido é impactante e tem a sua cifra tensiva "mais acelerada". Já a metonímia, vale-se de procedimento inverso: reconstitui-se o todo pela parte; por isso, há uma desaceleração, com cifra tensiva "menos acelerada".

Para Tatit (1997, p. 22), na aceleração as descontinuidades provocam as omissões de etapas do discurso e, dessa forma, abreviam-se as durações, provocando cortes, e, nesse caso, temos a metáfora, que nada mais é que precipitação, colaborando para um processo de concentração. Na desaceleração, o andamento retoma as continuidades e com elas a duração, e, nesse caso, temos todas as etapas intermediárias. É a metonímia que permite que o ritmo recupere a extensão.

A metáfora e a metonímia, portanto, são recursos tropológicos, que, do ponto de vista tensivo, atribuem ao discurso andamento, acelerado ou desacelerado, o que nos leva a concluir que o valor não está só nos extremos, mas na duração, na graduação. E é justamente o meio que garante esses extremos.

A duração, mote do destinador, e os limites, mote do antissujeito, reguladores dos avanços e recuos das narrativas, constituem uma espécie de ritmo, a ser tratado na seção seguinte.

\subsection{Do ritmo}

O ritmo resulta do rápido e do lento, primeiro opostos, depois concordes.

Platão

Se tomarmos o significado dicionarizado de ritmo, verificaremos que se trata de uma sucessão de tempos fortes e fracos que se alternam com intervalos regulares (HOUAISS, 2001, verbete ritmo).

Ochoa (In: LANDOWSKI; DORRA; OLIVEIRA, 1999, p. 245-246) entende que "o ritmo como a propriedade de uma sucessão de acontecimentos no tempo [...] produz no observador o efeito de uma proporção entre as durações dos diferentes acontecimentos" (tradução nossa). Citando Pius Servien, Ochoa distingue dois tipos de ritmo: um que é a divisão regular do tempo, e outro em que não existe tal regularidade, mas uma repetição 
marcada por intensidades, por acentos tônicos, que não se reproduzem em intervalos regulares, mas atuam criando desigualdades, seja nas durações, seja nos espaços metricamente, produzindo pontos privilegiados, cuja iteração produz uma espécie de ritmo sobreposto ao primeiro. Tal repetição é muito mais profunda que a reprodução de elementos ordinários ou homogêneos.

Segundo O. Brik (In: EIKHENBAUM, 1978, p. 131), em geral, empregamos a palavra ritmo para designar toda alternância regular e "não nos interessa a natureza do que o alterna. O ritmo musical é a alternância dos sons no tempo. O ritmo poético é a alternância das sílabas no tempo. O ritmo coreográfico, alternância dos movimentos no tempo". Ainda para O. Brik, à página seguinte do livro citado, tentamos provar que o ritmo das obras artísticas é uma consequência do ritmo natural: "o ritmo das palpitações do coração, o ritmo do movimento das pernas durante a caminhada". Cientificamente, para O. Brik o ritmo é uma apresentação particular dos processos motores e não tem relação com a alternância natural dos movimentos astronômicos, biológicos, mecânicos. Não podemos confundir a disposição gráfica dos quadrinhos com o ritmo; o que dá ritmo às HQs é a alternância dos dois funtivos da missividade.

Greimas e Courtés (1989, p. 386), com base em Zilberberg e Valéry, afirmam no verbete ritmo que ele pode ser definido como uma espera, que se consegue por meio da aspectualidade incoativa, da modalidade do querer ser, "aplicada no intervalo recorrente entre agrupamentos de elementos assimétricos, que reproduzem a mesma formação". Afirmam ainda que, contrariando a acepção corrente que vê no ritmo um arranjo particular do plano da expressão, optam por uma definição do ritmo que "o considera como uma forma significante, e, por conseguinte, da mesma natureza que os outros fenômenos da prosódia". Tal concepção liberaria o ritmo dos laços com o significante sonoro, reconhecendo-Ihe a possibilidade de estar presente no nível do conteúdo. Daí a razão para sugeri-lo no estudo das HQs em Território de bravos.

Neste capítulo, vamos examinar como se pode dar o ritmo na linguagem das HQs analisadas no capítulo 3. O ritmo aqui funda-se na alternância de quadrinhos abertos (emissivos) e fechados (remissivos), como mencionado nesta dissertação. Essa alternância pode dar-se de forma átona ou tônica, constituindo um movimento que se caracteriza por 
durações diversas, ou seja, os intervalos não são necessariamente homogêneos, produzindo dessa forma efeito de sentido próprio.

Wisnik (2006, p. 19), após relacionar o ritmo da linguagem ao do nosso pulso sanguíneo e da respiração, afirma que tradicionalmente ritmo está associado à categoria de andamento, "que tem sua medida média no andante, sua forma mais lenta no largo, e as indicações mais rápidas associadas já à corrida afetiva do allegro e do vivace (os andamentos se incluem num gradiente de disposições físicas e psicológicas)".

É de observar que o ritmo caracteriza-se por um andamento, que pode ser mais lento, menos lento, mais acelerado, menos acelerado. Essas categorias compõem um continuum. Assim, como na música, teríamos cifras tensivas (quadro 4.3).

Quadro 4.3 Andamento musical.

\begin{tabular}{|r|c|l|}
\hline Andamento & \multicolumn{1}{|c|}{ bpm } & Definição \\
\hline Gravissimo & $\begin{array}{c}\text { Menos } \\
\text { de } 40\end{array}$ & Extremamente lento \\
\hline Grave & \multicolumn{1}{c|}{40} & Muito vagarosamente e solene \\
\hline Larghissimo & $40-60$ & Muito largo e severo \\
\hline Largo & $40-60$ & Largo e severo \\
\hline Larghetto & $60-66$ & Mais suave e ligeiro que o Largo \\
\hline Lento & $60-66$ & Lento \\
\hline Adagio & $66-76$ & Vagarosamente, de expressão terna e patética \\
\hline Adagietto & $66-76$ & Vagarosamente, pouco mais rápido que Adagio \\
\hline Andante & $76-108$ & Velocidade do andar humano, amável e elegante \\
\hline Andantino & $84-112$ & Mais ligeiro que o Andante, agradável e compassado \\
\hline Moderato & $108-120$ & Moderadamente (nem rápido, nem lento) \\
\hline Allegretto & $112-120$ & Nem tão ligeiro como o Allegro; também chamado de Allegro ma non troppo \\
\hline Allegro & $120-168$ & Ligeiro e alegre \\
\hline Vivace & $152-168$ & Rápido e vivo \\
\hline Prestissimo & $200-208$ & Muito rapidamente, com toda a velocidade e presteza \\
\hline Fonte: Dispon & $168-180$ & Mais rápido e vivo que o Vivace; também chamado de molto vivace \\
\hline
\end{tabular}

Fonte: Disponível em: <http://pt.wikipedia.org/wiki/Andamento>. Acesso em: 17 fev. 2011.

Se atentarmos para o léxico de cada um desses termos, notaremos também que configuram estados de alma, uma paixão. Por exemplo, no allegro, a definição é de alegre e ligeiro, o que nos possibilita depreender uma cifra da aceleração mais um estado de alma de 
descontração. Grosso modo, "Futboil" se aproxima do allegro. Já "Entradas e bandeiras" se aproxima mais do grave, como na escultura clássica, é mais vagaroso e solene.

Caracteristicamente, o ritmo pode ser regular e assimétrico, e é elemento constitutivo da linguagem. Essa a razão pela qual dedicamos este capítulo ao exame do ritmo nas HQs de Território de bravos.

Ao tonificar determinados quadrinhos, quando concentra, fecha, o enunciador dáIhe um destaque temporal. Examinando a relação do ritmo com a temporalidade, Zilberberg afirma que ela muda de significado conforme o termo do paradigma do tempo selecionado. Zilberberg avalia positivamente, no artigo "Observações sobre a base tensiva do ritmo" (2010, p. 6), o tempo diretivo das volições, estabelecido por Octavio Paz em O arco e a lira. 0 jogo de quebras e pausas, como ocorre no fazer missivo estudado, imprime uma direção, constituindo-se em um ritmo que provoca uma espera. Nas interrupções, dá-se um choque, uma parada (remissivo). Nos prosseguimentos emissivos, aflora o sobrevir, ou seja, uma latência remissiva da ordem do impacto. O ritmo modela essa disposição de alma: ou esperamos um objeto do desejo (ainda não), ou nos impactamos com o survenir (já é).

No capítulo 2, vimos que o antissujeito é responsável pela direção do sentido. Da mesma forma, o ritmo também o é, com a diferença de que configura um andamento tônico ou átono: "o ritmo é uma marcha na direção de alguma coisa" (Octávio Paz Apud ZILBERBERG, 2010, p. 6). Assim, a marcha em direção ao objeto pode ser lenta ("Entradas e bandeiras") ou veloz ("Futboil”).

A dinâmica do ritmo compreende, portanto, tanto a tonicidade quanto a atonia, bem como a aceleração (rapidez) e a desaceleração (lentidão). Tonificar um quadrinho é aplicar sobre a matéria visual uma energia que se configura em afeto, paixão. Daí, termos analisado os quadrinhos concentrados, tônicos, como nominais e passionais. Seriam as exigências do andamento que levariam o enunciador à escolha de um ritmo mais acelerado ou menos acelerado. Havendo necessidade de concentração, o enunciador opta por desacelerar, advindo, então, um fazer remissivo. Havendo necessidade de difusão, o enunciador opta por acelerar, advindo, então, um fazer emissivo. No capítulo 3, vimos que, em "Entradas e bandeiras", é dominante a remissividade, a concentração e, em "Futboil", é dominante a emissividade, a difusão. Daí, a primeira aproximar-se mais da escultura 
clássica, mais desacelerada, enquanto a segunda, de movimentos rápidos, avizinhar-se mais do cinema e da estética barroca, ambos mais acelerados.

Se o leitor retomar nossa contagem de todas as HQs de Território de bravos, verificará que o ritmo produzido pela alternância de emissividades e remissividades configura um andamento nas narrativas.

Em "Entradas e bandeiras", prevalece a remissividade (fechamento); o enunciatário depara com uma temporalidade durativa. Nesse caso, os movimentos são de câmera lenta. Observe o leitor que as focalizações de pés, membros, cabeça das estátuas impedem um andamento célere. É uma concentração metonímica que produz um efeito passional.

Em "Futboil", por sua vez, a emissividade produz um andamento acelerado de filmes concentrados no fazer, em uma ação. As sucessivas aberturas configuram movimentações rápidas, cujo objetivo não é outro senão a conjunção com o objeto do desejo dos meninos (o balão). Não se trata aqui de preocupar-se com o ser, mas com o fazer. Daí a sucessividade de quadros que simulam "instantâneos" da vida cotidiana, um correcorre desenfreado dos meninos de rua atrás de um balão que despenca. A instância enunciativa não poderia escolher outro ritmo que não o que produzisse tal andamento rápido. São, pois, a emissividade e a remissividade as categorias responsáveis pelo ritmo nas HQs, delas advindo os efeitos das escolhas enunciativas.

Quando a HQ concentra, portanto, ela realça paixões e temos quadrinhos mais tônicos. No outro extremo, quando temos quadrinhos difusos, abertos, o que se nota é uma atonicidade, um desenrolar no percurso do sujeito (emissividade). No primeiro caso, prevalecem valores do ser, passionais, no segundo, valores do fazer.

Retomemos as contagens já realizadas no capítulo 2 .

Em "Entradas e bandeiras", o ritmo de quadrinhos abertos e fechado é o seguinte:

AAFF $\rightarrow$ AFFFFFFFFFFFFF $\rightarrow$ AFFFF $\rightarrow$ AFFFF $\rightarrow$ AFFF $\rightarrow$ AF $\rightarrow$ AFFAAFFA $\rightarrow$ FF $\rightarrow$ A

Abrem a HQ dois quadrinhos abertos (emissivos), em seguida um fechado (remissivo) e um misto. Esse ritmo alternado é rompido para dar lugar a quadrinhos remissivos (fechados) que imprimem à narrativa uma concentração. E ao escolher a 
concentração, o enunciador privilegia valores passionais. A tonicidade dessa concentração, como se pode observar, é durativa, à semelhança do que ocorre na temporalidade musical.

Segundo Zilberberg (2010, p. 6), Valéry estabeleceu a espera como chave para a compreensão do ritmo: uma nota musical esperar ou não a outra constitui o ritmo. A depreensão do "ritmo" ou o "não ritmo" é independente de uma enumeração, possuindo a memória a quantidade requerida, sem numerar. Ela não coloca a questão das unidades. No nosso caso, não importaria a quantidade de quadrinhos fechados ou abertos, como unidade, mas a espera da emissividade ou da remissividade, conforme a dominância.

Suponhamos "Entradas e bandeiras", de dominância remissiva. Não importa o número sucessivo de quadrinhos fechados, mas a espera de que em algum momento irrompa a emissividade. Em "Futboil", ocorre o contrário: temos uma sucessividade de quadrinhos abertos que leva à espera de um fechamento a qualquer momento. A contagem de quadrinhos abertos e fechados nas HQs, realizada nesta dissertação, serviu-nos para verificar a dominância de emissividade ou remissividade nas histórias.

Para contrabalançar a remissividade reiterativa ("mais mais") que poderia levar ao cansaço, ao esgotamento narrativo, sobrepõem-se quadrinhos abertos, emissivos, cuja finalidade é atenuar um fechamento desmedido (cf. TATIT, 2010, p. 75).

Agora, vejamos a outra estratégia rítmica utilizada em Território de bravos. É em "Futboil" que encontramos um exemplo de dominância emissiva, diferentemente de "Entradas e bandeiras", de dominância remissiva:

A $\rightarrow$ FFFFA $\rightarrow$ FFFAA $\rightarrow$ FFFFAAAAAAAAFAAAAAAAAAAAFAAFAAFFAFAAFAAA $\rightarrow$ FF $\rightarrow$ AFF $\rightarrow$ AA AAAAA $\rightarrow$ FFAAAAFFAA $\rightarrow$ FAAAAAAAA $\rightarrow$ FA $\rightarrow$ FA $\rightarrow$ FA $\rightarrow$ FFFFA $\rightarrow$ FAA $\rightarrow$ FA $\rightarrow$ FA $\rightarrow$ FF $\rightarrow$ AA $\rightarrow$ FAF $\rightarrow$ AFAAFF $\rightarrow$ AFFA

Nesse exemplo, a emissividade dominante leva à escolha de quadrinhos em geral abertos. A necessidade de imprimir velocidade ao andamento conduz a opção pela difusão, configurando um ritmo semelhante ao desenrolar célere das cenas de um filme. Se em "Entradas e bandeiras" a passionalização é resultado do "mais mais" da remisividade, aqui em "Futboil" prevalece o fazer que é resultado de um "mais mais" de abertura. Enquanto na 
primeira $\mathrm{HQ}$ a abertura permanece latente, vindo à tona para o equilíbrio da narrativa, na segunda o fechamento é latente e aflora sempre que a narrativa atinge uma abertura desmedida. Esse ponto de contenção imprime uma oscilação rítmica nas narrativas em geral. $\mathrm{Na}$ vida moderna, essas durações rítmicas são reguladas por cruzamentos, semáforos, trânsitos, como se pôde observar em "Entradas e bandeiras" (cf. WISNIK, 2006, p. 20). Elas determinam interrupções ao andamento acelerado do cotidiano metropolitano e são responsáveis por paradas no percurso dos sujeitos, chamando a atenção para outra ordem de valores que não os utilitários. Ao valor da cronologia temporal sobrepõe-se um tempo subjetivo que faz o sujeito voltar-se para sua interioridade. Assim, quanto maior o tempo de parada (que corresponderia à altura melódica na música) maior o efeito passional.

Nesse sentido, a vida moderna não é destituída de um ritmo, de uma frequência, visto que o homem pode encontrar espalhadas pela cidade inúmeras possibilidades para refrear o escoamento do tempo cronológico (ver em "Entradas e bandeiras" as placas, os faróis, os transeuntes, as estátuas). O próprio cotidiano se encarrega de introduzir antiprogramas no programa do sujeito. Não seria, pois, adequado dizer que a vida na metrópole é pura aceleração. Ela tem um ritmo, que muitas vezes passa despercebido dos sujeitos. Seria impossível uma existência de extrema abertura e de extremo fechamento, sem conhecer seus limites, introdutores de sentido, de direção para o sujeito.

Semáforos, placas, cruzamentos, interrupção de trânsito, o fazer do percurso do sujeito (atores estátuas) em "Entradas e bandeiras" são fazeres remissivos no percurso do sujeito (atores passageiros) que podem ser vistos euforicamente. Diferentemente, pois, dos valores que assumem os habitantes da cidade que veem os obstáculos disforicamente. A quebra da difusão no percurso do sujeito lhe possibilita observar o que normalmente não vê (arte), ampliando-Ihe a percepção em seu campo de presença. À objetividade da vida utilitária sucede um espaço para a subjetividade.

Para Wisnik (2006, p. 29),

o ritmo está na base de todas as percepções, pontuadas sempre por um ataque, um modo de entrada e saída, um fluxo de tensão/distensão, de carga e descarga. 0 feto cresce no útero ao som do coração da mãe, e as sensações rítmicas de tensão e repouso, de contração e distensão vêm a ser, antes de qualquer objeto, o traço de inscrição das percepções.

Da mesma forma, cada fazer, emissivo e remissivo, não pode ter duratividade absoluta; um deles está sempre latente. Por exemplo, em "Entradas e bandeiras", a 
presença do antiprograma ganha em densidade quando a instância do destinador, com seus valores emissivos, enfraquece. Essa oscilação missiva configura uma forma de evolução, que se reproduz no plano do conteúdo, podendo ser analisada tanto no nível tensivo como no narrativo.

Tensivamente, temos um ritmo aspectual que faz das narrativas um continuum que porta limites e durações, paradas e retomadas, como vimos no capítulo 2. Para Tatit (2010, p. 79 e 85), essa alternância da continuidade e de paradas que tendem a recobrar o fluxo é o que direciona os textos.

Narrativamente, há os liames actanciais que dão sustentação ao programa narrativo: o destinador é responsável pela emissividade e o antissujeito pela remissividade. Enquanto uns "abrem o campo de ação do sujeito", outros o fecham (TATIT, 2010, p. 85).

Os meninos de "Futboil", movidos pelo acontecimento da queda do balão, experimentam a redução da duratividade desse acontecimento, estabelecida pela conversão do sobrevir em devir. A queda desse balão proporciona um grande impacto no cotidiano dos garotos que "estabelece um máximo de mais numa progressividade tensiva que absorve totalmente a atenção do sujeito". Daí que o sujeito se "arruma" para avaliar o acontecimento e, nesse ato, "desacelera" o que se apresentou de forma veloz e se programa para transformar o sobrevir em devir (TATIT, 2010, p. 82 e 86).

É possível ver aqui o mesmo efeito da engrenagem silábica, cuja explosão anuncia uma implosão latente e vice-versa. Como afirma Saussure (1996, p. 68-73), o ponto vocálico, constituído por uma abertura sonora maior ou menor em relação aos fonemas adjacentes, determina o fechamento sonoro subsequente, que é responsável pelo efeito de fronteira silábica.

Tatit (1999, p. 63) afirma que é compreensível que Hjelmslev (1985) tenha adotado apenas o sentido categorial atribuído à sílaba ("classe munida de função") e o tenha expandido não apenas no interior do plano da expressão e do conteúdo, "sem deixar de sugerir sua transferência, como noção operacional, a outros sistemas semióticos", como o das HQs.

Hjelmslev, em Nouveaux essais (1985, p. 165), afirma:

La syllabe n'est pas nécessairement de nature phonique. Dans toute expression linguistique, c'est-à-dire dans tout ensemble de sons, d'écrits, de gestes, de signaux, etc. des syllabes peuvent êtres ou non présentes, selon la structure de l'expresson considérée. [...] 
La syllabe peut être manifestée par une chaîne de sons, ou de caractères ou de tous autres symboles utilisables à cet effet. La syllabe doit être définie indépendamment de as manifestation spécifique ${ }^{3}$.

Desse modo, os movimentos de abrir (explosivo) e de fechar (implosivo) são duas tendências gradativas e funcionais. No fechamento, há implosão; na abertura, explosão (no plano da expressão); esse mesmo fenômeno dá-se no plano do conteúdo pela missividade. Há uma tensão contínua entre o fechamento e a abertura, responsável pela constituição do processo nas HQs: a implosão caminha para a explosão e vice-versa, exceto se interrompermos o discurso (TATIT, 1997, p. 19).

Esse ritmo, para Saussure (1996, p. 70-71), dá origem aos conceitos de "fronteira silábica", que representa as demarcações e os limites, e de "ponto vocálico", que representa as segmentações e as extensões ${ }^{4}$.

Para Zilberberg (2006a, p. 44-45), com base em Saussure,

não se deve, portanto, "terminar" pela sílaba, mas "começar" por ela e conservar essa ancoragem. [...] Saussure distingue, como constituinte da sílaba, não os traços distintivos, mas a implosão, grafada [>], e a explosão, grafada [<]. Daí resultam "quatro combinações teoricamente possíveis": o "grupo explosivoimplosivo" [<>], o "grupo implosivo-explosivo" [><], o "elo explosivo" [<<] e o "elo implosivo" [> >]. [...] À segunda combinação, [><], Saussure concede uma posição de destaque, uma "existência própria", uma vez que a "primeira implosiva", qualquer que seja sua característica fonológica, produz aquilo que ele chama de "ponto vocálico". A questão é reconhecer, prioritariamente, "funções na sílaba" que comandam a identificação dos traços, a qual surge "em seguida", e não "de início"

Retomando Tatit (1997, p. 19), verificamos que, considerando o plano do conteúdo, reencontramos o ritmo que regula a alternância dos valores missivos. A remissividade, quando dominante, convoca o fazer emissivo, que é relativo à extensão gradativa, para

\footnotetext{
${ }^{3}$ A sílaba não é necessariamente de natureza fônica. Em toda expressão linguística, ou seja, em todo conjunto de sons, de escrita, de gestos, de sinais etc., sílabas podem ou não estar presentes, segundo a estrutura da expressão considerada. [...] A sílaba pode ser manifesta por um canal de sons, ou caracteres, ou de todos os outros símbolos utilizáveis para esse efeito. A sílaba deve ser definida independentemente de sua manifestação específica (tradução nossa).

${ }^{4}$ Para Tatit (2001, p. 177-178), podemos chamar esse ritmo de "ritmo tensivo", pois "contém as sugestões inerentes ao modelo silábico de Saussure: o destino do limite fornecido pela 'fronteira silábica' é a abertura realizada pelo 'ponto vocálico' e vice-versa". Ainda com Tatit (2001, p. 178), "no plano profundo, a seleção privilegiada dos valores de limite potencializa a participação, iminente ou tardia, dos valores de transgressão. No plano narrativo, o confinamento passional do ser torna cada vez mais urgente a convocação de um fazer".

${ }^{5}$ Valemo-nos aqui de tradução ainda em andamento de Ivã Carlos Lopes, Luiz Tatit e Waldir Beividas, fornecida na disciplina Teoria da Narrativa e do Discurso: Desenvolvimentos Atuais, ministrada pelo Prof. Dr. Waldir Beividas no Programa de Pós-graduação de Linguística e Semiótica, no primeiro semestre de 2009. Todavia, a referência da citação foi feita pela numeração das páginas do livro da edição francesa (2006a, cf. Referências no final desta dissertação).
} 
retomar a continuidade ameaçada pelo antiprograma. O excesso de emissividade resulta em parada, em estabelecimento de limites comprometidos com valores remissivos. Daí Tatit (1997, p. 19) afirmar que nada impede "uma homologação das categorias silábicas com as categorias aspectuais que estão na base da construção do sentido no plano do conteúdo".

Da mesma forma que todo o efeito vocálico já traz a marca da implosão, todo fazer emissivo traz latente o fazer remissivo. O recrudescimento de uma tonicidade tende a atingir um ponto a partir do qual começa o processo inverso; há uma desativação do processo ascensional. Para Tatit (2010, p. 86), com base em Élements de grammaire tensive (2006a) de Zilberberg, nesse momento "o mais se converte em demais (além da conta) e, imediatamente, atualiza um basta". Ativa-se, então, um processo de descendência tensiva; vai se retirando do acontecimento um pouco de mais.

No caso de "Futboil", a concentração do momento da queda do balão perde a tonicidade e inicia-se um processo difuso, ou seja, a expansão emissiva atrás do balão. De objeto de contemplação, o balão passa a objeto de disputa, com as consequências que daí advêm. Enquanto no ar o balão era acontecimento; ao se aproximar dos garotos passa-se do acontecimento para a assimilação. Idealmente, seria melhor que permanecesse objeto de encantamento (inesperado), do sobrevir, mas isso não é possível, porque, ao iniciar a corrida, de inesperado passa o balão a ser esperado, até a sua destruição pelos próprios sujeitos. Há dois momentos: (1) o da surpresa (o balão caindo = excesso de subitaneidade); (2) o da espera (excesso de previsibilidade = saber que o balão vai cair, e eles o desejam).

Com base em Da Imperfeição de Greimas, Ochoa (In: LANDOWSKI; DORRA; OLIVEIRA, 1999, p. 252) afirma que o estudo do ritmo nos conduziria a compreender certos acontecimentos do cotidiano. A imperfeição, segundo Greimas (2002, p. 83-90), não pode ser vista de forma "imperfeita", "negativamente", visto que não haveria uma perfeição a aspirar em nossa vida cotidiana fosse um continuum de perfeições. É pois o ritmo da vida cotidiana com suas rupturas, seus corte e fraturas que proporcionam a riqueza dessa espera do inesperado, da "perfeição", portanto.

No caso dos garotos de "Futboil", a queda do balão constitui uma fratura no cotidiano de imperfeições; daí aspirarem à perfeição, que é figurativizada na percepção desse balão inesperado. A perfeição seria um continuum de acontecimentos estéticos, que apenas se deixam ver por meio de cortes e fraturas: 
A desigualdade, o desequilíbrio, as rupturas, a superposição de ritmos é condição para a existência; isto é o que nos diferencia dos seres inanimados. Se nossas vidas se assemelham à poesia, que é o que as faz dignas de se viver, é precisamente o desigual, os assomos disso que chamamos estético, que assim aparece, dosificado, em instantes (OCHOA in: LANDOWSKI; DORRA; OLIVEIRA, 1999, p. 252) [tradução nossa].

Para finalizar, as forças antagonistas (remissividade, no nível narrativo, antissujeitos) valorizam a evolução narrativa. Elas provocam desigualdades que rompem as expectativas do sujeito e a previsibilidade do discurso. Ao mesmo tempo, retira o sujeito de seu tempo cronológico e leva-o a retomar a continuidade, na busca da conjunção com o objeto.

Assim, a ausência de oscilação entre concentração (remissivo) e difusão (emissivo) implicaria em tirar do discurso a direcionalidade; noutros termos, teríamos a falta do sentido. Por isso, Tatit (1997, p. 22) afirma que caberia ao sujeito estabelecer "um ritmo adequado às suas aspirações", acionando as variedades de andamento. 


\section{Conclusão}

Por isso é melhor paciência Pois todo começo começa e vai embora

O problema é saber se já foi

Ou se ainda é começo.

Luiz Tatit 
A conclusão é o momento de costurar o início e o fim, medindo o que se queria com o "fazer científico" e o que se obteve como resultado, o último sopro para convocar o enunciatário a aceitar o contrato enunciativo proposto e, nas palavras de Aristóteles, considerar o que pode ser conveniente para persuadir.

Desse modo, em um primeiro momento, examinamos inicialmente um sujeito que, ao saber que seu objeto Ihe escapa, obstina-se, tendo em vista "ser aquele que publica sua obra, Território de bravos". O princípio fundamental que rege esse estado de alma é o conhecimento do antissujeito em seu percurso, configurando um excedente modal que se caracteriza como alimento para o obstinado. Se assim não funcionasse, ele se desesperaria diante do primeiro obstáculo e abandonaria, então, seu objeto do desejo. Ao contrário, Luiz Gê, ator discursivo de nosso estudo, perfaz um percurso de dezoito anos em meio a "secas áridas" para conseguir publicar a obra que nos serviu de corpus de pesquisa.

Como foi visto nesta dissertação, a obstinação carrega a cifra tensiva da duratividade: se objeto se antecipasse, por exemplo, estaria descaracterizado esse estado de alma em nosso enunciador. Além disso, a obstinação acumula os paradoxos de um querer fazer que sobrevive a um não poder fazer que the nutre, um estado continuativo que não cessa, um sujeito que acumula o "querer ser aquele que quer fazer", diferentemente de dizer apenas que se trata de um sujeito que "quer fazer".

Daí que para o obstinado conseguir satisfazer seu querer é menos importante do que "ser". Peça-chave da cena deste trabalho é o antissujeito que move o sujeito em sua jornada; sem esse obstáculo, teríamos o vazio, o final da narrativa, não havendo nada mais a esperar.

Em um segundo momento, com base no fazer missivo de Zilberberg (2006b), realizamos uma contagem de quadrinhos para investigar as dominâncias emissivas e/ou remissivas nas narrativas das HQs de Território de bravos. O resultado de $75,47 \%$ de dominância remissiva no livro de Luiz Gê nos levou à conclusão de que os enunciados das HQs desse livro, em sua maioria, são passionais, concentrados e nominais. Isso confirmou o 
éthos sugerido do enunciador obstinado nesta dissertação. A dominância remissiva, com seu antiprograma e antissujeito do nível narrativo, seria um rastro do enunciador nos enunciados (FIORIN, 2008b, p. 139).

Ainda para entender essa "obstinação do progresso narrativo", concluímos que quanto maior é a presença do antissujeito, mais acentuado é o efeito de descontinuidade entre sujeito e objeto. Essa falta desarmoniza o sujeito que obstinadamente se põe em direção ao objeto que lhe falta. Ao mesmo tempo que o antissujeito é o desarranjador da ordem "sujeito $\rightarrow$ objeto", é ele que alavanca o percurso da narrativa. Sem esse obstáculo, haveria harmonia absoluta e exaurimento da história.

Outro resultado alcançado diz respeito ao destinador que, regulado paralelamente com o antissujeito, é responsável pela continuidade do processo, auxiliando o sujeito a superar as paradas em seu percurso. Notamos aí uma espécie de engrenagem, em que as peças encaixadas distendem e retêm, difundem e contraem a narrativa, tensão necessária aos textos e à vida. Esse movimento de concentração (remissividade) e difusão (emissividade) configura, por reiteração, uma lei que nos permitiu sugerir uma gramática tensiva como constituidora das HQs. A progressão narrativa, então, mostrou dependência do jogo dessa emissividade e remissividade. Na emissividade, teríamos difusão, abertura, verbalização (fazer); na remissividade, haveria concentração, fechamento, nominalização (ser). Enquanto na remissividade, prevaleceu o ser, na emissividade, o fazer.

Em um terceiro momento, levando em conta essa missividade, analisamos comparativamente duas HQs de Território de bravos: "Entradas e bandeiras" e "Futboil". A primeira, dominantemente remissiva, apresenta-se com enunciados passionais, nominais e concentrados, o que nos fez aproximá-la da escultura clássica, solene e desacelerada, se comparada com "Futboil", de dominância emissiva, da ordem do fazer, da difusão. Esta última aproxima-se da arte barroca e do cinema, no que se refere ao dinamismo, à aceleração.

Essa gramática mostrou-nos que a transitividade de um destinador, que atua no âmbito do sujeito e também no do antissujeito, pode ser traduzida por valores remissivos a serem ultrapassados, quando surgem os valores emissivos latentes. A reiteração constituiu, portanto, uma lei narrativa: a latência de um é a dominância do outro. Tal gramática garante-nos "a ideia" de progresso narrativo. 
Em um quarto momento, verificamos que esse movimento produz um ritmo que se constituiu em um continuum portador de limites e durações, de paradas e retomadas, um jogo de movimento que caracterizou as narrativas de nosso corpus de análise.

Constatamos ainda que as metáforas e as metonímias das HQs sob estudo configuram um jogo gestaltiano. Enquanto a metáfora permite a identificação do todo imediatamente, na metonímia teríamos o processo inverso. E isso nos possibilitou chegar a um resultado tensivo desses tropos. Nessa identificação imediata do todo, a metáfora seria tensivamente mais acelerada, enquanto a metonímia, porque reconstrói esse todo, seria menos acelerada, portanto.

O resultado tensivo do estudo desses tropos possibilitou-nos resgatar o movimento de concentrações e difusões, emissividade e remissividade. Essa oscilação nos aproximou do estudo da sílaba nas HQs: o jogo missivo do conteúdo resulta em silabação na expressão, que configurou movimentos de aproximação e afastamento. Ao aproximar-se, fecha, e temos a escolha de um valor remissivo; ao afastar-se, abre, e temos a opção por um valor emissivo; enfim, um jogo que não cessa.

Esse ritmo traduz-se em continuidade, promovida por um valor emissivo, que, em certo momento, tende a parar devido a um valor remissivo. Da mesma forma, o que cessa tende a continuar, e o que continua tende a cessar, e assim poderia ser infinitamente.

Por fim, o antissujeito, presença maciça em Território de bravos, alimenta as descontinuidades, assegurando-nos a duração do estado de alma, ou seja, a cada parada da continuação tem-se a condição propícia para a apreensão estética (TATIT In: LANDOWSKI; DORRA; OLIVEIRA, 1999, p. 200). E foi o fato de um enunciador obstinado deixar rastros de obstinação nos enunciados que nos levou a considerar Território de bravos uma HQ de ordem artística que tem como princípio a "conservação", que é da égide da duratividade; portanto, se assim não fosse, estaríamos diante de um objeto apenas utilitário. Afinal, toda estética é conservadora (Zilberberg, 2006b, p. 144).

Ainda com relação à oposição dos valores utilitários e artísticos, nas "Tiras de Presidente Reis", se o enunciatário acompanhar todas elas do início ao fim, verificará nas narrativas que o espaço urbano, ao privilegiar valores materiais do mundo cotidiano, transforma-se numa armadilha, que leva à extinção do sujeito. Ao retomarmos a tira que antecede à HQ "Perdidos no espaço", ficamos surpresos com o Presidente Reis encurralado, 
ilhado, gritando: “Há alguém vivo aí???". Em um cotidiano em que prevalece a multidão, o sujeito se sente sozinho na mais completa solidão.

Enfim são as paradas, as irrupções do antissujeito, que promovem o progresso narrativo. Ao mesmo tempo ele é o desarranjador da ordem "sujeito $\rightarrow$ objeto", mas responsável por impulsionar o percurso narrativo, assim como impulsionou a paixão de nosso enunciador obstinado. Se não houvesse antissujeito (seria essa mesma a nomenclatura adequada?), a relação entre sujeito e objeto provocaria o exaurimento dessas HQs.

Para [não] concluir

Por meio dessa estrutura gramatical, pesquisada com o apoio no fazer missivo, poderíamos reduzir as HQs artísticas em mais barrocas ou mais clássicas? Uma investigação que levasse em consideração a aceleração e a desaceleração, em um continuum de tonicidades e atonicidades, não poderia proporcionar maior luz sobre o fazer artístico? As divisões de estilo consagradas na história da arte não poderiam receber, com o apoio da semiótica tensiva, designações mais simplificadas e pertinentes? Essas são inquietações de um "fazer científico" movidas por um sujeito obstinado.

Não fosse isso era menos, não fosse tanto era quase.

Paulo Leminski 


\section{Referências}

ANDRADE, Mário de. Poesias completas. Edição crítica de Diléa Zanotto Manfio. Belo Horizonte: Itatiaia, 1987.

ARISTÓTELES. Retórica. Tradução de Marcelo Silvano Madeira. São Paulo: Rideel, 2007.

Retórica das paixões. Tradução de Isis Borges B. da Fonseca. São Paulo: Martins Fontes, 2003.

ARISTÓTELES, HORÁCIO, LONGINO. A poética clássica. Tradução de Jaime Bruna. 12. ed. São Paulo: Cultrix, 2008.

ASSIS, Machado de. Obra completa. Rio de Janeiro: Nova Aguilar, 1997. v. 3.

BADIR, Sémir. A noção de texto em Hjelmslev. Cadernos de Semiótica Aplicada, v. 3, n. 2, dez. 2005.

. Hjelmslev. Paris: Les Belles Lettres, 2004.

; KLINKENBERG, Jean-Marie. Figures de la figure: sémiotique et rhétorique générale. Limoges: Pulim, 2008.

BANDEIRA, Manuel. Estrela da vida inteira. 20. ed. Rio de Janeiro: Nova Fronteira, 1993.

BARBOSA, João Alexandre. A metáfora crítica. São Paulo: Perspectiva, 1974.

BARNABÉ, Arrigo. Tubarões voadores,. 1985. Disponível em: <www.cliquemusic.uol.com.br/discos/ver/turarõesvoadores>. Acesso em: 20 out. 2009. 
BARROS, Diana Luz Pessoa de. "De la perfection": duas reflexões. In: LANDOWSKI, Eric; DORRA, Raúl; OLIVEIRA, Ana Claudia de. Semiótica, estesis, estética. São Paulo: Educ: Puebla: UAP, 1999. p. 119-134.

Paixões e apaixonados: exame semiótico de alguns percursos. Cruzeiro semiótico, jul./jan. 1989-1990.

. Teoria do discurso: fundamentos semióticos. São Paulo: Atual, 1988.

. Teoria semiótica do texto. 4. ed. São Paulo: Ática, 2007.

BARTHES, Roland. A aventura semiológica. Tradução de Mario Laranjeira. São Paulo: Martins Fontes, 2001.

A câmara clara. Tradução de Júlio Castañon Guimarães. Rio de Janeiro: Nova Fronteira, 1984a.

. O óbvio e o obtuso. Tradução de Isabel Pascoal. Porto: Edições 70, 1984b.

BEIVIDAS, Waldir. Inconsciente \& sentido: ensaios de interface psicanálise, linguística e semiótica. São Paulo: Annablume, 2009.

Semióticas sincréticas (o cinema): posições. São Paulo: Edição particular em meio eletrônico, 2006. Disponível em: <http://www.fflch.usp.br/dl/semiotica/>. Acesso em: jun. 2009.

; LOPES, Ivã Carlos. Argumentação e persuasão: tensão entre crer e saber em “Famigerado", de Guimarães Rosa. Alfa, 53(2), 2009, p. 443-455.

BENVENISTE, Émile. Problemas de linguística geral I. Tradução de Maria da Glória Novak e Maria Luisa Neri. 5. ed. Campinas: Pontes, 2005. v. 1.

. Problemas de linguística geral II. Tradução de Eduardo Guimarães et al. 2. ed. Campinas: Pontes, 2006. v. 2.

BERGSON, Henri. Matéria e memória. Tradução de Paulo Neves. 2. ed. São Paulo: Martins Fontes, 1999.

. Memória e vida. Tradução de Claudia Berliner. São Paulo: Martins Fontes, 2006. 
BERTRAND, D. Caminhos da semiótica literária. Tradução do Grupo Casa, sob a coordenação de Ivã Carlos Lopes. Bauru: Edusc, 2003.

. Entimema e textualização. Tradução de Dilson Ferreira da Cruz Jr. Casa, v. 7, n. 2, dez. 2009.

BOSI, Alfredo. O ser e o tempo da poesia. 7. ed. São Paulo: Companhia das Letras, 2004.

CAGNIN, Antonio Luiz. Os quadrinhos. São Paulo: Ática, 1975.

CAMÕES, Luís de. Obra completa. Rio de Janeiro: Nova Aguilar, 2003.

CAÑIZAL, Eduardo Peñuela; CAETANO, Kati Eliana (Org.). O olhar à deriva: mídia, significação e cultura. São Paulo: Annablume, 2004.

CARMO JR., José Roberto. A enunciação musical em duas interpretações de um prelúdio de Chopin. Alfa, 53(2), 2009, p. 479-499.

Da voz aos instrumentos musicais: um estudo semiótico. São Paulo: Annablume: Fapesp, 2005.

DELEUZE, Gilles. Diferença e repetição. Tradução de Luiz Orlandi e Roberto Machado. 2. ed. Rio de Janeiro: Graal, 2006.

DORFLES, Gillo. O devir das artes. Tradução de Pier Luigi Cabra. São Paulo: Martins Fontes, 1992.

DUBOIS, Jean et al. Dicionário de linguística. Tradução de Frederico Pessoa de Barros et al. São Paulo: Cultrix, 1988.

ECO, Umberto. A estrutura ausente. Tradução de Pérola de Carvalho. 2. ed. São Paulo: Perspectiva, 1974.

La struttura assente: la ricerca semiótica e II método strutturale. Milano: Bompiani, 2004

EIKHENBAUM et al. Teoria da literatura: formalistas russos. Tradução de Ana Mariza Ribeiro Filipouski et al. Porto Alegre: Globo, 1978.

FIORIN, José Luiz. As astúcias da enunciação: as categorias de pessoa, espaço e tempo. São Paulo: Ática, 1996. 
FIORIN, José Luiz. 2. ed. São Paulo: Ática, 2001. . Elementos de análise do discurso. São Paulo: Contexto, 2008a.

FIORIN, José Luiz. Em busca do sentido: estudos discursivos. São Paulo: Contexto, 2008b. José Luiz Fiorin, semiótica e paixão. Revista Online de Literatura e Linguística, ano I, n. 2, dez. 2008c. Disponível em: <www.ufpe.br/revistaeutomia/pdfn02/n02artigo4.pdf>. - Objeto artístico e experiência estética. In: LANDOWSKI, Eric; DORRA, Raúl; OLIVEIRA, Ana Claudia de. Semiótica, estesis, estética. São Paulo: Educ: Puebla: UAP, 1999. p. 101-118.

- O projeto hjelmsleviano e a semiótica francesa. Disponível em: <http://glossematics.org/forum/pdfs/FIORIN O projeto.pdf>. Acesso em: 9 jun. 2009. . Paixões, afetos, emoções, sentimentos. Cadernos de Semiótica Aplicada, v. 5, n. 2, dez. 2007a.

Semiótica das paixões: o ressentimento. Alfa. São Paulo, 51 (1), p. 9-22, 2007b.

FLOCH, Jean-Marie. Petites mythologies de l'oeil et le l'esprit: pour une sémiotique plastique. Paris: Editions Hadès-Benjamins, 1985.

FONTANILLE, Jacques. Semiótica do discurso. Tradução de Jean Cristtus Portela. São Paulo: Contexto, 2007.

; ZILBERBERG, Claude. Tensão e significação. Tradução de Ivã Carlos Lopes, Luiz Tatit e Waldir Beividas. São Paulo: Discurso Editorial: Humanitas, 2001.

GÊ, Luiz. Quadrinhos em fúria. São Paulo: Circo Editorial, 1984.

Território de bravos. São Paulo: Editora 34, 1993.

GOMBRICH, E. H. A história da arte. Tradução de Álvaro Cabral. 16. ed. Rio de Janeiro: LTC, 2009.

GREIMAS. A. J. Da imperfeição. Tradução de Ana Claudia de Oliveira. São Paulo: Hacker, 2002.

. De la imperfección. Presentación, traducción y notas de Raúl Dorra. México: Fondo de Cultura Económica, 1997. 
GREIMAS. A. J. Dell'imperfezione. Introduzione de Paolo Fabbri. Traduzione di Gianfrancesco Marrone. Palermo: Sellerio, 2004.

. Du sens II: essais sémiotiques. Paris: Éditions du Seuil, 1983.

- Semiótica figurativa e semiótica plástica. Significação: Revista Brasileira de Semiótica, n. 4, jun. 1984.

. Sobre o sentido: ensaios semióticos. Ana Cristina Cruz Cezar et al. Petrópolis: Vozes, 1975.

; COURTÉS, J. Dicionário de semiótica. Tradução de Alceu Dias Lima et al. São Paulo: Cultrix, 1989.

; Sémiotique: dictionnaire raisonné de la théorie du langage. Paris: Hachette, 1986. v. 2.

; FONTANILLE, Jacques. Semiótica das paixões. Tradução de Maria José Rodrigues Coracini. São Paulo: Ática, 1993.

; __ Sémiotique des passions: des états de choses aux états d'âme. Paris:

Seuil, 1991.

HAUSER, Arnold. História social da arte e da literatura. Tradução de Álvaro Cabral. São Paulo: Martins Fontes, 2003.

HJELMSLEV, Louis. Ensaios linguísticos. Tradução de Antônio de Pádua Danesi. São Paulo: Perspectiva, 1991. - La categoria dei casi: studio di grammatica generale. A cura di Romeu Galassi. Lecce: Argo, 1999. . La categoria de los casos. Madrid: Gredos, 1978. . La structure fondamentale du langage. Paris: Les Éditions de Minuit, 1968. . Le langage. Paris: Les Editions de Minuit, 1966. Nouveaux essais. Paris: PUF, 1985. . Principios de gramática general. Madrid: Editorial Gredos, 1976. 
HJELMSLEV, Louis. Prolégomènes a une théorie du langage. Paris: Les Éditions de Minuit, 1968.

. Prolegômenos a uma teoria da linguagem. Tradução de J. Teixeira Coelho Netto. São Paulo: Perspectiva, 1975.

. Teoria del linguaggio. Résumé. Vicenza: Terra Ferma, 2009.

HOUAISS, Antônio; VILLAR, Mauro de Salles. Dicionário Houaiss da língua portuguesa. Rio de Janeiro: Objetiva, 2001.

HUIZINGA, Johan. Homo ludens. Tradução de João Paulo Monteiro. São Paulo: Perspectiva, 1996.

JAKOBSON, Roman. Linguística e comunicação. Tradução de Izidoro Blikstein e José Paulo Paes. 20. ed. São Paulo: Cultrix, 2005.

Linguística. Poética. Cinema. Tradução de Francisco Achcar et al. 2. ed. São Paulo: Perspeciva, 2007.

Saggi di linguistica generale. Traduzione di Luigi Heilmann e Letizia Grassi. 3. ed. Milano: Feltrinelli, 2008.

KANT, Immanuel. Crítica da razão pura. Tradução de Valerio Rohden e Udo Baldur Moosburger. São Paulo: Nova Cultural, 1999.

LALANDE, André. Vocabulário técnico e crítico da filosofia. Tradução de Fátima Sá Correia et al. 15. ed. Porto: Rés, 1985. 2 v.

LANDOWSKI, Eric. O livro de que se fala. In: GREIMAS, Algirdas Julien. Da imperfeição. São Paulo: Hacker Editores, 2002. p. 125-150.

; DORRA, Raúl; OLIVEIRA, Ana Claudia de. Semiótica, estesis, estética. São Paulo: Educ; Puebla: UAP, 1999.

LAUSBERG, Heinrich. Elementos de retórica literária. Tradução de R. M. Rosado Fernandes. 5. ed. Lisboa: Fundação Calouste Gulbenkian, 2004.

LE ROBERT MICRO. Dictionnaire de la langue française. Rédaction dirigée par Alain Rey. Paris: Le Robert, 2006. 
MARSCIANI, Francesco; ZINNA, Alessandro. Elementi di semioticai generativa: processi e sistemi della significazione. Prefazione di A. J. Greimas. Bologna: Progetto Leonardo, 1991. MENDO, Anselmo Gimenez. História em quadrinhos. São Paulo: Unesp, 2008.

MERLEAU-PONTY, Maurice. Fenomenologia da percepção. Tradução de Carlos Alberto Ribeiro de Moura. 3. ed. São Paulo: Martins Fontes, 2006.

. O visível e o invisível. Tradução de José Artur Gianotti e Armando Mora d’Oliveira. 4. ed. São Paulo: Perspectiva, 2007.

MOTTA, Ana Raquel; SALGADO, Luciana (Org.). Ethos discursivo. São Paulo: Contexto, 2008.

OLIVEIRA, Ana Claudia; TEIXEIRA, Lucia (Org.). Linguagens na comunicação: desenvolvimento de semiótica sincrética. São Paulo: Estação das Letras e Cores, 2009.

; LANDOWSKI (Ed.). Do inteligível ao sensível: em torno da obra de Algirdas Julien Greimas. São Paulo: Educ, 1995.

PAZ, Octavio. O labirinto da solidão. Tradução de Eliane Zagury. 4. ed. Rio de Janeiro: Paz e Terra, 1984.

PIETROFORTE, Antonio Vicente. Análise do texto visual: a construção da imagem. São Paulo: Contexto, 2007.

Análise textual da história em quadrinhos: uma abordagem semiótica da obra de Luiz Gê. São Paulo: Annablume: Fapesp, 2009.

. O livro das músicas. São Paulo: Annablume, 2010.

. Semiótica visual: os percursos do olhar. São Paulo: Contexto, 2004.

PROPP, Vladimir I. Morfologia do conto maravilhoso. Organização e prefácio de Boris Schnaiderman. Tradução de Jasna Paravich Sarhan. Rio de Janeiro: Forense Universitária, 1984.

RAMOS, Paulo. A leitura dos quadrinhos. São Paulo: Contexto, 2009.

ROSA, Guimarães. Primeiras estórias. 13. ed. Rio de Janeiro: Nova Fronteira, 1985.

SAUSSURE, Ferdinand de. Curso de linguística geral. Tradução de Antônio Chelini, José Paulo Paes e Izidoro Blikstein. São Paulo: Cultrix, 1996. 
SAUSSURE, Ferdinand de. Escritos de linguística geral. Tradução de Carlos Augusto Leuba Salum e Ana Lucia Franco. 12 ed. São Paulo: Cultrix, 2004.

SARAIVA, F. R. dos Santos. Dicionário latino-português. 11. ed. Belo Horizonte; Rio de Janeiro: Garnier, 2000.

SILVA, Ignacio Assis. Figurativização e metamorfose: o mito de narciso. São Paulo: Editora da Universidade Estadual Paulista, 1995.

SPINA, Segismundo. Na madrugada das formas poéticas. 2. ed. São Paulo: Ateliê Editorial, 2002.

TATIT, Luiz. Adoração estética. In: LANDOWSKI, Eric; DORRA, Raúl; OLIVEIRA, Ana Claudia de. Semiótica, estesis, estética. São Paulo: Educ; Puebla: UAP, 1999. p. 195-212.

. Análise semiótica através das letras. São Paulo: Ateliê Editorial, 2001.

. Corpo na semiótica e nas artes. In: SILVA, Ignacio Assis. Corpo e sentido: a escuta do sensível. São Paulo: Editora da Universidade Estadual Paulista, 1996.

. Hjelmslev e as bases tensivas do semissimbolismo. São Paulo: Editora CPS, 2007. . Musicando a semiótica. São Paulo: Annablume, 1997.

. Semiótica à luz de Guimarães Rosa. São Paulo: Ateliê Editorial, 2010.

. Semiótica da canção. São Paulo: Escuta, 1999.

VALÉRY, Paul. Cahiers. Paris: Gallimard: La Pléiade, 1973. t. I.

. Cahiers. Paris: Gallimard, 1997. v. VI.

. Quaderni. 4. ed. Milano: Adelphi Edizioni, 1986.

. Variedades. Organização de João Alexandre Barbosa. Tradução de Maiza Martins de Siqueira. São Paulo: Iluminuras, 2007.

WISNIK, Miguel. O som e o sentido: um outra história das músicas. 2. ed. São Paulo: Companhia das Letras, 2006.

WÖLFFLIN, Heinrich. Conceitos fundamentais da história da arte. Tradução de João Azenha Jr. 4. ed. São Paulo: Martins Fontes, 2006. 
ZILBERBERG, Claude. Causerie sur la sémiotique tensive [2008]. Disponível em: <www.fflch.usp.br/dl/semiotica/.../zilberberg2008/cz-causerie.pdf> . Acesso em: abr. 2009. . Eléments de grammaire tensiva. Limoges: PULIM, 2006a.

ZILBERBERG, Claude. Observações sobre a base tensiva do ritmo. Tradução de Lucia Teixeira e Ivã Carlos Lopes. Estudos Semióticos, v. 6, n. 2, p. 1-13, 2010.

Razão e poética do sentido. Tradução de Ivã Carlos Lopes, Luiz Tatit e Waldir Beividas. São Paulo: Edusp, 2006b.

Síntese da gramática tensiva. Revista brasileira de semiótica. Significação, n. 25, jun. 2006c, p. 163-204. 
Anexo 


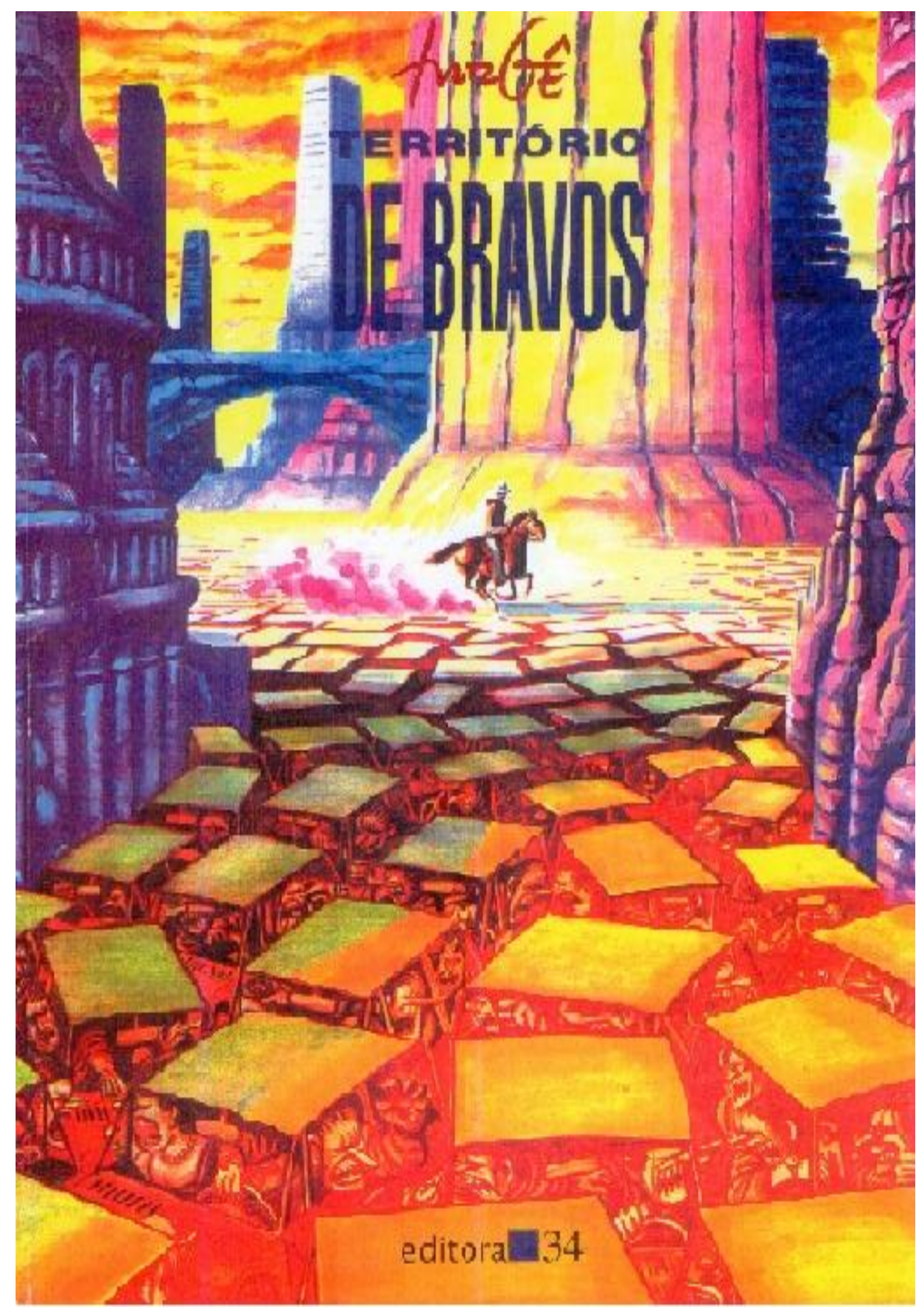


$\mathrm{E}$, do mar dez léguas pouco mais ou menos, a duas léguas de uma povoaçāo de João Ramalho a que chamam Piratinim, onde Martim Afonso primeiro povoou, ajuntamos todos os que Nosso Senhor quer trazer à sua Igreja... e vai se fazendo uma formosa povoação...

Padre Manuel da Nóbrega, 1553 

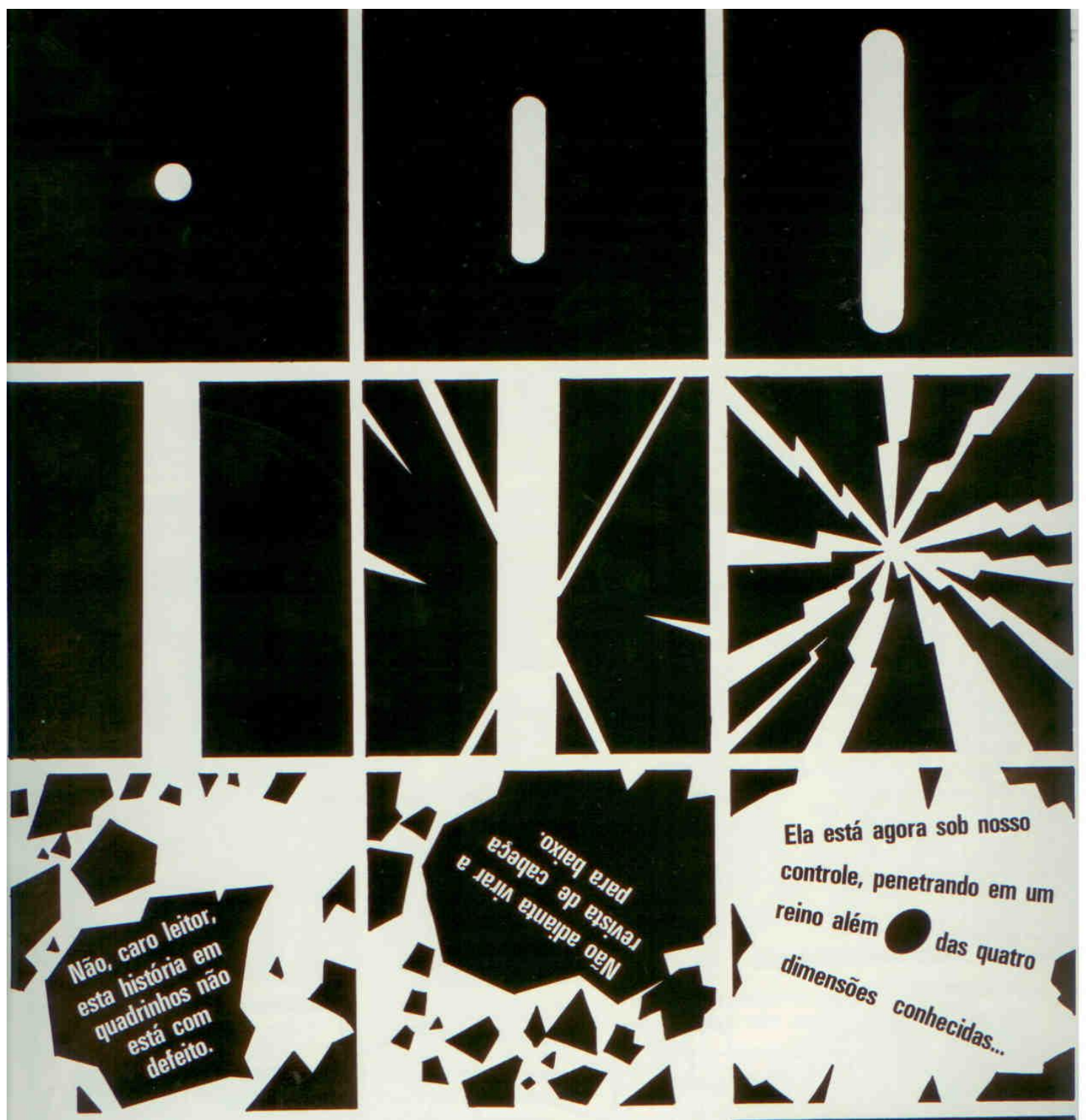

Ela está agora sob nosso

controle, penetrando em um
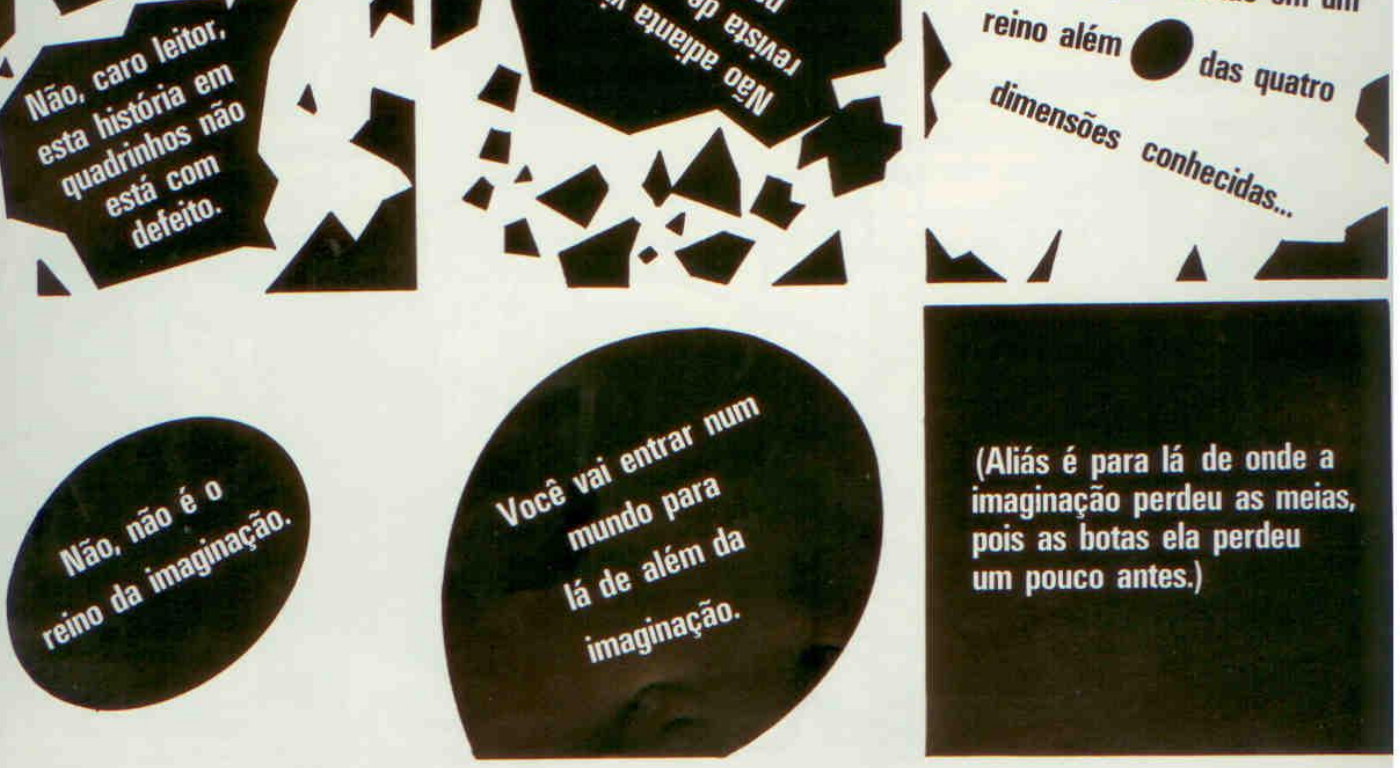


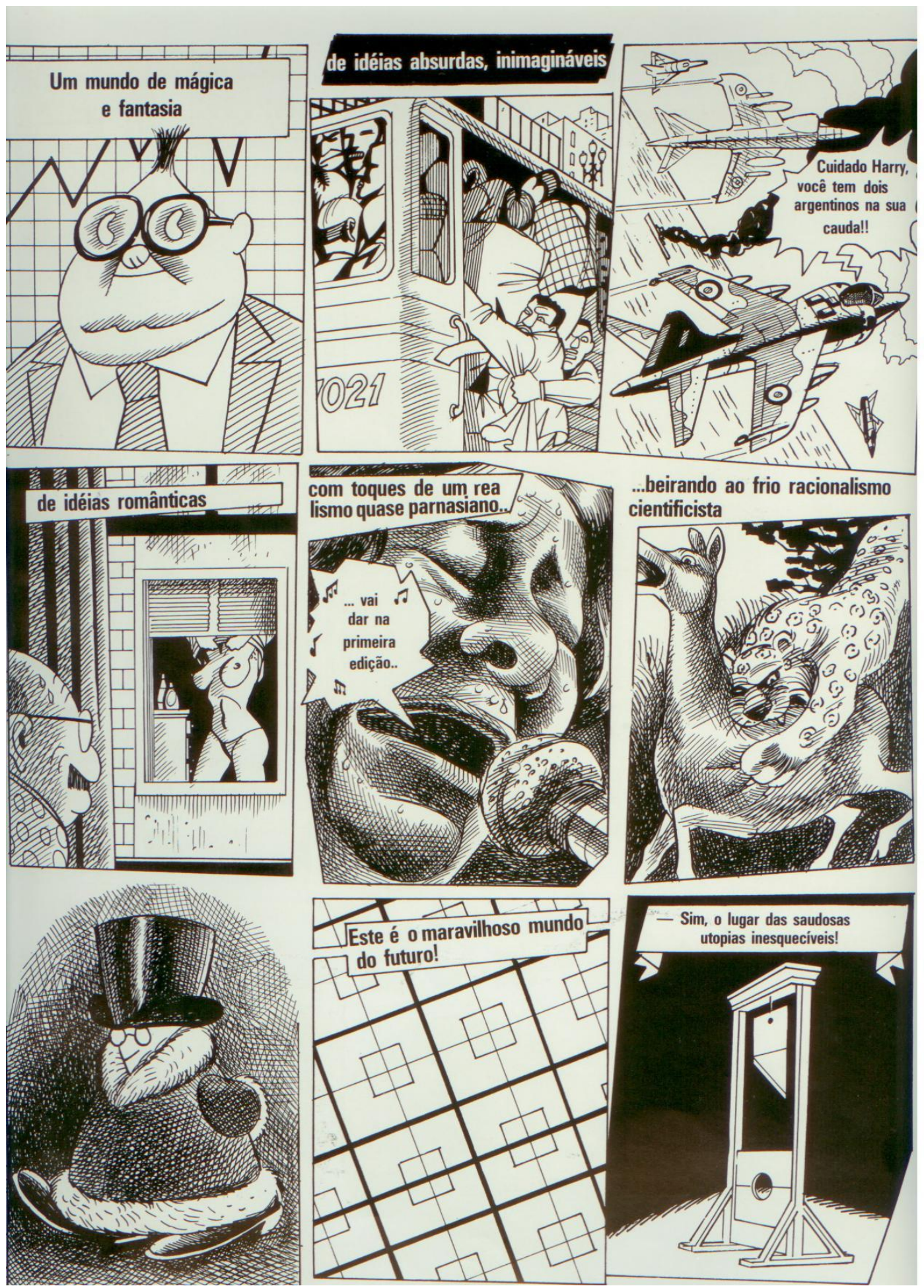




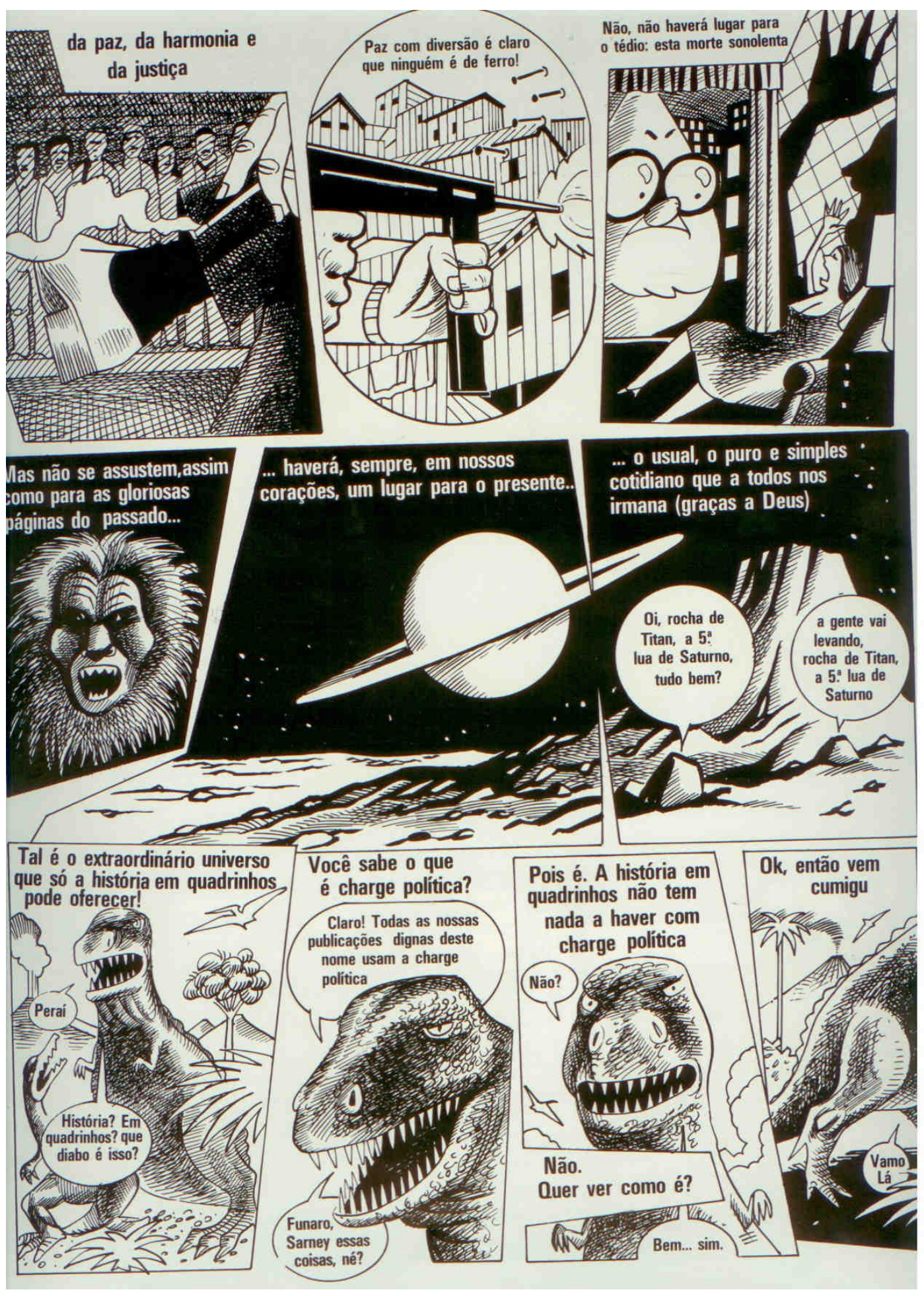




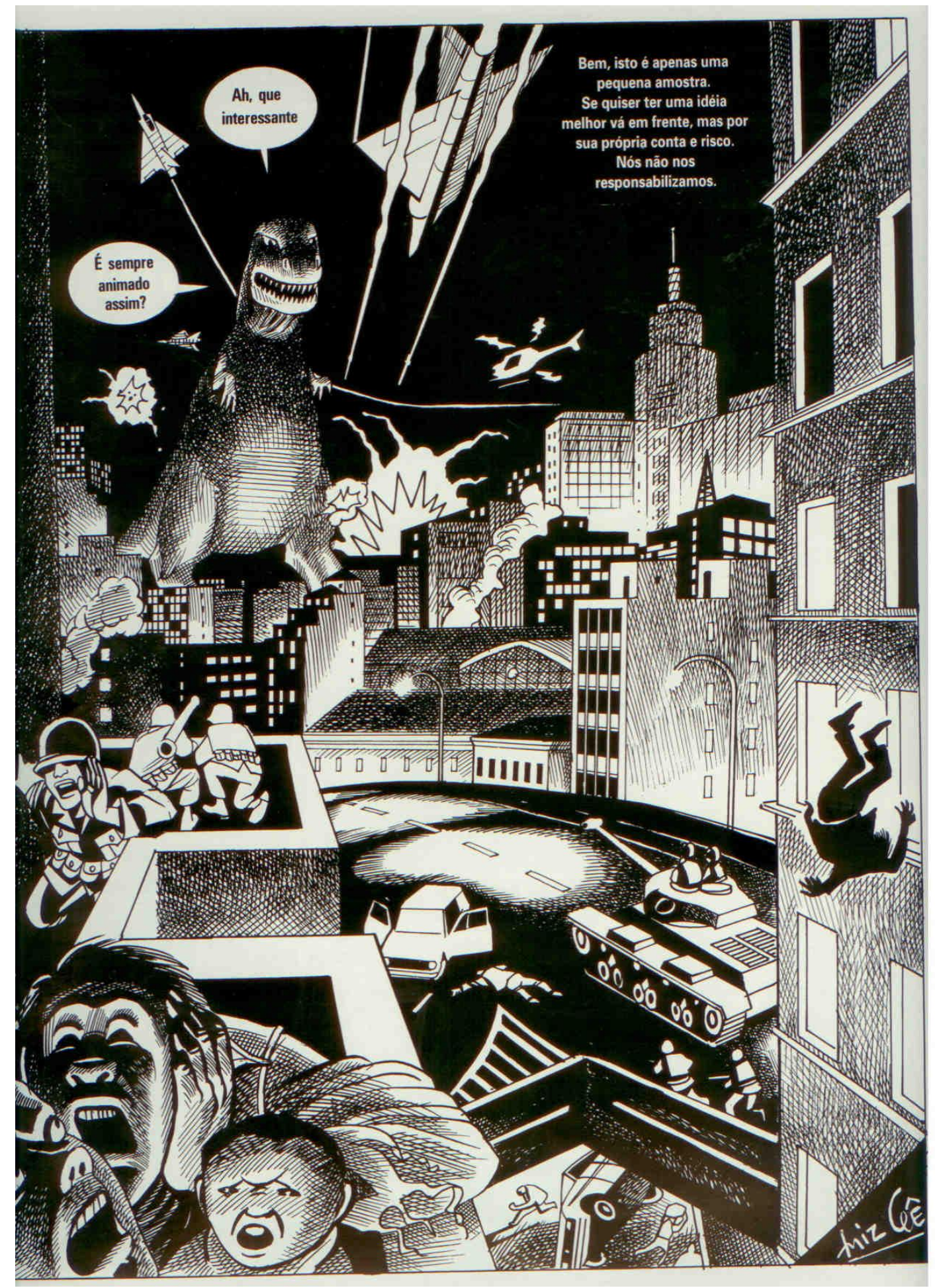




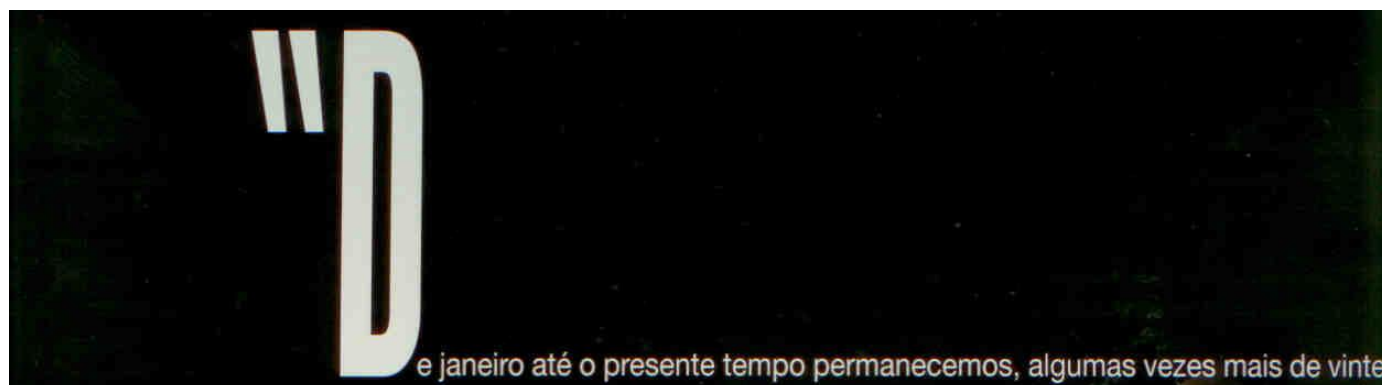
m uma pobre casinha feita de barro e paus, coberta de palhas, tendo quatorze passos de comprimento e ape as dez de largura, onde estão ao mesmo tempo a escola, a enfermaria, o dormitório, o refeitório, a cozinha, espensa; todavia, não invejamos as espaçosas habitações, de que gozam em outras partes os nossos Irmãos ois N. S. Jesus Cristo se colocou em mais estreito lugar."

Padre José de Anchieta, 155
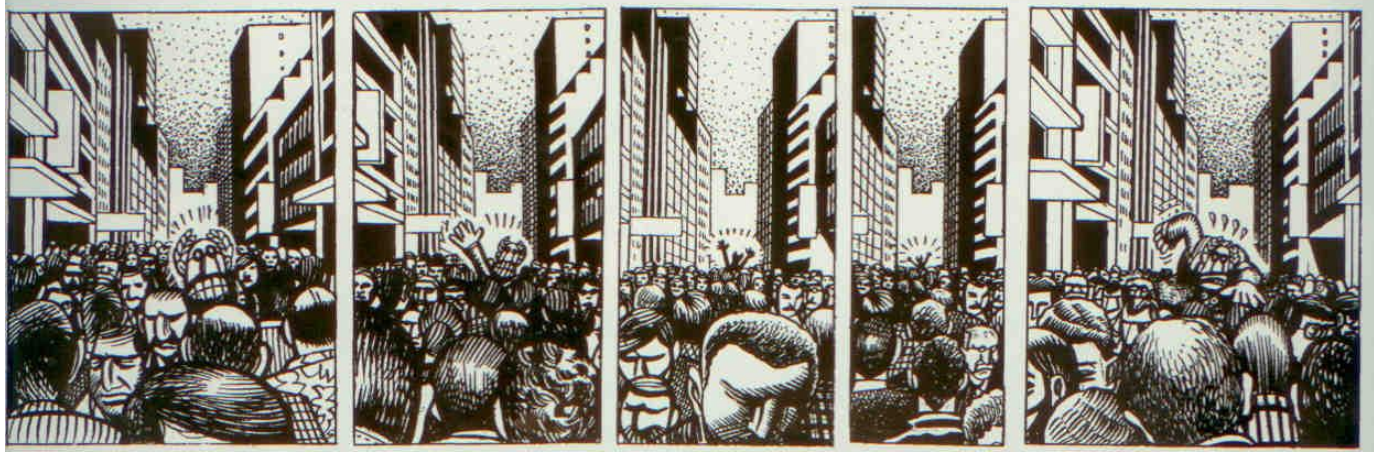


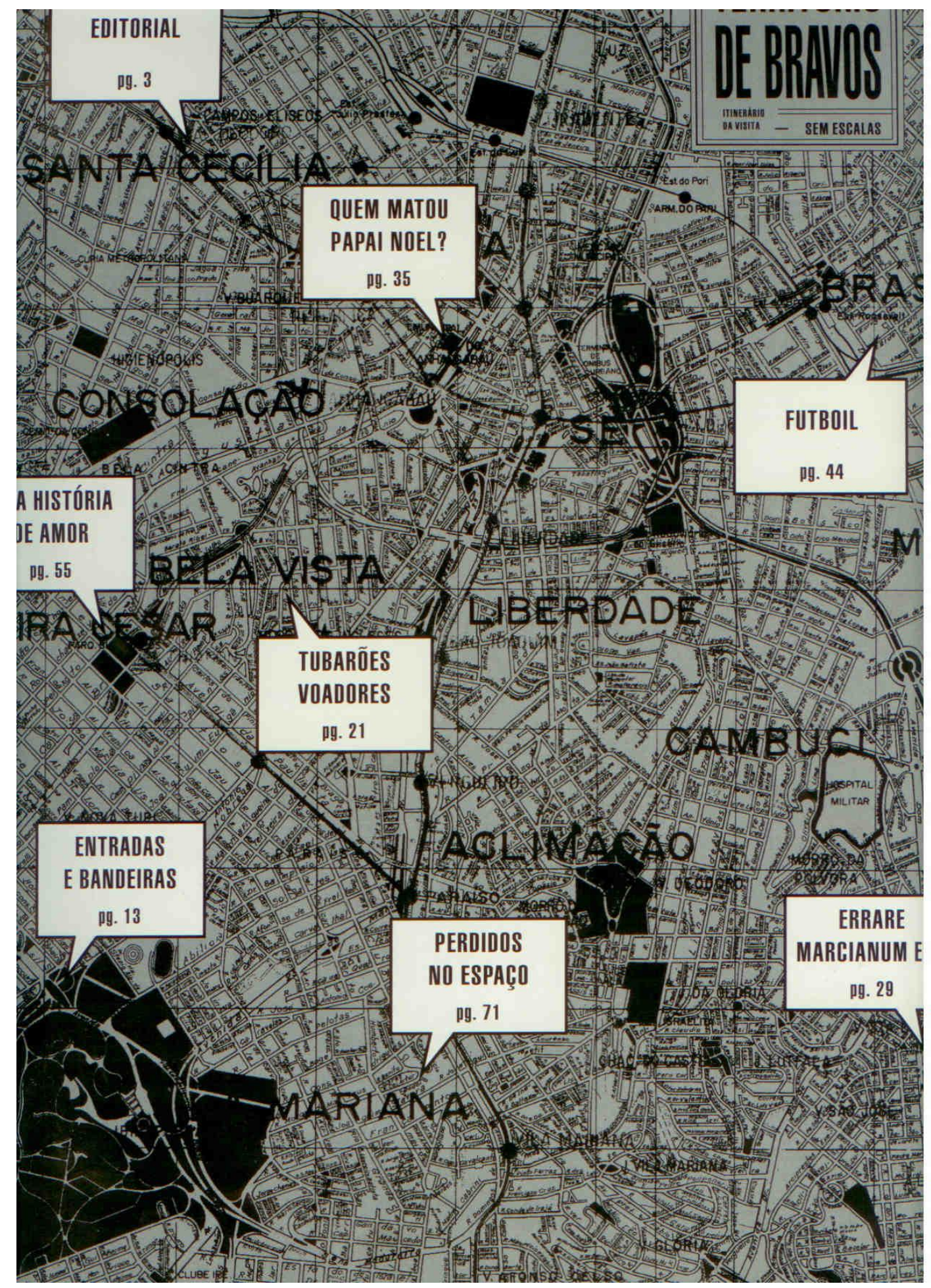




\section{twirgêt}

\section{TERRITÓRIO

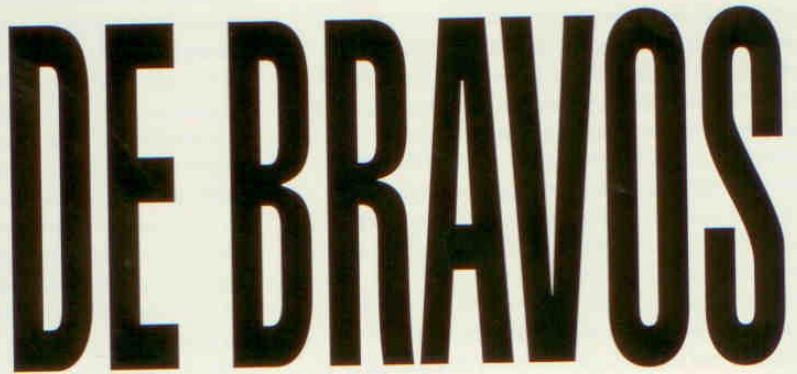

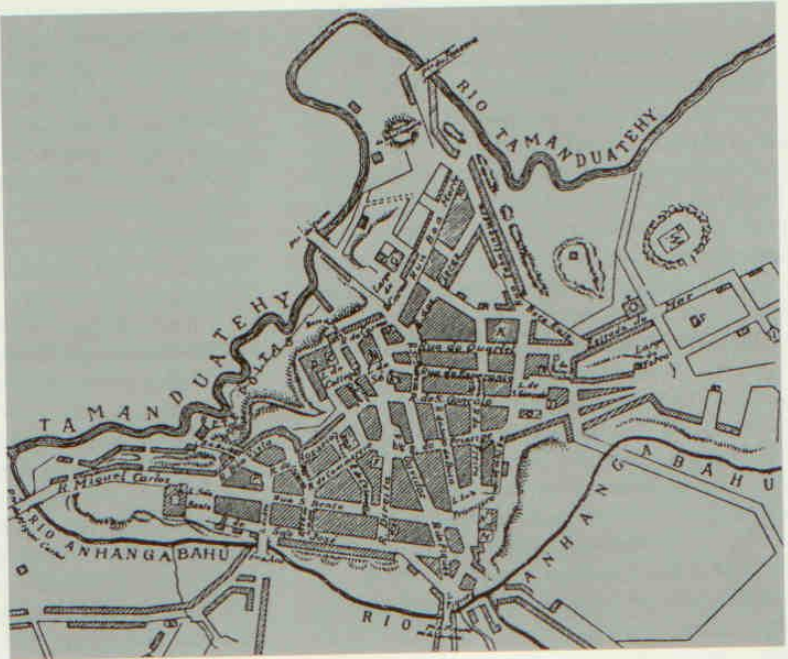

editora 34 


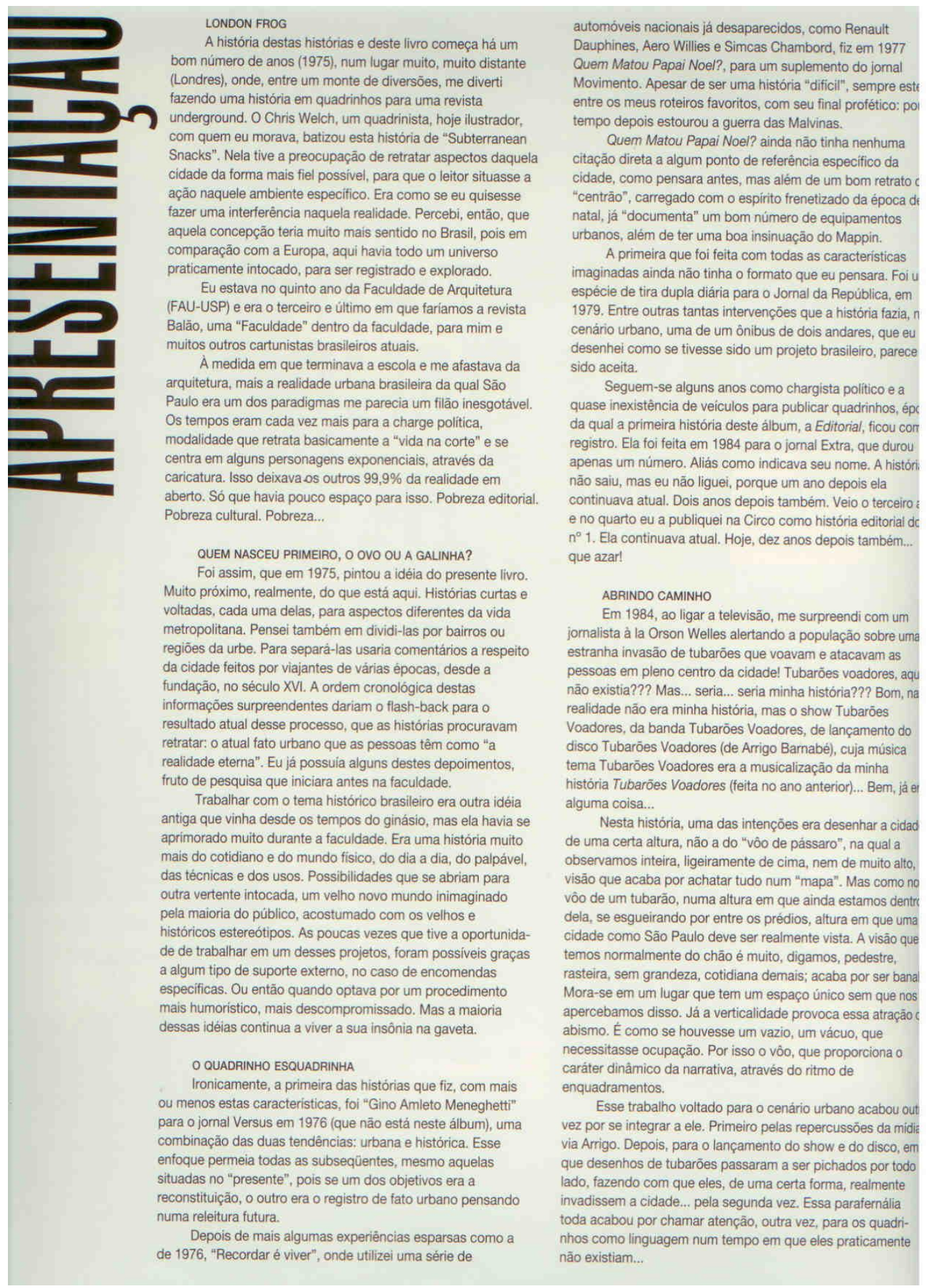


Ainda para a Extra, em 1984, elaborei uma idéia que tinha surgido como muitas outras no tempo do Jornal da República, da história Entradas e Bandeiras. Assim como o túnel da Av. vove de Julho, ela enfocava um outro ponto de referência da idade: a estátua do Brecheret, no lbirapuera, o Monumento às 3andeiras, vulgo Estátua do Empurra. Esta estátua, talvez um Jos monumentos urbanos de maior valor artistico do pais, lavia preenchido por um certo tempo a dificil função de simbolo da cidade. Naquele momento, estava aparentemente, "ultrapassada" e parcialmente pichada. A cidade dos parques, ardins e monumentos, dos bandeirantes, do cidadāo, havia desaparecido jả há algum tempo, desde o início dos anos 60 aproximadamente. Agora era a cidade dos carros, e aquele ocal năo passava de uma rotatória com uma estátua no meio. Estava na hora de puxar os carros! Ela saiu na Chiclete com Banana $n^{\circ} 1$.

No periodo que se seguiu à Extra fui editor de arte da revista Status, publiquei meu primeiro livro só de $H Q$, um dos primeiros da Editora Circo, e voltei ao jornal diário (tinha saido da Folha em 1984), com uma tira e uma coluna semanal para o Estadão. Alguma coisa desta tira já foi publicada em livro pela Melhoramentos e ainda está em catálogo: "Kid Senil e os

Darkinhos". Eles eram, na verdade, personagens secundários da tira do Presidente Reis, que por sua vez tem a sua própria história bem atribulada, por sinal, por causa de uma longa "introduçāo", e parou quando estava praticamente começando. São tiras desta fase inicial/final que "costuram" esse livro.

\section{A CIRCO PEGA FOGO}

No final deste periodo, as coisas estavam prontas para o aparecimento da revista Circo. Me foi possivel, pela primeira vez na vida, ter constância na prática da $\mathrm{HQ}$. São desta fase, $e$ revista, as histórias restantes deste livro.

Em primeiro lugar, a menos "urbana" (de 1987): Errare Marcianum Est (eu sel que é martianum, mas ai o leitor com certeza iria pronunciar errado). Essa história, que acompanha os acontecimentos imediatos que antecederam o "grito do Ipiranga", foi baseada no relato de uma das testemunhas oculares presentes naquele dia, o padre Belchior M. Pinheiro. Mas aquelas colinas do Ipiranga, em 1822, são espaços tâo distantes quanto Marte, hoje, para o desmemoriado cidadão brasileiro.

Registro explicito do pouco estudado folclore urbano e Futboil, de 1986. Essa história diz muito a respeito do potencia da linguagem dos quadrinhos, no que concerne a registros especificos da realidade.

Assim, numa viagem de retorno à infância $e$ adolescência, aquela "aventura" que concentra em tão curto espaço de tempo uma série de acontecimentos tão intensos como a da corrida atrás do balāo, é um destes aspectos, uma dessas experiências que existem para ser registradas apenas por linguagens com a dos quadrinhos... e neste caso, como a do cinema (eu acho que esta história daria um ótimo curta). Ainda assim, certas tomadas, cenas aéreas e travellings, como as de cima mostrando 0 balâo caindo $\theta$ as crianças correndo atrás dele lá embaixo na rua, são muito mais fáceis e baratas de serem feitas nos quadrinhos. Essa liberdade propiciada pelo desenho é uma das marcas registradas da linguagem.

Quantos outros costumes como este apareceram e desapareceram praticamente sem registro? E se não forem registrados visualmente, nem precisa registrar, porque vão pras cucúia mesmo.... Os quadrinhos são relativamente fáceis de produzir. Caso houvesse um mercado rico em publicaçōes, temas como esse com certeza varreriam muitas áreas diferentes do cotidiano e acabariam por construir um universo para a memória. Este é o sentido paradigmático que eu vejo nesta história. É um crime que editoras grandes passem batido pela produçāo nacional, que não invistam nela.

Os quadrinhos sâo enriquecedores porque captam a realidade por ângulos que normalmente não seriam registrados por outras linguagens. Em geral, são aspectos aparentemente desnecessários de lançar mão, no caso de um texto ou de uma música. Ou são por demais impessoais, tratados superficialmente ou pasteurizados no caso do cinema ou da TV. Ou entấo porque a mobilidade e facilidade de produção dos quadrinhos propiciam uma maior versatilidade, ironicamente, até para cavaleiros medievais! Certas histórias - à parte a homenagem a certos artistas plásticos brasileiros como o Grassmann, o Portinari e o Brecheret, e que por si só lhes dariam sentido se inserem em um imaginário e um sentir brasileiro. Como, por exemplo, Uma História de Amor, de 1987 (a idéia era muito mais antiga, por volta de 1977), que tem sido usada com sucesso pela escritora e educadora Anna Flora para criar atividades paradidáticas em núcleos da periferia desde 1990

As opções sâo amplas e vão, como dizia o professor Flávio Motta, do particular para o geral e do geral para o particular. Tudo vale, mesmo se o particular for tâo particular quanto um tatu-bolinha - como na história Perdidos no Espaço, de 1987

Esse bicho de quintal, bicho que no campo passaria solenemente desapercebido, eclipsado por muitos outros, provavelmente nunca deve ter sido desenhado neste pais antes. Mas nas cidades, nunca deixou criança com olhos esquadrinhadores desinteressada do seu casco de "geometria variável" e aspecto de ônibus miniatura, ideal para ser usado em "cidadezinhas".

A alguns pode parecer nẫo importante que 0 desenho procure reproduzir diretamente a realidade do entorno no qual 0 artista vive. Mas é. Alguém disse que a arte se reporta muito mais à própria arte para se desenvolver do que à realidade propriamente dita. É verdade, É muito mais fácil. No Brasil, pais sem tradiçāo forte de artes visuais, sem boas escolas, os desenhistas desenvolvem seus estilos sob influência de outros artistas aos quais tem acesso via revistas ou outras publicaçōes. Em geral estrangeiros.

Romper com essa avassaladora e praticamente inescapável influência estrangeira e criar um novo olhar (nem tanto por nacionalismo, mas até por personalismo), uma nova contribuição, que năo seja o mero carbono da última onda da Europa ou dos EUA, passa por vários caminhos (ter veiculos para se expressar, por exemplo), mas seguramente um deles é a observação e retrataçäo da realidade.

As histórias do presente álbum tem uma aproximação estilistica entre elas completamente diferente das do álbum anterior ("Quadrinhos em Fúria") que tinham um jeito mais "Pop", isto é, mais metalingüístico, voltado para o próprio desenho "tradicional" dos quadrinhos. As histórias deste livro são muito mais voltadas para fora, para o real. E para esse tipo de representação ele tev que se adequar. Era um novo aprendizado.

Tais são alguns dos retratos do territó rio de bravos. Devido à selvageria do ambiente, nã̃o foi possivel fazer mais, infeliz mente. Mas os que aqui ficam me parecem bons caminhos ou sementes. Ja vivi o suficiente para ver que alguns deles até já frutificaram nos intervalos entre as secas crônicas.

Luiz Gê, 1993

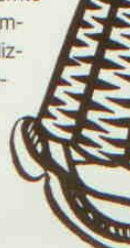

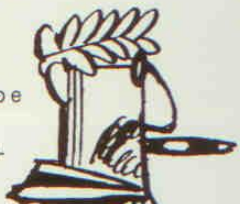

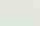




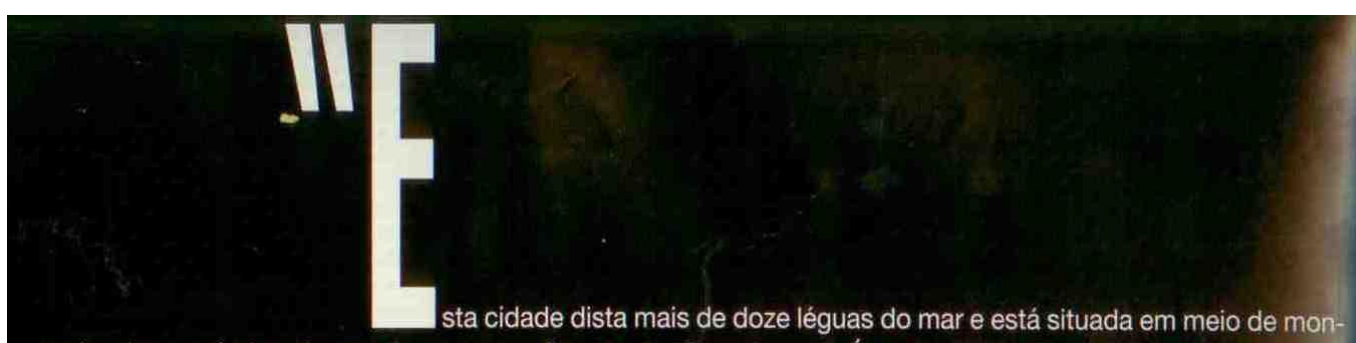

tanhas inacessíveis e da grande e espessa floresta de "Pernabacca". É uma espécie de república originariamente composta de toda a casta de gente sem fé nem lei, mas que a necessidade da conservação forçou a adaptar certa forma de governo. (...) A tirania dos governadores do Brasil deu origem a esta pequena república, tão ciosa de sua independência que não permite a forasteiro algum a entrada em seu domínio. (...) Nos últimos quinze ou vinte anos, porém, o seu número multiplicou-se pelo menos dez vezes. Dizem-se livres e não querem estar sujeitos aos portugueses. (...) Quando algum forasteiro se apresenta para fazer parte da república, tem de sujeitarse a uma espécie de quarentena, não por motivos sanitários, mas afim de ser observado quanto às suas aptidões e designios. Depois de prolongada observação é enviado a fazer extensas e penosas jornadas, com ordem de trazer dois escravos índios. Estes escravos são empregados nas minas e no cultivo da terra. O noviço que fraqueja na prova, ou procura desertar, é morto sem misericórdia. Quem se alista entre os paulistas o faz por toda a vida, pois só com muita dificuldade concedem permissão para alguém se retirar."

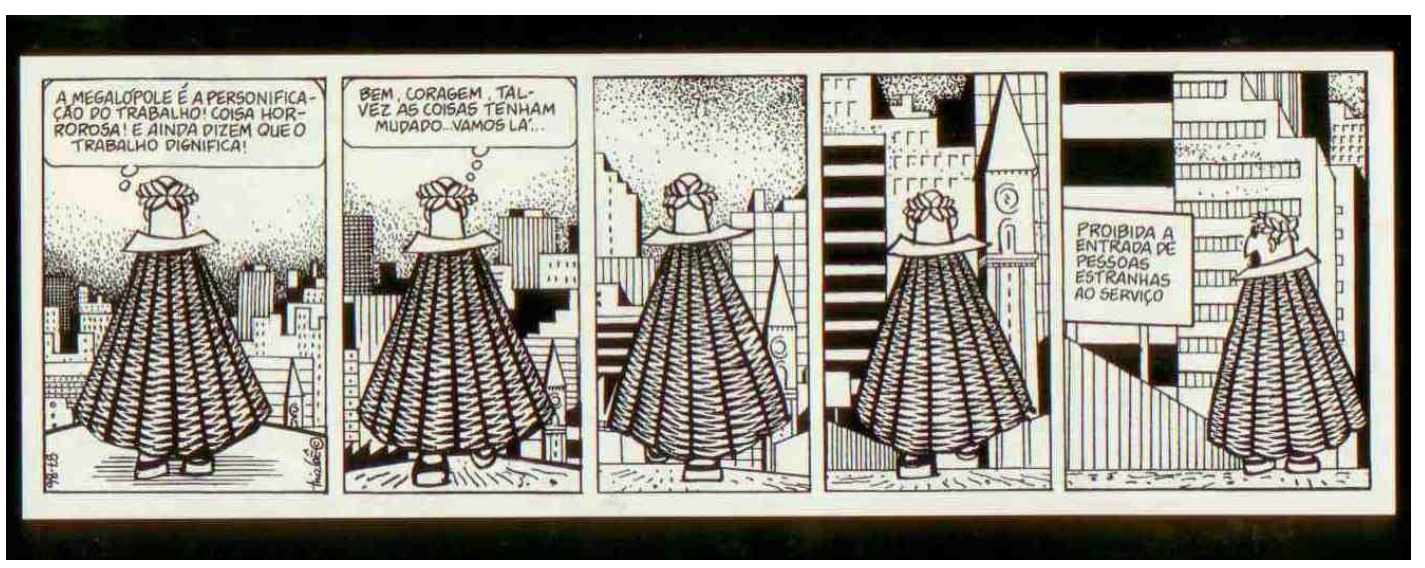




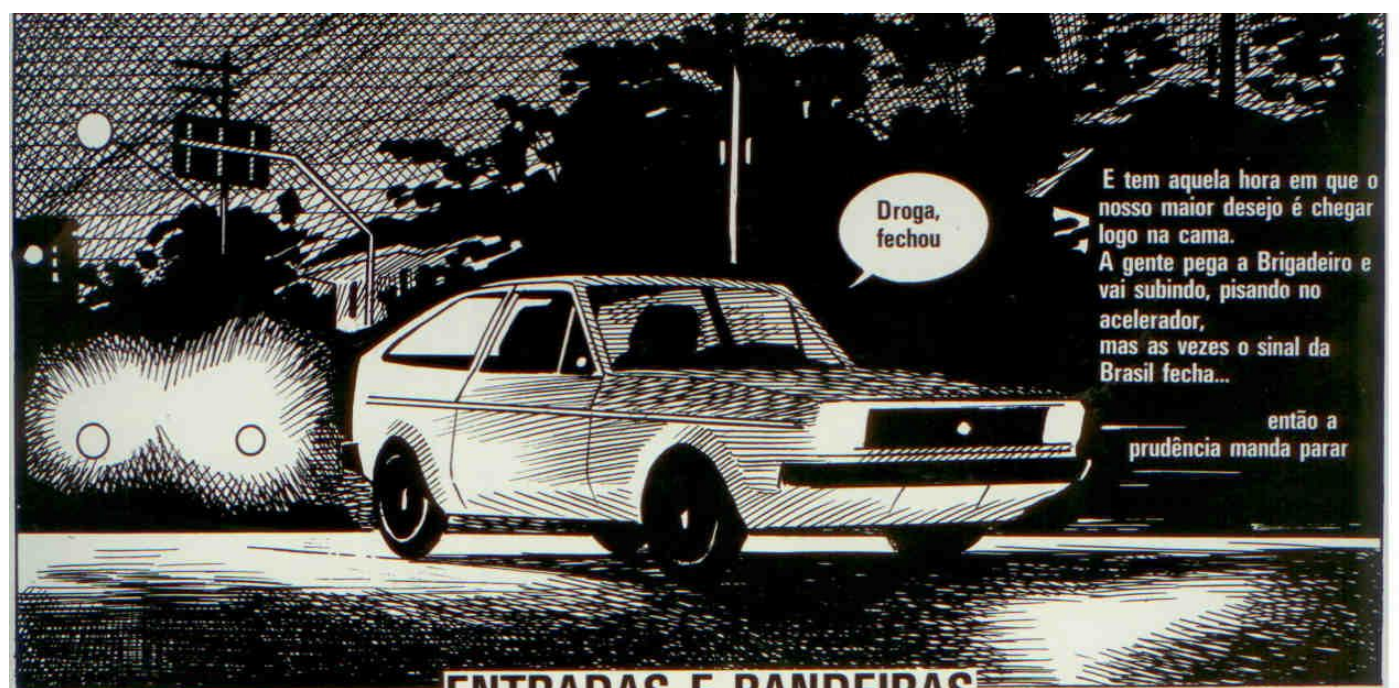

Histórias Extraordinárias apresentam ENTRADAS E BANDEIRAS uma H.O. (história em quadrinhos)
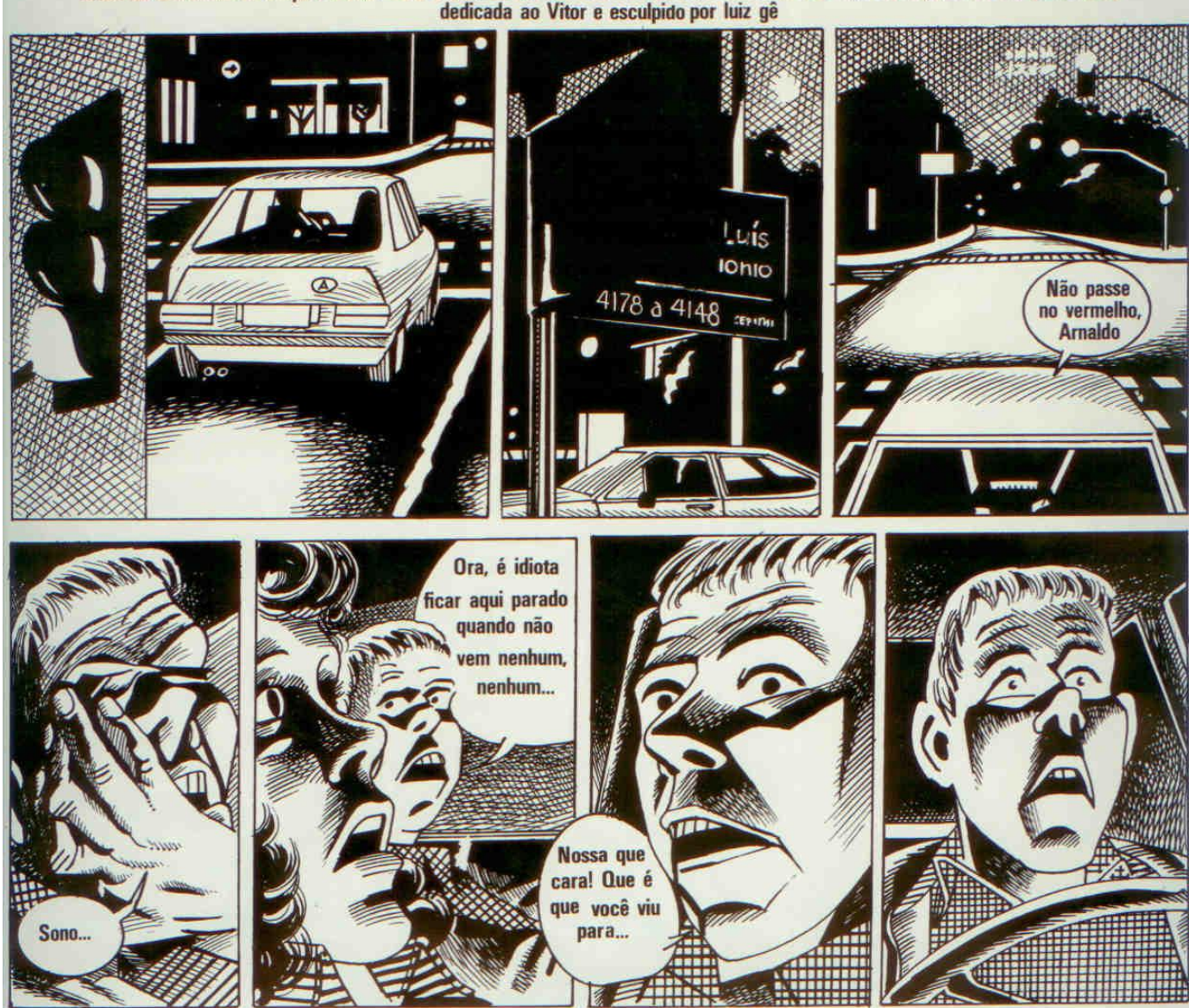


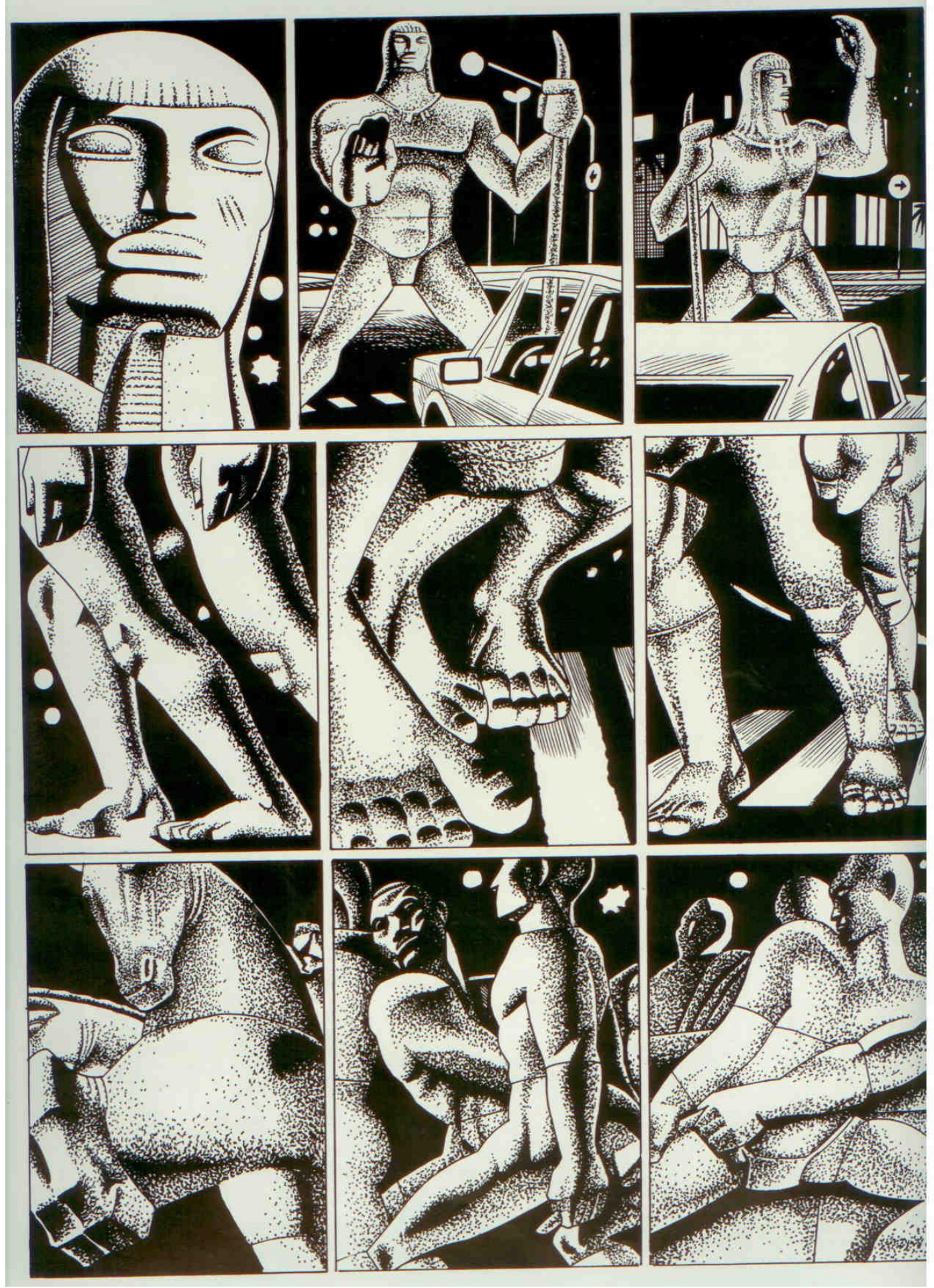




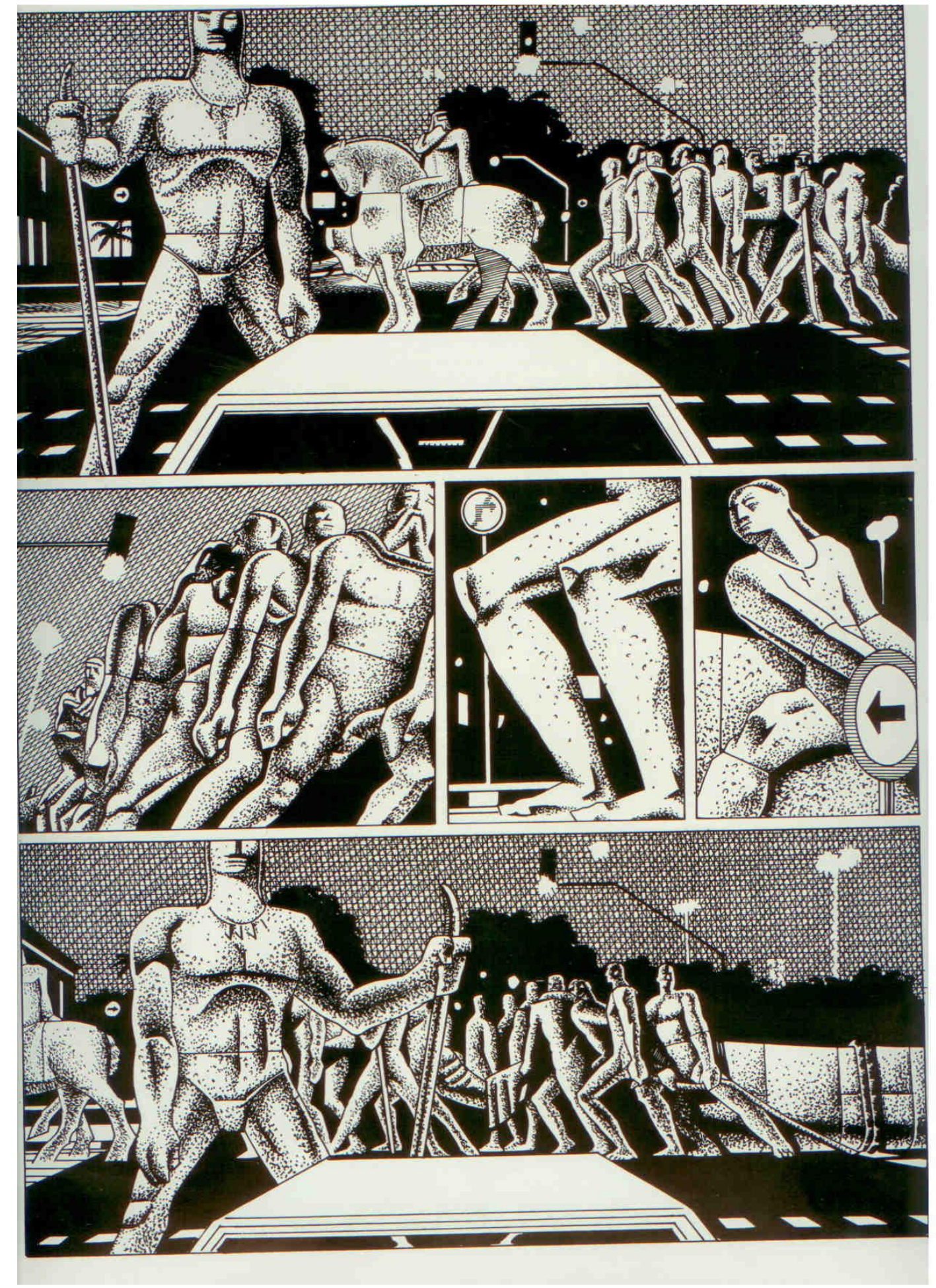




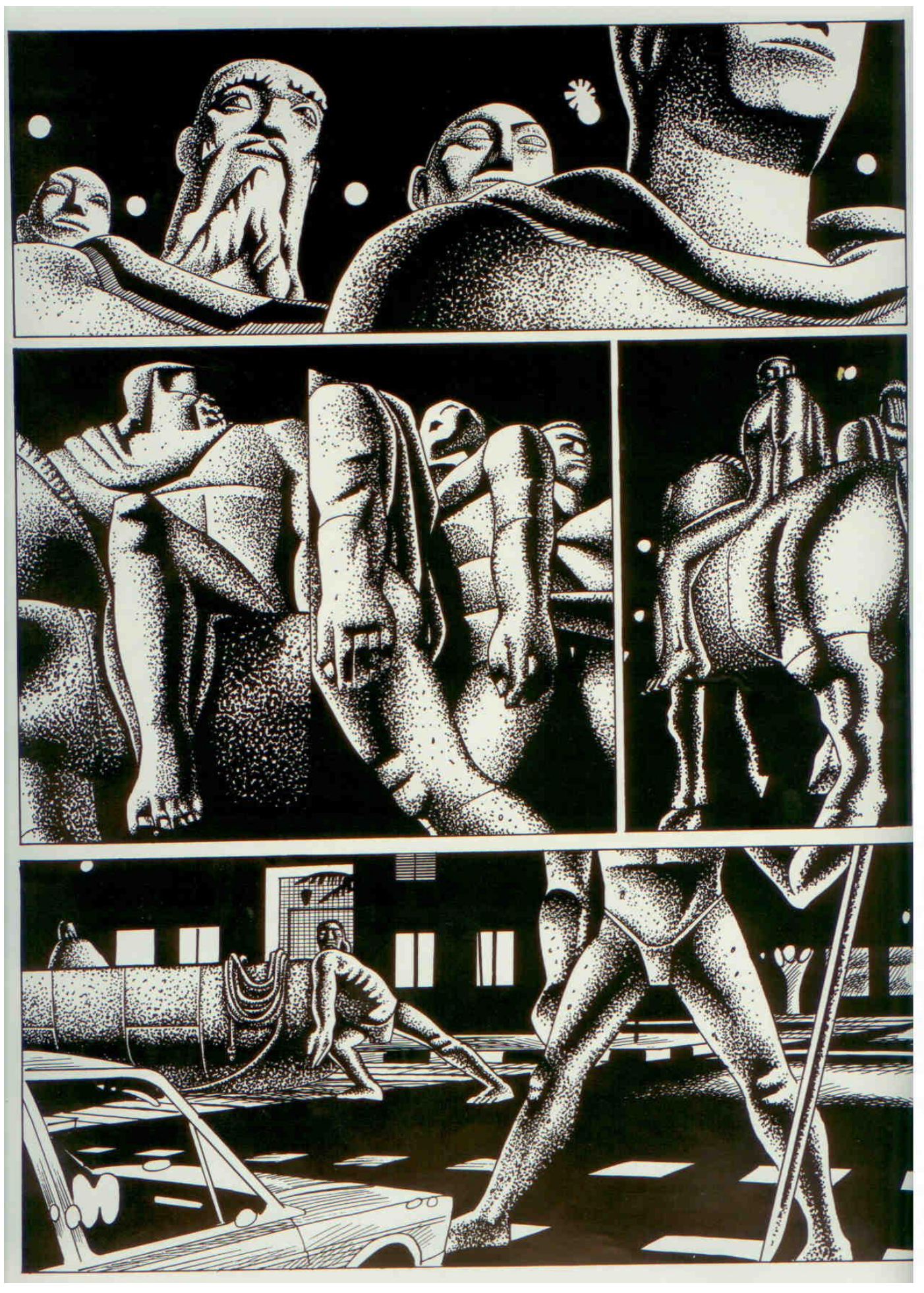




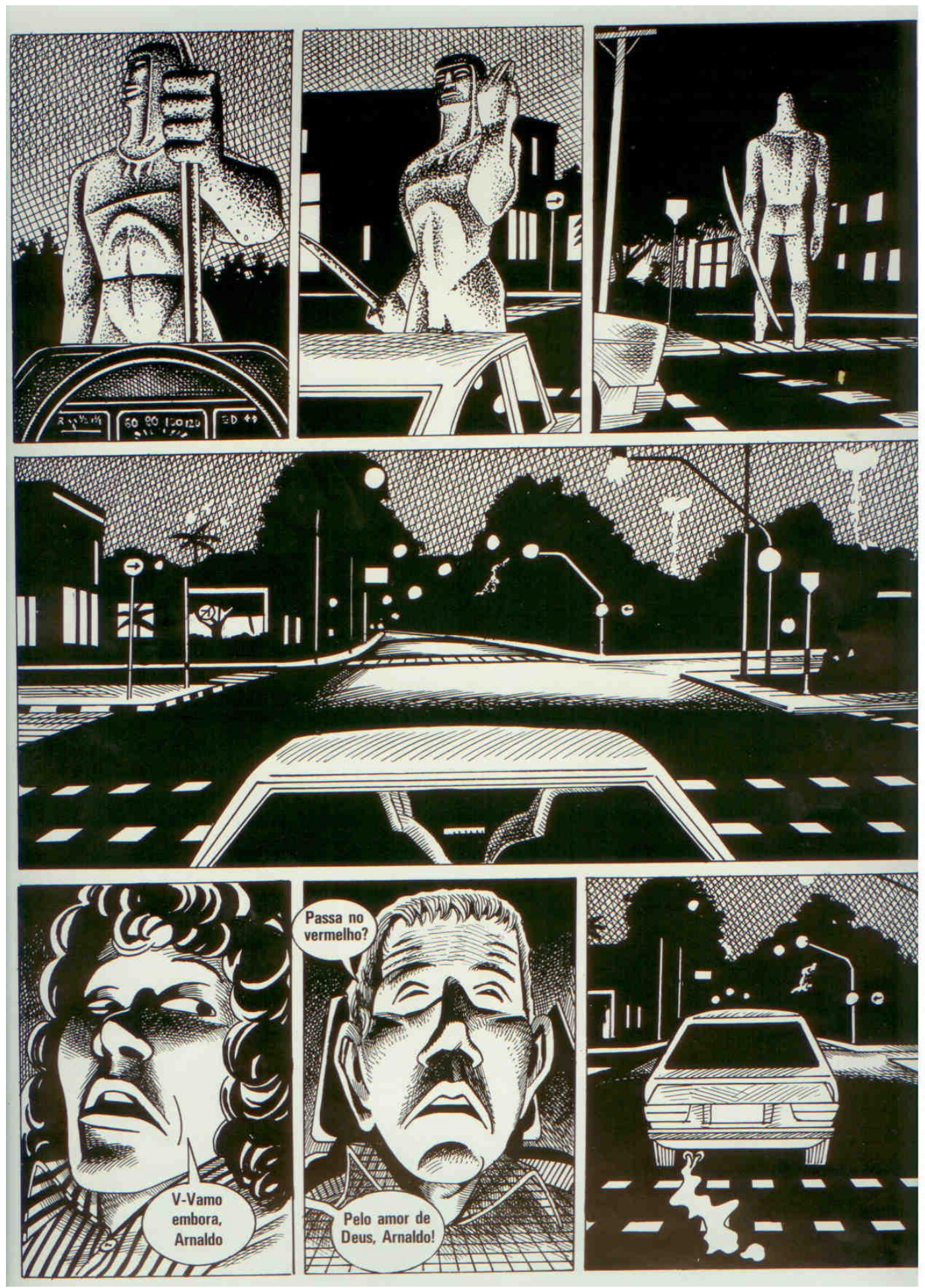




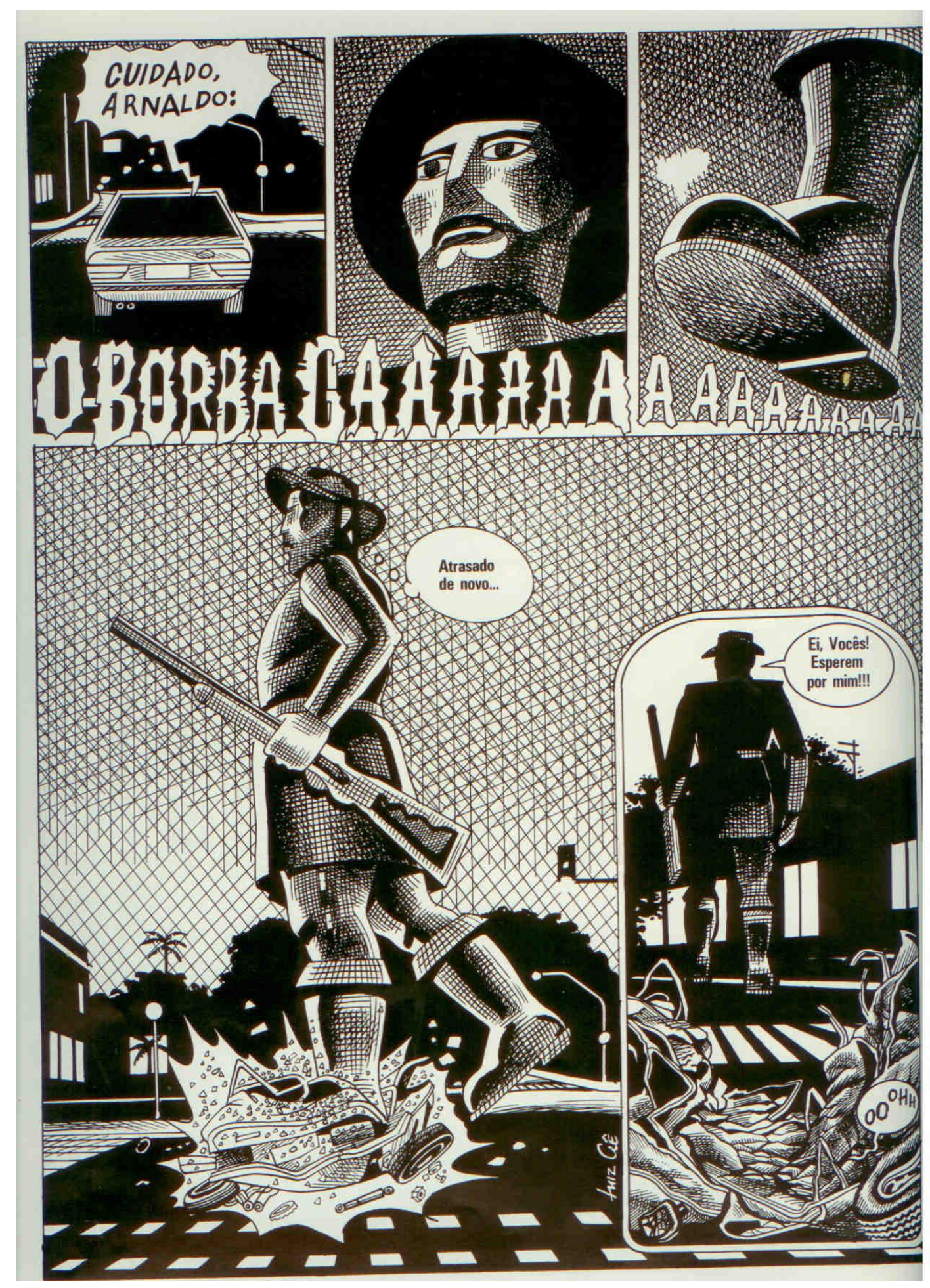




\section{"1}

s paulistas de hoje já não têm o mesmo valor, e resolução, que tinham os seus

antepassados: que gostam de viver mais regaladamente, e que já se não expõem a passarem pelos trabalhos e descômodos que tiveram seus avós."
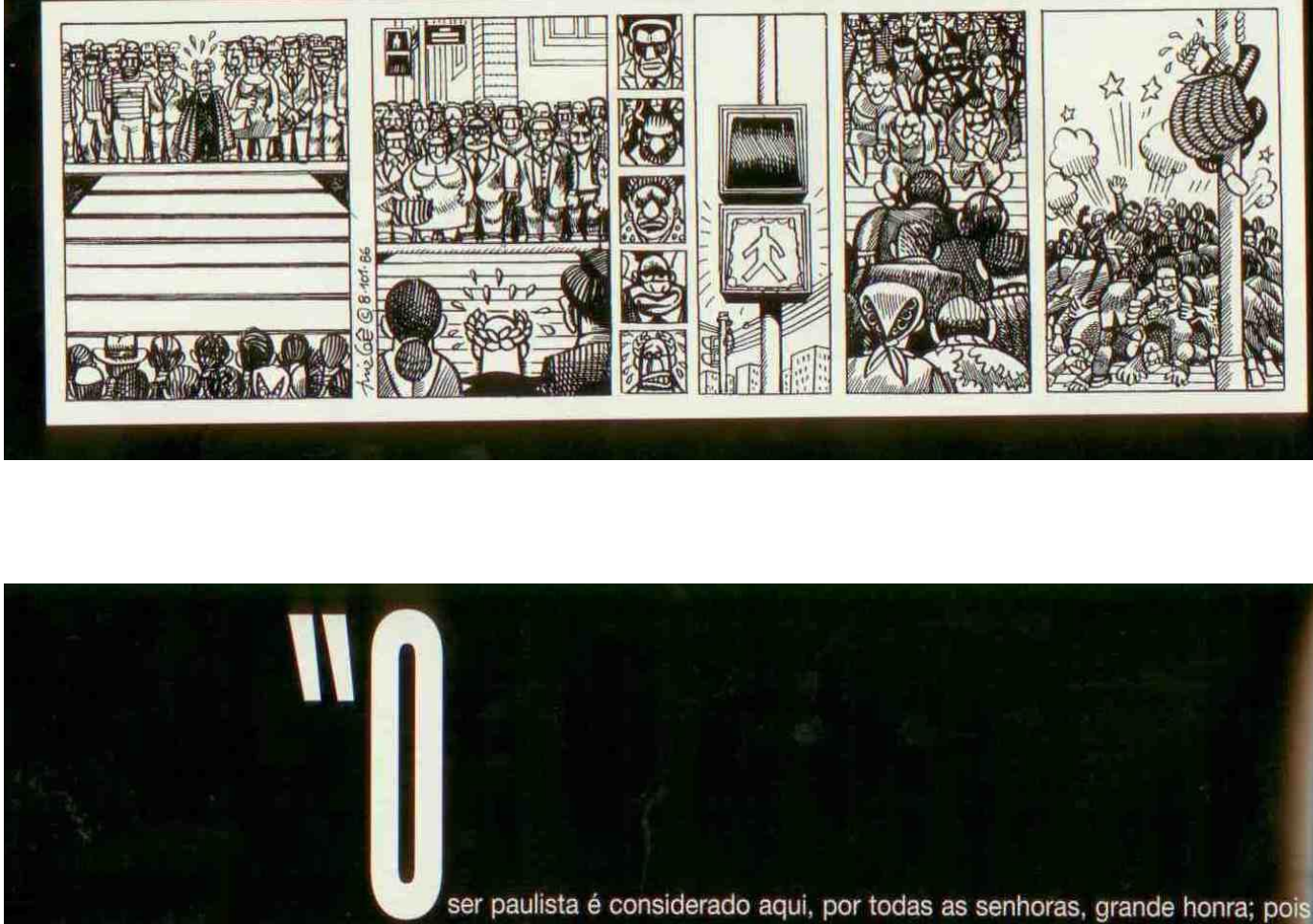
os paulistas são decantados, em todo o Brasil, pelos seus atrativos e dignidade de caráter. Extremamente abstêmios à mesa, seu divertimento favorito é a dança, em que revelam grande vivacidade e graça."

John Mawe, 1808

"O tempo passa depressa em um lugar onde se gozam tantas finezas como em São Paulo. Passamos uma semana inteira em divertimentos, entre os quais, além de bailes e teatros, devo mencionar um passeio campestre a cavalo, organizado pela Marquesa de Alegrete, da cidade até o outro lado do rio Tietê, onde passamos um dia inteiro brincando. Muitas senhoras casadas e bonitas moças compunham a comitiva que, toda unida, partiu da cidade, acompanhada por um enxame de ordenanças e criados."

"A situação de São Paulo é encantadora e é puro o ar que ali se respira. É fino o trato dos homens das classes elevadas, e a polidez dos paulistas estende-se até as classes inferiores." 

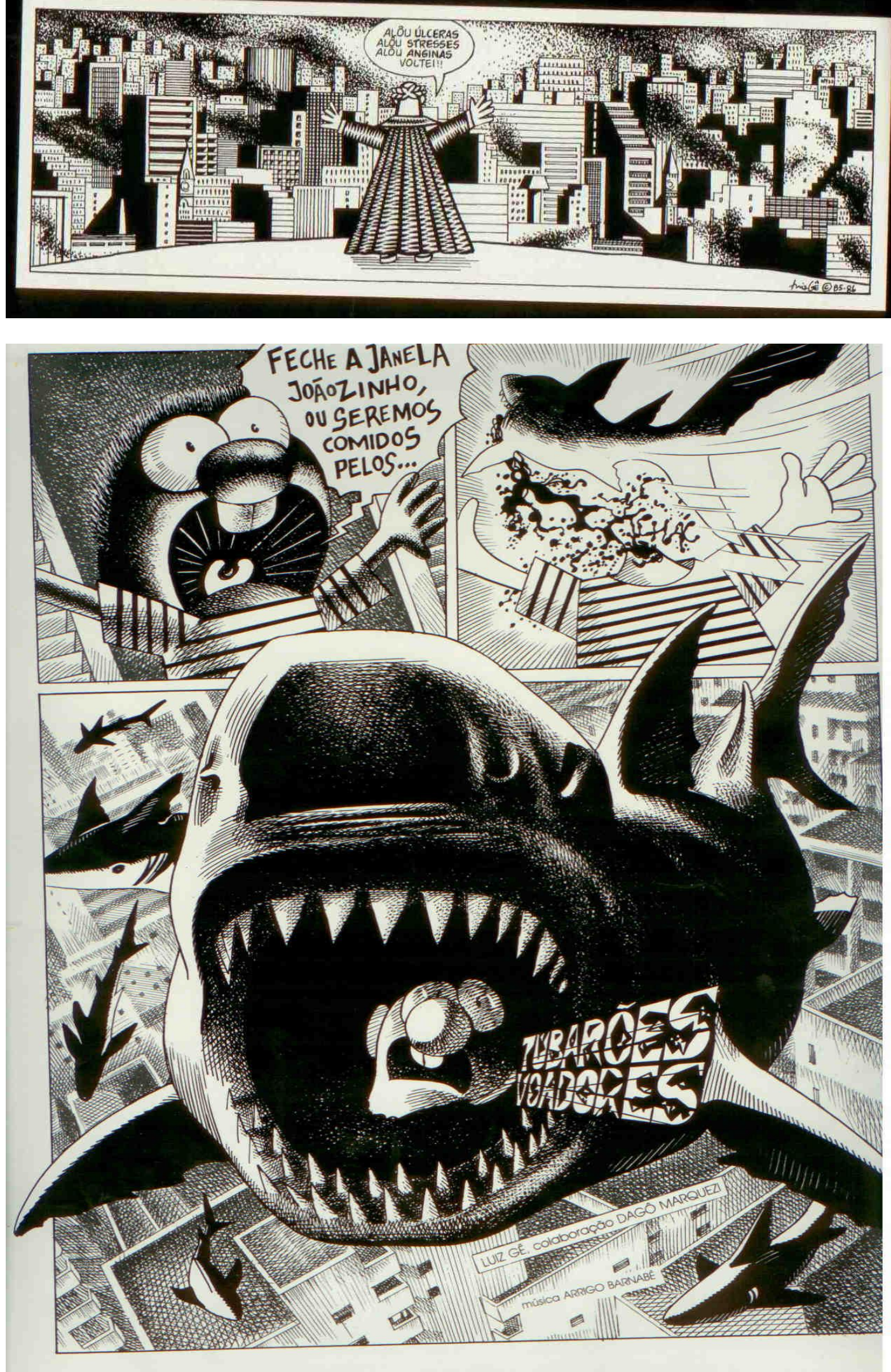


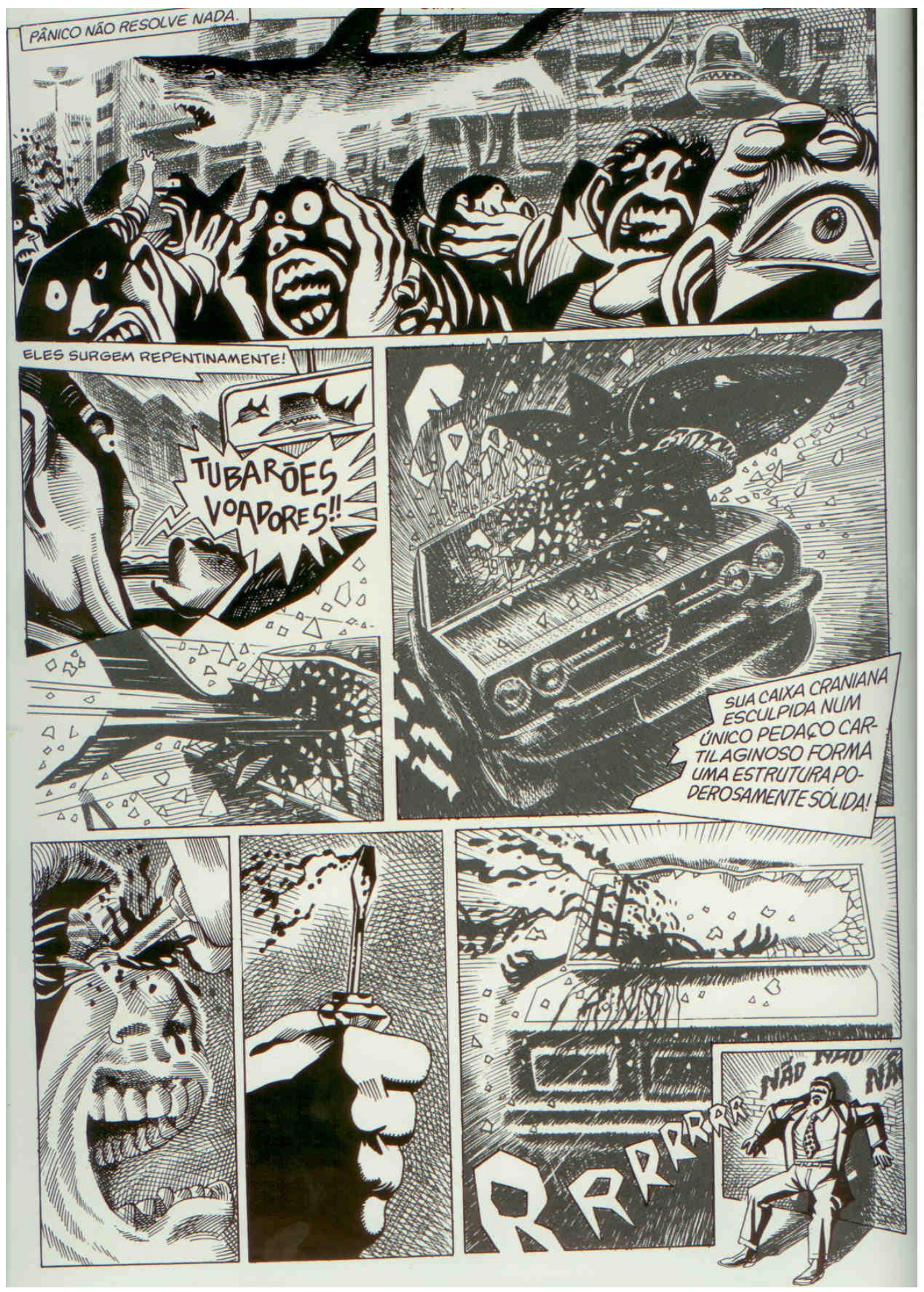




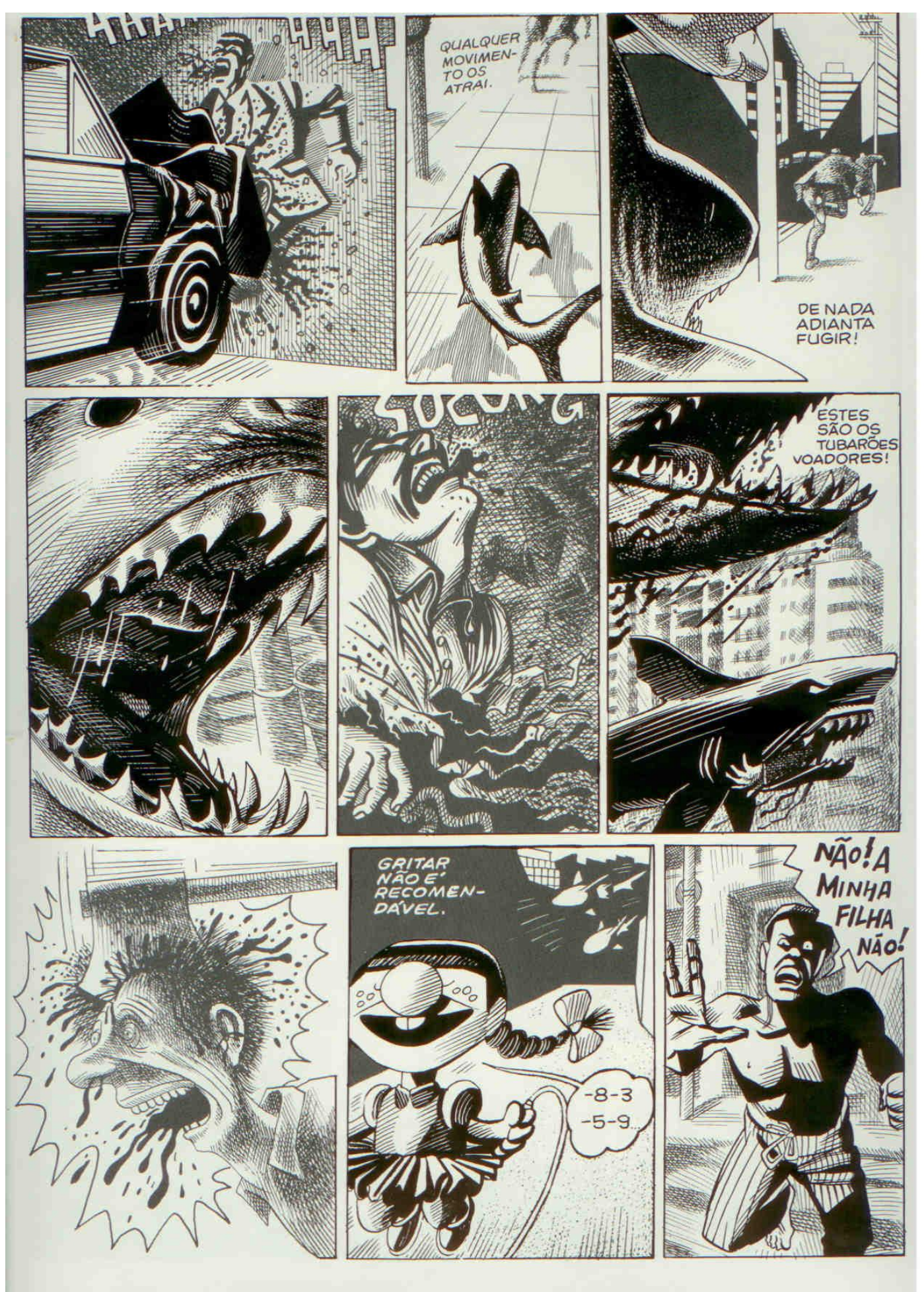




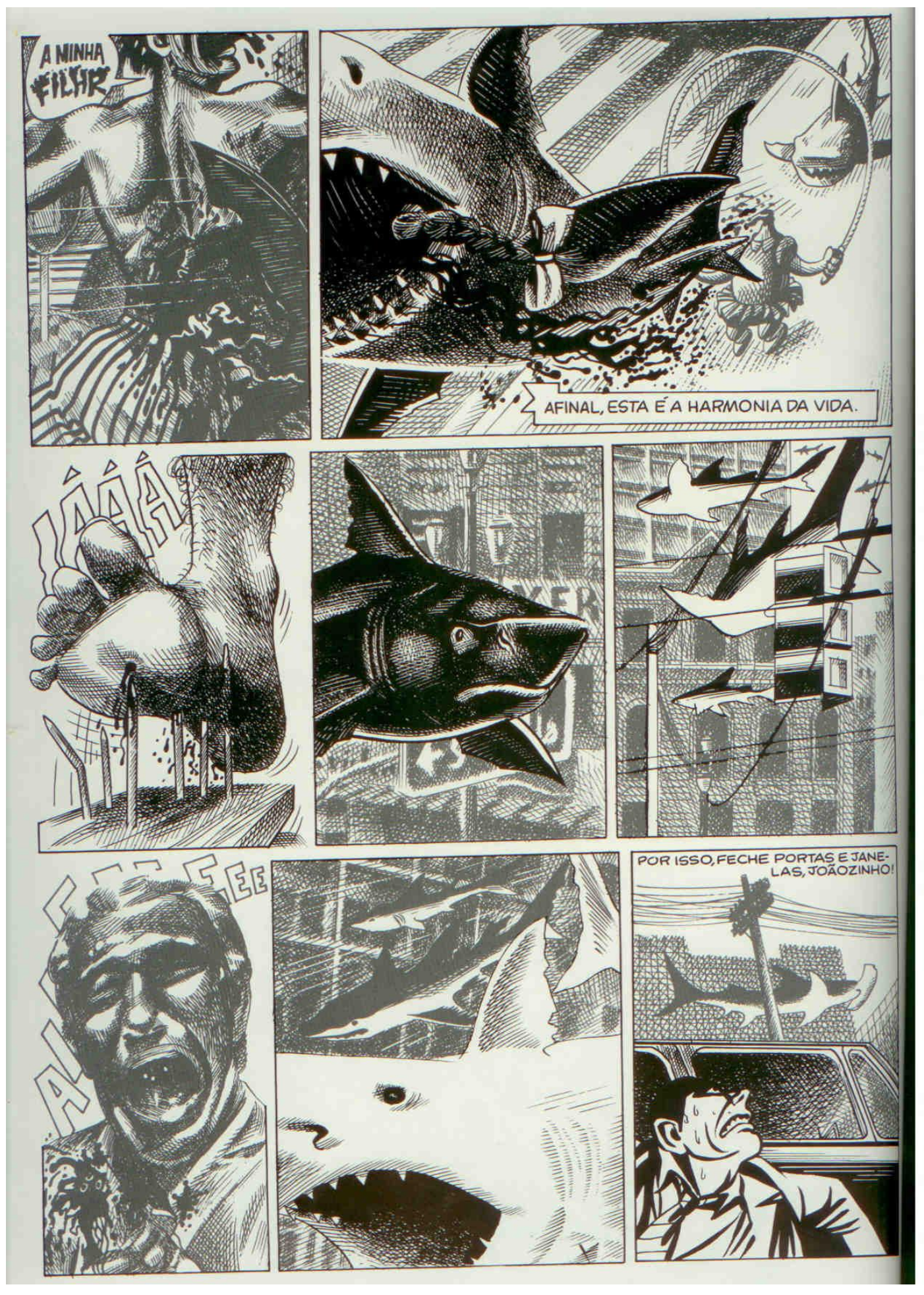




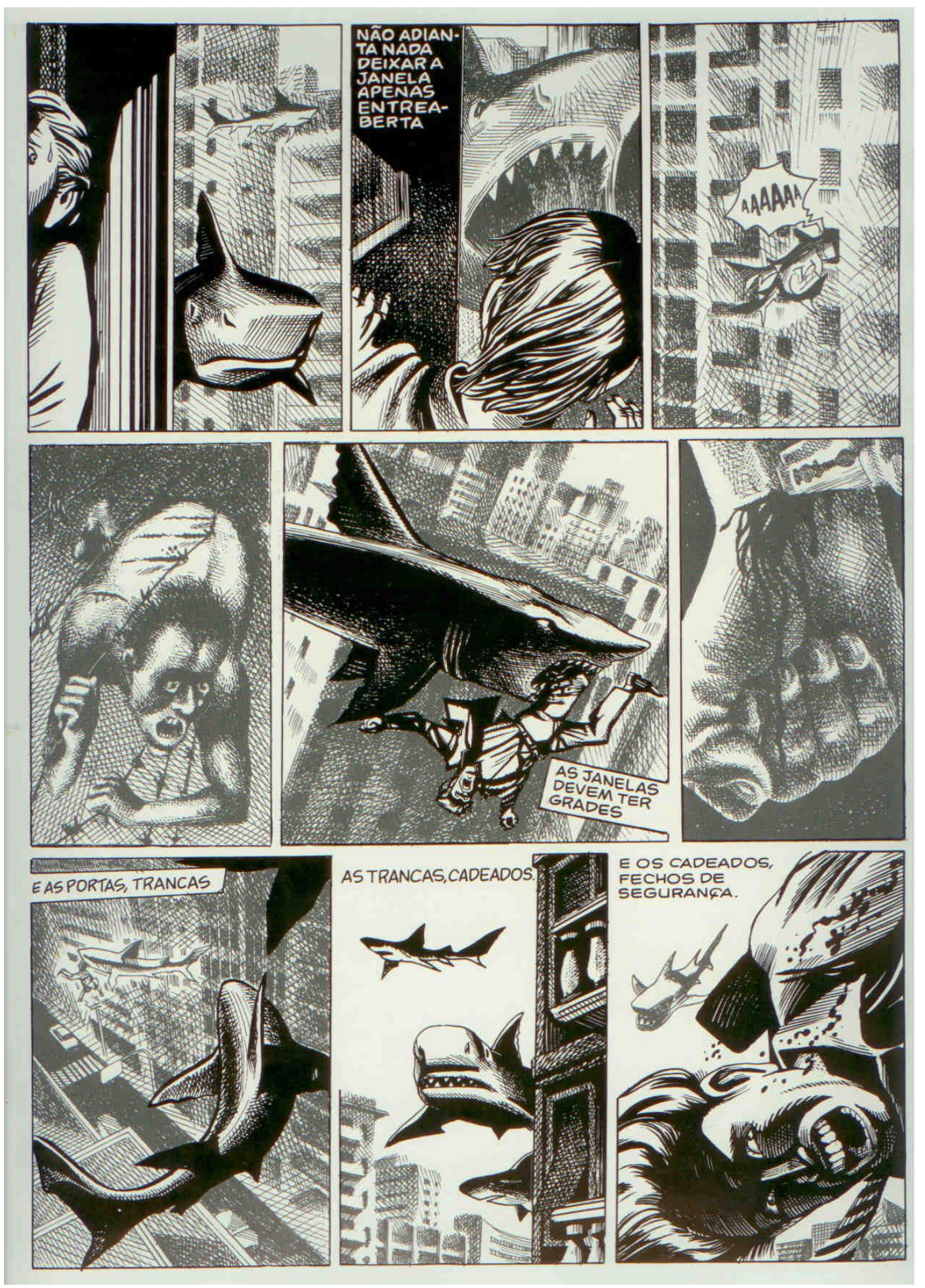




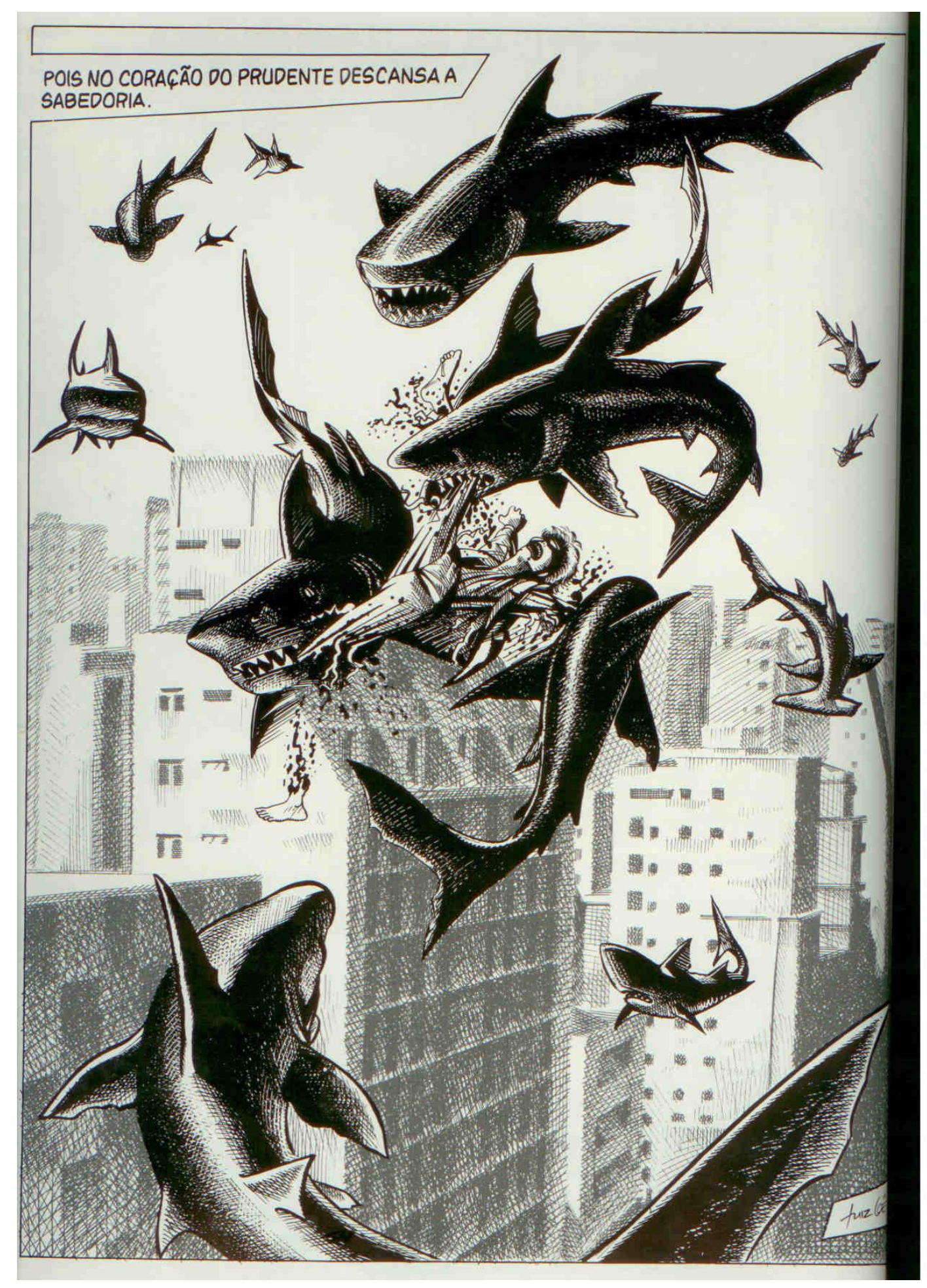




\section{III}

desenvolvimento, mas pouco se lhes dá se será com perda das feiçōes próprias do caráter Paulistano ou a custa de um abalo na posição dos paulistas. Olham para a Província como uma máquina produtora e um elemento de possivel aumento da receita do orçamento. Eu, porém, com quanto não quero ceder a estes em amor à Província, não ambiciono uma transformação tão rápida. Quero que o aumentado desenvolvimento da Província simbolize fielmente a aumentada felicidade da velha população Paulistana. (...) Eu não concebo verdadeira grandeza em um povo sem um passado, - sem um forte sentimento de nacionalidade - sem homogeneidade - $e$ estremeço do progresso que se faz em aplainar as saliências e as distintivas do caráter e dos costumes Paulistanos que rapidamente se efetua e que alguns aplaudem como uma garantia da unidade do Império! - No meu ver, a uniformidade de pensamento - de costume - de gosto - de caráter é um presságio da decadência de qualquer grande Império, porque sendo em si uma coisa forçada e não natural só pode provir da indébita influência da Corte ou de qualquer centro e é sempre indício de uma falta de seiva - de virilidade - nos povos assim uniformizados que ficam desta sorte preparados para o Despotismo."
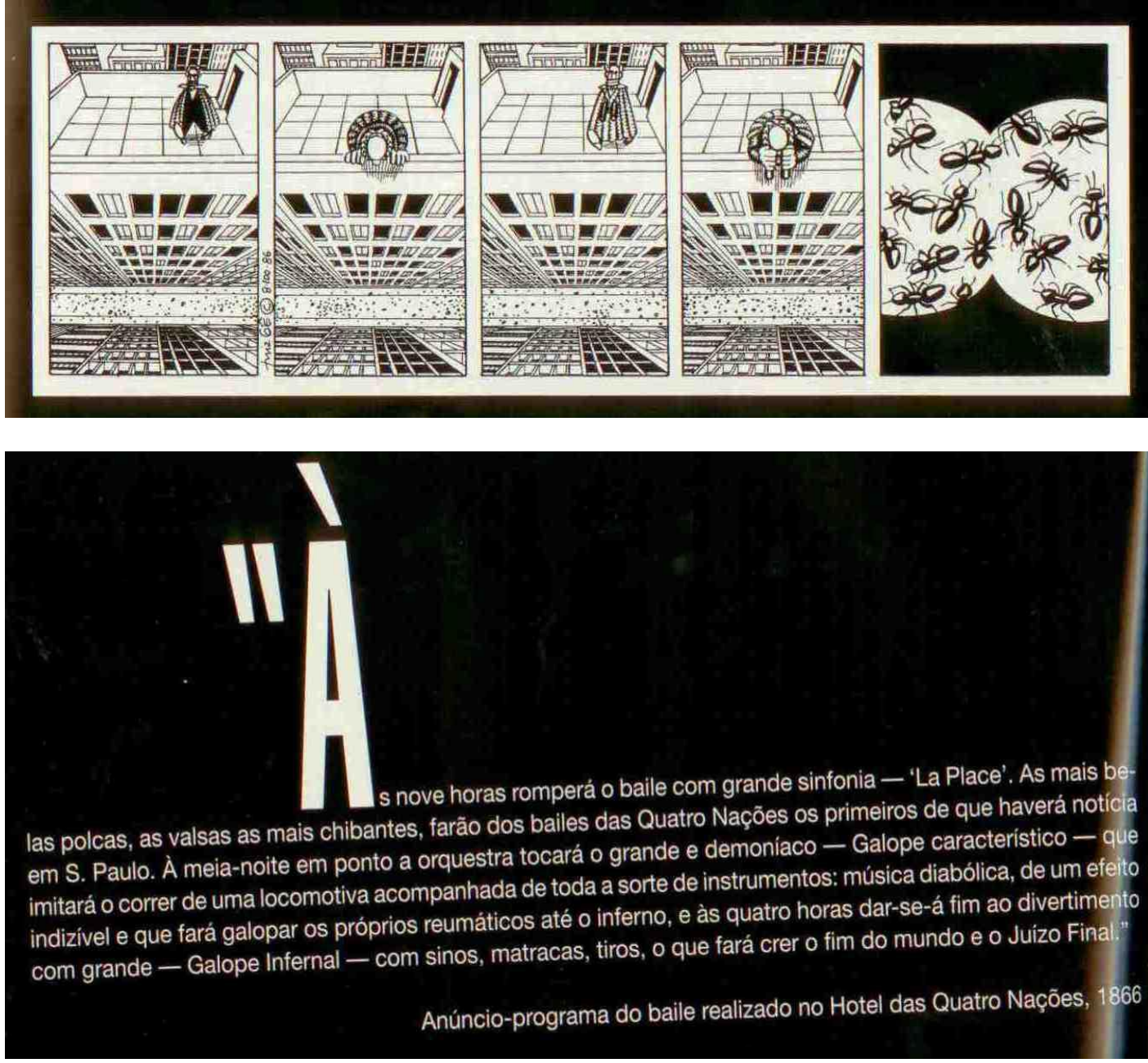

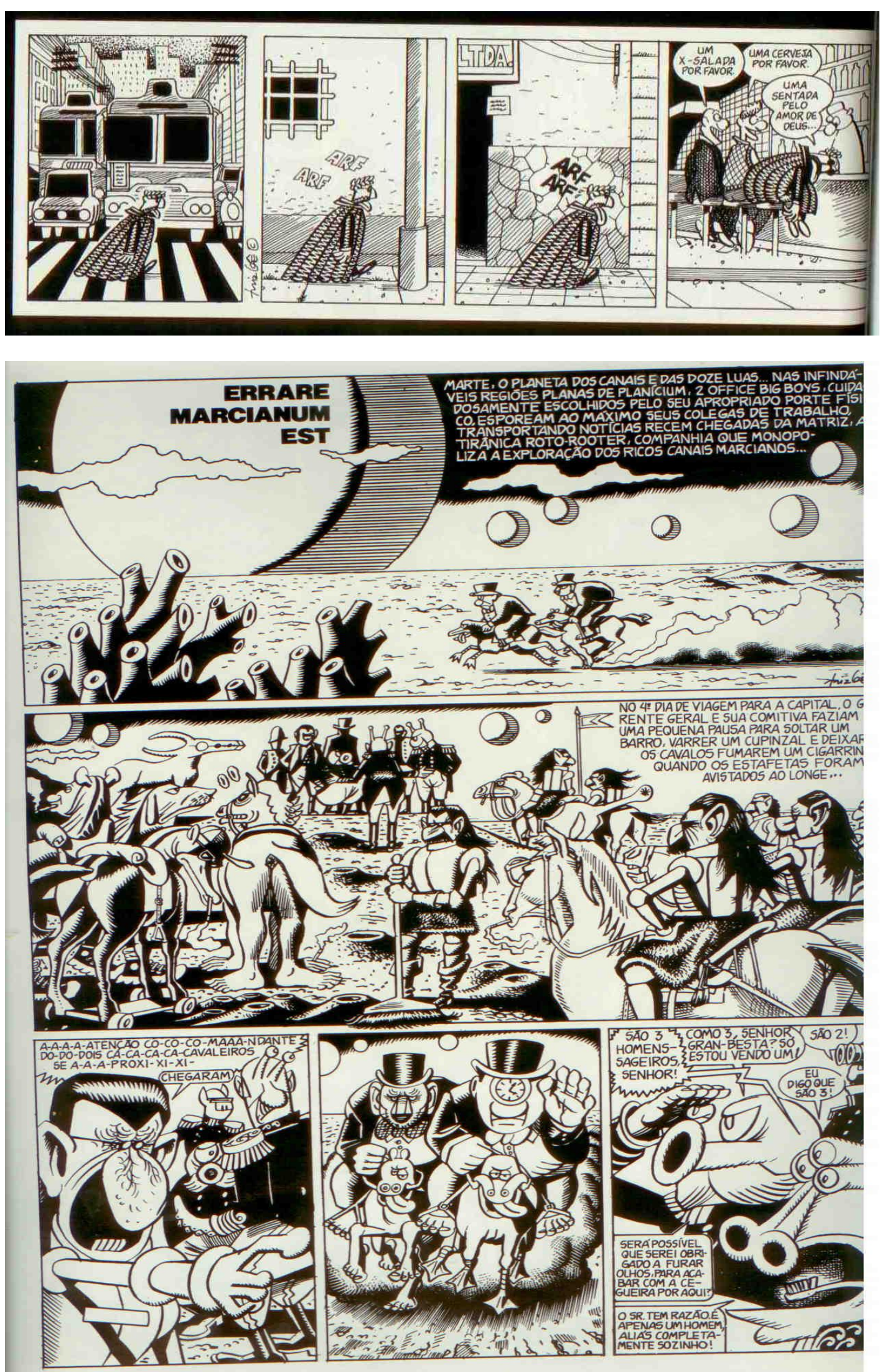

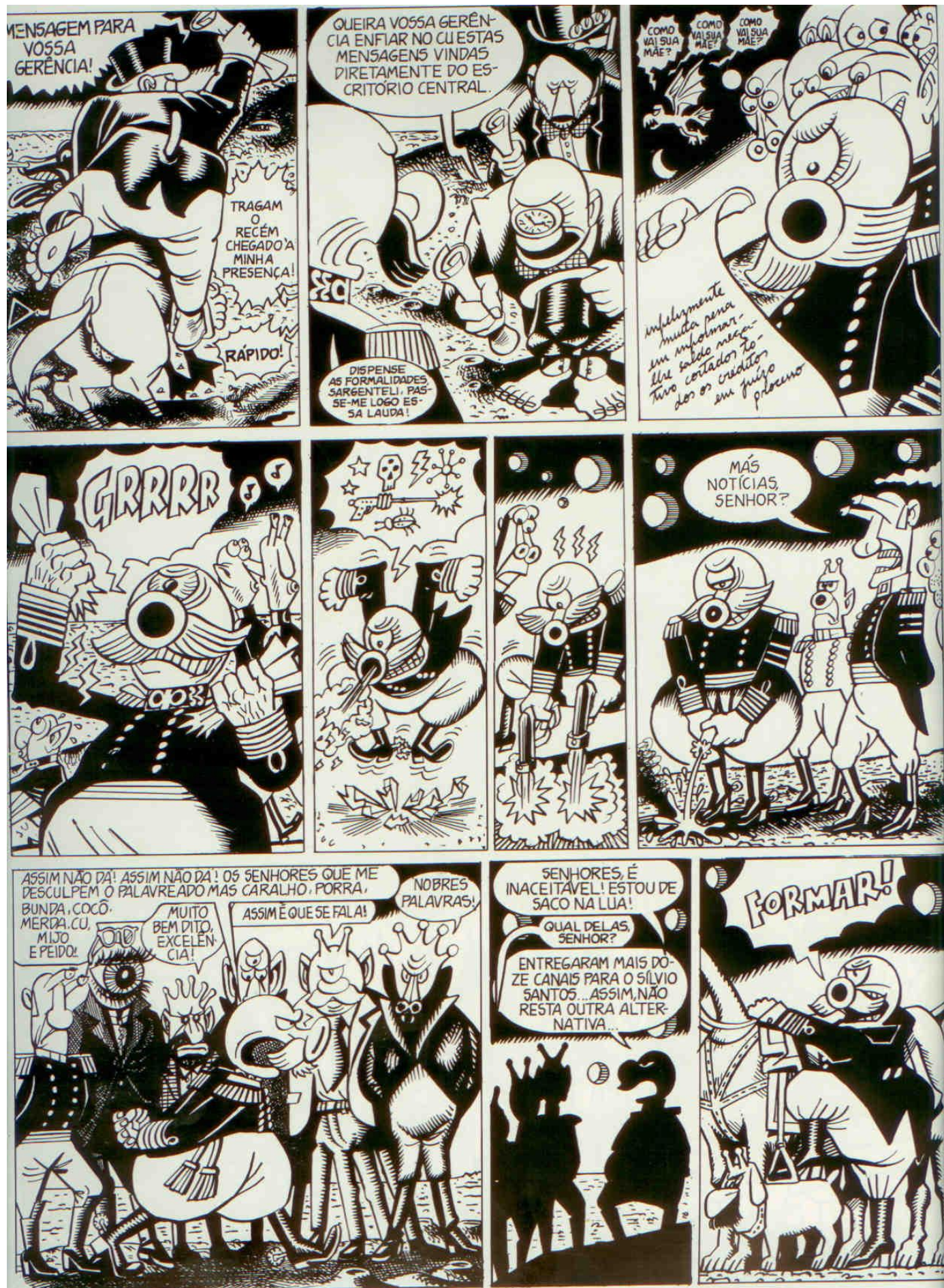


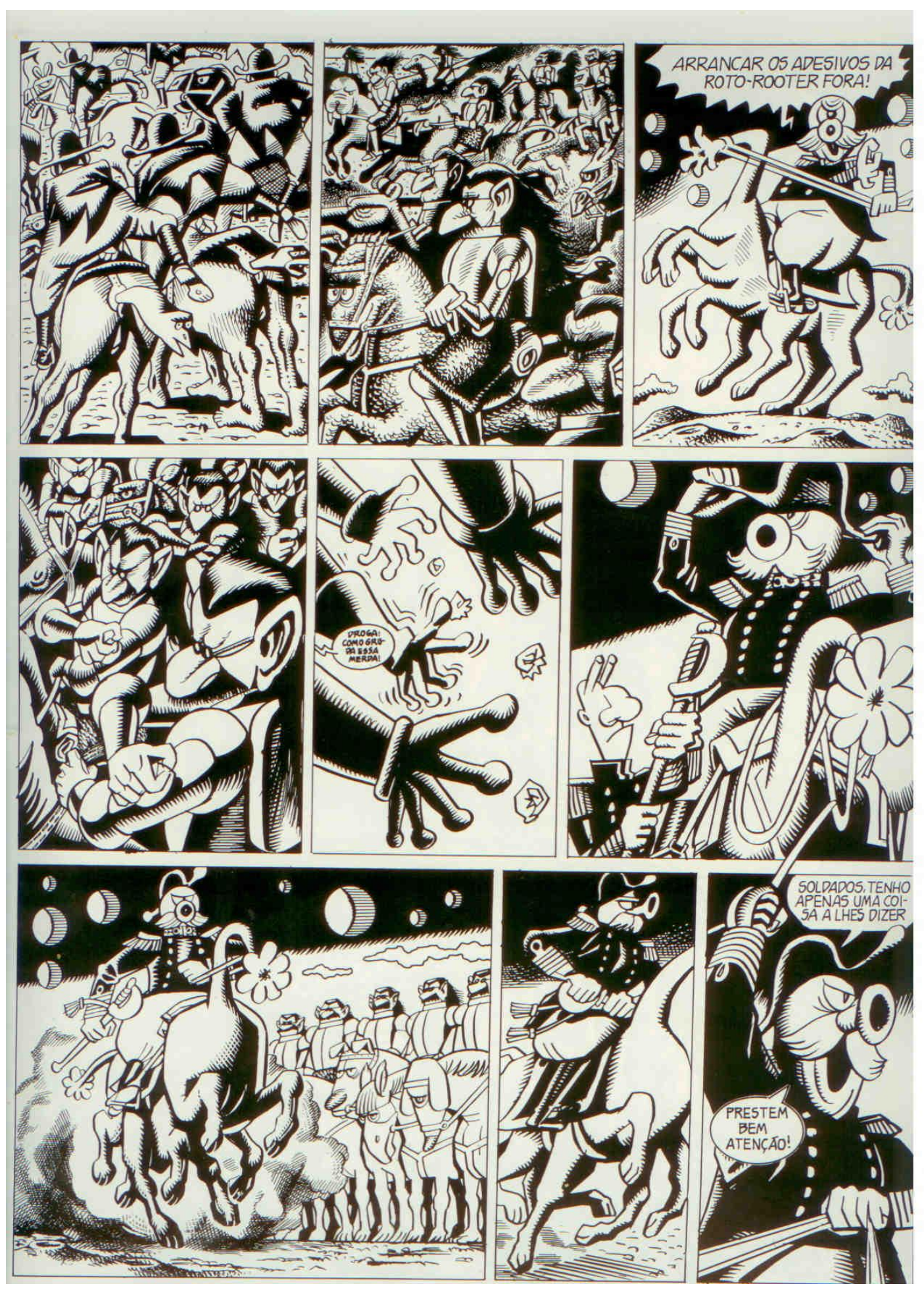




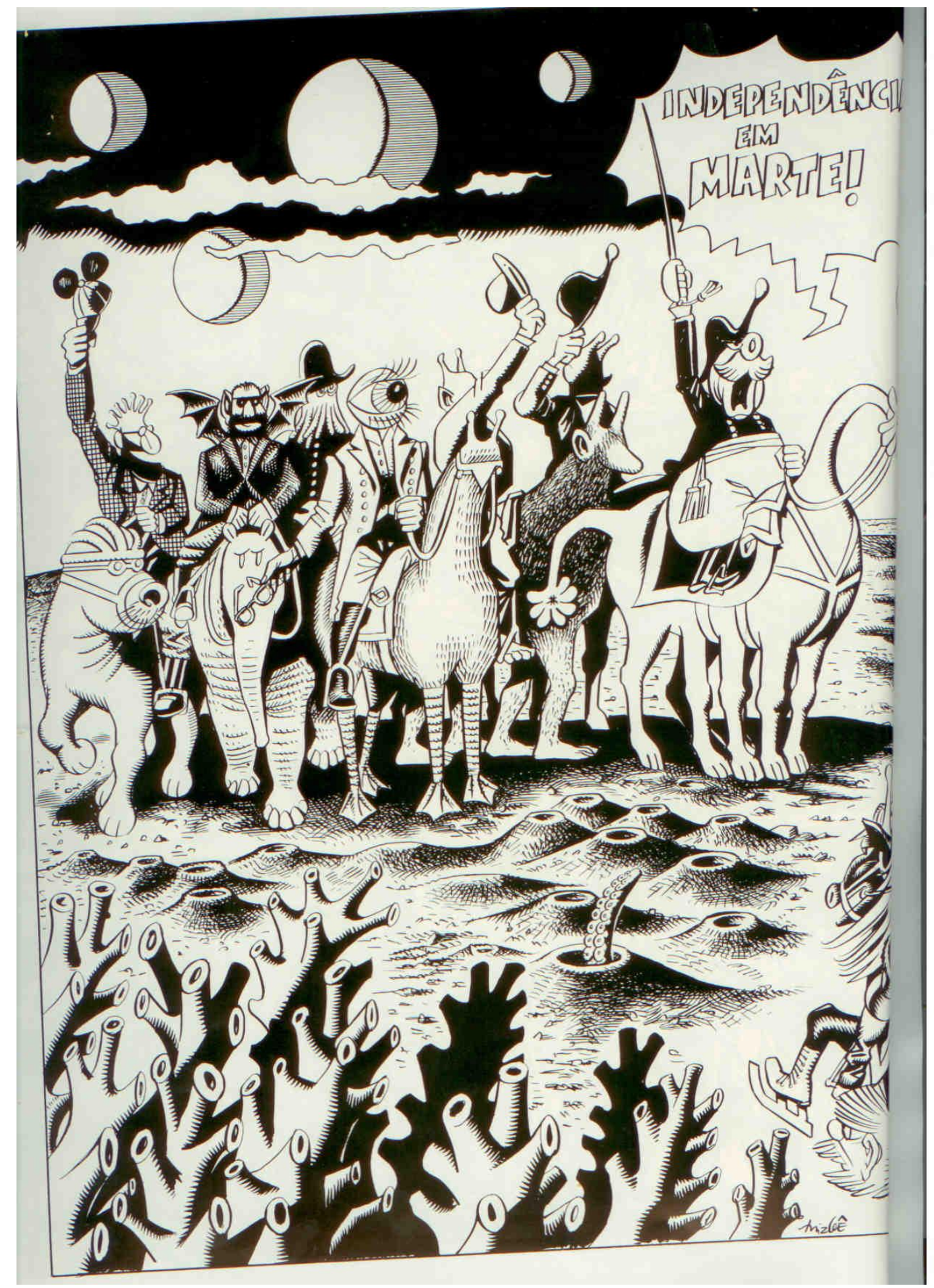




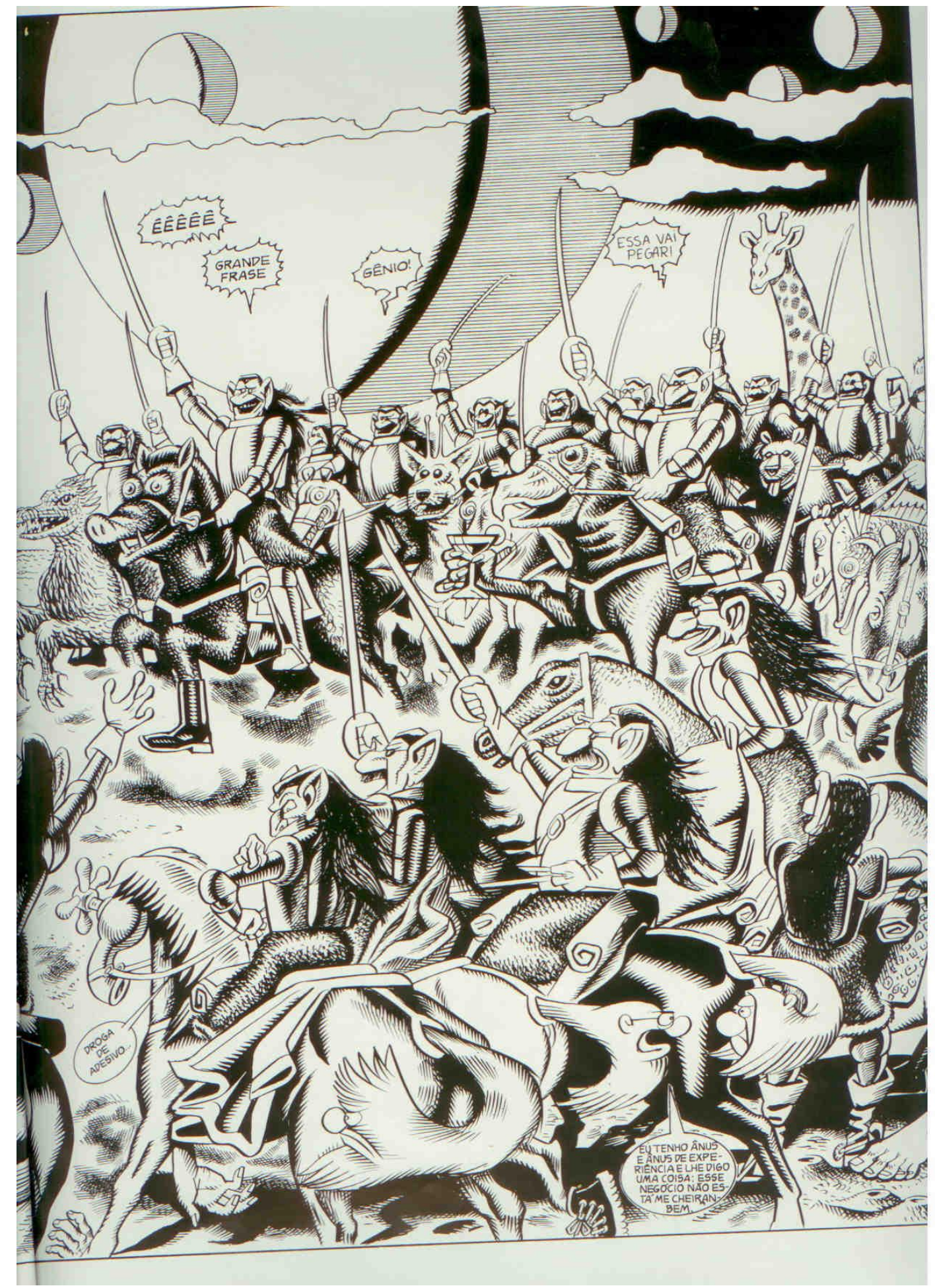




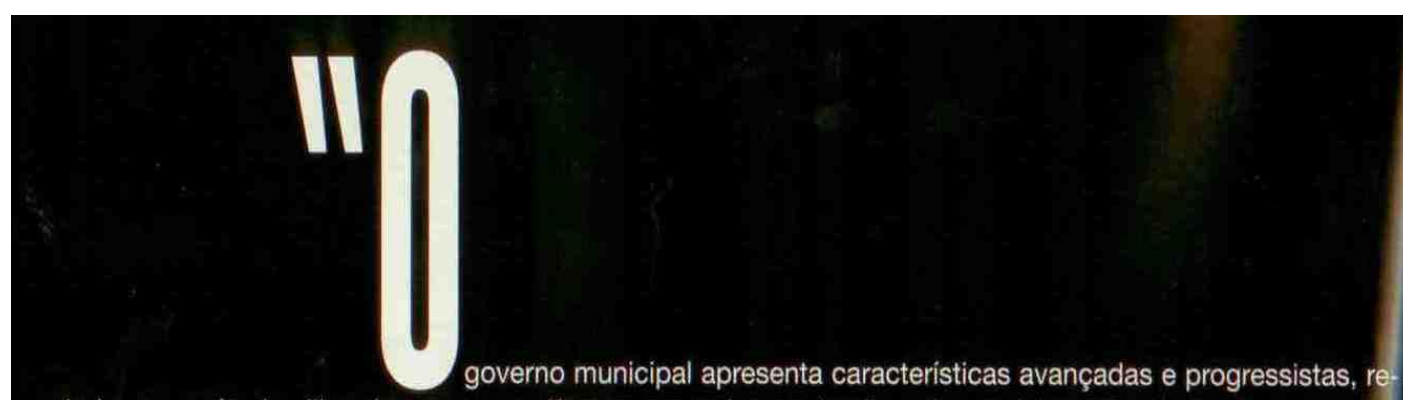
veladas por métodos liberais que se manifestam em todos os detalhes da administração. A cidade é uma das maiores e mais atraentes do Brasil, sendo notável por seus belos edificios públicos, parques bem conservados e lindos bairros. (...) Carro-chefe das atividades educacionais no Brasil, São Paulo é essencialmente uma "cidade colegial", mantendo aproximadamente oitocentas instituiçöes de ensino. (...) Como em muitas cidades col giais, as ruas são embelezadas por numerosas árvores frondosas e os parques provocam a admiração geral, po sua aparência convidativa."

Marie Robinson Wright, 1902

"(...) logo à primeira vista, em São Paulo, nos impressiona muito agradavelmente o esmero das construções. Há nesta cidade uma orientação artística, um bom gosto geral, que faz com que ela seja, nos seus monumentos e nas suas habitações, nas suas casas e nos seus palácios, na arquitetura pública e na arquitetura particular, uma cidade atraente, belamente edificada... (...) Há muito que admirar e bastante que aprender. Uma volta pachorrenta por ai fora dá a idéia de se estar folheando um álbum vistoso de edificação moderna. (...) São Paulo desdobra, como folhas de álbum, as suas vistosas, as suas diverissimas construções que, unidas aos seus suntuosos edificios públicos (...) transformam, semeadas por essas ventiladas e ajardinadas avenidas, em saboroso prazer o passear, e devem tornar em felicidade viver nelas e sonhar nas noites de bruma desta amável e gentilissima cidade da garoa."

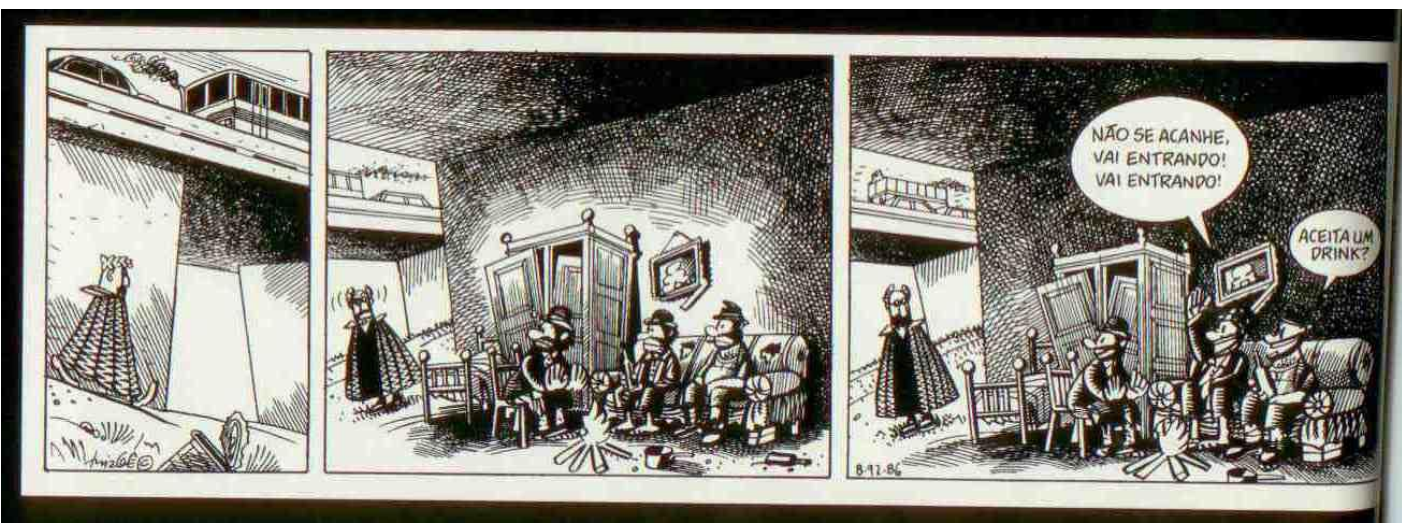




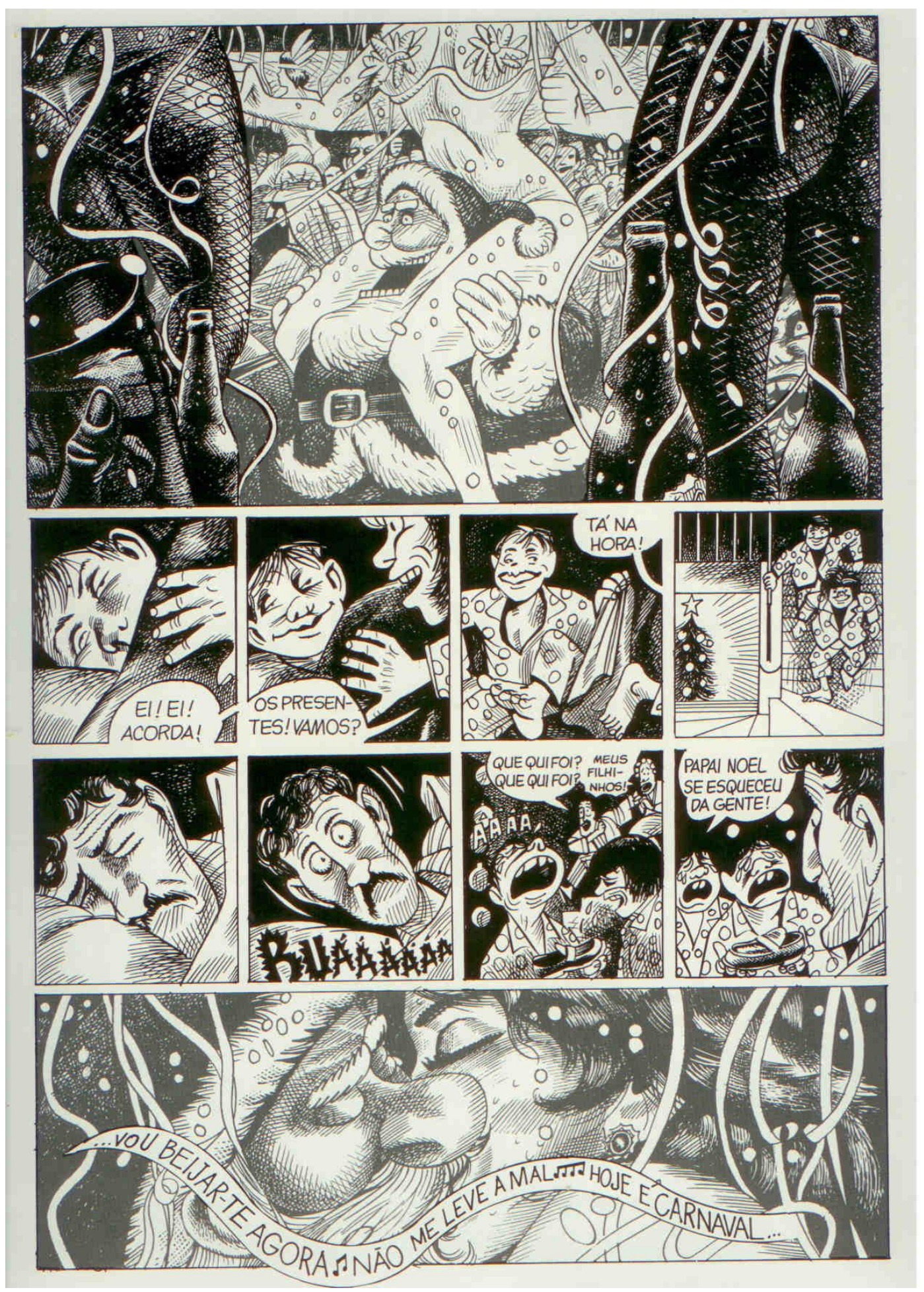




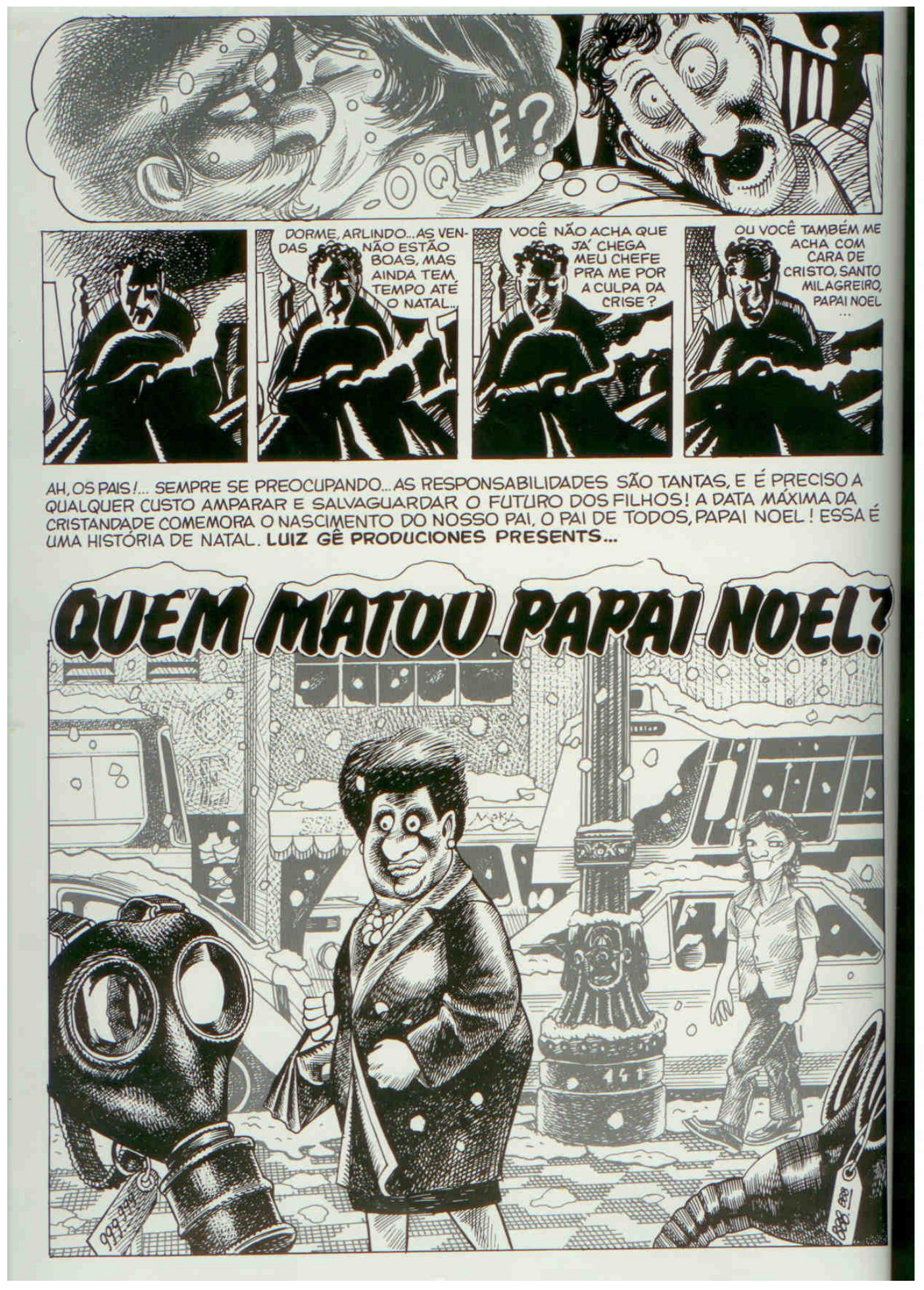




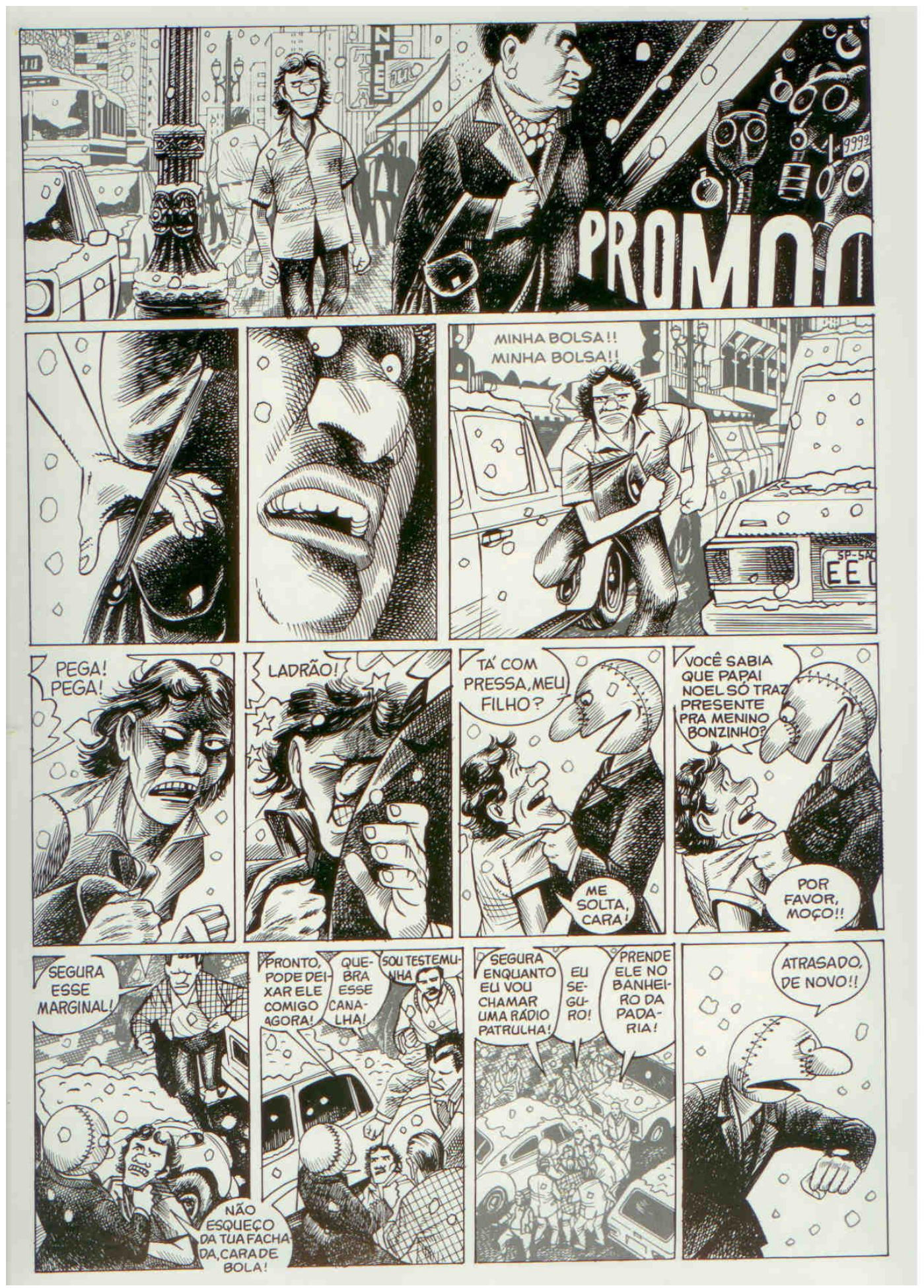




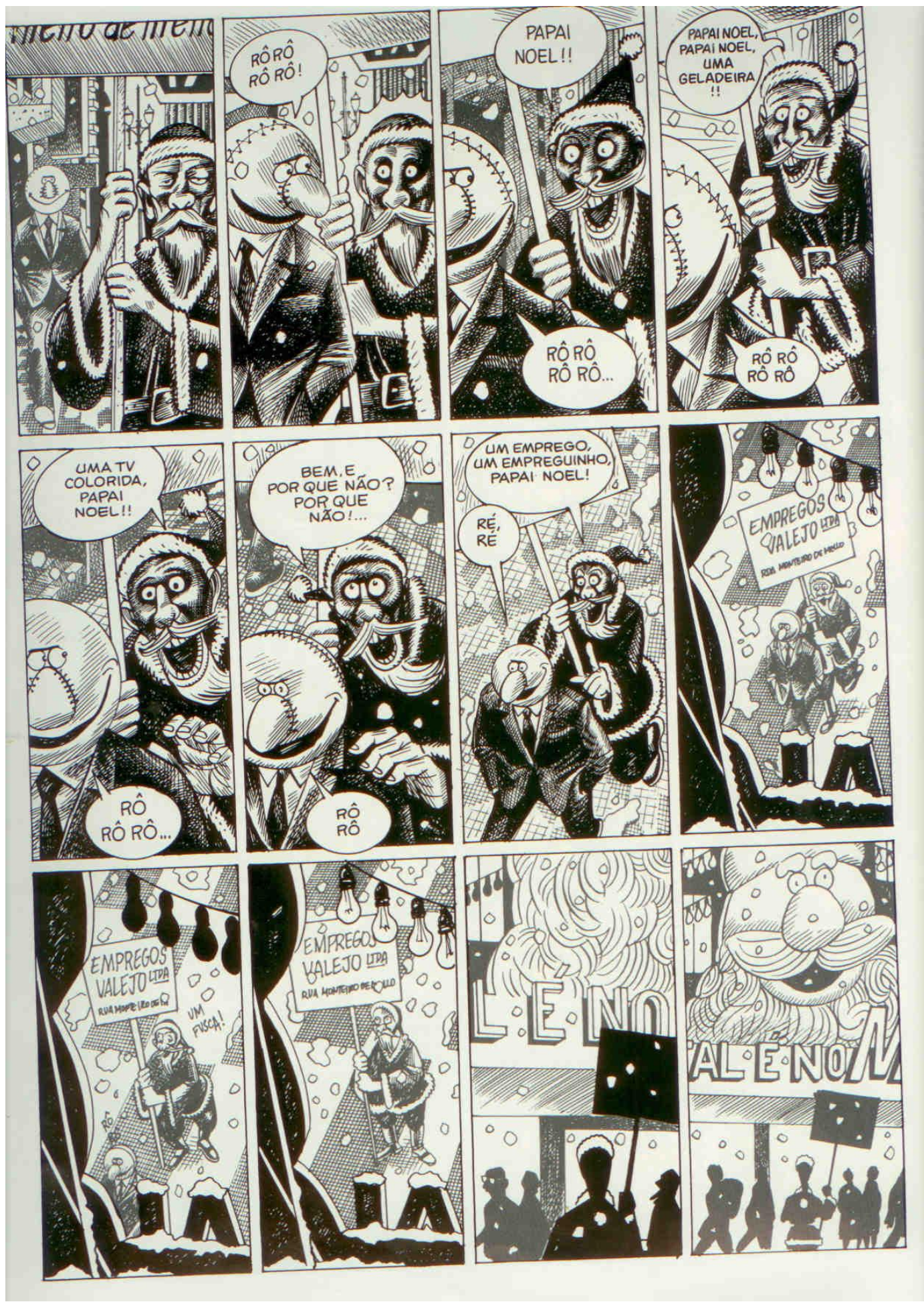




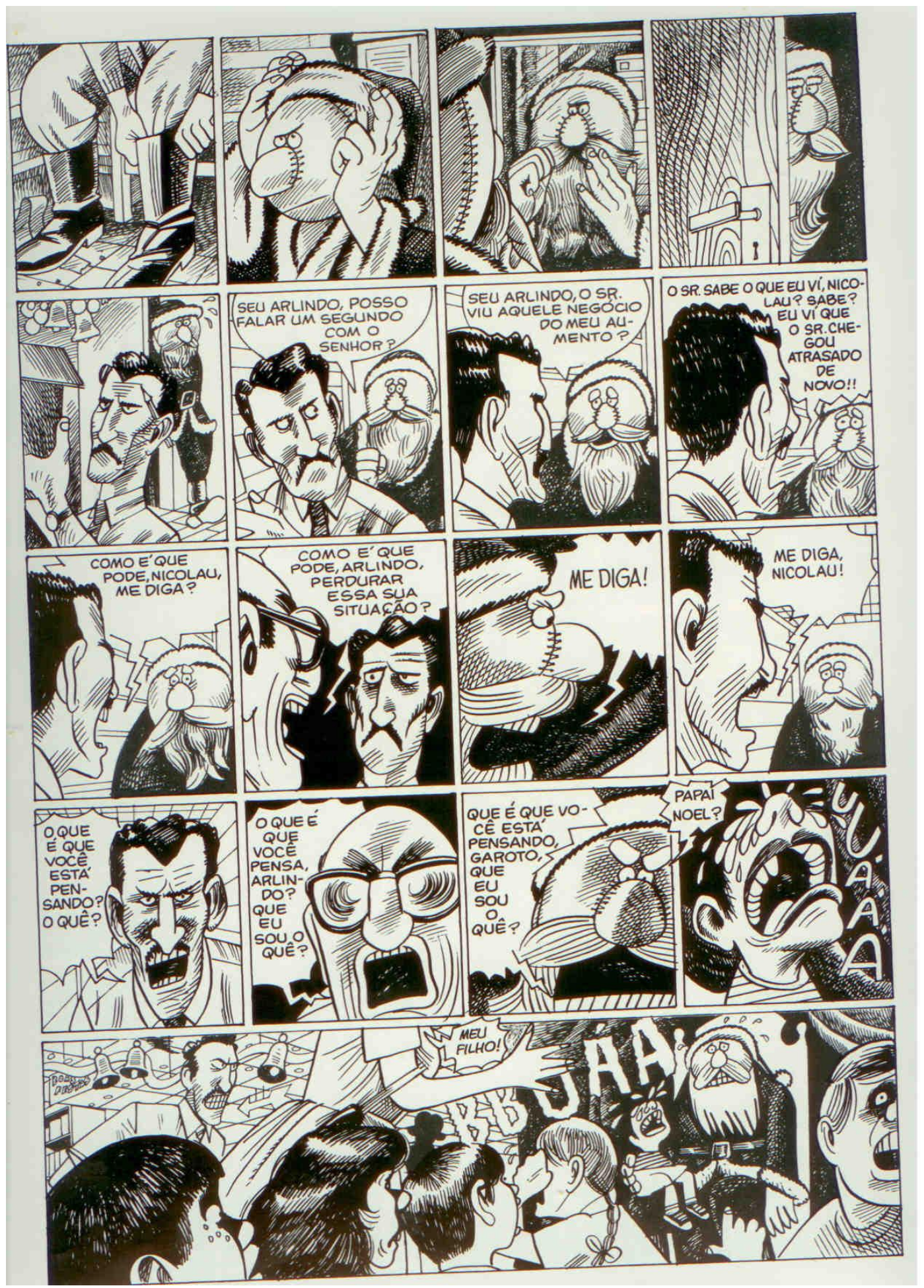




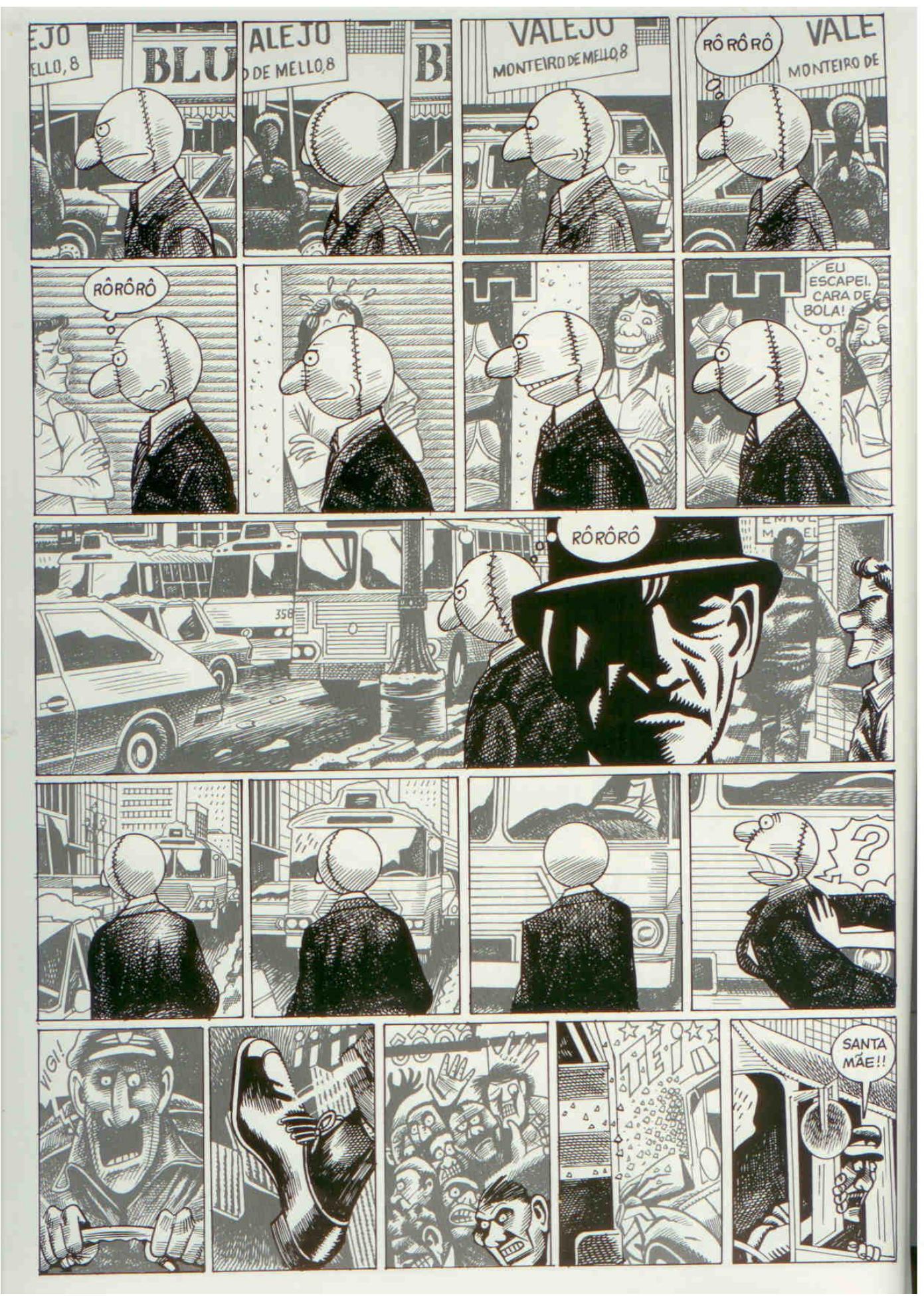




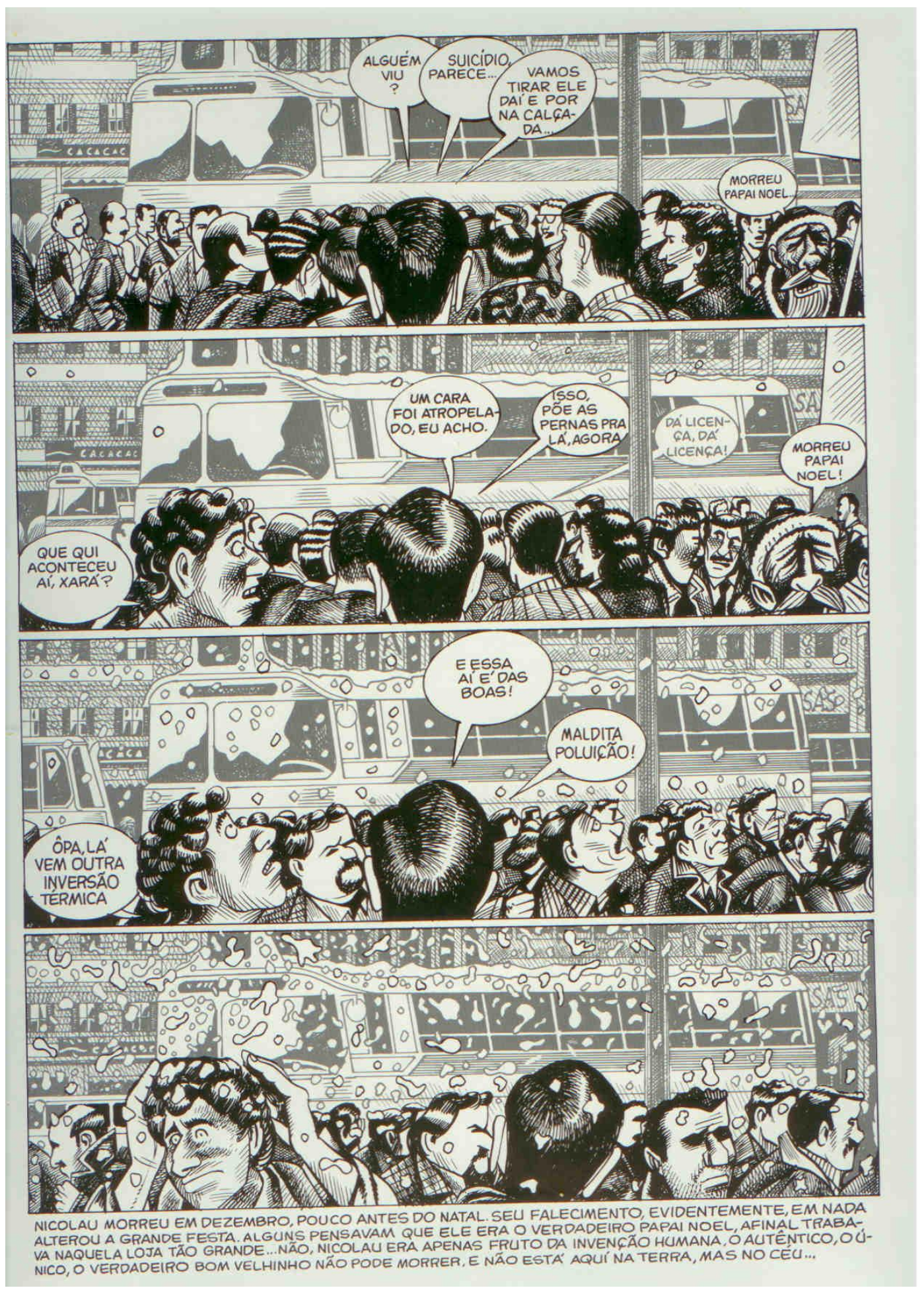




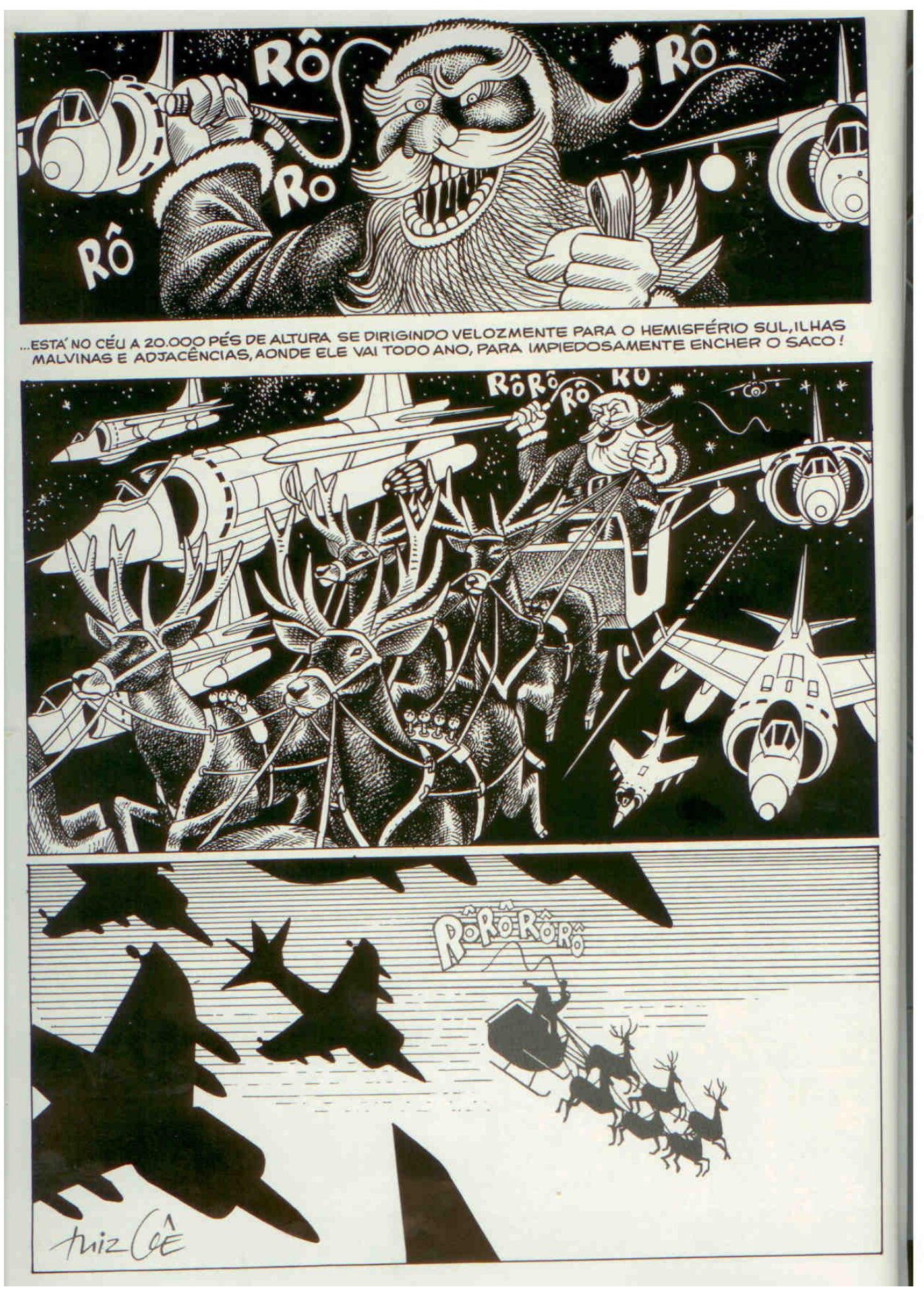




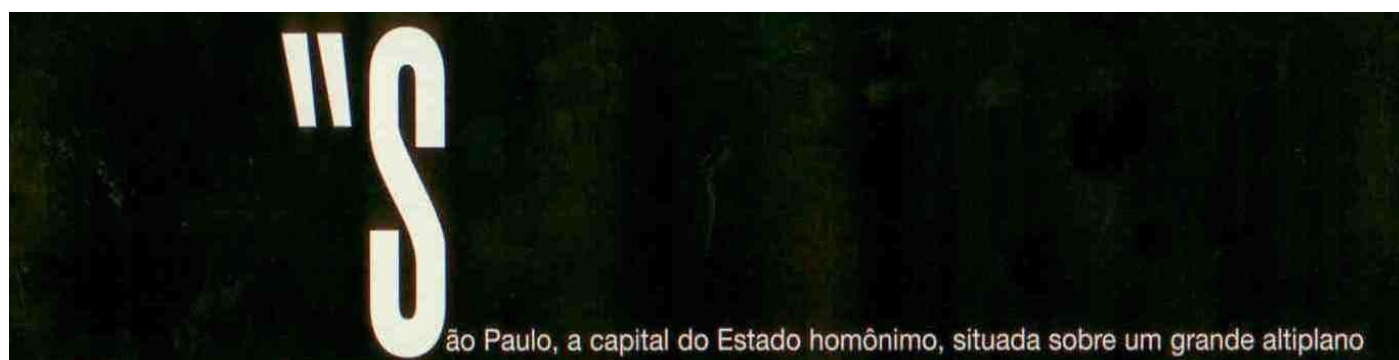
ondulado que dá a impressão de se estar nos arredores de Florença, desperta a admiração de todos os brasileiros, embasbacados e orgulhosos de terem, também eles, uma cidade 'americana', isto é, imbuida daquele espirito de orgulho, de empreendimento, de ardor, de atividade incessante que falta às antigas capitais brasileiras."

"Capital do Estado do mesmo nome, São Paulo classifica-se como a segunda cidade do Brasil e a terceira de toda a América Latina. E isto não é mero bairrismo, mas sim um fato reconhecido, que refuta a idéia de que os brasileiros não podem fazer o que seus vizinhos já fizeram - construir uma cidade que até mesmo a civilizada Europa não se envergonharia de possuir. (...) A sociedade de São Paulo é, portanto, tão cosmopolita quanto qualquer idealista poderia sensatamente desejar. Mas o dinheiro, como em todos os países republicanos, é a lei."

Domville-Fife, 1909

"São Paulo é, sem contestação, a cidade mais ativa do Brasil; pode-se dizer que ela é sua capital comercial e industrial. Sem dúvida seu desenvolvimento tem sido algo de muito precoce, digamos, de muito americano."

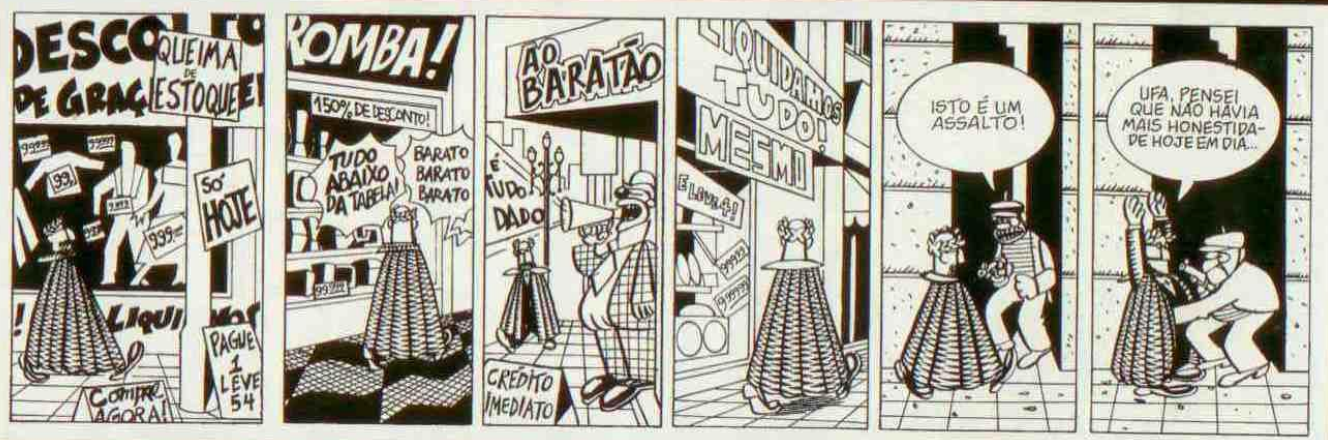




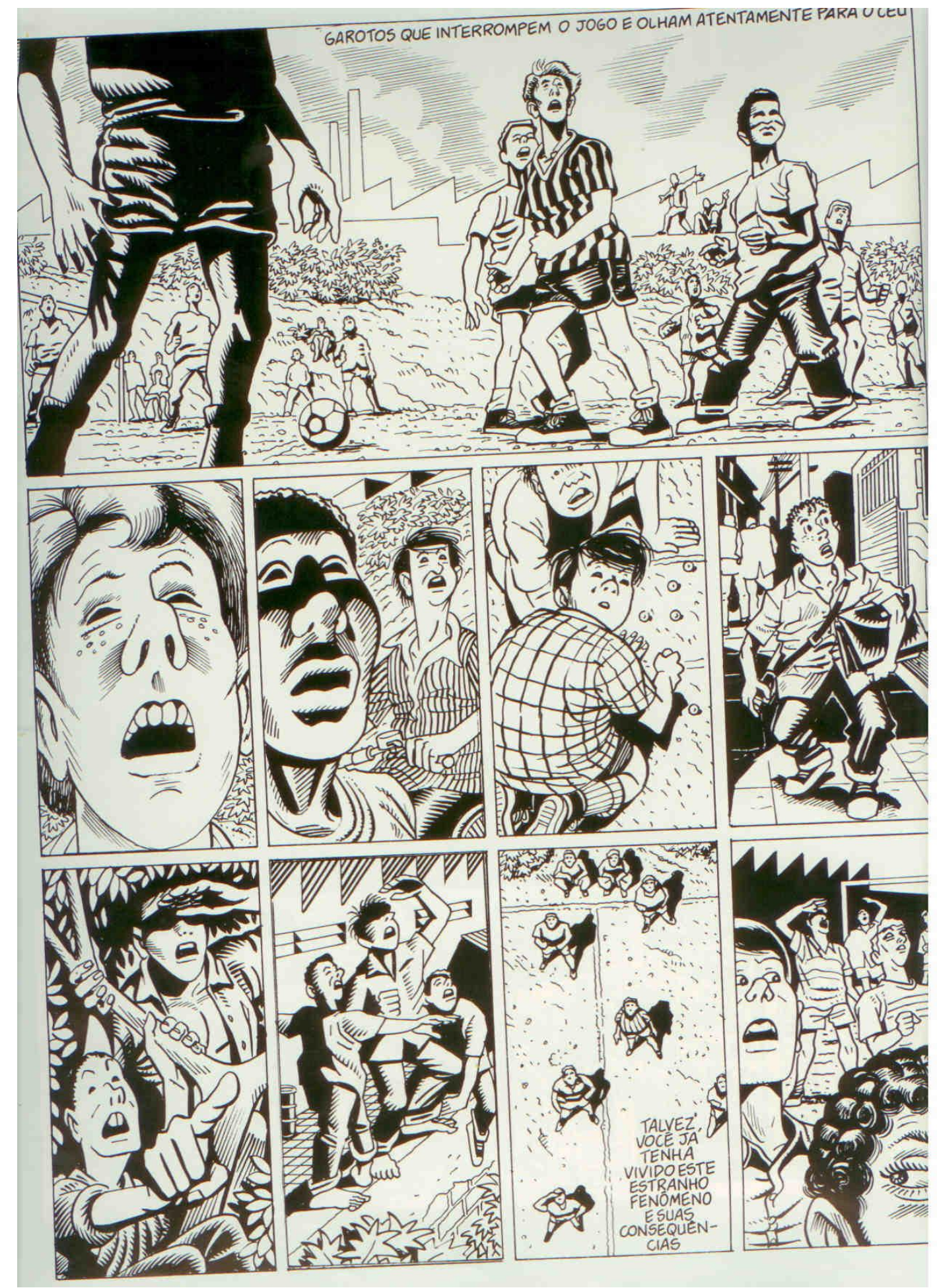




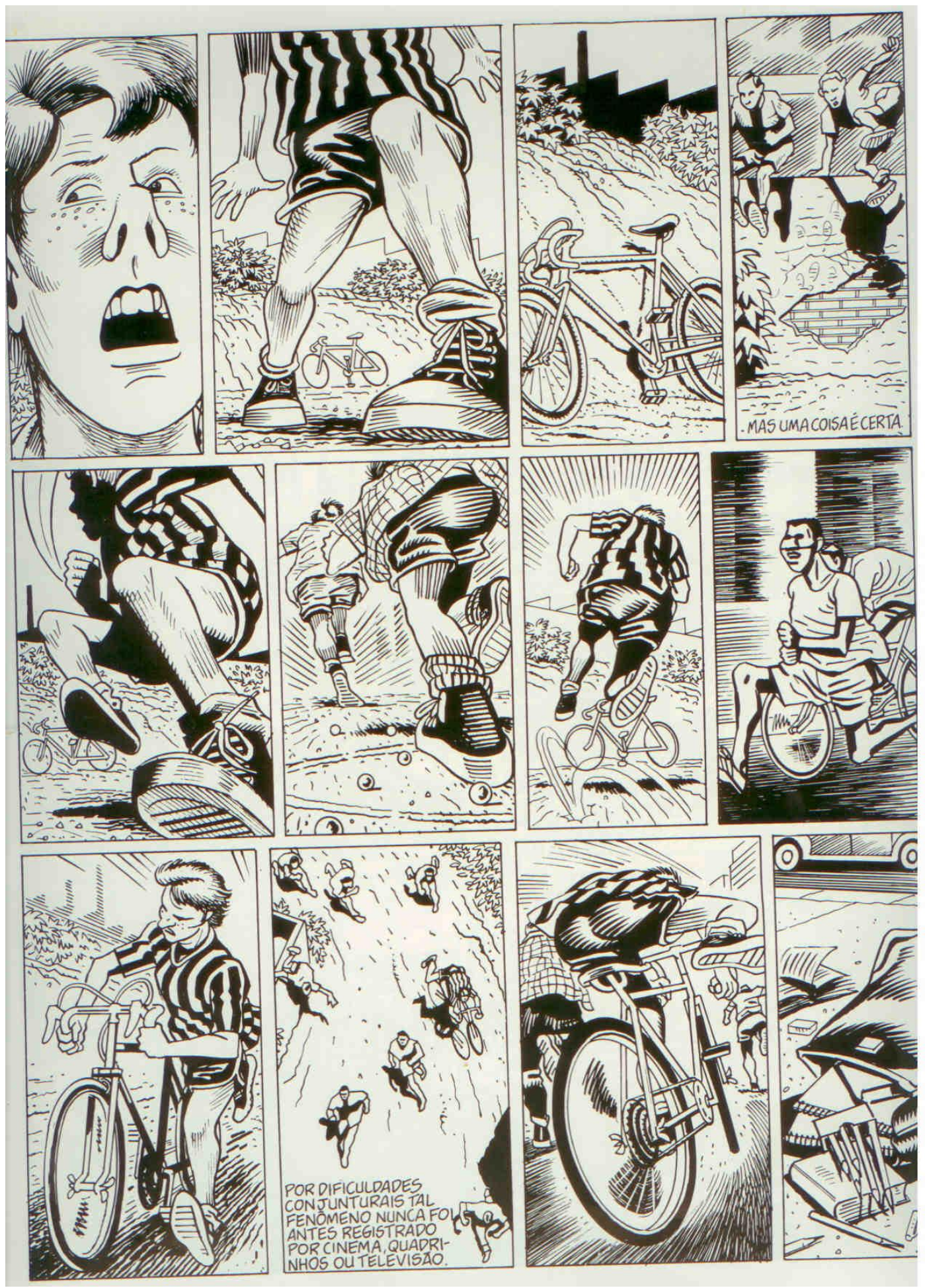




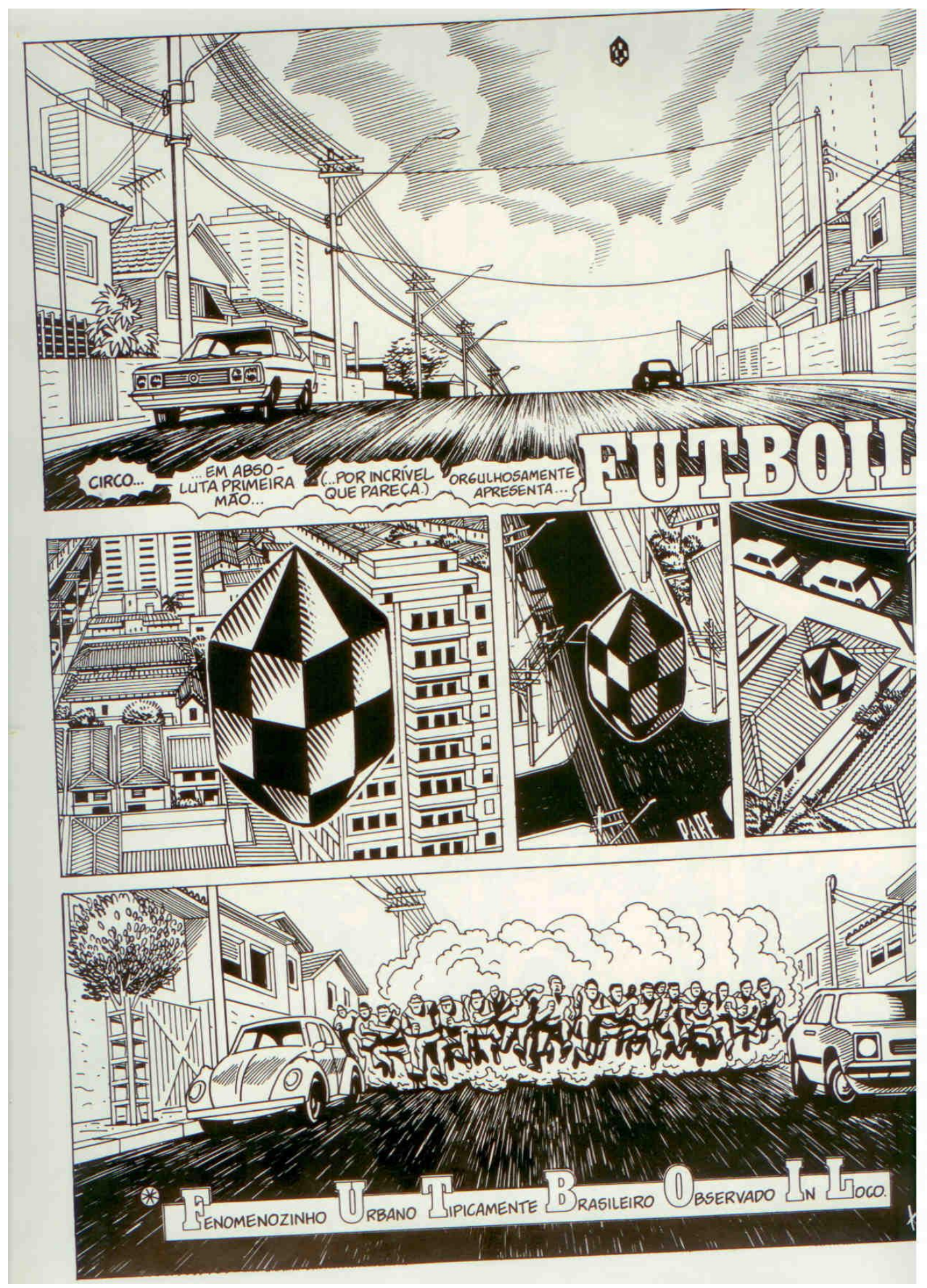




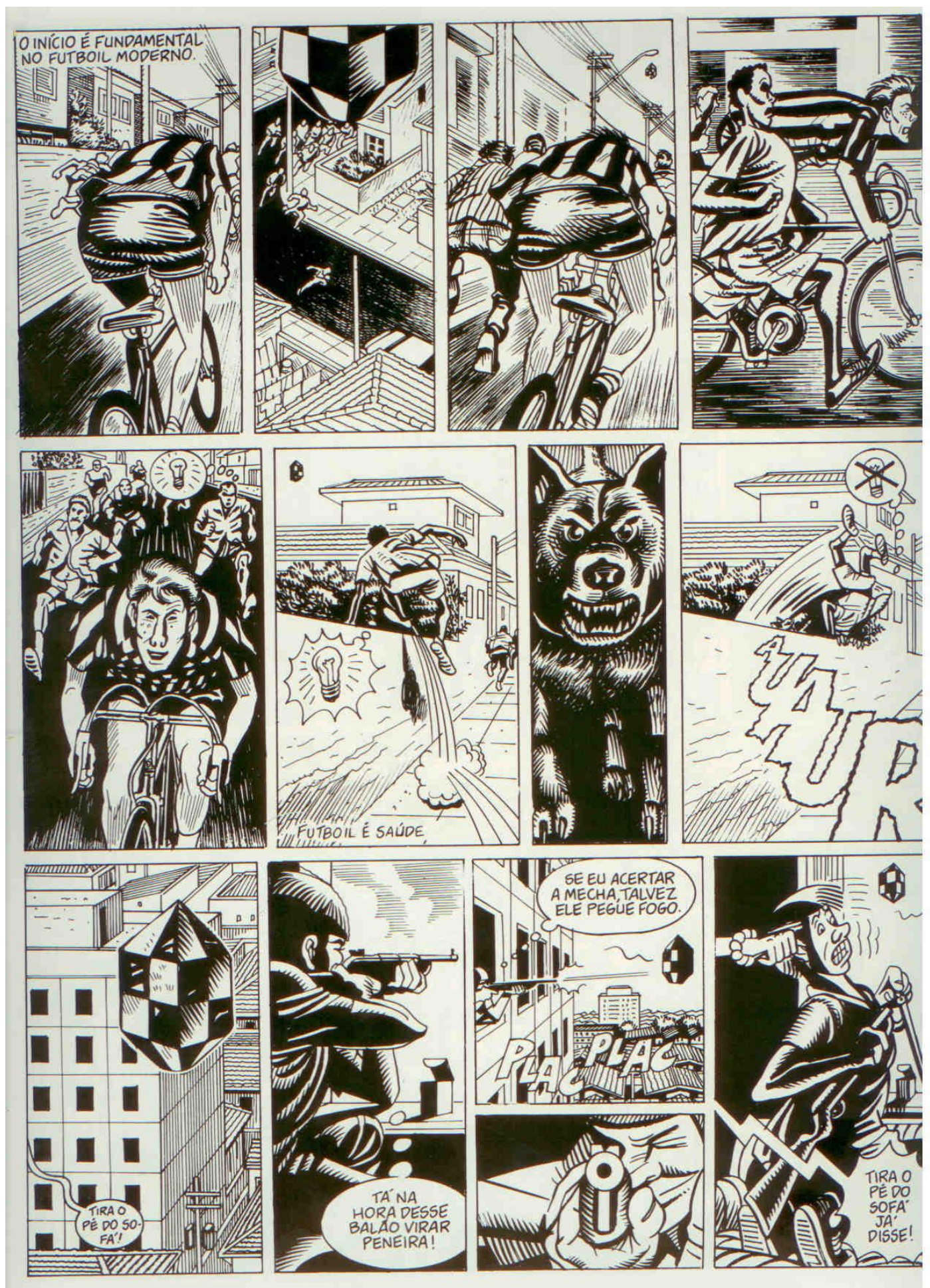




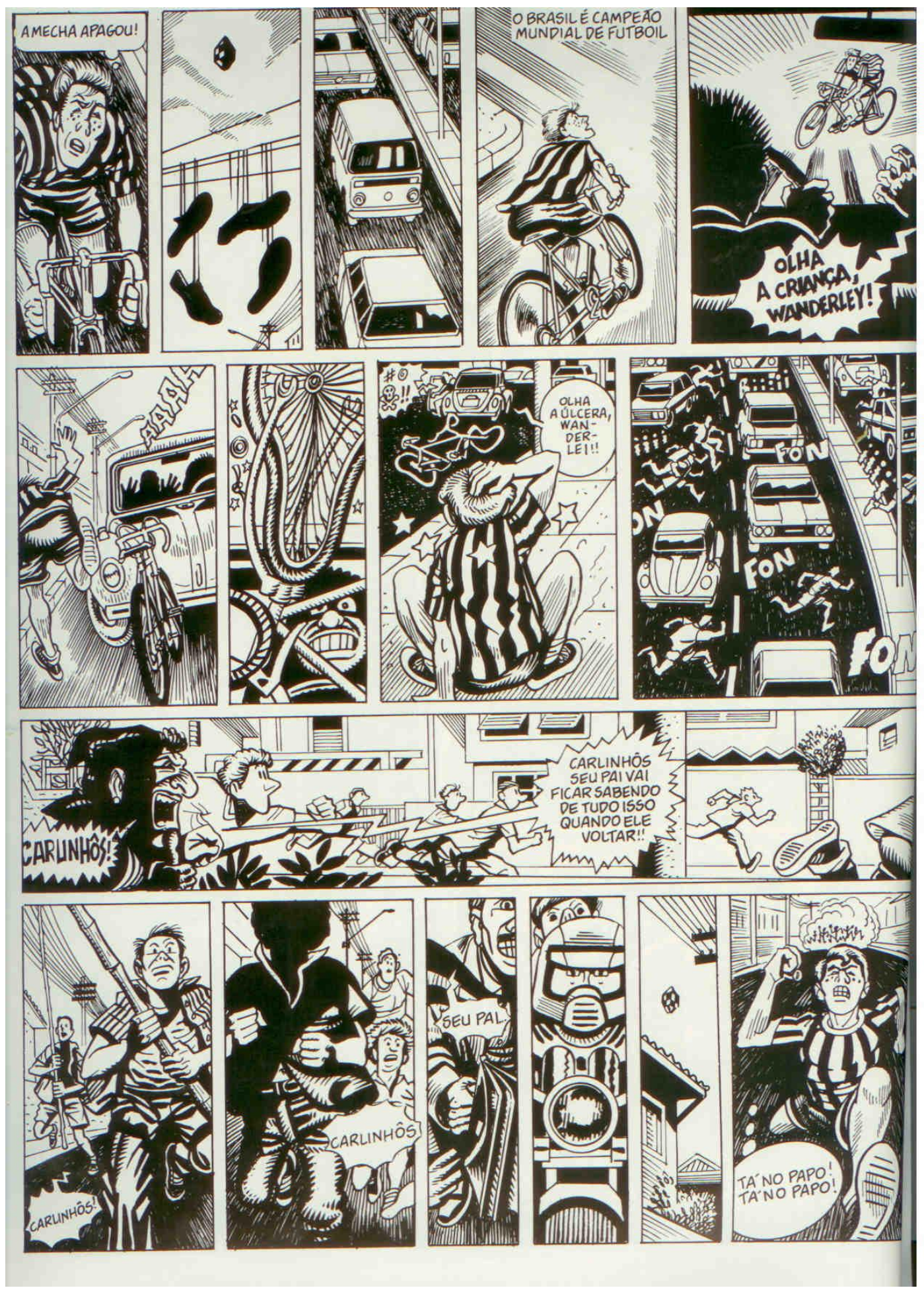




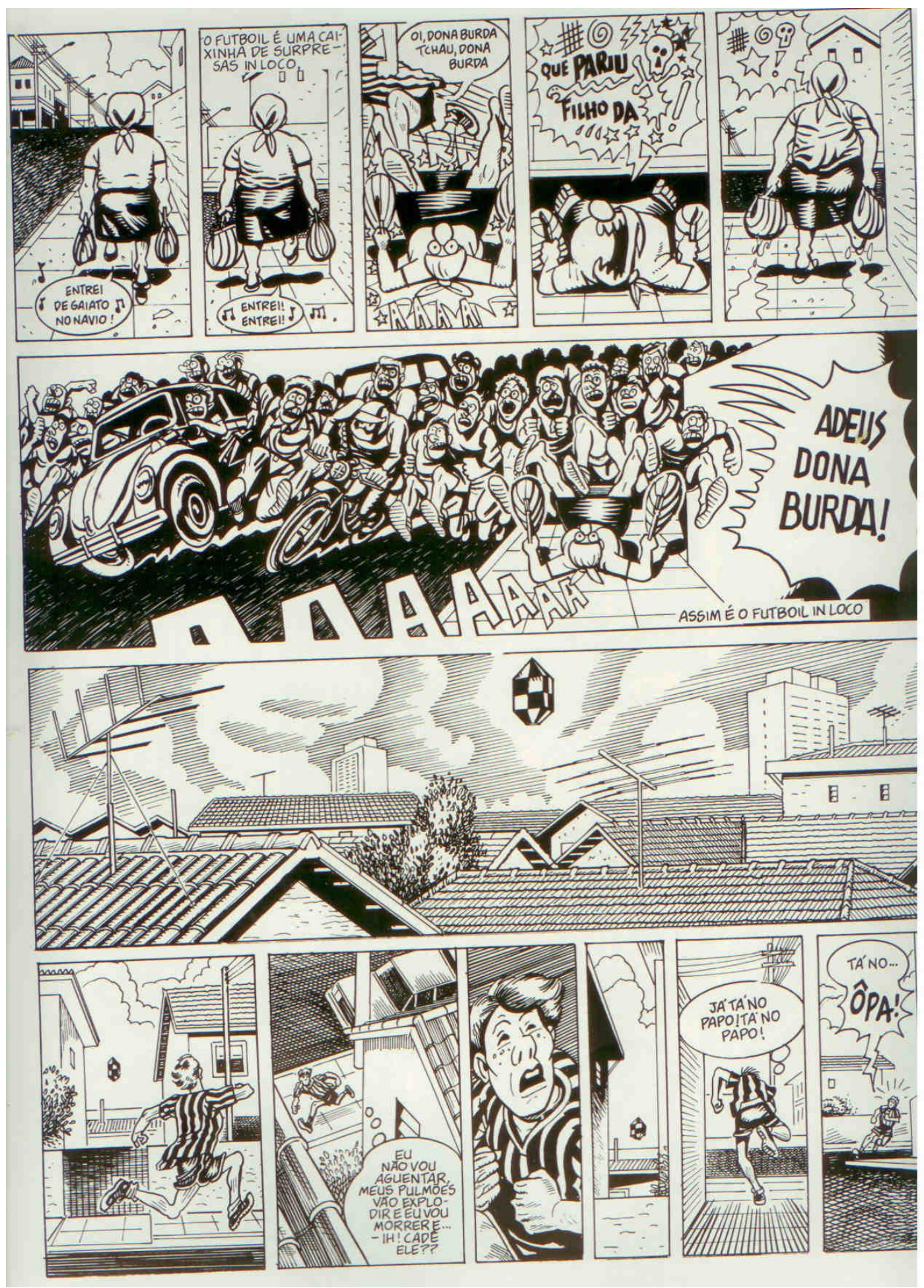




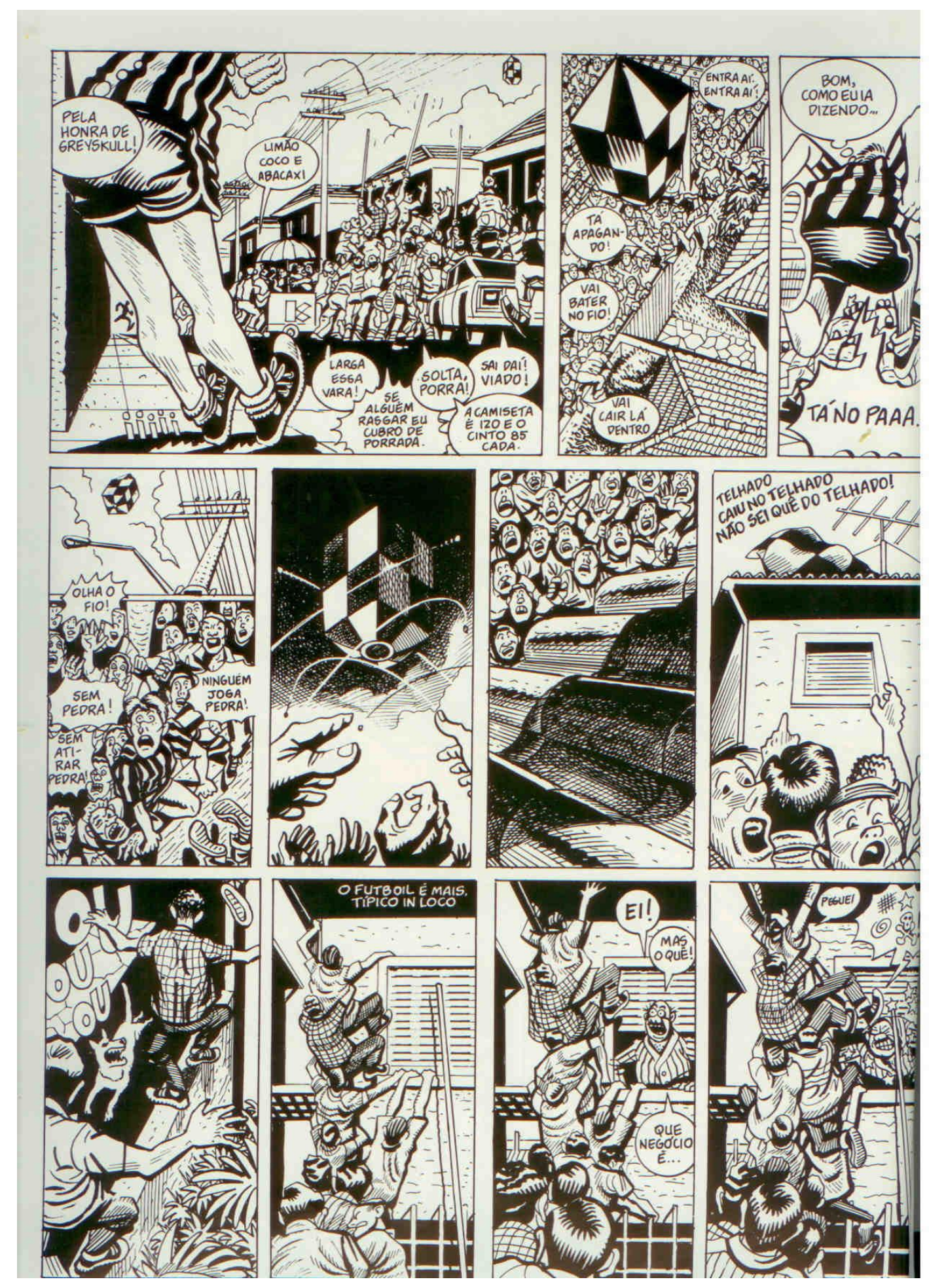




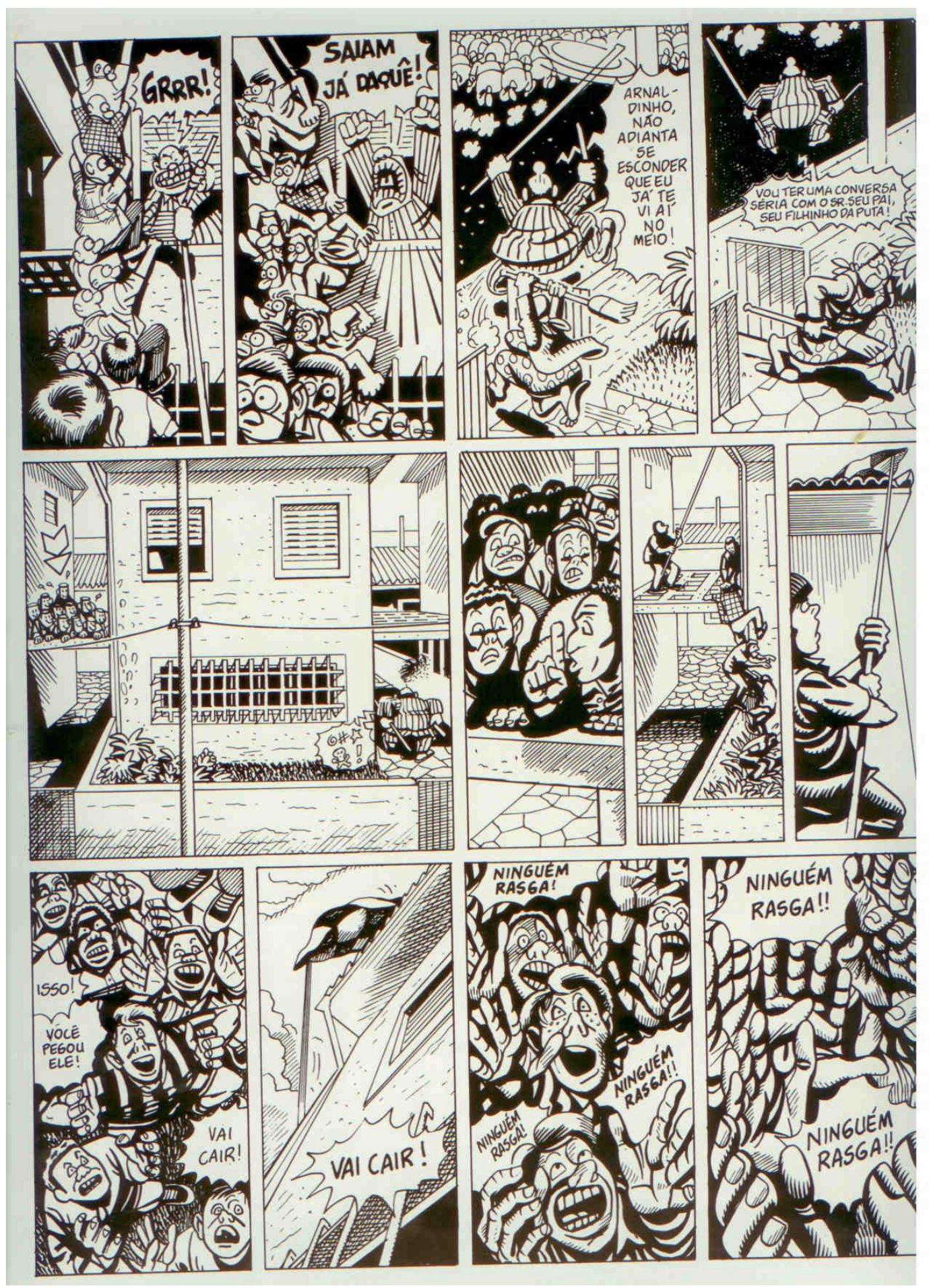




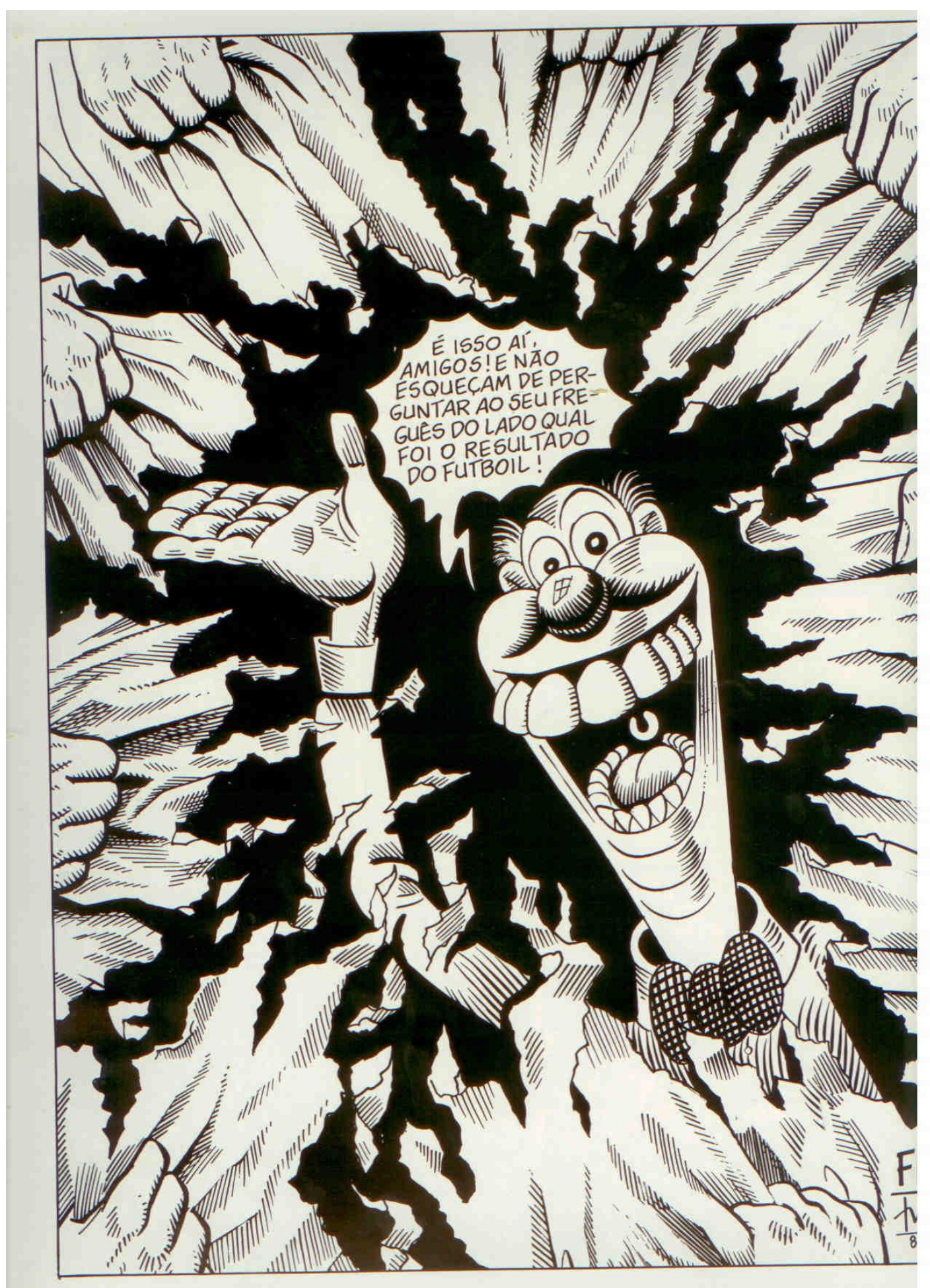




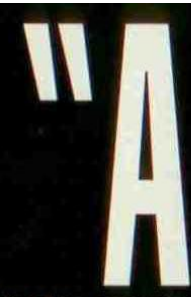

impressão que se recebe, ao chegar a São Paulo, é estupenda: por toda parte vêem-se ruas arborizadas, passeios, parques, jardins bem conservados, onde as crianças brincam alegremente sob a vigilância das pajens. Há, por toda parte, uma profusão de casas brancas, iluminadas pelas torres e cúpulas que Ihe infundem o aspecto de Nice ou de uma cidade italiana."

"(...) bom gosto e harmonia são dignos das mais nobres cidades da Europa. (...) De passagem, admiro a decoração vegetal que a municipalidade dispôs por todos esses bairros novos. Não creio que haja duas avenidas próximas ornamentadas com as mesmas árvores. Plátanos do Canadá, carvalhos da Europa, lilás do Japão, substituem as essências mais notáveis do país, os gigantes de folhas envernizadas e brilhantes, com ramos multicores que resplandecem, através das ruas, como uma orgia de luz. (...) São Paulo, com seus desdobramentos recentes de parques e de propriedades opulentas, é uma das cidades mais agradáveis para se visitar. Abundam as perspectivas pitorescas; nenhuma monotonia, nenhuma fadiga (...) e esta sucessão ininterrupta de jardins."

L. A. Gaffre, 1910

"Creio que nenhuma cidade do mundo tenha tanto luxo de vegetação, tanta riqueza floral em seu centro urbano e tanta graça arquitetônica nas numerosas vilas, todas orladas de jardins perfumados, que certos bairros de São Paulo."
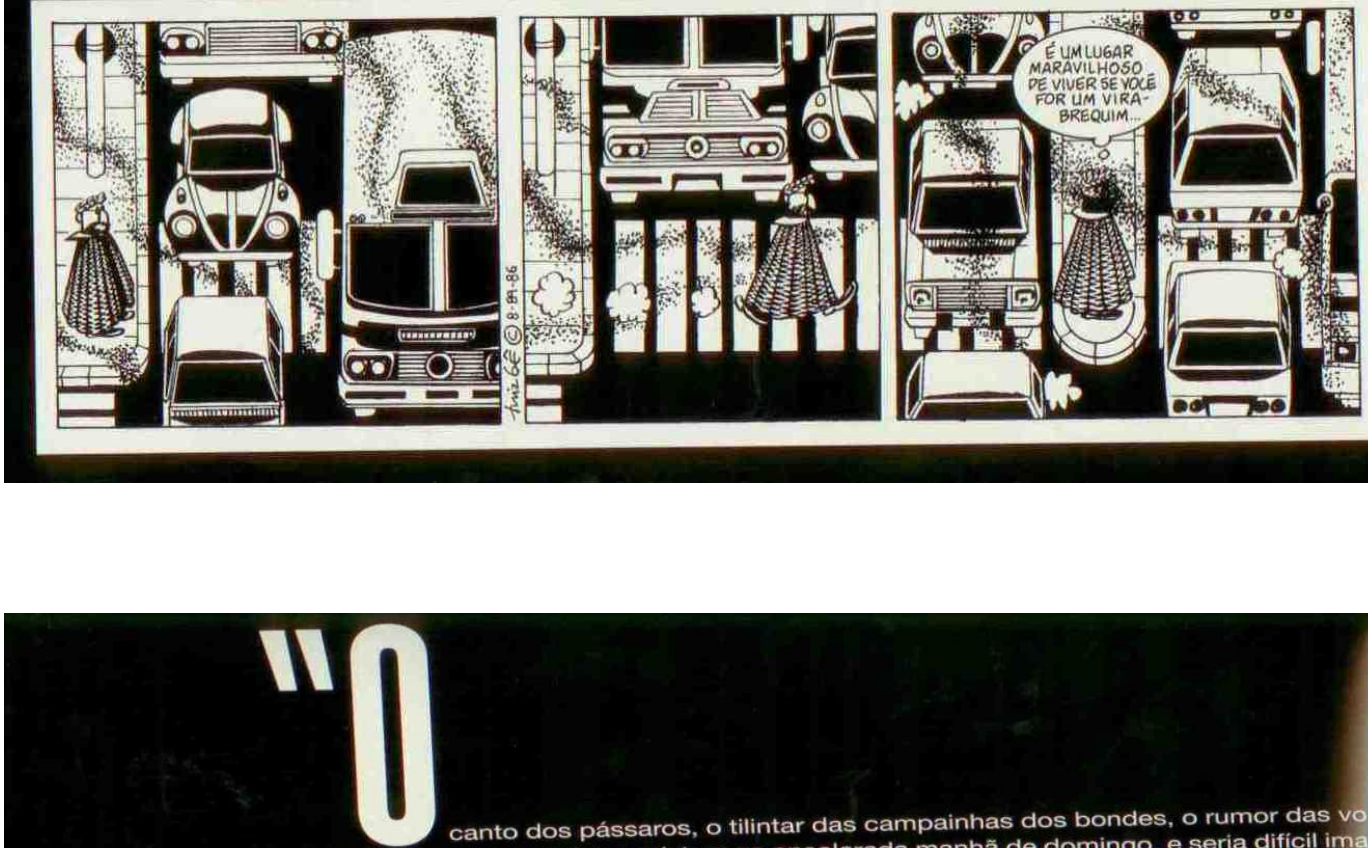

canto dos pássaros, o tilintar das campainhas dos bondes, o rumor das vo edores, tudo se mistura na ensolarada manhã de domingo, e seria dificil imaginar uma cidade e um povo mais felizes.

Do que nẫo posso me esquecer é dos jardins... O paulistano compreendeu que seu monumento natural demonstra um amor que se traduz em cuidado universal pelas plantas era a vegetação e por ela demonstre virgem, com a vantae pelas flores. (...) Em alguns locais, ele parece verdadeiramente achar-se no me das florestas ainda não tocadas gem de que a cidade próxima elimina o tédio da grave monotonia que ernerge dificação moderna; mas a bele: pelo homem. (...) Não faltam, também aqui, alguns notáveis monumentos de edirtérias, transmitem ao coraçāo

maior está no conjunto. Os novos bairros especialmente, as novas grandes arte

Ernesto Bertarelli, 1913

ins após outros, conduzindo os paulistas "Numerosos e sucessivos, os bondes elétricos apressam-se, uns após outros, conduzindo ó paurebros es que essa riqueza assalaria, exalta, honra e gratifica. Com suas palhetas e seus trajes claros, os céres legaram corações desses passantes vivem no orgulho da ciência e do poder, no orgulho da conquista que alemã, qualquer os Jesuitas, que Ihes legaram os Bandeirantes. Indigena, portuguesa, crioula, muta, na energia do seu caráter. que seja sua já remota origem, esses paulistas têm a mesma fé em seu gento coletio e na energia do seu carm. 1914 

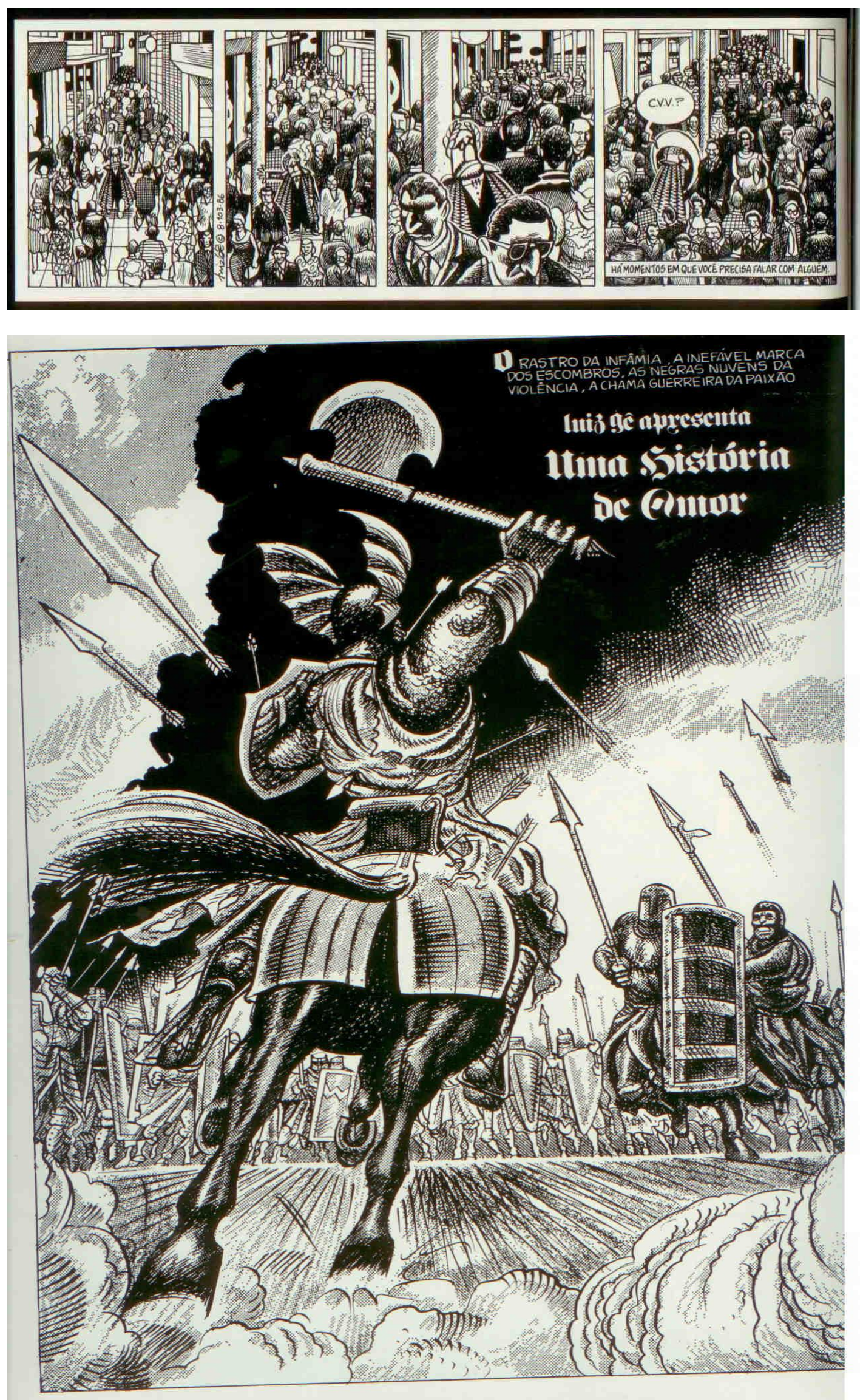


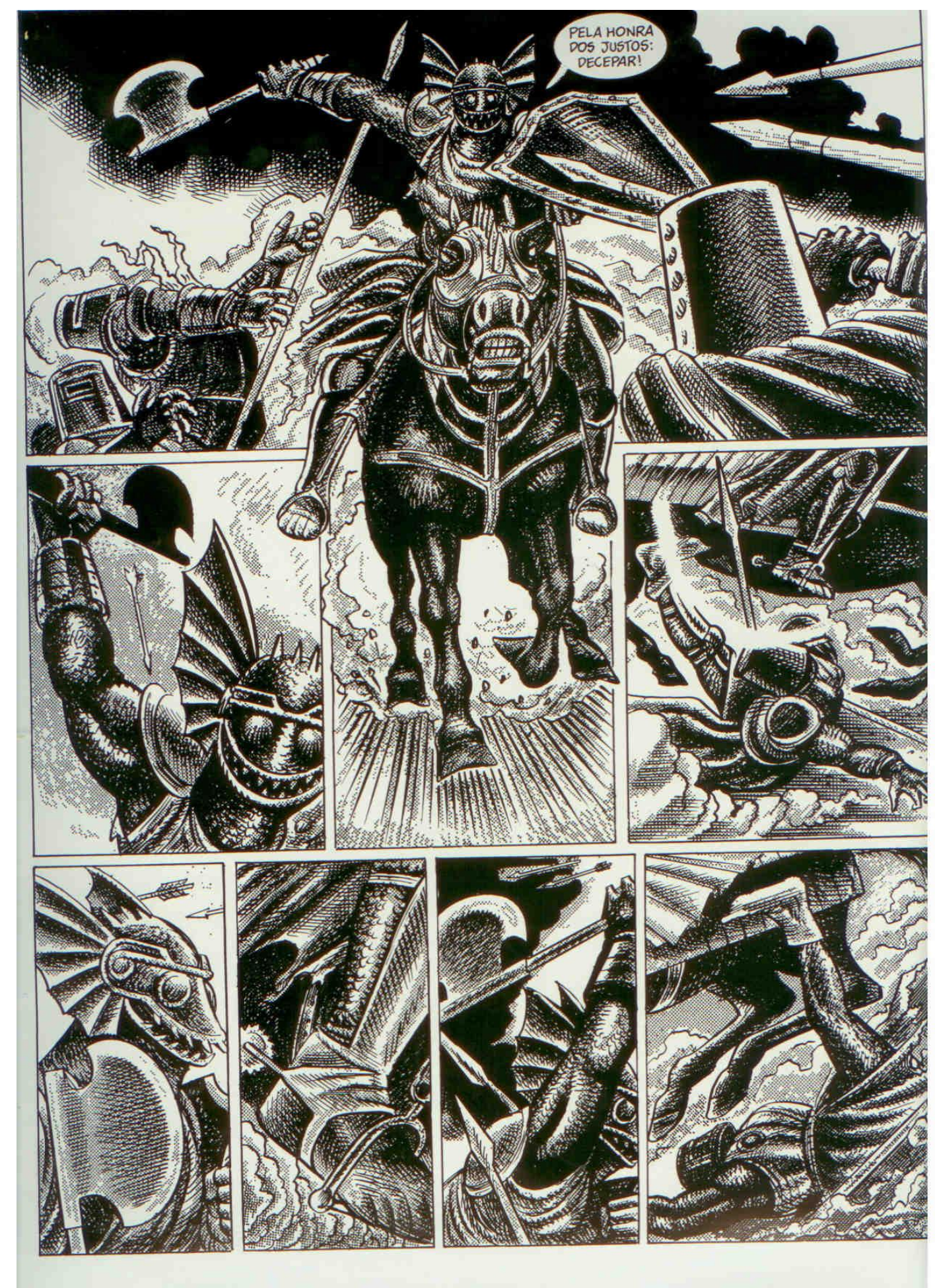



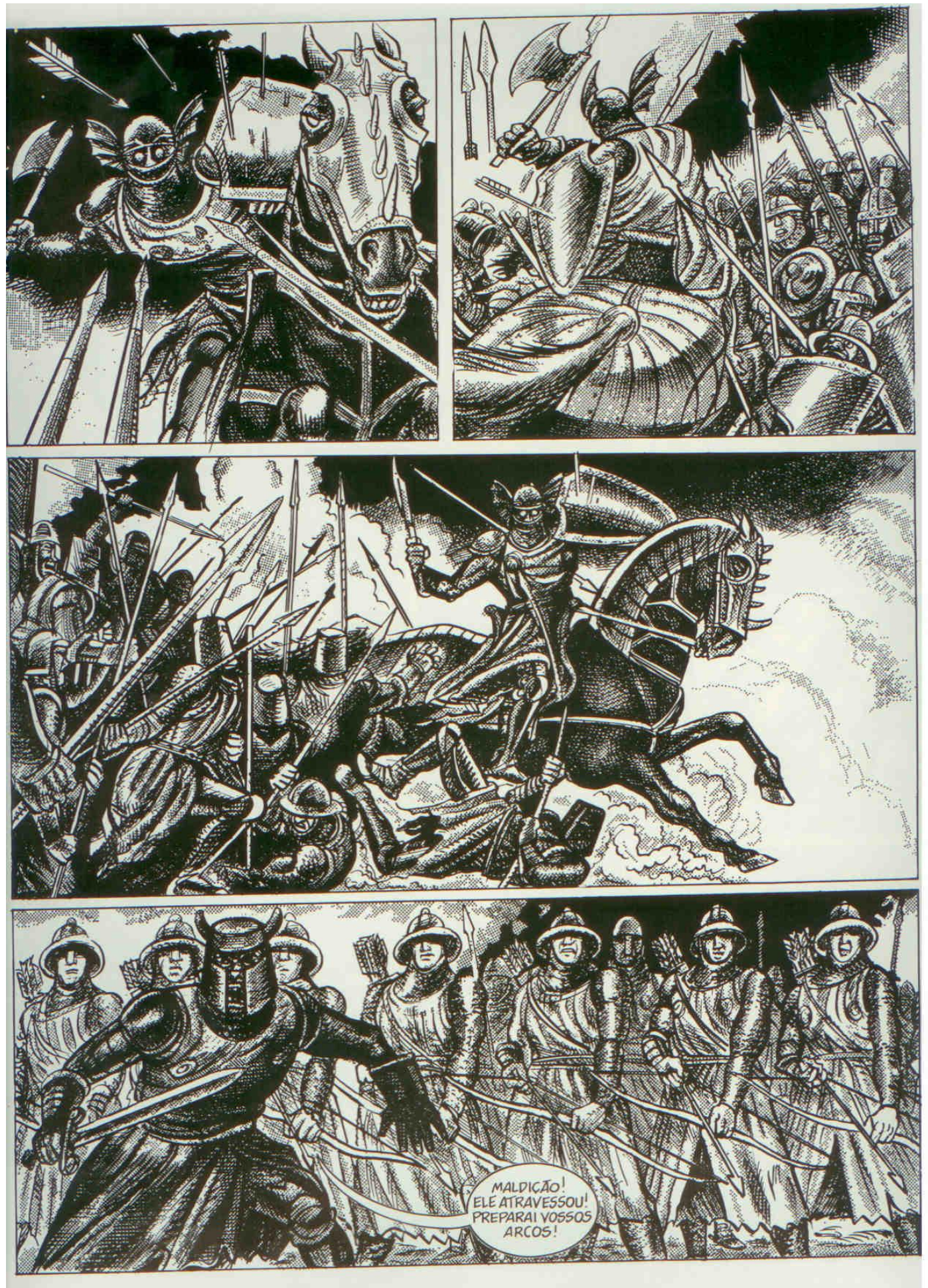

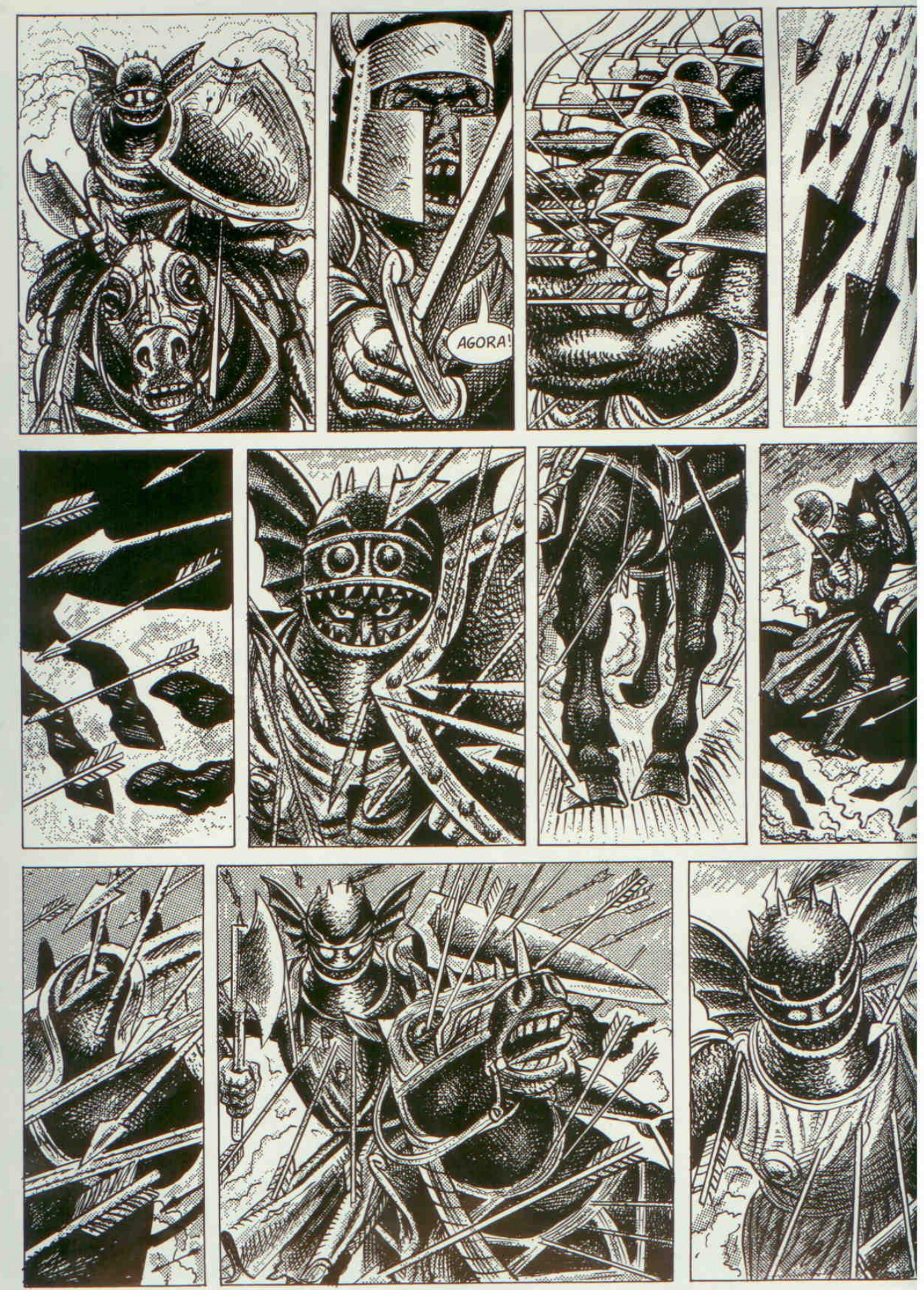

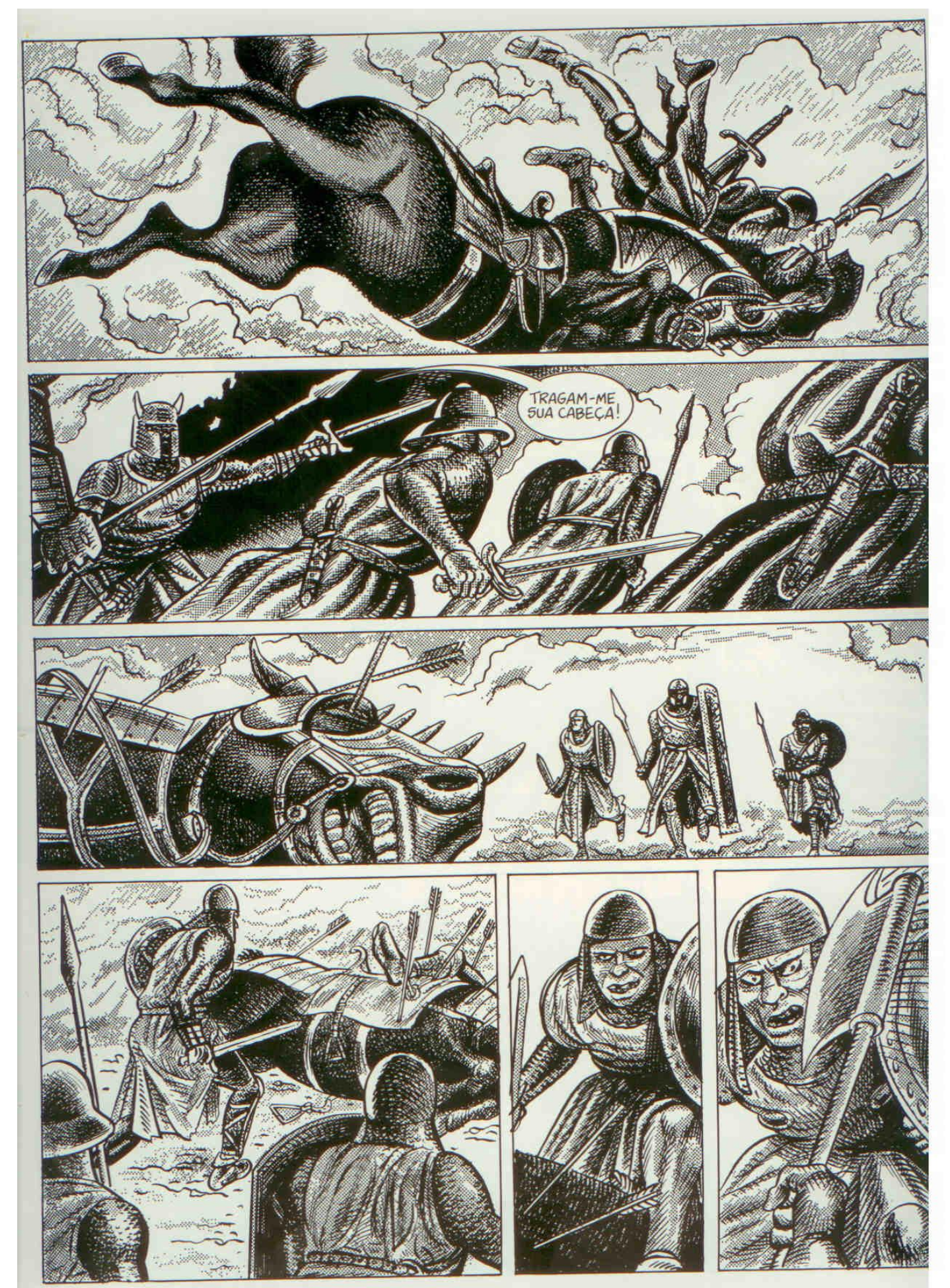


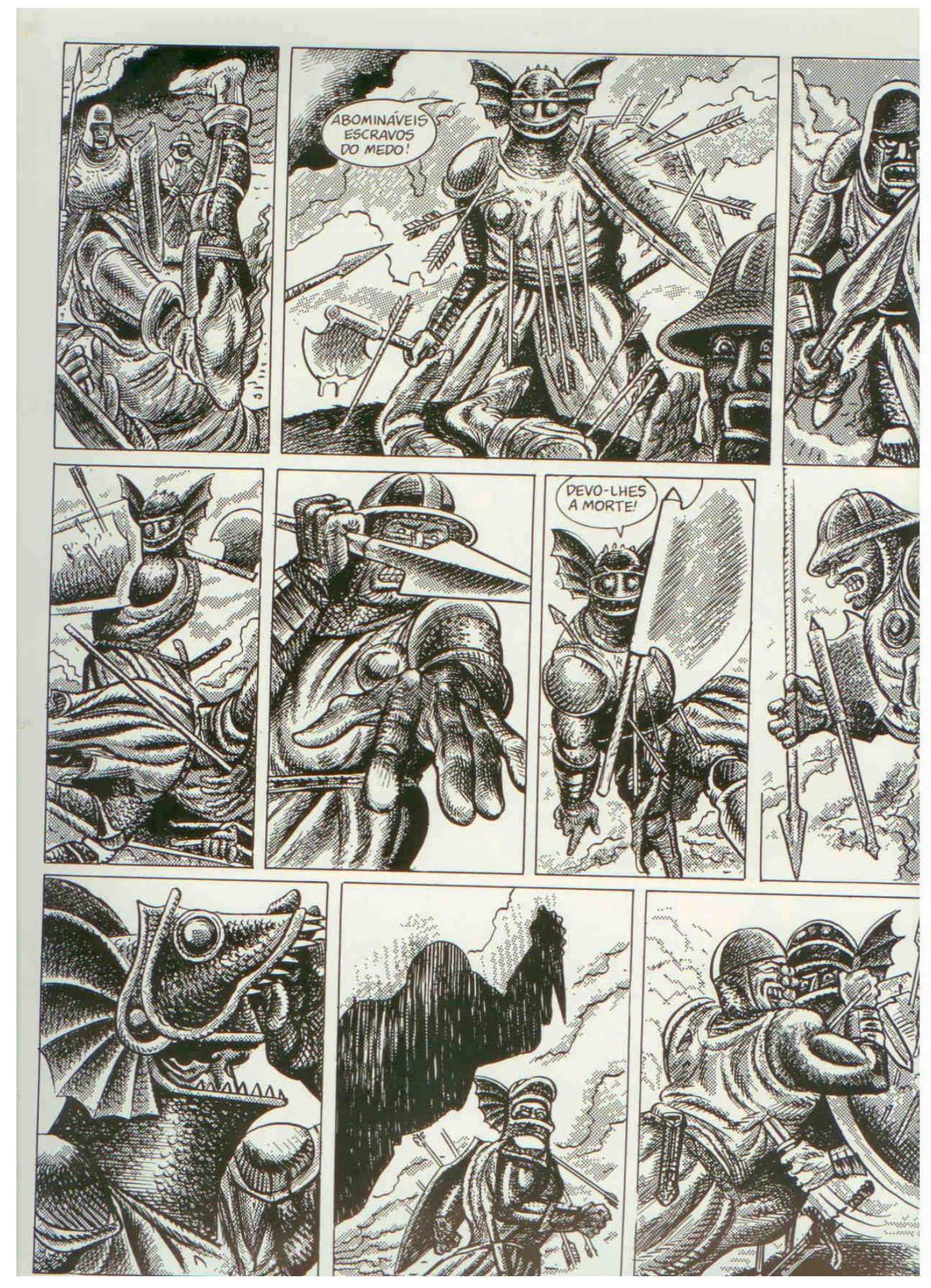




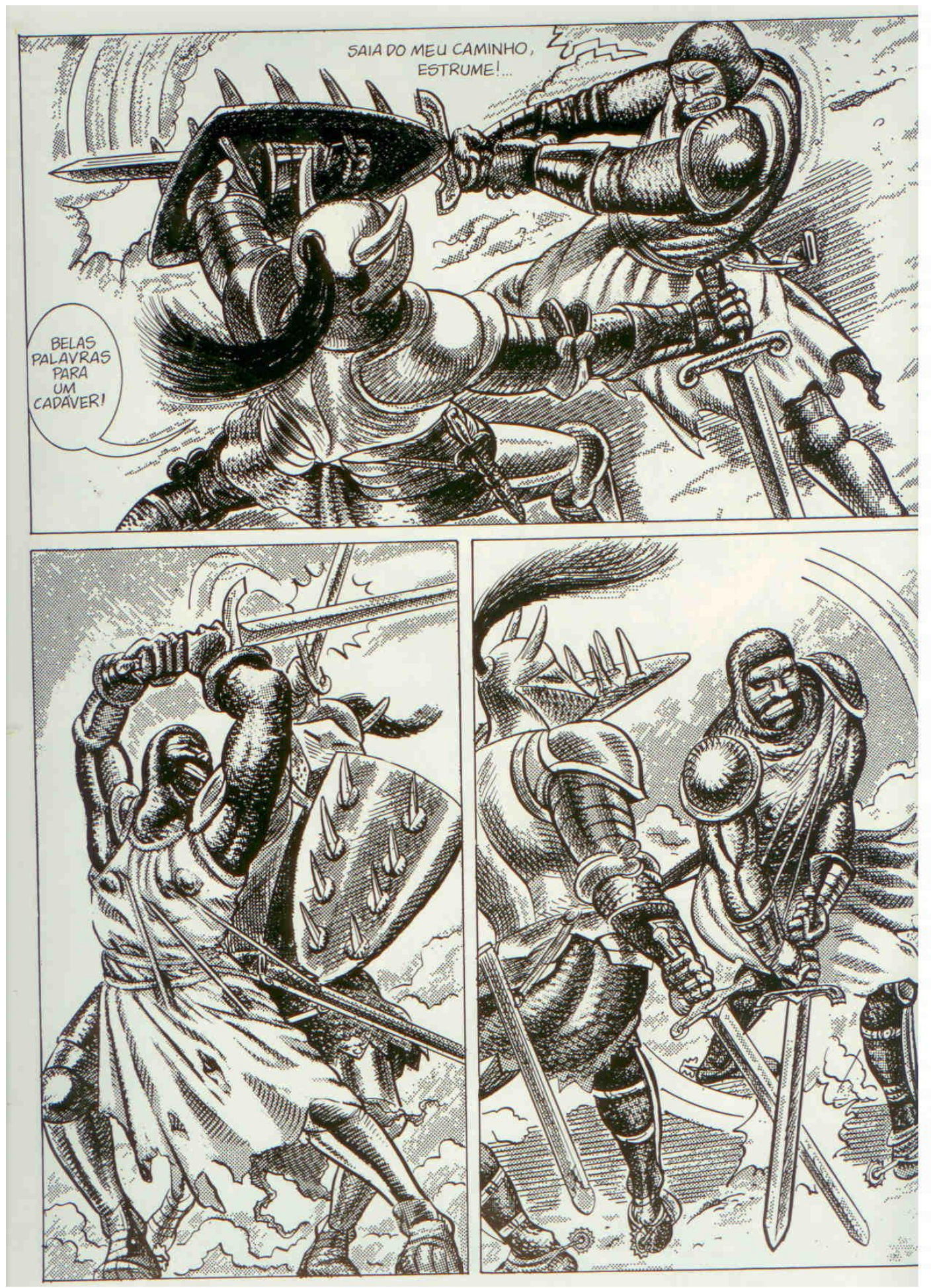




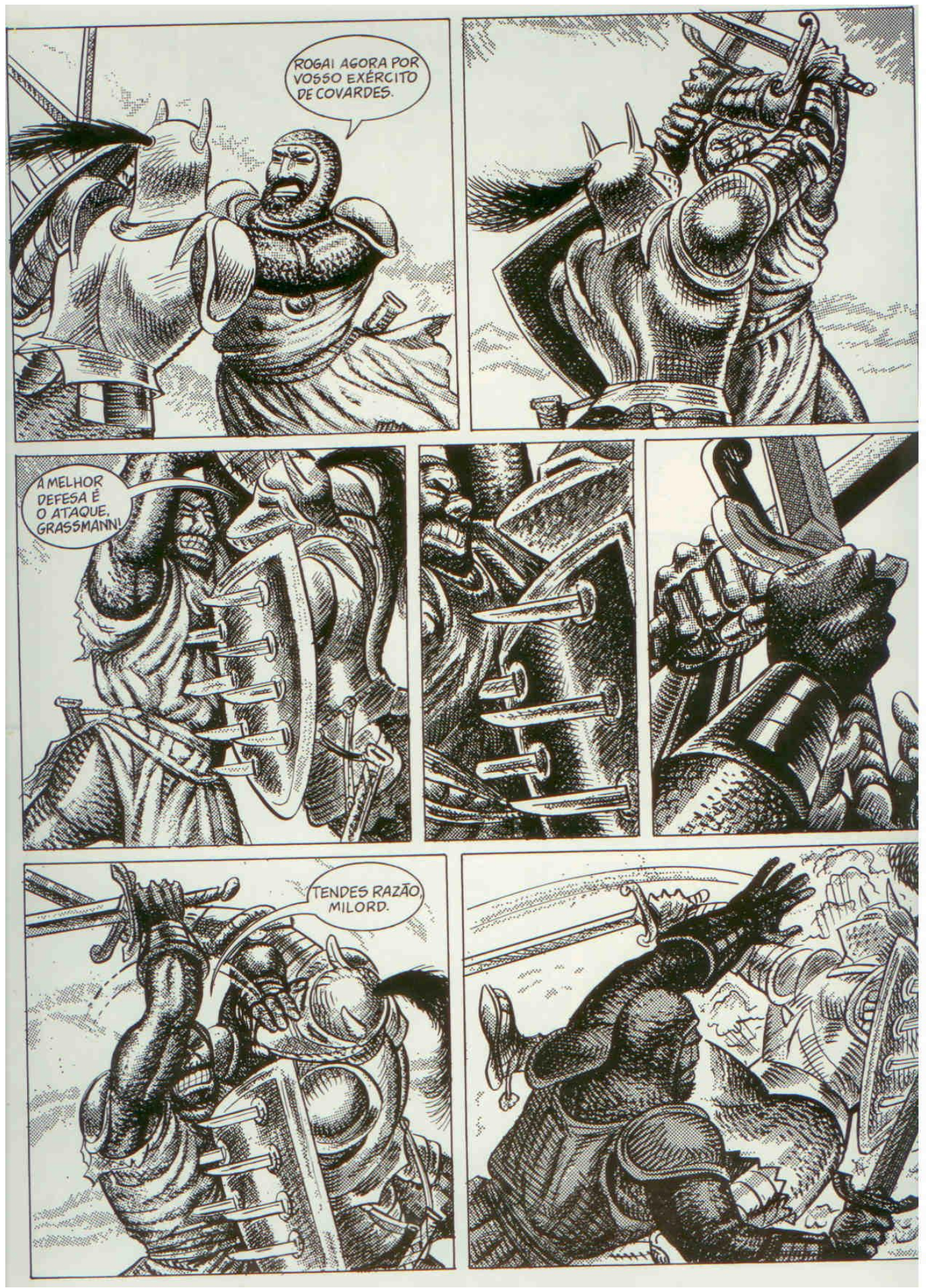



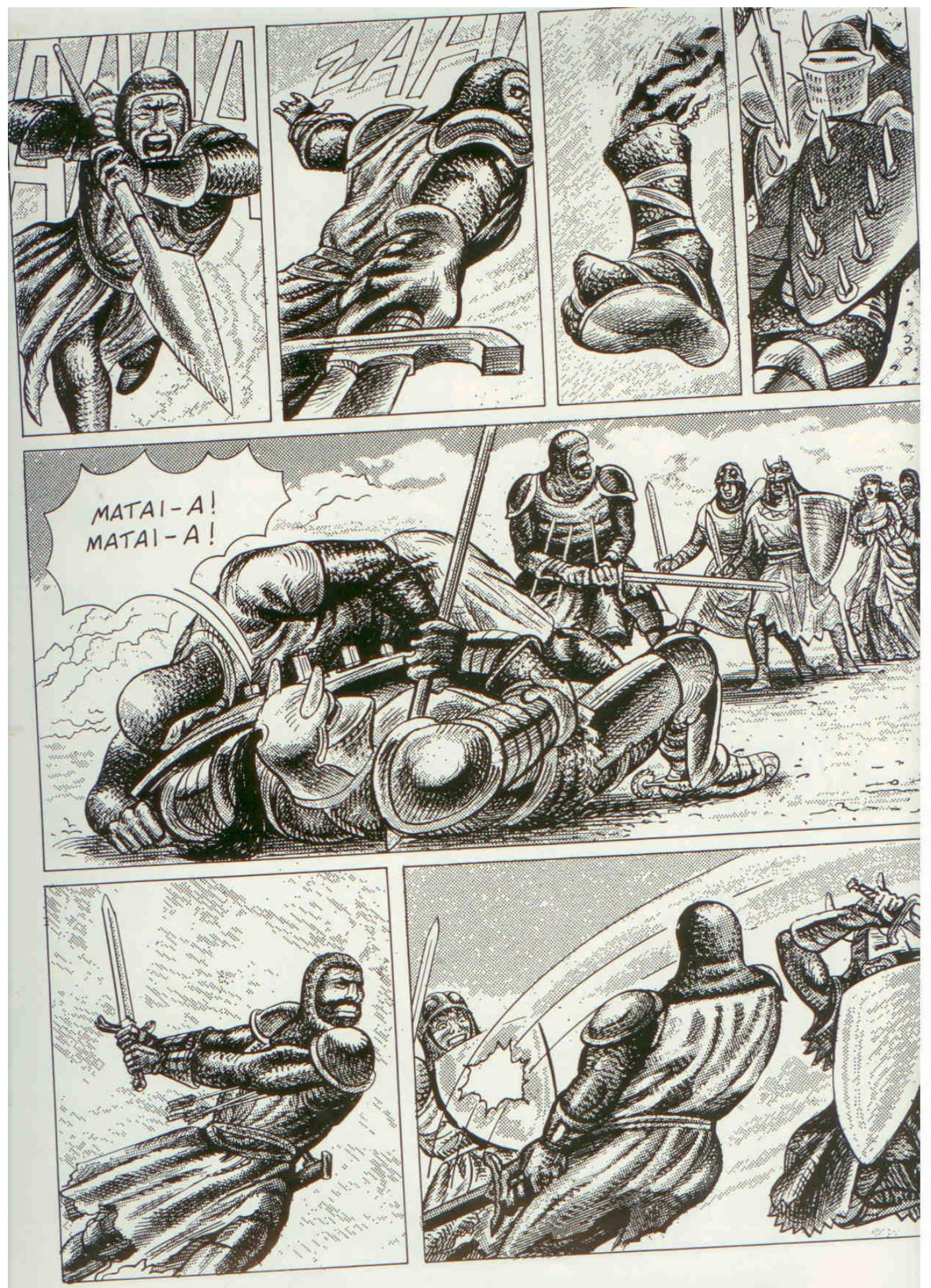


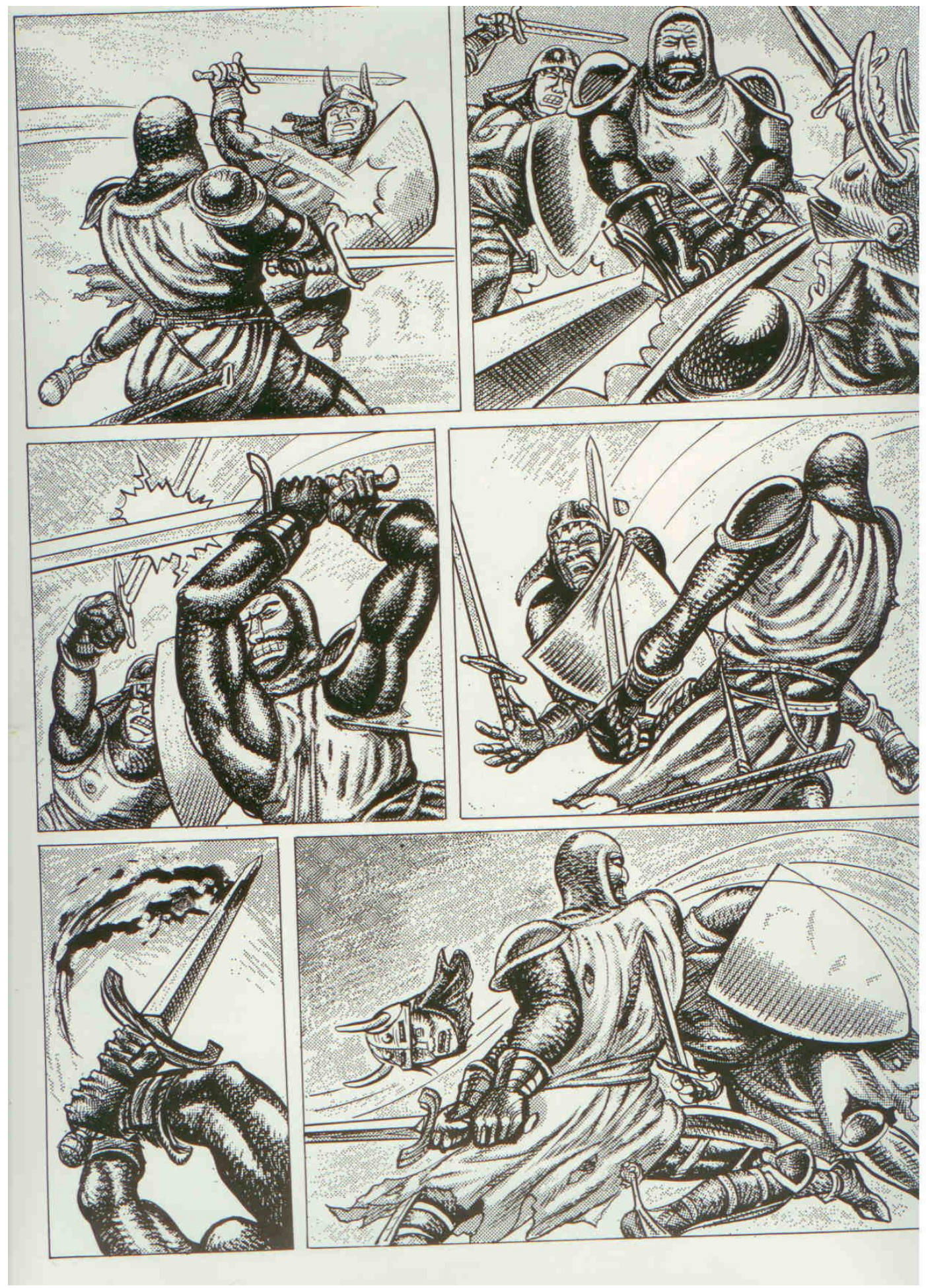



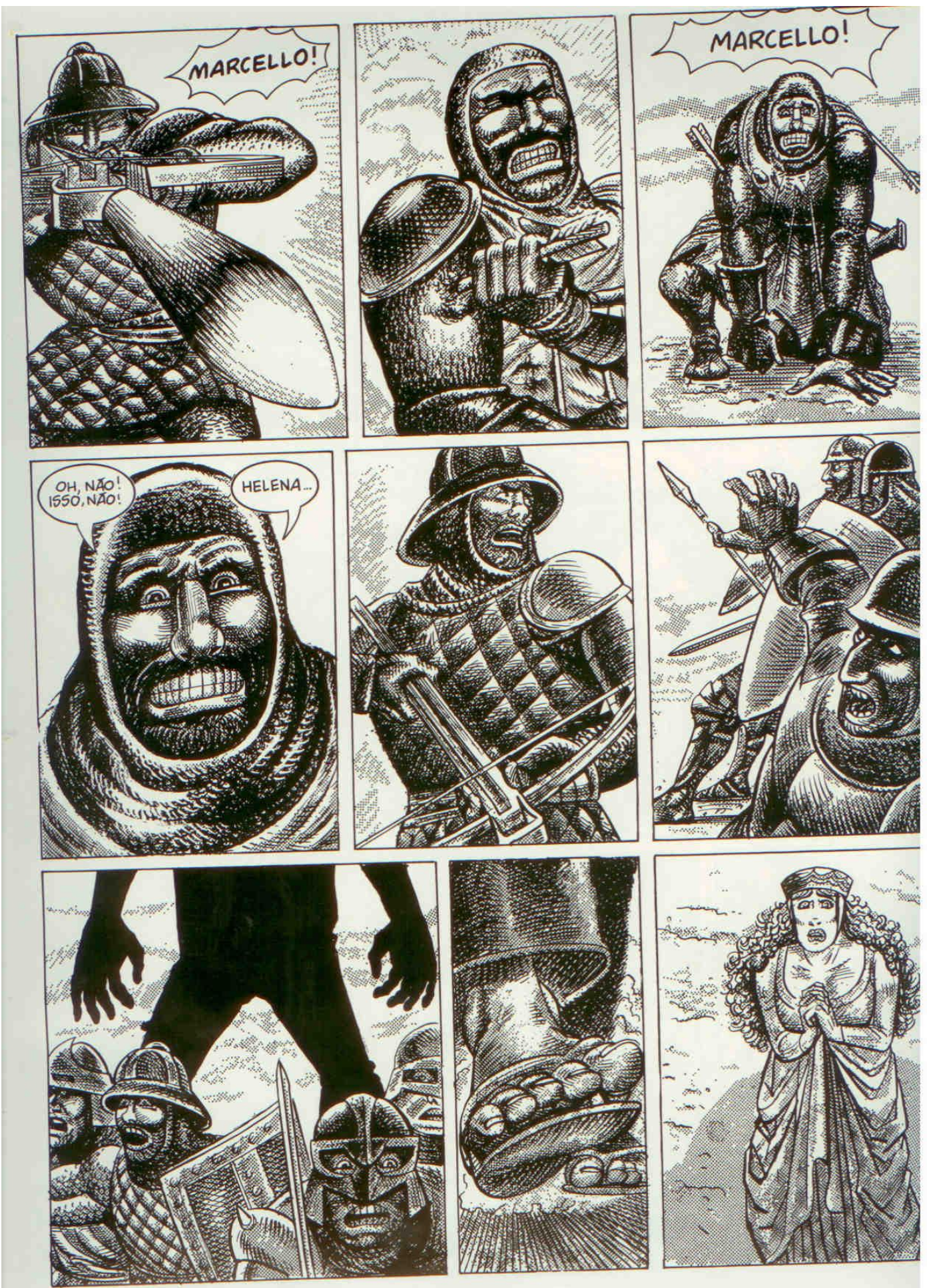


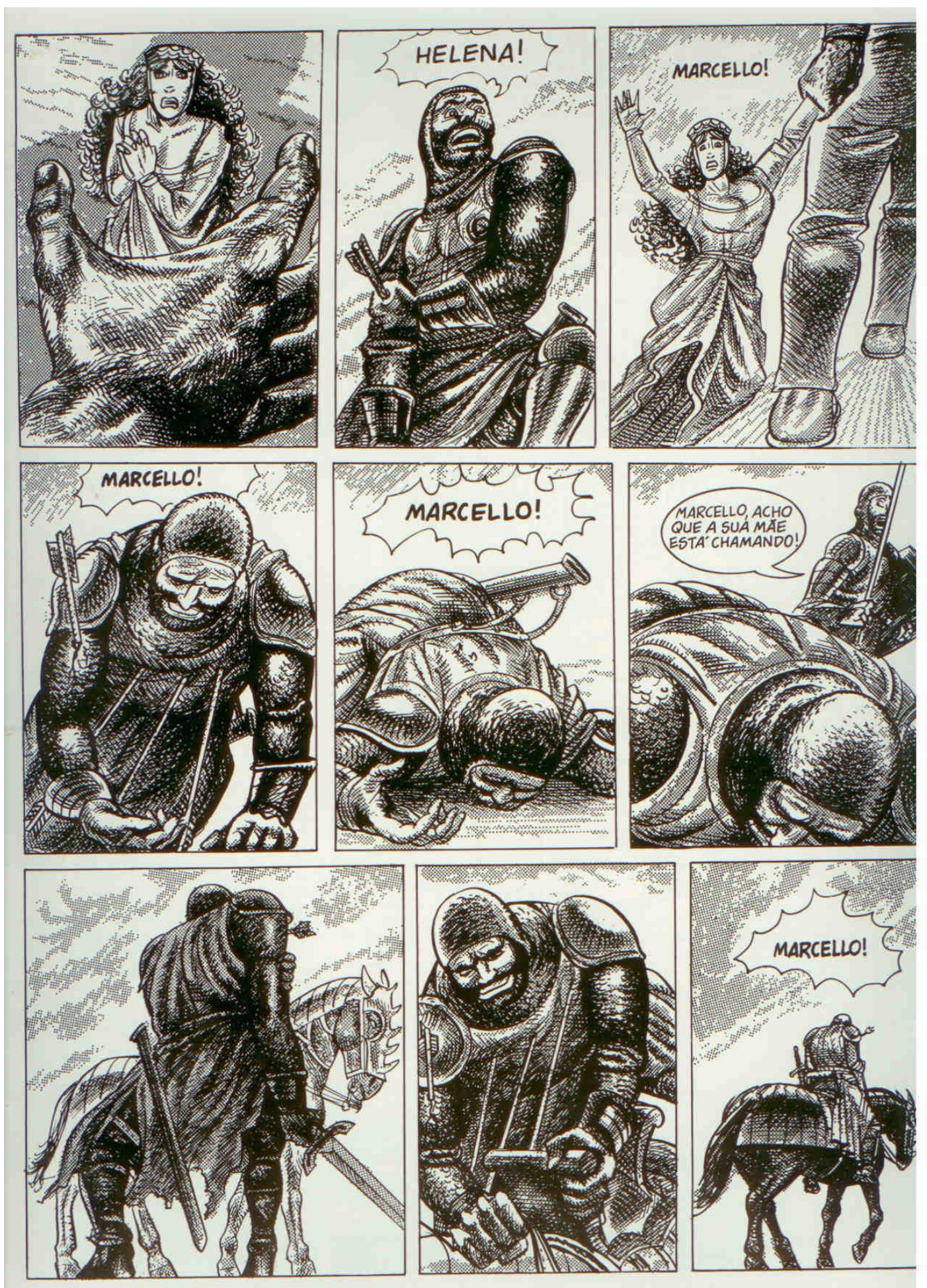




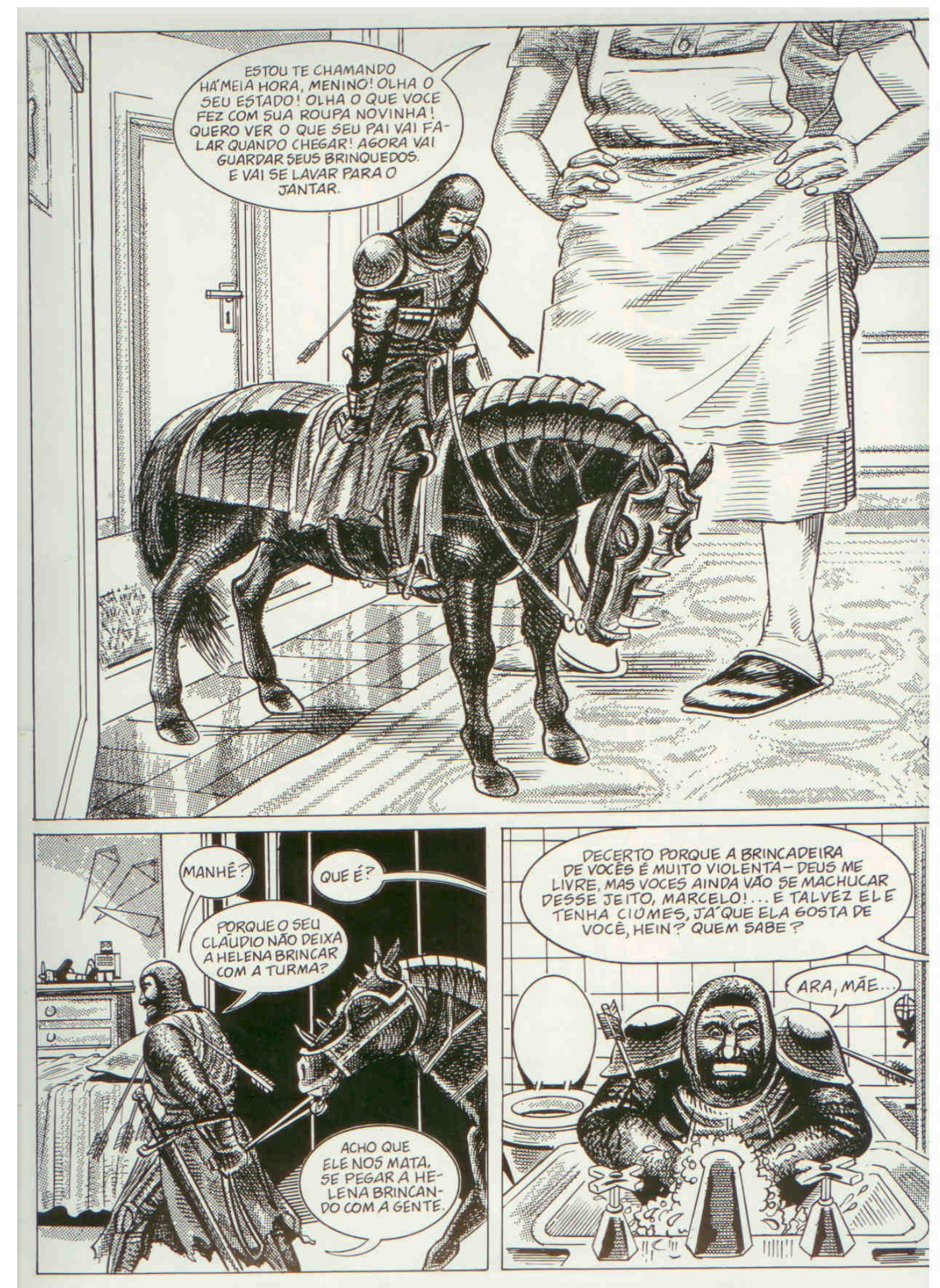




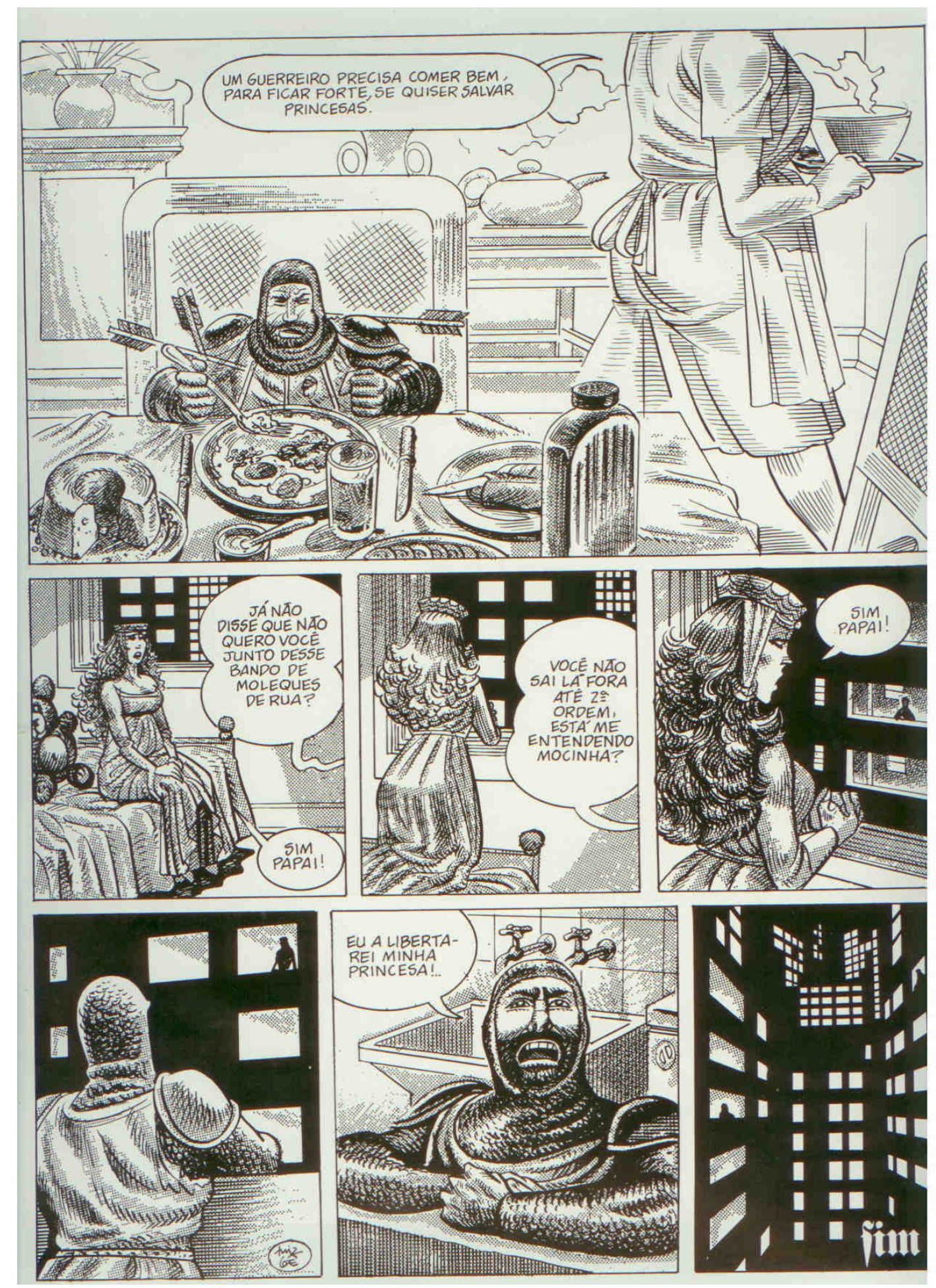




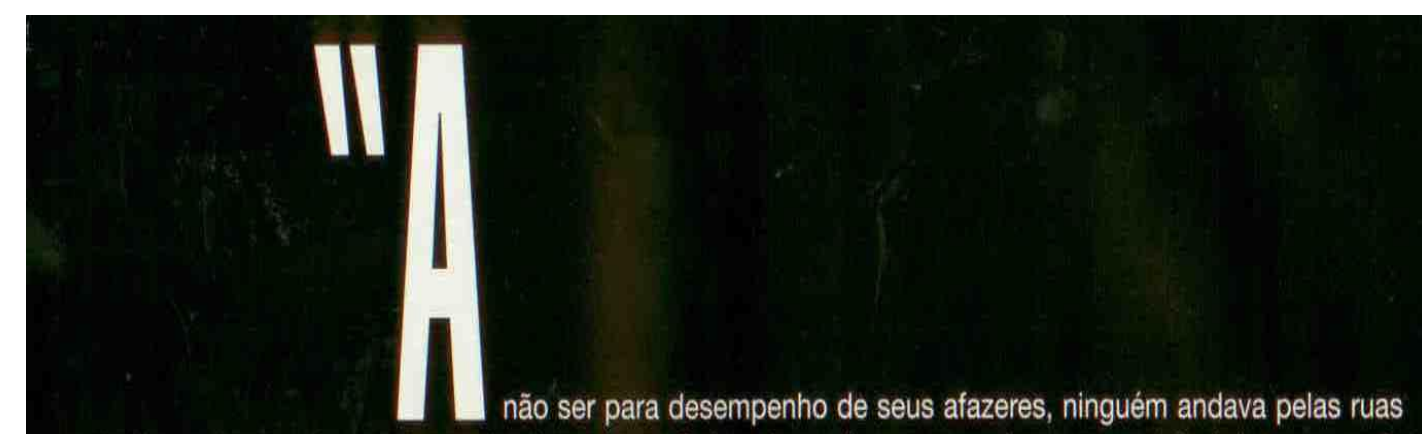
solitárias, calçadas de grandes pedras irregulares. Sobre elas rodavam aos solavancos as três únicas seges da cidade, pertencentes ao Bispo, à Marquesa de Santos e ao Comendador B."

Maria Pais de Barros, 1870

"Hoje já quase ninguém sai à janela para ver quem passa de carro: há muitos, de particulares e de praça. Durante certas horas do dia já o incessante rodar de carros e carroças torna-se incômodo a quem não está habituado; ao antigo silêncio sucedeu este concerto, pouco agradável, de sons produzidos pelo atrito nas calçadas de tantos veículos de diversas espécies, uns de construção leve e elegante, outros de forma grosseira, pesados e apropriados aos gêneros a cujo transporte se destinam, uns de duas e outros de quatro rodas; também há pequenas carroças para a condução de hortaliças, de frutas e de flores, as quais são movidas a mão. (...) Os veículos de aluguel em São Paulo eram carros de praça (fiacres), tilburis e landôs. Os particulares eram vitória (de um só cavalo), landô, caleça e cupê."

"Existe na cidade um número considerável de automóveis, em sua maioria pertencentes a particulares e o restante formado de táxis. Há também boa quantidade de carruagens descobertas, puxadas por cavalos."

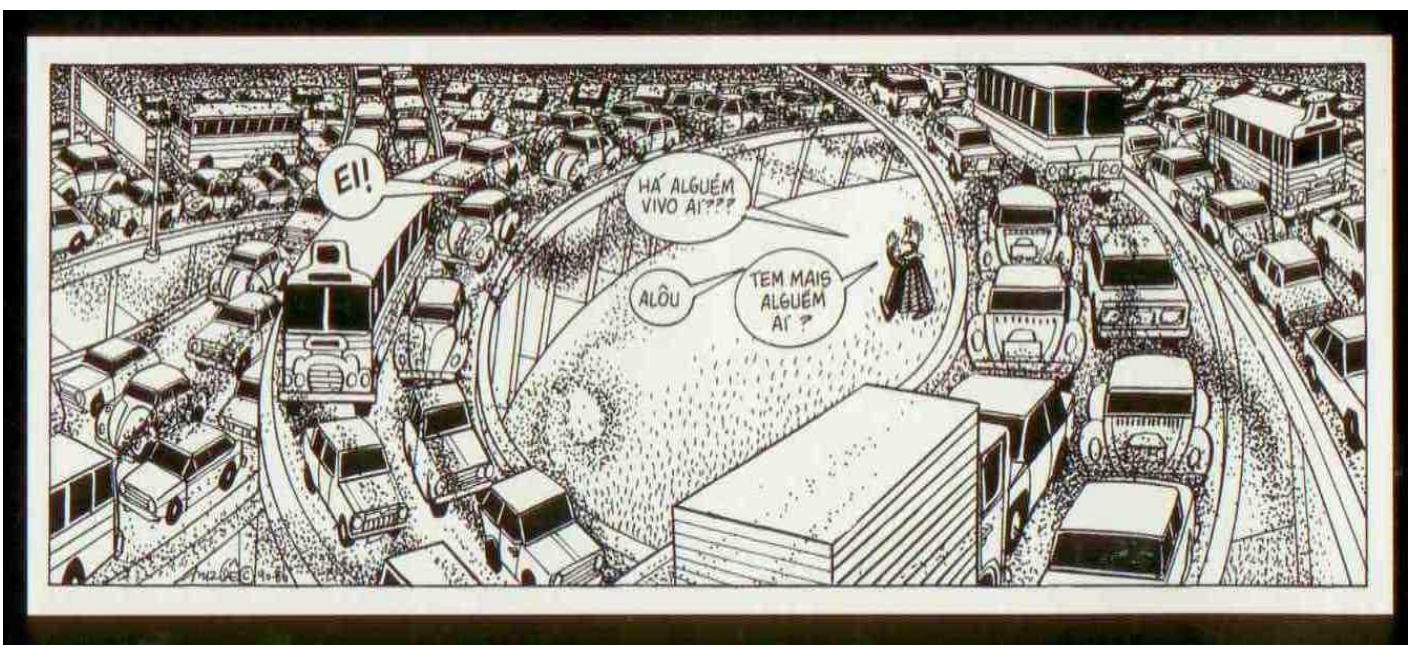




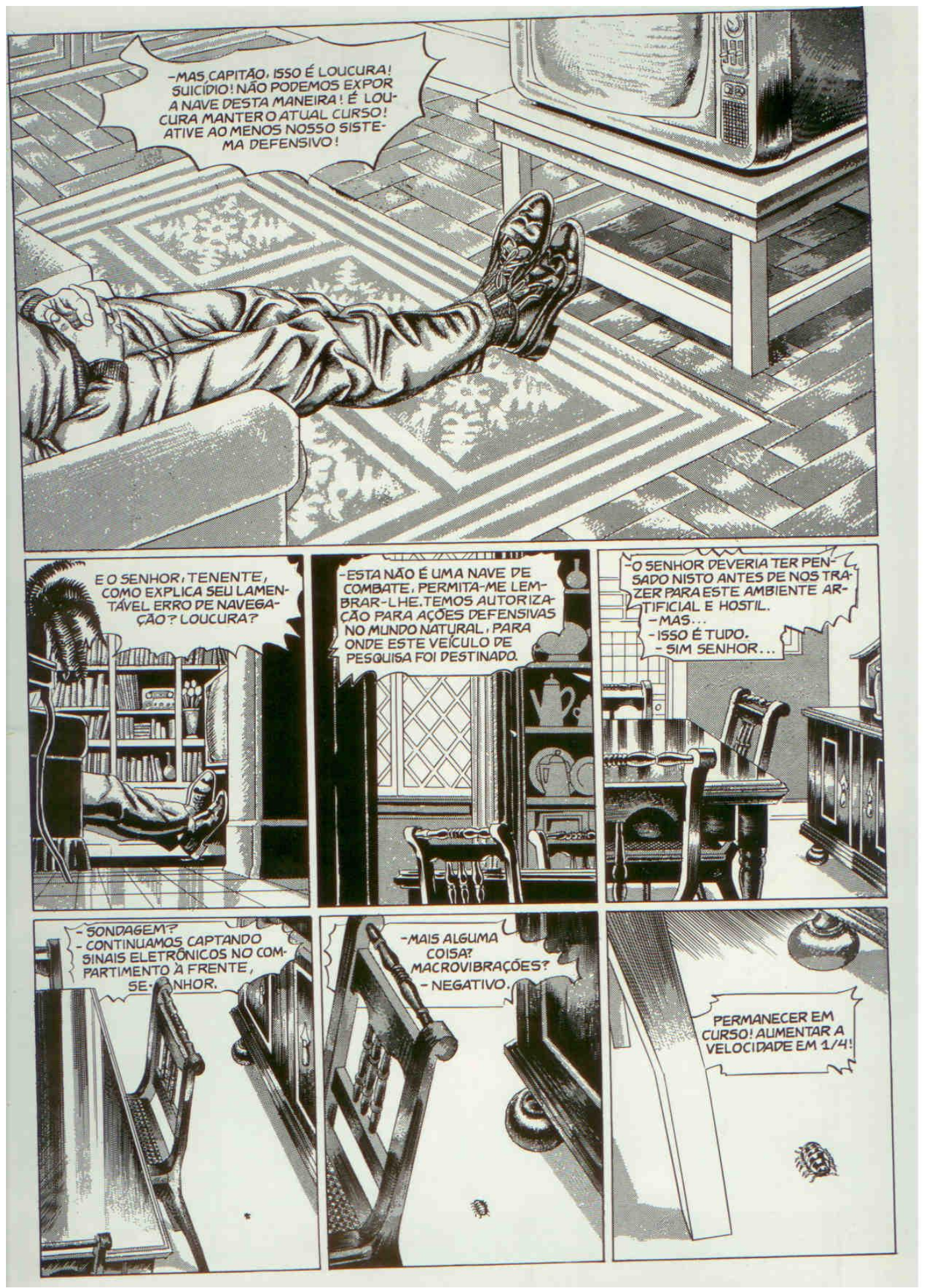




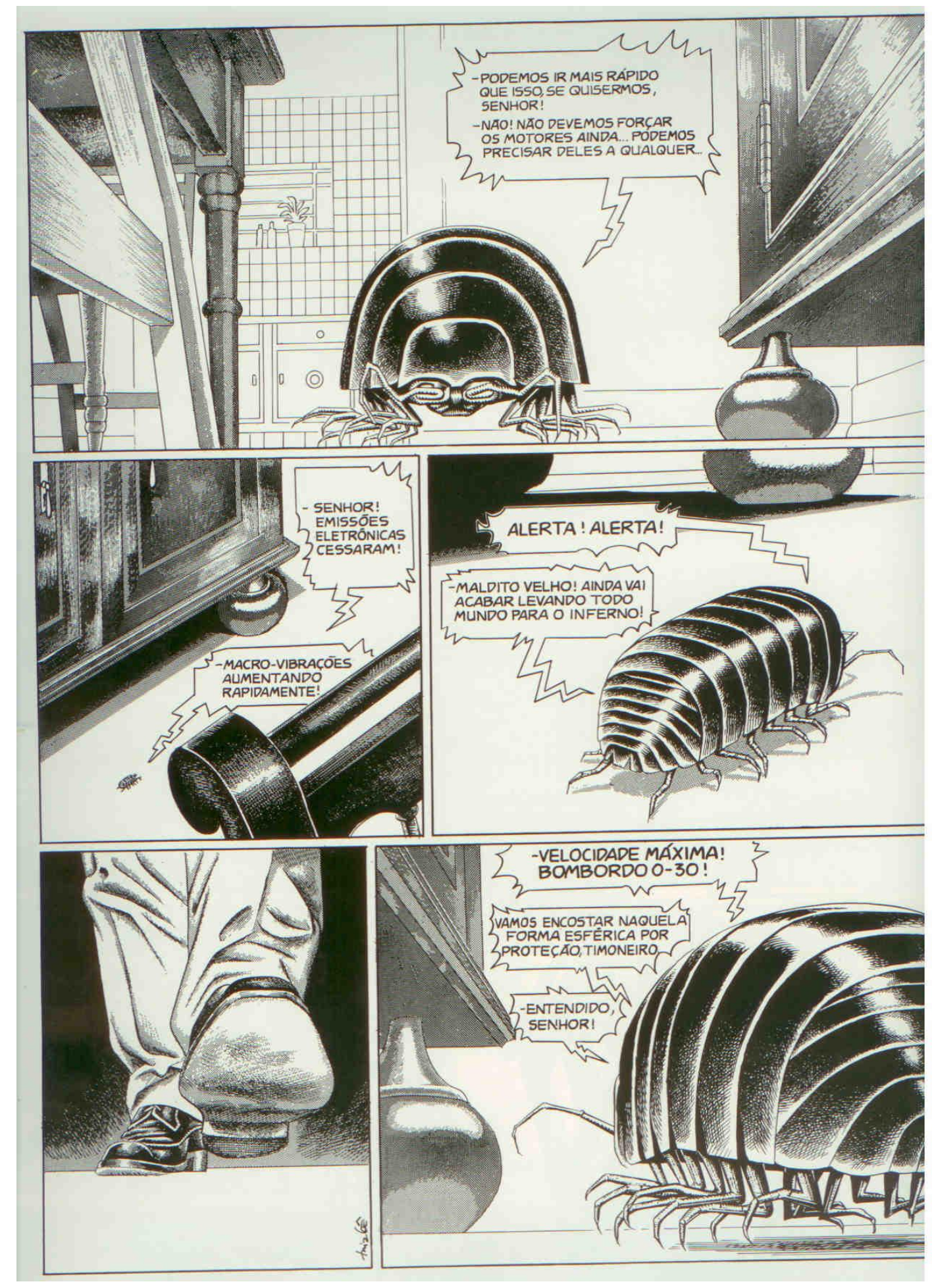




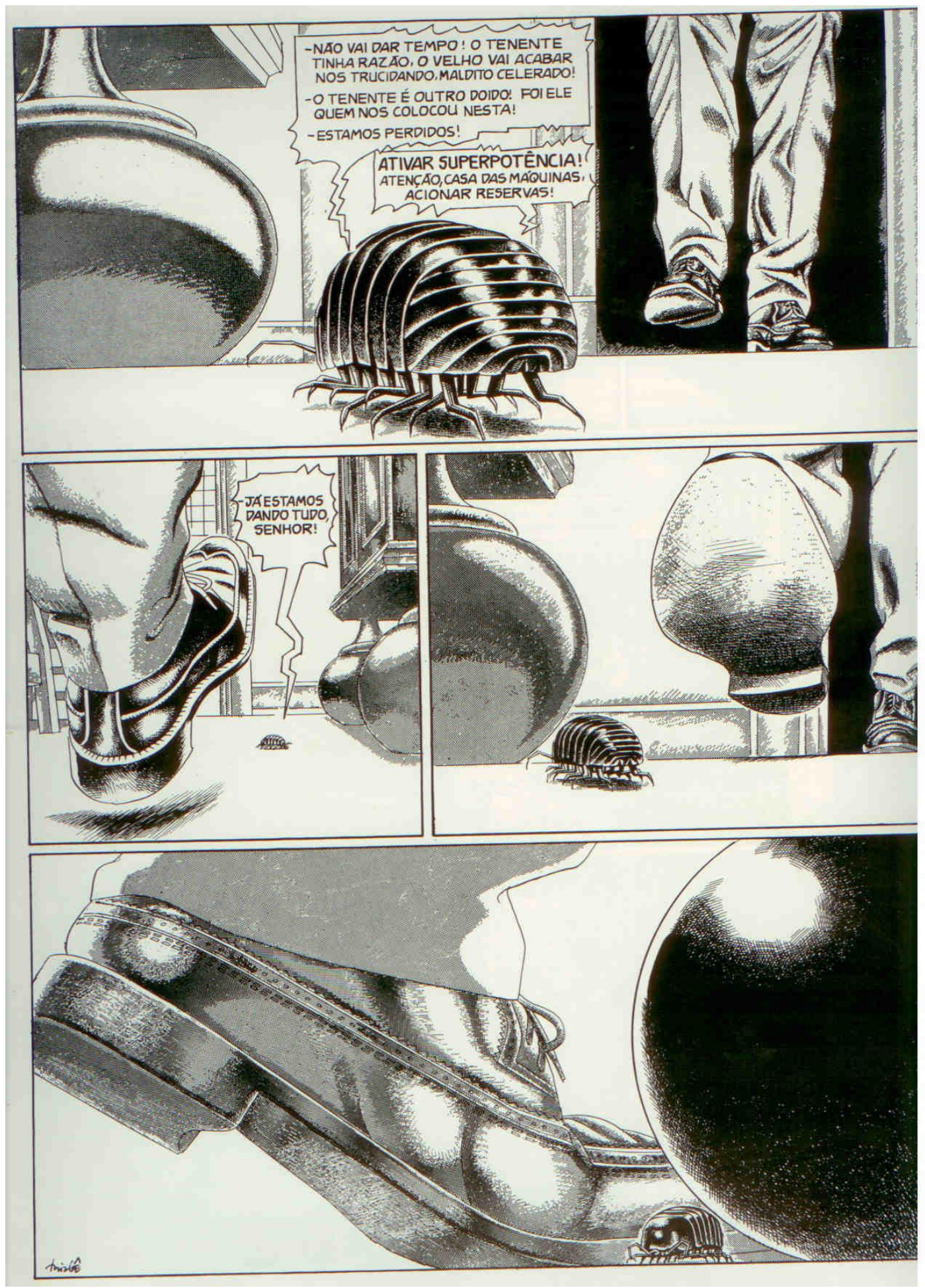




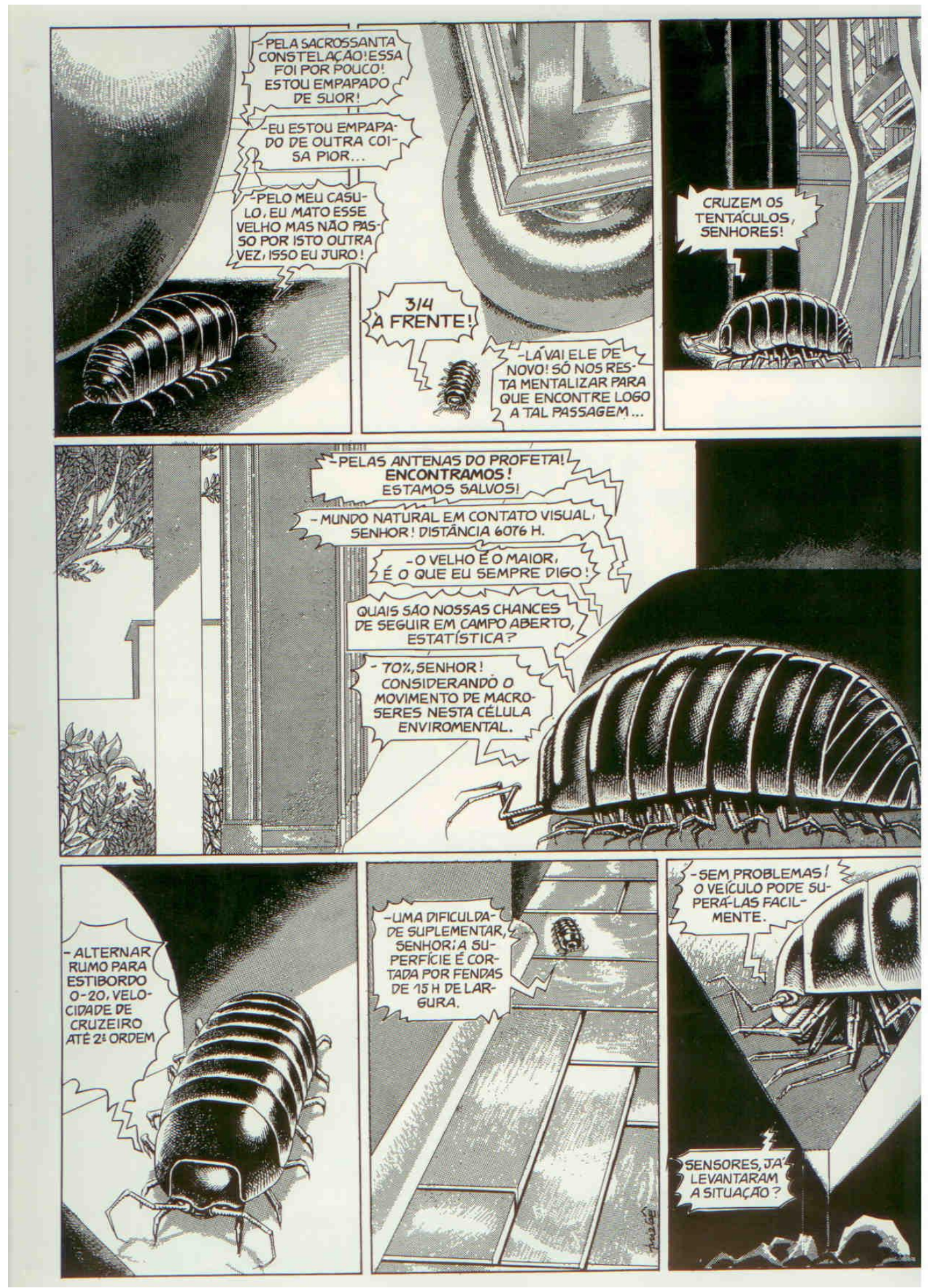




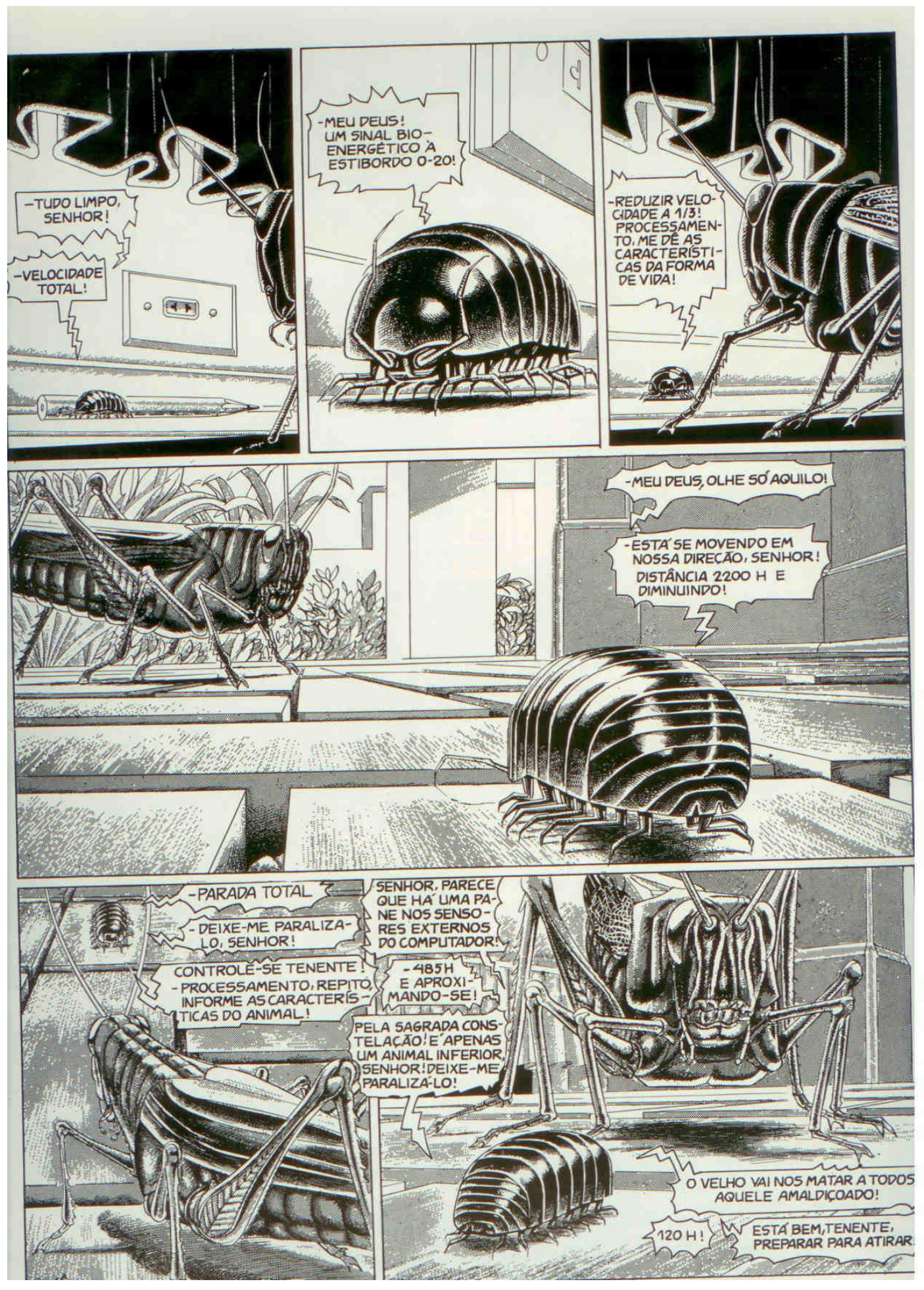




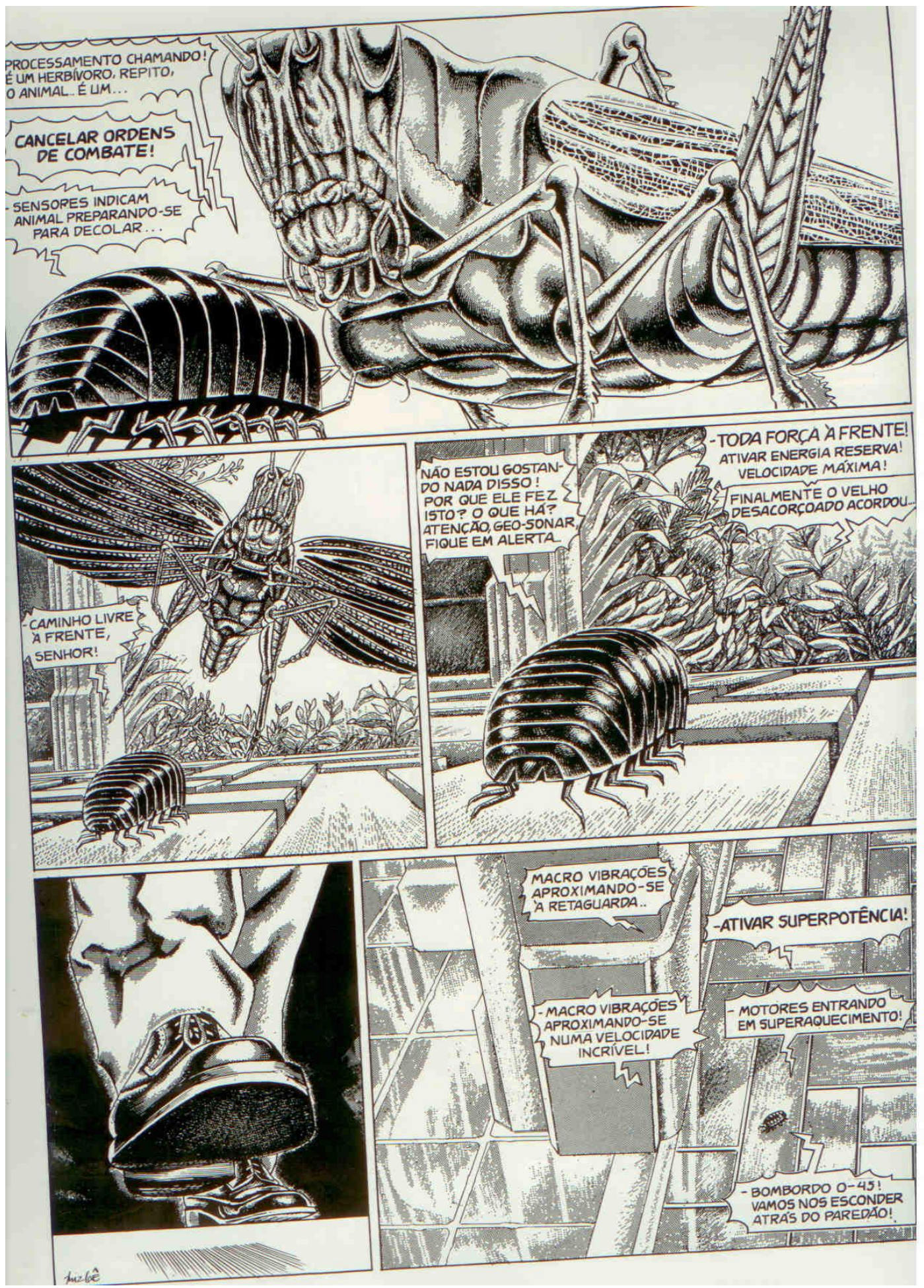




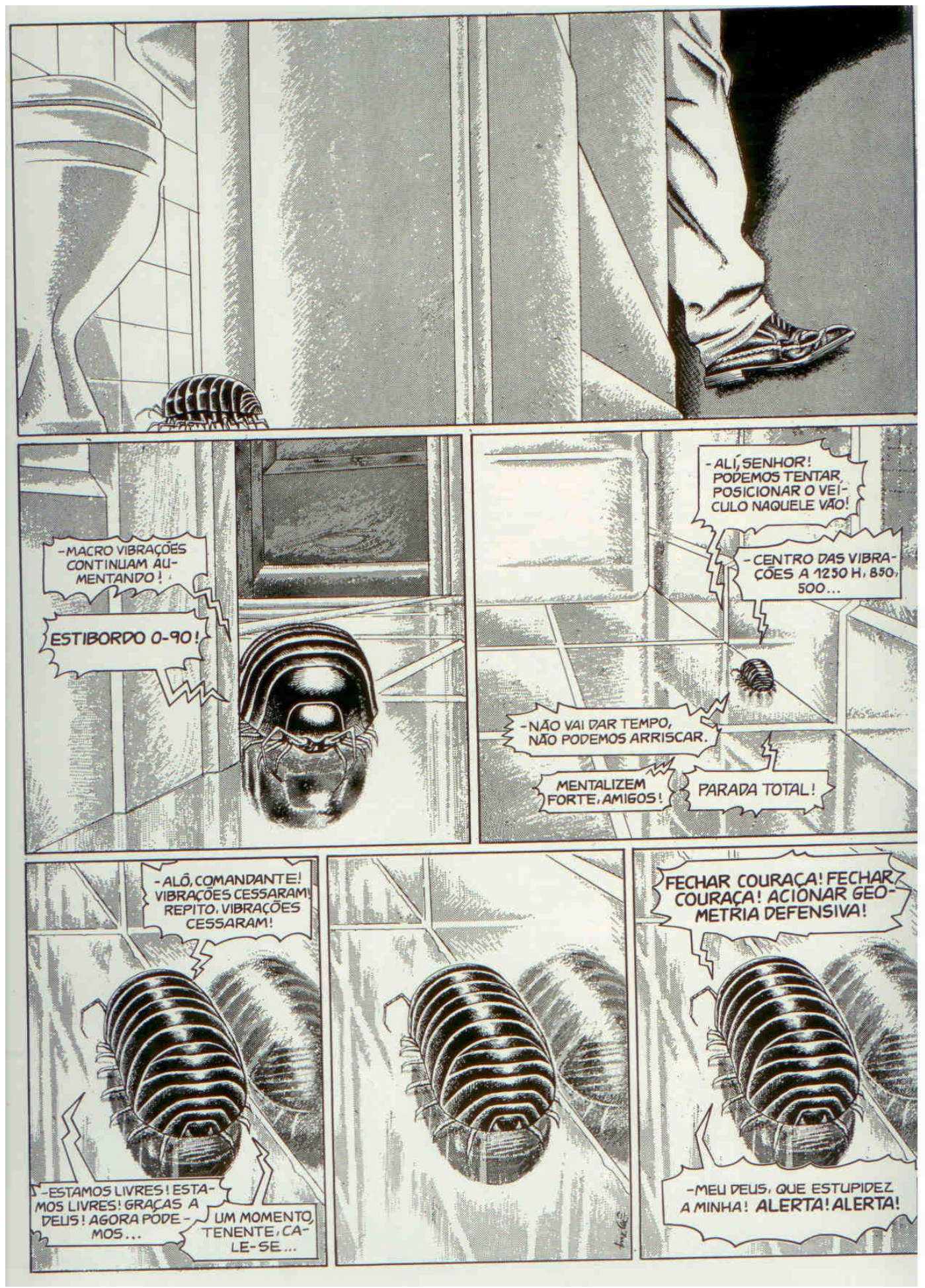




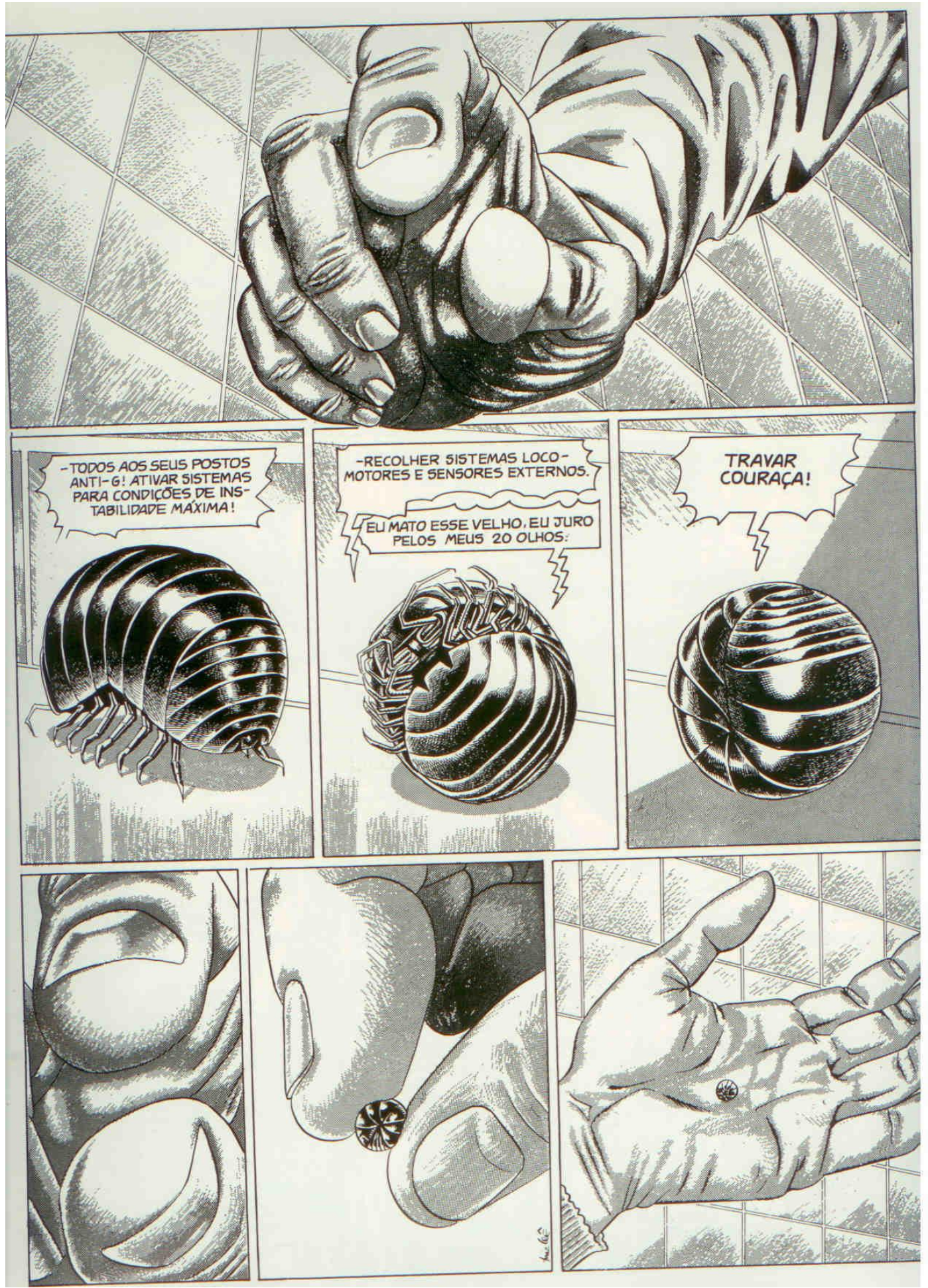




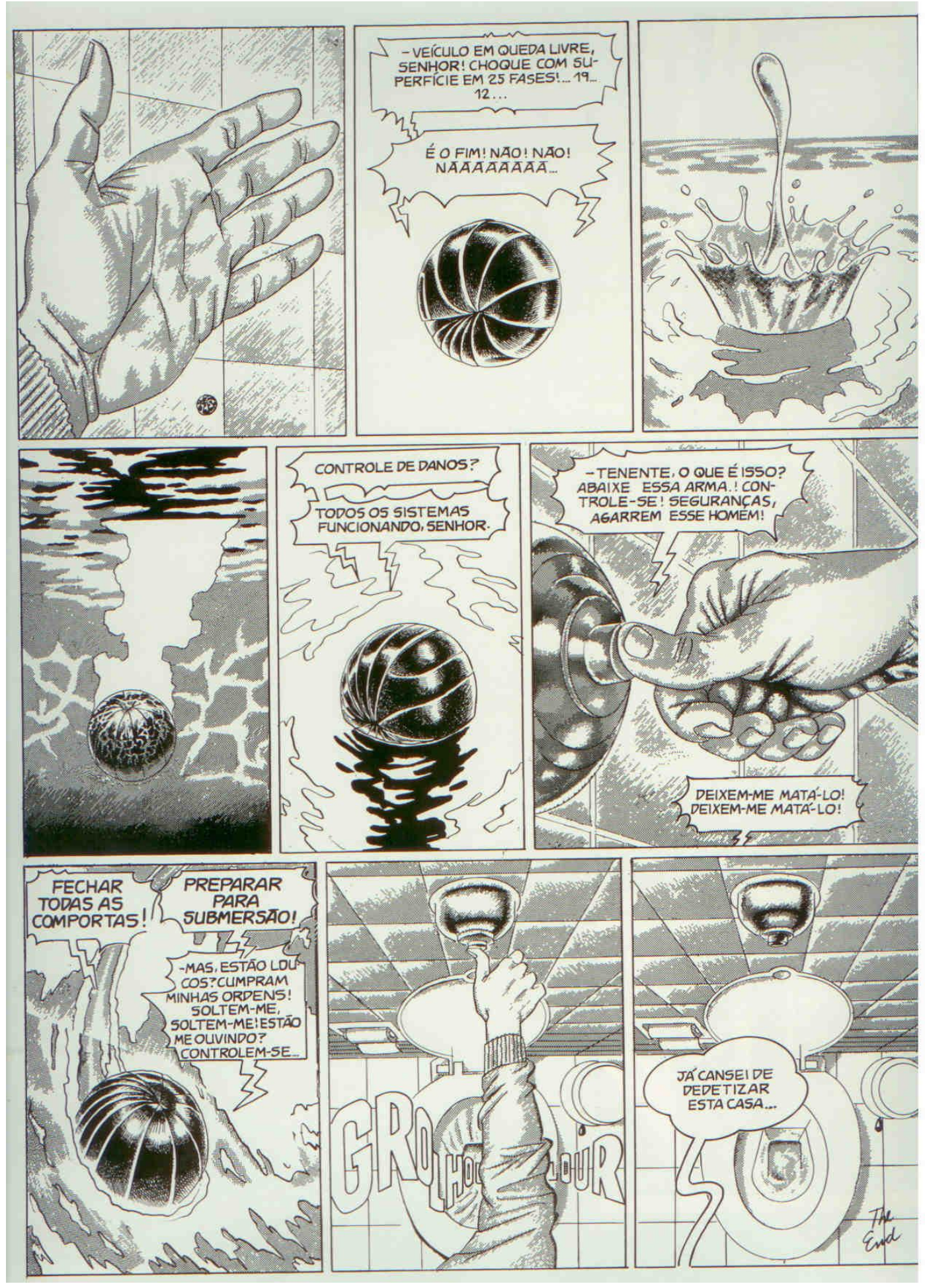




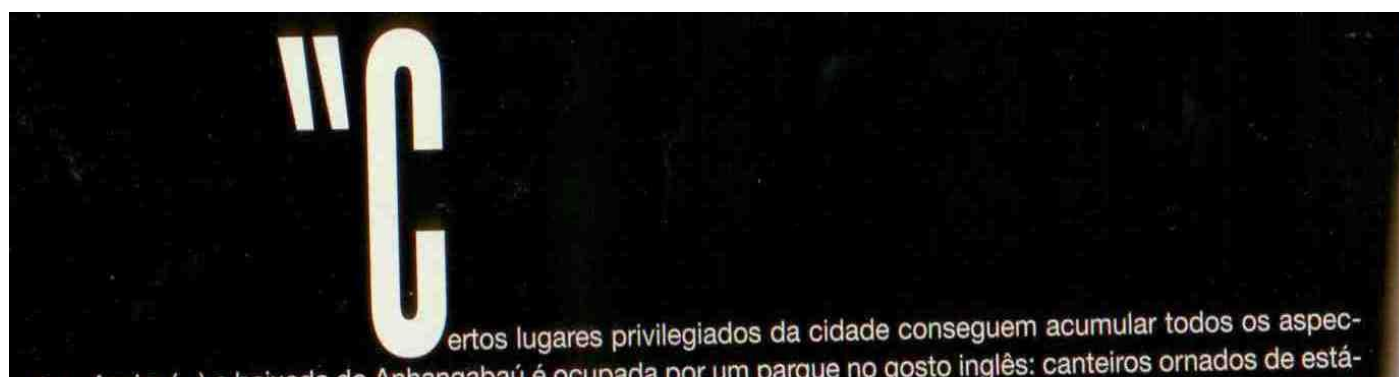

tos. Assim (...) a baixada do Anhangabaú é ocupada por um parque no gosto inglês: canteiros ornados de estátuas e quiosques, enquanto na vertical dos dois taludes se elevam os principais: o Teatro Municipal, o Hotel Esplanada, o Automóvel Clube, os escritórios da companhia canadense que fornece a luz e os transportes. Suas massas heteróclitas se afrontam numa desordem imóvel. Esses edifícios em batalha evocam grandes rebanhos de mamíferos reunidos à tarde em torno de um ponto de áqua, por alguns instantes hesitantes e imóveis; condenados, por uma necessidade mais urgente que o medo, a misturar temporariamente suas espécies antagônicas. A evolução animal se realiza segundo fases mais lentas que as da vida animal; $e$, se eu contemplasse hoje o mesmo lugar, verificaria, talvez, que o hibrido rebanho desapareceu: esmagado por uma raça mais rigorosa e mais homôênea de arranha-céus, implantados nessas margens que uma auto-estrada fossilizou de asfalto."

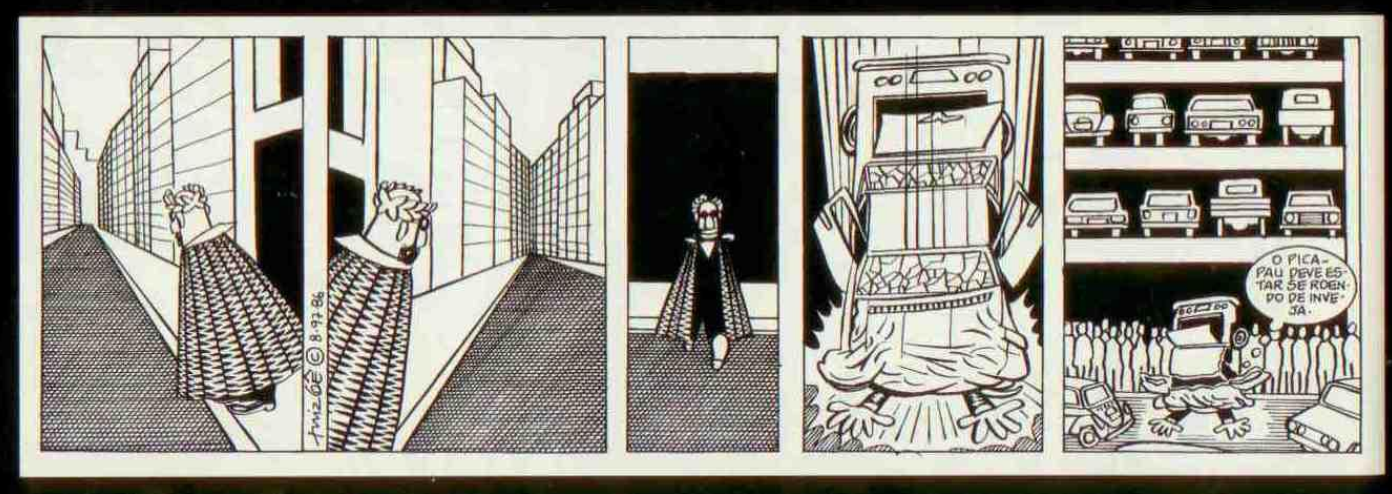

